Universidad Politécnica de Madrid

Escuela Técnica Superior de Arquitectura de Madrid

\title{
La huella de Borromini: \\ forma y espacio en la arquitectura postmoderna
}

Tesis Doctoral

Patricia Fernández García

arquitecta 

Departamento de Proyectos Arquitectónicos

Escuela Técnica Superior de Arquitectura de Madrid

\section{La huella de Borromini: \\ forma y espacio en la arquitectura postmoderna}

Tesis Doctoral

\section{Patricia Fernández García}

arquitecta

\section{Directores}

Juan Miguel Hernández León, arquitecto catedrático de la UPM

Teresa Oñate y Zubía, filósofa catedrática de la UNED 

Tribunal nombrado por el Mgnfco. y Excmo. Sr. Rector de la Universidad Politécnica de Madrid, el día

Presidente D.

Vocal D.

Vocal D.

Vocal D.

Secretario D.

Realizado el acto de defensa y lectura de Tesis el día en la Escuela Técnica Superior de Arquitectura de Madrid.

Calificación:

EL PRESIDENTE

LOS VOCALES 

AGRADECIMIENTOS 
¿Hay un tiempo para la tesis, o debería hablarse de una edad para la tesis?. Estas son las dos cuestiones que Jaques Derrida plantea al comienzo de su texto El tiempo de una tesis. Cuando lo leí me animé pensando que Derrida leyó su tesis a los 50 años, y aunque todavía era algo más joven que yo, pude comprobar en su texto que le invadía el mismo sentimiento de ser joven y mayor a la vez, como una especie de desdoblamiento, como él dice, un cierto trastorno de la identidad. Hay en ello también una especie de gusto por hacer algunas cosas a des-tiempo, cosas que no llegan nunca a su hora, algo intempestivas, pero que, por ello, actualizan todo continuamente, rejuvenecen. Siempre se trata de la lucha contra Chronos.

A pesar de lo intempestivo han sido muchas las personas que me han animado en el camino. Las más importantes han sido mis dos directores de tesis: Juan Miguel Hernández León y Teresa Oñate. Sin ambos esta tesis no hubiera sido posible. Juan Miguel me animó a seguir este tema de tesis y me dio sabios consejos y una información privilegiada que no se si habré sabido aprovechar suficientemente. En las largas conversaciones con Teresa se suspendía el tiempo, pero se abría el espacio del enlace con la filosofía; ella sabe mejor que nadie transmitir el amor por la filosofía, y así lo ha hecho conmigo. Las aportaciones de ambos, por tanto, se encuentran entrelineas en esta tesis. Quizás no hayan sido suficientemente citados, pero su contribución imprescindible no se puede citar, pues se encuentra implícita en todo el texto.

Mi sincero agradecimiento a la Academia de España en Roma, por haberme brindado la oportunidad de conocer tan de cerca a Borromini y vivir la experiencia de sus espacios tan cotidianamente.

Gracias a la cátedra HERCRITIA por posibilitar siempre el fructífero intercambio entre disciplinas y la participación en la filosofía.

A Ramón Gámez tengo que agradecerle que haya siempre respaldado mis intromisiones en espacios intempestivos, a pesar de 
todo. Además de su sincera ayuda en muchos momentos, por escuchar, leer, corregir, aportar, posibilitar...

Esta tesis no podría haberse desarrollado sin la ayuda de todo el equipo del estudio Cuarq, en unos momentos y en otros, de unas y otras formas, durante todos estos años. Especialmente mis agradecimientos a Rubén Conde, por su paciencia infinita haciendo mapas y diagramas... y su colaboración imprescindible siempre. También a Cristina Ramírez, por su esmerada y cuidadosa maquetación, y a Berta, por comenzarla. Todos han escuchado, opinado y corregido. Son parte de la tesis.

Olga Gómez me ha ayudado en cada cosa que he necesitado, con una rapidez y una disposición admirables. Espero estar a la altura cuando ella necesite mi ayuda. Se la brindo desde aquí. A María Altozano y a Inés Martín Padura les agradezco sus ánimos, sus apoyos y su cariño de amigas.

Rodrigo de la O y David Escudero han sido mis jóvenes acompañantes, que, siendo más jóvenes, iban delante; David abriendo el camino que luego yo he transitado de tan cerca, gracias por hacerlo tan bien y dejar tu ejemplo.

Gracias a mis padres y a Bea por estar ahí. Y a mis hijos, a Berta y a Guille, que han vivido el día a día del trabajo, a ellos les dedico esta tesis, para animarles a que tengan esta experiencia enriquecedora antes..., o después. 
ÍNDICE 
2.1. Criterios metodológicos del análisis

2.2. Ámbitos de la investigación

2.3. Estructura de la tesis

PARTE I. APROXIMACIONES PRELIMINARES: antecedentes y límites sobreel temade la tesis

1. ESPACIO POSTMODERNO: el término postmoderno en el contexto de la tesis

1.1. Deslizamiento del ámbito del Postmodernismo en arquitectura

1.2. El Postmodernismo en filosofía

1.3. Discusión sobre el Postmodernismo

2.1. Observaciones semánticas e históricas sobre el Barroco

2.1.1. Aproximaciones semánticas

2.1.2. Aproximaciones históricas

2.1.3. Crisis, decadencia y barroco

2.2. Consideraciones contemporáneas sobre lo barroco

2.3. El Barroco en su reflexión fenomenológica y la estética de lo virtual

2.4. Barroco y Neobarroco a través de El Pliegue de Deleuze

2.5. Barroco y espacio postmoderno 
3.1. Los paradigmas barrocos: el Barroco romano 100

3.2. El ejemplo paradigmático: la arquitectura de Borromini 103

4. LA RECEPCIÓN DEL BARROCO EN LA TEORÍA DE LA ARQUITECTURA 107

4.1. La teoría de la arquitectura a raíz de la publicación de El Pliegue y la French Theory $\quad 108$

4.2. La aportación de Robert Venturi en relación con la recepción del Barroco 113

$\begin{array}{ll}\text { 4.3. La geometría y la tecnología digital } & 117\end{array}$

5. EL SIGNIFICADO DE LA FORMA-PLIEGUE: en la filosofía de Leibniz a partir de Deleuze $\quad 121$

6.ACERCA DE LA TEMPORALIDAD Y LOS DESPLAZAMIENTOS 125

6.1. La aportación de la hermenéutica postmoderna $\quad 127$

6.2. Aby Warburg. Supervivencias y Pathosformel 132

PARTE II. EL ESTATUTO DE LA FORMA EN SU RELACIÓN CON EL ESPACIO

INTRODUCCIÓN A LA PARTE II 143

1. LA INFLEXIÓN Y SUS EFECTOS 147

$\begin{array}{ll}\text { 1.1. Los modos de la inflexión } & 148\end{array}$

1.1.1. Acontecimiento del terreno 157

1.1.2. Unidad compleja 159

1.2. El pliegue 163

1.2.1. Un pliegue intensivo $\quad 165$

1.2.2. El pliegue laminar. Ambigüedad tectónica $\quad 167$

1.2.3. Pliegue dinámico 171

1.2.4. Pliegue e infinito 173

$\begin{array}{ll}\text { 1.3. Discusión sobre la inflexión } & 179\end{array}$

2.EL MODO DE LA REPETICIÓN 183

2.1. La producción del movimiento. Movimiento y repetición $\quad 185$

2.2. Repetición: contingencia y descomposición 191

2.2.1. La expresión de lo accidental 196

2.2.2. Diferencia y repetición 197

2.3. Discusión sobre la repetición 199 
3.1. Sobre el espacio

\section{EL ESTATUTO DE LA ENVOLVENTE}

5.1. La relación interior-exterior. El infinito tiene dos pisos

5.2. Consideraciones sobre el límite

5.3. Ingravidez y simulacro

5.4. La piel profunda

5.5. Los límites difusos

5.5.1. Aclaraciones sobre tectónico-atectónico

5.5.2. Lo tectónico en la Mediateca

5.5.3. Lo a-tectónico, la piel de la Mediateca 353

5.6. Ingravidez dinámica del ámbito-piel 356

5.7. Envolturas textiles: el principio del revestimiento 361

5.8. Arquitectura de lo intermedio $\quad 364$

5.9. Hipersuperficies 368

5.9.1. Las pieles tatuadas $\quad 369$

5.9.2. Camuflajes biológicos y táctiles $\quad 369$

5.10. Discusión sobre el ámbito-piel 374 
6. REFLEXIÓN SOBRE EL TIEMPO. La noción de naturaleza: Una estética de lo efímero

6.1. La naturaleza como Physis 379

6.2. Residuos. El pathos barroco $\quad 385$

6.3. Sobre el tiempo 393

6.4. Una estética de lo efímero 395

6.5. Discusión sobre el tiempo (y el espacio) 400

$\begin{array}{ll}\text { CONCLUSIONES GENERALES } & 405\end{array}$

$\begin{array}{ll}\text { BIBLIOGRAFÍA } & 419\end{array}$

o.1. Libros y capítulos de libro $\quad 421$

$\begin{array}{ll}\text { o.2. Revistas } & 432\end{array}$

o.3. Artículos, catálogos 433

o.4. Tesis doctorales $\quad 435$

o.5. Material audiovisual $\quad 435$ 
RESUMEN 


\section{RESUMEN}

La obra de Borromini es sin duda singular en relación con el resto de la arquitectura barroca romana de mediados del siglo XVII, pues se aleja en sus planteamientos de otras grandes figuras contemporáneas a él. Sin embargo, resulta ser especialmente relevante en relación con el sentido que adquieren algunas categorías formales en su arquitectura, que sorprendentemente, se dejan pensar de la misma manera que en muchas obras de arquitectura contemporánea. A través del uso del pliegue, la inflexión, lo topológico o lo in-forme, descubrimos en la arquitectura de Borromini una cierta negación a determinarse en una apariencia formal concreta.

Los principios que rigen la forma, es decir, su estatuto, en la obra de este arquitecto y en otros lugares del arte del Barroco, comparte un mismo sentido con muchas de las obras de arquitectura contemporánea de las últimas décadas, donde algunos arquitectos van a extender el mismo modo de comprensión del espacio, a nuevas maneras de exploración de la forma, produciéndose así una renovada lectura de este periodo histórico. La posibilidad de un Neobarroco ha sido ya propuesta y defendida y se evidencia en muchas disciplinas. Esta tesis pretende poner en carga y argumentar a través del análisis de obras de arquitectura, las teorías que defienden este resurgir.

La investigación se desarrolla en torno a la reflexión sobre la relación forma-espacio en la obra de arquitectura, articulada a través de una serie de parámetros o rasgos significativos. Se observan en primer término en la obra de Borromini, pero se dejan fácilmente extender en su comprensión a obras de arquitectura de las últimas décadas. Estos rasgos característicos apuntan todos ellos a una determinada comprensión del espacio como lugar de posibilidad en su sentido más amplio; el uso de determinados recursos vinculados a la inflexión, la expresión de continuidad, el procedimiento metamórfico, el enmascaramiento de lo tectónico mediante simulacros formales o el estatuto de la envolvente como lugar privilegiado de expresión, son rasgos compartidos por ambos periodos. Todos ellos señalan, no tanto a la forma completada, como al lugar-espacio donde esta se determina, su condición de posibilidad. 
El estatuto o régimen de la forma no parece evidenciar una forma acabada y determinada en plenitud, sino más bien una cierta inestabilidad en su expresión, en su configuración, en su estructura, en sus límites.

El rumbo del pensamiento filosófico a partir de las últimas décadas del siglo XX está conducido por las propuestas de numerosos autores: desde Heidegger, Gadamer, Lyotard, Deleuze, Benjamin, Vattimo, entre otros. Estos planteamientos/teorías ponen en cuestión el proyecto moderno emancipador y estructurado según un progreso ilimitado. Cada autor propone un debilitamiento del mismo desde su diferente versión. Esta tesis considera cómo este debilitamiento tiene su correlato en arquitectura. 


\begin{abstract}
Borromini's work is undoubtedly unique in the context of mid$17^{\text {th }}$ century Roman baroque architecture, and his approaches are very different from those of his principal contemporaries. Nevertheless, his work is particularly relevant when it comes to the meaning of certain formal categories in his architecture, which, maybe surprisingly, can be thought about in the same way in many contemporary works of architecture. Through the use of the fold, inflection, topological elements or un-forme, in Borromini's architecture we discover a certain refusal to individuate into a concrete formal appearance.
\end{abstract}

In his work as well as in other Baroque art representations, there can be found some principles that govern the form (its statute) shared with several contemporary architectural works of the last decades. These contemporary architects extend the space concept to new ways of thinking on the form, thus leading to re-interpretations of this historical period. The possibility of a neo-baroque, which has already been proposed and defended, has been approached by some other disciplines. This dissertation tests and discusses some of these theories that support the idea of neo-baroque through the analysis of architectural works.

This research reflects on the form-space relationship in architecture, assuming that it is articulated through a series of significant parameters or features. On the one hand, they can be found in Borromini's works. On the other, they are also present in several works of architecture built during the last decades. These significant features reveal a certain understanding of space as a place of possibility in its broadest meaning. Then, the use of some resources related to inflection, the expression of continuity, the metamorphic procedure, the camouflage of tectonic strategies by using formal simulations or the building envelope's role as a privileged place of expression, are traits shared by both periods. All of them do not point out the completed form, but rather the place-space where it is determined, its condition of possibility. The statute of the form does not seem to reveal a completed and determined 
form, but a certain instability in its expression, configuration, structure and limits.

The directions of philosophical thinking from the last decades of the twentieth century has been led by the proposals of numerous authors, such as Heidegger, Gadamer, Lyotard, Vattimo, Deleuze, or Benjamin, among others. Their approaches call into question the modern emancipatory and structured project that relies on an unlimited progress. They have proposed different types of weakening of the modern project. Therefore, this dissertation discusses whether this weakening can be found in architecture. 


\section{INTRODUCCIÓN}

1. PRESENTACIÓN DE LA TESIS, OBJETIVOS Y ANTECEDENTES

2. PROPUESTA METODOLOGICA, ÁMBITO Y ESTRUCTURA DE LA TESIS

3. ACLARACIÓN DE TÉRMINOS

4. ARTICULACIONES INTERDISCIPLINARES E INTERTEMPORALES 


\section{PRESENTACIÓN DE LA TESIS, OBJETIVOS Y ANTECEDENTES}

Podríamos considerar que la obra de Borromini no es representativa en el conjunto de la arquitectura barroca romana de su época, sin embargo, notamos en ciertos rasgos de su obra un sentido que se identifica posteriormente en muchas obras de arquitectura contemporáneas. A través del uso de ciertos recursos formales, descubrimos en la arquitectura de Borromini un régimen particular de la forma, una cierta negación a determinarse, una inestabilidad formal. Resulta además singularmente significativo su procedimiento y proceso de proyectar, que podemos conocer a través de muchos de sus croquis. El método que utiliza Borromini de búsqueda de forma tiene una estrecha relación con los resultados construidos de su arquitectura; él hace de la metamorfosis formal un argumento de proyecto. Su resultado formal parece llevar en sí potenciales no actualizados produciendo formas en metamorfosis, una forma in-formada.

Estos principios formales se han localizado también en otros lugares del arte del Barroco, como la pintura de Caravaggio o la escultura de Bernini, y comparten un mismo sentido con muchas de las obras de arquitectura contemporánea de las últimas décadas, donde algunos arquitectos van a extender el mismo modo de comprensión del espacio, a nuevas maneras de exploración de la forma, produciéndose así una renovada lectura de este periodo histórico.

Se atiende, por tanto, a un aspecto singular de la arquitectura, el estatuto que adquiere la forma en su relación con el espacio, haciendo transcender esta cuestión al ámbito filosófico, que es utilizado de fondo en todo el análisis. Esta reflexión en torno a la relación forma-espacio se articula a través de una serie de rasgos significativas, que se observan en primer término en la obra de Borromini, pero que se dejan fácilmente extender en su comprensión a obras de arquitectura de las últimas décadas, a través de la creación de ciertos objetos teóricas que serán operacionales en el análisis. 
Todos los parámetros significativos se encuentran a su vez vinculados y conectados unos con otros, como en una red de enlaces que les hacen regresar una y otra vez por diversos caminos, pues apuntan todos ellos a una determinada comprensión del espacio. El uso de determinados recursos vinculados a la inflexión, la expresión de continuidad, el procedimiento metamórfico, el enmascaramiento de lo tectónico mediante simulacros formales o el estatuto de la envolvente como lugar privilegiado de expresión, son rasgos compartidos por ambos periodos, y todos ellos señalan, no tanto a la forma completada, como al lugar-espacio donde esta se determina, su condición de posibilidad. El estatuto o régimen de la forma no parece evidenciar una forma acabada y determinada en plenitud, sino más bien hay una cierta inestabilidad en su expresión, en su configuración, en su estructura, en sus límites.

Es a partir de la obra de Borromini donde comienza la investigación. Este arquitecto es a su vez singular, dentro de la arquitectura de su entorno, y paradójicamente, paradigmático. Se considera que la huella de Borromini, es también de alguna manera, la huella del Barroco, pues se verá como otros ejemplos de arte del barroco histórico en general, se presentan como oportunos a lo largo del análisis. Por ello se tratan también, además de algunas figuras del arte plástico como Caravaggio, otros elementos del contexto cultural de Borromini, filosóficos principalmente, extendiendo así, el posible vínculo con la postmodernidad, a la cultura del Barroco en general como otros autores ya han propuesto.

Por otra parte, y con respecto al ámbito que se ha llamado postmoderno, se observa que el rumbo del pensamiento filosófico a partir de la segunda mitad del siglo XX, con las propuestas de numerosos autores desde Heidegger, Gadamer, Vattimo, Lyotard, Deleuze, Benjamin, entre otros, pone en cuestión el proyecto moderno emancipador y estructurado según un progreso ilimitado, proponiendo un debilitamiento del mismo a través de diferentes versiones según cada autor. Esta tesis considera cómo este debilitamiento tiene su correlato en arquitectura.

La tesis, según lo anterior, apuesta por una extensión temporal de lo que habitualmente se viene llamando Postmodernismo en arquitectura, asimilando el periodo postmoderno al que se considera habitualmente en otros ámbitos culturales y que alcanza, al menos, a los primeros años de nuestro siglo, lo que podíamos llamar contemporáneo. Y esta cuestión se defiende, además de por lo anterior, porque encontramos en algunos presupuestos teóricos de los últimos años de la década de los 70 y principios de loa 80 , 
los primeros indicios de este modo particular de atender al espacio y su consecuencia en el estatuto de la forma, que se extiende casi hasta nuestros días. En cualquier caso, no se trata de delimitar el periodo en el tiempo, se trata, por el contrario, de enlazar el tiempo a partir de la similitud de sentidos de las obras.

\section{Esta extensión temporal del Postmodernismo en arquitec-} tura hasta la arquitectura contemporánea figura como hipótesis derivada de la tesis, siempre que se adjudique al término postmodernismo los rasgos característicos que se definirán en la parte I de esta tesis y no otros.

La posibilidad de un Neobarroco ha sido ya propuesta y defendida', en algunos casos incluso el término Neobarroco sustituye explícitamente al de postmoderno, por haberse desnaturalizado su significado original ${ }^{2}$. Esto además se evidencia en muchas disciplinas. También en arquitectura, donde se desencadenan una serie de estrategias discursivas en este sentido, que ocupan un gran número de textos críticos, especialmente en Norteamérica y en Francia, ya desde las últimas décadas del siglo pasado.

El filósofo francés Gilles Deleuze publica en 1989 su texto titulado El Pliegue, Leibniz y el Barroco ${ }^{3}$. En él, el filósofo traza un recorrido interdisciplinar entre la filosofía y las manifestaciones artísticas en general del Barroco. Pero no se limita al periodo barroco de la filosofía de Leibniz, sino que nota cierta correspondencia con las expresiones culturales contemporáneas. La publicación de Deleuze abre un debate en arquitectura que se extiende desde la filosofía y la arquitectura francesa a algunas universidades norteamericanas y que es especialmente fructífera a la hora de producir textos e interpretaciones. Algunos arquitectos se implican especialmente; principalmente el francés Bernard Cache4, los norteamericanos Greg Lynn y Peter Eisenman, como más adelante analizaremos.

1. Hay varios autores que escriben sobre esta relación en general a parte de Gilles Deleuze. Es significativo en este sentido el texto de Omar Calabrese, publicado un año antes que el de Gilles Deleuze. OMAR CALABRESE, L'età neobarroca, Gius, Lacerta \& Figli Spa, Roma-Bari, 1987. Traducción al castellano Anna Giordano, La era neobarroca, Ed. Cátedra, Grupo Anaya, 1989.

2. Es precisamente Omar Calabrese el que en la introducción a su texto menciona explícitamente esta sustitución de términos, y con ello su casi equivalencia. OMAR CALABRESE, op. cit., pág. 28.

3. GILLES DELEUZE. Le pli. Leibniz et le Baroque, 1989. Edición en castellano: El pliegue, Leibniz y el Barroco. Paidós 2014.

4. Bernard Cache (Francia 1958) desarrolla su tesis con Gilles Deleuze. Este le cita en su texto sobre El Pliegue... en varias ocasiones.

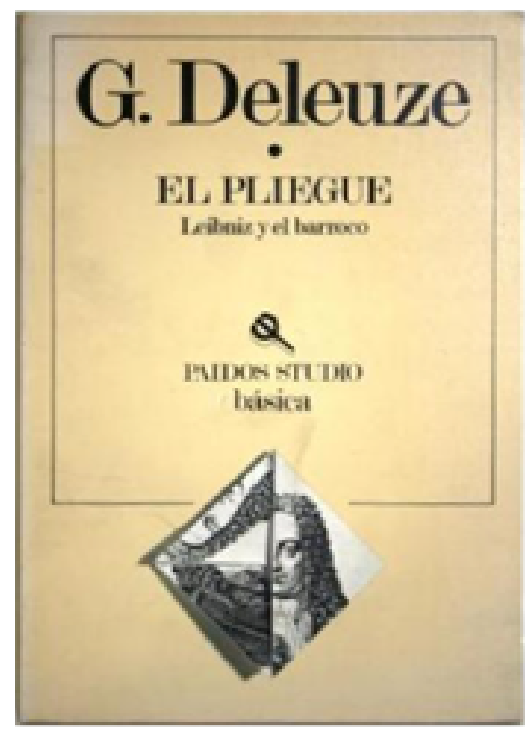

1.01. Edición en castellano (1889) de El Pliegue, Leibniz y el Barroco. GILLES DELEUZE (1989) 
El texto de Deleuze traza unas líneas relacionales, propone términos, además del de pliegue, como: inflexión, continuidad, variación, bucle..., todos ellos son reflexionados filosóficamente y relacionados con formas que se expresan en el Barroco. Esta tesis tratará de seguir también esta estrategia de enlaces en una línea interdisciplinar. Podría considerarse que la comprensión del espacio que pone en juego la arquitectura de Borromini, no estará enteramente recibida sin la contribución del pensamiento deleuziano y sin la reinterpretación a la luz de su análisis del Barroco y del concepto del pliegue como forma ontológica de la que participa su arquitectura. E inversamente, podríamos sostener que gracias a la arquitectura de Borromini podemos comprender toda la riqueza y potencia de la ontología deleuziana. Eso, respecto al modo de expresión barroco. Pero ¿no es Deleuze un pensador dentro del ámbito postmoderno?, ¿no señala este hecho ya a una vinculación entre los dos periodos históricos?.

El régimen formal que se advierte en ambos periodos, sugiere un cuestionamiento de la noción tradicional de forma en un sistema hilemórfico. La forma de-formada o in-formada apunta a considerar problemática la cuestión de la forma como forma ideal, vin-

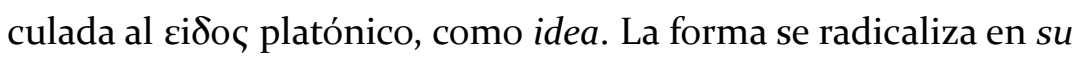
expresión, que siempre será particular y no responderá a modelo alguno ni se regirá por analogías. Lo que se opone con ello es la expresión frente a la representación; proponemos que es la expresión, más que la representación, la que opera en este régimen de la forma en arquitectura en ambos periodos.

Omar Calabrese en su texto, ya ha notado esta cuestión como esencial en la consideración de un Neobarroco:

En que consiste un Neobarroco (...) Consiste en la búsqueda de formas - y en su valorización - en la que asistimos a la pérdida de la integridad, de la globalidad, de la sistematización ordenada, a cambio de la inestabilidad5.

El hilo conductor de la interpretación filosófica de la arquitectura, el estatuto de la forma en la arquitectura de Borromini y su repercusión en la expresión del espacio, así como su deriva en el modo de la arquitectura postmoderna-contemporánea, son las directrices de la tesis, cuestiones que antes de nada hay que centrar en cuanto a sus límites, alcance y al criterio que se va a considerar.

5. OMAR CALABRESE, op. cit., pág. 12 


\section{PROPUESTA METODOLÓGICA, ÁMBITO Y ESTRUCTURA DE LA TESIS}

\subsection{CRITERIOS METODOLÓGICOS DEL ANÁLISIS}

Vamos a considerar que existe una forma subyacente, en ambas épocas, que permite comparaciones y afinidades en su sentido último, y decimos forma como principio de organización que se extrae de los fenómenos, en este caso, obras de arquitectura.

Esta forma en las obras expresa una serie de caracteres o rasgos característicos y, tras su análisis teórico, se constituyen una serie de objetos teóricos derivados, con ayuda de la filosofía. Quizás se trate, como ya advertía Calabrese, de hacer decir a las obras analizadas más de lo que ellas dicen, buscando una especie de inconsciente de la obra 6 . Pero la idea es que se pueden encontrar estas formas profundas como características comunes a fenómenos muy diferentes, a través de la búsqueda de su sentido, en último término, filosófico. Es esta cuestión la que Deleuze lleva a cabo en su obra sobre el Pliegue.

Para ello habrá que interrogar a las obras desde una misma perspectiva o coherencia interpretativa. Esta se centrará en el estatuto o régimen de la forma, y en como esta afecta a la expresión del espacio.

\section{Rasgos Característicos}

Para acercarnos al sentido de la estructura de la forma es necesario escoger una serie de referencias que evidencien su régimen. Los fenómenos se pueden constituir en series o familias, según sus recíprocas pertenencias. Analizaremos cada localidad, cada característica, que consideramos un indicio de su estatus formal, pero estas constituyen una red de cualidades asociadas que no puede romperse.

Se han establecido, para estructurar la investigación en este sentido, una serie de rasgos o figuras características que funcionan 
como parámetros y que son el objeto del análisis; rasgos singulares que caracterizan determinados atributos de la forma y su repercusión en la lectura del espacio en la arquitectura de Borromini.

\section{Objetos teóricos}

Los rasgos característicos se comportan como figuras operacionales que sirven de nexo entre la obra y los objetos teóricos que se extraen. Estos rasgos o figuras se someten a un análisis teórico en el que intervienen las compresiones filosóficas sobre esa figura y de este análisis derivan los objetos teóricos. Sería el caso de la virtualidad o la potencia que se deduce de la figura pliegue.

Los objetos teóricos son los que generan el ámbito comparativo sobre el que se establecen los nexos o enlaces, a través de las mismas u otras figuras características en la forma de la obra contemporánea-postmoderna. En este proceso se deduce también la diferencia, que se muestra precisamente en la ausencia de coincidencia de las figuras significativas o al menos en el distinto modo de presentarse, aunque el sentido de la forma sea coincidente.

Tanto las figuras características como los objetos teóricos extraídos de la reflexión sobre la obra de nuestro autor se dejan desenvolver, e incluso intensificar, en la comprensión de las obras contemporáneas con facilidad. Se trata de notar la repetición del sentido último que adquieren estas categorías, pero sin dejar también de percibir la diferencia que es lo propio del devenir, si bien esta diferencia se evidencia en la presencia misma de la obra, en su propio modo de expresión.

Cada capítulo de la parte segunda se destina al análisis y la reflexión de una categoría diferente. Pero, a su vez, estas categorías se encuentran enlazadas unas con otras, en esta red de cualidades, o topología relacional, de forma que cada una de ellas arrastra a las demás a la escena del análisis, y una y otra vez retornan las ya nombradas y analizadas. Todas ellas parece que expresan una misma cosa, abordada desde diferentes perfiles.

La metodología que se presenta no es, por tanto, lineal ni progresiva, no hay importancia creciente o decreciente en los parámetros, se ha establecido el orden que se ha considerado adecuado para una mejor comprensión de la cuestión general que subyace en el fondo de la reflexión. A pesar del criterio fijado, este no se despliega rigurosamente durante el análisis. El análisis tiene algo 
de rizomático, pues hay determinadas obras o cuestiones que proliferan por su cuenta, y otras que intervienen transversalmente y de manera solapada.

Como hemos anticipado, la reflexión sobre las obras se apoya en la filosofía, con el fin de elaborar ese objeto teórico que nos proporcione la posibilidad comparativa. Así se enlazan cuestiones que se hayan incluidas en las propuestas filosóficas de ambos periodos. El pensamiento del siglo XVII se entreteje con el contemporáneo, enriqueciendo la lectura de la obra. Esto significa que el régimen de la relación forma-espacio en la obra de Borromini no se reflexiona únicamente a partir, o con la ayuda de la filosofía del Barroco, sino que en ella intervienen, con igual alcance, las propuestas del pensamiento contemporáneo. E inversamente sucede lo mismo; las obras actuales se reflexionan en muchos casos a partir del pensamiento de Leibniz o de Spinoza, con el mismo estatus que las interpretaciones articuladas sobre el pensamiento contemporáneo.

Es obvio que, en arquitectura, ni las condiciones constructivas coinciden en las dos temporalidades, ni la técnica disponible es la misma, ni los programas de uso se parecen. En definitiva, se trata de una episteme diferente, enormemente diferente, pero donde ya muchos autores han encontrado modos de comprensión similares a los que conforman el ámbito de nuestra cultura. Y precisamente por esta fundamental diferencia epistemológica, no se trata de encontrar similitudes de lenguaje arquitectónico, sino de localizar mismos modos de comprensión del espacio y de la forma. Por ello, las obras escogidas, tienen intencionadamente un lenguaje que difiere y se aleja de posibles similitudes literales con el Barroco.

La justificación de la elección de la obra de Borromini dentro de su contexto cultural se aborda en un capítulo de la parte I. En cambio, no pretendemos justificar la elección de las obras contemporáneas, el panorama arquitectónico actual es inmenso, y los modos de abordar la arquitectura completamente diversos. Se escogen obras significativas, las más conocidas por la autora, que han sido experimentadas muchas de ellas, como lo fueron las de Borromini. Se trata de obras que, desde uno u otro parámetro, expresan bien el rasgo concreto sobre el que se reflexiona en cada momento. En ellas se observarán determinados aspectos; no se trata de llevar a cabo un análisis exhaustivo de ninguna de ellas, sino de caracterizar un determinado aspecto. 


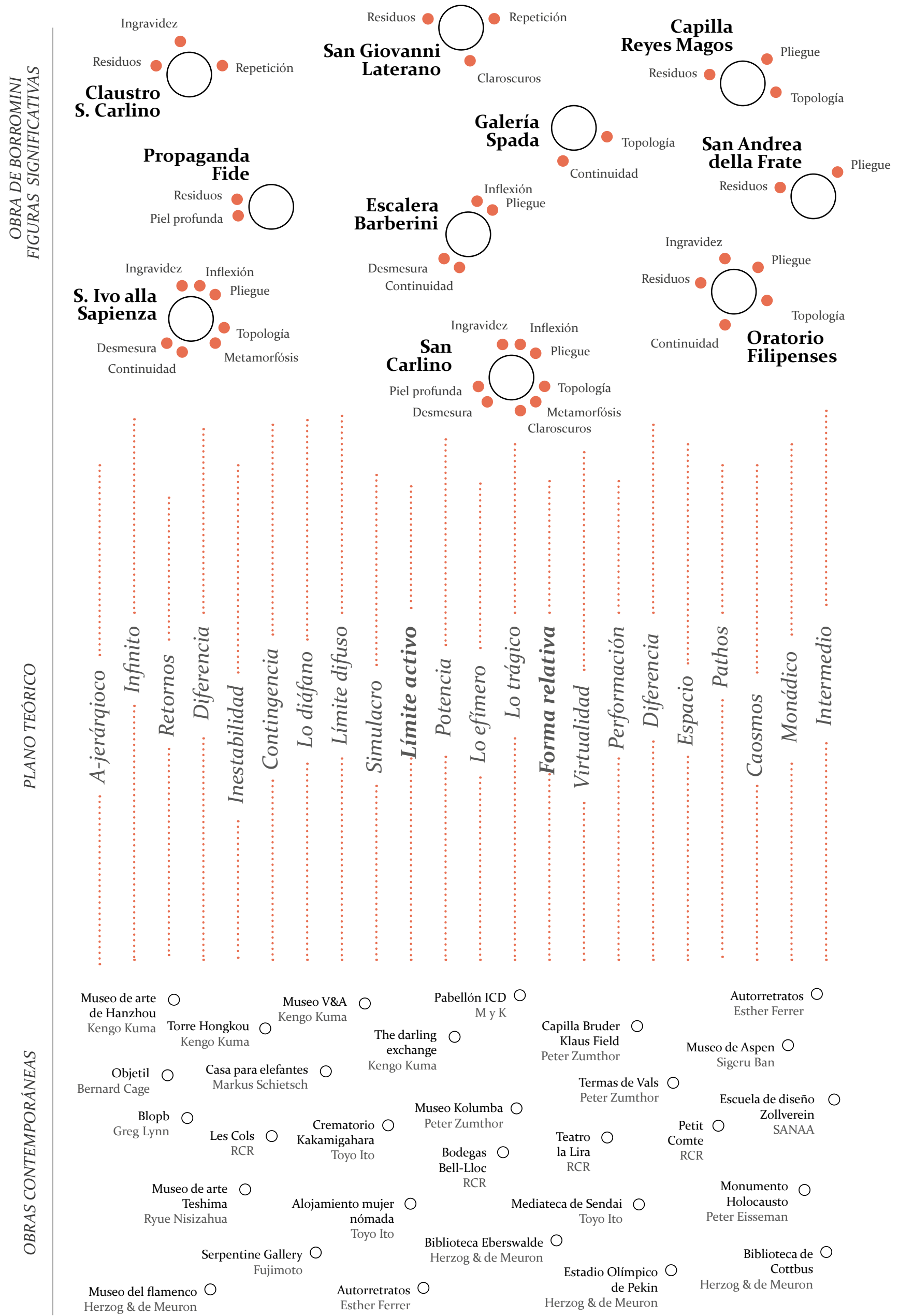




\section{2. ÁMBITOS DE LA INVESTIGACIÓN}

Respecto al ámbito de la investigación se considera que hay dos núcleos fundamentales en torno a los cuales se estructura el análisis: la obra de Borromini, y un conjunto amplio de obras postmodernas-contemporáneas.

Hemos observado ya, como la figura de Borromini es singular a la vez que paradigmática en cuanto al objeto de este análisis. En ella se advierte, más que en muchas otras obras de su entorno cultural, el singular régimen de la forma que opera de igual modo en el ámbito contemporáneo. Sin embargo, es excéntrica en su periodo histórico, pues se aleja en sus planteamientos de otras grandes figuras de la arquitectura, aunque, supuesto todo el entorno cultural, se puede vincular mejor con ámbitos artísticos distintos al arquitectónico: en pintura (por ejemplo: Caravaggio, Velázquez) o escultura (por ejemplo: Bernini escultor).

Aunque este núcleo primero, representado por Borromini, es ya excéntrico al Barroco en general, la pretensión de esta investigación es integrarlo en su conjunto cultural, sirviendo todo él de ámbito de referencia también, trayendo al plano del análisis tanto, puntualmente, figuras de su entorno, como regularmente, pensadores de su época. Es decir, que, la huella de Borromini se extienda a la consideración del sentido de lo barroco.

El segundo núcleo es más impreciso, y se forma por un conjunto de obras que responden a los enlaces, a los objetos teóricos. Estas no son las únicas, actúan a modo de ejemplos, pues la extensión de la obra contemporánea es inabarcable. En este caso, este núcleo de obras es también excéntrico con respecto al ámbito inicialmente trazado y que se menciona en el título: postmodernidad.

La postmodernidad a la que la investigación se refiere viene definida en el capítulo primero de la parte $\mathbf{1}^{7}$. El que este núcleo de arquitectura contemporánea forme parte de este ámbito cultural postmoderno figura como hipótesis derivada de esta tesis, pues el ámbito del postmodernismo en arquitectura que se viene considerando se cierra en un corto espacio de tiempo centrado en las décadas 70-80 del siglo pasado.

7. Véase infra, pág. 55-64. 
Es decir, lo postmoderno en arquitectura se con-figura articulándolo de este modo:

1. Partiendo de los presupuestos filosófico-culturales que le dan su nombre inicial al postmodernismo como respuesta a la modernidad, descritos en el capitulo correspondiente, se configura un ámbito donde una serie de objetos teóricos operan.

2. El postmodernismo en arquitectura se genera también y en la misma época y con presupuestos similares en cuanto a respuesta a la arquitectura del llamado movimiento moderno o sus supuestos teóricos.

3. Por otra parte, se observa que el régimen de la forma en la obra de arquitectura contemporánea, analizada a través de las figuras comparativas, participa en el mismo sentido de estos objetos teóricos postmodernos.

4. Por tanto, el ámbito general del postmodernismo cultural se forma a partir del enlace entre estas obras y estos presupuestos teóricos. Podríamos decir que son las propias obras y objetos teóricos los que van a configurar el ámbito.

De este modo, el núcleo segundo considerado, de obras contemporáneas, es también excéntrico a su contexto.

La investigación se configura entonces entre dos ámbitos culturales amplios, que se articulan a partir de dos núcleos excéntricos que son los que intercambian figuras significativas con el mismo sentido teórico y que extienden su influencia a través de relaciones con el resto. 

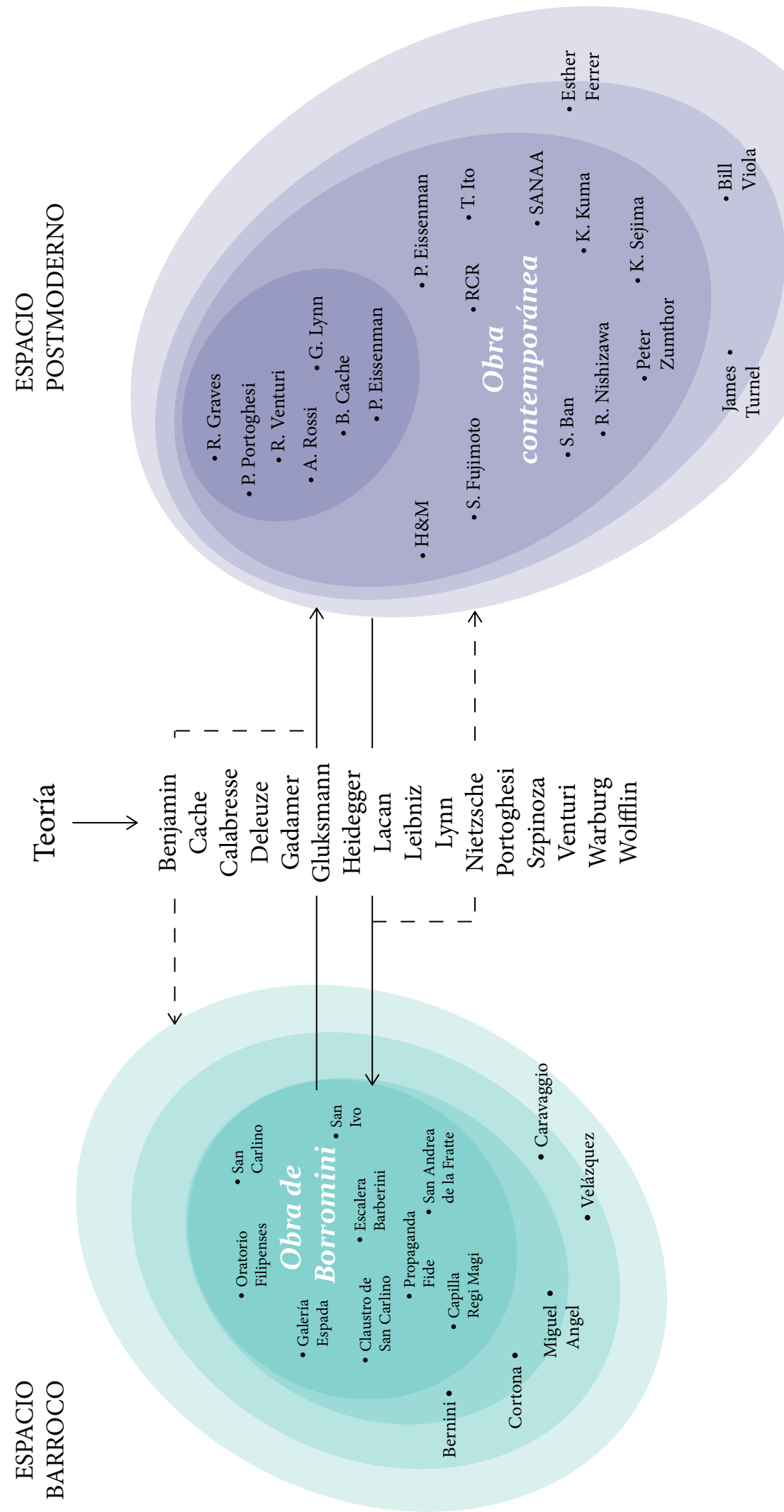
La estructura de la tesis responde a dos partes fundamentales, que quedan complementadas con esta introducción y unas conclusiones generales.

La introducción se ocupa de la presentación general de la tesis, sus antecedentes, su metodología y su estructura, además de aclarar algunos términos necesarios para la buena comprensión del texto.

\section{PARTE I}

En la parte I se exponen algunas aproximaciones preliminares que se han considerado necesarias para abordar el sentido de la tesis y delimitarlo, antes de comenzar la investigación propiamente dicha. Se trata de:

Aclaraciones sobre los términos que intervienen o figuran en el título, tales como: Postmodernidad y Barroco. En este punto se prestará especial atención al significado y el alcance que en la tesis tiene el término postmoderno, relacionándolo con el contenido general de la investigación y con los temas que se abordan en la parte II.

Justificación de la elección de la figura de Borromini dentro de su contexto cultural. Con la elección de Borromini se está también escogiendo un lugar concreto de recepción del Barroco, la Roma del siglo XVII.

Antecedentes concretos sobre la recepción del Barroco en la teoría de la arquitectura de finales del siglo XX. Este tema resulta, dentro de los múltiples antecedentes ya citados que han establecido la relación entre estas dos temporalidades, el más pertinente, pues se funda a partir de una propuesta filosófica (la de Gilles Deleuze con la publicación de El Pliegue), y se extiende a una reflexión sobre la arquitectura llevada a cabo desde el propio ámbito de la misma. Se trata del mismo enlace interdisciplinar que esta tesis pretende llevar a cabo.

Relaciones entre arquitectura y filosofía a través de Gilles Deleuze. Se aborda aquí la perspectiva deleuziana a propósito de la fertilidad intelectual de las transferencias interdisciplinares, puesta a prueba en su obra sobre El Pliegue. 
Contribuciones que pueden llegar a aclarar ciertos aspectos que se abordan en la tesis, como el modo de afrontar la reflexión, o la posibilidad de un Neobarroco, como supervivencia o remolino de la historia. Se trata de dos temas que también pueden aportar argumentos sobre la posibilidad del enlace entre las dos épocas. Se aborda aquí, por tanto, el tema del tiempo y la posibilidad de los retornos. Son dos las contribuciones que se aportan:

Por una parte, se trata de aclarar lo que significa la hermenéutica, que se puede considerar que es el mecanismo que en último término se va a utilizar en la reflexión de la tesis. Su sentido se tomará de la propuesta de Hans Georg Gadamer, es decir, una hermenéutica alternativa, no como simple método de interpretación, sino introduciendo el tiempo y la historia, a partir de la posibilidad del retorno.

Por otra parte, se trata de reflexionar sobre la interpretación de la historia de Aby Warburg, en la que su concepto de Nachleben como supervivencia, o remolino en la historia, es muy pertinente de cara a su aplicación a nuestra propuesta inter-temporal.

\section{PARTE II}

La parte segunda es el cuerpo de la investigación. Se estructura según seis figuras características de la obra de Borromini que funcionan a modo de parámetros o categorías.

Cada capítulo, que se encarga de reflexionar sobre una figura o parámetro, comienza describiendo como estos atributos se perciben en la obra de Borromini. Los diferentes aspectos característicos son analizados en su sentido más profundo, de acuerdo con las consideraciones de filósofos relevantes derivando en objetos teóricos. Posteriormente se puede comprobar como estos objetos se dejan extender con facilidad, siempre considerando su sentido filosófico, a las obras de arquitectura contemporáneas.

Los parámetros de análisis o capítulos son los siguientes:

1. La inflexión y sus efectos.

2. El modo de la reptición.

3. La condición del espacio: topologías.

4. Lo in-forme: desmesura, metamorfosis e individuación.

5. El estatuto de la envolvente. 
6. Reflexión sobre el tiempo. La noción de la naturaleza: una estética de lo efímero.

Reflexión sobre el tiempo. El estatuto de la naturaleza: una estética de lo efímero.

Todos ellos se mencionan de forma transversal en cada uno de los capítulos, pues, en último término, apuntan a lo mismo, formando una especie de red de relaciones.

Al final de cada capítulo se establece una conclusión intermedia o preliminar a modo de discusión sobre el tema donde no solo se señala la coincidencia de sentido entre las obras, sino, solapadamente, sus diferencias constituyentes.

Finalmente, se exponen las conclusiones generales sobre la reflexión y el análisis. 


\section{ACLARACIÓN DE TÉRMINOS}

Se hace necesario, antes de comenzar, la aclaración del sentido en el que se van a utilizar los términos más importantes que intervienen en la investigación, pues su significado y alcance en el texto es fundamental para la correcta comprensión de lo que estamos tratando.

Se abordará también un análisis pormenorizado sobre otra serie de términos fundamentales, que derivan de estos primeros a lo largo de la investigación en los diferentes capítulos, según se vayan tratando.

\section{Forma}

El término forma al que este texto se refiere es, sin duda, la forma arquitectónica, como la configuración en el espacio de la materia arquitectónica. La forma es un principio de organización que distingue a los fenómenos. Este principio o régimen se encuentra aquí relacionado con la forma relativa al individuo, como determinación de su materia. En definitiva, en un sentido clásico del término forma como el عĩoo griego, siempre de acuerdo con el significado que le da Aristóteles, como forma específica, y no en el sentido platónico, más extendido, de forma ideal. Se trata de la forma como determinación de un individuo, en este caso un individuo arquitectónico. Todo ello, sin perjuicio de poder poner en cuestión su estatuto tradicional.

La materia, por tanto, sin una forma que la soporte, es una indeterminación. La materia, por si sola, se escapa a toda posibilidad de discurso para definirla. La materia no es lo mismo que el material.

Cuando se dice: estatuto de la forma, nos referimos a su régimen, a los principios que la rigen. 
Espacio

Con respecto al término espacio, que se examina también en el texto, desde el punto de vista de su relación con la forma, en ningún caso se interpretará como un vacío; el espacio es ámbito, es medio, lugar de lo posible. La forma siempre es dependiente del espacio donde se genera, del medio que la hace posible, solo intensifica en mayor o menor medida su presencia, que siempre es anterior. El espacio es el medio donde la determinación tiene lugar. La arquitectura pone en obra el espacio, un espacio óntico que remite, a través de su representación adecuada, al espacio ontológico $^{8}$, podemos decir que la forma arquitectónica, pone en obra el espacio óntico, expresando quizás, así, un mayor alcance del espacio como espacio ontológico. Hablaremos así de lo diáfano, ${ }^{9}$ en el sentido de lo despejado, lo que posibilita o vehicula, donde hay virtualidad, pero nunca es un vacío en el sentido de una nada, pues en la tradición aristotélica lo virtual no se opone a lo real, solamente a lo actual, por ello es un aspecto de la realidad, es sustancial. Cuando todo remite a lo in-formal o hasta a lo in-material, emerge el medio, el espacio. Lo diáfano se dice de un cuerpo que deja pasar a través de sí o que tiene claridad, pero siempre de una sustancia o entidad y no de una nada-vacío.

El espacio ha sido objeto de complejas reflexiones a lo largo de toda la historia de la filosofía. A lo largo de la investigación se abordan puntualmente muchas de estas reflexiones. Destacamos especialmente la que lleva a cabo Martin Heidegger en su último periodo en el que subyace en su obra una renovada atención sobre el sentido último del espacio. Esto se describe bien en dos de sus obras: El arte y el Espacio, texto dedicado a Eduardo Chillida, y Tiempo y Ser.

En el primero advierte como la plástica no podrá considerarse nunca, si de arte se trata, como un dominio o una conquista técni-

8. Seguimos también a Aristóteles en este sentido. Él no concibe nunca una especie de espacio vacío inerte y abstracto, al modo de Demócrito o Leucipo, habla de lugar, como el espacio de posibilidad. Sobre este tema también consultar: HENRI BERGSON, Quid Aristóteles de loco senserit. Thesim facultati litterarum Parísiensi proponebat (París: Edebat F. Alcan, 1889), Trans. Antonio Dopazo, El concepto de lugar en Aristóteles, (Madrid: ediciones encuentro, 2013). Para la diferencia entre espacio óntico y espacio ontológico véanse numerosos textos de la ontóloga española. TERESA OÑATE, por ejemplo: "Por la vía noética del espacio ontológico", en su libro: Estética y Paideía Hermenéuticas contra la Violencia I. Dykinson, Madrid, 2019, págs. 65-86. O bien, dentro del mismo volumen: "La Hermenéutica como Ontología Estética del Espacio-Tiempo (perspectivas aristotélico-heideggerianas)”. Ibid. pp. 213-234.

9. Sobre el concepto de lo diáfano, también consultar: CHRISTINE BUCI-GLUCKSMANN, Esthétique de l'ephémère, Editions Galilée, París 2003. Trans. Santiago E. Espinosa, La Estética de lo efímero, Arena libros, Madrid 2006. 
ca del espacio; el espacio no se subordina al cuerpo plástico. Heidegger se pregunta por el espacio en cuanto a espacio, para describirlo como apertura, lugar que posibilita, es un espacio-acción que espacia: un espaciar.

En el segundo texto el espacio es centro de atención de nuevo, aunque en el título no se nombre. Es esencial en su comprensión del tiempo, pues el espacio congrega los tres éxtasis del tiempo: presente, pasado, futuro, condición de posibilidad del Ser, frente al tiempo del ente.

No obstante, el texto dedica un apartado completo al análisis del espacio en el capítulo 3 de la parte II $^{10}$.

\section{Sustancia}

Sustancia, en griego ov̉oía $\alpha^{11}$, le daremos el sentido también aristotélico, es decir, entidad, se trata de lo real.

\section{Acontecimiento}

El término acontecimiento es utilizado en filosofía de diferentes maneras, en el caso de Deleuze es un cambio que implica generación, la aparición de un punto intensivo con potencial para generar modificaciones, nuevos modos. En el texto tiene este sentido, y es aplicado con referencia a la inflexión y al pliegue, ambos términos están provistos de esta potencialidad de generar algo nuevo o de contener algo con posibilidad de desarrollo (desplegado).

Así, por ejemplo, una línea de doble curvatura se tomará aquí en sentido general, puede integrarse en un plano o puede tener un carácter tridimensional. Si hablamos de la planta será el primer caso, pero lo significativo para nuestro argumento es su cambio de curvatura a partir del punto de inflexión que es donde concentra su potencialidad. 
Punto de inflexión y acontecimiento estarán unidos al concepto de continuidad que se analiza con detalle a lo largo del texto ${ }^{12}$.

Pliegue

El pliegue es en esta tesis un concepto operacional.

El pliegue es la forma pliegue, una especie de doblez, que se da sobre algo continuo flexible que deja, por el plegado, de estar extendido (desplegado). En este sentido, se trata de un acontecimiento en un continuo.

El concepto de pliegue, en el contexto de la obra de Gilles Deleuze que aquí utilizaremos, se relaciona con la filosofía de Leibniz. Deleuze utiliza el pliegue como forma para caracterizar un modo de individuación de la Mónada leibniciana. El pliegue se da como acontecimiento en un continuo, utilizando el punto de inflexión, como punto potencial que él llama punto-pliegue, como singularidad intrínseca del continuo, no generada desde fuera. El pliegue, a través de la inclusión, genera un punto de vista que es donde se instala el alma o Mónada (según la lectura de Leibniz que hace Deleuze). La causa del pliegue es la Mónada, lo que no significa que se rompa en ningún caso el continuo sobre el que el pliegue se genera.

No se trata de una mera analogía pues en ambos casos, forma y mónada, es su capacidad de desarrollo potencial lo que caracteriza al término. El pliegue simboliza la continuidad de la materia. Para Leibniz, según Deleuze, la distinción real entre partes no entraña separabilidad. Así, la unidad de la materia, su elemento más pequeño, es el pliegue y no el punto.

Tanto el pliegue como el punto de inflexión son formas potenciales, que además implican continuidad.

\section{Topología}

El término topología es tomado en el texto como sistema de relaciones de respectividad. La unidad topológica se configurará como sistema relacional; una unidad intensiva formada de relaciones simultáneas, que remite a lo espacial, pasando el tiempo así a ser secundario en la relación.

12. Véase infra, parte II, capítulo 1, La inflexión y sus efectos, págs. 147-182. 


\section{Límite}

El límite en arquitectura es la envolvente del edificio, su piel, su cierre. Pero la forma de abordarlo en el proyecto de arquitectura dará a la obra un sentido u otro. Por ello conviene reflexionar sobre el sentido del límite.

Sobre el concepto de límite sus acepciones son múltiples y han sido minuciosamente estudiadas en el pensamiento filosófico y en otros ámbitos. El límite puede nombrarse en muchos sentidos, pero en cuanto a la obra plástica o la arquitectura, donde la configuración acontece en la delimitación, el límite puede tratarse en sentido negativo, como exclusión de lo otro, como contorno, o bien, en sentido positivo, como ámbito que da lugar a la cosa.

Solo diremos aquí, que en el sentido que adquiere en el texto, y que resulta de su significado en las obras que tratamos, el límite no es contorno sino límite dinámico. El límite es ambiguo es como una zona que está implicada en la formación de la cosa, es por ello, activo y no estable. Tiene un carácter positivo, como comienzo del ser, lugar donde una cosa se con-forma ${ }^{13}$, y no negativo como limitación.

En el texto se desarrolla este concepto y todos sus significados de un modo más detallado y matizado ${ }^{14}$.

13. Heidegger también se referirá a este límite como apertura: El límite no es donde alguna cosa cesa, sino, como los griegos habían observado, es donde alguna cosa comienza a ser, en MARTIN HEIDEGGER, Batir Habiter Pender, en Esssais et Conférences, Vorträge und Aufsätze, 1954. Trans. de Eustaquio Barjau, Construir, habitar, Pensar, en Martín Heidegger, Conferencias y Artículos, ed. El Serval, Barcelona 1994.

14. Véase infra, parte II, capítulo 5, apartado 5.2. Consideraciones sobre el límite, págs. 329-335. 


\section{ARTICULACIONES INTERDISCIPLINARES E INTERTEMPORALES}

\section{Campos disciplinares}

Esta tesis se desarrolla a través de las aportaciones de dos disciplinas: arquitectura y filosofía, respondiendo a la forma de co-dirección que por ello se ha elegido: un arquitecto, Juan Miguel Hernández León, y una filósofa, Teresa Oñate y Zubía. Estas disciplinas, aunque aparentemente diferentes, ofrecen un campo rico para la investigación en su cruce. No se establece ninguna jerarquía disciplinar y se utiliza, por tanto, el lenguaje y vocabulario de ambas, generando un espacio común para la reflexión y el análisis.

Se trata de pensar en último término, o llevar hasta el final lo que significa la forma en arquitectura, lo cual trasciende al propio campo de esta disciplina y requiere la incorporación de otros ámbitos de conocimiento, y la filosofía proporciona unas herramientas útiles para abordar esta reflexión.

\section{Arquitectura, hermenéutica, postmodernidad}

Los textos que Deleuze dedica a los pensadores barrocos son numerosos. Uno de sus primeros escritos, que fue su tesis doctoral, está dedicado a Spinoza (Spinoza y el problema de la expresión ${ }^{15}$ ) y en cambio, cierra casi su carrera el texto sobre Leibniz citan$\mathrm{do}^{16}$. ¿Quizas podríamos decir que la filosofia de Deleuze está recorrida por una especie de complejidad barroca, pues él piensa la complejidad como categoría filosófica? ¿Su interés especifico por la filosofía del Barroco no lo une a ella de una manera particular? Parece que resulta imprescindible la lectura de Deleuze para una interpretación contemporánea del Barroco, a la vez que nos preguntamos por la causa de este interés particular y por la posibilidad del desplazamiento a otras disciplinas como la arquitectura.

15. GILLES DELEUZE, Spinoza et le probléme de l'expression, Éditions de Minui, París 1968. Edición en castellano. Spinoza y el problema de la expresión, traducción de Horst Vogel, Muchnik editores, colección Atajos, 1996.

16. La Obra de Deleuze se desarrolla en parte como reinterpretación de la obra filosófica de muchos pensadores. Spinoza y Leibniz son dos de ellos, sin embargo resultan ser espacialmente significativos considerando el conjunto del pensamiento deleuziano. 
Las constantes aportaciones, la riqueza de sugerencias y relaciones que la lectura del pensamiento postmoderno (o postestructuralista) aportan a una interpretación de las obras barrocas, abren una nueva vía de exploración de la forma, que se deja extender a la arquitectura contemporánea, a la vez que dan cuenta de la fecundidad de la articulación entre las dos disciplinas.

La aplicación demasiado directa en arquitectura de ciertos conceptos relacionados con la filosofía de Deleuze, no solo el pliegue, sino en muchas otras de sus obras ${ }^{17}$, conceptos como desterritorialización, nomadismo, rizoma, lo liso y lo estriado etc., todos ellos con evidentes connotaciones físicas y formales, ha sido siempre problemática y abre la polémica de si es legítima la exportación de estos conceptos a las formas concretas de la arquitectura. Deleuze afirma claramente que esta alienación de disciplinas en torno a conceptos comunes, es legítima, pues si se trata de disciplinas creadoras, su límite es común, todas se dan en el espacio-tiempo. Y es además fértil, pues ambas disciplinas se nutren las unas a las otras con elementos creativos.

Si yo alineo entonces disciplinas definidas por su actividad creadora (...) podría darme cuenta que existe un límite común a todas ellas... que es el espacio/tiempo... ${ }^{18}$

No podemos considerar la obra de arquitectura como un objeto simple, disponible, atendiendo únicamente a su extensión o a su utilidad, en definitiva, no podremos cosificarla, es necesario hacer notar su especificidad como obra, o como objeto artístico, en tanto que ha sido recibida y reconocida como tal y es susceptible de ser interpretada en su ser arquitectura y no como un mero objeto, al que aplicarle una forma conceptual determinada. La obra de arquitectura, la filosofía y cualquier otro tipo de expresiones creativas tienen ese límite común al que se refiere Deleuze, que las permite ser interpretadas en su relación, en su vinculación a través de un espacio común.

\footnotetext{
17. Ver, entre otras: GILLES DELEUZE y FELIX GUATTARI, L'Anti-Edipe, 1972; GILLES DELEUZE y FELIX GUATTARI, Mil plateaux, capitalisme et schizophrenie, 1988, Traducción al castellano de José Vázquez Pérez, Mil Mesetas, Pretextos, Valencia 2002; GILLES DELEUZE Y FELIX GUATTARI, Qu'est-ce que la philosophie?, Les editions des Minuits, París, 1991. Traducción al castellanao: ¿Qué es la filosofía?, Anagrama, Barcelona 1993.

18. Conferencia de en GILLES DELEUZE la FEMIS (Escuela Superior de Oficios de Imagen y Sonido, 1987), ¿Qué es el acto de creación?.
} 
Este enfoque, también podría ser leído desde la hermenéutica, en el sentido en el que Hans-Georg Gadamer reconfigura la hermenéutica en la postmodernidad, es su destino ontológico, no como mera metodología de interpretación. Con ello la comprensión de cuestiones formales en arquitectura a la luz de ciertos conceptos filosóficos de carácter metafísico u ontológico será pertinente, pues trataremos la arquitectura como un texto, susceptible de ser interpretando como obra, no como simple objeto frente a un sujeto en un espacio plano. La arquitectura tiene su lenguaje propio y el lenguaje como tal, es un lugar, un espacio en el sentido ontológico, donde se abre la posibilidad de interpretación. El espacio es esta condición de posibilidad de la arquitectura y, como espacio ontológico, el lugar donde se da su lenguaje. Se trata así de considerar la arquitectura en el estatus que le corresponde, como manifestación cultural-artística específica, como Obra susceptible de ser interpretada y portadora de potencialidades.

Esto es especialmente claro al tratar la arquitectura de Borromini, pues su obra, como obra canónica, ha sido recibida una y otra vez, asentada ya, sedimentada, perteneciendo a lo que Gadamer llama historia de los efectos ${ }^{19}$, como urdimbre de la tradición, cuya autoridad como monumenta asegura la potencialidad de su sentido, que, como un texto, es capaz de ser comprendida e interpretada una y otra vez. Así la consideraremos, como obra-texto que ha alcanzado el estatuto de monumenta y es por ello capaz de ser leída de nuevo desde la contemporaneidad aportando todo un potencial plástico, relacionado directamente con el resurgir barroco que ya ha sido recibido y expresado en numerosos textos teóricos que exploran nuevas formas en la arquitectura.

\section{Desterritorializaciones y actualizaciones}

Los préstamos de conceptos procedentes de otros ámbitos suponen un desplazamiento dialéctico hacia otros lugares, al modo de la desterritorialización deleuziana. Aunque la investigación aborda más temas, vamos a seguir aquí el rastro de lo que sucede en el texto sobre el Pliegue de Deleuze.

La desterritorialización es una transferencia de un concepto desde un ámbito que le es propio a otro que, en principio le es ajeno. ¿Cómo funcionan estas transferencias y cuál es su sentido? Se 
trata del propio método que Gilles Deleuze emplea en El Pliegue. El propio Deleuze dice que en ningún caso hace un uso metafórico de estos conceptos, se sirve de los términos desterritorializandolos, es decir, sacándolos de sus ámbitos para utilizar una noción ${ }^{20}$. El pliegue se encuentra desarraigado de su ámbito para ser reutilizado en otro. De alguna manera se desestabiliza la lengua haciendo viajar las ideas más allá de sus fronteras. La desterritorialización propone una evolución en paralelo; los conceptos forman parte del dominio universal, cada uno se los puede apropiar. Lo que parece importar es que el concepto que viaja ya no importa en su significado sino en su operación, es productivo en su operacionalidad. Es decir, cómo opera y que sugiere, es lo que importa, más que el significado concreto del concepto.

El interés de un Barroco desterritorializado que nos propone Deleuze y que también nosotros manejaremos en este texto, se sitúa en el viaje del pensamiento, en el desplazamiento de la mirada, su descentramiento, en la relación entre las épocas y los ámbitos de conocimiento, apunta siempre a una riqueza relacional.

Deleuze crea conceptos nómadas, como dice Christian Girad: vectores de exploración y de interconexión de instancias múltiples y heterogéneas ${ }^{21}$.

El pliegue es un artificio intelectual, que actúa como operador, apuntando a un modo de actuar más que a una figura concreta. El Barroco utiliza el pliegue y lo hace de un modo determinado, donde trata de expresar movimiento, potencia y con ello posibilidad. Es su sentido lo que se traslada. Así, la arquitectura contemporánea que tratamos de analizar, no se pliega literalmente, aunque en sus diversas manipulaciones, en muchos casos se han utilizado analogías formales literales.

La operacionalidad del concepto no debe olvidar su dimensión metafísica. Esto es muy claro en el caso del pliegue, según lo expone Deleuze. Es decir, el concepto apunta a una dimensión filosófica, y es esta precisamente la que debe operar, trasladarse, desterritorializarse, tanto en términos temporales comoformales; el estatuto de la forma y la condición del espacio son los que re-

20. Cifr. GILLES DELEUZE Y CLAIRE PARNET, Dialogues, Flammarion, París 1997. Traducción al castellano Diálogos, Pre-textos, Valencia 1995.

21. CHRISTIAN GIRARD, Architecture et concepts nomads: traité d'indiscipline, éditions Mardaga, 1986. 
cogen en último término el traslado del sentido, son el objeto del desplazamiento.

Tipo de relación con el Barroco. Analogía y homología

Debemos preguntarnos por cuál es el tipo de relación que se está estableciendo con el Barroco, ¿se trata de una analogía formal?, ¿solo de una semejanza?, ¿o se trata más bien de una vinculación estructural, que compromete a la constitución interna de la estética y de la cultura del Barroco?

Tratamos de mostrar que es en su profunda estructuración, en las relaciones que induce, donde la referencia al Barroco adquiere su significado. En este sentido podemos decir que la relación que queremos establecer con el Barroco es de tipo homológico más que de tipo analógico.

Pongamos un ejemplo referido al uso del pliegue. Podemos reunir algunos proyectos que, según criterios formales, son el resultado de un plegamiento, o uso más o menos literal (aunque no igual) de la forma pliegue. Pero cuando el pliegue se interpreta como proceso o como potencia o singularidad en un continuo, alcanzamos otro registro.

Las diferencias entre las propiedades quedan claras puesto que no es una comparación de carácter funcional; solo las relaciones y la estructura entre los elementos son comparables. Son las semejanzas estructurales las que, a nuestro juicio, son las portadoras de significado. La homología se ocupa de vincular estructuraciones internas.

Partimos del análisis de la arquitectura de Borromini en su relación particular con el arte y la cultura del Barroco. Pero a su vez se trata de una interpretación de la obra desde el ámbito filosófico. Se analiza el régimen formal que opera en el resultado de la obra, el significado de lo que expresan determinadas configuraciones. El sentido o significado del régimen formal se extrae de su interpretación, con ayuda de la filosofía, y es este sentido el que se traslada de temporalidad y se pone en relación homológica con la contemporaneidad en último término, como expresión del espacio. 


\section{PARTE I. APROXIMACIONES PRELIMINARES: antecedentes y límites sobre el tema de la tesis}

1. ESPACIO POSTMODERNO:

el término postmoderno en el contexto de la tesis

2. CONSIDERACIONES SOBRE EL BARROCO

3. EL BARROCO HISTÓRICO Y LA ARQUITECTURA DE BORROMINI 4. LA RECEPCIÓN DEL BARROCO EN LA TEORÍA DE LA ARQUITECTURA 5. EL SIGNIFICADO DE LA FORMA-PLIEGUE: en la filosofía de Leibniz a partir de Deleuze.

6. ACERCA DE LA TEMPORALIDAD Y LOS DESPLAZAMIENTOS 


\section{INTRODUCCIÓN A LA PARTE I}

Estas aproximaciones preliminares tratan de concretar o determina el alcance de algunos de los términos que se tratan en la tesis, establecer un cierto ámbito, y centrar el criterio, justificando también la utilización concreta de determinadas figuras para el análisis.

Las categorías que se mencionan en esta tesis, son, por decirlo de alguna manera, provisionales, y se prestan a ponerse en cuestión. Pero es necesario utilizar ciertos términos para referirnos a algunas cuestiones. Así la categoría Barroco o la categoría Postmoderno serán objeto de análisis en este apartado, sin la intención de cerrar su ámbito, sino de simplemente aproximarnos a un contenido abierto, facilitando así el desarrollo de los análisis arquitectónicos y su descripción.

En primer lugar, se realiza una aproximación al ámbito que podría abarcar el esquivo y problemático término Postmoderno al que se refiere el título de la tesis. No se trata de una delimitación, que sería imposible de realizar, sino más bien de una aproximación, intentando con ello centrar más bien, un cierto ambiente de recepción del Barroco. Vamos a denominar a este ámbito: espacio postmoderno, considerando con ello el espacio que se forma, no a partir de un tiempo cerrado, sino de las expresiones culturales propias con las que se reconoce una misma comprensión de la realidad y del mundo.

Será abordado a continuación el tema del Barroco en cuanto al contenido del término y a lo que queremos referirnos con él. En relación con ello y a continuación, se justifica la referencia concreta a la figura de Francesco Borromini, explicando las razones por las cuales se elige su arquitectura para afrontar la investigación.

Se describirán después, a modo de antecedentes, los vínculos explícitos existentes entre la arquitectura reciente (sobre todo desde un plano teórico) y el Barroco, y que se realiza precisamente con préstamos y reflexiones que proceden de la filosofía. 
Por último, se profundiza en la cuestión de la temporalidad, determinando cómo será tratada y de qué manera nos enfrentaremos a ella a lo largo del texto. Para estas dos últimas cuestiones, se analizarán las aportaciones de dos autores, cuya obra contribuye a ofrecer una nueva perspectiva sobre el tema, siendo clarificadora en relación con el sentido de los desplazamientos que vamos a realizar en la tesis. 


\section{ESPACIO POSTMODERNO:}

el término postmoderno en el contexto de la tesis

"La obra de arte emerge entre la materialidad insignificante de los cuerpos de la naturaleza y la plenitud de sentido de lo histórico social”22

El término postmoderno, es equivoco, ambiguo y problemático. A pesar de esta inexactitud, se insiste en utilizarlo, y es porque no es sencillo encontrar una palabra mejor. La equiparación que se produce de lo nuevo con lo moderno satura el territorio de lo nombrable, es como si fuera necesario ampliarlo girando en parte su contenido ${ }^{23}$.

Se trata aquí de trazar una serie de rasgos mínimos a través de los cuales poderse referir al término postmoderno. Un cierto carácter que lo aleja, sin separarlo, de la modernidad. Su cualidad fundamental es el cuestionamiento de lo moderno y, en este sentido, no lo supera, lo lleva incluido en su propia denominación.

Se podría aquí haber nombrado el periodo al que la tesis se quiere referir con cualquier otro término, quizás con el de Neobarroco - dado el vínculo con el Barroco que se pretende y tal como hace Omar Calabrese ${ }^{24}$ - pero se ha preferido adoptar el polémico y muchas veces rechazado o malentendido término postmoderno. ¿Por qué? Simplemente porque el término lleva implícita la modernidad y su relación con ella y esto aquí interesa en relación con el fondo de la investigación. El cuestionamiento de la modernidad, en la vía que toma en las últimas décadas del siglo pasado, se gira del lado de su debilitamiento, tal como Gianni Vattimo ya ha propuesto hace tiempo tan lúcidamente ${ }^{25}$. Hoy en día este debilitamiento es especialmente pertinente por su íntima relación con la ecología y el problema del deterioro medioambiental.

22. FREDIC JAMESON, The Postmodernism or the Cultural Logic of Late Capitalism, New Left Review, Oxford 1984.Traducción al castellano de Jose Luis Pardo Torio, El postmodernismo o la lógica cultural del capitalismo avanzado. Paidós Ibérica, 1991.

23. Cifr. ALEJANDRO ESCUDERO PÉREZ, La modernidad explicada por Quintín Racionero, sobre una recopilación de artículos de Quintín Racionero. Apuntes UNED Campus virtual.

24. En su texto La era Neobarroca, Omar Calabrese se refiere a esta sustitución del término postmoderno por el de Neobarroco. OMAR CALABRESE, op. cit., págs. 2833.

25. Para ampliar sobre el pensamiento de Vattimo y sobre el significado del pensamiento débil, GIANNI VATTIMO, Il pensiero debole, 1983. Traducción al castellano de Luis de Santiago, El pensamiento débil, Cátedra, Colecc. Teorema, Madrid 1988. 
Calabrese había rechazado el término Postmoderno (en beneficio del de Neobarroco), por haberse desnaturalizado su significado original. Aquí se pretende naturalizarlo de nuevo, o más bien, atender a su sentido original que se cree que proviene de una actitud filosófica que nace a mediados del siglo pasado a partir de las propuestas de varios filósofos, comenzando quizás por Heidegger. Todos ellos tienen quizás en común una renovada lectura y recepción de Nietzsche, que genera propuestas muy distintas. El primer pensador que se refiere explícitamente a la postmodernidad es el filosofo francés Jean Françoise Lyotard ${ }^{26}$. A continuación, abordamos el contexto en el cual, y las cuestiones en cuanto a las cuales, surge este postmoderno que propone Lyotard. Aunque es el primero que utiliza este término aplicado a la filosofía, la sociología americana de los años 60 ya lo recogía explícitamente ${ }^{27}$, Lyotard lo reelabora como noción filosófica.

Es improcedente entender el post, de la palabra Postmodernidad, en el sentido de un puro después de la modernidad. Si el post se convirtiera en un después, se estaría confirmando aquello que precisamente el Postmodernismo trata de evitar; la lógica moderna de un tiempo lineal sucesivo, progresivamente ascendente. Invita precipitadamente a creer que ya está teniendo lugar un cambio de época, y aun siendo este, innegablemente, un periodo de cambios, no cabe sostener con rigor que haya ya ocurrido un cambio perfectamente consolidado y asentado ${ }^{28}$.

¿Hay algo distinto en la actualidad del mundo que se pueda calificar con el término de Postmodernidad? El debate sobre esto no carece de importancia, más bien es ineludible, tanto en arquitectura como en su relación con otros ámbitos de la cultura contemporánea. Está enraizado en un fenómeno innegable que es la profunda crisis del mundo moderno, un mundo que parece estar a la vez en auge expansivo y en descomposición, que, en definitiva, protagoniza una tensión que subyace culturalmente, en política, filosofía, arte, ciencia, tecnología etc. Habría que investigar si la crisis de la modernidad debe plantearse aplicando sus mismos

\footnotetext{
26. JEAN FRANÇOISE LYOTARD La condition postmoderne: rapport sur le savoir, Éditions de Minuit, 1979. Traducción al castellano La Condición Postmoderna, Ed. Cátedra, 1984.

27. Los sociólogos citados son: DEREK BELL, The comming of Post-industrial society, Nueva York 1963; IHAB HASSAN The Dismemberment as Orpheus: Toward a Post Modern Literature, Nueva York 1971; M. BENAMOU, C. CARAMELLO, Performance in Post-modern culture, Wisconsin 1977. Citado por OMAR CALABRESE en op. cit., pág. 29. 
parámetros modernos, o si, por el contrario, solo puede ser afrontada desde parámetros distintos a los propios de la modernidad. Quizás este sea el debate fundamental que parece suscitarse.

Siguiendo Lyotard, el mundo moderno se legitima en un relato según el cual se constituye como meta de la Historia Universal de la Humanidad. El siglo XX ha demostrado que esta narración ha dejado de ser verosímil y con ello comienza a desencadenarse una deslegitimación de los relatos modernos. El concepto moderno de historia continua, lineal, acumulativa, teleológica etc., enlaza firmemente dos conceptos básicos: el Sujeto y la Razón, a partir de los cuales se estructura la modernidad, componiendo el núcleo del proyecto moderno.

Abordándolo desde la filosofía el proyecto moderno aboga por conseguir la clausura de un mundo anclándolo a un fundamento; la totalidad de los fenómenos está regida por una lógica de la identidad, es decir por la permanencia, la universalidad, la necesidad, la unicidad y la presencia. Hay una crítica a la metafísi$c a$, entendiendo por metafísica esta necesidad de un fundamento exterior $^{29}$ (fuera de la física), al que toda la realidad es referida. Más bien, el pensamiento, a partir de Heidegger, se ocupa de la ontología, a la manera en la que Heidegger la entiende ${ }^{30}$.

El mundo moderno podríamos decir que surge con la sustitución del Teocentrismo, propio de la Edad Media, por el Antropocentrismo, en filosofía con las primeras contribuciones de Descartes y Hume, y más tarde con la figura definitiva de Kant. El fundamento, se afirma, ya no es Dios sino el Hombre, el único Sujeto de la Razón. El Mundo Moderno pasa a ser el único mundo verdadero adecuado a la Razón. El Sujeto alcanza su reinado y por tanto su

\footnotetext{
29. Meta, en griego ( $\left.\mu \varepsilon \tau \alpha^{-}\right)$significa «después»o «más allá».
}

30. La consideración de Heidegger del concepto de ontología, proviene de una mejor traducción de lo que Aristóteles pretende decir con el estudio del ser en cuanto a ser. El concepto de metafísica proviene de la clasificación que Andrónico de Rodas hace de las obras de Aristóteles. Él coloca el libro de la Filosofía Primera de Aristóteles, después del libro sobre la Física, por lo que la Filosofía Primera de Aristóteles ha pasado a la historia con el nombre de Metafísica. Sin embargo, el contenido de este libro de Aristóteles, y según sus palabras, se centra en el análisis del ser en cuanto a ser, según sus propias palabras, que es algo más cercano a lo que significa el término ontología (ciencia del ser), que no parece que implique, en principio, ninguna trascendencia. Este es el análisis que a Heidegger le interesa y desde dónde explica su diferencia ontológica. Se tendrá en cuenta también, que algunos de los filósofos nombrados, que podrían ser los protagonistas de un posible postmodernismo filosófico, son discípulos de Heidegger, o al menos, filósofos de la generación posterior que estudian su filosofía, por la que son influidos. MARTÍN HEIDEGGER, Sein und Zeit, 1927, Traducción al castellano de Jorge Eduardo Rivera, Ser y Tiempo, Editorial Universitaria, Santiago de Chile 1997; Editorial Trotta, Madrid 2009. 
emancipación. La reflexión se centra entonces sobre la puesta en cuestión del Sujeto Moderno y su Razón, como portador de valores únicos. Para ello parece necesaria una radical deconstrucción de este sujeto, en la que se impugne en primer lugar esa lógica de la identidad, haciendo emerger un pluralismo que el discurso moderno había velado a través de una construcción uniforme de la subjetividad, superando las diferencias a través del relato del progreso universal.

Es por tanto la introducción de la pluralidad y la emergencia de la diferencia el tema principal de la postmodernidad. Hay así un doble movimiento en práctica en la cultura postmoderna; por una parte, la transversalidad con las que se recorre el estado de las cosas, que supone un reajuste donde emerge la pluralidad y la dislocación de los referentes históricos-conceptuales de sentido. A pesar de ello y de la evidencia de la existencia de una crisis profunda de la modernidad, no resulta posible afirmar que la modernidad haya terminado. Lo que parece que sucede es la emergencia de una consideración diferente con las connotaciones descritas, a la que, asumiendo la ambigüedad y la inexactitud del término, cabe calificar de postmoderna, al menos en el sentido de que no acepta como obvias y evidentes las premisas modernas descritas ${ }^{31}$. ¿Pero cuáles son los rasgos propios de estos procesos emergentes?

Brotan dos principios, el principio de la pluralidad y el principio de la diferencia. Pluralidad y diferencia son originarias y ambas requieren estar enlazadas y articuladas, y lo estarán en un punto intermedio entre el escepticismo y el dogmatismo, un punto que remite a considerar la complejidad como fenómeno de base.

Este enfoque, que pone en primer plano la diferencia, va irremediablemente vinculado a una interpretación que da cuenta de la pluralidad. Pone en el centro la interpretación del mundo, la perspectiva. La actitud postmoderna, no remite a una verdad absoluta, sino que está en perpetua transformación. La verdad no está ni en el sujeto ni en el mundo sino en el acto de su lectura y en esa infinita búsqueda de un sentido que siempre se fuga.

Pero, ¿no es el perspectivismo una de las claves en torno a las cuales también se había estructurado en el Barroco la propuesta filo- 
sófica de Leibniz ${ }^{32}$ ? Postmodernismo y Barroco parecen estructurarse a partir de estos similares principios de relación.

Otro fenómeno surge de estas consideraciones que es la emergencia de una nueva temporalidad, que ya no va unida a la noción de progreso. Hay como un nuevo paradigma del tiempo que ya no concibe solo el tiempo lineal del progreso, sino que, por ejemplo, el pasado permanece inacabado o abierto, como para Benjamin, o surgen diferenciales del tiempo, éxtasis pasados, como en Proust. Un tiempo donde lo simultáneo tiene lugar, tiempo sincrónico, o tiempo del acontecimiento y del kairós. Todo ello se debe a una toma de conciencia sobre una transitoriedad, una realidad en perpetua transformación; el Ser ya no es más que su aparecer inestable.

Toda la postmodernidad pivotará entonces entre la complejidad y la pluralidad del mundo; una intrincada red de diferencias irreductibles; y la primacía de la posibilidad, de lo virtual, sobre lo actual y sobre lo ideal, la irrupción del acontecimiento ${ }^{33}$. La noción de potencia, tal como se entiende en la tradición aristotélica, donde no se opone a lo real, sino a lo actual, pertenece al campo de lo virtual, y está estrechamente vinculada a la emergencia de esa nueva temporalidad. Así, algunos fragmentos de la cultura contemporánea, en la ciencia, en la filosofía, en el arte en general, en la política etc., son distintos desde hace algún tiempo a lo hasta ahora conocido en tanto que incorporan estos principios citados. A estos fragmentos de la cultura cabría calificarlos con el esquivo nombre de postmodernos. Es el germen de una alternativa a la modernidad que no renuncie a sus logros pero que corrija sus excesos y deficiencias internas, en definitiva, se trata de su debilitamiento o disolución que admita la posibilidad, por tanto, la pluralidad y la diferencia.

\section{Espacio postmoderno}

El cuestionamiento de la forma en arquitectura que vamos a rastrear, su descomposición como forma ideal o modelo, se manifiesta en la expresión de su disolución o pérdida de integridad en muchos sentidos, en definitiva, también en su debilitamiento

\footnotetext{
32. Analizamos las propuestas filosóficas de Leibniz a través de la interpretación de Deleuze más adelante. Véase, Parte I, Capítulo 5, pág. 121-124. A lo largo del resto del texto se irá ampliando más toda esta cuestión del perspectivismo y su interpretación.

33. En las artes plásticas, las nociones de inflexión y pliegue, irán vinculadas a esta emergencia de lo potencial.
} 
como forma o determinación absoluta, que queda compensado por la emergencia de la expresión del espacio como ámbito relacional, de posibilidad y de diferencia. Se considera, por tanto, que el modo de debilitamiento, respecto a lo moderno, de la postmodernidad, tiene su correlato en arquitectura y lo leemos en el paralelo disolverse de la forma. Esta es la razón por la cual se adopta, para el conjunto de la temporalidad a la que nos queremos referir, el nombre de postmodernidad, aunque sin tratar de definir sus límites precisos, más bien se configurará por las topologías relacionales que se vayan extrayendo, como en una especie de tiempo configurado desde el espacio. Lo llamaremos el espacio postmoderno.

Analizaremos a continuación, a través de una aproximación, lo que el término postmoderno lleva acarreado en las dos disciplinas que más nos interesan en esta investigación: la arquitectura y la filosofía, avisando de antemano que, en arquitectura, tanto lo moderno como lo postmoderno, llevan consigo otras connotaciones, tienen quizás otras referencias, se remiten a significados más específicos. Se considera conveniente empezar por introducir en la tesis la terminología general de lo postmoderno dentro del campo de la arquitectura, remitiéndolo así a lo más general-cultural que se acaba de describir. 


\subsection{DESLIZAMIENTO DEL ÁMBITO DEL POSTMODERNISMO EN ARQUITECTURA}

Habitualmente en arquitectura, el término postmoderno se viene identificando con un periodo de tiempo bastante acotado, un corpus teórico determinado y podríamos decir que un lenguaje arquitectónico de algún modo característico que tiene lugar durante ese momento concreto.

Se suele establecer su comienzo coincidiendo con la publicación de una serie de textos que tiene lugar durante la última parte de la década de los 60 del siglo pasado. El arquitecto estadounidense Charles Jencks, teórico e historiador de la arquitectura, comienza a generar una denominación de esta arquitectura y podríamos adjudicarle la institución del término en su libro denominado El lenguaje de la arquitectura postmoderna34, publicado en 1980, justo después de la publicación del texto de Lyotard.

Lo postmoderno aparece como una contestación a lo moderno, y aunque las interpretaciones son múltiples, en esto parece que hay cierto consenso. Con ello habría, por tanto, que determinar cuál es ese referente moderno sobre el que se establece tal contestación.

La condición postmoderna, a pesar de presentar un espectro de posiciones encontradas (...), ha emergido desde los años sesenta teniendo como uno de sus aglutinantes el cambio generalizado de actitud hacia el mítico Movimiento Moderno35.

Pero la pregunta siguiente es ¿de qué Movimiento Moderno se trata?, pues son múltiples las expresiones de la arquitectura que se dan bajo estos términos; algunas más cercanas a los postulados teóricos, las más ortodoxas; otras más heterodoxas y marginales, pero que se manifiestan en los mismos periodos de tiempo y bajo algunos de los supuestos teóricos que se esgrimían. Algunos autores dirán que el funcionalismo se ha impuesto como la característica más ortodoxa del Movimiento Moderno, siendo casi encumbrado a una ideología ${ }^{36}$. En cualquier caso, se debe tener

\footnotetext{
34. CHARLES JENCKS, The Language of Post-Modern Architecture, New York 1977. Versión en castellano: El lenguaje de la arquitectura postmoderna. Barcelona 1980. Gustavo Gili.
}

35. SIMON MARCHAN FIZ, La condición postmoderna en la arquitectura. Lección inaugural del curso 1981-1982 en la Universidad de Valladolid. Universidad de Valladolid 1981, pág. 17.

36. Cifr. ibid. 

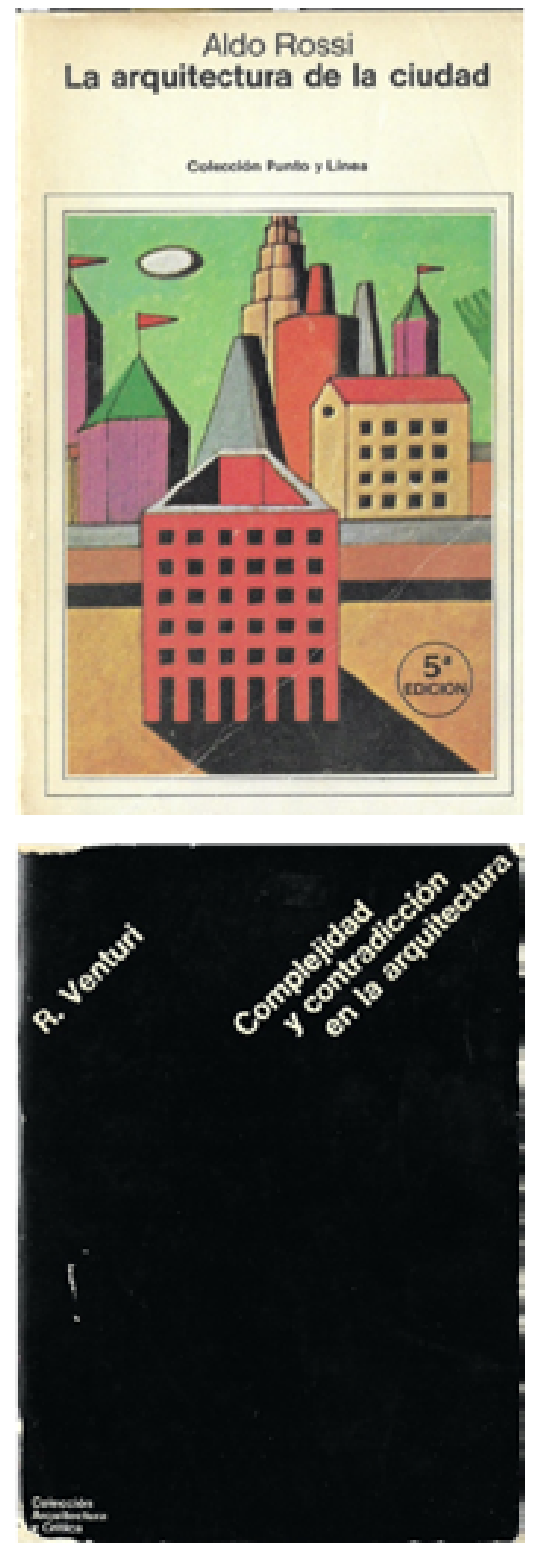

1.04. Edición en castellano (1981) de La Arquitectura de la Ciudad (1966). ALDO ROSSI

1.05. Edición en castellano (1978) de Complejidad y Contradicción en la arquitectura (1966). ROBERT VENTURI. en cuenta que se están mostrando caracterizaciones ideales muy rudimentarias y típicas, que pueden ser fácilmente criticadas por su obvia distancia con respecto a las complejas realidades a las que intentan aproximarse.

Desde esta tesis, y al no considerarse que la delimitación del Movimiento Moderno y su respuesta, si es que existe, sea el tema central de la investigación, pretendiendo este capítulo servir solo de antecedente o de descripción de un panorama general, se puede abordar una caracterización del postmodernismo en arquitectura, a partir de dos textos que podrían ser representativos, publicados ambos por primera vez en 1966, de dos autores fundamentales, que abren el debate e inician el cambio de paradigma si así se puede llamar.

En primer lugar el texto de Aldo Rossi La arquitectura de la ciu$d a d^{37}$, publicado en Europa, concretamente en Italia y en el seno del grupo Tendenzza, pone en cuestión las concepciones modernas sobre la ciudad situando a la arquitectura como pieza articuladora, como estructura en el espacio, esencial para comprender el proyecto humano colectivo que es la ciudad.

En segundo, el texto de Robert Venturi Complejidad y Contradicción en la Arquitectura ${ }^{3}$, publicado en los EE. UU. en 1966, cuestiona los ideales de simplicidad, orden, racionalidad y sencillez, que venían presidiendo el discurso arquitectónico durante el periodo anterior, señalando el hecho complejo que supone cualquier proyecto de arquitectura y apuntando a una visión positiva de la contradicción como un valor más a tener en cuenta. En definitiva supone una crítica abierta al funcionalismo reivindicando la autonomía de la forma arquitectónica.

Este último texto, contiene, referidas a la arquitectura, muchas de las claves expuestas sobre lo que podría significar el esquivo término de postmodernismo, y aunque el término postmoderno no se emplea en el libro, pues todavía no ha aparecido en escena, los términos que presiden el discurso a lo largo del texto son suficien-

37. ALDO ROSSI, l'Architettura della cità, Marsilio Editori, Padua 1966. Edición en Castellano: La arquitectura de la ciudad, traducción Josep María Ferrer-Ferrer, Gustavo Gili 1971.

38. ROBERT VENTURI, Complexiti and Contradiction in Architecture, The Museum of Modern Art, New York, 1966. Versión en castellano, Complejidad y Contradicción en arquitectura, traducción Antón Aguirregoitia, Gustavo Gili, 1974. 
temente explícitos en relación con lo que podría ser el carácter postmoderno, comenzando por el propio título del libro.

A finales de los años 40 ya habían surgido las primeras críticas al texto más importante que caracteriza las concepciones modernas sobre la ciudad: la Carta de Atenas. Pero el punto de inflexión se produce con la publicación de los textos citados. Ambos arquitectos, Robert Venturi y Aldo Rossi, no son únicamente teóricos de la arquitectura, sus postulados pueden ser confirmados, con más o menos acierto, en sus proyectos y obras construidas.

La figura del arquitecto-teórico Paolo Portoghesi, es una cita también importante. Paolo Portoghesi hace del Barroco una referencia para su época que califica de postmoderna, heredera de esta postura crítica y de esta búsqueda de la novedad. Hace gala de una ideología anticlásica, respecto a los valores de la arquitectura moderna. Sus propuestas sugieren las figuras lingüísticas - tan vinculadas al barroco - de la metáfora, la antítesis, la alegoría, o incluso la elipse, a fin de producir herramientas para desarrollar una crítica de la arquitectura moderna.

Su reflexión llega a la madurez tras la Bienal de Venecia que él dirige en 1980. En la sección de arquitectura, La presenza del passato: il postmodern, se proponen proyectos que sorprendentemente ponen su inspiración, no en un presente que no parece ofrecer nada bueno, sino en un pasado desbordante. Esta exposición sugiere una visión sincrónica de la historia, reserva ilimitada de imágenes y referencias en la que los arquitectos ponen elementos decorativos, formas, estilos. Portoghesi presenta allí su célebre proyecto de la Strada Novissima, una recomposición en interior de una calle constituida por veinte fachadas diseñadas por arquitectos diferentes, como una especie de decorado de teatro que simula representar una calle hipotéticamente postmoderna. El catálogo fue titulado Postmodern por el propio Portoghesi39.

El cambio operado resulta evidente en las expresiones arquitectónicas europeas y norteamericanas, con sus matices y diferencias. No se intenta aquí analizarlas, y menos todavía se pretende darles una unidad, es precisamente la diversidad la marca de la época. La muestra de estas marcadas diferencias las podemos comprobar en la arquitectura de algunos de los autores más significativos de este periodo que se despliega desde la década de los 70 y durante 


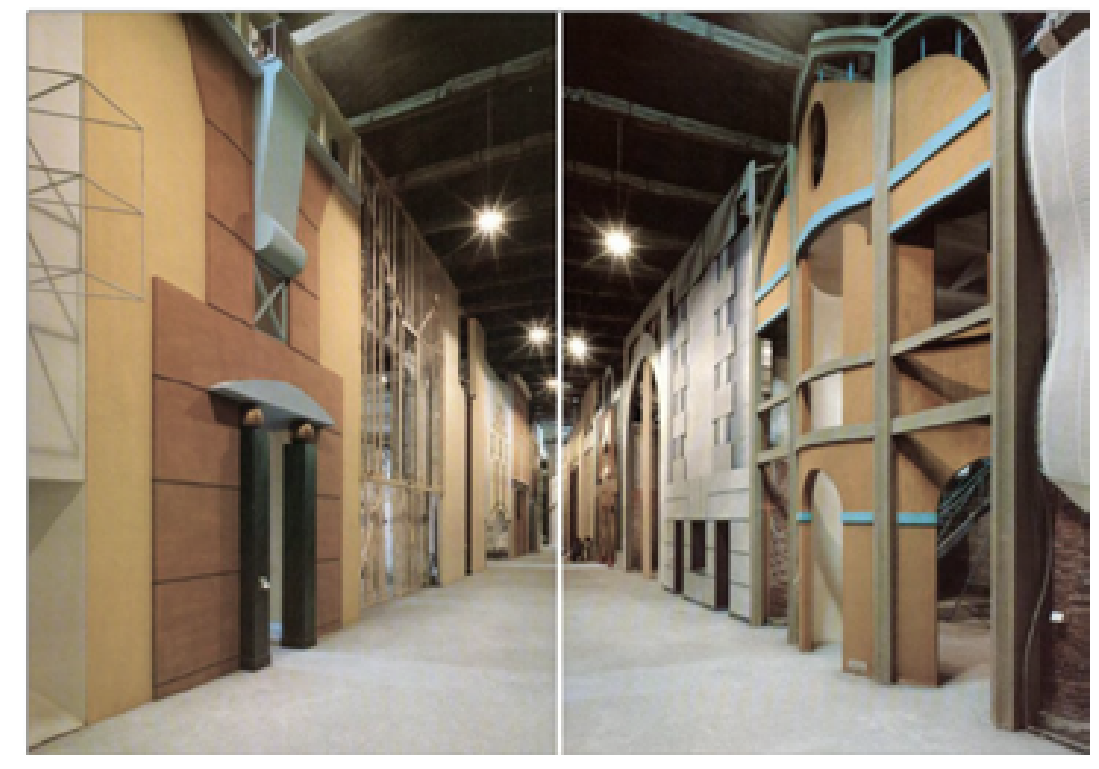

1.06. Doble página aparecida en Domus de la Strada Novissima, vista de la instalación. $1^{\mathrm{e}}$ exposición internacional de arquitectura de la bienal de Venecia, dirigida por Paolo Portoghesi, 1980. 20 fachadas han sido construidas por diferentes arquitectos en cartón, escayola y papel mâché para reconstruir una calle interior escala 1:1. Fuente: Domus n605, Abril 1980.

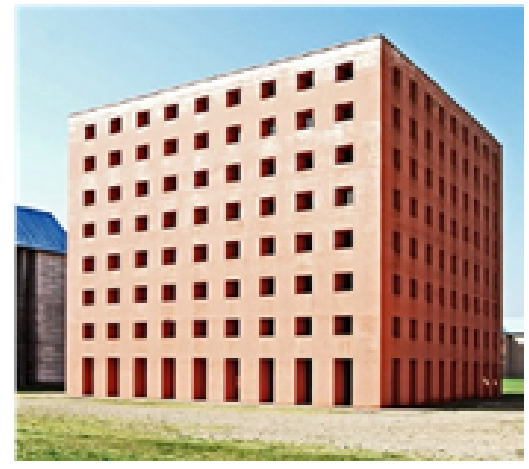

1.07. Cementerio de San Cataldo . Módena (1972). ALDO ROSSI. los años 8o: Venturi, Stirling, Charles Moore, Aldo Rossi, los Five, los Krier, Grassi, Michael Graves, John Utzon, la última parte de la obra de Sainz de Oiza y Enric Miralles en España etc.

Para tratar de dar cierta coherencia a todas estas expresiones, se han señalado algunas características comunes y propias, que distan mucho de ser pautas o reglas. Así, el profesor Simón Marchan ha señalado como lo postmoderno participa de una voluntad lingüística, pretende ante todo un entendimiento de la arquitectura como lenguaje y, a través de algunas consideraciones del arquitecto norteamericano R. Stern, señala también tres notas sobre las que se puede establecer un diálogo fructífero: el contextualismo, o la consideración del edificio como parte de un todo, el carácter alusivo, o entendimiento de la arquitectura como un arte que debe dar respuestas culturales, y la valoración de la piel, como médium del significado arquitectónico ${ }^{40}$.

Las posturas más sólidas no consideran la reacción que significó la puesta en cuestión de lo moderno como un enfrentamiento dialéctico, sino como la oportunidad de hacer emerger algunas consideraciones valiosas de ciertos aspectos de las arquitecturas del Movimiento Moderno que habían pasado desapercibidas. De esta forma, la oposición se convierte en integración o enriquecimiento de lo existente, en la línea de lo que nuestro espacio postmoderno viene proponiendo; no se trata de ruptura sino de registrar lo complejo, la multiplicidad y la diferencia, una reacción rupturista no estaría en la línea de este cambio de actitud. 
(...) hablo de una arquitectura compleja y contradictoria basada en la riqueza y la ambigüedad de la experiencia moderna ${ }^{41}$.

Este carácter que atiende a una multiplicidad compleja es el que nos interesa en esta investigación, y a partir del cual trataremos de hacer ceder los límites de tal Postmodernidad. ¿No podría extenderse y recoger algunos valores de arquitecturas anteriores a estos años 1960, como podía ser, por ejemplo, la arquitectura de Alvar Alto o ciertas obras de le Corbusier?, ¿y no encontramos también complejo el carácter de nuestra arquitectura actual? ¿En qué momento se podría decir que este postmodernismo descrito pierde fuerza?

Así como creo que existe, siguiendo el rastro de los dos textos citados, un punto de inflexión bastante claro en los comienzos, tanto en los supuestos teóricos de la arquitectura como en sus manifestaciones (lo cual no significa que no encontremos arquitecturas afines a este modo de hacer en el periodo anterior), no hay un hito parecido en el que poder señalar una disolución más o menos clara. ¿Es que quizás lo postmoderno sigue manifestándose aunque con otras modulaciones, otros lenguajes menos reactivos y más diversos que los iniciales y que han sido además afectados por las nuevas tecnologías digitales?

En 1995, Ignasi Solá Morales, escribe otro texto bien significativo, que subraya la importancia de la diferencia como creadora de relación y de correspondencias enlazadas en un espacio topológico, tema que atañe a lo esencial de la condición posmoderna que hemos relatado. El texto lleva como título: Diferencias: topología de la arquitectura contemporánea ${ }^{42}$. La fundamental característica del espacio postmoderno, el tema de la convivencia múltiple de las diferencias, es tematizado.

En el texto, Solá Morales, establece una relación entre las diferentes expresiones arquitectónicas contemporáneas y las diferentes corrientes en el pensamiento y en el arte, trazando una topología que da cuenta de la diversidad, la tensión, el contraste, en las dinámicas del presente, haciendo así más inteligible la arquitectura de su tiempo. En este recorrido, y en su relación con la arquitectura, se mencionan algunas figuras del pensamiento (que hemos llamado Postmoderno), como Gianni Vattimo, Benjamin, o Gilles
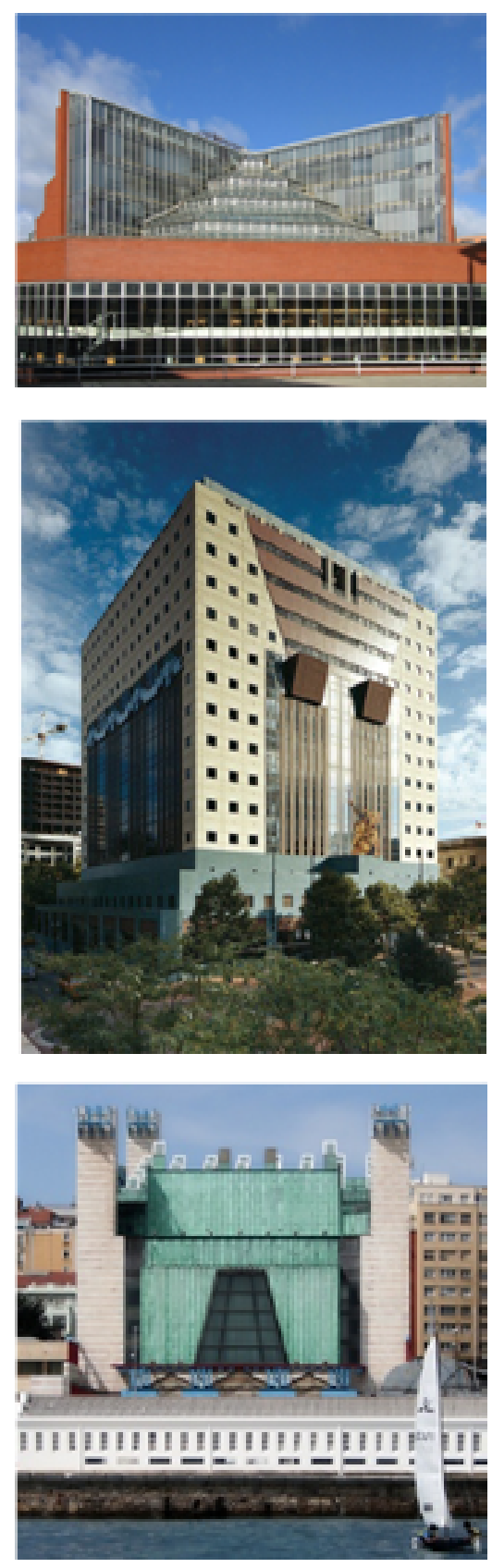

1.08. Facultad de historia de la universidad de Cambridge (1868). JAMES STIRLING

1.09. Edificio Portland. Oregón (1982). MICHAEL GRAVES

1.10. Palacio de festivales de Santander (1990.) FRANCISCO JAVIER SAINZ DE OIZA. 
Deleuze, para caracterizar algunas de las expresiones arquitectónicas. De esta forma describe como las señas de identidad de la época están precisamente en la ausencia de señas concretas, en la no necesidad de grandes discursos teóricos o tratados, más bien en la convivencia de una diversidad de expresiones y reflexiones. Así lo especifica Peter Eisenman en el prólogo:

(...) condujo a Solá Morales, a argumentar continuamente contra la necesidad de cualquier tratado o discurso fundacional (...) no hay necesidad de un discurso teórico coherente, de ningún "gran proyecto, sino solo de una serie de discursos divergentes pero solapados.

¿No expresa esto ya una suerte de continuidad con ese postmodernismo complejo y diverso descrito por Venturi? La ausencia de discurso también conduce a pensar en una continuidad, aunque sea divergente y diversificada.

Entre medias, durante los primeros años de la década de los 9o, se desencadena en EE. UU. y en Francia, a partir de la publicación del texto de El Pliegue de Gilles Deleuze y del análisis en general de la filosofía postestructuralista francesa, una serie de textos y publicaciones que parecen estar tomando distancia sobre las posiciones iniciales de Robert Venturi y los teóricos de su generación. Los protagonizan el francés Bernard Cache y el norteamericano Greg Lynn y están ligados a la emergencia de la tecnología digital en el proyecto de arquitectura. Estas propuestas tienen una continuidad en las arquitecturas posteriores, cuando la tecnología, aplicada también a la técnica y no solo al diseño, ha ofrecido enormes posibilidades de expresión. Las propuestas de Cache y Lynn, por su gran repercusión en la noción de forma y en su estatuto o régimen, las estudiaremos más detenidamente un poco más adelante ${ }^{43}$.

Otra forma de interpretación de una posible postmodernidad neobarroca, tiene también su origen en el ámbito de la filosofía, pero con claras referencias al campo de la estética, a través fundamentalmente del arte, no tanto de la arquitectura, aunque su lectura arquitectónica es bien fructífera. La filósofa francesa Christine Buci-Glucksmann, publica en 1986, pocos años antes de la publicación de El Pliegue de Deleuze, el cual tuvo mucha más repercusión en el mundo de la arquitectura, La Folie du voir. De l'esthéti-

43. Describiremos en capítulos siguientes en qué consisten concretamente estas posiciones teóricas. Véase infra págs. 108-112. 
que baroque ${ }^{44}$, donde en el propio título ya se tematiza la estética barroca, y dónde propone también un Neobarroco con nuevos matices. Glucksmann escribirá, ya en los primeros años de este siglo, otros dos textos que actualizan o matizan, de alguna manera, el primero: La folie du voire. Une esthétique du virtual (2002) ${ }^{45}$, y Esthétique de l'éphémère $(2003)^{46}$.

La postura de Glucksmann relaciona tres momentos históricos: el Barroco del siglo XVII, la modernidad baudeleriana también en relación con Benjamin, que llama Walter Benjamin y la razón barroca, y una estética de lo virtual propia de la contemporaneidad. Esta triple relación, que tiene como lugar común o como raíz el Barroco, llega hasta nuestros días en lo que Glucksmann denomina la estética de lo efímero, que más adelante analizaremos con más detalle, pero que señala el poder dramático de la visión barroca como la alternativa más significativa al estilo visual hegemónico en la modernidad, derivando en una estética presidida por las transparencias de lo efímero, una estética de lo fluido que ella llama lo efímero cósmico.

La hipótesis de un Postmodernismo Neobarroco en arquitectura con plena vigencia hoy en día parece, desde esta perspectiva, posible. Esta hipótesis situaría a la arquitectura postmoderna en un ámbito más amplio, temporalmente hablando, que el que viene considerándose habitualmente, y que coincide más o menos con el de otros ámbitos de la cultura.

Es cierto que Omar Calabrese ${ }^{47}$, por ejemplo, cita a la consideración del postmodernismo desde la arquitectura, como uno de los tres ámbitos principales donde se genera, junto con la sociología americana y la filosofía. Pero que su comienzo se localice como fundante, no dice nada a cerca de su sentido mas profundo, que bien puede extenderse si llegamos a encontrar indicios de ello.

\footnotetext{
44. CHRISTINE BUCI-GLUCKSMANN, La folie du voir: del esthetique baroque, Editions Galilée, París 1986.

45. CHRISTINE BUCI-GLUCKSMANN, La folie du voire. Une esthétique du virtual, Editions Galilée, París 2002.

46. CHRISTINE BUCI-GLUCKSMANN, Esthétique de l'éphémère. Traducción al castellano de Santiago E. Espinosa, La estética de lo efímero, Arena libros 2006. 
¿Será quizás la relación con lo barroco lo que enlaza el conjunto de este espacio postmoderno como una topología de respectividades, dando así la razón a Omar Calabrese que desplaza el término Postmodernismo en beneficio de un Neobarroco ${ }^{48}$ ?

No limitaremos en el ámbito de esta tesis, el término Postmoderno, referido a la arquitectura, a las décadas en las que habitualmente se considera, ni a los lenguajes y supuestos teóricos que lo desencadenan, que proceden de los textos teóricos publicados en los años 6o, liderados por el citado texto de Venturi y sus correspondientes respuestas construidas, cuyos lenguajes son tan característicos del llamado generalmente postmoderno arquitectónico. Vamos a tratar, por tanto, de desmontar el establecido término postmoderno en la arquitectura entendido como el que abarca una arquitectura muy determinada y con un lenguaje muy reconocible que se desarrolla a lo largo de las décadas de los años 70 y 80 . Este ámbito reducido y muy concreto no coincide con la acepción más general del término postmoderno en el conjunto cultural. Extenderemos por tanto su ámbito, tanto como se viene haciendo en otros espacios de la cultura, a la comprensión de la arquitectura que se relaciona con todas las nociones que analizamos y caracterizan lo que hemos llamado espacio postmoderno, tanto en la teoría arquitectónica como en las obras construidas.

La consideración de la arquitectura actual como todavía postmoderna, tiene su justificación también en la ausencia rupturas, o de una especie de cuerpo teórico que las proponga. La práctica es lo que hay, y, aunque evidentemente es diversa y extensa, en ella hemos encontrado ciertas confluencias con el Barroco. Estas confluencias ya estaban planteadas desde la década de los 80 como se ha comentado, lo que, junto con nuestro análisis, nos lleva a defender una especie de continuidad con los planteamientos teóricos de las últimas décadas del siglo pasado. A esto sumamos que encontramos también concomitancias entre la Postmodernidad filosófica y la filosofía del Barroco.

Por ello, la extensión del ámbito postmoderno en arquitectura hasta lo contemporáneo, es decir, la inclusión de nuestra arquitectura en este espacio postmoderno trazado, figura, así, como hipótesis de la tesis, pues se muestra como vinculada a una misma comprensión con el espacio barroco, configurado a partir de Borromini, que es lo que se trata de probar. 


\subsection{EL POSTMODERNISMO EN FILOSOFÍA}

Una vez realizado este acercamiento general a lo que se considera el Postmodernismo en arquitectura, pasamos a describir que connotaciones puede tener este mismo término dentro del pensamiento filosófico y hasta donde se extiende, con el fin de contextualizarlo y entender muchos de los contactos interdisciplinares que producen durante las últimas décadas. Esperamos no caer en la simplificación al describir el panorama filosófico durante la segunda parte del pasado siglo que nos ofrece una aproximación al término.

Podemos defender que en el caso de la filosofía el Postmodernismo abarca un campo más amplio que en lo habitualmente considerado en arquitectura en todos los sentidos. ¿Podríamos decir que existe en este caso también un punto de inflexión en el modo de expresión de la filosofía que daría cuenta del inicio de un periodo postmoderno?

Si pudiéramos reconocer algo así, tal vez habría que remontarse al resurgimiento de un interés por la filosofía de Nietzsche y su reinterpretación, no como una mera crítica a la cultura de Occidente o de la burguesía decimonónica, sino como un pensador más fructífero, que elabora una ontología alternativa: la del tiempo y la historia, a partir del pensamiento del Eterno Retorno ${ }^{49}$. Es en realidad la recepción de la filosofía de Nietzsche con todo su potencial de interpretación que tiene lugar en la segunda mitad del siglo XX, la que desencadena el desarrollo de un pensamiento que podríamos llamar postmoderno, en el sentido de giro filosófico en varias direcciones, que tienen como hilo conductor un cuestionamiento del progreso moderno y de los grandes relatos y fundamentos sobre los que se asienta.

Esto moderno que pone en entredicho Nietzsche es la deriva que ha tenido la civilización occidental a partir de un momento concreto de la cultura de la Grecia Clásica, y en su recepción postmoderna tiene múltiples interpretaciones, que suponen todas ellas un cuestionamiento de las posiciones modernas establecidas como único enfoque posible de desarrollo desde la ilustración. La temporalidad del Eterno Retorno estará también siempre subyacente en las propuestas del espacio filosófico. postmoderno. 


\section{LA CONDICION POSTMODERNA Jean-Françols Lyotard}
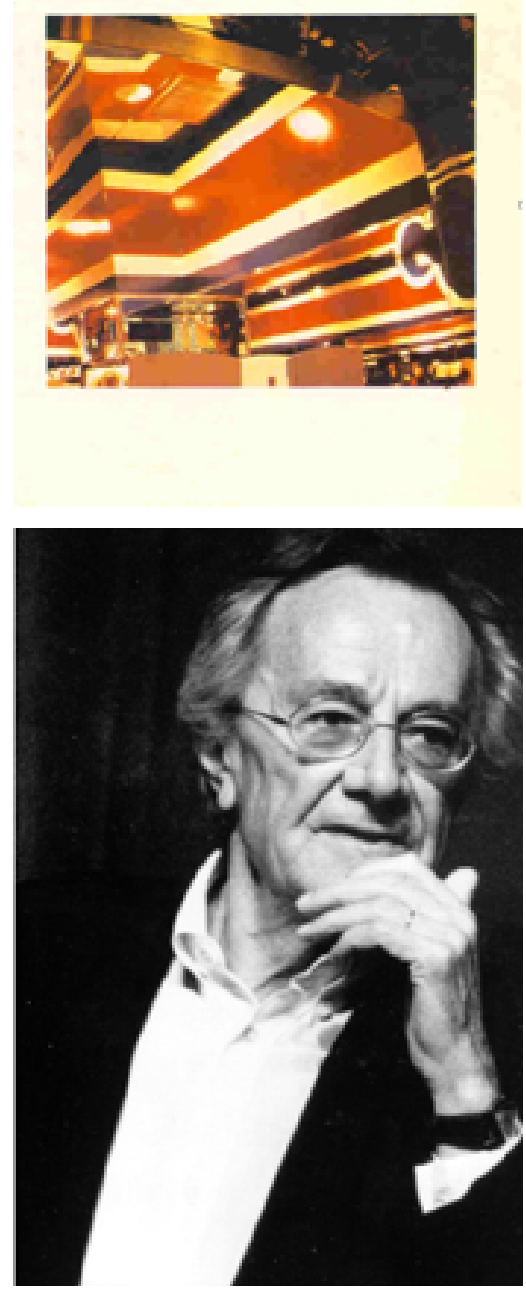

1.11. Edición en castellano (1984) de La Condición Postmoderna (1979). JEAN FRANCOISE LYOTARD, y foto del autor.
Convergen, en lo que podríamos llamar postmodernidad filosófi$c a$, varias expresiones de pensamiento: la hermenéutica ${ }^{50}$ según su tratamiento, no como un mero método de interpretación de textos, sino dándole un carácter ontológico de la mano de Gadamer; el postestructuralismo francés ${ }^{51}$, que propone una crítica desde muchos pontos de vista (critica antropológica, crítica de la filosofía del lenguaje, crítica política en la línea postmarxista, crítica del psicoanálisis, deconstructivismo etc.) y el neo-pragmatismo $^{52}$ que pone la primacía en la acción.

Muchos son los filósofos que proclaman ese giro filosófico siguiendo a Nietzsche. El primero que utiliza específicamente el término postmoderno, ya lo hemos visto, es Jean Françoise Lyotard ${ }^{53}$. El Postmodernismo se entiende a partir de ahí, en general, como la ruptura con los presupuestos más enérgicos de la modernidad. Más que una ruptura Lyotard diría que se trata de una disolución.

Como ya se ha notado, el tema de la posmodernidad es la emergencia de la cuestión de la diferencia. Lyotard llega a ella a través del análisis de la cultura y de los relatos imbricados en ella. Otros autores contemporáneos atienden al tema de la diferencia analizando la cuestión desde otros ámbitos y de otros modos. Jaques Derrida, propone una no oposición presencia-ausencia a través de la huella. La huella es la marca de la diferencia ontológica, lo que llama grama o differance ${ }^{54}$, algo como diferencia siempre diferida, juego sistemático de las diferencias. También Gilles Deleuze, desde una filosofía critico-afirmativa de la inmanencia, señala el carácter positivo y constituyente de la diferencia ${ }^{55}$. Deleuze construye una metafísica de la diferencia; la diferencia libre es

50. El filósofo alemán Hans Georg Gadamer es el representante más característico de la hermenéutica. HANS GEORG GADAMER, Verdad y Método, op. cit.

51. Los escritores cuyas obras a menudo se caracterizan como postestructuralistas incluyen: Roland Barthes, Jacques Derrida, Michel Foucault, Gilles Deleuze, Judith Butler, Jean Baudrillard, etc.

52. El representante más característico del Neo- pragmatismo es el filósofo estadounidense Richard Rorty.

53. JEAN FRANÇOISE LYOTARD, La Condición Postmoderna, op. cit.

54. Uno de los textos de Derrida, donde expresa el concepto de Differance es De la Gramatología. JAQUES DERRIDA, Semiologie et Gramatologie, Information sur les sciences sociales VII, 1968. Edición en castellano De la gramatología, Siglo XIX, México, 2003.

55. Deleuze se ocupa de esta cuestión en todos sus textos, pero en particular en Diferencia y Repetición, que fue su tesis principal para obtener su doctorado de La Sorbona. En este texto hace una crítica de la subordinación de la diferencia a la identidad. GILLES DELEUZE, Différence et répetitión, Presses Universitaires de France, 1968. Traducción en castellano: Diferencia y Repetición, Amorrortu editores, 2012. 
la diferencia sin negación, su funcionamiento no es de oposición, sino de distinción. Hans Georg Gadamer realiza una relectura de la hermenéutica tradicional y su pensamiento se estructura a partir de una ontología de la comprensión; la hermenéutica no es un método para alcanzar un conocimiento cierto y seguro, el conocimiento está sujeto a interpretación.

Podemos citar más autores, pero quizás Gianni Vattimo sea el más pertinente, pues en su crítica a la metafísica moderna, lidera junto con Lyotard el pensamiento más propiamente postmoderno, proponiendo un pensamiento debilitado frente a los grandes sistemas filosóficos. Un debilitamiento que es, en la actualidad, especialmente pertinente, como ya se ha señalado, con respecto a la emergencia a primer plano de todas las cuestiones referentes a la ecología.

Por otra parte, Heidegger es el pensador que determina de modo decisivo toda la lectura contemporánea de Nietzsche, y es Heidegger el filósofo más presente en la formación de esta generación ${ }^{56}$. Ya desde sus presupuestos notamos este cuestionamiento de lo moderno y la influencia de Nietzsche, en su noción de temporalidad, por ejemplo, o en el planteamiento de la diferencia ontológica $^{57}$.

¿Es legítimo englobar a todo este conjunto diverso bajo el término Postmoderno?

Hay otras consideraciones más críticas con la Postmodernidad aunque probablemente este concepto no se articule, en este caso, sobre el mismo contenido - como son las del crítico y teórico literario estadounidense Frederic Jameson. Su comprensión de la postmodernidad no coincide con la que venimos describiendo, ni en contenido, ni en su deriva política, ni sus consideraciones sobre una arquitectura que restringe a casos de un periodo y una estética muy determinadas, y que, desde aquí creemos que son insuficientes. Jameson se ha ocupado especialmente de lo post-

56. Heidegger dedica dos volúmenes a estudiar a Nietzsche. MARTIN HEIDEGGER. Nietzsche (1961).

57. Aunque la diferencia ontológica ya está expuesta desde Tiempo y Ser, Heidegger acusa más su relación con este espacio postmoderno en sus textos de su última etapa: MARTIN HEIDEGGER, Zur Sache des Denkesns, Auflage, Max Niemeyer Verlag, Tubingen, 2000. Edición en Castellano de Manuel Garrido, Tiempo y Ser, Tecnos 2011; Vorträge und Aufsätze. Traducción al castellano de Eustaquio Barjau, Conferencias y artículos, ed. El Serval, 1994; Die Kunst und der Raum, Vittorio Kolestermann, Frankfurt del Meno, 2007. Traducción al castellano de Jesús Adrián Escudero, El Arte y el Espacio, Herder 2009. 
moderno, pues sus textos se refieren explícitamente en el título a este término, pero este está considerado como ligado indefectiblemente al capitalismo globalizado, y no a una respuesta a la modernidad que parece haberlo generado, por ello su postura es siempre crítica. Aunque la cita de este autor no puede obviarse, no vamos a tratar aquí sus consideraciones, pues se alejan de los presupuestos que estructuran nuestro concepto de postmodernidad, que tiene un sentido positivo.

Por otra parte, no todo el pensamiento de este periodo puede comprenderse bajo el término postmoderno, existen otras posturas que reivindican una revisión de la modernidad en sus propios términos y lenguaje. Son numerosas las críticas a las posturas postmodernas en todos los ámbitos del pensamiento, la ciencia etc. No entraremos aquí a analizarlas, pero sí que es necesario señalar la convivencia de nuestro espacio postmoderno con ellas, su solapamiento temporal y la dificultad de establecer los límites. 
Hal Foster, edita un texto con una recopilación de ensayos sobre la cultura postmoderna ${ }^{58}$, y en su introducción, haciendo un recuento de las diferentes percepciones sobre el Postmodernismo de todos los autores cuyos artículos integran el libro, concluye que, todos ellos, excepto Jürgen Habermas, sostienen una creencia común, que el proyecto de la modernidad se ha vuelto profundamente problemático. El autor concluye diciendo que parece que el Postmodernismo existe, pero se pregunta qué quiere decir, si es un concepto o una práctica, la materia de un estilo local, o el resultado de una nueva fase económica, y por cuáles son sus formas, sus efectos.

Foster también afirma que lo moderno, como práctica no ha fallado, es más, podría decirse que, como tradición, ha ganado. Pero se trata de una victoria disfrazada, más bien parece una derrota, pues la modernidad se encuentra diluida en todos los aspectos de la vida. Si originalmente pareció revolucionaria y emancipadora, incluso en un determinado momento, a través del marxismo, desafío el orden cultural de la burguesía, ahora su presencia es anónima y conservadora y se entremezcla en todas partes. Como Habermas señala en su artículo, parece dominante pero muerta.

El postmodernismo es por ello una especie de actitud, una comprensión distinta, un carácter, más que una práctica. Se presenta como una especie de espejismo, una intención, una acción como apartada de una realidad que es consecuencia de una modernidad desvirtuada. Pero la conciencia sobre la crítica a la modernidad existe de hecho en nuestra cultura, y podríamos decir con Foster, que la modernidad tiene un límite histórico en las condiciones específicas sobre las que se construye, y se puede trazar un punto de inflexión, marcar donde y cómo se produce el cambio. Y sí tenemos que afirmar este cambio, podríamos reconocerlo en la expresión estética, filosófica, cultural, si se quiere, en sus diversas modulaciones.

El Postmodernismo, como hemos visto ha ido tomando diferentes máscaras, se ha ido manifestando de diferentes modos. En arquitectura, desde sus expresiones en torno a las propuestas de Venturi y Rossi (como paradigmas), pasando por los proyectos teóricos 
de Greg Lynn y Bernard Cache, articuladas respecto a la comprensión deleuziana de la forma-pliegue y a la emergencia de las tecnologías digitales, o las propuestas contemporáneas sustentadas en una estética de lo efímero y lo fluido, en torno a las investigaciones de C. Buci-Glucksmann, encontramos una pluralidad de expresiones que se articulan todas ellas según lo que podría ser una cierta comprensión común.

El periodo de desencadenamiento del pensamiento postmoderno coincide en términos temporales con el postmodernismo arquitectónico, del mismo modo sucede en lo que se refiere a su postura argumental que promueve un debilitamiento del discurso hegemónico, promoviendo un impulso a la cuestión de la diferencia como elemento constituyente, y por ello a la complejidad en términos generales, como apuntará Venturi y que dará lugar a una forma de análisis basada en las interpretaciones contextuales. El discurso postmoderno en general no lleva en su genética la exclusión, ni la oposición dialéctica, más bien promueve siempre la inclusión. Y de esta forma no se puede interpretar como ruptura de la modernidad, sea del tipo que sea, sino más bien como inclusión de esta en un sistema más complejo, que permita la emergencia de las diferencias.

Con esta aproximación podríamos concluir que existen algunos aspectos comunes que unen muchas de las manifestaciones culturales que vienen teniendo lugar desde finales de la década de los 6o del siglo pasado. Pero no podemos acotar el Postmodernismo como una posición cerrada sobre sí misma y bien delimitada, pues convive con otras actitudes y expresiones distintas, comprensiones de la realidad diferentes. Mas, teniendo en cuenta, que en su esencia está la pluralidad y una actitud de no superación, sino más bien de integración con otros modos de ser. Tampoco se pretende hacer una delimitación temporal concreta, sino, más bien, que las propias vinculaciones entre fenómenos construyan una red que configure el ámbito temporalmente. 


\section{CONSIDERACIONES SOBRE EL BARROCO}

\subsection{OBSERVACIONES SEMÁNTICAS E HISTÓRICAS SOBRE EL BARROCO}

Uno de los términos fundamentales en torno a los cuales gira la investigación es el de Barroco. Aunque esta investigación considere lo barroco a través de la figura de Borromini, él es un arquitecto de lo que va a llamar aquí Barroco histórico, y el carácter de su obra puede considerarse cercano a la figura de Caravaggio en pintura, de Bernini en escultura o de Góngora en literatura, por citar algunos ejemplos. Pero el término tiene una especial complejidad en sí mismo por cuestiones de diversa índole. Tiene una doble versión: puede ser utilizado como sustantivo o como adjetivo.

Nuestra propuesta pasa por un enlace de la cultura contemporánea con un carácter peculiar que tratamos de extraer de la obra de Borromini, pues se trata de caracterizar el Barroco a través de Borromini. Por tanto, aunque la tesis fundamental va a aflorar de la arquitectura, hay que comenzar por una aproximación previa que nos permita poder seguir hablando del término, de lo que significará el Barroco y lo barroco.

La pregunta que primero surge podría referirse a su estatuto en el tiempo, ¿se refiere la cultura barroca a un periodo histórico concreto centrado en torno al siglo XVII y como consecuencia de la disolución del Renacimiento (o bien la evolución), o bien lo barroco es una categoría aplicable a otros periodos o en general, a otras formas de expresión como algunos autores han propuesto?

Si se escribe el término con mayúsculas, es decir, como nombre propio, parece que la referencia es al periodo histórico aproximado que se localiza entre las últimas décadas del siglo XVI y el siglo XVII, y donde las manifestaciones artísticas se caracterizan de una condición concreta y peculiar en relación con otros periodos, aunque con ello no estemos determinando ni cerrando el periodo completamente, ni siquiera pensando en contraposiciones, sino quizás en continuidades. Todo ello se irá perfilando. Pero en el contexto donde nos vamos a mover, barroco va a aparecer más 
bien como adjetivo, un adjetivo que tiene su referencia principal en este carácter propio del periodo histórico que inicialmente se ha llamado Barroco y que ha sido ya manifiestamente reconocido.

Actualmente, la pregunta por el Barroco puede considerarse una constante, ¿por qué surge este interés o preocupación por el contenido de este término?, ¿por qué no se problematiza hoy en día del mismo modo, por ejemplo, el periodo del Renacimiento, o lo que ello significa?59.

La segunda cuestión se centraría en los límites disciplinares, ¿podemos considerar que el Barroco se reconoce únicamente en las artes plásticas, que quizás sea donde tiene su origen? El ámbito se deja fácilmente extender a otras manifestaciones artísticas, como la música, la literatura, poesía, teatro etc., que también se califican habitualmente de barrocas. ¿Pero qué pasa con disciplinas como la filosofía, podríamos considerar que existe una filosofía barroca?

Desde este texto se va a considerar que, además de las interpretaciones estilísticas, el término debe adquirir una mayor profundidad. El Barroco al que queremos aproximarnos, no solo nos remite a una serie de características de estilo y composición de la arquitectura y del arte en general, sino que estará inmerso en consideraciones de mayor alcance, que implican al contexto cultural completo donde se inscribe y considera las conexiones históricas e interdisciplinares que sus representaciones inducen. Gilles Deleuze $^{60}$ es un autor de referencia en este sentido, pues enlaza y vincula la filosofía con las artes plásticas precisamente en el Barroco histórico, utilizando transferencias entre términos y deslizamientos desde unas a otras disciplinas.

Pero todo ello parece que requiere de un cierto límite, que permita hablar del término, bien como sustantivo o bien como adjetivo, sin perdernos completamente en imprecisiones o generalidades. Es necesario que el término adquiera una cierta entidad. A modo de antecedente o introducción, consideramos necesario, abordar en este apartado las diferentes transformaciones, evoluciones y

59. Aby Warburg sí problematizó en su obra el periodo renacentista. Warburg elabora la noción de Nachleben en el marco del Renacimiento italiano. Esto ya en sí resulta una provocación, pues supone juntar los términos renacimiento y supervivencia. ABY WARBURG, Die Erneuerung der heidnischen Antike. Kulturwissenschaftliche Beiträge zur Geschichte der europäischen Renaissance, Berlín, Teubner, 1932. Traducción al castellano, El renacimiento del paganismo: aportaciones a la historia cultural del Renacimiento europeo, Madrid, Alianza, 2005. 
consideraciones, tanto semánticas como culturales, del término a lo largo del tiempo, que enriquecerán, en cualquier caso, nuestras consideraciones posteriores. Para ello necesitamos, en primer lugar, observar su construcción semántica e histórica, no para construir uno de los múltiples estudios sobre esta noción que ya existen, sino para rastrear, cómo lo que está inicialmente vinculado a una respuesta artística que tiene lugar en el siglo XVII, se convierte en el sujeto de retornos y resurgencias.

\subsubsection{Aproximaciones semánticas}

Las interpretaciones de lo barroco tienen dos siglos de antigüedad. Tanto lo barroco como lo clásico son etiquetas que han aparecido a posteriori, a finales del siglo XVII o en el XIX. Ningún artista de la época barroca se calificaba como tal.

La etimología del término es imprecisa. Es bien conocida su acepción como perla que no es completamente redonda o perla irregular (barrueco). En este sentido podría considerarse como algo a mitad de hacer, metáfora de la perla barrueco, que no ha alcanzado su perfección. En este sentido remite a un proceso de formación, a una metamorfosis, a un cambio que está en tránsito. También su origen aparece vinculado a la verruga de origen latino (veruca).

Parece que el término surge también en la escolástica medieval, a comienzos del siglo XII, correspondiendo al término latino baroco, recordando a ciertas formas rebuscadas para simbolizar ideas complicadas en exceso. A partir de esto último, se podría admitir que, vinculado a lo barroco, existe una cierta retórica de la opacidad de la expresión. Se podría extender, desde el lenguaje arquitectónico hasta la literatura, donde tendría su manifestación más reveladora, a través del uso de perífrasis, comparaciones, metonimias o metáforas, donde las ideas que se expresan parecen perderse dentro de los rodeos, descomponerse.

Hasta aquí, su significado parece que tiene que ver siempre con un objeto singular, irregular, diferente (que despectivamente se llama defectuoso) o con la complicación, el exceso y la complejidad. Sin embargo, este significado general continuará vigente en todas las connotaciones posteriores, aunque el tono despreciativo (quizás) de su origen se va eliminando poco a poco.

En la Gran Enciclopedia del siglo XVIII, conoce ya el término en un sentido parecido al que nosotros le damos; Barroco, adjetivo 
en arquitectura, es un matiz de caprichoso. Pero ¿cómo pasa lo barroco a ser el Barroco?, ¿cómo pasa el término de un adjetivo a un sustantivo que señala un periodo o modo de hacer determinado?

\subsubsection{Aproximaciones históricas}

Durante mucho tiempo el término Barroco tuvo este sentido despectivo, y fue revalorizado a fines del siglo XIX por Jacob Burckhard $t^{61}$, que es el que traduce este término peyorativo a un estilo, una voluntad de singularizarse, de diferenciarse del Renacimiento. Ya en 1888, cuando apareció el estudio comparativo entre Renacimiento y Barroco de Heinrich Wölfflin ${ }^{62}$, los historiadores del arte habían intentado en múltiples oportunidades postular una permanente oscilación entre los dos estilos. Wolfflin, Riegl o Benjamin, hablan de voluntad de estilo, voluntad de diferenciarse de lo actual (Renacimiento). Hay, por lo tanto en el término algo que apunta a la novedad.

Además, lo barroco, señala a una cierta fuerza deformante de lo dado, de lo ya establecido, una cierta voluntad de diferenciarse. El ejemplo de la piedra o perla deforme ya lo anticipa, es una pieza diferente, que solo se caracteriza en sí misma, que se aleja del modelo de perla redonda y perfecta. Desde estos dos últimos sentidos podría ser invocado desde cualquier novedad en el arte, reduciendo su capacidad historiográfica.

Se produce una cierta distorsión de la analogía. La analogía deja de tener una capacidad universal de conceptualización. Aparecen cosas in-formales, que no se adaptan al modelo, que no pueden ser clasificadas por analogía. El ejemplo deja de tener validez, el contexto que acompañaba al Renacimiento ha cambiado, se ha caído el paradigma y el ejemplo ya no es un modelo que hay que imitar. Asistimos a la desaparición de la mímesis como representación. El Barroco, como perla distinta, solo remite a sí mismo, es única, no tiene ejemplo. Así, el Manierismo ya señala a una multiplicidad de modelos, ya no se trata de una forma de hacer cerrada y canónica como se establece en los tratados renacentistas, ya se trata de hacer a la maniera de, lo que apunta a una profusión de modelos.

61. JACOB BURCKHARDT, El Cicerone. Iberia, Barcelona 1953.

62. HEINRICH WÖLFFLIN, Renaissance und Barock, Schwabe and Co, Basilea 1968. Traducción al castellano de José Moreno Villa, Renacimiento y Barroco, Espasa libros, Barcelona 2011. 
En este sentido señalamos la mucho menos proliferación de tratados sobre arte y arquitectura a lo largo del periodo llamado Barroco. El tratado del arquitecto austriaco Bernhard Fischer von Erlach, publicado a su muerte en 1725, es una excepción.

Wölfflin señala en su texto que, a diferencia del Renacimiento, el Barroco no se acompaña de ninguna teoría, el estilo se desarrolla sin modelos. No se da nombre preciso al estilo, aparece, en su época, como estilo moderno, pero a partir de él hacen su aparición algunos conceptos hasta entonces desconocidos como capriccioso, bizzarro, stravagante, y se experimenta placer por aquello que es singular, que va más allá de las reglas. El Barroco suscita muchos debates, pues parece que está construido sobre un temperamento, un estado del espíritu, una sensibilidad artística que quiere siempre desvincularse de la tradición, de la autoridad de los tratados.

Como muchos otros autores, Wölfflin ha estudiado el tema del Barroco en profundidad. Sería objeto de otra tesis específica entrar en un estudio de todos los autores que se han referido al Barroco. Wölfflin es citado numerosas veces por Gilles Deleuze en El Pliegue. Por eso, en esta aproximación previa del Barroco, nos fijaremos en él especialmente. Además, Wölfflin lleva a cabo un análisis donde subyacen consideraciones del Barroco que llevan consigo una especie de intención estructural, no solo histórica o estilística. Wölfflin analiza el Barroco poniéndolo en relación con el Renacimiento, no tanto para señalar su oposición, (casi más bien insinúa continuidad), sino para observar la transformación sufrida, estudiando los síntomas que nos hablan precisamente del cambio que tiene lugar. Pero Wölfflin señala algo que va más allá, y que aquí resulta muy relevante; él ha estudiado también como el arte clásico de la antigüedad muestra una evolución paralela, en donde el nombre Barroco a través de la historia del arte se va introduciendo paulatinamente, hasta poderse hablar de un $\mathrm{Ba}$ rroco romano: el arte clásico muere presentando unos síntomas parecidos a la muerte del arte en el Renacimiento ${ }^{63}$. Este punto de vista denota ya un renacer de una sensibilidad artística y a la vez un retorno que se repite, o una supervivencia que está o no latente de una forma alternativa.

Wölfflin demuestra que el arte del Barroco no puede comprenderse más que en su complementariedad positiva con lo Clásico.

63. El propio Wölfflin señala en una nota, el texto Weltgeschichte der Kunst, de L. von Sybel en 1888, donde este autor dedica un capítulo al Estilo barroco romano. Citado por Wölfflin en op. cit. 
Aunque pueda considerarse una simplificación del análisis, que no contempla la complejidad de ciertas obras que no se pueden reducir a este esquema, se podría establecer una tabla con el texto de Wölfflin, mostrando pares de características que se vinculan entre sí y que establecen la tensión entre lo Clásico y lo Barroco. Con la descripción de Wölfflin podemos decir que se esbozan unas primeras trazas limitadas al campo del arte y la arquitectura pero que podrían dar lugar a un análisis más extenso, y que tendremos en cuenta como primera aproximación. A continuación se resume este posible cuadro a título indicativo:

\begin{tabular}{|c|c|c|}
\hline & CLÁSICO & BARROCO \\
\hline 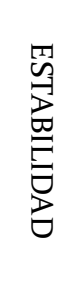 & $\begin{array}{l}\text { Estático: } \\
\text { belleza apacible } \\
\text { equilibrio } \\
\text { plenitud }\end{array}$ & $\begin{array}{l}\text { Efecto-devenir: } \\
\text { movimiento } \\
\text { sobresalto, éxtasis, embriaguez } \\
\text { impresión instantánea } \\
\text { acontecimiento } \\
\text { inestabilidad, tensión }\end{array}$ \\
\hline 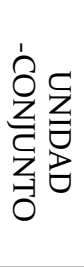 & $\begin{array}{l}\text { Pluralidad: } \\
\text { partes articuladas reuni- } \\
\text { das en un conjunto pro- } \\
\text { porción y acabado }\end{array}$ & $\begin{array}{l}\text { Unidad: } \\
\text { conjunto sintético } \\
\text { gran composición homogénea: } \\
\text { efecto global } \\
\text { proporciones impuras y disonan- } \\
\text { cias. }\end{array}$ \\
\hline 眾 & $\begin{array}{l}\text { Materia dura: } \\
\text { materia ideal interna- } \\
\text { mente estática } \\
\text { tectónica }\end{array}$ & $\begin{array}{l}\text { Materia blanda: } \\
\text { sensación de masa } \\
\text { materia con vida interior: se dila- } \\
\text { ta, se disuelve } \\
\text { se disuelve la estructura tectónica }\end{array}$ \\
\hline 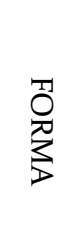 & $\begin{array}{l}\text { Forma cerrada: } \\
\text { encuadramiento y equi- } \\
\text { librio } \\
\text { forma determinada } \\
\text { reconocimiento de partes }\end{array}$ & $\begin{array}{l}\text { Forma abierta: } \\
\text { diagonales que multiplican el } \\
\text { espacio } \\
\text { pérdida de la forma exacta } \\
\text { partes sin distinción }\end{array}$ \\
\hline 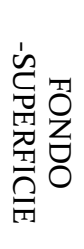 & $\begin{array}{l}\text { Superficie } \\
\text { plano } \\
\text { permanencia e inmovi- } \\
\text { lidad } \\
\text { composición }\end{array}$ & $\begin{array}{l}\text { Profundidad } \\
\text { efectos de masa } \\
\text { obligación de movimiento del } \\
\text { observador } \\
\text { fondo orgánico }\end{array}$ \\
\hline$\overline{\mathcal{S}}$ & $\begin{array}{l}\text { Claridad absoluta } \\
\text { luz regulada }\end{array}$ & $\begin{array}{l}\text { Oscuridad relativa } \\
\text { contrastes luz y sombra } \\
\text { fronteras engañosas }\end{array}$ \\
\hline
\end{tabular}


Tras Renacimiento y Barroco, que delimitaba aún el Barroco a una época vastamente definida, Wölfflin, a través de la publicación en 1915 de los Principios fundamentales de la historia del arte ${ }^{64}$, confirma su intuición dando una extensión considerable a la noción. Las categorías mencionadas anteriormente se convierten en formas de representación universal. Desvinculado de su fundamento religioso y social, el Barroco se transforma en un fundamento de la historia de las formas. Toca otros períodos de la historia del arte.

Además de Wölfflin son múltiples los autores y los enfoques que se han llevado a cabo sobre el Barroco histórico. Sólo citaremos brevemente algunas perspectivas que nos han parecido de interés para la investigación.

Aloïs Riegl pone el acento en la continuidad de los estilos, rechazando así de antemano los estilos llamados decadentes. No opone en este caso el Barroco al Clasicismo, y no hablará nunca de ruptura sino de continuidad. Para Riegl, cada artista es dependiente de su lugar en la historia. Para ninguno de los dos autores citados es pertinente delimitar el estilo barroco, menos todavía establecer límites temporales.

Eugenio d'Ors propone una concepción más original en una de las primeras aproximaciones estructurales explícitas del Barroco $^{65}$. Establece la noción de eón, una entidad presente eternamente que resucita cíclicamente en la historia de las formas. Propone una nueva definición de lo barroco, desafiando todas las fronteras, culturales, geográficas o históricas. El Barroco nos reenvía a una manifestación nostálgica de la vida salvaje en relación a un clasicismo civilizado y ordenado. Propone así una concepción atemporal, contra las pretensiones de limitar el Barroco a una época concreta. Irreductible a una norma; dirá d'Ors: el eón barroco absorbe todo lo que es inclasificable, fantasioso, su irreverencia está íntimamente ligada a la naturaleza. El historiador lo asocia al panteísmo, libertinaje, naturalismo y salvajismo. Relativo, en este caso, al resurgir del inconsciente colectivo, el Barroco recobra así terrenos mucho más extensos que una elemental cuestión de un estilo, puesto que opone a dos grandes nociones filosóficas: la vida y la razón.

64. HEINRICH WÖLFFLIN, Kunstgeschichtliche Grundbegriffe, Munich, 1915, Traducción al castellano de José Moreno Villa, 1955 Conceptos fundamentales de la historia del arte, Espasa Libros ,2011. 
El barroquismo de Eugenio d'Ors es una permanencia morfológica que surge de una dicotomía entre el eón barroco y el eón clásico. Sus estudios son, así, mucho más imprecisos que los de Riegl o Wölfflin. El Barroco se caracteriza, por ejemplo, por formas que

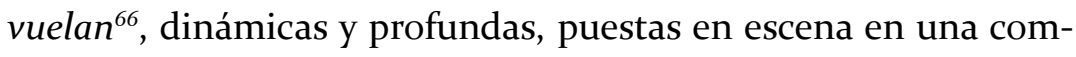
posición pintoresca. El orden de los clásicos siempre permanece opuesto al caos barroco.

Otro historiador, en el mismo momento, desarrolla una tesis similar aunque más moderada. Henri Focillon es partidario de un Barroco que constituye uno de los fundamentos de toda la historia del arte. El Barroco es también transhistórico y transcultural. Las formas atravesarían sucesivamente, según los ciclos más o menos largos e intensos de cada estilo, un período experimental, una etapa clásica, una etapa de refinamiento, y una etapa barroca.

(El estado barroco) es un momento de la vida de las formas, y sin duda, el más liberado ${ }^{67}$

El Barroco sobrevendría, así, al final del ciclo, cuando la tradición se agota, como una forma de desvinculación o de emancipación. El arte pasa por estos cuatro estados sucesivos que pueden repetirse (habría así un barroco helenístico, gótico...).

Transhistórico, el Barroco sobrepasa desde la década de 1920 las fronteras de la historia del arte y de la arquitectura.

Erwin Panofsky, por otra parte, en su célebre conferencia titulada Qué es el Barroco? (1934), trata de mostrar las características visuales del Barroco. Remarcando la confusión inicial que preside la noción, trata de rehabilitarla en un contexto que pretende separarse de una noción del Barroco siempre difusa e inestable. Sobrepasa el análisis académico cronológico para proponer una aproximación psicológica del Barroco, inspirándose en la tentativa de Eugenio d'Ors. Pone también en cuestión las oposiciones simétricas entre el Renacimiento y el Barroco.

Podríamos considerar que el Barroco puede no sólo ser el estilo de una época de la cultura y de las artes, sino un periodo donde se registró la emergencia de una de las constantes universales an-

66. Ibid.

67. Henri Focillon, Vie des formes, suivi de Éloge de la main (1931), París : Presses Universitaires de France, 2013, p.22. Autor importante porque inspirará, vía Bergson, la estética de Deleuze. 
tagónicas pero complementarias, que concurren en el despliegue diacrónico de lo que podríamos considerar la sincronía del ser o, en términos Hegelianos, del espíritu. Así, las características más visibles de lo barroco se habrían visto reaparecer en otros momentos de la sucesión histórica, parece que vinculadas a periodos de decadencia.

\subsubsection{Crisis, decadencia y barroco}

Considerando el Barroco con el sentido de actitud o modo de ser recurrente, también se ha registrado su relación con las épocas de decadencia. En estos periodos se hace más latente la fragilidad de la vida, la caducidad y la persistencia del cambio; en general se puede considerar que emerge una toma de conciencia sobre lo efímero, y con ello, sobre la imposibilidad de captar verdaderamente lo real.

En relación con los contextos históricos donde las distintas manifestaciones artísticas han tenido lugar, lo barroco parece emerger siempre en épocas de crisis políticas o de pérdida de valores socialmente estructurantes.

Así, Walter Benjamin caracteriza estos periodos como aquellos dotados de una poderosa potencia artística:

(...) la del Barroco es sin duda una época no tanto de práctica artística propiamente dicha como de voluntad artística inquebrantable. Así sucede siempre en los llamados periodos de decadencia, en los que la realidad suprema del arte es la obra cerrada y aislada. (...) Son épocas de decadencia de las artes, épocas de su voluntad. ${ }^{68}$

De alguna manera se insinúan una alternancia de dos enfoques que se van relevando en continuidad, basándose en un doble movimiento de rechazo y liberación. Uno de los dos tipos de acontecimientos culturales es opresivo; impone imágenes, símbolos y modelos, que se transportan por un método. El otro es comprendido en la rebelión, que se opone a un régimen dominante, o bien que se desencadena por la decadencia del mismo.

Nietzsche ya había formulado esta relación de continuidad y alternancia cuando había destacado la tensión entre Apolo y Dionisos 
en su Nacimiento de la Tragedia. ${ }^{69}$ Apolo, dios de la justicia, la medida y la claridad y de las formas armoniosas, se enfrenta continuamente en la historia del arte a Dionisos, dios de la embriaguez, de la desmesura y del drama. La figura de Dionisos puede estar implicada en una poética arquitectónica y conceptual vinculada al Barroco y su potencial mitológico, como más adelante veremos. La dinámica dionisiaca y el Barroco se acercan, ya que reflejan ambos un momento de crisis caracterizado por una pérdida de centro como una pérdida del sentido. La invocación a Dionisos permite así pensar el cambio, la transformación, la transgresión, la aproximación a lo desconocido. Así, en un tipo de transferencia como la que pretendemos desarrollar, la comisaria de la exposición $D y o-$ nisiac $^{70}$, Chistine Macel, que tiene lugar en el Centro Pompidú en 2005, implica a la figura de Dionisos como una clave para entender el arte contemporáneo.

La sensibilidad inspirada por la figura de Dionisos es fruto de la captación de las potencias que envuelven y golpean al mundo. Dionisos nombra lo innombrable, lo que escapa al acto del nombramiento porque es inaccesible a la inteligencia. Veremos más tarde la relación del Barroco con lo dionisiaco.

69. FRIEDRICH NIETZSCHE, Die Geburt der Tragödie, aus dem Geiste der Musik, 1872. Traducción al castellano de Andrés Sánchez Pascual, El nacimiento de la tragedia, Alianza Editorial, Madrid 1973.

70. CHISTINE MACEL, L'art en excés de flux uo le tragique contemporain, catálogo de la exposición Dyonisiac, dirigida por Christine Macel, París, Centro Georges Pompidu, marzo de 2005. 


\subsection{CONSIDERACIONES CONTEMPORÁNEAS SOBRE}

LO BARROCO

Los años 1970 y 1980 son una etapa importante en la construcción de la noción de lo barroco. Las lecturas del Barroco ponen de relieve un estado espiritual transgresivo, bajo la perspectiva de una oposición entre antiguo-moderno, conformistas y anticonformistas. Se enfrentan dos orientaciones interpretativas: las que limitan el Barroco a un período histórico definido, en la línea de los historiadores del arte alemanes, y las que se refieren a un Barroco transhistórico, identificando resurgencias hasta el siglo XX.

Esta historia del Barroco va en paralelo, en arquitectura, a un cierto rechazo a las referencias estilísticas en el marco de los valores defendidos sobre todo por el Movimiento Moderno de postguerra. Ya se ha señalado esta cuestión; se trata de un movimiento de reacción frente a esta idea de auto referencialidad de la arquitectura, un cierto olvido de la historia, y un pretendido elitismo. Arquitectos como Robert Venturi, Peter Eisenman, Aldo Rossi y algunos otros preconizan una recuperación histórica de una cultura arquitectónica según ellos, a la deriva, por carecer de raíces. Si todos se muestran críticos contra el Movimiento Moderno y se posicionan como rupturista contra él, el arquitecto e historiador Charles Jencks valora, pese a todo, el haber superado el esnobismo del clasicismo:

Una consecuencia positiva del Movimiento Moderno, ciertamente inesperada, es que, por medio de su ruptura con la tradición occidental, ha puesto fin al dominio del clasicismo en la construcción pública, al mismo tiempo que su reivindicación de universalidad, a su monopolio de edificios pretenciosos, o sea, a su esnobismo ${ }^{71}$.

Criticando así al clasicismo, Charles Jencks insinúa cierta afiliación con el Barroco. Así mismo, esta cultura será nostálgica y centrada sobre la forma a través de una cultura de citas históricas. Podría localizarse ahí una auténtica vinculación con el Barroco, a través, entre otras cosas, de la obra de Venturi, Complejidad y Contradicción en la arquitectura, como ya se ha señalado en el capítulo anterior. 
La figura del arquitecto-teórico Paolo Portoghesi ${ }^{72}$ es una referencia relativa a la recuperación del interés que suscita el Barroco en la esfera arquitectónica en esta época. La atención de Portoghesi se aprecia desde el inicio de su carrera de historiador con los trabajos que dedica a Guarino Guarini y a la actitud transgresiva de Borromini. Investiga en el arquitecto las figuras específicas de su lenguaje arquitectónico tan particular entre el de sus contemporáneos, caracterizado por la puesta en duda de las reglas del Renacimiento. Tendremos amplias referencias de esta cuestión en capítulos posteriores. El Barroco remite a la búsqueda de un orden innovador, y a la crítica del orden antiguo. Paolo Portoghesi hace del Barroco una arqueología de su época.

Es relevante también el trabajo de Omar Calabrese. Él publica con éxito L'età neobarocca ${ }^{73}$ en 1987, que también se traducirá al inglés. El autor trata de comprender ciertos fenómenos (culturales, artísticos, científicos...) de su época, yendo más allá del calificativo postmoderno ${ }^{74}$, que se ha convertido, según él, en genérico. Propone ahora otra noción estética organizativa: el Neobarroco. No hace de ello una generalización, y lo concibe como un rasgo de carácter dominante de su época, ve en el Neobarroco la calificación de cierto gusto contemporáneo:

Pero ¿cuál es el gusto privilegiado - si existe - de nuestra época, aparentemente tan confuso, fragmentado e indescifrable? Yo creo que lo he encontrado, y querría proponer un nombre para él: Neobarroco. (...) Neobarroco es simplemente un "espíritu de su tiempo" que impregna numerosos fenómenos culturales de hoy en día en todos los campos del conocimiento, encontrándose familiares los unos a los otros 75

Este espíritu de su tiempo, difícilmente descriptible, le proporciona la ocasión de vincular temas de estudio tan dispares como el

\footnotetext{
72. PAOLO PORTOGHESI, Francesco Borromini, Electa, Milano, 1967.

73. OMAR CALABRESE, La era neobarroca, op. cit.

74. Calabrese desarrolla un retorno a las interpretaciones americanas de los años 60 concerniente a la literatura y el cine, o incluso de la obra de J.F. Lyotard, La condition Post-moderne. Se pregunta sobre todo por el enfoque citacional y decorativo de Paolo Portoghesi tras la exposición en la bienal de Venecia de 1980 La presenza del passato: il postmodern.

75. OMAR CALABRESE, op. cit.
} 
film Alien $^{76}$, la serie televisiva americana de éxito Bonanza ${ }^{77}$, ciertas obras de diseño contemporáneo, la novela Il nome della Rosa de su contemporáneo y colega Umberto Eco, la teoría de los fractales, la teoría del chaos... Conecta todos estos elementos desiguales, y este método es la clave para comprender el paso del Barroco a todas las disciplinas. Gracias a esta noción multiforme, Calabrese traza una línea entre las artes plásticas, la música, la literatura, la filosofía, la arquitectura etc. Por contra, rechaza toda tentativa de recuperación del antiguo Barroco por el nuevo, incluso reconociendo sus semejanzas. El Neobarroco sería un descendiente del Barroco, pasado por el prisma de muchas generaciones de manifestaciones artísticas. En ningún caso es el doble del Barroco.

En esta década de los 80 y desde el ámbito filosófico, el Barroco genera un gran interés, dando lugar a trabajos significativos de cara a la construcción del sentido de lo barroco. Dos ideas distintas y complejas del Barroco emergen en la escena filosófica francesa: la de Gilles Deleuze y la de Jacques Lacan. Ambas se complementan con el trabajo de Walter Benjamin ${ }^{78}$ que escribe su célebre texto sobre el Trauespiel. Deleuze parte de una interpretación del Barroco como paradigma. Lacan entiende el Barroco como una estética del vacío, configurada a través de un juego de sensaciones que giran en torno a la brecha de lo real79. La interpretación deleuziana será ampliamente difundida a través de su obra de El Pliegue y sus traducciones, contrariamente al de Lacan que quedará confinado a la transcripción de algunos seminarios.

76. Realizado por Ridely Scott, en 1979.

77. Serie western familiar de David Dortort, 430 episodios difundidos entre 1959 y 1973.

78. WALTER BENJAMIN, El Origen del Trauespiel..., op. cit.

79. JAQUES LACAN, expone estas cuestiones en varios seminarios, el más significativo es: Du baroque, Séminaire XX, Encore, 1975, París, Seuil, 2002. 


\subsection{EL BARROCO EN SU REFLEXIÓN FENOMENOLÓGICA Y LA ESTÉTICA DE LO VIRTUAL}

Además de las anteriores reflexiones se pueden subrayar otro tipo de connotaciones en relación al Barroco, que desembocan, a través de una orientación que parte de la experiencia visual, en consideraciones que tienen que ver con la estética de lo virtual.

La filosofía reciente, y desde un enfoque, podríamos decir, fenomenológico, propone un análisis a través de la implicación del modo de ver que puede tener lugar de diferentes formas. En este sentido ha escrito el historiador Martin Jay ${ }^{80}$, que hace notar cómo, partiendo del perspectivismo renacentista, o de la manera de ver en el Renacimiento, podemos considerar la posición problemática en la que se encuentra el sujeto, pues ese ojo en el vértice de la pirámide del espectador podía interpretarse como trascendental y universal, es decir, exactamente el mismo para todo observador, ocupando el mismo lugar en el tiempo y en el espacio; o bien como contingente, solamente subordinado a la visión particular e individual de diferentes espectadores, con sus propias y concretas relaciones con respecto a la escena enfrente de ellos. Cuando la primera posibilidad se transforma explícitamente en la segunda, las implicaciones relativas a lo que significa la perspectiva empiezan a poder trazarse con facilidad. Esta parece ser la posición barroca postulada desde el pensamiento de Leibniz e invocada por Deleuze para su delimitación de un Barroco del pliegue. Este potencial fue manifiesto, pero trajo muchas implicaciones problemáticas. Éstas no fueron subrayadas de manera explícita y celebradas, hasta finales del siglo XIX por Nietzsche ,que rechaza de raíz cualquier visión trascendental del mundo, y subraya la posibilidad de la diferencia y la interpretación. Ya para Leibniz cada mónada expresa el Mundo en su totalidad, aunque solo expresara claramente una parte de la serie. Deleuze dirá a este respecto que:

(...) la región clara de una mónada se prolonga en la porción clara de otra (...), la porción clara se prolonga definitivamente en las zonas oscuras, puesto que cada mónada expresa el mundo entero. ${ }^{81}$

80. Cifr. MARTIN JAY, Scopic Regimes of Modernity, en Hal Foster (ed.), Vision and Visuality. Dia Art Foundation Discussions in Contemporary Culture Nr. 2, Bay Press. Seattle, 1988, pp. 3-23.

81 . GILLES DELEUZE, El Pliegue... Ed. cit, Razón suficiente, pág. 69. 


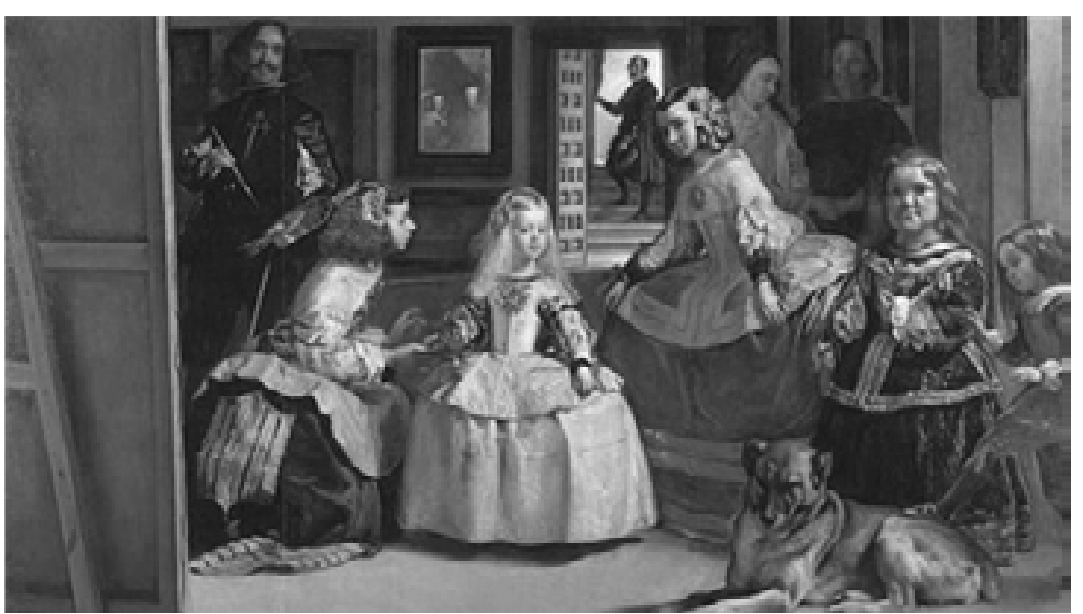

Hay una visión particular del mundo según cada mónada-individuo, sólo una región clara. Hay una imposibilidad de abarcar un infinito que se compone de las diversas perspectivas; un mundo compuesto de claroscuros que se complementan. Es así como la pintura barroca se expresa, poniendo de relieve la imposibilidad de abarcar un punto de vista único, marcando los límites que subordinan la visión particular: las zonas iluminadas de las Meninas de Velázquez o los oscuros contrastados de los cuadros de Caravaggio. Sólo podemos focalizar un punto, atender a una parte y esta cuestión se plasma en la opacidad de los fondos de las pinturas; sus zonas iluminadas contrastan con este fondo opaco.

Para la filósofa francesa Christine Buci-Glucksmann, es precisamente el poder dramático de la visión barroca lo que se ve como la alternativa más significativa al estilo visual hegemónico hasta el momento. Coincide Martin Jay en que, celebrando el exceso de imágenes complejo y sugestivo, la desmesura en la experiencia visual barroca, enfatiza su rechazo a la geometrización monocular de la tradición anterior, con su ilusión de un espacio homogéneo tridimensional visto como una visión divina desde lejos ${ }^{82}$. El espacio barroco no puede ser asimilado desde un punto de vista único, debe ser recorrido, debe ser interpretado. Rechaza así cualquier intento de reducir la multiplicidad de espacios visuales a una única entidad esencial. En términos filosóficos, el pluralismo de Leibniz de puntos de vista monádicos puede resultar expresivo del modo de ver barroco en general.

El trabajo de Glucksmann, reúne en él la interpretación benjaminiana y lacaniana del Barroco con el fin de estudiar una estética de lo virtual, que posiblemente califica mejor a la sociedad actual que

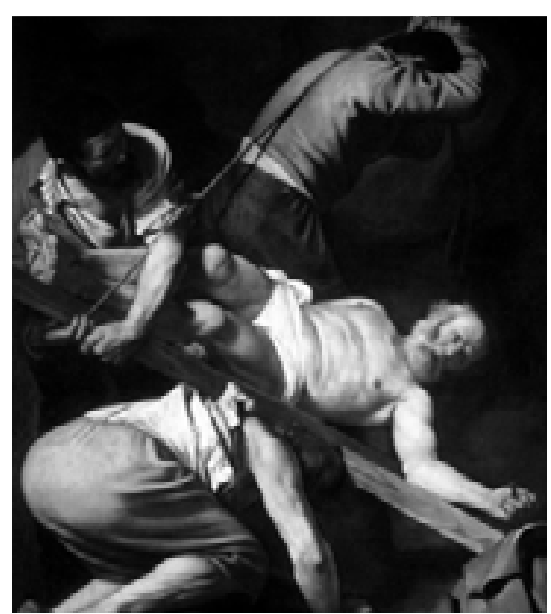

1.12. Las meninas. VELÁZQUEZ. 1656. 1.13. Crucifixión de San Pedro. CARAVAGGIO. 1600. 
a la del siglo XVII. Christine Buci-Glucksmann publica en $1984^{83}$ un trabajo sobre la estética barroca. Se podría decir que su análisis enfoca a la versión del Barroco en la obra de Benjamin, a través del psicoanálisis de Lacan y la fenomenología de Merelau-Ponty. Ella propone una arqueología de lo moderno que toma su origen en las obras del siglo XVII, cuando nace lo que llama una locura de ver, del parecer y del artificio, locura de lo visual que está hoy en día mundializada por nuestras pantallas y nuestras interconexiones. La autora cuestiona la cultura de lo virtual actual en relación con el poder de la visión barroca.

La ambigüedad del Barroco se encontraría en la teatralización de las cosas, que apunta a la imposibilidad de captar verdaderamente lo real. Esta cultura, que tematiza la inestabilidad de lo real, lo efímero, en un nuevo paradigma del tiempo, se encontraría también en el flujo de imágenes actual, en los dispositivos polisensoriales de nuestra actual cultura virtual. Esta cultura se expresaría por una estética hecha de topologías, de artefactos, de envolturas, de superficies, de segundas pieles... que encontrarían sus raíces directamente en la estética del Barroco. Las obras contemporáneas que se inspiran en todo ello desarrollan una estética ambivalente, entre simulacro y sublimidad.

La filósofa desarrolla una tesis según la cual, para el Barroco ser es ver. Insiste entonces en la paradoja de la mirada barroca, que pone todas las cosas observadas en entredicho. Este cambio parece estar formado a partir de la multitud de nuevas teorías que emergen en el siglo XVII: el descubrimiento del heliocentrismo, la teoría de las órbitas elípticas de Kepler, de las cónicas y de las matemáticas infinitesimales de Leibniz especialmente. Cada uno a su manera, desplazan el orden de lo visible, dando así consistencia a lo imaginario. La autora reafirma que la retórica barroca es esencialmente figurativa; el ver y el decir están, desde ahora, inexorablemente intrincados en las metáforas y las alegorías.

Emerge una especie de enigma de la visibilidad, que se aloja en un cuerpo a la vez vidente y visible. Merlau-Ponty subraya también esta especie de locura de la visión en relación con el cuerpo; veo y me dirijo a un mundo al que yo pertenezco, pero, sin embargo, con toda evidencia, las partes de este mundo no coexisten $\sin \mathrm{mi}^{84}$. La

83. Cifr. CHRISTINE BUCI-GLUCKSMANN, La folie du voir, op. cit. 
visión, en este sentido desorienta al sujeto, le otorga como una especie de salidas fuera de sí; no se trata de ver afuera, sino de ser visto por ese afuera, una especie de envolvimiento, como un pliegue, existir ahí fuera, ser seducido. El cuerpo aquí cobra la importancia perdida; sentirse como un cuerpo inmerso es verse como una imagen fragmentada y parcial.

El enlace de estas últimas consideraciones con el pensamiento de Leibniz es evidente; un ver plural sometido a los puntos de vista de las mónadas, que hace del ser una especie de intersección de las miradas, un sistema de múltiples entradas, una especie de topología de respectividades. El mirar, así, nunca es objetivable, flota en ese sistema múltiple.

También Glucksmann sugiere que el Barroco buscó representar lo irrepresentable. Así estaba más cercano a lo que una larga tradición de estetas llamaron lo sublime, en contraste con lo bello, a causa de su intenso anhelo por una presencia que nunca puede llenarse. También el deseo, tanto en sus formas eróticas como metafísicas, (estás últimas expuestas con exhaustividad por la filosofía de Spinoza ${ }^{85}$ ) discurre por el arte del Barroco. El cuerpo regresa para destronar a la mirada desinteresada del espectador cartesiano; Spinoza así dirá: no sabemos lo que puede un cuerpo ${ }^{86}$. La visión que retiene al deseo; la visión desde el contexto preciso de un cuerpo en el mundo puede no siempre ver las cosas visibles desde un punto de vista objetivo y uniforme, puede, más bien, como en el espacio barroco, considerar la pluralidad y la multiplicidad ${ }^{87}$.

La visualización del concepto y una voluntad de retórica equívoca, produce un engranaje de los puntos de vista, y conduce a una espacialidad barroca, cercana al concepto de composibilidad de Leibniz $^{88}$, y, según Glucksmann, próxima a la forma abierta ${ }^{89}$, tema

85. BARUNCH SPINOZA, Ethica, traducción al castellano de Vidal Peña, Ética

demostrada según el orden geométrico, Alianza editorial, 2011.

86. Ibid., Parte III, Proposición II, Escolio.

87. Cifr. MARTIN JAY, Scopic Regimes of Modernity, op. cit.

88. El concepto de composibilidad será explicado a lo largo de este texto en varias de sus partes. Véase, p.e., infra, pág. 121-124.

89. Siguiendo a Umberto Eco quien emite la idea de que el Barroco propone una visión abierta de la forma: La búsqueda del movimiento y del espejismo excluye la visión privilegiada, unívoca, frontal, e incita al espectador a desplazarse continuamente para ver la obra bajo aspectos siempre nuevos, como un objeto en perpetua transformación. (...) La obra de arte ya no es un objeto cuya belleza consolidada se contempla sino un misterio por descubrir, un deber que cumplir, un estimulante para la imaginación. UMBERTO ECO, L'œuvre Ouverte (1962), París : Editions du Seuil. 
que encontramos en los cinco axiomas de Wölfflin. Por ejemplo, el círculo, figura teológicamente perfecta, representa la unicidad y el punto de vista único, la Idea. En la lógica barroca, el círculo se transforma en una elipse constituida por un doble foco, dando así un efecto de dinamismo y de vacío ausente en el círculo, como la espiral, torbellino sin fin productor de falsas perspectivas, que trata Borromini en algunas de sus obras ${ }^{90}$. El vacío, la nada y lo informal se muestran así en su centro. El Barroco correspondería para Christine Buci-Glucksmann, con una puesta en práctica de la imagen asociada a un punto de vacío formal (de la espiral o de la elipse) y de una retórica figurativa (la metáfora y la alegoría).

Es por lo que el Barroco es considerado, a veces, como para los autores de la recopilación de Résurgences baroques, como:

(...) una red de relaciones múltiples que no cesan de extenderse y de impregnar la cultura contemporánea, entre la literatura y el cine, la pintura y las artes del espectáculo, la imagen y la palabra, o incluso la estética y la política. ${ }^{91}$

90. Por ejemplo, en la escalera del palacio Barberini o el remate de la linterna de San Ivo. Véase infra págs. 174-178. 


\subsection{BARROCO Y NEOBARROCO A TRAVÉS DE EL PLIEGUE DE DELEUZE}

De un estado del espíritu contemporáneo de Calabrese, pasamos a un paradigma barroco en Buci-Glucksmann. El Barroco ya no es un dato histórico, ni siquiera un estilo en la historia de las artes visuales, sino una representación del mundo. Lo que se instituye no es una comprensión definitiva del pasado, es más bien una construcción estratégica. Lo que parece cierto es que el Barroco aporta referencias para delimitar y comprender lo contemporáneo, aunque no exclusivamente. Constituye, sobre todo, gracias a la aportación deleuziana, una herramienta para pensar y para hacer. Trataremos de mostrar que para la visión actual, el Barroco, en tanto que útil epistemológico y heurístico, tiene todas las probabilidades de ser fructífero.

Gilles Deleuze pretende superar las disputas de los historiadores por una definición del Barroco según la aproximación paradigmática. Para el filósofo, el Barroco no reenvía a una esencia, sino, sobre todo, a una función operatoria, a un trazo ${ }^{92}$. Así, la duda histórica de la noción se encuentra convertida en un gesto absoluto, transportable e imitable, un trazo que él designa con el nombre de pliegue:

Para nosotros, en efecto, el criterio o el concepto operatorio del Barroco es el pliegue, en todas sus acepciones y su extensión: pliegue según pliegue. Si se puede extender el Barroco fuera de sus límites históricos precisos, nos parece que siempre es en función de este criterio, que nos hace reconocer Michaux cuando escribe «Vivir en los pliegues», o Boulez cuando invoca a Mallarmé y compone «pliegue según pliegue», o Hantaï cuando hace del 'plegamiento un método. Ysi por el contrario se remonta al pasado, ¿qué razones tendríamos de encontrar ya el Barroco, en Uccello por ejemplo?93

Deleuze inventa la figura del pliegue para demostrar su visión del sujeto y es de gran eficacia para explicar su interioridad absoluta, que no es ni la reflexión (o el cogito), ni la relación con la visión (o la intencionalidad), ni el punto de vista estricto. Ni Descartes, ni Husserl, ni Lacan ${ }^{94}$. Leibniz proporciona así a Deleuze una ima-

92. Cifr. GILLES DELEUZE, El Pliegue..., op. cit.

93. Ibid. pág. 49.

94. El pliegue es considerado como una respuesta a la teoría psicoanalítica de Lacan sobre el Barroco, que reenvía a «la exhibición de cuerpos que evocan el gozo. El barroco 
gen, la del pliegue, que atraviesa todo su sistema filosófico y permite situarlo en relación a los discursos circundantes. Propone así una alternativa a la aproximación merelau-pontiana de Christine Buci-Glucksmann y supera también los estudios semióticos de Calabrese ${ }^{95}$.

Sin embargo y a través más que de nadie de Leibniz podemos considerar la posición problemática en la que se encuentra el sujeto, como contingente, subordinado a la visión particular e individual del Mundo en sus zonas de claridad. Un Mundo en perpetuo flujo, formado por las diferentes interioridades que lo contienen de una manera problemática, un Mundo que se com-pone en armonía a pesar de todo. De lo que se deduce que existen confluencias entre todos estos autores, que estriban principalmente en la reivindicación nietzschana que rechaza de raíz cualquier visión trascendental del mundo, y subraya la posibilidad de la diferencia y la interpretación.

Deleuze responde también a todos los que han teorizado el Neobarroco. Sostiene la tesis según la cual el Barroco (su Barroco) se traduce por un aumento de la armonía y el Neobarroco por la irrupción de acordes disonantes o series divergentes (caosmos), frente a las series convergentes y la armonía Barroca ${ }^{96}$. Así, ¿el Neobarroco no será, contrariamente a lo que su denominación léxica presupone, una simple resurgencia de un movimiento pasado sino, sobre todo, un elemento manierista perturbador de las armonías preestablecidas? No será un retorno a un Barroco con un enfoque conservador, sino, sobre todo, un retorno a un modelo estético con el objeto de revolucionar los valores y prácticas del presente. En este sentido, coincidente entonces, con nuestra descripción del espacio postmoderno.

Más allá de un estudio temático delimitado a un período estilístico, el Barroco deleuziano designa a una sensibilidad artística que produce, a continuación, elementos estilísticos:

se convertiría entonces en el espejo de nuestro inconsciente y de la colectividad a la que pertenece, tendencia personal y colectiva. JACQUES LACAN, Du baroque, Séminaire XX, Encore, 1975, París, Seuil, 2002. Citado por FLORENCE PLIHON, Architectures Numériques et Résurgence Baroque: Bernard Cache, Greg Lynn et le Pli de Deleuze, Architecture, aménagement de l'espace. Université Charles de Gaulle - Lille III, 2016.

95. Cifr. Ibid.

96. GILLES DELEUZE, El Pliegue..., op. cit., págs. 155-177. El tema de la ruptura de la armonía está tratado en la parte II de este texto, véase Parte II, capítulo 2, págs. 191, 192. 
Esto es el Barroco, antes que el mundo pierda sus principios: un espléndido momento en el que se mantiene cualquier cosa más que nada, y en el que se responde a la miseria del mundo con un exceso de principios. ${ }^{97}$

Para Deleuze, el Barroco no es, por tanto, un estilo, sino un efecto figurativo creado a partir de un estado del espíritu inquieto promovedor de cambios de lo contemporáneo. Es un arte que agita y perturba la evolución de las artes y de la imaginación.

Seguimos siendo Leibnizianos, aunque ya no sean los acordes los que nuestro mundo o nuestro texto. Descubrimos nuevas maneras de plegar como también nuevas envolturas, pero seguimos siendo leibnizianos porque siempre se trata de plegar, desplegar, reple$\operatorname{gar}^{98}$.

Este entusiasmo va acompañado de un escepticismo creciente. Frente a esta extensión transhistórica y transcultural, algunos teóricos llegan incluso a negar este concepto. Otros lo intentan reducir a su periodo histórico-artístico, tomándolo únicamente como un estilo y negando su permanencia transcultural. El término está siempre en el límite entre facilidad retórica y profunda sensibilidad artística. Vemos igualmente esta decadencia del término, su banalización en ciertas obras para el público en general, que celebran una cultura del exceso, de la seducción, del lujo, de la profusión y de las apariencias. El Barroco se reduce de forma alarmante a imágenes de formas alocadas y exuberantes. Estas interpretaciones se alejan de los aires científicos que le proporcionan al término los historiadores, arquitectos, filósofos y otros pensadores estudiados que nos interesan. El Barroco es una noción que, desprovista de su complejidad y reducida a algunas imágenes fácilmente mediatizables, reenvía a un corpus de esquemas compartidos por una gran parte del público de cultura occidental: ilusión, subversión, fasto en las decoraciones y complicación de formas a discreción. No es este, desde luego el sentido que pretendemos rastrear en esta investigación, sino precisamente su trascendencia cultural y su interpretación actual como sistema complejo y rico en matices y posibilidades.

97. GILLES DELEUZE, El Pliegue..., op. cit. 
Sintetizando lo anterior, esta resurgencia del Barroco ha sido posible gracias a una definición extensiva del Barroco, fruto de una historia etimológicamente agitada. La construcción de la noción toma su raíz en el vocabulario desde los historiadores del arte alemanes del siglo XIX como Heinrich Wölfflin, y llega hasta la filosofía de Deleuze y C. Buci-Glucksmann.

Inicialmente, el Barroco define un período en los estilos de las artes visuales relativamente bien delimitado, que se extiende hasta el siglo XVII. En los años 1980, su definición se amplía para calificar numerosas manifestaciones artísticas e incluso un estado del espíritu, un movimiento artístico y arquitectónico propio de la época más allá de las fronteras originariamente europeas. En 1989, Deleuze propone una obra sobre el Barroco, inspirada en la filosofía barroca de Leibniz, hasta el punto de convertirla en una noción a la moda desplazando su sentido. Para Deleuze, el Barroco sobrepasa con mucho su marco histórico para convertirse en una representación del mundo, en un modelo coherente que reposa sobre una base definida por un sistema filosófico. En suma, el Barroco se convierte en un concepto.

Desde la constitución del Barroco como paradigma, o como para Deleuze, como concepto operatorio cuyo trazo fundamental es el pliegue, el Barroco se convierte en una construcción estratégica, que proporciona a los artistas una herramienta para definir su práctica en plena mutación, así como para crear. A esta construcción estratégica, la podríamos llamar ficción ${ }^{99}$. Parece que el sistema filosófico general del pliegue, es decir, la modulación de lo real según una multiplicidad de puntos de vista, se expresa mediante ideas que deben contener esta reserva de virtualidad. La ficción, en tanto que expresión de un mundo posible, es una herramienta esencial en un proceso que explota esta reserva de virtualidades.

Hay un modo de expresión vinculado a una especie de ilusión de forma. Lo barroco trata de representar la ilusión de algo que fluye, que se escapa. Abandona, así, todo modelo de permanencia y perturba la noción de forma, que es pensada como flujo de energía 
y fuerzas múltiples. Toda forma se reduce a su apariencia, que solo es un efecto de superficie ${ }^{100}$.

A partir de lo anterior podemos extraer algunas conclusiones preliminares de la relación de lo barroco con lo que hemos llamado espacio postmoderno.

Atendiendo, por ejemplo, al análisis de Glucksmann sobre el modo de ver, si consideramos el perspectivismo que podríamos llamar plano o cartesiano, un ver singular y el modo de ver barroco como un ver plural, parece que, en el siglo $\mathrm{XX}$, aunque sería inexacto afirmar que el perspectivismo cartesiano ha desaparecido, es realmente notable hasta qué punto ha sido enérgicamente contestado, tanto en la filosofía como en las artes visuales ${ }^{101}$. El ascenso de la hermenéutica, el retorno del pragmatismo, la profusión de las formas de pensamiento del estructuralismo y del posestructuralismo, todos ellos han convertido en muy problemática la tradición epistemológica derivada de Descartes; todo ello es lo que podríamos considerar que forma parte de nuestro espacio postmoderno.

El Postmodernismo retoma la complejidad barroca, la complejidad en el sentido de mirar y de ver; también, podríamos decir, la complejidad derivada de una toma de conciencia de la finitud, de lo efímero, de lo fugaz. Se trata de un nuevo pero viejo paradigma del tiempo: el Ser como un aparecer inestable, que se muda, una toma de conciencia sobre la impermanencia, una nueva expresión de lo trágico. Ambas cosas: un modo de componer el mundo a través de pluralidades, y una toma de conciencia sobre lo efímero, lo inestable, están relacionadas, y apuntan ambas a la grieta que abre Nietzsche sobre el modo de pensar en la modernidad, en la medida que esta defiende un punto de vista unitario o una forma de progreso y temporalidad lineal. Es en este sentido en el que podemos considerar una Postmodernidad neobarroca, oscilante entre estas dos cuestiones, que darán lugar a diferentes expresiones culturales y muchos más matices, evoluciones y sugerencias, en torno a ellas. Nos fijaremos en la arquitectura. 


\section{EL BARROCO HISTÓRICO Y LA ARQUITECTURA DE BORROMINI}

A continuación se exponen las justificaciones de por qué escogeremos en esta investigación un modo especial de entender el Barroco, que se desarrolla en la Roma de la Contrarreforma, durante lo que se ha venido llamando Barroco tardío. También y en especial, por qué escogemos a un actor singular como Francesco Borromini para localizar el carácter de lo barroco en arquitectura y sus connotaciones generales.

Aunque esta investigación solo trata de seguir la huella de Borromini en la arquitectura actual, también se apoya en varias ocasiones en otros ejemplos del arte barroco en general, como es el caso de la pintura de Caravaggio o Velázquez y la escultura de Bernini. Lo que en arquitectura sucede con la forma en la obra de Borromini, bien pudiera también notarse en los poemas de Góngora o en otros ejemplos aquí no tratados de la literatura del siglo XVII. Con esto se quiere señalar, que, aunque la obra de Borromini es el fenómeno a través del cual se localizan los objetos teóricos que serán la fuente de interpretación, también se trata de caracterizar rasgos de época, pues la tesis se estructura también a través de ese retorno, que no sería tal si la figura de Borromini fuera un mero caso aislado y particular. Por ello se recurre puntualmente a otros casos de manifestaciones artísticas barrocas, y, por ello, también, nos referimos al pliegue de Deleuze, que él caracteriza como trazo fundamental del Barroco como concepto operatorio.

La figura de Borromini es singular dentro de la arquitectura romana de su época, pero a la vez, paradójicamente, es paradigmática. Ello sucede si tenemos en cuenta el conjunto cultural completo, no solo la arquitectura. Y, sobre todo, es paradigmática en cuanto al uso del pliegue, la inflexión, la continuidad... etc., y con ello, de todas las consecuencias que arrastran estos recursos y que estructuran la investigación. 
Aunque todas las reflexiones anteriormente expuestas, parece que nos llevan a considerar al Barroco, no como un periodo de la historia del arte, sino más bien como una especie de manera de ver, o de interpretar la realidad y el mundo, el término Barroco, parece que se tematiza de forma primaria para referirse a las manifestaciones culturales que se desarrollan, más o menos durante el siglo XVII y la última parte del siglo XVI. Parece entonces que las expresiones que en ese momento tienen lugar podrían ser tomadas como paradigma que representara mejor que ninguna otra época lo esencial y característico del barroco. De hecho, todas las reflexiones que se han hecho sobre el tema del barroco toman en consideración primeramente este momento histórico o alguna de las manifestaciones artísticas o culturales del mismo.

Sería entonces importante, en primer lugar, aclarar el sentido del término paradigma. Distintos autores se han referido a este término de diferentes maneras ${ }^{102}$. Un paradigma es un ejemplo capaz de explicar un conjunto de elementos relacionados. No es un ejemplo cualquiera, es singular, pues logra definir por analogía las características y la norma del grupo de elementos.

El paradigma es siempre particular, es un elemento del grupo, por ello no se puede perder, en todo caso puede dejar de ser paradigmático o representativo de la especificad. Disolver el paradigma es encontrarse ante un cambio de paradigma, quizás en un umbral epistemológico ${ }^{103}$ al que se refiere Foucault.

Hay dos usos distintos del término paradigma en la tesis:

1. Por un lado, el sentido de paradigma quiere referirse más bien a una especie de cambio epistemológico, una modificación de las condiciones que dan lugar al contexto. La disolución del paradigma quiere operar como un cambio de referencias. En este sentido

102. Para aclarar su contenido, es muy pertinente el texto de GIORGIO AGAMBEN. “QQué es un paradigma” En: ¿Qué es un paradigma? En: Signatura rerum. Sobre el método. Anagrama, Barcelona 2010, donde se analiza el significado del término en relación al sentido en el que lo utilizan varios autores. El texto pone en relación el sentido del término en la obra de Thomas S. Khun (La estructura de las revoluciones científicas) y las cuestiones que M. Faucault (Las Palabras y las Cosas, Arqueología del saber) elabora en relación con él, como el concepto de episteme, régimen discursivo o figuras epistemológicas.

103. M. FOUCAULT. La Arqueología del saber. 
operaría, por ejemplo, en el cambio que observa Wölfflin entre Renacimiento y Barroco.

No se trata tanto de determinar una figura, como de detectar campos de fuerzas, cambios en las condiciones, de estudiar cómo se comporta la arquitectura en este trance de cambio en relación con las otras manifestaciones culturales que operan simultáneamente. Se pretende señalar un cambio epocal marcado por la pérdida de vigencia de un paradigma (o también una figura epistemológica) que se está disolviendo como tal, dando paso simultáneamente a otro emergente en el sentido que señalaría Kuhn ${ }^{104}$.

2. Por otro lado, nos vamos a referir también a un ejemplo paradigmático (aquí será la obra de Borromini la que actuará como paradigma), que revela y hace inteligible un conjunto determinado.

Actúa como caso singular, que se aísla del contexto para exhibir su propia singularidad, y así volver inteligible el conjunto, constituyendo su homogeneidad. No obedece a relaciones metafóricas que trasladarían el sentido, sino a la analogía del ejemplo. Podríamos decir que funciona como una alegoría. Sería:

Un objeto singular que, valiendo para todos los otros de la misma clase, define la inteligibilidad del conjunto del que forma parte y que, al mismo tiempo, constituye. ${ }^{105}$

Agamben señala que es imposible separar en un ejemplo su condición paradigmática, su valer para todos, de su ser un caso singular entre los otro. Y lo compara con un campo magnético, que no está compuesto de cantidades extensivas sino de intensidades.

Según estas consideraciones y, en primer lugar, para detectar el carácter barroco, sus síntomas, sus connotaciones, para introducirnos en el espacio barroco, para escoger la arquitectura que nos debe orientar en el recorrido de la investigación sobre la forma arquitectónica del Barroco, tomaremos como modelo de estudio lo que vamos a llamar, o hemos llamado ya, Barroco histórico, que es el que se desarrolla en el mundo occidental durante el periodo de tiempo señalado. Dentro de la multiplicidad de manifestaciones que este Barroco histórico tiene, en los diferentes lugares, en 
Europa y América donde se desarrolla, tomaremos, también como paradigma, dentro del paradigma, el Barroco romano. En este sentido, nos apoyaremos de nuevo en las consideraciones de Wölfflin. Este autor insiste en que en Italia la transformación operante desde el Renacimiento tiene una significación esencialmente diferente de la de la del resto de Europa.

Lo interesante del proceso que se puede observar en Italia, reside en el paso de un arte riguroso a un arte libre y pintoresco, de una forma estricta a una ausencia de forma ${ }^{106}$.

En el mismo texto, señala que es en Roma donde el Renacimiento ha alcanzado el máximo grado de maduración debido a la presencia de los monumentos antiguos. Por ello cualquier relajamiento de la forma debía en Roma ser sentido más que en ninguna otra parte.

Por último, nos parece que el Barroco tardío, si bien tiene menos interés para reconocer el proceso de cambio que se desarrolla a partir del Renacimiento (como hará Wölfflin), sí resulta singularmente interesante en esta investigación, pues muestra un modo de expresión ya bien afianzado y reconocido, con el contexto histórico de la Contrarreforma y de la Guerra de los treinta años de fondo. 


\subsection{EL EJEMPLO PARADIGMÁTICO: LA ARQUITECTURA DE BORROMINI}

Una vez acotado el periodo de estudio, toca justificar la elección de la arquitectura de Borromini como ejemplo paradigmático, como figura de referencia singularmente representativa, que caracteriza la arquitectura barroca tardía.

Quizás, si de lo que se tratara fuera de definir la arquitectura barroca romana de su época, la figura peculiar de Borromini no sería demasiado representativa, pues ya hemos notado su singularidad con respecto a sus contemporáneos. Sin embargo, en su relación con las expresiones arquitectónicas contemporáneas, su arquitectura constituye una referencia muy pertinente y enriquecedora. También si, como hemos adelantado, consideramos el punto de vista de Deleuze, donde la forma pliegue y sus efectos (inflexión, continuidad, metamorfosis, punto de vista etc.), son los trazos del Barroco. Estos trazos no tienen la misma fuerza ni presencia en las arquitecturas de Bernini o Pietro de la Cortona, las otras dos grandes figuras en la arquitectura romana del XVII.

Borromini podría situarse tal vez en lo periférico de la arquitectura Barroca. En primer lugar porque su obra es considerada por la historiografía del arte como barroco tardío. También porque él no construye para el poder central de la iglesia católica como lo hace Bernini. Únicamente durante un breve espacio de tiempo, con el papado de Inocencio X, tuvo la oportunidad de trabajar en obras de relevancia como San Juan de Letrán o los comienzos de la iglesia de Sant' Agnese de la piazza Navona. Las obras más significativas de Borromini, como San Carlino y San Ivo, donde su arquitectura es más expresiva, donde trabaja sin limitaciones y puede exhibir al máximo su creatividad, son siempre obras para órdenes religiosas y no son proyectos oficiales del poder papal. Por otra parte, durante dos siglos, Borromini figuró como un artista sin sensibilidad para la majestuosa sencillez de la antigüedad ${ }^{107} \mathrm{y}$, aunque posteriormente su arquitectura ha sido ensalzada y reconocida, parece que es Bernini el gran arquitecto barroco de la ciudad de Roma. Hoy todavía se encuentran guías de Bernini por cualquier lugar turístico de Roma, pero hay que ir a San Carlino para hacerse con una guía turística de Borromini. Además la obra 
de Borromini está bañada por una particularizad que la hace singular entre sus contemporáneos.

Pero sin embargo consideramos, y también comprobaremos a lo largo del texto, como las obras de Borromini representan mejor que ninguna de las construidas en la Roma de su época, o al menos, de una manera más intensa, el pathos del Barroco, su tragicidad que parte de la imposibilidad de representar lo invisible. Es este carácter el que nos interesa, el que se vincula de una manera más esencial con las expresiones contemporáneas y quizás con el sentido más general de lo barroco.

Por otra parte, y siguiendo este enlace con lo contemporáneo, el poderoso dominio que nuestro arquitecto tiene de la geometría, y que podemos comprobar en el análisis de sus múltiples dibujos conservados, le vincula también a nuestra contemporaneidad en relación con los medios digitales, de los que más adelante trataremos.

Sus interiores mezclan la complejidad matemática y creaciones imaginativas con un ánimo de innovación que se separa del modelo clásico griego y romano canónico y se fija en otros modelos de periodos tardíos, de arquitecturas procedentes de partes más periféricas del imperio o de arquitectura doméstica, como la villa Adriana o la Domus áurea.

Señala Sigfried Giedion ${ }^{108}$, que el rasgo distintivo de la época barroca es el desarrollo de una clase específica de universalidad, el nuevo poder para modelar el espacio y crear una unificada totalidad a partir de las partes más variadas. Borromini traslada a su arquitectura de manera plena esta idea. Su expresión no es a base de ornamento, hay plasticidad, flexibilidad, continuidad espacial, un trato paradójico de la piedra como material elástico, que se disuelve perdiendo su materialidad en membranas porosas. $\mathrm{Su}$ tratamiento teatral de la luz es significativo como expresión de la infinitud. Toda esta escenografía lleva implícita la complejidad del periodo en que está teniendo lugar. Su arquitectura expresa plenamente una tensión trágica. Sus formas revolucionarias de actuar sobre el espacio no se limitan al espacio interior, se extienden a través de la fachada al exterior, modificando la percepción urbana (muy presente en la fachada de San Carlino a le Cuatro Fontane). 
Otro rasgo peculiar son las permanencias presentes en su arquitectura, formas procedentes de otros momentos históricos, impurezas, injerencias anacrónicas, que dan un interés especial a su arquitectura y que también nos hablan de un peculiar espíritu barroco que no se da en la obra de ningún otro arquitecto romano contemporáneo de Borromini. Como todo gran creador Borromini mantuvo contactos con el pasado, no imitó formas pasadas sino que hizo que fueran parte de sus propias creaciones.

Parece que el carácter innovador estaba en su voluntad de hacer su arquitectura. Esto es también significativo; la pretensión de innovar lleva siempre aparejado una voluntad de cambio, una nueva forma de expresión, de lenguaje y de concepción del espacio; Borromini introduce La diferencia. A esta voluntad innovadora parece que se refiere él mismo en su Opus Architectonicum ${ }^{109}$. Borromini expresa como desea hacer cosas nuevas, y lo justifica refiriéndose a Miguel Ángel, que hizo lo mismo.

Pero la fuerte apuesta por la innovación no implica en ningún caso para Borromini la negación del pasado, no se puede interpretar esta actitud de nuestro arquitecto como una violenta ruptura con la tradición. Borromini recoge una herencia y es consciente del legado, de la importancia del pasado en la creación del presente, del valor de la tradición. Todo ello es lo que confiere a su obra una riqueza que hace posible una infinidad de lecturas. Borromini consigue conciliar muchas cuestiones; tradición e innovación; rigor geométrico y tolerancia en las formas, razón y sentimiento, fuerza apasionada y juego y simulacro. Es una arquitectura intensiva, llena de riqueza. Se mueve en la contradicción, en una actitud puramente Barroca, crea desde la tensión, reflejándola, formalizándola en el espacio, lo que hace que sus edificios sean unidades complejas con múltiples significados, una arquitectura densa.

La arquitectura de Borromini no tiene antecedentes, solo inspiraciones en arquitecturas clásicas no canónicas y residuos de otras procedencias. Tampoco tiene seguidores, únicamente Guarino Guarini, unos años después, sigue el rastro de la arquitectura de

109. Opus architectónicum Equitis Francisci Borromini es uno de los pocos testimonios escritos que quedó de Borromini, redactado en 1648 a raíz de la construcción del Oratorio de San Felipe Neri. La obra está ampliamente ilustrada y su introducción, aunque escrita en primera persona, fue redactadas según indicación del artista, por su protector y amigo Monseñor Vigilio Spada. El arquitecto Paolo Portoghesi, gran estudioso de Borromini, señala esta cuestión en su texto Francesco Borromini, Electa, 1990, pág. 10. 
Borromini. Hay que buscar otros estratos históricos para encontrar su huella. Es ahí donde podemos encontrar lo significativo de nuestro artista. Benjamin ${ }^{10}$ señala la necesaria orientación hacia lo extremo en la investigación filosófica, que en el caso del Barroco tiene doble sentido pues sus reglas son extremas, excéntricas, por lo que la atención a lo periférico-residual alcanza un valor simbólico.

Borromini resulta residual, periférico, extremo, y por ello quizás el análisis de sus obras arroja luz sobre la forma del Barroco, no define su concepto, no se trata de eso aquí. Benjamin observa que:

(...) lo que tales nombres no pueden hacer como conceptos lo consiguen sin duda en cuanto a ideas, en el seno de las cuales lo parecido no llegará al solapamiento, pero lo extremo llegará hasta la síntesis. ${ }^{11}$ 


\section{LA RECEPCIÓN DEL BARROCO EN LA TEORÍA DE LA ARQUITECTURA}

En este apartado se trata de hacer un resumen de los antecedentes teóricos, dentro del ámbito de la arquitectura, donde la relación Barroco- Postmodernidad es explícita, sin entrar ahora en el análisis de obras que se llevará a cabo más adelante.

¿Cómo entra en escena el Barroco en el panorama postmoderno en arquitectura? Las bases para admitir un sistema complejo ya están en marcha como hemos podido observar a través de los textos de Venturi en el capítulo anterior, pero surge un interés explicito, donde se nombra lo barroco, que proviene del campo de la filosofía pero que se extiende a la teoría y a una pretensión de práctica, en la arquitectura, y dará lugar a numerosas especulaciones.

En arquitectura, la entrada en contacto con el Barroco es un hecho que se manifiesta en el interés que la teoría de la arquitectura, sobre todo en Francia y en los EE. UU., muestra por aspectos formales y filosóficos del Barroco a partir de las últimas décadas del siglo pasado. Parece que hay dos desencadenantes de este interés que se refieren a aspectos distintos. Por una parte la recepción de la obra del Deleuze, El Pliegue, Leibniz y el Barroco, tanto en Francia, donde se publica por primera vez, como en EEUU a raíz de su traducción. Por otra, las nuevas posibilidades en la generación de proyectos que se abren a raíz del desarrollo tecnológico de herramientas digitales, también durante estas décadas. 
En arquitectura, en torno a los años 9o, la palabra Barroco empieza a cobrar importancia, y lo hace precisamente a raíz de la publicación de una serie de textos filosóficos que podríamos situar dentro del pensamiento del postestructuralismo francés. Este interés se manifiesta especialmente en algunas universidades norteamericanas y en Francia de la mano del arquitecto Bernard Cache que está trabajando con Gilles Deleuze.

Hay una clara implicación del Barroco en las estrategias discursivas de esta época. En torno a 1990 la palabra Barroco resurge en ciertos discursos, sobre todo en su relación con las nuevas herramientas digitales que están empezando a aparecer. Hay especialmente dos arquitectos teóricos que estructuran su discurso en torno al Barroco: Bernard Cache (1958), en Francia y Greg Lynn (1964) en los EEUU. Ambos se basan en la interpretación del texto citado de Gilles Deleuze El Pliegue, Leibniz y el Barroco ${ }^{112}$, publicado en Francia en 1989 y en EEUU en 1992 y que, en sí mismo, es ya una determinada interpretación del Barroco.

Bernard Cache defiende una tesis que vincula arquitectura y filosofía y que dirige Gilles Deleuze. Cache es citado por Deleuze en El Pliegue, y publica una obra que procede de su tesis doctoral, Terre Meuble ${ }^{13}$, curiosamente publicada primero en ingles en el MIT en 1995, antes que en francés.

Greg Lynn, arquitecto con un importante bagaje filosófico y vinculado a la universidad de Columbia, va a ser el que sitúe en la escena teórica norteamericana la interpretación de El Pliegue de Deleuze. Gregg Lynn será coeditor de un número de Architectural Design titulado Folding in Architecture ${ }^{114}$, cuya influencia en este debate será decisiva, y que será analizado más tarde. En este número escriben una serie de arquitectos de diferentes nacionalidades, que exploran cada uno a su manera diferentes formas de continuidad, o lógica del continuo, vinculada al pliegue en la arquitectura. El articulo central Architectural Curvilinearty, lo escribe Lynn, y en

112. GILLES DELEUZE, El Pliegue... op. cit.

113. BERNARD CACHE, Terre Meuble, Orleans, HYX, 1997. Traducción al ingles Earth Move: The Furnishing of Territories, Cambridge (MA): MIT Press, 1995.

114. Co-editado por GREG LYNN, Folding in Architecture, Architectural Design, № 63, 1993. 
él señala la diferencia significativa que se establecía entre El Pliegue de Deleuze y la deconstrucción de Jaques Derrida, con la cual, la arquitectura de Peter Eisenman, otra figura decisiva en este debate, había estado especialmente vinculada ${ }^{15}$. Lynn lo presenta como un cambio de paradigma. La vinculación con el Barroco no siempre es evidente en todos los textos de este número, mientras si lo es en el texto que escribe Cache.

Todo ello se puede englobar en la recepción de lo que en EE.UU. se denominó la French Theory y que hace referencia a la filosofía de los post estructuralistas franceses, entre los que se encuentra Deleuze junto con Felix Guattari, también Jaques Derrida, Lyotard, Foucault entre otros. La recepción norteamericana engloba a muchos de estos autores a pesar de sus grandes diferencias, y el impacto que esta tuvo en las artes visuales en general está estudiada en la obra French Theory and American Art ${ }^{116}$. A partir de 1970 la corriente se extiende al análisis de varios autores y comienza a institucionalizarse en el medio académico ${ }^{117}$.

Las colaboraciones y transferencias se suceden. Así Derrida trabaja con Eisenman en el proyecto de La Villette, por ejemplo. A la vez, los filósofos se nutren también del arte para enriquecer y profundizar en sus teorías. También Faucault hace un exhaustivo análisis de las Meninas de Velázquez en Les mots et les choses ${ }^{18}$, de la misma forma que el citado texto del Pliegue se nutre, como ya hemos visto, de estas transferencias. Pero lo que se ha llamado French Theory dista mucho de ser un corpus homogéneo, y menos lo es su recepción en el ámbito artístico, y esta transferencia del dominio de la filosofía al de las artes se ha juzgado en ocasiones como afectada por un exceso de literalidad.

El encuentro del pensamiento de Deleuze con la publicación de El Pliegue y la arquitectura fue muy productivo, dio lugar a numerosas publicaciones en algunas universidades y centra la línea del

115. Esta relación se describe en el texto de JEFFREY KIPNIS y THOMAS LEESER, Jaques Derrida y Peter Eisenman, Monacelli Press, New York, 1997.

117. Para una mayor profundización sobre este tema se puede consultar: FLORENCE PLIHON, Architectures Numériques et Résurgence Baroque: Bernard Cache, Greg Lynn et le Pli de Deleuze, Architecture, aménagement de l'espace. Université Charles de Gaulle - Lille III, 2016. 
debate teórico unos años más tarde de la recepción de la French Theory y como continuación de la misma.

La traducción de El Pliegue al inglés se hace en 1992 y un año más tarde Greg Lynn publica Folding in Architecture. Es en este momento cuando esta recepción de Deleuze se añade a la historia de la French Theory. El Pliegue se estudia fundamentalmente en la universidad de Columbia, donde el filósofo francés Sylvere Lotringuer estaba ya difundiendo las ideas de Deleuze desde 1970. El Institute of Architecture and Urban Affairs (IAUA) ${ }^{119}$, que preside por aquella época Peter Eisenman, y donde realiza sus investigaciones Rem Koolhas, reúne a pensadores del mundo arquitectónico pero también a otros procedentes de otras disciplinas. Hay en este grupo una intención de desvincularse de las posiciones que se habían llamado postmodernas representadas por figuras como Robert Venturi o Colin Rowe, inflexionando la teoría hacia interpretaciones deleuzianas. El tema de la complejidad que propone Venturi será lugar de controversias en este debate. Peter Eisenman se interesa por Deleuze, replanteándose los principios deconstructivistas que había defendido. Eisenman se había interesado por el concepto derridiano de Differance, que aunque en filosofía es un concepto ontológico, él aplica a sus operaciones espaciales. Hace la misma operación con el concepto del pliegue y aprovecha un certamen de urbanismo convocado en Frankfurt-am-Main para desligarse de la filosofía de Derrida en beneficio de la Deleuze en su proyecto para Rebstock Park ${ }^{120}$.

Por otra parte, en la década de los 90 se están desarrollando las primeras herramientas informáticas aplicadas al diseño arquitectónico, que van a incrementar exponencialmente las posibilidades formales mediante la manipulación de superficies en tres dimensiones, y revolucionando la práctica tradicional del proyecto arquitectónico.

Bernard Cache, vincula las nuevas tecnologías informáticas con la filosofía y la arquitectura, y con ayuda de algunos colaboradores participa personalmente en el diseño de herramientas. La máquina se encuentra para Cache integrada en el diseño en una espe-

119. El Institute of Architecture and Urban Affairs es un grupo de reflexión dirigido por Peter Eisenman desde 1973 hasta 1982 y seguido de otros directores, para impulsar la emergencia de corrientes críticas independientes en las instituciones universitarias.

120. Las pretensiones teóricas de Eisenman en este proyecto pueden acreditarse en el catálogo de la exposición. PETER EISENMAN, Frankfurt Rebstock Park, catálogo de la exposición, 1992. 
cie de continuo, donde se puede sentir la máquina. Pero mientras Bernard Cache es un caso aislado en Francia, Lynn está vinculado a un grupo pluridisciplinar que reúne a arquitectos teóricos y críticos, Anyone Corporation. En 2003 se inaugura una exposición dirigida por Frédéric Mygayrou en el Centro Pompidou de París titulada Architectures non standard, donde coinciden los dos arquitectos Greg Lynn y Bernard Cache. Esta exposición, junto a la publicación de Folding in architecture, pueden considerarse los dos hitos fundamentales que articulan este panorama.

Pero ¿hasta qué punto la transferencia entre el concepto del pliegue, que en Deleuze es una forma ontológica puede trasladarse a la arquitectura?, y si es posible ¿en qué sentido lo hace?. En El Pliegue, Deleuze hace del Barroco una reserva de potencialidades que es posible actualizar en cualquier momento. El pliegue funciona como forma característica que aporta un potencial creativo que puede ser leído una y otra vez de un modo dinámico, dando lugar a diferentes interpretaciones que también podríamos llamar actualizaciones del concepto. Y el interés por esta forma ontológica coincide en el Barroco y en la postmodernidad y lo hace interdisciplinarmente, aunque su lectura sea necesariamente diferente en cada uno de los periodos. Así Bernard Cache y Greg Lynn proponen prácticas intelectuales basadas en el desplazamiento, en relación con el concepto deleuziano de desterritorialización ${ }^{121}$ como acción de actualización de un concepto en diferentes contextos.

El Pliegue da pie a discursos exploratorios, durante este periodo de los 9o, que derivan en algunas arquitecturas que utilizan esta lógica de la continuidad que señala a su forma concreta de un modo más o menos literal. Por otra parte tal como se había hecho con la deconstrucción derridiana en arquitecturas como la de Peter Eisenman. Este interés explicito, reafirmado por otro interés implícito que también analizaremos más adelante, confirma la existencia de una estética barroca postmoderna o contemporánea que ha traspasado las épocas y las culturas configurando una nueva lectura de la misma.

121. El concepto de desterritorialización es descrito por GILLES DELEUZE y FELIX GUATTARI en las obras L'Anti-Edipe, 1972, op. cit., y Mil plateaux, capitalisme et schizophrenie, 1988, op. cit. También en ¿Qué es la filosofía?, op. cit. 


\section{Una puesta en cuestión}

Frente a toda esta transferencia de ideas y formas estéticas que se está produciendo hay también voces críticas que ponen en cuestión los propios principios de las productivas relaciones generadas. Así Alan Sokal, profesor de física de la universidad de Nueva York, y Jean Bricmont ${ }^{122}$, profesor de física de la universidad de Lovaina, denuncian la impostura intelectual de la llamada filosofía postmoderna. Los autores muestran la improcedencia del uso de la retórica y de las transferencias analógicas entre disciplinas. Se posicionan como defensores de una objetividad científica en oposición a un supuesto relativismo postmoderno. Esta reflexión toca especialmente a las interpretaciones de El Pliegue de Deleuze, particularmente a la que llevan a cabo Bernard Cache y Greg Lynn.

122. ALAN SOKAL y JEAN BRICMONT, Impostures intellectuelles, Éditions Odile Jacob, París, 1997. Publicado en inglés Intellectual imposture, Profile Books, Londres, 1998. Traducción al castellano de Joan Caries y Guix Vilaplana, Imposturas intelectuales, Ediciones Paidós Ibérica, 1999. 


\subsection{LA APORTACIÓN DE ROBERT VENTURI EN RELACIÓN CON LA RECEPCIÓN DEL BARROCO}

Una vez mostrado el panorama teórico que tiene lugar durante todos estos años en los ambientes universitarios, cabría preguntarse si este corpus teórico de la arquitectura, nacido a partir de la influencia de la filosofía francesa y que señala explícitamente al Barroco, es el único síntoma de nuestra vinculación cultural con este periodo histórico. Y aunque este episodio demuestra ya por sí mismo que el interés por el Barroco es un hecho cierto, quizás no haya que buscar su origen en los textos de filosofía, sino en los propios textos de arquitectura anteriores que llevan, implícitamente, el carácter barroco.

Antes de que todo este panorama estuviera teniendo lugar, Robert Venturi ya había publicado su texto Complejidad y Contradicción en arquitectura en 1966. Este texto se considera que es otro apunte fundamental para completar las aportaciones teóricas a propósito de la recepción del Barroco, porque, aunque Venturi no se refiere nunca a una posibilidad de resurgencia del Barroco, solo muestra, en algunas frases, su afinidad con él, ya desde el título del libro, se anuncian términos que son pertinentes para una lectura en este sentido.

La aportación de Venturi deriva, en la práctica, en una estética postmoderna, muy característica en la arquitectura de este periodo y donde el término postmoderno en arquitectura se quedó atrapado, probablemente por la intensidad de la ruptura con los presupuestos modernos, o por la especificidad del lenguaje utilizado.

Hay que señalar también que todo el corpus teórico que acabamos de describir, de los años posteriores a esta arquitectura postmoderna, vinculado con la French Theory, tiene también por objeto una reacción y una crítica a la arquitectura producida en la década anterior en torno a las propuestas de Venturi.

Venturi utiliza expresiones como arquitectura equívoca, ambigüedad, inflexión, arte impuro, tensión, lo uno y lo otro, tensión exterior-interior, el difícil conjunto etc., para considerar y describir la arquitectura de la complejidad y la contradicción. Notamos con estos términos ya con claridad la referencia, no explícita en su libro, al Barroco. Esta cuestión queda respaldada por las consideraciones expuestas en el capítulo anterior sobre el Barroco, y se 
1.14. Casa Vanna Venturi. ROBERT VENTURI, 1962

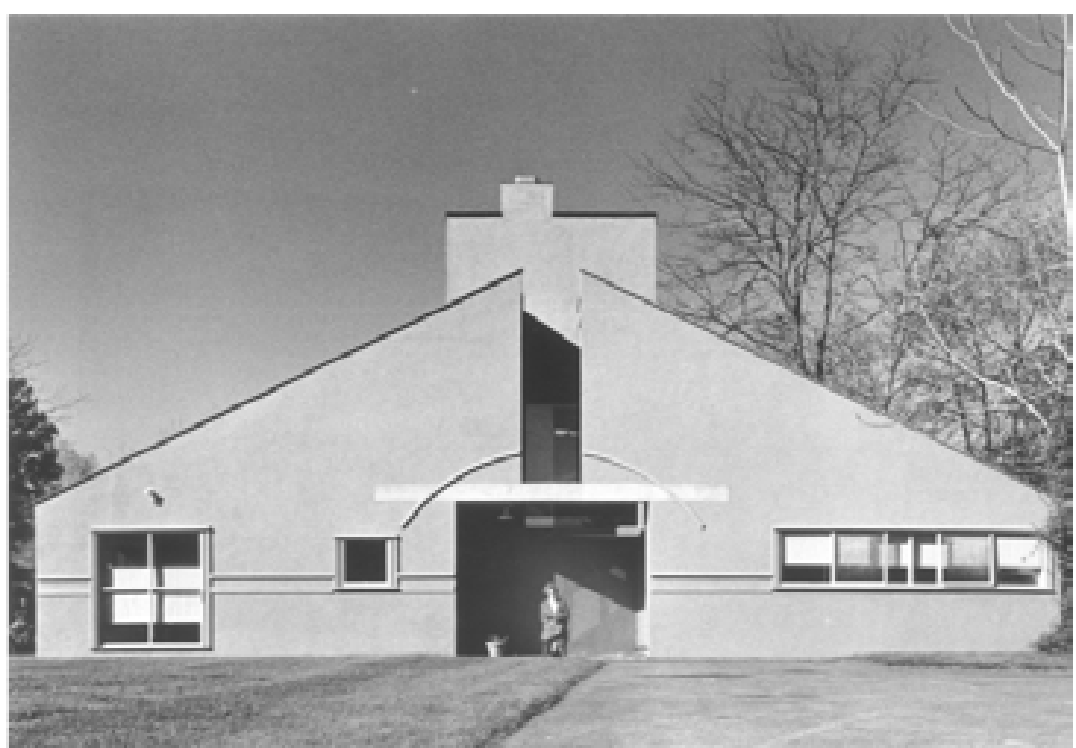

verá reforzada cuando, más adelante, determinemos cómo todos estos rasgos y caracteres, los hayamos también de la arquitectura de Borromini.

El texto de Venturi es significativo en cuanto que introduce en el campo de la arquitectura todas las claves de la Postmodernidad, aunque tampoco el término postmoderno aparezca en ningún caso en sus textos. El acercamiento a la Postmodernidad que se ha pretendido llevar a cabo, está recorrido por algunas claves que se desarrollan a partir de la consideración de cuestiones relacionadas con la pluralidad, la emergencia de la diferencia como clave que rechaza una visión unitaria de la realidad y la complejidad que todo lo anterior conlleva. Todas ellas aparecen en el texto de Venturi referidas a la arquitectura.

En el prólogo del texto se puede leer:

Los ejemplos elegidos reflejan mi inclinación hacia ciertas épocas: Manierismo, Barroco y Rococó.

La propia complejidad, a la que alude en el título, es un tema típicamente barroco. Venturi habla además de la inflexión, de la tensión, de la contradicción..., como características propias de una nueva expresión de la arquitectura. Las referencias de su obra, podría decirse que se encuentran vinculadas con la atención a la complicación y multiplicidad que son también los temas del Barroco.

(...) prefiero los elementos híbridos a los puros, los comprometidos a los limpios, los distorsionados a los rectos, los ambiguos a los 
articulados, los integradores a los excluyes, los redundantes a los sencillos $(\ldots)^{123}$

Cita expresamente la actitud barroca de la exuberancia como síntoma de complejidad, y se refiere a cómo nuestro tiempo ha sustituido la serenidad por la tensión, que sería análoga a la antigua exuberancia. Para Venturi, el deseo de una arquitectura compleja con sus contradicciones, es una actitud común con los periodos manieristas, que se repiten en la época helenística del arte clásico, o en el manierismo del siglo XVI. Esta actitud, nos dice, hoy es otra vez pertinente ${ }^{124}$.

Venturi recurre a términos como ambigüedad. Se fija en la tensión intrínseca a la percepción que se genera al yuxtaponer lo que una imagen es y lo que parece, para señalar la complejidad y la contradicción que emergen de este proceso inmerso en la ambigüedad. La ambigüedad se funda en el carácter confuso de la experiencia. Entra en juego la ficción a la que ya nos hemos referido, en tanto que expresión de un mundo posible, como herramienta esencial en un proceso que explota una reserva de virtualidades. La ambigüedad, se encontraría en la teatralización de las cosas, que apunta a la imposibilidad de captar verdaderamente lo real, tematizando la inestabilidad de lo real, lo efímero.

A lo largo de ejemplos procedentes del arte, la teoría o la literatura, señala lo esencial de esta ambigüedad en cualquier proceso artístico. La ambigüedad y la tensión serán valores generales en la arquitectura de la complejidad. Se detiene Venturi en el análisis de San Carlino alle Cuatro Fontane de Borromini, como prolífico en manifestaciones ambiguas.

Ensalza también cuestiones como la arquitectura impura o la imprecisión de significado, arquitectura equívoca, el fenómeno de lo uno y lo otro, el elemento de doble función etc. Todo ello señala a la multiplicación de puntos de vista propia del Barroco, la multiplicidad de referencias y modos de ver, que no se ajustan a la consideración de un mundo estable y unívoco.

El tema barroco del contraste entre el interior y el exterior es señalado como una de las manifestaciones principales de la contradicción en arquitectura, señalando especialmente la condición de 
organismo alojada en los interiores, lo cual remite al Barroco histórico de una forma muy directa, como es apreciable además por los ejemplos que son considerados en este capítulo: el Teatro Marítimo de Villa Adriana (podría ser un manierismo de la arquitectura clásica), la columnata de San Pedro de Bernini, Santa María della Pace de Pietro da Cortona, La capilla de los Sforza en Santa María Maggiore de Miguel ángel, etc.

Su último capítulo se titula El compromiso con el difícil conjunto. En él trata el tema importante de la inclusión. Citando a Herbert A. Simon señala que:

Un sistema complejo incluye un gran número de partes que se interrelacionan de una manera no simple. ${ }^{125}$

Él lo llama el difícil conjunto, señala la diferencia entre la difícil unidad conseguida mediante la inclusión, frente a la fácil unidad conseguida con la exclusión ${ }^{126}$. Considera con ello una pluralidad fundacional que dará lugar a topologías y respectividades propias de la conciencia plural de un postmodernismo filosófico, pero también propia del pensamiento Barroco, como podemos comprobar a través del pensamiento de Leibniz. Esta cultura se expresaría por una estética hecha de topologías, de envolturas y pieles, de superficies, que encontrarían sus raíces directamente en la estética del Barroco.

Aunque en una acepción restringida del postmodernismo, se lo ha definido por su voluntad figurativa, lo que si que encontramos en el análisis de la terminología del texto de Venturi, en su complejidad y su contradicción, es una intensificación de la forma.

Toda esta propuesta teórica se ve materializada en una estética muy particular y característica de estos años que se extiende por Europa y por el mundo, y a la que, en cierta manera, las propuestas de Bernard Cache y Greg Lynch, quieren responder.

125. HERBERT A. SIMON, Proceedings of the American Philosophical Society, vol 106, no 6, septiembre de 1962. Citado por Venturi en op. cit. 
En la década de 1960 podemos fijar el punto del comienzo de la relación de la arquitectura con la tecnología digital. Otro hito importante es la aparición de los ordenadores personales y el programa Autocad en los años 8o. Progresivamente el espacio de la pantalla sustituye al de la hoja de papel.

Pero el verdadero cambio surge con el desarrollo del dibujo en ${ }_{3} \mathrm{D}$; los nuevos programas permiten modelizar fácilmente líneas con curvas complejas. Se están desestabilizando las bases de la metodología tradicional del proyecto arquitectónico y esto llama también a una puesta en cuestión del propio objeto arquitectónico y a un reposicionamiento del propio hacer del arquitecto. Bernard Cache y Greg Lynn forman parte de la generación de pioneros y

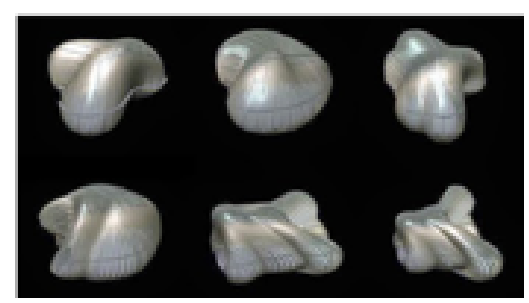

1.15. Casas embriológicas. GREG LYNN FORM. 1999. estudian y analizan la efervescencia tecnológica. Los programas no solo aceleran el proceso de diseño sino que multiplican sus posibilidades. Los diseños tienen una voluntad innovadora de transición de la arquitectura hacia lo digital vehiculando una estética concreta; amebas y formas geométricas amorfas proliferan, la curva se convierte en una constante. Greg Lynn produce gran cantidad de textos teóricos probando los límites de los programas, que tendrán gran repercusión.

Bernard Cache conciben objetos capaces de transformarse virtualmente de adaptarse y variar, proponiendo así el concepto de objetil, al que Deleuze se refiere en El Pliegue; este distorsiona el sistema hilemórfico tradicional, proponiendo una variación continua: la relación forma materia no es estable y se constituye, no a través de un molde, sino más bien a través de una modulación que es capaz de absorber las variaciones. Una serie de objetiles son identificables porque los diferentes objetos de ella son homólogos entre sí.

El objeto no se define ya por una forma esencial, sino que responde a una funcionalidad pura, como declinando una familia de curvas encuadrada por parámetros, inseparable de una serie de declinaciones posibles (...). ${ }^{127}$

El algoritmo que genera el objetil determina unas ciertas normas estructurantes y permanece fluctuante en función de parámetros 

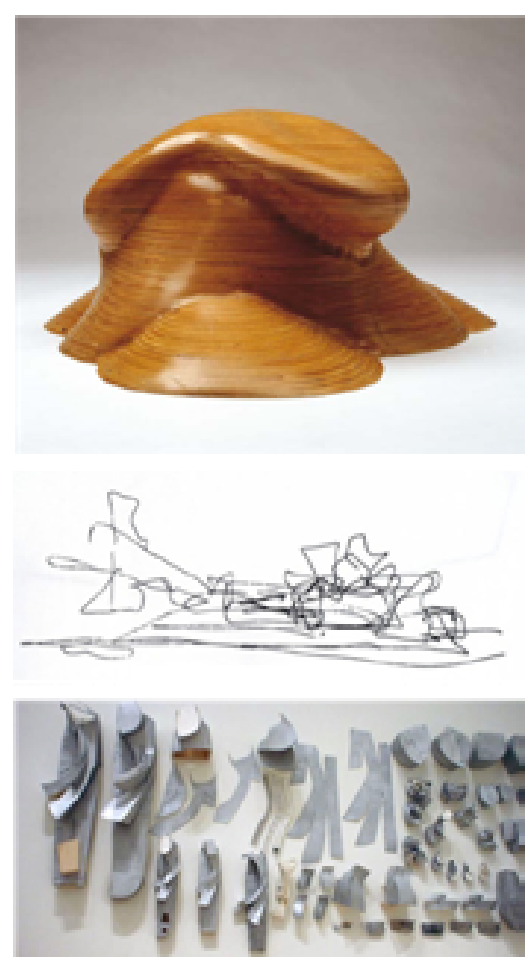

1.16. Objectile. BERNARD CACHE, PATRICK BEAUCÉ. Sans Titre, 1998

1.17. Croquis y despiece del Guggenheim de Bilbao. FRANK GHERY, 1995 externos o internos; lo aleatorio no altera la estructura general, cada escultura es específica pero el algoritmo les proporciona un trazo común, una especie de sustancia o genética común, como metáfora biológica, con referencias biomórficas y semejanzas a un organismo en continua modificación. Todo ello permite la reflexión sobre la forma; ya no hay una forma pura, es más bien una fluctuación de la norma. Hay un devenir-objeto, donde el interés reside también, aparte de su intención estética, en el proceso de concepción ${ }^{128}$.

Frente a estas propuestas teóricas, Frank Ghery, sin embargo, es el primero en producir formas construidas gracias a las oportunidades digitales. Apoyado por un equipo que hace posible trasladar sus famosos croquis a mano alzada a una modelización que puede ser parametrizada para llevarla a la construcción, creando un nuevo lenguaje de superficies complejas.

Peter Eisenman en su proyecto para Rebstock Park propone una visión alternativa del urbanismo directamente extraída de la experiencia de la informática. Eisenman caracteriza las transformaciones según el paso del paradigma mecánico al paradigma electrónico, pasando por alto de este modo, los contextos sociales, culturales, políticos y económicos, en definitiva, las circunstancias exteriores a la disciplina.

¿Pero a qué se debe esta proliferación de estas formas?, ¿es únicamente a una fascinación por las posibilidades de la nueva tecnología, que permiten la manipulación de formas que no se podrían diseñar con regla y con compás? Considerar únicamente esta razón de ser de una determinada expresión arquitectónica que parece imponerse, sería no estar teniendo en cuenta componentes culturales de otro tipo que trascienden la disciplina y que deben ser consideradas. Aloïs Riegl había hablado de una especie de voluntad artística (Kunstwollen) ${ }^{129}$, una pulsión o fuerza creadora inscrita en una energía más global que sería la que acoge favorablemente este tipo de formas curvas; existe una fuerza del espíritu humano que hace nacer afinidades formales dentro de una misma época, en todas sus manifestaciones culturales.

128. Cifr. FLORENCE PLIHON, Architectures Numériques et Résurgence Baroque: op. cit.

129. ALOÏS RIEGL, Der moderne Denkmalkultus, 1903. Traducción al castellano de Ana Pérez López, El culto moderno a los monumentos: caracteres y origen, Visor, Madrid 1987, La balsa de la Medusa. 
Aunque la arquitectura siempre fue dependiente de este tipo de evoluciones tecnológicas (basta pensar en las transformaciones sucedidas con la aparición de la perspectiva durante la época del Renacimiento), no creo que la aparición de las herramientas digitales y la nueva posibilidad de exploración de la forma arquitectónica a la que estas dan lugar, sea la consideración fundamental que haya que establecer en la relación barroco-postmodernidad, como en algún caso se ha defendido ${ }^{130}$. Parece más bien que las investigaciones formales sobre la inflexión y las superficies complejas se encuentran constituidas por configuraciones contextuales. Considerarlo de otro modo sería empobrecer la cuestión drásticamente. Los textos teóricos de Venturi y Rossi, confirman una relación más sólida, y anterior a la aparición de los programas 3 D. Del mismo modo esto se confirma por el interés en la filosofía francesa y en particular en el texto de Deleuze sobre el Barroco.

La exploración de la forma en el Barroco como referencia a tener en cuenta, nace simultáneamente en la arquitectura y en la filosofía y ambas disciplinas se enriquecen con las obras y los textos de la otra. El interés por el Barroco está presente en muchas de las manifestaciones culturales de la época, y en su interpretación postmoderna es especialmente fructífera.

El conocimiento geométrico es esencial en los desarrollos formales de los proyectos en ambos periodos. En los proyectos de Borromini, la herramienta es geométrica, hecho que comprobaremos a través del análisis de sus dibujos, y funciona como dispositivo geométrico de la misma manera que lo hacen los programas $3 \mathrm{D}$, aunque estos ofrezcan posibilidades imposibles de alcanzar en el siglo XVII, por mucha destreza en el uso de la geometría que se adquiriera. El desarrollo de herramientas digitales posibilita y facilita la exploración de la forma barroca llevándola hasta lugares que el propio barroco hubiera soñado.

Así, el Pliegue, que comienza siendo un concepto filosófico a partir de la interpretación deleuziana, se convierte también en una herramienta contra las imposiciones de la arquitectura moderna. A través de la herramienta digital se posibilitan las exploraciones de la forma que dan lugar a una arquitectura no estandarizada ${ }^{131}$; el objetil de Cache, proporciona los argumentos para esta consideración.
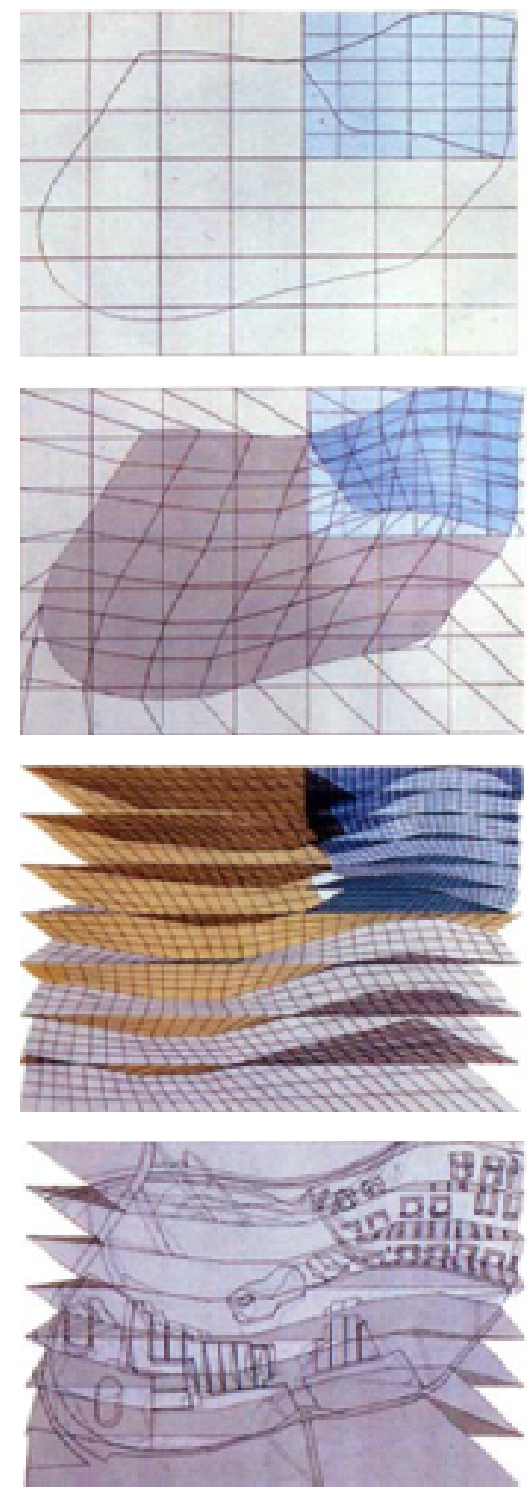

1.18. Masterplan, PETER EISENMAN, Rebestock park, Frankfurt, 1993 


\section{EL SIGNIFICADO DE LA FORMA-PLIEGUE:}

en la filosofía de Leibniz a partir de Deleuze

El pliegue es la forma barroca por excelencia según defiende Deleuze, en la pintura, la escultura, en la arquitectura, en la música, en los distintos modos de expresarse la cultura. La arquitectura barroca se pliega, se inflexiona como más adelante veremos. Pero Leibniz no habla del pliegue, habla de las Mónadas como sujetos o puntos metafísicos, no físicos. Las mónadas son algo vital, la naturaleza de las mónadas está en la fuerza; lo propiamente real es la fuerza, la potencia, la fuerza activa. Esta mónada como punto intensivo, lleva en su ser implícito todo su desarrollo, que está plegado en sí; plegado quiere decir aquí, oculto, no explícito, no desarrollado. Pero en este pliegue a la vez está contenida la fuerza para su desarrollo. Esto es lo que Deleuze llamará repliegues del alma.

Hay otro tipo de pliegues, los repliegues en la materia. Para Deleuze no hay separabilidad en la materia y esta hay que entenderla de tal modo que su unidad más pequeña sea el pliegue y no el punto, hay una continuidad. El alma aparece entonces como principio de unidad de la materia, y el alma se expresa en pliegues, que encierran estos impulsos o fuerzas (mónadas), pues la unidad de movimiento siempre tiene que ver con un alma.

El pliegue es producido siempre por una inflexión. En una línea de doble curvatura la inflexión alberga el lugar de cambio entre concavidad y convexidad; el punto de inflexión. Este punto de inflexión es el que genera el plegado y este punto tiene una función genética en la línea activa ${ }^{132}$. La línea activa es para él generadora de forma y su origen es un punto en movimiento, pone en marcha el proceso formativo. ¿ No tiene esa mónada de Leibniz, como fuerza activa, metafísica, su correspondencia en esa línea activa de Paul Klee que es algo físico? ¿Por qué el arte en el Barroco se desarrolla en torno al pliegue y a la vez el modo de pensamiento genera paralelismos conceptuales en la forma ontológica pliegue? 


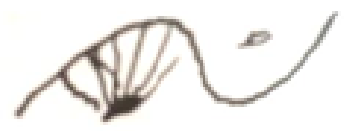

1.19. Dibujo en El pliegue, Leibniz y el Barroco. Los pliegues del alma. DELEUZE

\section{El pliegue y la inflexión llevan implícito el concepto de po-} tencia, de virtualidad.

Deleuze considera que el punto de inflexión es un Acontecimiento de la línea, una singularidad intrínseca a ella. Y es a partir del punto de inflexión, donde, al generarse el pliegue se generan, para ese pliegue, dos puntos de vista desde ambos lados de la línea plegada. Los puntos de vista son los puntos donde confluyen los vectores de curvatura del lado de la concavidad, donde se encuentran las perpendiculares a las tangentes de un tramo de la curva. Este punto (cada uno) dirá Deleuze que no es exactamente un punto sino un lugar, una posición, un sitio, y lo llama punto de vista en la medida que representa la variación en sí mismo. Este es el fundamento del perspectivismo de Leibniz; si el punto es considerado como un sujeto, la cosa no dependerá de un sujeto definido previamente, es más bien un sujeto lo que se instala en ese lugar, habiendo entonces una completa interdependencia del objeto y del sujeto.

Es una definición del lugar como posibilidad, un foco posibilitante, que hace posible una perspectiva sobre el mundo, y la mónada de Leibniz es ese punto vital que hace posible que la verdad se presente de un modo determinado a un sujeto. Es por ello una forma modal de comprensión y ya no esencialista. No podemos tampoco entenderlo como un relativismo pues, no es una variación de la verdad según el sujeto, sino la condición bajo la cual la verdad de una variación se presenta a ese sujeto ${ }^{133}$.

El perspectivismo es la perspectiva desde un lugar, desde un foco que posibilita la representación de la realidad. Según Deleuze, el foco es una potencia de ordenar, una condición para la manifestación de la realidad. Es desde aquí desde dónde emerge el problema de la interrelación entre estas mónadas plegadas que observan una realidad desde diferentes puntos o focos. Las mónadas no reciben influjo de fuera; lo extenso no puede influir en lo inextenso. No hay modo de explicar cómo la mónada pueda ser afectada por un accidente, son sólo un desarrollo de su propia esencia, todo lo que ocurre es autodespliegue. Según las propias palabras de Leibniz: la mónada no tiene ventanas.

Pero cada una de las mónadas contiene el mundo. Él habla del mundo como una serie convergente, única e infinita, que cada mónada expresa en su totalidad, aunque solo expresará claramente

133. GILLES DELEUZE, El Pliegue..., op. cit., Los pliegues del alma, pág 31. 
una parte de la serie. ¿Cómo entonces se compone el mundo?, porque la porción clara de una mónada se prolonga en la porción clara de otra y es aquí donde aparece el otro concepto esencial en la filosofía de Leibniz: la composibilidad.

Leibniz concibe un solo mundo que se compone, cada vez, desde las múltiples perspectivas (o expresiones) de la diferentes Mónadas o esencias, que crean como centros de envolvimiento. Hay un continum de este mundo com-posible, sino no sería posible. A través de esta composibilidad solo se da el mejor de los mundos posibles $^{134}$ ¿No es también la continuidad una regla estructurante de las composiciones de Borromini?

Pues como todo es un plenum - lo que hace que toda la materia esté conexa- y como en el plenum (...). ${ }^{135}$

\section{El plenum, además de asegurar la continuidad de la materia, apunta al campo de la virtualidad.}

El objeto (mundo-realidad-variación) y el sujeto, que es solo un lugar o punto de vista que capta esta variación, están interrelacionados y son interdependientes. Dice Deleuze que en el Barroco el alma tiene con el cuerpo una relación compleja, pues el pliegue pasa entre la materia y el alma y las separa, pero a la vez que las separa están necesariamente vinculadas, pues el sujeto solo tiene sentido en su relación con el objeto, que es su razón de ser. Esta contradicción Leibniz la solventa con el concepto de armonía; la armonía preestablecida remite al orden divino.

Para representar esta cuestión, Deleuze nos ofrece otro símil arquitectónico, incluso lo dibuja de forma alegórica. El Barroco diferencia los pliegues según dos tipos: los repliegues en la materia y los pliegues en el alma, como si el infinito tuviera dos pisos, nos dice. Abajo se acumula lo material, arriba las almas, y en el piso de arriba no existen ventanas. El gran montaje barroco de Leibniz está entre el piso de abajo perforado de ventanas y el piso alto ciego y cerrado $^{136}$. Dos pisos comunicados, pero con condiciones diferentes y una relación compleja ¿Por qué el problema del pensamiento barroco se despliega entorno al problema de esa correspondencia entre la extensión o lo material (realidad-mundo) y las almas, del

134. Cifr. G.W. LEIBNIZ, Monadología, en 48 o 55, por ejemplo. Trad: Juan Velarde, Biblioteca nueva, Madrid 2012.

135. G.W. LEIBNIZ, Monadología 61, 71, 73.

136. GILLES DELEUZE, El Pliegue..., op. cit., Los repliegues de la materia, pág. 11 y 12. 
mismo modo que la arquitectura construye interiores cerrados sobre sí mismos que no corresponden con las composiciones exteriores que articulan el espacio urbano?

Deducimos, por tanto una doble vinculación; por una parte una misma forma de expresión a través de la forma-pliegue, que es forma ontológica a la vez que es lenguaje arquitectónico, como modo de expresión cultural de un problema de fondo, que atañe a la comprensión del mundo-realidad; por otra parte, y relacionada con la primera, la atención a la problemática de la conexión entre el interior y el exterior en arquitectura, o lo que es análogo, la cuestión de cómo captan la misma realidad esas Mónadas sin ventanas, cual es la conexión entre esos dos pisos.

El pliegue, es una forma ontológica, es decir, una analogía formal que explica la ontología que propone Leibniz. En arquitectura el pliegue es una forma real, por medio de la cual la arquitectura se con-forma y se expresa, de un modo similar al que Leibniz se expresa con su pensamiento. Existen diferentes modos de expresión de las manifestaciones culturales; el pensamiento traza pliegues del mismo modo que los traza la materia arquitectónica o el mármol de la escultura, pero los pliegues de la filosofía nunca podrán ser materiales, aunque Deleuze tenga el ingenio necesario para describir los pliegues del pensamiento.

El pliegue es siempre potencial, y por ello señala a una especie de ámbito de virtualidad (ese plemum de Leibniz), donde la forma ha perdido su integridad. El pliegue apunta siempre a la continuidad de la materia, formada por pliegues y no por puntos.

Virtualidad - forma in-formada - continuidad, ¿no son los recursos de la arquitectura barroca? ¿y no vienen a ser también, de otro modo, los de la arquitectura contemporánea?

El pliegue es un concepto operacional e intermedio que describe el modo barroco de comprender el mundo. 


\title{
6. ACERCA DE LA TEMPORALIDAD Y LOS DESPLAZAMIENTOS
}

\author{
$Y$, sin embargo, esos seres del pasado viven en \\ nosotros, en el fondo de nuestras inclinaciones, \\ en el latir de nuestra sangre. Pesan sobre nuestro \\ destino. Son ese gesto que se remonta así desde la
} profundidad del tiempo ${ }^{137}$

Se considera oportuno, ya que la tesis trata de enlazar dos temporalidadades diferentes y llevar a cabo otros desplazamientos, realizar un breve análisis sobre algunas de las aportaciones más relevantes que se han hecho en relación con el sentido del tiempo y el papel de la cultura, procedentes de diversas disciplinas; desde el pensamiento filosófico, antropológico e histórico. Se examinan los enfoques de dos autores que han considerado decisivo el tema de la temporalidad en su obra. El problema de las transferencias interdisciplinares aparece implícito en las consideraciones sobre el tiempo de ambos.

Se esbozan así dos modos similares de atender a las transferencias que podemos llamar heterogéneas. Las consideraciones sobre la cuestión de la temporalidad se abordan en términos no estrictamente cronológicos, examinando cuestiones como los retornos, las supervivencias y los renaceres, explorando la posibilidad de establecer topologías inter-temporales.

La primera referencia procede de la filosofía, en concreto de la hermenéutica, y en el contexto de lo que se ha llamado postmodernidad. Se trata de las propuestas del filósofo alemán Hans Georg Gadamer. Esta hermenéutica, como casi todo el pensamiento que se configura alrededor del postmodernismo filosófico, tiene como antecedente a Nietzsche y se despliega en torno a su consideración de interpretación. Desde esta primera perspectiva se trata de fundamentar las correspondencias interdisciplinares o intertemporales desde el diálogo con las obras, la comprensión y la interpretación.

Nuestra segunda referencia procederá de otra temporalidad, otro contexto y otra disciplina. Se trata de la interpretación transversal 
de la historia del arte que propone el historiador del arte alemán Aby Warburg ${ }^{138}$, y que se articula a través de su término Nachleben, que se refiere a la supervivencia de las manifestaciones culturales, surgido a partir del análisis que hace del arte del Renacimiento. La noción de temporalidad en el pensamiento de Nietzsche parece que es también la que subyace bajo el modo de pensar el tiempo de Warburg.

Esta alusión nos parece muy pertinente en el contexto de la tesis, pues ayuda a comprender bien, no solo el sentido de la temporalidad que se maneja, sino también de alguna manera, la condición de la forma que analizamos a través de su noción de Pathosformel.

En definitiva, como el tema de la tesis trata de dar significado a los desplazamientos temporales en la historia de la arquitectura, no en un sentido literal, sino más bien como retorno de una diferencia, resultan muy relevantes las consideraciones de estos dos autores, cuya contribución se pretende que ayude tanto a la comprensión de estas transferencias temporales como de los desplazamientos disciplinares, dos cosas que parecen presentarse aquí como vinculadas.

138. ABY WARBURG Hamburgo (1866-1929), es un historiador del arte alemán. Sus obras principales: Die Erneuerung der heidnischen Antike. Kulturwissenschaftliche Beiträge zur Geschichte der europäischen Renaissance, Berlín, Teubner, 1932. Traducción al castellano, El renacimiento del paganismo: aportaciones a la historia cultural del Renacimiento europeo, Madrid, Alianza, 2005. Schlangenritual: Ein Reisebericht, Berlín, Klaus Wagenbach, 1988. Trad.: El ritual de la serpiente, Madrid, Sexto Piso, 2008. Der Bilderatlas Mnemosyne. Trad.: Atlas Mnemosyne, Madrid, Ediciones Akal, 2010. 


\subsection{LA APORTACIÓN DE LA HERMENÉUTICA POSTMODERNA}

La experiencia del arte, nos dice Gadamer, nos habla de un modo inmediato, como si no hubiera ninguna distancia histórica, existiendo una especie de simultaneidad entre la obra y el que la contempla. La obra no se deja limitar al horizonte histórico originario. Hay así una inagotabilidad en toda declaración artística; esta siempre, inevitablemente abierta para nuevas interpretaciones. El desplazamiento temporal entonces, no pasara por una contextualización o una restitución de la distancia histórica, Gadamer nos habla de esta inmediatez en la recepción, que invita a pensar en una especie de simultaneidad temporal, de conexión inmediata. La obra de arte es así de un presente intemporal, aunque esto no quiera decir que no suscite un problema de comprensión, incluso de origen histórico ${ }^{139}$.

Pero la obra es portadora de una función vital con significado en un espacio cultural y social determinado en el cual se genera, y que es donde se determina plenamente su sentido. Por ello, ¿la obra procedente de otra temporalidad se convierte en mero objeto de un placer estético-histórico y no dice nada más que lo que expresaba originalmente? ${ }^{14^{0}}$ Está pregunta que se hace Gadamer está en realidad vinculada a determinar lo esencial artístico. Plantea un problema de fondo en el cuál, la obra de arte se expone entre su significado original que proviene de la percepción histórica del mundo en el que se realiza, y su capacidad de expresión inmediata.

Hay una especie de expectativa de sentido que regula desde el principio la comprensión de la obra, una especie de potencialidad que lleva implícita. La hermenéutica tiende un puente sobre la distancia entre espíritu y espíritu, revelando así la extrañeza del otro. Esta revelación de lo extraño, no quiere decir aquí acceder a una reconstrucción histórica donde la obra tenía su significado original; tiene que ver también con la recepción directa de lo que dice. La obra se actualiza cada vez, contiene un potencial de significado que excede su historicidad y su autoría; hay un exceso de sentido en la obra misma, y donde reposa su inagotabilidad.

139. Cifr. HANS GEORG GADAMER, Estética y hermenéutica (recopilación de textos), Traducción al castellano de Antonio Gómez Ramos, Tecnos 1996. Capitulo 1: Estética y hermenéutica, 1964. 
De este modo podemos decir que se trata de una ontología hermenéutica, que crea un espacio de posibilidad a-temporal relacionado con el Ser. Este espacio congrega los tiempos diversos, congrega las cosas en su mutua pertenencia. Como nos dice Heidegger:

La plástica (o la obra de arte): la corporeización de la verdad del ser en la obra que instaura lugares ${ }^{14}$.

La intención de esta investigación es abordar las obras del Barroco histórico en su estatus como obras de arte, por tanto, y siguiendo a Gadamer, aún abiertas para su lectura e interpretación, aún portadoras de sentido. No se trata de aceptarlas o tomarlas como un mero objeto, como un ente común, sin lectura ni interpretación posible más que en lo que se refiere a su pura descripción. No se trata tampoco de una lectura histórica de estilo ni de composición. Se trata más bien de recibirla en el espacio arquitectónico contemporáneo, de reinterpretarla en su esencialidad arquitectónica, recibirla en ese espacio que podríamos llamar ontológico del que habla Heidegger.

Deleuze, en su ontología del Pliegue, se está refiriendo a formas ontológicas. Las formas del arte no se quedan en la pura objetualidad, encierran la potencialidad de lo que transmiten, hay una recepción de la obra de arte que del mismo modo escapa a la consideración de la obra únicamente como ente. La obra, el concepto filosófico, mantienen su palabra dispuesta para todo futuro, las constelaciones históricas determinan de modo variable nuestra receptividad ${ }^{142}$. Estas constelaciones forman la misma geografía a la que se refiere Deleuze. La referencia a una constelación, como topografía, es también espacial, geográfica.

Gadamer habla del gran contexto de sentido como tarea para la interpretación. Para él comprender una obra no quiere decir actualizar de nuevo en sí los pensamientos del autor, y así, nos dirá que el lenguaje del arte está dotado también de un exceso de sentido que reside en la obra misma y sobre el que reposa su inagotabilidad.

141. MARTIN HEIDEGGER, El Arte y el Espacio, op. cit., pág. 33 
Una expectativa de sentido regula desde el principio el esfuerzo de comprensión ${ }^{143}$.

La comprensión, además, es algo dinámico y cambiante, una especie de acontecer incesante, protagonizado por el lógos de la obra: su potencialidad o capacidad de producir sentido. La comprensión tiene su enclave principal en el diálogo. Es como si el conjunto de las obras se diera en sincronía, permitiendo así el diálogo directo con textos y obras de otras epocalidades. Podríamos decir que pone en obra un espacio ontológico y relacional, abre un espacio de posibilidad.

¿Qué aporta a esta investigación el análisis de la hermenéutica? Principalmente se trata de abordar el significado de la comprensión y la interpretación de obras, que es donde reside el contenido principal de esta tesis. Se trata de argumentar la forma de abordar el trabajo. Las propuestas de la ontología hermenéutica de Gadamer, son el argumento que resuelve tanto la posibilidad de nuevas lecturas de las obras, como la legitimidad de las transferencias de conceptos entre disciplinas. Pues si la obra es únicamente objeto, su lectura desde campos ajenos a su contexto físico, científico o técnico no será pertinente, pero si de lo que se trata es de una obra plástica, si se trata de arte, como nos recuerda Heidegger, abre lugares, ella misma es un lugar, congrega las cosas en su mutua pertenencia ${ }^{144}$.

Gadamer, en su texto sobre Heidegger, se pregunta cómo es posible la comprensión, se pregunta por el conjunto de la experiencia humana del mundo y de la praxis vital:

La analítica temporal del estar ahí humano en Heidegger ha mostrado en mi opinión de una manera convincente, que la comprensión no es uno de los modos de comportamiento del sujeto, sino el modo de ser del propio estar ahí; la hermenéutica abarca el conjunto de su experiencia en el mundo (del Dasein). ${ }^{145}$

La comprensión no es nunca un comportamiento subjetivo respecto a un objeto dado, sino que pertenece a la historia efectual, esto es, al ser de lo que se comprende. ${ }^{146}$ 
El pensamiento de Gadamer se presenta según una ontología de la comprensión que, radicalizando la hermenéutica tradicional, considera que la vida humana está íntegramente inmersa en el acaecer de la comprensión. Va más allá de la forma tradicional de la hermenéutica donde esta consistía solo en un método para alcanzar un conocimiento cierto y seguro. El comprender se encuentra más allá de la distinción metódica. La verdad es previa, anterior y superior a la cuestión secundaria del método ${ }^{147}$. Hay siempre una co-implicación en la comprensión de una obra, donde la distancia original entre el texto-obra y el espectador-lector se congregan en una especie de fusión de horizontes. Gadamer elimina así la mera oposición sujeto-objeto; en el punto de partida de la comprensión están co-implicados los seres humanos y el mundo, hay entre ellos una recíproca pertenencia.

¿No estaríamos simplificando el análisis, o al menos empobreciéndolo si consideramos el Pliegue de Deleuze como una simple metáfora explicativa sin relación posible con la arquitectura, el arte y la cultura? ¿No hay otras implicaciones que conciernen a otras disciplinas y que pueden ser comprendidas, interpretadas, que abren lecturas y significados, que dan sentido a la obra? Es el gran contexto de sentido al que se refiere Gadamer al que queremos dirigir el análisis. El contexto de sentido que el espacio postmoderno ofrece para la interpretación y la comprensión, el carácter potencial de la obra.

La obra se encontrará en un presente absoluto para cada presente respectivo, y a la vez, mantiene su palabra dispuesta para todo futuro $^{148}$.

El panorama filosófico postmoderno se funda también a partir de una interpretación: la lectura contemporánea de los textos de Nietzsche. Quizás pueda tratarse de un elemento común a casi todos los autores que forman este espacio postmoderno. Gadamer, al trazar el sentido de la Obra, como espacio abierto a la posibilidad de su lectura, se fundamenta en la idea nietzschana del Eterno Retorno. Un retorno de la diferencia, pues, la apertura de sentido que en la obra reside, presenta la diferencia de lectura cada vez; lo uno (las obras) son múltiples y forman espacio; lo mismo, lo que vuelve, su lectura e interpretación, es siempre diferencial. Solo retorna la diferencia.

147. Cifr. HANS GEORG GADAMER, Verdad y método, op. cit. 
Gadamer propone dejar hablar a la obra, en particular dice: dejar que la obra vuelva a hablar, como si su recepción se produjera cada vez. De este modo se opera una apertura del pasado; los pasados son posibles y surge un pasado anterior ${ }^{149}$.

La obra de arte de las artes plásticas, así como la arquitectura, hay que aprender a verla, tendremos que leerla como si fuera un texto, aprender casi a deletrearla. No se trata de que un observador que apresa un objeto, en la interpretación y la comprensión de una obra sucede otra cosa: se forma parte en la figura de sentido que con-figura la obra, algo que no se deja alcanzar ni regular en su carácter de dato objetivo, sino que irradia un significado que la distingue como conformación ${ }^{150}$.

La obra de arquitectura no es un objeto cualquiera para analizar únicamente en su composición, es su particular con-formación la que nos permite llevarla más allá, la que revela su sentido y su significado. Las aportaciones de otras disciplinas, serán en este sentido, otros lenguajes que nos permiten ampliar la recepción de la obra, y las lecturas de obras históricas aún permanecen abiertas a la interpretación. No estamos hablando, por tanto, de objetos cualesquiera, las obras tratadas son Obras que han sido admitidas y subrayadas, recibidas como Arquitectura. La obra de Borromini en particular, como obra canónica, ha sido recibida y asentada, sedimentada, perteneciendo ya a lo que Gadamer llama historia de los efectos ${ }^{151}$, como urdimbre de la tradición, cuya autoridad como monumenta asegura la potencialidad de su sentido, que, como un texto, es capaz de ser comprendida e interpretada una y otra vez.

\footnotetext{
149. Sobre los pasados posibles y el futuro anterior se puede consultar: TERESA OÑATE, CRISTINA G. SANTOS y MIGUEL ÁNGEL QUINTANA: Hans-Georg Gadamer: Ontología Estética y Hermenéutica. TERESA OÑATE, La teología de la esperanza oculta en el límite de la Hermenéutica.
}

150. Cifr. HANS GEORG GADAMER, Estética y hermenéutica, op. cit., Sobre la lectura de edificios y de cuadros. 
Se analiza aquí brevemente la comprensión del tiempo que nos propone Warburg, estructurada en torno a los conceptos de $\mathrm{Na}$ chleben y Pathosformel, ambos organizados alrededor del significado nietzschano de Eterno Retorno. El propio concepto de Pathosformel, como intensificación de la forma y expresión del devenir y el movimiento, está vinculado a nuestra comprensión de las formas que investigamos.

\section{Nachleben}

Para Warburg la historia del arte no es como un hilo continuo donde las cosas se transmiten de un punto a otro, sino más bien un sistema tenso lleno de remolinos, una especie de complejidad simbólica. Y este modo de entenderla ayuda a la comprensión de todo renacer de las imágenes, que es el camino por donde esta investigación quiere transitar.

Aby Warburg propone una expresión transversal de la historia del arte a través de un nuevo modo de interpretar la imagen, que se articula en torno a los conceptos de Nachleben, como supervivencia, o vida que pervive, y Pathosformel. El concepto de Nachleben ha sido central en la reflexión de historiadores, filólogos y antropólogos durante el siglo XX, Freud, Simmel o Benjamin son un ejemplo. Todos ellos han centrado sus intereses, aunque desde puntos de vista distintos, en la supervivencia de las manifestaciones culturales. Pero este concepto se emparenta espacialmente con el sentido de las propuestas de Nietzsche sobre el Eterno Retorno y, por ello, con toda la herencia que se desencadena con la recepción de este último autor en las últimas décadas de este siglo, vinculado al espacio postmoderno descrito. El interés por los retornos y la supervivencia de las manifestaciones culturales es también de interés para este texto.

Warburg sugiere una perspectiva de la historia fuera de la habitual linealidad, remite a una concepción no cronológica y no cancelada, abriendo una multiplicidad de tiempos. El historiador no se encuentra en una posición de dominio sobre el material temporal, no es el amo de un tiempo explicado, sino súbdito de un tiempo 
implicado ${ }^{152}$. Elabora la noción de Nachleben en el marco del Renacimiento italiano. Esto ya en sí resulta una provocación, pues supone juntar los términos Renacimiento y supervivencia. El análisis del Renacimiento abre una polémica teórica sobre el estatus mismo del discurso histórico.

En el modelo cultural de la historia que propone Aby Warburg, los tiempos se expresan por estratos, bloques híbridos, rizomas, complejidades, sustituyendo un modelo ideal de la historia por un modelo fantasmal ${ }^{153}$, que se expresa por supervivencias. Esto podría ser análogo al modo en el que la forma-pliegue, como forma barroca, sobrevive y se presenta como actual.

La historia del arte, en el sentido moderno, define un ideal artístico que se aleja de términos como expresión, violencia, alteración etc., podríamos decir que se delimita en la negación del pathos, recurriendo a la imitación como idea articuladora, y la imitación no permite un renacimiento sino es con la condición de imitar un ideal. Es de este modo como se había construido la historia del arte en el humanismo con Vasari y como se articula también en el neoclasicismo con Wilckelmann. Lo que Warburg se pregunta es si puede existir un retorno de las imágenes que no estén sometidas a la imitación, un cierto género de similitud que no sea la imitación de un ideal.

El enfoque de esta tesis quiere ser coincidente con este modo de pensar lo que sobrevive o se repite o vuelve, sin imitación. Un posible Neobarroco, que no parece tratar de imitar una imagen del Barroco, sino que responde a interrogantes culturales, y es detectado más bien por síntomas. ¿Por qué ese interés por una nueva interpretación de la forma-pliegue aplicada al uso de las nuevas tecnologías?, ¿o por qué se reivindica la complejidad en la arquitectura y la contradicción como pulsión o potencia de movimiento?

George Didi-Huberman, también historiador del arte y ensayista, dedica un texto completo a la interpretación de la historia del arte de Warburg a través de las imágenes ${ }^{154}$. El tiempo de la imagen no

152. Cifr. GEORGES DIDI-HUBERMAN, L'Image supervivante, Historie de l'art et temps des fantomes selon Aby Warburg, Les editions des Minuit, 2012. Traducción al castellano: La Imagen Superviviente, historia del arte y tiempo de los fantasmas según Aby Warburg. Georges Didi Huberman (1953), historiador del arte y ensayista francés, se ha ocupado en este texto de analizar en profundidad el concepto de Nachlaben de Warburg.

153. Cifr. Ibid.

154. Cifr. Ibid. 


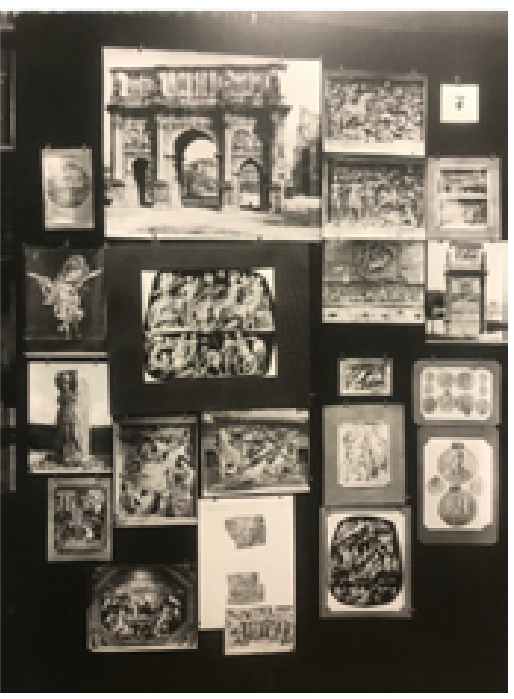

1.20. Imagen del atlas Mnemosine. ABY WARBUG es el tiempo de la historia, Warburg plantea desvincular la imagen del tiempo que lleva consigo. Se trata de sacar a la luz la complejidad de las relaciones que constituyen una imagen, él utiliza la perspectiva antropológica; la antropología desplaza y desfamiliariza, y la imagen emerge así como un fenómeno antropológico total, que se estructura en relaciones que no tienen que ver con una historia cronológica sino con una sedimentación.

La imagen no puede disociarse del actuar global de una sociedad, y Warburg pasa así de una historia del arte a una ciencia de la cultu$r \mathrm{r}^{155}$. De esta manera se puede interpretar el arte como un depósito de relaciones, un espacio relacional, cercano al espacio ontológico de Heidegger. La obra de arte no es considerada como un objeto cerrado sobre su propia historia, sino como un encuentro dinámico de instancias históricas heterogéneas. Estas consideraciones vinculan la teoría de Warburg directamente con la hermenéutica de Gadamer, en cuanto a la apertura de interpretación que la propia obra desencadena, o la posibilidad de un depósito de sentidos.

Lo que constituye la expresión de la cultura es para Warburg el síntoma, lo inesperado, lo anacrónico, las supervivencias fantasmales, que renacen como nudos de anacronismos, mezcla de cosas pasadas y presentes, mostrando un presente que está entretejido con múltiples pasados. Esta imagen superviviente no sobrevive triunfalmente sino sobrevive fantasmalmente, apareciendo en un momento donde no se la espera ${ }^{156}$. Warburg lo entendería como la delimitación de un objeto inaudito y anacrónico, fabricando un sistema de préstamos heterogéneos, en línea con las heterocronías de Michael Foucault ${ }^{157}$, como convivencias simultáneas, sincrónicas de tiempos heterogéneos.

Didi-Huberman señala que para Warburg la vida de la historia tiene que ver con una morfología, con un juego de formas, entendiendo por formas la cristalización sensible de la dialéctica que se establece entre los elementos estables y los potenciales móviles de una cultura. Y no hay una morfología o análisis de la forma sin un análisis de las fuerzas latentes en ella ${ }^{15^{8}}$. Se trata de compren-

155. Cifr. Ibid.

156. Cifr. Ibid.

157. MICHAEL FAUCAULT, Le corps utopique. Les heterotopies, Nouveles editions Linges 2009, de Des espacies Autres. Espace, savoire et pouvoire, Editions Gallimard 1994. Traducción al castellano de Victor Goldstein, El cuerpo utópico y las heterotopías, ediciones Nueva Visión, 2010.

158. Cifr. DIDI-HUBERMAN, op. cit. 
der el tiempo como un juego de fuerzas y de potencias. Para Warburg una imagen no es algo cuyas fronteras precisas podamos trazar, sino el resultado de movimientos que provisionalmente han cristalizado en ella ${ }^{159}$. Estos movimientos, esta inestabilidad, la atraviesa completamente. Habría entonces que pensar la imagen como un momento energético o dinámico. Se trata de representar lo que no se ve.

El tiempo arrastra tras de sí las formas, que son el soporte de la vida del espíritu (....). ${ }^{160}$

La forma es entonces para Warburg también el lugar del análisis de la cultura, paralelamente será para nosotros el lugar de significado, en último término, del enlace épocal entre nuestra actualidad y el Barroco.

Warburg va a utilizar una metáfora similar a la del pliegue para expresar su sintomatología del tiempo; el juego temporal de latencias y crisis es formulado como las oleadas. Las ondas de la memoria atraviesan a la cultura. El pathos, para Warburg es lo que recoge los movimientos invisibles. A modo de un sismógrafo Warburg recoge estas ondas, registra todas las patologías del tiempo. Aunque Warburg es contemporáneo de Nietzsche, piensa a la vez que él (o quizás lo leyera) ${ }^{161}$ la posibilidad de los retornos, pues Nietzsche planteaba ya esta sismografía del tiempo con su noción del Eterno Retorno, incluso quiso darle una expresión gráfica dibujando algo así como el movimiento del tiempo. El tiempo para ambos está pensado en relación con la fuerza:

El tiempo prueba que una fuerza está desprovista absolutamente de permanencia. ${ }^{162}$

No parece que Nietzsche se esté refiriendo a una relación entre el tiempo, la fuerza y el movimiento de tipo cinético. Más bien

159. Cifr. Ibid. Veremos más adelante como esta afirmación se adentra plenamente en la comprensión de la forma en el Barroco.

160. J. BURCKHARDT, Considérations sur l'historie universalle. Citado por Didi Huberman.

161. Nietzsche y Warburg son contemporáneos. Nietzsche es un poco mayor que Warburg pues nace en 1844 y Warburg en el 66. Esa diferencia de poco más de veinte años hace que sea posible que Warburg leyera el Zaratustra de Nietzsche, publicado en 1883.

162. FRIEDRICH NIETZSCHE, Fragments posthumes, Gallimard, París 1990. Traducción al castellano Fragmentos póstumos, Tecnos 2008. Citado por G. Didi-Huberman, op. cit. 
parece que plantea el movimiento en una contradicción entre el espacio y el tiempo, algo así como establecer las relaciones temporales según las fuerzas actuantes, ver la diferencia en la repetición, una especie de tiempo discontinuo dominado por estas ondas $u$ oleadas, trazadas por fuerzas, pero fuerzas que nunca pueden ser exactamente iguales:

Solo pueden actuar fuerzas absolutamente modificables, fuerzas que no sigan siendo ni por un instante idénticas a sí mismas. Todas las fuerzas no son sino una función del tiempo ${ }^{163}$.

En estas oleadas sucede la misma cosa que en el gran contexto de sentido de Gadamer, las fuerzas que retornan en estas sismografías, nunca son iguales: solo retorna la diferencia.

Nietzsche dibuja una línea quebrada compuesta por puntos, no hay más que puntos temporales totalmente diferentes, nada de línea, escribe. Y después registra por encima de todo ello los tiempos redundantes, pequeños y grandes retornos: en definitiva, es un entrelazamiento de los tiempos ${ }^{164}$.

Warburg explora la temporalidad desde la investigación de las imágenes,. Podría su forma de abordar el tiempo estar vinculada a una especie de pliegue, a una cierta comprensión de la forma plegada como contenedora de potencia, portadora de fuerzas capaces de desplegarse, también en relación con un desplegamiento del tiempo. Parte de aquí su concepto de Pathosformel, que contiene en sí una tensión inconclusa, que proviene de una forma originaria de entender el arte.

\section{El Pathos}

Nietzsche, en su obra El Nacimiento de la Tragedia ${ }^{165}$, ya había advertido el sentido tensional que le tragedia griega, que él consideraba el centro-matriz que el arte mismo ${ }^{166}$, llevaba implícito. La tragedia contenía una especie de dolor originario que renacía cada

163. Ibid.

164. Cifr. Didi-Huberman, Op, cit.

165. FRIEDRICH NIETZSCHE, Die Geburt der Tragödie, aus dem Geiste der Musik, 1872. Traducción al castellano de Andrés Sánchez Pascual, El nacimiento de la tragedia, Alianza Editorial, Madrid 1973. 
vez. En ella los polos apolíneo y dionisiaco se mostraban como contradicción no aplacada. Trataremos este tema más adelante ${ }^{167}$.

Hay dos elementos que nos interesan en su interpretación; por una parte, la supervivencia de esta especie de dolor que saca a la luz los elementos no estetizantes, sino más bien vitales del sentido del arte; por otra la tensión, la polaridad entre lo apolíneo y lo dionisiaco que Nietzsche considera como base original de la tragedia ${ }^{168}$. Por tanto, tenemos una transposición temporal, una supervivencia que se reproduce una y otra vez, pero siempre modificada, como sentido originario del arte; y una tensión siempre implícita que nos remite a un vitalismo o fuerza vital contenida en el arte y que no podremos reducir nunca a elementos objetivos.

Encontraremos todos estos elementos en la obra de Borromini: una fuerza vital contenida en la forma, y un elemento trágico. El modo de canalizar la fuerza vital contemporáneo tendrá otras expresiones, pero lo encontramos igualmente en nuestra arquitectura. La noción de Pathos de Warburg es especialmente relevante para nuestro análisis.

Warburg considera todas estas cuestiones precisamente en su análisis del arte del Renacimiento, del momento del renacer de la cultura griega y romana. El arte del Renacimiento es pensado habitualmente como un modo de expresión equilibrado, natural y sereno, sujeto a normas, proporciones e ideales artísticos (véase la proliferación en arquitectura de tratados ${ }^{169}$ ). Warburg descubre un Renacimiento que califica de impuro, no es posible simplificarlo bajo su lectura supeditada a la imitación de un ideal; la mezcla de elementos heterogéneos muestra lo que hay de vital en esta cultura. En la idea de Renacimiento se arrastra un resurgir de un helenismo vital, que Warburg descubre en detalles y ejemplos, en síntomas, acceder a ello requiere una especie de psicología de la cultura. Este helenismo llevará implícito el espíritu de Dionisio, y con él la violencia, la desmesura, el exceso. Notaremos más adelante, como esta desmesura cristaliza en la obra de Borromini. Así

167. Véase infra, págs. Parte II, Capítulo 4, págs. 295-299.

168. Nietzsche en su texto sobre la tragedia griega considera que el origen de la tragedia en el coro trágico y este coro habla la sabiduría dionisiaca de la tragedia, nos dice. FRIEDRICH NIETZSCHE, op. cit.

169. Por ejemplo el que dedica Alberti a la arquitectura: LEON BATTISTA ALBERTI, De re aedificatoria, ed. Akal, 2007. También hay que señalar la emergencia de las grandes utopías morales que llevan aparejadas descripciones físicas de modelos ideales de ciudades: Utopía de Tomas Moro, La Ciudad del Sol de Campanella, o Nueva Atlántida de Bacon. 

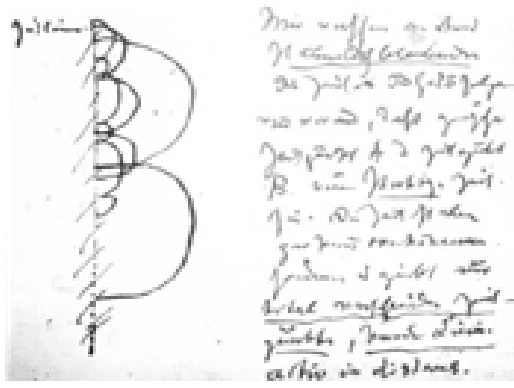

1.21. Esquema dinámico del tiempo, dibujo a tinte tomado de los Fragmentos póstumos. FRIEDRICH NIETZSCHE, 1873 mismo, la forma-pliegue en el texto de Deleuze, también participa en su formación de esta idea trágica de la desmesura:

El elemento formal del pliegue (...) solo puede aparecer con lo infinito, en lo inconmensurable y en la desmesura, cuando la curva variable ha destronado al círculo ${ }^{170}$.

Si Warburg en el Renacimiento, a través de la deriva helenística del arte clásico, encuentra ya la noción de Pathos, podríamos decir que Borromini también la localiza en lugares dispersos y periféricos, pues las fuentes donde se inspira son siempre arquitecturas no canónicas, residuales; es donde el encuentra este Pathos del que toda su obra participa.

Warburg traspasa la polaridad nietzschana entre apolíneo y dionisiaco a una oposición entre el ethos y el pathos. Y su comprensión de una civilización la establece a partir de sus síntomas y malestares $^{171}$, en relación con el espíritu trágico antiguo como matriz de la cultura occidental, así, para Warburg la cultura es esencialmente trágica.

Nietzsche había reivindicado la historia como una cuestión vital, un devenir, que no podrá nunca reflejarse en una imagen fija, necesitando el movimiento, la metamorfosis, los flujos y los retornos intempestivos ${ }^{172}$. El devenir tiene, por tanto, su raíz en el movimiento, y este no estriba más que en una articulación de fuerzas, como lo es la polaridad ethos-pathos, cuyo juego recíproco hace posible este movimiento. Es como una especie de nudo de tensiones, una complejidad puesta en marcha ${ }^{173}$.

¿No parece esta comprensión del devenir establecida sobre la existencia de fuerzas y tensiones, algo análogo al significado último del punto de inflexión como generador del pliegue? El punto de inflexión es un elemento potencial en un continuo; una idea del devenir casi como una materia plástica, capaz de todas las transformaciones, pero donde algo permanece, sobrevive, ese conti-

170. GILES DELEUZE, El Pliegue... op. cit., ¿Qué es el Barroco?, pág. 54.

171. Se puede observar también su vinculación con Freud en este punto.

172. FRIEDRICH NIETZSCHE, Consudérations inactuelles, citado por Didi-Huberman, op. cit.

173. GEORGES DIDI-HUBERMAN, op. cit., La imagen Pathos. 
nuo, que solo admitirá el cambio a través de la metamorfosis, una metamorfosis capaz de una difuminación relativa ${ }^{174}$.

Supervivencia y metamorfosis terminarán por representar el eterno retorno mismo, en el que la repetición no se dará jamás sin su propio exceso y la forma sin su irremediable vocación a lo informe ${ }^{175}$.

La forma en devenir, no podría nunca representarse. Hay una cierta contradicción entre forma y fuerza, que podría resolverse en este concepto de lo in-forme. Pero en el arte plástico, en la arquitectura, forma y fuerza deben unirse necesariamente, en el intento de representar lo invisible, esa fuerza o potencia generada por la tensión. Es a través del concepto de Pathosformel como Warburg consigue unir estas dos cosas que el pensamiento parece concebir como contradictorias: la fuerza y la forma. El Pathosformel es por lo que la imagen late, se mueve, se debate en la polaridad de las cosas.

Ernst Cassirer hablando sobre este término warburiano dirá que:

Allá donde otros habían visto formas determinadas delimitadas, formas que descansaban en sí mismas, él veía fuerzas en movimiento, lo que él llamaba las grandes formas del pathos, que la antigüedad había creado como patrimonio perdurable de la humanidad ${ }^{176}$.

Es como una expresión de la expresión como explicitar el contenido del símbolo. En el concepto de Pathosformel aparece implícito este problema teórico de la expresión (y con él las filosofías de la inmanencia $\left.{ }^{177}\right)$, tanto como las filosofías del símbolo.

En la interpretación de Didi-Huberman, la noción de Pathosformel, no solamente no se opone a la forma, sino que la lleva a su grado más alto, la intensifica, le da vida y movimiento. También Deleuze en su texto sobre el Pliegue señala que no se debe enten-

174. Didi-Huberman señala que es una especie de relación inédita entre lo universal y lo singular, donde lo universal sabe deformarse bajo el impulso del objeto local. GEORGES DIDI-HUBERMAN, op. cit., La imagen Pathos.

175. GILLES DELEUZE, Diferencia y Repetición, op. cit.

176. ERNST CASSIRER, Éloge funébre du professeur Aby Warburg, Euvres XII, Éscrits sur l'art, 1929. Citado por Georges Didi-Huberman, op. cit.

177. Este tema de la expresión en la filosofía de la inmanencia lo desarrolla en profundidad Gilles Deleuze en Spinoza et le problème de l'expression, Minuit 1968. Traducción al castellano de Horst Vogel, Spinoza y el problema de la expresión, Muchnik editores, Barcelona 1996. 
der lo informe como negación de la forma, sino más bien expresa la forma como plegada. En su despliegue, a estas formas Deleuze las llama maneras. Hay que entender lo informe como el extremo donde la forma se desvanece en su expresión para pasar a otra distinta, es algo llevado al extremo, sobre-expresado, que contiene todo ese pathos originario del que habla Warburg.

Esta tesis trata de investigar formas que expresan fuerzas, ¿no se estará entonces siempre aquí hablando de Pathosformel?

Estas nociones se encuentran oscilando en el centro de la investigación, tanto en el contenido de lo que se investiga, o, podríamos decir en el resultado de la investigación, como en su propuesta general de relaciones inter-temporales como los retornos intempestivos. 
PARTE II. EL ESTATUTO DE LA FORMA EN SU RELACIÓN CON EL ESPACIO

\author{
1. LA INFLEXIÓN Y SUS EFECTOS \\ 2. EL MODO DE LA REPETICIÓN \\ 3. LA CONDICIÓN DEL ESPACIO: TOPOLOGÍAS \\ 4. LO IN-FORME. DESMESURA, METAMORFOSIS E INDIVIDUACIÓN \\ 5. EL ESTATUTO DE LA ENVOLVENTE \\ 6. REFLEXIÓN SOBRE EL TIEMPO \\ La noción de la naturaleza: una estética de lo efímero
}




\title{
INTRODUCCIÓN A LA PARTE II
}

\author{
Para producir un monstruo, de poco sirve la pobre \\ receta de amontonar determinaciones heteróclitas \\ o de sobredeterminar el animal. Más vale hacer \\ subir el fondo y disolver la forma ${ }^{178}$.
}

En la primera parte de esta investigación hemos ya señalado como, desde la década de los 70 del siglo pasado, viene manifestándose un reiterado interés por la reinterpretación del Barroco histórico. El tema de la posibilidad de un Neobarroco viene respaldado por varios autores de una manera más o menos explícita y asociado, en muchos casos, al periodo llamado postmoderno.

Omar Calabrese, Gilles Deleuze, Jaques Lacan, Walter Benjamin, Christine Buci-Gluksmann; y en arquitectura, figuras como Bernard Cache Greg Lynn, Peter Eisseman, e indirectamente Robert Venturi, son algunos de los nombres más relevantes que se puedan citar.

Todas estas propuestas son teóricas (salvo quizás las de Venturi, aunque lo que interesa aquí es más bien el contenido teórico de sus textos). También las que se refieren a la arquitectura de la mano de Cache y Lynn, aunque se pongan en práctica a partir de maquetas y modelos digitales, pero no consiguen dar el salto de escala. Lo que esta tesis pretende es poner en carga esta relación con el Barroco a través del análisis de obras de arquitectura, que es la cuestión que se aborda en esta parte segunda.

Aunque la reinterpretación neobarroca del arte actual se resiste a forzar analogías estrictas con el entendimiento clásico del Barroco histórico, trataremos de buscar un fondo común en la comprensión general y un mismo sentido en el modo de expresión de la arquitectura en ambos periodos. Se trata de detectar vinculaciones profundas que se alejen de similitudes formales superficiales, por ello se recurre al respaldo de la interpretación filosófica.

Con esta intención se inicia el análisis propiamente dicho poniendo en relación la obra de Borromini (ya se ha justificado en la parte 
I la elección de este autor) ${ }^{179}$, a través de una serie de rasgos o figuras significativas, a modo de parámetros de referencia que se han extraído del propio análisis de su obra, con obras del lo que se ha considerado el espacio postmoderno.

La mayoría de los casos que se tratan de este espacio postmoderno en el ámbito de la arquitectura, proceden del periodo que podríamos llamar contemporáneo, desarrollado a partir del cambio de siglo. Sin embargo, se recurre también en el plano teórico a autores anteriores, como los textos de Venturi y Rossi o las propuestas de Bernard Cache y Greg Lynn, que son utilizados en la argumentación, y nos dan la base para considerar como muchas de sus propuestas siguen vigentes. También se acude a otras manifestaciones artísticas más o menos contemporáneas y quizás más dispersas en el tiempo, como son los casos de Bill Viola, James Turrell o Esther Ferrer. Todas las obras consiguen trazar un ámbito a través de sus relaciones recíprocas que es lo que hemos llamado espacio postmoderno. No se pretende justificar la elección de las obras escogidas de esté espacio, ni tampoco de elaborar un análisis exhaustivo de las mismas. Solo se considerarán los aspectos que sean más oportunos para cada figura que se esté analizando en cada caso.

Con respecto a los rasgos significativos, se extraen del análisis de la obra de Borromini, que se aborda siempre en primer lugar en todos los capítulos. Para ello, necesariamente, ha tenido que haber un proceso previo de análisis y reflexión por parte de la autora para identificar estos rasgos ${ }^{180}$, que, convertidos en parámetros, estructuran la investigación y dan nombre a los diferentes capítulos. Estos parámetros de referencia, como se verá, guardan entre ellos una interdependencia.

La intuición primera, la que desencadena el desarrollo de esta tesis, procede atendiendo al sentido que adquieren algunas categorías formales en muchas obras de arquitectura contemporánea, que parecen dejarse comprender de del mismo modo que en la arquitectura de Borromini. La obra de Borromini es especialmente

179. Véase supra, parte I, capítulo 3, págs. 103-106.

180. Podría este texto estar estructurado a partir del análisis de la obra de Borromini, extrayendo de ella los parámetros comparativos, para pasar luego al estudio de los mismos en la obra contemporánea, en una tercera parte. Pero, se ha considerado que, mostrando conjuntamente los dos periodos a través de la estructura de los parámetros, los resultados se presentaban más expresivos y sugerentes, apreciándose las confluencias de fondo a la vez que sus diferencias de lenguaje más claramente, de modo más narrativo y explícito. 
explícita en relación con la relevancia que se otorga a la expresión del espacio y la singular consideración de la forma. La forma, de algún modo, queda puesta en cuestión a favor del espacio, que, como ámbito de posibilidad de la forma, refuerza su expresión.

Por tanto, y resumiendo lo anterior, la hipótesis de partida se refiere a una cierta perturbación de la noción de forma de la arquitectura, y los recursos mencionados se desarrollarán en cada capítulo para las dos temporalidades a modo de parámetros de referencia, con la intención de profundizar en su sentido último, con ayuda de la interpretación filosófica de los mismos. 


\section{LA INFLEXIÓN Y SUS EFECTOS}

El punto de inflexión es un punto potencial pues contiene en sí mismo la posibilidad de variación. Tiene que ver con el devenir, en el sentido en el que Deleuze lo utiliza, no como sinónimo de movimiento cronológico sino como elemento creativo, que permite un cambio o variación. Es un punto intensivo, pues contiene la potencia para realizar el cambio. Pero a la vez, forma parte de la episteme a la que pertenece, de donde toma las condiciones de su potencia. Es aquello que se desvía, y este término es ya espacial. Se trata de abrir un espacio, una posibilidad para el cambio, un cambio creativo, se trata de espaciar.

El sistema del devenir, como la inflexión, forma parte de una inmanencia, es decir el cambio se produce desde las propias condiciones, no se genera desde un afuera. Los puntos de inflexión son por ello como intensidades, elementos de potencia, capaces de generar nuevos espacios.

No se trata tanto de simular movimiento como de explorar en la posibilidad del cambio. Refiriéndose en el mismo sentido a la pintura, Merlau Ponty, lo ha expresado así:

La pintura no busca el exterior del movimiento sino sus cifras secretas. $^{181}$

El punto de inflexión tiene su referencia en la extensión, es decir, en el cambio de curvatura, sea en el plano o en el espacio, de una curva dada. Pero su significado es el mismo, lo usemos geométricamente, $\mathrm{u}$ ontológicamente; señala a un cambio, a una potencia de cambio generada desde una continuidad. Línea de doble curvatura se toma aquí geométricamente, en sentido general, puede integrarse en un plano o puede tener un carácter tridimensional. Si hablamos de la planta será el primer caso, pero lo significativo para nuestro argumento es su cambio (de curvatura) a partir del punto de inflexión que es donde concentra su potencialidad. El punto de inflexión es un acontecimiento en la línea. 


\subsection{LOS MODOS DE LA INFLEXIÓN}

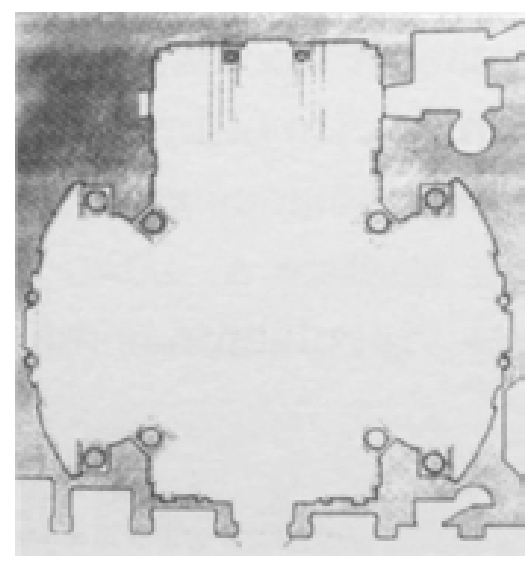

2.01. Planta de la capilla de los Sforza en S. María Maiore. MIGUEL ANGEL. Roma, 1560.
El giro de un pilar, un movimiento que altera el equilibrio del clasicismo $^{182}$, un impulso que transmite una fuerza centrífuga, una diagonal, así se rompió la estabilidad y surgió la curvatura como posibilidad de variación. Es un punto de inflexión, y la inflexión fue inseparable de una variación infinita; la inflexión fue un Acontecimiento $^{183}$. De ella se obtiene la fuerza para redondear los ángulos según la exigencia barroca, haciendo proliferar la curva. El elemento genético ideal de la curvatura variable o del pliegue es la inflexión. Siempre hay una inflexión que convierte la variación en un pliegue y que puede llevar el pliegue hasta el infinito. El pliegue es la potencia y la propia potencia es acto, es el acto del pliegue ${ }^{184}$, nos dice Deleuze.

En la capilla de los Sforza de la iglesia de Santa Maria Maggiore en Roma, Miguel Ángel desdobla los elementos verticales articulando una descomposición. Incorpora los cuerpos laterales al espacio central a través de un giro aumentado en el eje de las columnas que los flanquean. El contrafuerte se revuelve diagonalmente transmitiendo al conjunto una fuerza centrífuga, impulsando directrices diagonales de expansión. Esta composición dará lugar a un espacio unificado, cuyas partes no se reconocen de forma independiente como se hacía habitualmente en el Renacimiento; los dos cuerpos laterales, que ya no se pueden llamar capillas, se inscriben en arcos muy poco profundos que distan mucho de ser semicirculares, las capillas se incorporan al espacio que discurre plegándose por el perímetro ${ }^{185}$.

Miguel Ángel niega la bidimensionalidad de la pilastra pues ahora se independizan del muro, y la curvatura de los transeptos re-

182. Con Clasicismo, me refiero fundamentalmente, a lo largo del texto, al Renacimiento, pero también las arquitecturas griegas y romanas que lo inspiran, y a los posteriores desarrollos alrededor de estas mismas fuentes.

183. El término acontecimiento es utilizado en filosofía de diferentes maneras, en el caso de Deleuze es un cambio que implica generación, la aparición de un punto intensivo con potencial para generar modificaciones, nuevos modos. Implica una potencia creativa capaz de dar cuenta del devenir, no como movimiento cronológico sino como elemento creativo capaz de generar lo nuevo o distinto. En el texto tiene por ello un doble sentido, con referencia a la inflexión, y con referencia al cambio que se opera en arquitectura con el gesto de Miguel Ángel, cuyo potencial, desarrolla más adelante Borromini.

184. Cifr. Gilles Deleuze, El Pliegue..., op. cit. págs. 26-31.

185. Cifr. ANTHONY BLUNT, Borromini, Penguin Books, Middlesex 1979. Traducción al castellano Fernando Villaverde, Alianza Editorial, Madrid 1979. 
fuerza este carácter tridimensional del espacio. Aparecen tensiones diagonales en la planta, reforzando la idea del espacio como constitutivo del resultado formal de la arquitectura ${ }^{186}$. En la capilla Sforza, las formas espaciales más que yuxtapuestas se encuentran articuladas entre sí, integradas en el espacio debido a la posición diagonal de los pilares, que actúan como puntos de inflexión.

Lo que está entrando en juego es una cierta manera de entender la inflexión como elemento integrador, tal como la define el arquitecto inglés Trystan Edwards:

La inflexión, nos dice, asegura la subordinación de las partes al todo y también establece la relación del todo con aquello que está fuera de él. ${ }^{187}$

Robert Venturi en su texto de 1966 sienta las claves de un posible Neobarroco. El texto lleva ya un nombre que incluye categorías barrocas: Complejidad y Contradicción en la arquitectura. Venturi también señala la inflexión como elemento constitutivo de las composiciones complejas:

La inflexión en arquitectura es la forma mediante la cual el todo está implicado desarrollando la naturaleza de las partes individuales, antes que su posición o número. Mediante la inflexión hacia algo fuera de ellas mismas, las partes consiguen sus propios lazos de unión: las partes inflexionadas están más integradas al conjunto que las partes no inflexionadas. La inflexión es un medio de distinguir las partes diferentes connotando a la vez continuidad ${ }^{188}$.

Venturi señala que la inflexión depende de algo que está fuera y en cuya dirección el conjunto se inflexiona. Y es así como se integraron las partes en la capilla Sforza, inflexionando las unas hacia las otras, creando un espacio de respectividad, un espacio topológico complejo. Es en este sentido en el que Venturi habla de espacio orientado, un espacio que se inflexiona en la dirección de otro del que depende.

186. Cifr. EUSEBIO ALONSO GARCÍA, San Carlino: la máquina geométrica de Borromini, COACYLE de Valladolid, Universidad de Valladolid, Valladolid 2003.

187. Aunque Edwards se referirá tanto a las relaciones partes-todo, como papel interno de la inflexión, como a las relaciones que se establecen entre la arquitectura y lo que aparece fuera de ella, que sería su papel externo. Trystan Edwards, Good and Bad Manners in Architecture, 1924. 


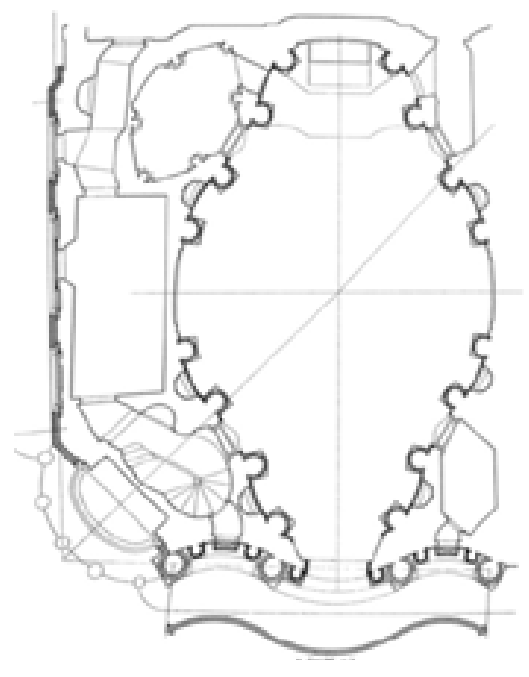

2.02. Planta de San Carlino alle Quattro Fontane. BORROMINI. Roma, 1634. Dibujo de Eusebio Alonso García.
Venturi reflexiona de esta forma a cerca del origen fragmentario sobre el que se realiza la inflexión, como alteración de un orden preestablecido, tal como se produce en la capilla Sforza; las partes funcionan relacionalmente las unas respecto a las otras, inflexionandose cada una en su relación compleja con las demás.

En San Carlino alle Quattro Fontane, Francesco Borromini reinterpreta el gesto inflexionado de su maestro en la capilla Sforza y las pilastras-columnas se abren completamente en la planta generando una forma continua, desplegando la insinuación de Miguel Ângel. Así, las pilastras que estructuran la composición del muro, ya no responden a la lógica bidimensional de los planos principales perpendiculares, se aíslan ligeramente del paramento, articulando entre sus distintas posiciones una curva continua que discurre tras ellas, y que absorbe lo que pudieran ser las capillas, haciendo fluir la envolvente de una manera completamente nueva. Los tramos se han vuelto curvos siguiendo una continuidad; una curvatura variable.

Ya no es posible reconocer partes en este espacio complejo y continuo; se rompe definitivamente el principio fundamental de la arquitectura renacentista de hacer que cada uno de los espacios que integran el edificio sean independientes y completos. El nuevo modo de inflexión ha convertido el espacio en unitario y complejo y lo que Borromini proyecta es entonces una unidad compleja.

A este respecto, también Venturi distingue entre la difícil unidad conseguida con la inclusión y la fácil unidad conseguida con la exclusión $^{189}$, señalando la primera como la que es capaz de generar estos espacios de complejidad. Parece que se trata entonces de una espacie de unidad intensiva, donde las partes son dependientes la unas de las otras formando una topología.

Decimos topología refiriéndonos a un sistema de relaciones de respectividad. La unidad topológica se configurará como sistema relacional; una unidad intensiva formada de relaciones simultáneas, que remite a lo espacial, pasando el tiempo así a ser secundario en la relación. En la topología es la relación lo que importa; la relación adquiere como un cierto grado de independencia respecto a sus términos. La relación no es tratada como desarrollo en el tiempo sino como relación simultánea, es por eso esencialmente espacial.

189. ROBERT VENTURI, op. cit., cap. 10: El compromiso con el difícil conjunto, pág. 141. 
Esta unidad se alcanza por relaciones de inclusión y estas relaciones, en el caso de Borromini, serán de naturaleza geométrica compleja, como veremos en este texto más adelante; Borromini utiliza la geometría de una manera relacional, creando topologías ${ }^{190}$, que ponen en primer término lo espacial de las relaciones.

Esta unidad intensiva, donde las partes confluyen y es inclusiva, siguiendo el razonamiento de Venturi, se opondría a la unidad extensa, formada por partes indiferentes, que realmente nunca es unidad sino totalidad, y que para alcanzar la unidad lo hará siempre por exclusión. Es en este sentido en el que podemos señalar la inflexión como elemento integrador y relacional, generador de unidades complejas, de unidad intensiva.

Para el arquitecto francés Bernard Cache ${ }^{191}$, la inflexión no deja de ser un elemento integrador de las partes en el todo, pero él la toma como operación matemática, donde la parte es un elemento diferencial dentro de un continuo. La señala como una singularidad intrínseca, y distingue dos tipos de singularidad: por un lado, están los extremos, el máximo y el mínimo en una curva dada, y por otro lado están aquellos puntos singulares que, en relación con los extremos, figuran como intermedios. Estos son los puntos de inflexión, que son diferentes de los extremos ya que son definidos solo en relación con ellos mismos, mientras que la definición de los extremos presupone la elección previa de un eje o una orientación.

La inflexión se corresponde con una operación formal específica: en la línea de doble curvatura, su característica es albergar el lugar de cambio entre concavidad y convexidad; el punto de inflexión. Señalará Cache que su representación primordial la ofrece Paul Klee ${ }^{192}$ en sus cuadernos pedagógicos, donde aparece

190. El término topología es tomado en el texto como sistema de relaciones de respectividad. La unidad topológica se configurará como sistema relacional; una unidad intensiva formada de relaciones simultáneas, que remite a lo espacial, pasando el tiempo así a ser secundario en la relación.

191. Cifr. BERNARD CACHE, Terre Meuble. Traducción al inglés Earth Moves: The Furnishing of Territories. Cambridge, MA.: MIT Press, 1995.

192. En 1956 se publican los cuadernos pedagógicos de Klee y dentro de la Teoría para la Producción de Forma de estos cuadernos explica la línea activa como aquella que se mueve jugando libremente y cuyo agente es un punto en movimiento. Los cuadernos originales son publicados en: Paul Klee. Paul Klee notebook Volumel. The thinking eye. (Londres: Lund Humphries, 1961 [1956]); Paul Klee, Paul Klee notebooks Volume 2. The nature of nature. (Londres: Lund Humphreis,1973 [1970]). Para la redacción de este texto se ha consultado: Paul Klee, Esbozos pedagógicos en Théorie de l'art moderne, Trans. de Pablo Ires, Teoría del arte moderno, (Buenos Aires: ed. Cactus, 2007) 71. 
definida como línea activa. En 1956 se publican los cuadernos pedagógicos de Klee y dentro de la Teoría para la Producción de Forma de estos cuadernos, el autor describe la línea activa como tipo particular de línea inflexionada. La línea activa es para Klee un agente de forma cuyo origen es un punto en movimiento. Tiene el valor de poner en marcha un proceso formativo y opera en relación dinámica frente al plano en el que se sitúa, construyéndolo.

La noción de línea activa, nos dice Cache, es la raíz de la inflexión. Su uso permite realizar la inflexión como una función de forma en sí misma y no como procedimiento practicado sobre elementos preexistentes. Esta diferencia es significativa, y defiendo que podría aplicarse a las diferencias esenciales entre la composición de la capilla Sforza y la iglesia de San Carlino. En esta última no podríamos distinguir partes previas ni reconocer formas independientes, la propia inflexión con base geométrica es generadora de forma por sí misma a través de una línea activa, mientras en la capilla Sforza, las partes se podría decir que se orientan, al modo que describe Venturi, para ser integradas en un espacio que pretende ser unitario a través de la inflexión, pero que conserva todavía huellas de fragmentos heterogéneos, un origen fragmentario.

Cache iguala la inflexión a esta línea activa y señala sus efectos en una serie de categorías formales: pliegue, topología, pero también, lo in-forme, o in-formado, lo que todavía no ha alcanzado su forma estable. El valor de la línea activa es el proceso formativo que pone en movimiento, por ello su acción debe ser tomada literalmente.

Gilles Deleuze también se refiere a la línea activa de Klee; la inflexión es el elemento genético de la línea activa. La considera como puro Acontecimiento ${ }^{193}$ de la línea, en el sentido de singularidad intrínseca señalado por Cache.

Así, esta singularidad, al igual que el pliegue es autoreferencial, pero contiene una potencia creativa y generadora.

En relación con el comienzo, toda inflexión subsiguiente tendrá un valor diacrítico, será una relación de la línea consigo misma, formará una aventura, una historia (...). ${ }^{194}$ 
Llamaremos aquí a este modo de inflexión, que se genera como singularidad intrínseca y que se produce a través de la línea activa, modo de inflexión activa. Y atendiendo a ella es como las pilastras de San Carlino, que se han separado del muro, actuarán a partir de ahora como puntos de inflexión, como singularidades intrínsecas, que señalan esos lugares donde cambia la curvatura, donde el pliegue se produce para integrar el espacio en una topología de relaciones geométricas complejas.

¿Puede la obra de Borromini ser realmente singular en cuanto al uso específico que él hace de la Inflexión?

Aunque el pliegue será, tal como Deleuze señala, el rasgo característico del Barroco, si nos referimos al ámbito concreto de la arquitectura, y por proximidad, nos fijamos en otros ejemplos de arquitectura romana, podríamos defender esta singularidad. Los modos de la inflexión que están interviniendo no son siempre los mismos, y si nos ceñimos al ejemplo concreto de San Carlino, (aunque, como veremos, se extiende a la mayor parte de la obra de Borromini), el modo de entender la inflexión como generadora de la línea activa, sí resulta singular frente al resto de los casos de otros autores, qué más bien atienden al modo venturiano de espacio orientado.

Tres son las figuras más relevantes en la arquitectura romana de mediados del siglo XVII: Lorenzo Bernini, Pietro da Cortona y Francesco Borromini. Los tres son contemporáneos y nacen con diferencias de apenas dos años. Borromini comienza la construcción de San Carlino alle Cuattro Fontane en 1538.

En la vecina iglesia de San Andrea del Quirinal, construida por Bernini, 20 años después de que Borromini comenzara la de San Carlino, situada en la misma calle, la Via Pia, podemos apreciar ciertas diferencias respecto al uso de la inflexión en su composición. El conjunto se articula más bien como suma de fragmentos, aunque se dirige hacia la unidad, e incide en la capacidad de adaptar y acomodarse a la calle en el sentido de espacio orientado, inflexionado según un exterior. Se genera desde la yuxtaposición de fragmentos reconocibles, lo que se aprecia bien en la composición de la planta, si bien estos elementos se estructuran respectivamente y de un modo inclusivo; las partes evidencian su origen fragmentario sobre el que se realiza la inflexión.

Los modos de inflexión que se emplean se acercan más bien a la concepción venturiana de inflexión, que al modo de singularidad

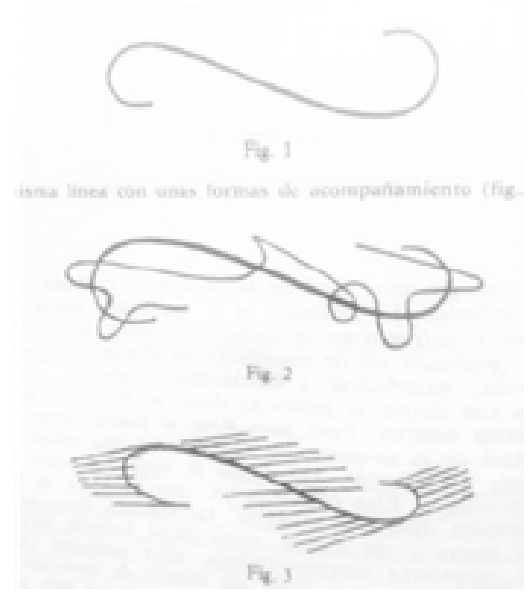

2.03. La línea activa. PAUL KLEE. Fuente: El Pliegue, GILLES DELEUZE, pág. 26.
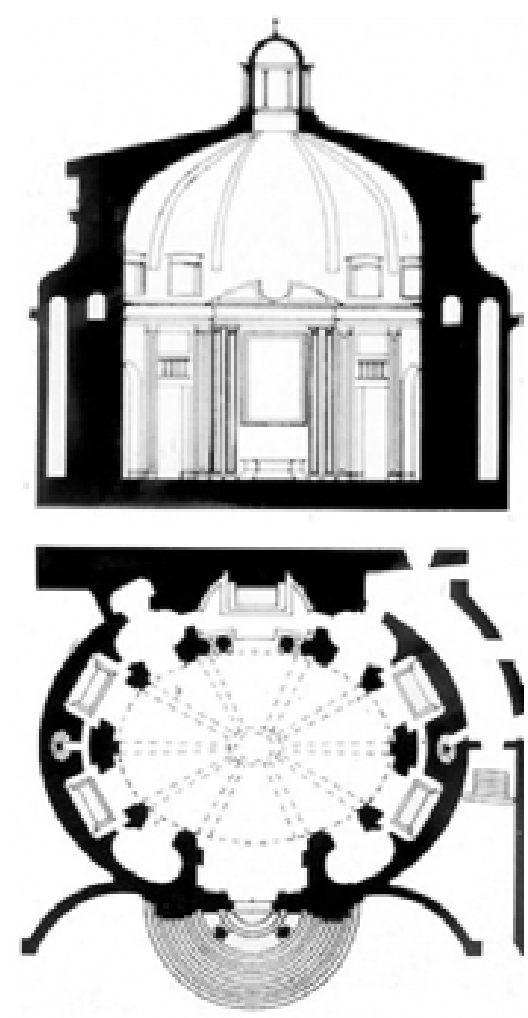

2.04. Planta y sección de San Andrea del Quirinal. BERNINI. Roma, 1670 

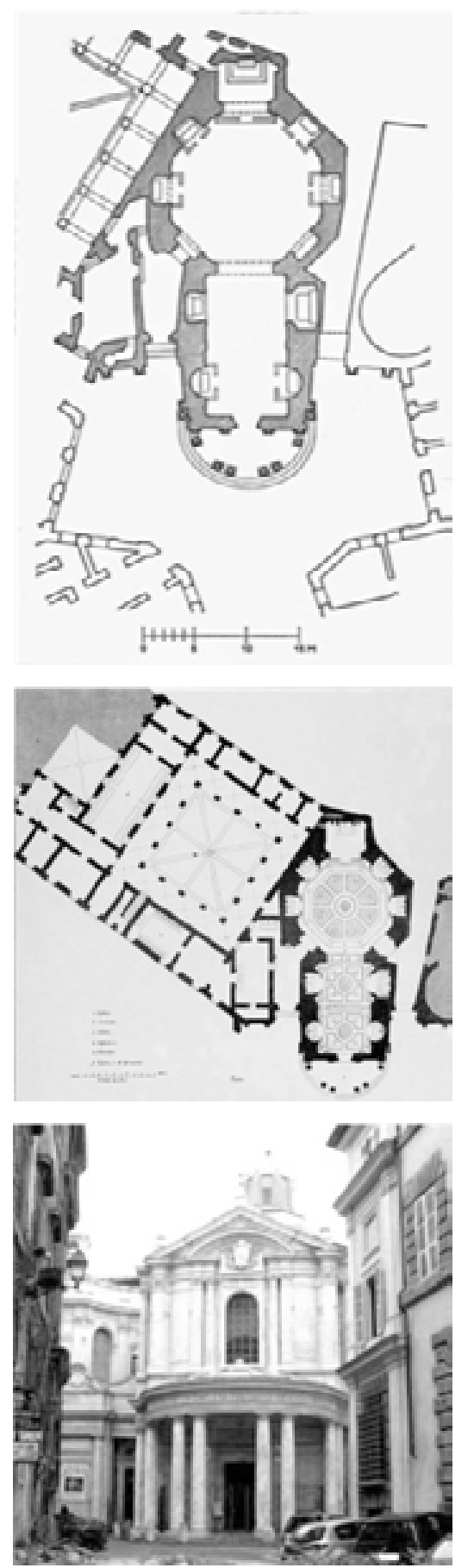

2.05. Conjunto de Santa María della Pace y entorno urbano de la iglesia. PIETRO DA CORTONA. Roma, 1667. intrínseca y uso de la línea activa con el que San Carlino se proyecta a lo que hemos denominado inflexión activa.

Todos los elementos que forman el conjunto se reconocen formalmente y las curvas se articulan con una cierta oposición y no por despliegue o proliferación como sucede en San Carlino.

El otro caso romano es el de la Iglesia de Santa María della Pace, que Pietro da Cortona restaura sobre una iglesia preexistente casi simultáneamente a San Andrea del Quirinale, en 1656. El sentido de espacio orientado cobra más presencia si la analizamos en el entorno donde se construye, y según la operación urbana que comporta. Desde el conjunto del claustro, la iglesia gira para orientarse a la plaza. La intervención más importante de Cortona consiste en articular el espacio de la plaza desde la iglesia, y sus elementos empujan la iglesia hacia el exterior de forma muy rotunda, tratando de simular una especie de marco teatral con un pórtico semicircular, que casi llena la pequeña plaza; varias casas tuvieron que demolerse para que Pietro da Cortona crease este escenario, como un verdadero objeto urbano barroco.

Las partes que añade Cortona sobre la plaza pueden, sin embargo, seguir comprendiéndose independientemente en su planta como formas geométricas reconocibles que se inflexionan, y el modo de inflexión al que atienden se orienta al exterior. Cortona emplea los elementos que componen la intervención como formas transitivas. El destinatario de todo ello es el espacio exterior. La iglesia es un conjunto unitario pero heterogéneo, cuyas partes se orientan las unas hacia las otras según una subordinación al todo, pero también establece la relación del todo con aquello que está fuera de él. ${ }^{195} \mathrm{El}$ modo de uso de la inflexión es inclusivo, pero resalta la importancia del pórtico semicircular que se adelanta frontalmente como elemento predominante, señalando a una especie de jerarquía que opera en un sentido contrario a las estrategias de orden inflexionado que se dan en San Carlino.

El conjunto de San Carlino, en cambio, se manifiesta como producto puro de la inflexión en su modo más auténtico, como generador del pliegue y de la unidad topológica. Su planta no deja reconocer elementos independientes ni jerarquía alguna, comprendiéndose solamente como unidad compleja.

195. Cifr. TRYSTAN EDWARDS, Good and Bad Manners in Architecture, 1924. Ver nota 6. 


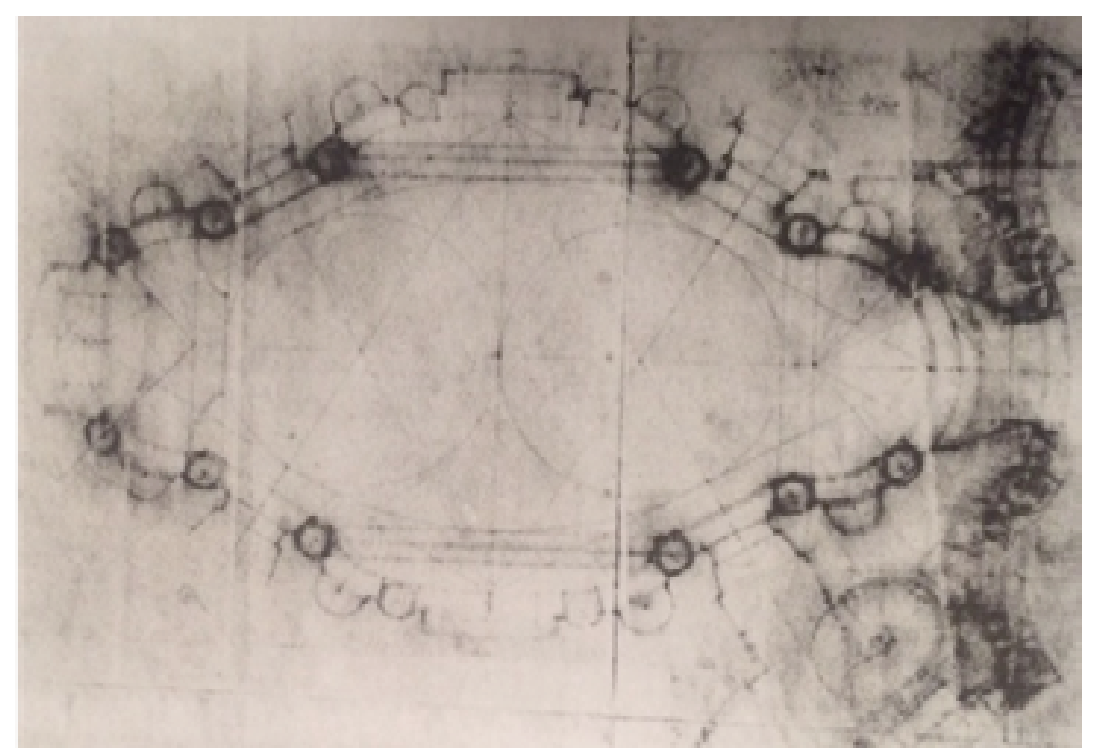

El sistema de Borromini es dinámico y abierto a soluciones que podríamos llamar impredecibles; son singularidades, como acontecimientos dentro del sistema, capaces de salirse de él al generar en sí mismos nuevas potencialidades. Esto es precisamente lo que le aleja de un modo de proyectar basado únicamente en mecanismos compositivos. Podríamos decir que, en cierto modo, su sistema está sujeto a la impredecibilidad de un devenir. El espacio surge con la determinación formal de sus límites y la convulsión que estos experimentan es lo que determina la aparición de singularidades que estimulan y reorientan el desarrollo del organismo. Nada estará definido a priori, las razones formales devienen de la evolución del sistema a partir de sus singularidades.

Omar Calabrese ha notado en su texto sobre el Neobarroco, que las nociones de azar, caos o irregularidad, están insertadas en esta estética neobarroca. Hay una tendencia a valorar o atender más a los fenómenos imprevisibles, o ininteligibles, que, a los fenómenos previsibles, cuya causalidad y origen resultan claros $^{196}$.

En San Carlino, la evolución proyectual de las columnas, las sucesivas correcciones y desplazamientos que sufren en sus dibujos, nos señalan que en ellas debe recaer la mayor dosis de singularidad del conjunto. Recogen diferentes perturbaciones del sistema y son los elementos que reordenan la mutación formal. En topología, la noción matemática de singularidad tiene un carácter análogo al que observamos en el sistema de Borromini.
2.06. Planta de San Carlino alle Quattro Fontane. BORROMINI. Albertina 169 


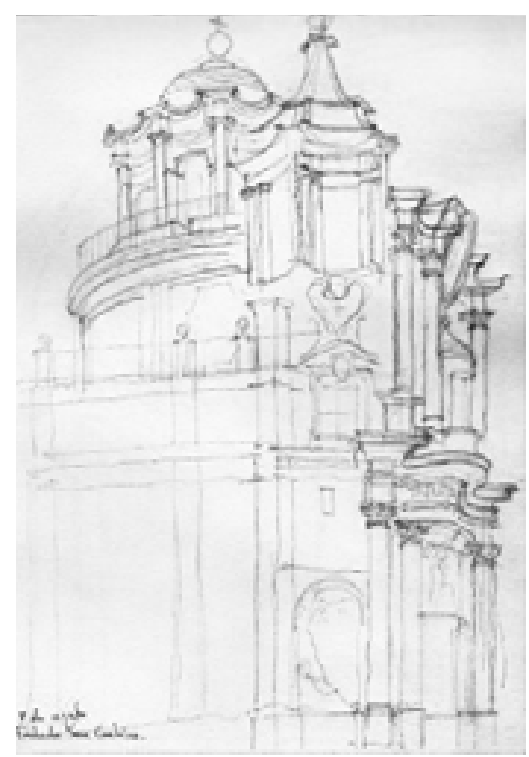

2.07. Croquis de la visita de San Carlino desde la Via delle Quattro Fontane. BORROMINI. Dibujo de la autora.
En topología, se puede considerar como sistema una curva cualquiera controlada por los parámetros que respeten una función. La curva está a su vez constituida por una serie de puntos. Tales puntos se llaman regulares cuando obedecen sólo y únicamente a la ley de la función representada por la curva. En cambio, se llaman singularidades a aquellos puntos que, aún obedeciendo a la función, siguen al mismo tiempo también otra. ${ }^{197}$

La singularidad del sistema como punto productor tiene una vinculación directa con el significado del acontecimiento en relación con el sentido de devenir en la obra de Gilles Deleuze. Un acontecimiento como espaciamiento, o creación de un espacio en el sentido de posibilidad (abrir un espacio o hacer posible). Es una potencia diferenciadora y creadora dentro de un sistema. El devenir, así, no será una mera sucesión en el tiempo, sino habla de lo que deviene, en lo que se transforma, lo que se modifica; un elemento que crea y genera, con base en la función (o sistema) existente, pero generador de potencialidad.

La solución de cada una de las columnas de San Carlino tiene la condición de excepcionalidad, en su orientación, su entrega en el muro, los detalles de sus basas y capiteles. Todo ello nos revela el detalle riguroso de su sistema topológico. La solución diferenciada de las columnas está más en relación con la posición que ocupan en el espacio, que con su posición en la pared. ${ }^{198}$

El trazado de la fachada de San Carlino, su articulación, responde a su vinculación con los problemas volumétricos del edificio. Toda la composición en planta gira en torno al eje de la fuente ya existente en el chaflán. La inclusión de la fachada en la composición volumétrica con el lucernario y la linterna resulta muy evidente al aproximarnos por la via delle Cuatro Fontane desde la Piazza Barberini; encontramos una visión simultánea de ambas fachadas de la iglesia. La relación dual de la linterna ${ }^{199}$ con la fachada y el campanario se refleja sucesivamente en este recorrido. El trazado plegado del primer cuerpo de fachada, en su convexidad central, retoma el trazado del ábside de acceso, y esta forma establece una relación volumétrica con el tambor de la cúpula y fundamentalmente con la linterna.

197. OMAR CALABRESE, op. cit., pág. 94. Citado por Eusebio Alonso, op. cit., pág. 254. 198. Cifr. EUSEBIO ALONSO, op. cit., pág. 254-255.

199. El profesor Alonso explica en detalle como Borromini realiza la inclusión de la fachada en la organización volumétrica de San Carlino. Cifr. Eusebio Alonso, op. cit., pág. 353. 
Todo el conjunto se organiza en reacciones de respectividad formando un único organismo compositivo en continuidad, que, a la vez, se compone exteriormente con el trazado urbano.

El tema de la continuidad está singularmente presente en San Carlino, y la inflexión y sus efectos, se aplican siempre a un sistema continuo; el punto de inflexión actúa como acontecimiento de un sistema continuo.

\subsubsection{Acontecimiento del terreno}

En arquitectura y en las artes visuales, se reúnen las condiciones para que la inflexión sea elevada a su más alta potencia, mientras que esta imagen no era más que el signo de una indeterminación en el plano moderno. ${ }^{200}$

¿No lleva al extremo esta idea de espacio unitario y de continuidad Ryue Nisizahua en su Museo de arte Teshima?, y ¿no se trata también de una composición continua y unitaria en lo que se refiere a su relación con el entorno, aunque se trate de entornos muy diferentes?

No se trata, por supuesto, de una analogía directa con las obras barrocas, de una analogía de similitud; los lenguajes son muy diferentes, así como los modos de construcción. Pero si vemos en ello el mismo principio rector de un cambio en las condiciones del espacio, podríamos llamarlo, siguiendo un análisis de la analogía que desarrolla Deleuze ${ }^{201}$, analogía orgánica o de relación (la cual no produce semejanza), o bien homología.

El museo aparece como un suave promontorio más del lugar, un pliegue más en el continuo del terreno. Su figura tiene analogías biológicas y parece que simula una gota de agua cayendo, ¿no se trata así de dar forma, a una especie de acontecimiento en el territorio, una especie de irregularidad en la topografía del terreno?.

El elemento de lo impredecible, aparece más ligado al azar que a cualquier composición intencionada. Pero, además, el museo sugiere una inestabilidad formal, un objeto que no ha terminado de 

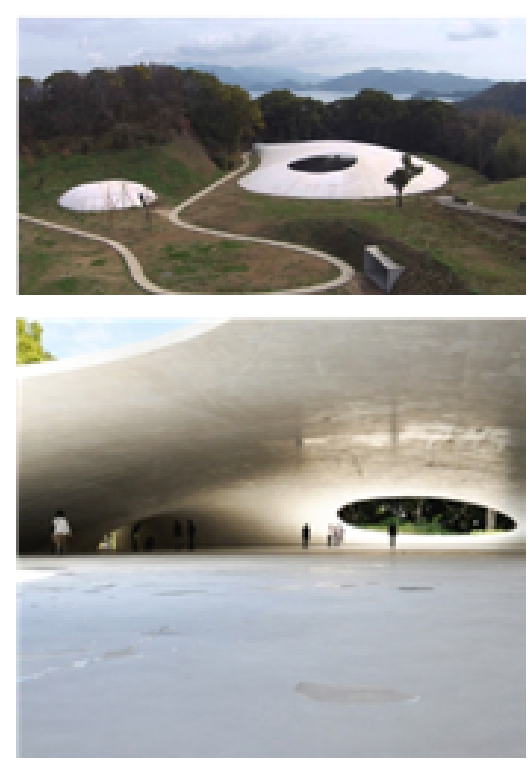

2.08. Museo de Arte Teshima. RYUE NISIZAHUA. Kagawa, Japón, 2010

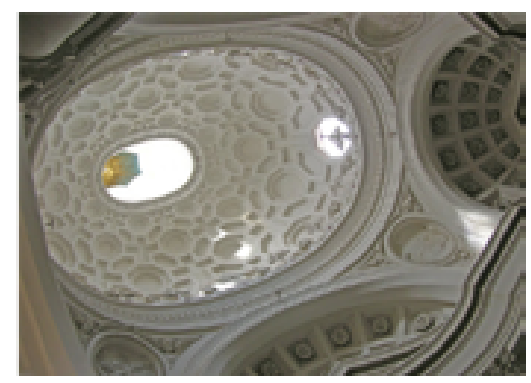

2.09. Cúpula y linterna de San Carlino alle Quattro Fontane. BORROMINI formalizarse, una gota recién caída que todavía no se ha expandido completamente o ha sido absorbida por el terreno. El museo de arte adquiere una forma natural y orgánica a través de una piel que se curva en el terreno y que no parece estable. Su propia interioridad se observa de una manera inestable, pues la cáscara-techo no responde en el interior a una geometría identificable con la que asimilar o reconocer la forma.

La piel-pliegue lo abarca todo, incluso su juntura con el terraplén o suelo se pierde, pues el color y el material dan al espacio una continuidad envolvente. Es a la vez techo, recinto y terraplén: una unidad inclusiva, que ya no dispone de parte alguna, donde lo particular se genera siempre por inflexión o plegamiento ${ }^{202}$, donde la continuidad abarca, no solo al objeto de arquitectura, sino al lugar que lo acoge.

En el interior, el plegado del techo-cáscara, genera distintas secuencias espaciales o ámbitos cualificados únicamente por las diferencias en su altura libre, generados en continuidad, o por la diferencia en la entrada de luz. El espacio interior no tiene otras referencias que le otorguen algún rango o categoría, carece, en su composición, de cualquier elemento jerárquico, pone en valor lo diáfano, el medio, el espacio que ha capturado, un espacio que se matiza sólo por el pliegue y por la luz, cuyo límite es el encuentro del plano horizontal con la cubierta-cáscara. El límite tradicional, como cerramiento vertical, se ha anulado; se trata más de un horizonte, una especie de límite al infinito.

El espacio único-continuo es abarcante ${ }^{203}$, y así entraría en relación con algunos espacios que Borromini proyecta, como la Capilla de los Reyes Magos o el Oratorio de los Filipenses, donde el techo se incorpora en continuidad con los paramentos verticales ${ }^{204}$. Pero su composición en continuidad también tiene una referencia en el espacio de Sant'Ivo o incluso en la continuidad muraria de San Carlino como antecedente.

La cubierta laminar dispone de dos aperturas elípticas y una entrada al espacio interior. Este interior es una única sala sin ángulos, sin fondo, un ambiente en el que la luz y la cobertura completa de color blanco son los únicos dos elementos configuradores del

202. El mismo tema veremos más tarde en la iglesia de la Sapienza, donde Borromini logra una continuidad total entre envolvente y cubierta. Véase Infra, págs. 213, 214

203. EUSEBIO ALONSO, op. cit., pág. 112.

204. Véase infra, pag. 247, 248. 
espacio. Los óculos de luz como singularidad en la superficie plegada de la cubierta, funciona como una linterna postmoderna, que deja a la luz escurrir por el espacio, con sus efectos singulares. Pero la centralidad de la linterna ha desaparecido del todo, replicándose en dos.

Las aperturas en la parte superior ponen en valor la luz que se introduce, la presencia abstracta de la materialidad de la luz. La luz, el aire y el espacio se generan por la continuidad del material que los envuelve.

Es como un pliegue más del terreno que encierra un espacio por el que la naturaleza se cuela a través de agujeros que relacionan exterior-interior de una manera ambigua, pues la continuidad de la piel en el interior diluye los límites espaciales.

El infinito del pliegue barroco continúa en el pliegue contemporáneo: infinito, pliegue, continúo. No le falta forma ni determinación; el espacio se agencia la forma, la propia forma tiene como referencia el espacio, el medio que la posibilita, lo que la in-forma, que remite a un transfinito ${ }^{205}$. El caparazón piel abre espacio, espacia, generando la posibilidad del lugar.

\subsubsection{Unidad compleja}

La unidad compleja de San Carlino no se articula, discurre en continuidad, y las partes laterales no tienen ninguna autonomía. Todo se inflexiona según un principio intrínseco, un principio que parte de sí mismo, no proviene de referencias externas, según la noción de inflexión activa que ya se ha tratado.

El carácter de imprevisibilidad que ya hemos notado en la obra de Borromini, va ligado a otro, que anuncia una solución a esta imposibilidad de explicación de lo impredecible. Se trata del concepto de complejidad, que promueve más bien un principio de relativi-

205. El transfinito es un término acuñado por Georg Cantor (1845-1918), que él establece como puente con lo finito, para operar con los conjuntos infinitos. Podemos decir que hace de intermediario entre lo finito y lo infinito. El transfinito, está ligado también con el infinito actual que opera en el Barroco, o con un infinitamente pequeño. GEORG CANTOR, Gesammetle Abhandlugen Mathematichen und philosophichen inhalts, Ed. Ernst Zermelo, Heidelhem, Georg Olms Verlagsbuchhandlung, 1966. Se puede leer en castellano la interpretación filosófica de ese término en: MANUEL CABADA CASTRO, La fundamentación filosófica del transfinito en G. Cantor y la cuestión de infinito, Revista PENSAMIENTO, vol. 65 (2009), núm. 246, págs. 669_711. Para la interpretación del infinito en el Barroco: GILLES DELEUZE, En medio de Spinoza, ed. Cactus, Buenos Aires 1981. 


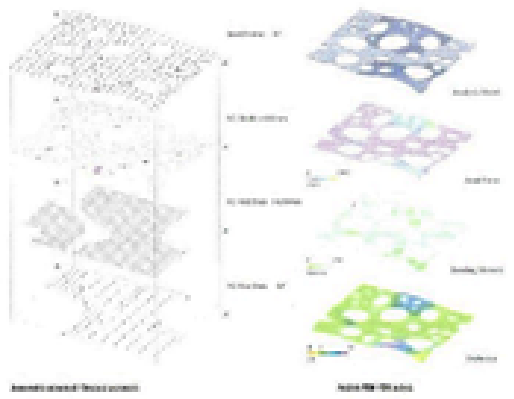

2.10. Modelos digitales del Rolex Center. SANAA, Lousane, Suíza, 2010 dad en las explicaciones y una orientación hacia el desafío de la complejidad. La complejidad está, por tanto, ligada a la época barroca, pero no menos que a la estética contemporánea. Ya Robert Venturi anuncia en el título de su texto de 1966 la importancia de este término en la arquitectura, que tendrá su desarrollo peculiar a partir de entonces, con diferentes modos de expresión ${ }^{206}$. También Omar Calabrese en su texto dedica un capitulo al tema de la complejidad, donde encuentra un horizonte para explicar el fenómeno estético una vez que se rechaza el idealismo artístico, y emparenta esta emergencia de la estética de la complejidad con algunas concepciones filosóficas contemporáneas, como el deconstructivismo o el pensamiento débil ${ }^{207}$.

¿No se rige también por este principio la unidad compleja, continua, inflexionada en su totalidad del Rolex Center de SANAA, donde la propia inflexión es generadora de espacios, de ámbitos, como tematizando la correspondencia de su solución morfológica con el régimen de lo posible?

La herramienta digital permite que los modos de expresión que se ensayan en el Barroco se puedan llevar al extremo. Las investigaciones de Bernard Cache ${ }^{208}$ sobre las posibilidades de las herramientas $3 \mathrm{D}$ que ya hemos descrito, nos llevan a la consideración de un nuevo cuestionamiento del proceso hileomórfico, donde la relación materia-forma ya no se entiende de una manera tradicional. De esta consideración nace su concepto de objetil, del que Deleuze nos dice:

El objeto no se define ya por una forma esencial, sino que responde a una funcionalidad pura(....). ${ }^{209}$

Hay que señalar en este punto, que la inflexión que da lugar a la curva barroca, desarrollada por geometrías convencionales, está construida por partes que remiten a puntos que son centros de las diferentes curvaturas; está de alguna forma construida por partes todavía articuladas, no es totalmente continua como lo son las curvas generadas por ordenador. Los puntos en el Barroco sim-

206. ROBERT VENTURI, op. cit.

207. Omar Calabrese habla en varios lugares de su texto sobre el Neobarroco del tema de la complejidad en sus diferentes formas de presentarse. OMAR CALABRESE, op. cit., pág. 134. Dedica un capítulo completo titulado Complejidad y disipación, págs. 160-169.

208. BERNARD CACHE, op. cit.

209. GILLES DELEUZE, El Pliegue... 
plemente se multiplican para enlazar un continuo; ahora la curva es, podríamos decir, perfectamente continua. A este respecto Greg Lyn dirá:

Hay una diferencia crítica entre la geometría discreta del espacio barroco- una geometría de puntos múltiples- y la continuidad de la topología- una multiplicidad sin punto. ${ }^{210}$

Pero el sentido como efecto en el espacio es el mismo. La tecnología actual permite desarrollarlo de una forma perfeccionada.

El Rolex, configurado a través de la aplicación de evolucionadas herramientas tecnológicas contiene esta multiplicidad topológica compleja. Así, sugiere lo in-forme, lo deformable, lo potencial, lo que da lugar a. A través de los planos inflexionados los usos se establecen en su variabilidad, en su posibilidad de modificación.

El resultado formal del conjunto carece de estructura previa, carece de esquema geométrico que lo componga. La forma apunta a su variabilidad, a su inestabilidad, quiere solo dar una base a la experimentación del espacio.

(...) un edificio es equivalente al diagrama que se usa para describir de forma abstracta las actividades cotidianas que en él se presuponen. ${ }^{211}$

La inflexión contemporánea intensifica la continuidad del espacio, pero también la des-centralización del mismo, impulsando hacia el extremo la fuerza de la composición. La excentricidad, que ya en la arquitectura barroca se consolida como rasgo general de las composiciones en el espacio, ordena una presión hacia los márgenes del espacio.

Así, su forma tiene que ver con el movimiento y la alteridad, con lo variable, y con la posibilidad, no estando sujeta a estructura compositiva que la restrinja y determine. El espacio arquitectónico se mueve de nuevo en el ámbito de la potencia, remite a él más que a una configuración formal concreta.

La configuración del Rolex Center contiene una inestabilidad de la figura arquitectónica, más bien, representa la inestabilidad.

210. GREG LYNN, Animate Form, Princeton Architectural Press, New York 1999, pág. 20.

211. TOYO HITO, Arquitectura diagrama, El Croquis 77, 1996.

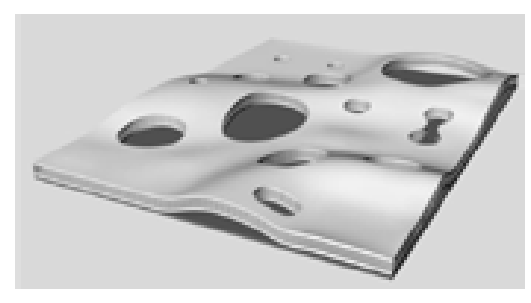

2.11. Modelado digital del Rolex Learning Center. SANAA, Lousane, Suíza 2010. 
Inestabilidad y metamorfosis son parte de ese carácter que Omar Calabrese había notado en la estética neobarroca ${ }^{212}$; se trata de formas que no tienen propiamente una forma, sino más bien, van en busca de ellas. En el caso del Rolex Center, esta cuestión se ve intensificada por el margen programático que el edificio deja para su uso. 
La inflexión, el pliegue, la referencia a la variación, son conceptos que remiten a una potencia, pero una potencia que no es cinética sino devenir. La potencia es posibilidad: remite al ámbito de las condiciones de posibilidad. Si admitimos que los recursos del pliegue, la inflexión, la variación, y con ello el movimiento, son recursos barrocos como considera Deleuze, la forma barroca podríamos decir que es por ello una forma relativa a este ámbito, al ámbito de la potencia de ser.

Gilles Deleuze en su obra sobre el Pliegue barroco comienza diciendo que el rasgo del Barroco es el pliegue que va hasta el infini$t^{213}$. Esta idea se estructura en torno a la noción de lo infinitamente pequeño, y los elementos infinitamente pequeños no tienen magnitud ni figura, y necesariamente serán elementos que no tienen forma, son in-formales.

Utiliza el pliegue como forma para caracterizar un modo de individuación de la mónada leibniciana. Utilizando la inflexión y el pliegue producido por ella, Deleuze llega hasta la inclusión que genera un punto de vista que es donde se instala el alma. Pero no se trata de una mera analogía pues en ambos casos, forma y mónada, es su capacidad de desarrollo potencial lo que caracteriza al término. El pliegue corresponde a una continuidad de la materia. Para Leibniz, según Deleuze, la distinción real entre partes no entraña separabilidad.

La idea de inflexión va ligada al pliegue, que es un envolvimiento de un continuo a partir de la inflexión. La idea de continuidad es fundamental en la filosofía de Leibniz, y él no encuentra contradicción alguna entre la ley de la continuidad y el principio de formación de las esencias-mónadas (principio de los indiscernibles), es decir, el continuo no se para, solo hay centros de envolvimiento, puntos notables. Con ello, observamos, que los cambios en un continuo solo se pueden dar por metamorfosis.

Señala así el error de Descartes o de los atomistas al considerar mínimos separables. Leibniz, a ello, opone un continuo. Y así, una línea no se disocia en puntos independientes, sino que es como un tejido que se divide en pliegues hasta el infinito. La unidad de la 
materia aquí, su elemento más pequeño, es el pliegue y no el pun$t^{214}$. Considerará que un cuerpo no se separa en partes de partes, sino que más bien se dividen hasta el infinito en pliegues cada vez más pequeños que conservan siempre una cierta cohesión; es el laberinto del continuo, que no es una línea que se disocia en puntos independientes, sino que es más bien como un tejido que se pliega o descompone en movimientos curvilíneos. El pliegue, al estar relacionado con lo infinitamente pequeño, se hace cargo de la idea de infinito que caracteriza al pensamiento y la matemática del siglo XVII ${ }^{215}$.

La obra de Borromini manifiesta, de forma singular, el uso de lo que hemos llamado la inflexión activa, pero también su obra contiene de manera acusada la forma-pliegue que elabora con diferentes sentidos según el alcance de la obra. El uso del pliegue, incidiendo en su relación con la fuerza generadora de variación, es singularmente explícito en su obra.

Borromini afronta con naturalidad en sus obras la continuidad del pliegue tanto en la planta como en la sección. Podemos observar una evolución que se debe a la madurez metodológica que experimenta nuestro autor entre el proyecto de San Carlino y el de Sant'Ivo. Deleuze ha notado que el problema está, no tanto en la creación del pliegue, como en el cómo continuar el pliegue, que es el problema Barroco.

El problema no es cómo acabar un pliegue, sino cómo continuarlo, hacer que atraviese el techo, llevarlo hasta el infinito. Pues el Pliegue (...), determina y hace aparecer la Forma y la convierte en una forma de expresión. ${ }^{216}$

En Sant'Ivo, como ejemplo más desarrollado, el orden de las pilastras articula la pared interior, pero esto no incide en el resultado espacial, solo contribuye a transferir el mecanismo del pliegue que genera la propia traza de los muros. Las pilastras son entendidas como un pliegue más de los muros perdiendo el orden de las mismas su autonomía formal. Todo ello incide en la inestabilidad formal del trazado. El orden de las pilastras se somete al muro como

214. Cifr. GILLES DELEUZE, El Pliegue... op. cit. pág. 14.

215. Se puede consultar sobre la idea de infinito en la época barroca en: GILLES DELEUZE, En medio de Spinoza, ed. Cactus, Buenos Aires 1981. También en: PAOLO ZELLINI, Breve storia dell'infinito, Adelphi, Milán, 1993, traducción al castellano: Breve historia del infinito, Siruela, Madrid 1991.

216. GILLES DELEUZE, El Pliegue..., pág. 50. 
envolvente del espacio. Se enmascara o camufla así, la tectonicidad del edificio; su estructura queda sumida en una piel plegada, como materia blanda.

Borromini en general se desprende de la subordinación al lenguaje codificado de los órdenes en favor de la plasticidad del material, que señala a través de la facilidad del plegado y de la continuidad de los pliegues.

\subsubsection{Un pliegue intensivo}

El plano de fachada en la iglesia de San Carlino, pasa entre un exterior colectivo y el interior espiritual y subjetivo, pero pasa en un pliegue continuo, casi infinitamente plegado, que otorga un espesor material a la piel del edificio. Se ha dicho que San Carlino es de piel profunda ${ }^{217}$, y esta característica define muy bien su composición compleja que podríamos denominar intensiva.

Es quizás en la fachada de San Carlino, que Borromini proyecta muchos años después que el trazado de la iglesia, donde mejor podemos caracterizar el sentido que cobra su composición respecto a las categorías que Deuleze señala en relación con la filosofía de Leibniz, pero que pueden extenderse, así mismo, a otros pensadores como Spinoza, en el que la noción de lo infinitamente pequeño puede estar también inscrita en la expresión borrominiana.

Así, observamos en la composición de la fachada, que el paño que contiene la puerta es convexo, pero se une a los cuerpos laterales con una curvatura cóncava, trazando como un S; un gran pliegue que contiene múltiples pliegues aumentando el espesor del plano, su entidad material. Un gran despliegue en curva de elementos plegados. Las columnas superpuestas en la fachada, dejan huecos entre ellas que admiten columnas de un orden menor, y entre ellas, nichos que contradicen la curvatura convexa del plano sobre el que se sitúan las columnas. Hay, por tanto, dentro del plegado en $\mathrm{S}$, un despliegue de elementos hacia adentro y hacia afuera, se ha desplegado en más pliegues menores hacia adentro que proliferan del primero y que podrían ir hasta el infinito. 

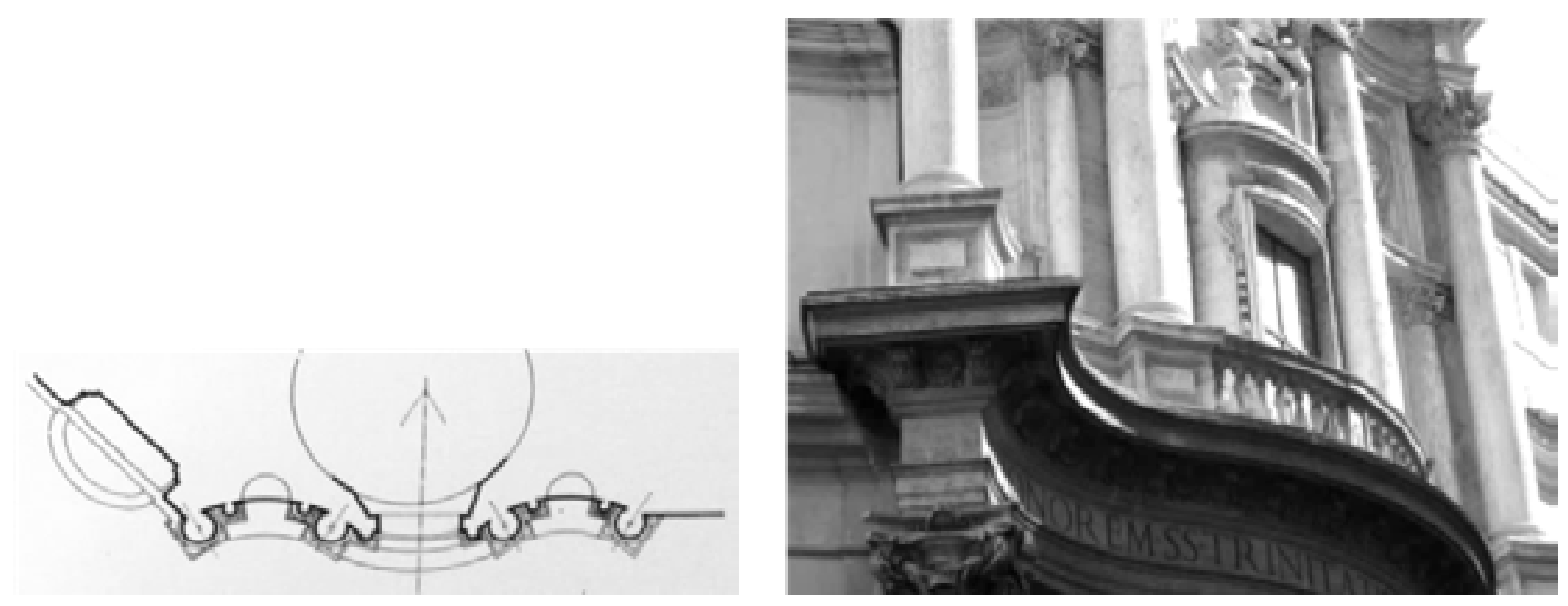

2.12. Fragmento de la fachada de San Carlino alle Quattro Fontane. BORROMINI.
De esta forma la piel, en cierto modo se disgrega, pierde así su papel de límite preciso; el espesor genera más bien un ámbito, una zona.

Son los repliegues de la materia que remiten siempre a los pliegues-fuerza que los sustentan. No hay ya en la fachada de San Carlino un lleno y un vacío, sino plegados sucesivos que ya no dejan subsistir vacíos; Deleuze llama a esto la línea barroca ${ }^{218}$.

La inflexión en sí misma es inseparable de una variación infinita, de una curvatura infinitamente variable, pues se hace intervenir la fluctuación que conlleva la posibilidad de añadir siempre un nuevo plegamiento. No se trata de introducir un punto entre otros dos por próximos que estén, sino más bien de la posibilidad de añadir siempre un rodeo, convirtiendo todo intervalo en el lugar de un nuevo plegamiento. ${ }^{219}$

En un análisis superficial podríamos describir como parecería haberse aplicado una fuerza, que pliega la fachada y la pone en movimiento, pero más que movimiento, la fachada de San Carlino contiene intensidad, se trata de una intensidad de potencia, los elementos se producen hacia adentro, se complican hacia adentro, se intensifican, captando el sentido de lo infinitamente pequeño. El plano deviene inestable; la curva se complica (pliegue dentro de pliegue) generando espesor, creando un umbral. Un umbral formado de materia y espacio, el máximo de materia para un mínimo de extensión; así es el plano barroco. Se trata de un plano geométrico, plano de intensidades, plano que contiene el infinito, plano relacional.

218. GILlES DELEUZE, El Pliegue..., op. cit. ¿qué es el Barroco?, pág. 52.

219. Cifr. Ibid. 
Hay una gran diferencia entre esta curvatura en continuidad, que propicia despliegues menores complicándose en una geometría compleja, pero que se extiende al espacio exterior a modo de telón unitario, con otras fachadas barrocas, por ejemplo, la de la vecina iglesia de San Andrea del Quirinale, ya mencionada.

En San Andrea la fachada se traza según un juego de curvas por oposición: un baldaquino de piedra sustentado por dos columnas hace las veces de pórtico o lugar de acceso y su curvatura se opone a la de los dos brazos que flanquean la fachada cubriendo el espacio de los jardines situados detrás. Todos los elementos que forman la fachada se muestran con su independencia formal y las curvas se generan por oposición y no por despliegue o proliferación como sucede en San Carlino, incidiendo en el uso de la inflexión como espacio orientado, cuyo resultado más próximo ya no es el pliegue, sino la composición orientada que delata su origen fragmentario. En San Andrea distinguimos todavía unidades, número de partes, y sabemos que el infinito es irreducible a los números; en el infinito el número está subordinado a la magnitud.

La complicación de San Andrea es de tipo aditivo, a diferencia de la complicación intensiva que habíamos observado en la fachada de San Carlino. San Andrea se compone por sí misma a través de unidades no integradas en continuidad, sino compuestas geométricamente.

\subsubsection{El pliegue laminar. Ambigüedad tectónica}

El pliegue que Borromini produce en la fachada del Oratorio dei Filippini es de una índole distinta, pero guarda en sí también las condiciones de continuidad, de despliegue.

El proyecto para el Oratorio resultaba, en sus condicionantes iniciales, más complejo que San Carlino, pues se trataba de un programa limitado por las piezas existentes. El Oratorio es la pieza más singular de este conjunto. Borromini proyecta esta pieza y la biblioteca situada justamente encima, y todo el conjunto situado al oeste de la iglesia existente (que ahora es conocida como la Chiesa Nova).

La fachada que proyecta Borromini para este conjunto está construida sobre una curva continua. En esto puede parecer similar a San Carlino, pero la curva es mucho menos pronunciada pues los planteamientos son bien distintos y responden a las diferen-

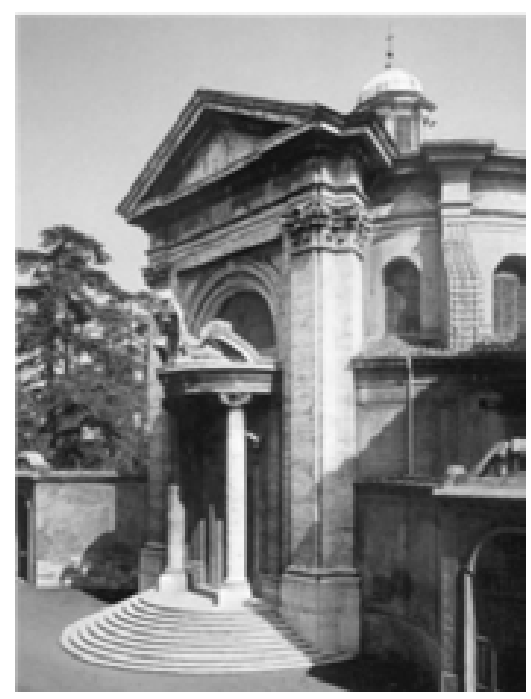

2.13. Fachada de la iglesia de San Andrea del Quirinal. BERNINI. Roma, 1678. 
tes necesidades y condicionantes. En primer lugar, la fachada de San Carlino está compuesta por columnas y la del Oratorio por pilastras. Parece que esta es una de las condiciones impuestas por los monjes: se exigía que no compitiera con la iglesia adyacente. También parece que por esta razón la fachada es de ladrillo. Puesto que no pudo tratarla de un modo escultórico, adopto el sistema contrario intentando señalar el plano como elemento dominante; las pilastras son de muy poco fondo, los entablamentos ligeros y las ventanas sobresalen menos de lo habitual. Borromini escribe en su Opus Architecttonicum ${ }^{220}$ : "qué maravilloso sería si pudiera construir la fachada de una única pieza de terracota". Al no poder llevar esto a cabo se aproxima al máximo, dispone ladrillos muy delgados y regulares, con poca argamasa, en un entramado finísimo. Resulta una forma plástica alcanzada a través de un pliegue sutil y continuo, que compone el material de la envolvente como lámina afectada por un espacio exterior que la pliega con facilidad.

Se conservan en la Albertina algunos croquis de las soluciones primeras que luego son modificadas. En la primera solución para la fachada, Borromini faceta el muro y sugiere una curva cóncava. Pero la forma prolifera y de ella surgen variaciones: concavidades que contendrán elementos convexos. En los primeros croquis notamos todavía cierta discontinuidad, ángulos y articulaciones, pero Borromini acaba evolucionando la forma en una continuidad plegada; toda la pieza se curva y a la vez se pliegan sus partes, dando lugar a nuevos elementos que la plisan como una lámina fina.

Si San Carlino es una gran masa de mampostería que se curva con riqueza hacia adentro, la fachada del oratorio trascribe el movimiento en su ligereza, plegándose levemente como una lámina metálica a la que se ha aplicado una ligera presión. La fachada del Oratorio es un pliegue laminar, donde se evidencia, en su manera singular, el modo activo de inflexión, aunque este requiera un apoyo en la base geométrica que le sirve de modo de modulación sobre el que la curva discurre.

Respecto a San Carlino, presenta diferencias sustanciales a pesar de estar ambas compuestas sobre el trazo de una curva. Si la articulación de la fachada de San Carlino se apoyaba en columnas, en

220. Opus architectónicum Equitis Francisci Borromini es uno de los pocos testimonios escritos que quedó de Borromini, redactado en 1648 a raíz de la construcción del Oratorio de San Felipe Neri. La obra está ampliamente ilustrada y su introducción, aunque escrita en primera persona, fue redactadas según indicación del artista, por su protector y amigo Monseñor Vigilio Spada. 


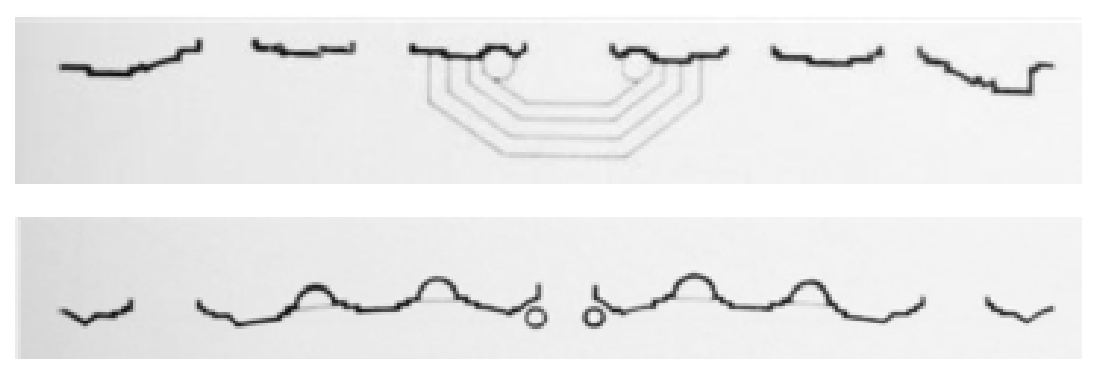

el caso del Oratorio se apoya en pilastras. Pilastras en las que aparecen señaladas las aristas del cambio de curvatura. Puesto que no pudo tratar la fachada de un modo escultórico, se desplazó al otro extremo remarcando el plano como elemento dominante. Se trata de un trazo, una curva continua, un trazo sencillo que va cogiendo complejidad; las pilastras son de muy poco fondo y las ventanas sobresalen menos de lo que en Borromini es habitual. Anthony Blunt dirá que esta fachada se caracteriza por una extraordinaria sutileza.

Pero la curva se complica, y en su parte central se interrumpe por un tramo convexo que enmarca la puerta y por una hornacina cóncava para un balcón en su parte superior que da a la biblioteca que él también proyecta.

La lámina ha de mostrar también su condición flexible, su fluidez; el ladrillo, de mínimas piezas, se ha tratado como un material continuo en su nueva condición laminar. Es también un trampantojo. Robert Venturi ha señalado a la ambigüedad como una de las características más notables de la arquitectura de la complejidad y la contradicción. La fachada del Oratorio goza de este carácter ambiguo; hecha de piezas de ladrillo se pliega como si su material fuera laminar y continuo, como una fina hoja metálica. La naturaleza del material y su forma específica generan una especie de equívoco visual.

(...) una paradoja intrínseca a la percepción y al proceso de significación en el arte: la complejidad y la contradicción como significado de la yuxtaposición de lo que una imagen es y lo que parece. ${ }^{221}$

Por último, el tratamiento de la fachada del oratorio, como tal lámina fina, enmascara su función portante. La fuerza de la gravedad, en estas obras, se diluye en el movimiento en direcciones contrarias a ella, de los elementos que las componen. Este mismo sentido de dinamismo y ligereza, esta misma a-tectonicidad, la
2.14. Primera solución de fachada del Oratorio de los Filipenses. BORROMINI. Roma, 1667. Dibuo Paolo Portoghesi 2.15. Solución definitiva de la fachada del Oratorio de los Filipenses. BORROMINI. Roma, 1667. Dibujo Paolo Portoghesi

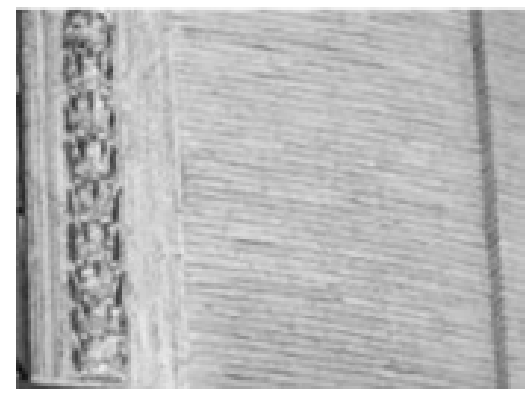

2.16. Detalle del ladrillo del Oratorio de los Filipenses. BORROMINI. Roma, 1667 
encontramos en las pieles plegadas y flotantes que la arquitectura contemporánea utiliza como cerramientos.

$* * * * * * * * * * *$

Similar condición de envolvente dinámica trasladada a la cubierta, parece mostrarnos el Crematorio en Kakamigahara de Toyo Ito, que es como un pliegue aéreo. Los pliegues contemporáneos pierden la pesantez material que condicionaba a la técnica del XVII, y expresan la ligereza que enmascara su condición tectónica de forma mucho más potente.

La envolvente, en esta obra, se reduce a una cubrición superior que protege las piezas situadas debajo. Es como un manto-membrana en movimiento que cubre el lugar. Una piel que cubre, pero no funciona como recinto, sino que deja mezclar el espacio exterior donde se desarrolla, con el espacio interior que convierte en semi-interior, interrelacionando ambiguamente exterior-interior.

Toyo Ito trabaja con la idea de camuflarse en un entorno natural rodeado de vegetación y montañas. Dispone una cubierta de hormigón que parece levitar sobre el lugar. La línea curva que determina su forma se funde con el paisaje, simulando una especie de nube sobre el lugar. Es una como ilimitada, parece querer seguir cubriendo, una piel-envolvente que no es en ningún caso contorno.

Se trata de una lámina finísima de hormigón blanco que desmaterializa la estructura que lo sustenta, confundiéndose con el paisaje, haciendo también que se desvanezca lo portante. La lámina de hormigón está sustentada por pilares de forma cónica. Estas columnas caen libremente, desde la superficie ondulada del techo, hasta el suelo y se perciben como una extensión de la superficie de la cubierta. Su forma contradice la realidad de las cargas estructurales que sustentan el sistema, y va perdiendo sección hacia el suelo, apareciendo como apoyadas sobre un hilo fino, que, además, con su reflejo en el agua, desmaterializa todavía más el apoyo.

La cubierta del edificio en este caso se convierte en lo fundamental de su cerramiento, como un velo en movimiento que cubre el espacio eventualmente. Un movimiento captado en el instante, un movimiento que remite a otro, a una inestabilidad, donde la forma se subordina a un fondo. 

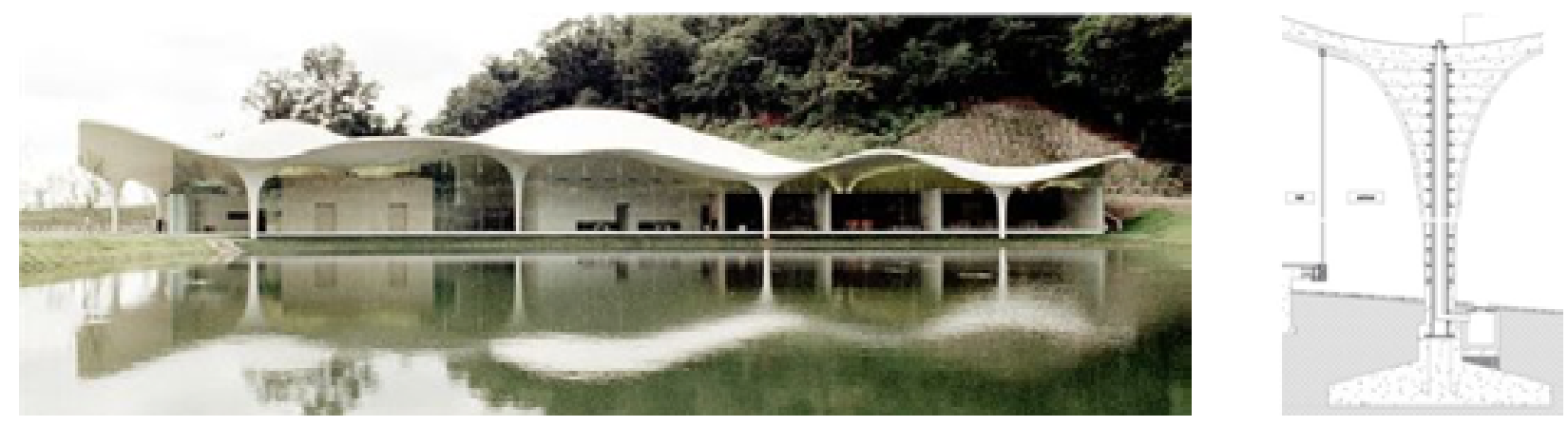

La analogía formal con los pliegues barrocos es bastante inmediata. Son abundantes los casos contemporáneos de pieles plegadas.

2.17. Crematorio de Kakamigahara. TOYO ITO. Gifu, Japón, 2006.

En el que nos ocupa, la ingravidez de la membrana es clave en su lectura como ejemplo de lo a-tectónico. El pliegue barroco aquí se modula llevándolo al límite, al límite de la des-formalización; aquí no se puede hablar de forma, más bien es una energía la que genera la cubrición, es como una forma subordinada a la energía. Un plegado donde lo que subyace es la energía que lo pliega, un plano inmanente, fondo sensible o medio, que permite modular esa energía. Esta es su condición poética, y la estructura se somete a ella.

El pliegue contemporáneo se ha liberado de toda estructura geométrica posible, conoce una liberación sin límite, abandona su soporte, su material, lo enmascara; hormigones convertidos en telas al viento. La materia es solo materia de expresión, como dice Deleuze $^{222}$ con respecto al pliegue barroco. Estos pliegues, determinan y hacen aparecer una forma, que ya no está modelada, es puramente un modo de expresión, línea infinita de inflexión.

La ambigüedad estructural y el pliegue van fuertemente unidos. Cuando la envolvente interior o exterior se somete a la inflexión, al pliegue o al movimiento, lo estable tectónico, lo gravitatorio, componente irrenunciable de la estabilidad arquitectónica, se niega en el resultado formal. Este enmascaramiento de la realidad TOYO HITO. Dibujo de la autora.

\subsubsection{Pliegue dinámico}

La fachada de la torre Hongkou en Shangai de Kengo Kuma, expresa un dinamismo diferente, es como una piel inestable y del mismo modo, la solución exterior se incorpora en el interior con 

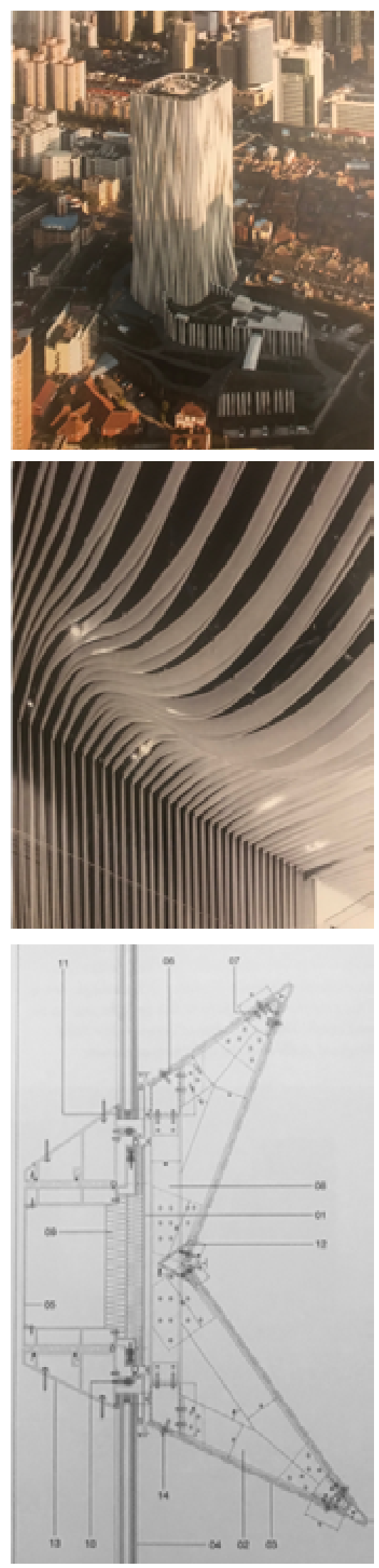

2.19. Torre Hongkou Soho. KENGO KUMA. Shanghai, 2015.

2.20. Sección constructiva de las piezas verticales de aluminio perforado de Torre Hongkou Soho. KENGO KUMA. una continuidad envolvente, compartiendo una misma estructura proyectual en continuidad.

Una envoltura de piezas verticales de chapa perforada de aluminio, que simulan unas fibras onduladas, casi textiles, recubren en toda su superficie esta torre de oficinas. Sobre el cerramiento de muro cortina, se dispone esta segunda piel, que pone en movimiento el volumen mediante esta especie de estrías que se revuelven en vertical.

Las piezas verticales de aluminio se fijan a una estructura auxiliar que a su vez se ancla a la fachada de muro cortina, constituyendo un ámbito espeso que envuelve un espacio, cuyo acabado interior, con una solución de lamas plegadas ondulantes, configura un espacio también fluido relacionado con la dinámica externa. Hay una profundidad en la piel de este edificio que recuerda a los espesores de las fachadas de Borromini; el límite aquí ya no es contorno, es ámbito, zona y se encuentra disgregado.

Las piezas exteriores son tridimensionales y sus secciones tienen una geometría que va variando de unas a otras. Las piezas se retuercen y doblan de forma orgánica, separándose más o menos del muro cortina. Todo el resultado exterior, hace que el aspecto del edificio sea cambiante, según la incidencia de la luz en las diferentes horas del día, potenciando la sensación de inestabilidad y dinamismo. Pero sobre todo se genera una especie de continuidad total, entre las diferentes orientaciones, entre exterior e interior, y en el propio encuentro con el cuerpo bajo, donde la envolvente se vierte sobre el plano horizontal.

Su dinámica propia le otorga ese aspecto cambiante, con una morfología que actúa en el mismo sentido que los pliegues profundos de la fachada de San Carlino, donde la incidencia de la luz rasante en la profundidad plegada arrojaba también sombras profundas a última hora de la tarde.

El exterior de la torre tiene una forma que podríamos llamar dinámica y que se alcanza a través del plegamiento de las piezas que configuran la piel del edificio. Se trata de una morfología que propiamente no parece remitir a ninguna forma estable, una entidad que se encuentra como en busca de su propia forma, una forma-informe. Morfología cercana a lo que representaría la teoría de las catástrofes de René Thom, a la que tanto Deleuze en El Pliegue, como Calabrese, en su Era Neobarroca, se refieren como sub- 
yacente tanto en el Barroco, como en el Neobarroco ${ }^{223}$. La teoría de las catástrofes es un análisis científico sobre la inestabilidad y la metamorfosis. Thom ha intentado proporcionar modelos diversos de descripción de mutación de la forma, teorizando la dinámica de las morfologías.

Calabrese, en su obra, describe la mutación formal de Thom precisamente a través de un pliegue que se interpone entre una forma y otra y que da lugar a la mutación. El pliegue, como la inflexión, lleva implícito el elemento del cambio, de la potencia y la mutación.

\subsubsection{Pliegue e infinito}

El tema del infinito es recurrente en cualquier manifestación cultural del Barroco. La matemática barroca se ocupa del infinito con el cálculo infinitesimal, descubre y concibe como actual lo infinitamente pequeño.

Deleuze observa que el Barroco no concibe en términos de sucesión del tiempo ${ }^{224}$, por ello se ocupa siempre de los problemas del espacio. El tiempo no es más que un auxiliar para la medida del espacio; se tiene la capacidad de constituir una serie indefinida en el tiempo como un conjunto de simultaneidades en el espacio. Deleuze nos describe como solo a partir de aquí se puede concebir la idea de un infinito actual no ligado a una síntesis del tiempo sucesivo. En el siglo XVII se piensa de esta forma y se ocupan del cálculo infinitesimal y diferencial en matemáticas. Por otra parte, la posibilidad de lo infinitesimal, o de la existencia de varios infinitos va siempre ligada a la geometría, pues todo infinito es irreductible a los números, solo se puede captar geométricamente, y así también, la geometría va inevitablemente ligada al espacio.

El siglo XVII nunca comprendió lo que era la síntesis del tiempo, pues se ocupa fundamentalmente de los problemas del espacio. ${ }^{225}$

Con el descubrimiento del tiempo de la modernidad, lo simultáneo, propio del espacio y de las topologías, pasa a ser una síntesis

223 . RENÉ THOM, Stabilité structurelle et morphogénèse, Denöel-Gonthier, París, 1978. Traducción al castellano, Estabilidad estructural y morfogénesis, Gedisa, 2015.

224. Cifr. GILLES DELEUZE, En medio de Spinoza, ed. Cactus, Buenos Aires 1981., págs. 352-359. En este texto Deleuze nos describe las diferencias entre las diferentes concepciones de lo infinito que corresponden al siglo XVII y del XVII en adelante. 
de una sucesión ${ }^{226}$; no se puede ya considerar una serie indefinida sucesiva como si fuera un conjunto infinito de coexistencias. Los elementos por sí solos de un conjunto ya no preexistirán al acto por el cual se consideran o crean, el tiempo pasará así en el siglo XVIII a primer plano en la forma de concebir las cosas como síntesis de una sucesión. Pero Deleuze añade refiriéndose a la actual noción del tiempo:

(...) pero actualmente todo cambia, porque me pregunto si de cierta manera no hemos vuelto, pero por desvíos, a una especie de siglo XVII. ${ }^{227}$

En el Barroco se concibe lo simultáneo y esto atañe al espacio, al todo como conjunto de unidades que pueden ser infinitas en acto (infinito actual) que coexisten, y por tanto lo hacen en el espacio, y no como una sucesión de una unidad en el tiempo.

El hombre del XVII parece así encontrarse arrinconado espacialmente entre dos infinitos: lo infinitamente grande, representado vagamente a través del cielo, y lo infinitamente pequeño.

En el pensamiento de Leibniz, que nos viene guiando en muchas de las interpretaciones, el tema de lo infinitamente pequeño está ligado a la cuestión de la continuidad que tan presente está en las expresiones de la arquitectura que venimos analizando. En la convergencia (es decir en el límite) de las diferencias infinitesimales, las diferencias propias de cada cosa se funden o terminan en las diferencias de la otra (principio de los indiscernibles). Así, en ese infinitamente pequeño lo esencial y lo inesencial (lo diferente) podríamos decir que se superponen o enlazan. Este punto, de enlace es un punto intensivo, de cambio, de inflexión, constituyen, lo que llama Deleuze, los puntos notables. Gilles Deleuze explica así, refiriéndose a Leibniz, su relación entre infinito (o límite infinitesimal, lo infinitamente pequeño) y continuidad:

El límite está definido por la convergencia. Los valores numéricos de una función encuentran su límite en la relación diferencial; las

\footnotetext{
226. Es con el pensamiento de Inmanuel Kant cuando cambia completamente la concepción del tiempo. Kant dirá que un conjunto infinito es un contrasentido pues los elementos del conjunto jamás existen simultáneamente, la síntesis por la cual los produzco es una síntesis sucesiva. Así las matemáticas posteriores al siglo XVII y hasta llegar al siglo XX deducen que el cálculo infinitesimal no tiene ninguna necesidad de los infinitamente pequeños que se conciben en la época barroca. INMANUEL KANT, Critik der reinen Vernunft, 1781 (Crítica de la Razón pura).
} 
relaciones diferenciales encuentran su límite en los grados de variación, y en cada grado, los puntos notables son el límite de las series que se prolongan las unas en las otras. (...) el límite es la potencia de lo continuo, así como la continuidad es la de los límites mismos. ${ }^{228}$

No será posible un continum sin la presencia de lo infinitesimal, que genera en continuidad estos puntos notables o relevantes, que en último término determinan las esencias o sustancias individuales (mónadas).

La noción de composibilidad del mundo, a través de la cual, dice Leibniz, solo se da el mejor de los mundos posibles, ${ }^{229}$ estará también íntimamente unida a la ley de la continuidad. Lebiniz concibe un solo mundo que se compone, cada vez, desde las múltiples perspectivas (o expresiones) de la diferentes Mónadas o esencias, que crean como centros de envolvimiento. Hay un continum de este mundo com-posible, sino no sería posible; en él, las relaciones diferenciales y los puntos relevantes determinan estos centros de expresión (mónadas o esencias individuales).

No podemos negar, que el concepto de lo infinito está presente también en las expresiones artísticas del Barroco. Ya los propios recursos de la inflexión y el pliegue, nos hablan de ello. El pliegue es nombrado por Leibniz con respecto a esta relación continuo-infinito:

Pero un alma (...) no puede desplegar todos sus repliegues a la vez, pues se extienden al infinito. ${ }^{230}$

La Mónada, en su expresión del mundo, permanece plegada y solo ve una región de la realidad, aunque contiene todo, el resto permanece plegado. Así estas regiones se componen, haciendo un mundo com-posible, y su condición, por ello, es la continuidad. Pliegue e inflexión llevan implícito, por tanto, la presencia de lo infinito, y por extensión, la ley de la continuidad. Pero el pliegue puede expresar más rotundamente lo infinito, lo infinitamente pequeño si lo encontramos plegándose en una especie de espiral cuya continuación convergería en un infinitamente pequeño.

228. GILLES DELEUZE, Diferencia y Repetición op. cit.

229. Cifr. G.W. LEIBNIZ, Monadología, en 48 o 55, por ejemplo.

230. G.W. LEIBNIZ, Monadología 61. 


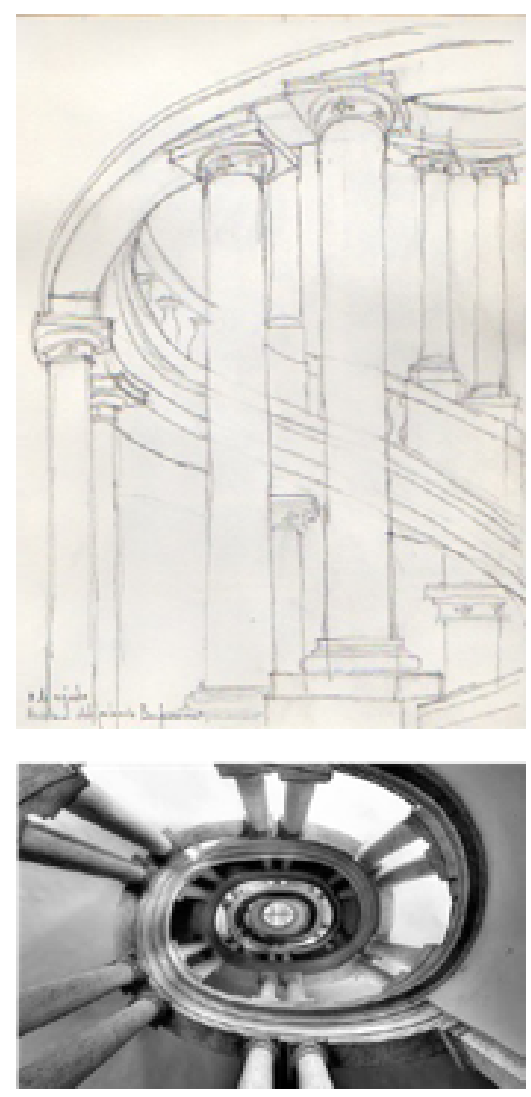

2.21. Escalera oval del Palacio Barberini BORROMINI. Roma, 1633. Dibujo e imagen de la autora.
Pero, por otra parte, en la espiral, el centro es un vacío, es ese lugar inaudito donde las series convergen. El círculo, figura teológicamente perfecta, representa la unicidad y el punto de vista único. En la lógica barroca, el círculo se transforma en una elipse constituida por un doble foco, dando así un efecto de dinamismo y de ausencia en el centro, como en la espiral, torbellino sin fin. El espacio vacío y lo informal se muestran así en su centro.

Dos elementos de Borromini ponen de relieve el tema del infinito, de un infinito interior, que tiende a lo pequeño, infinitesimal: la escalera del palacio Barberini y el remate de la linterna de Sant'Ivo.

La escalera es prácticamente una copia de la que construye Mascherino en el Palacio del Quirinal, pero la escalera de Borromini tiene elementos singulares que la identifican. La escalera es el pliegue al infinito. Un plegado sobre sí, hacia arriba, hacia lo alto. La escalera prolifera, es un único plano espeso que se enrolla sobre sí mismo, ascendiendo en un ritmo no uniforme.

El ritmo no podría ser uniforme en la mera sucesión no se manifiesta impulso ni potencia que remita a una variación, a un cambio. Se compone de pares de columnas que la sustentan y generan su movimiento ascendente; la multiplicidad de elementos se eleva moviéndose sobre el plano en un plegado ascendente.

Pero lo sorprendente es que Borromini aplasta la balaustrada en los últimos pisos de la escalera, intensificando así la perspectiva y dando la sensación de mayor profundidad, perdiéndose en lo alto; jugando con la idea del infinito, un infinito que se pierde en lo más pequeño, que intensifica el espacio.

Si la escalera del palacio Barberini señala a una especie de unidad interior que puede prolongarse en partes infinitamente pequeñas, el remate de la linterna de Sant'Ivo señala al cielo y se pierde en su infinitud, pero se pierde en el cielo mientras desaparece y se desintegra, se desmaterializa, intensificando así la presencia del espacio, de un fondo, que se funde con la forma, como diluyéndola.

En la linterna de Sant>Ivo alla Sapienza Borromini lleva al extremo este tema. La planta se genera por un triángulo equilátero que acaba formando una especie de estrella, como forma exterior, y un hexágono regular como espacio central interior. El resultado es una piel infinitamente plegada hacia adentro, un pliegue que a 
su vez es un despliegue de elementos, con un impulso ascendente hacia lo más pequeño. Sobre el tambor de la cúpula asciende la linterna que es un elemento muy característico del conjunto; una rampa en espiral que va enrollándose en torno al cono de la linterna y que se eleva hasta el punto culminante de todo el edificio; una estructura de hierro que, en forma de llama, sostiene una esfera y una cruz. El edificio asciende desde su planta de una manera continua y acaba desmaterializándose en el infinito del cielo.

La arquitectura de Borromini se despliega a partir del punto de inflexión, y el desplazamiento de las columnas como bisagras fuera de sus goznes da lugar a un movimiento que deviene infinito y se traduce en pliegues, repliegues, despliegues. Todos estos elementos tienen su correlato en lo inmaterial, pues si la forma, a través de estos recursos queda in-formada, perdiendo su con-figuración, la materia no subsiste sin el compuesto materia-forma, por lo que culmina, en última instancia, en una desmaterialización. El remate de la linterna de San't Ivo, se disgrega en una forma metálica que de lejos parece espuma, materia disgregada, como presintiendo la desmaterialización que era radicalmente en el modo de expresión contemporáneo en la que profundizaremos más adelante ${ }^{231}$.

¿No encontramos el tema de lo infinitamente pequeño también en nuestra arquitectura contemporánea en sus diversas expresiones? Ya los casos anteriores con los que hemos ilustrado el uso del pliegue o la inflexión, contienen implícitamente, como hemos visto, la idea del infinito.

Hay algún caso, como el que presentamos, con gran similitud formal o figural a los elementos vistos del Barroco histórico, y que corresponde también a programas de espacios sagrados.

En la capilla Bruder Klaus Field, Peter Zumthor proyecta un interior místico y reflexivo, donde la mirada se direcciona de forma evidente, hacia el punto donde el techo está abierto al cielo, marcando un infinitesimal, un nuevo transfinito. El interior es de forma cónica y desde la planta más ancha, el espacio asciende verticalmente según la textura estriada del cerramiento, que aumenta la sensación ascendente. Se trata también de un pliegue

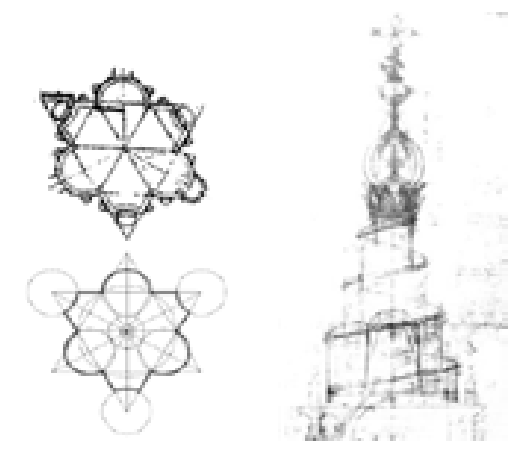

2.22. Planta de Sant'Ivo alla Sapienza y su generación geométrica. Alzado del remate de la linterna. BORROMINI. Roma, 1660. 
2.23. Escalera del palacio Barberini. BORROMINI, Roma, 1633.

2.24. Capilla Bruder Klaus Field. PETER ZUMTHOR Mechernich, Alemania 2007.
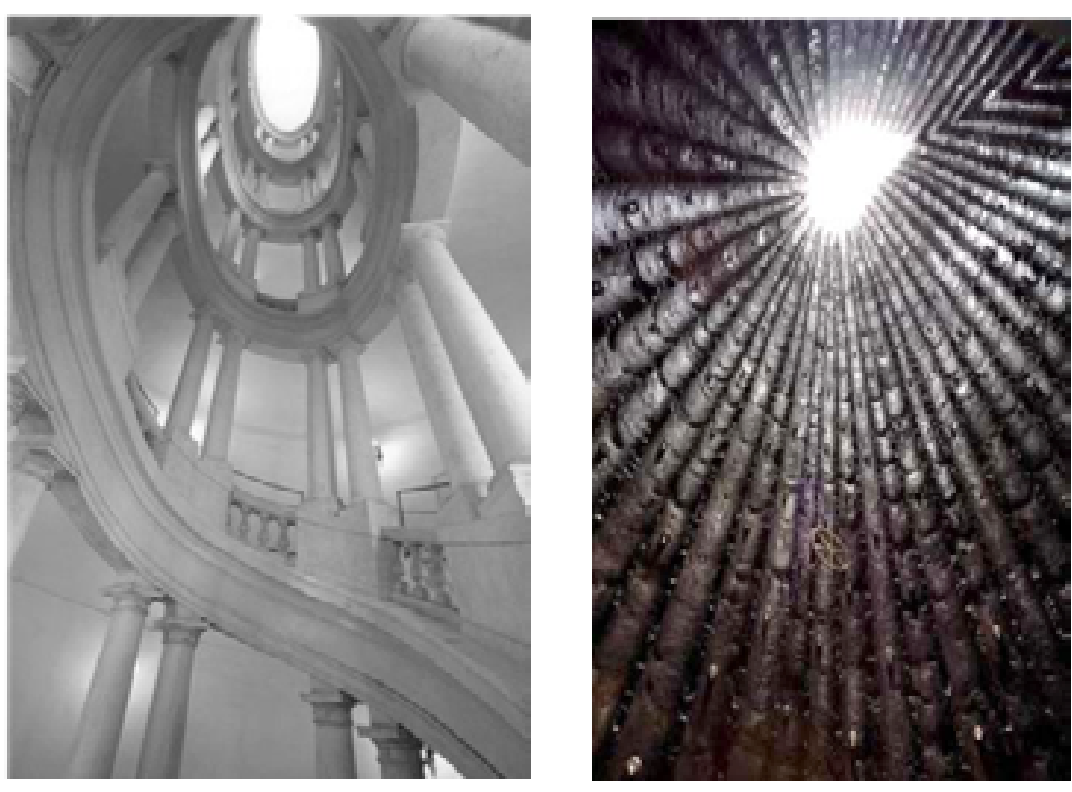

al infinito, a un infinitamente pequeño, representado por la forma cónica.

La construcción del conjunto se basaba en montar un encofrado con troncos en forma de cono, que darían forma posteriormente al vertido de hormigón armado, que quedó interrumpido en su parte superior generando la apertura al cielo, un óculo que proporciona la única luz directa para el pequeño espacio oscuro.

Además de por el óculo, la luz del día penetra en la capilla a través de unas pequeñas perforaciones en los muros de hormigón, que se disponen aprovechando los puntos de anclaje del encofrado. Así la envolvente, que es estructural queda perforada, disgregada, a la vez que texturizada, enmascarando de nuevo su función portante.

Para retirar el encofrado interior, se quemaron los troncos que una vez consumidos dejan un espacio que es la forma exacta en negativo del mismo; un vacío como una especie de interior monádico, sin ventanas, introvertido, con una textura de finos pliegues, como una dermis en carne viva ${ }^{232}$, iluminado únicamente desde arriba.

Los bocetos primeros de este proyecto son como la representación de una mónada; un continuo plegado formando una inclusión donde se ha establecido la mónada como causa final del pliegue.

232. GILLES DELEUZE, El Pliegue... , op. cit., pág. 12 
Si lo potencial, lo virtual es esencial para la expresión artística en el Barroco, será a través del concepto de inflexión como acontecimiento, que representa una singularidad, una expresión, una realización que se distingue del fondo de lo posible. La obra de Deleuze sobre El Pliegue, gira en torno al acontecimiento de la inflexión en su vinculación directa con el pliegue, y desde ahí se desencadena todo el análisis del Barroco en relación con la filosofía de Leibniz. La inflexión apunta a un cambio en las condiciones, a una potencia de cambio.

Pliegue e inflexión, remiten a un exceso formal, la forma, como forma en sí, pierde integridad, reconocimiento, lo que no quiere decir que pierda protagonismo. Hay, como Buci- Glucksmann nos ha señalado, una locura de ver, de querer verlo todo, ver hasta las fuerzas que actúan en la determinación, eso pre-formal ${ }^{233}$. Cuando la forma se deforma hasta el extremo tiende hacia un límite infinito (el tema del Barroco), donde las determinaciones se funden, las diferencias entre unas y otras se diluyen. La forma extrema necesariamente tiene como referencia un ámbito infinitesimal donde las diferencias se diluyen en una especie de fondo-matriz que las contiene a todas: el fondo de lo posible. Ese será el sentido de lo infinitamente pequeño que Leibniz propone como modo constituyente de sus esencias-mónadas.

Omar Calabrese cuando describe su Era Neobarroca, también nota esa especie de demasiado ${ }^{234}$, en el ámbito de la forma.

Es posible teorizar la inflexión en torno a diferentes entradas: la geométrica, la estética o la filosófica, al menos, son las que en este texto se han tocado.

Todas ellas señalan a un acontecimiento, pero también a una continuidad. Lo continuo es estructural en el caso del Barroco, es lo que posibilita la inflexión, y la propia inflexión en sí, como ya hemos visto, es un acontecimiento, una singularidad, pero una singularidad intrínseca, no proviene de coordenadas exteriores, ni un arriba, ni un abajo, un final o un principio. 
El Barroco o el Neobarroco tienen en común, a partir de este lenguaje, el intento de representar un fondo potencial que tiene su base, de una manera o de otra, en la inflexión, como forma del acontecimiento, en sus diferentes versiones entrelazadas, la geométrica, la estética o la filosófica.

Por tanto:

- Los recursos formales del pliegue y la inflexión son, así, elementos potenciales, objetos de virtualidad, remiten a una potencia más que a una forma, no muestran la forma como "completada", la determinación, sino más bien al ámbito donde las cosas se formalizan, al lugar anterior a la individuación.

- Tienen como referencia lo continuo, la ley de la continuidad, a partir de la cual se organiza todo el universo del infinito Barroco. Inflexión, pliegue, infinito y continuidad, vienen a ser elementos vinculados e inseparables en la comprensión barroca del mundo.

La arquitectura, como configuración en el espacio de la materia arquitectónica, remite al espacio que es su medio, su región de posibilidad. Un espacio entendido como extensión, espacio extenso y medible. Pero también entendido como un lugar de intensidades, de potencias, como espacio activo, lugar de generación de la forma, ámbito de posibilidad y creación, ámbito pre-formal. En este sentido, los recursos del pliegue, la inflexión, la variación, remiten al espacio como con-figurador de la arquitectura, a un espaciar, como un abrir lugar ${ }^{235}$, y hacen aparecer la forma como dependiente del espacio e intensificando su presencia; la notada presencia del espacio es un tema de la arquitectura barroca en general.

En el caso de la obra de Borromini, esta presencia del espacio se intensifica en detrimento del valor de la forma, que se de-forma debido al uso de estos recursos formales que la cuestionan en su estatuto tradicional. Pues es el espacio, que funciona como fondo-matriz, el que contiene las condiciones de lo posible: la potencia. En Borromini, estas categorías formales no son meros recursos, se obtienen de una coherencia integral en la manera de afrontar el proyecto como una unidad topológica que funciona en

235. Cifr. MARTIN HEIDEGGER, Zur Sache des Denkesns, Auflage, Max Niemeyer Verlag, Tubingen, 2000. Edición en Castellano de Manuel Garrido, Tiempo y Ser, Tecnos 2011, pág. 42. 
continuidad y que se irá metamorfoseando conjuntamente, como más adelante veremos.

El modelo o el tipo ha desaparecido en beneficio de la especificidad de la obra concreta, que toma un protagonismo en su singularidad, pues se ha formalizado en sus relaciones específicas de respectividad, como una topología.

El pliegue es una especie de función operatoria que actúa en lo barroco, y que es exportable; lo que define al Barroco no es una esencia sino un trazo, un trazo que remite precisamente a lo inesencial, a un punto de vista que convive con otros para componer un mundo que siempre difiere.

Todos los parámetros que a partir de ahora se van a tratar, estarán vinculados a este primero de los modos de la inflexión. No como referencia principal, sino como formando un conjunto coherente de referencias relacionadas entre sí, donde unas no se pueden leer completamente separadas de las otras. 


\section{EL MODO DE LA REPETICIÓN}

Retornar es pues la única identidad, pero la identidad como potencia segunda, la identidad de la diferencia, lo idéntico que se dice de lo diferente, que gira en torno a lo diferente. Semejante identidad, producida por la diferencia, es determinada como

"repetición."."236

La repetición, por sí misma, no sería percibida si no hubiera algo que cambia en el espíritu que la contempla. Esta es la tesis de Hume. No puede hablarse, por tanto, de repetición más que en función de la diferencia. Si no lo repetido se percibiría como lo mismo.

El tema de la repetición está, por tanto, ligado inevitablemente al de la diferencia. Se trata de una paradoja. Hay siempre algo que permanece, pero que solo podremos apreciarlo en lo que tiene de diferente con lo otro.

Por otra parte, la repetición se fundamenta en una síntesis del tiempo; se trata de una sucesión de instantes, independientes los unos de los otros, que se contrae en una duración, pero una duración que ya, en sí, implica cambio. La memoria, luego, reconstruye los casos particulares como elementos distintos, que decimos que se repiten.

El tema de la repetición está irremediablemente unido a una reflexión sobre la diferencia. ¿Y no es la diferencia la cuestión que se pone en juego en la distinción, en la propia individuación de la forma?

En el gusto del Barroco histórico se encuentran las variaciones de estilo, ejercicios sobre un tema, y tienen también que ver con la descentralidad organizadora que produce una especie de red de reglas enlazadas que generan siempre variación.

La variación se encuentra en la red de posibilidades implícita en los croquis que Borromini elabora para sus proyectos, en los que el arquitecto registra las variaciones sobre el proyecto en una suerte 
de metamorfoseado de la forma, como más adelante veremos ${ }^{237}$. Cuando el modelo de imitación o el tipo desaparece en el proceso de creación, cuando, además, el peso del centro se ha derivado a lo periférico, las posibilidades devienen múltiples, y el tema de la variación se introduce en el modo de expresión de la arquitectura. Ya no hay original, como ya no hay tipo, referencia o analogía. Ahora, la propia diferencia es el tema del proyecto.

La referencia al modelo, que era central en buena parte del arte del Renacimiento, se cuestiona con la repetición que hace desaparecer toda analogía jerárquica y pone en pie de igualdad a cualquiera de los elementos que se repiten. Podría considerarse que es la forma contraria de afrontar las cosas.

(...) lo repetitivo y lo serial se consideran (...) el punto opuesto y contrapuesto del original (...)..$^{238}$

El tema de la repetición es recurrente como motivo, tanto en la arquitectura del Barroco histórico como en nuestro arte contemporáneo en general, aunque podría considerarse que es una constante en cualquier manifestación estética de cualquier época. Pero el Barroco introduce una marca propia: en la repetición se hace explícita la diferencia, se introduce la variación. Es decir, los elementos se repiten, pero no de igual modo o manera, sino que se someten a cambio, de posición, se ritmo, de color.... Podemos decir que se hace tema de la diferencia en el acto de la repetición. Se explicita la cuestión o la reflexión sobre la diferencia. Wölfflin ${ }^{239}$ ya había hablado del ritmo como componente fundamental de la idea de movimiento en el Barroco histórico. Omar Calabrese $^{240}$ señala también un gusto por la repetición y el ritmo en la estética neobarroca.

Ritmo y movimiento son los dos efectos que la repetición con variación lleva aparejada. Pero también aflora una especie de fuerza, una potencia de cambio, que la variación lleva implícita y que es la que hace pasar de la reiteración a esa repetición rítmica y alterada. Hay como un impulso.

237. Véase infra, capítulo 4, págs. 284-294.

238. OMAR CALABRESE, op. cit., pág. 44.

239. HENRICH WÖLFFLIN, Reinassance und Barock, Schabe and Co, Basilea, 1968. Traducción al Castellano de Alberto Corazón (1978), Renacimiento y Barroco, Ed. Paidós Segunda parte: Las razones de la transformación estilística, págs. 92 y 93. 
En el pequeño claustro de la iglesia de San Carlino, reparamos en el tema del movimiento en relación con el ritmo y la repetición, que se introduce en un espacio de dimensiones muy reducidas.

Borromini inflexiona el trazado achaflanando las esquinas, deshaciendo la forma rectangular y unificando el espacio del claustro, que a partir de aquí va como a girar con movimiento y ritmo. Pero, además, en la implantación de las columnas introduce su innovación eliminando del peristilo las columnas de las esquinas. Esta modificación lleva aparejada otras dos: la aparición de la superficie convexa y la diferente dimensión de los intercolumnios con arquitrabe, ambas confluyen en un espacio continuo inmerso como en una especie de ritmo.

$\mathrm{Al}$ cortar las esquinas en ángulo consigue una continuidad en el plano. Además, las superficies de las esquinas adquieren formas convexas en el piso bajo, pero con la cornisa del piso de arriba en un chaflán recto, alterando a su vez la forma poligonal resultante. Dispone de muy poco espacio, pero resulta una fluidez casi musical que le presta la unidad que corresponde con sus pequeñas dimensiones.

Mediante las fuertes columnas del pórtico, reduce todavía más el espacio. Evita la simetría y distribuye los intervalos con un ritmo alterado eliminando los ángulos para que este ritmo gire en redondo, introduciendo así el sentido de la variación como desarrollo de un continuo.

En los extremos de su planta rectangular, las columnas giran, se abren produciendo el chaflán y el plegado del plano convexo de una manera que se aproxima a lo musical. El ritmo no es uniforme, lleva implícita una fuerza, contiene una energía potencial que admitiría una variación continua. El contorno del patio se pliega sobre sí mismo como concentrándose en una unidad pequeña pero compleja, una unidad intensiva y topológica; el claustro de San Carlino es la producción del movimiento para alcanzar un continuo.

Se trata de la introducción de una dinámica, frente a la estaticidad del modelo renacentista. La diferencia en la medida de lo intercolumnios genera una especie de repetición variada, como un ritmo

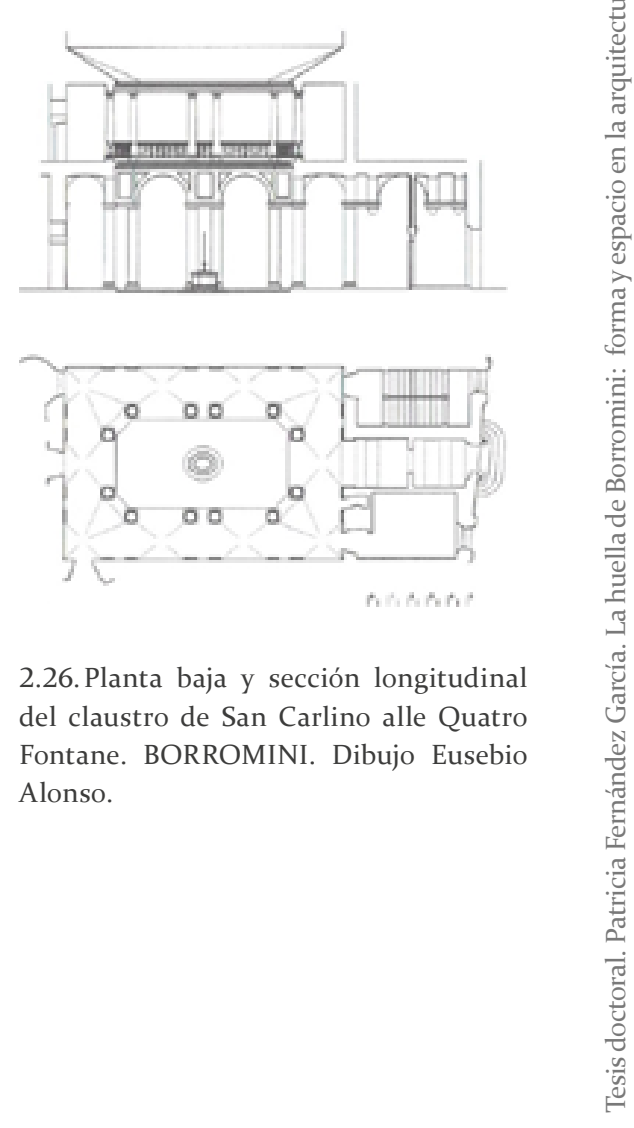

2.26. Planta baja y sección longitudinal del claustro de San Carlino alle Quatro Fontane. BORROMINI. Dibujo Eusebio Alonso. 

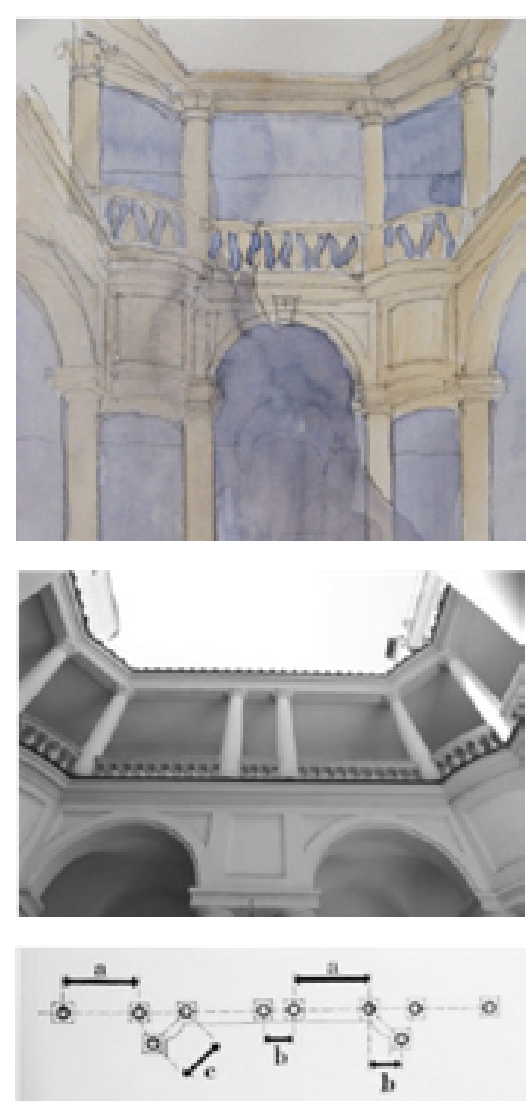

2.27. Acuarela del claustro de San Carlino alle Quattro Fontane con los claroscuros de las barandillas. BORROMINI. Dibujo de la autora.

2.28. Vista del claustro y esquema de Paolo Portoghesi del ritmo de las columnas del claustro de San Carlino. y un movimiento, que debido a l achaflanado de las esquinas, se produce en continuidad.

Así mismo, la solución continua de la bóveda anular del piso inferior del claustro, incide en mostrar de nuevo el carácter envolvente y continuo. La inflexión otorga al conjunto un dinamismo que proviene de su condición de continuidad. Parece como si el objeto arquitectónico estable, se hubiera puesto en movimiento y admitiera modificaciones continuas, impulsadas por una trama en la que se ha introducido una fuerza.

La inflexión, en la caracterización de Venturi, tiene el valor de reconfigurar las relaciones entre el todo y las partes, y por ello es el instrumento fundamental para acceder al cuestionamiento de la forma de conformar el espacio que había tenido lugar en el Renacimiento. Pero ahora la figura propia del fragmento da paso a la abstracción propia de la inflexión; la inflexión, dice Caché, produce consistencia en la transitividad ${ }^{241}$ y frente al modelo estático clásico, él nota que en el espacio de la inflexión no hay permanencia posible. La inflexión, como el pliegue, apunta a una fuerza, a la producción del movimiento.

Inflexión y repetición se hayan, por tanto, vinculadas.

En el claustro de San Carlino no existe esta permanencia, modula el reducido espacio de forma continua, girando alrededor. La simultaneidad de las relaciones geométricas ortogonales y diagonales nos nuestra una especie de heterogeneidad propia del hacer de nuestro arquitecto, creando relaciones diversas que se relacionan respectivamente, son topológicas, y resaltan el vacío espacial del patio.

Por último, Borromini sitúa las balaustradas del piso superior de forma alternada, invirtiendo un balaustre cada vez, provocando una vibración de sombras, como figuras en movimiento. Este recurso genera una especie de ritmo cambiante que contribuye a resaltar un movimiento espacial que pone en relieve el espacio vacío del claustro. Este recurso de alternar los balaustres es típico en su obra y lo encontraremos en más casos.

Como estamos viendo, se trata siempre de una repetición con variación. La repetición por sí misma apunta solo a una cierta dis- 
gregación, pero no tanto al movimiento; el sentido del cambio, la alteridad y el movimiento, solo se alcanza con la variación, donde el impulso, la fuerza o la potencia se han introducido. La repetición como tal, únicamente como reiteración de elementos, lleva aparejada una cierta estaticidad en la uniformidad; el cambio, la variación tiene necesariamente que referirse a una fuerza o potencia que pone la cosa en vibración.

Podríamos trasladar esta cuestión a la diferencia establecida por Heidegger entre lo idéntico y Lo mismo.

Lo mismo y lo igual no se recubren, como tampoco lo mismo y la uniformidad vacía de lo puro idéntico. Lo igual se une siempre a lo sin-diferencia, para que todo concuerde en él. Lo mismo, por el contrario, es la pertenencia mutua de lo diferente a partir de la reunión operada por la diferencia. ${ }^{242}$

Ese Lo Mismo es una reunión de lo diferente en su unión original, que se muestra en la variación que la propia repetición expresa.

Hay en el claustro de San Carlino una estética de la repetición en forma de variación organizada, para la posición de las columnas y de repetición variable, en los elementos invertidos uno a uno de la balaustrada.

La repetición remite siempre a un dinamismo, un dinamismo que ya hemos observado en la referencia a una morfología en proceso de configuración, a la que, en última instancia, apuntaba la forma-pliegue.

La variación barroca viene, en muchos de los casos, apoyada por el régimen de la luz, por su tratamiento a base de claroscuros. El claroscuro es un tema del Barroco y por ello es un recurso habitual de resaltar la variación.

En el proyecto para la rehabilitación de San Giovanni Laterano, Borromini vuelve a utilizar el tema de la repetición, en este caso variada por la introducción de zonas de sombra, por el uso de la luz y los claroscuros, pero también por los diferentes tonos de lo 


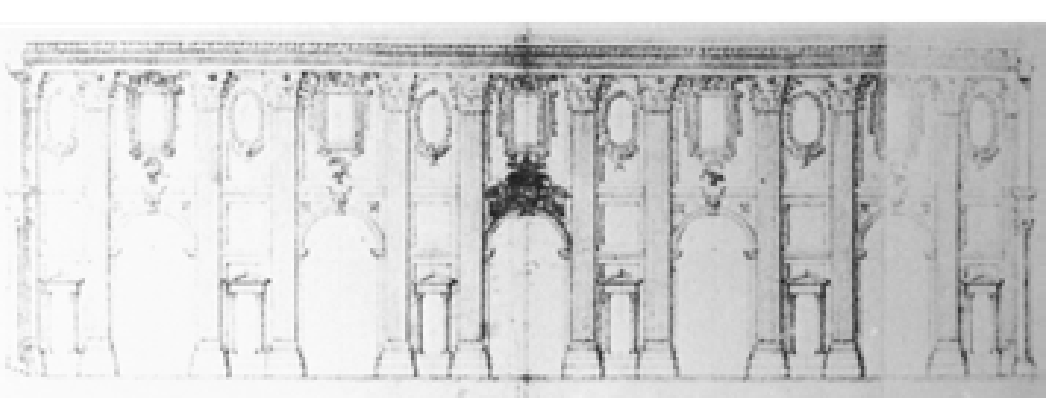

2.29. Dibujo del alzado de la nave central de San Giovanni Laterano. Rehabilitación por BORROMINI. Roma, 1649. Albertina de Viena.
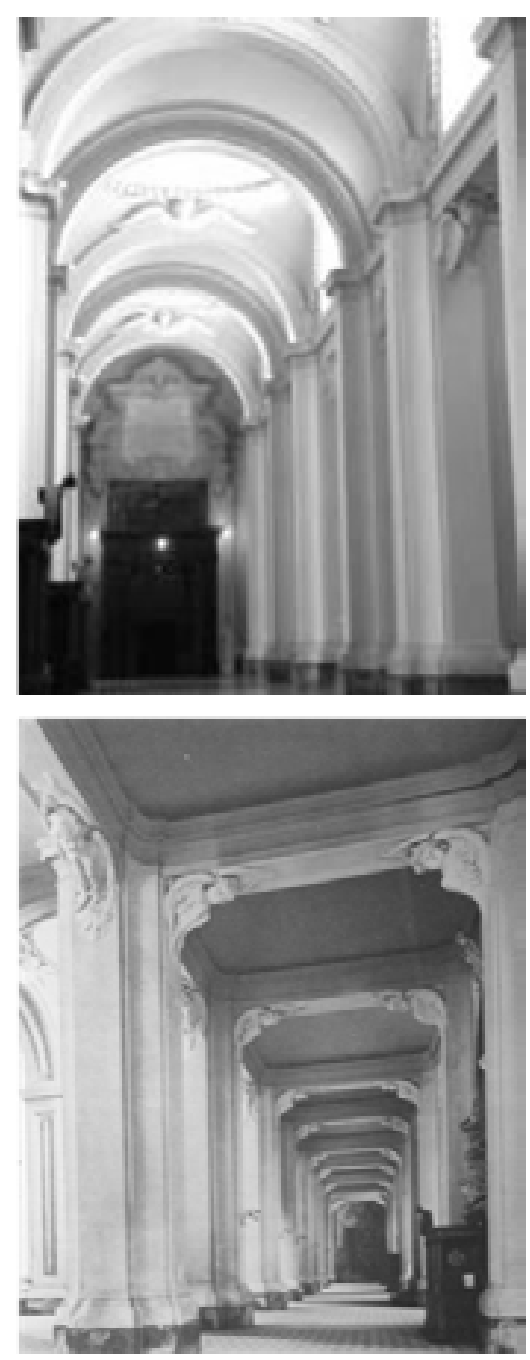

2.30. Naves laterales de San Giovanni Laterano. BORROMINI. materiales, en definitiva, es el tema del contraste, sobre el cual se significa la diferencia.

Borromini construye sobre un edificio existente, manteniendo el espacio central de la nave como memoria de la antigua basílica. Nuestro arquitecto se encuentra con unas naves laterales muy bajas y en disposición poco adecuada y se ve obligado a derribarlas y a volver a construirlas. La nueva construcción se integra perfectamente con la nave central cuyo espacio permanece integro con su cubrición original; consigue integrar la mayoría de las columnas en la nueva estructura.

Para el alzado de la nave central Borromini intenta evitar la monotonía que produce una repetición del mismo elemento sin variación; establece un ritmo, que le confiere el movimiento, un ritmo de alternancia entre tramos grandes y pequeños a lo largo de toda la nave, incluyendo los tramos de los extremos, que giran $45^{\circ}$. Cierra los vanos más pequeños colocando en ellos nichos para estatuas, de forma que, en vez de una alternancia de vanos anchos y estrechos, lo que tiene es una alternancia de vanos y pilares macizos. Se da cuenta de que el alzado no se verá habitualmente de frente, sino en escorzo, al pasar longitudinalmente por la nave, por lo que la alternancia de huecos grandes y pequeños no resulta tan eficaz. Hace resaltar del plano del muro los nichos de los pilares, introduciendo un recurso específico para la visión en escorzo. Para pronunciar este efecto, juega con la variedad en los materiales; los nichos están flanqueados por columnas de mármol serpentino, sus bases y frontones son de mármol gris oscuro, de forma que resaltan en contraste con el blanco de los pilares y las pilastras. Las ventanas son alternativamente ovaladas y rectangulares. Empuja también hacia afuera ligeramente el entablamento en los tramos constituidos por las parejas de pilastras.

En las naves laterales no se ve condicionado por la fábrica antigua, pero sí por el ritmo de tramos de diferentes tamaños que impone la nave central. Borromini aprovecha esta desigualdad y la 
subraya, introduciendo de nuevo variación en la repetición; deja en oscuridad los tramos pequeños e ilumina los mayores, lo que contribuye a pronunciar el ritmo y el movimiento al avanzar longitudinalmente. Lo hace a través de unas ventanas que puede abrir en el muro entre las dos naves laterales. Esta disposición de naves escalonadas seguía además la estructura de la basílica paleocristiana como replicándola en un gesto, respetando su memoria. El régimen de variación en este caso es la luz, un ritmo en variación reforzado por la luz, resultando una repetición de claroscuros que se suceden.

El tema de la variación en la iglesia de San Giovanni, esta fundamentado en los contrastes. Contrastes entre materiales, contrastes por claroscuros... La manera de realzar la diferencia, no se lleva a cabo por delimitaciones o contornos, sino por contrastes, haciendo del límite entre las cosas algo alejado de un contorno, tratándose más de una especie de ámbito ${ }^{243}$.

Las balaustradas de San Giovanni siguen el modelo de balaustres invertidos de las que cierran el piso superior del claustro de San Carlino. Pero Borromini añade esta vez una variación más, pues modela los balaustres de forma irregular, de tal manera que le permita también variar su posición en vertical, unos respecto a otros.

Además, toda la iglesia se encuentra decorada con unas figuras de angelotes o querubes, que Borromini repetirá en muchas de sus obras, son como su sello, pero que en San Giovanni forman parte del decorado repetitivo, haciendo tema de ello. Los querubes no son todos iguales, varían sus formas y posturas, pero se repiten como elemento, subrayando la diferencia en la repetición.

Por citar más ejemplos del empleo de este recurso de la variación, en la cornisa de la fachada del colegio Propaganda Fide, Borromini dispone los modillones variando su posición de manera alternada, produciendo un movimiento en profundidad visto desde la calle, que hace vibrar la cornisa, en una especie de baile de piezas. Su disposición alternada les da un aspecto de ligereza que contradice de nuevo su función portante de apoyo de la cornisa.

El tema de la repetición está presente en muchas de las obras de Borromini, es uno de los recursos que imprime movimiento a sus
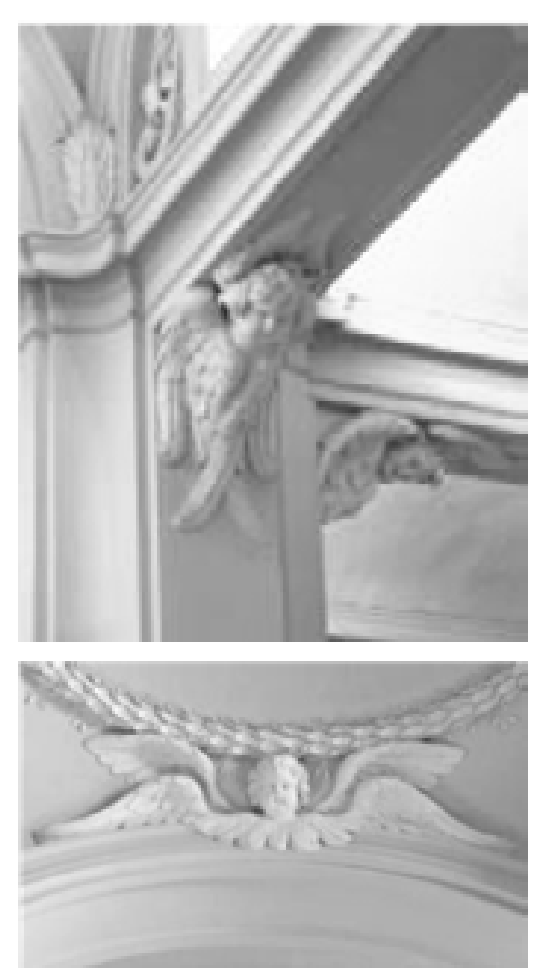

2.31. Decoración de Querubes en San Giovanni Laterano. BORROMINI. 
2.32. Cornisa de la fachada del Colegio Propaganda Fide. BORROMINI. Roma, 1667

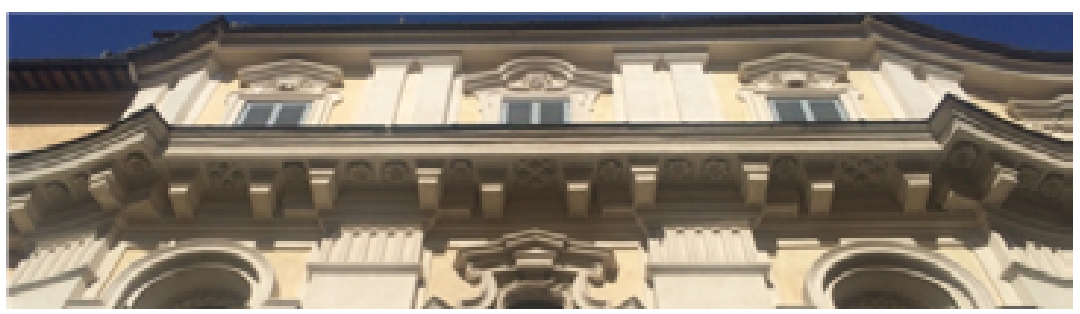

obras. Se trata siempre de una repetición con alteración de elementos, subrayando la diferencia y a la vez una especie de potencia generadora de la variación y el ritmo.

A su vez la repetición de elementos, la propia variación en sí, se aleja u opone a la presencia de un modelo o tipo; ya no existe original, el tema ahora es la diferencia, la hegemonía de la diferencia, de la alteridad y de la variación, que sustituye al modelo.

Potencia y alteridad son dos caracteres que podemos extraer de la lectura de este recurso en la arquitectura. 


\subsection{REPETICIÓN: CONTINGENCIA Y DESCOMPOSICIÓN}

Calabrese ha observado en la era neobarroca una estética de la repetición a través de la variación organizada, el policentrismo y la irregularidad regulada y el ritmo frenético, considerándolos desde el punto de vista formal componentes de un universal Barroco ${ }^{244}$.

¿No encontramos en la repetición de nuestra arquitectura actual un rasgo recurrente? ¿No comparte nuestra arquitectura este rasgo Neobarroco que Calabrese ha notado?

Aunque el recurso de la repetición se manifiesta marcadamente también en nuestra arquitectura contemporánea, esta presenta algunas diferencias significativas con la respecto al modo en el que lo hace en el Barroco histórico. Pero estas diferencias podríamos interpretarlas, más que como diferencias, como intensificaciones del efecto o del sentido que estas obras expresan.

En primer lugar, nuestra arquitectura insiste en el tema de la variación añadiendo una componente más que incide en el valor de la diferencia; se trata de la irregularidad. La repetición en las obras que vamos a analizar, no se limita a variar el ritmo de elementos, o a alternar los propios elementos con otros como hemos visto en la obra de Borromini, ahora se trata de repetir lo irregular, de introducir una espacie de azar.

La diferencia aparece como implícita en la repetición, como motivo de una composición continua; se trata de un continuo que se metamorfosea, que va cambiando, haciendo tema de la diferencia. Los elementos que se repiten realzan su diferencia: tamaños, inclinaciones, alturas, profundidades, tales son las diferencias que se distinguen. Pero hay algo común que deja que los elementos se lean como repetidos.

La segunda diferencia, también es más bien una intensidad de sentido. La repetición contemporánea viene aparejada a una des-composición formal, es como si la forma se disgregara en elementos. La repetición de estos elementos puede ser leída como modo de duración en nuestra memoria, produciendo esa continuidad de la que hablamos, que es, en definitiva, la manera de reconocer la forma como determinada. 
Deleuze ha notado en la forma contemporánea una nueva armonía; una armonía donde, sin embargo, los armónicos han perdido todo privilegio de rango ${ }^{245}$. Las relaciones pierden también todo privilegio de orden, y es así como se muestra lo contingente, el azar, lo accidental o la divergencia. Si en el Barroco las series que expresaban las mónadas para configurar un mundo regido por el principio de la armonía eran, por ello, necesariamente convergentes, ahora, las series se tornan divergentes, en expansión. Deleuze nombra a este mundo constituido por series divergentes caosmos. Sigue habiendo un punto de vista, pero las condiciones se han modificado y la figura y el plano están en movimiento en el espacio ${ }^{246}$.

El mundo ya no es composible, sino incomposible, y la mónada ya no se cierra en sí misma permanece como semiabierta. Ya no puede incluir un mundo entero, se abre como en una espiral inversa a la barroca, una espiral en expansión ${ }^{247}$. Esto tendrá sus implicaciones en la subsistencia del interior monádico. Lo veremos más adelante $^{248}$.

La irregularidad responde a esta falta de armonía, la descomposición a la divergencia de las series.

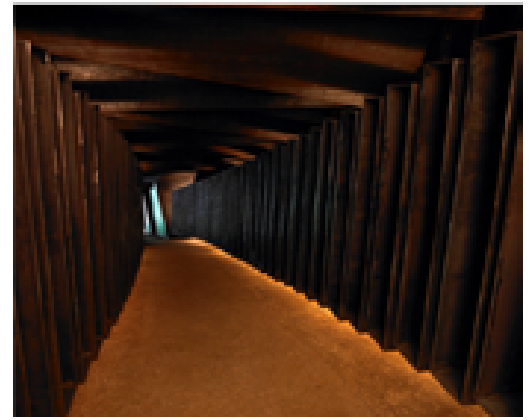

El equipo RCR en el conjunto espacial para las Bodegas Bell Lloc, en Palamós, basa en la repetición de elementos mucha parte de los efectos espaciales que encontramos en el recorrido. Desde los claroscuros y juegos de luz, hasta la propia estructura que conforma el espacio, se disponen en torno a la repetición.

La repetición, se basa en este caso en una especie de irregularidad

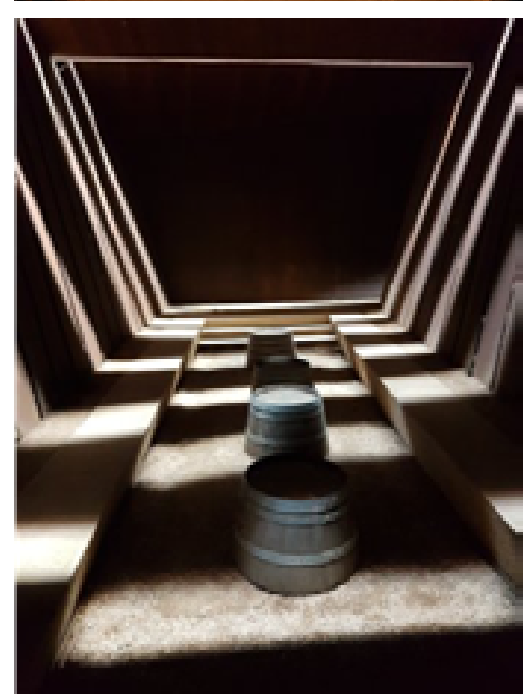

2.34. Interior de las bogas Bell-lloc. RCR. Palamós, 2007. regulada, o variación, no tanto organizada, sino más bien aleatoria, pero también se trata de una des-composición formal.

Hay una complejidad espacial que parte de un solo elemento material, una pieza de acero sin tratar que se repite formando las limitaciones laterales. Todas las piezas tienen el mismo ancho, pero longitud variable. Ofrecen superficies internas y externas, volúmenes y vacíos, sólidos y vanos; el material se impone por su

245. GILlES DELEUZE, El Pliegue..., op. cit., pág. 176.

246. Cifr. Ibid., pág. 175.

247. Cifr. Ibid., pág. 176.

248. Véase infra, págs. 314-328. 
textura en relación con la tierra, pero aparece disgregado, generando claroscuros que enfatizan el espacio. Las planchas de acero vertebran el espacio, pero están separadas unas de otras generando fuertes contrastes de luces y sombras. Aportan un orden al conjunto a la vez que proporcionan múltiples ritmos. El equilibrio entre luz y sombra cambia constantemente. Se trata de una vibración de luz, su modulación. La repetición, siempre variable, es utilizada para producir otra variación vinculada, la producida por la luz, intensificada por la oscuridad de los espacios enterrados. Hay una especie de ritmo intensificado.

La variación es un tema de la modernidad que se suele vincular a la producción industrial en serie, pero que está presente en la arquitectura:

Si la repetición ligada a la producción industrial había sido una de las máximas aspiraciones de la nueva construcción, no menos importante que ella es esa otra repetición a gran escala, a una escala impensable en otros campos del arte o de la técnica. La pérdida de la singularidad y la apertura a la repetición múltiple de la obra de arte ha sido reconocida, efectivamente, como una de las características más decisivas de la época moderna. ${ }^{249}$

Si Borromini, y la arquitectura barroca en general, ya habían reinterpretado la repetición como pura reiteración de elementos, introduciendo variables que rompían una monotonía que remitía a una cierta estabilidad, en la repetición contemporánea se introduce lo aleatorio. La repetición se encuentra no controlada, deja un margen a lo posible, en una especie de movimiento azaroso. $\mathrm{Si}$ en el Barroco la repetición siempre lleva implícita una variación, la arquitectura contemporánea introduce el azar como elemento característico. Tanto si se rige por un cierto orden estructural o programático, como si no, lo aleatorio es lo que el resultado formal quiere expresar como razón compositiva.

Contraponiéndose a los conceptos de orden, regla, causalidad o finitud, vemos como sus contrarios: desorden, irregularidad, azar o caos, son emergentes en la cultura contemporánea. La variación barroca remitía, en último término, a una armonía, ahora, las disonancias ya no tienen que ser resueltas ${ }^{250}$.

249. JUAN ANTONIO CORTÉS Y MARIA TERESA MUÑOZ, La repetición en la arquitectura moderna 2, revista de Arquitectura no 230 mayo-junio, 1981, págs. 56-62. 
El azar, el caos, el desorden, cuestiones a las que hace referencia esta irregularidad aleatoria que observamos en nuestra repetición contemporánea, pueden también referirse al ámbito de lo preindividual. Por ejemplo, la filosofía presocrática imaginaba el orden del cosmos como derivado de un caos originario. En cualquier caso, lo accidental o aleatorio parece estar dirigiendo la mirada a una cierta de-formación, un des-orden anterior de la estructura que configura la determinación. Por ello, también se refiere a una cierta forma in-formada y a una zona donde todavía se encuentran las cifras indescifrables del ámbito de lo posible.

Calabrese, en su texto, se refiere al concepto de turbulencia. La turbulencia, dice, es un modo de aparecer caótico de un fenómeno cíclico cualquiera, que sustituye una regularidad común por el caos. El ejemplo es la aceleración de un ritmo, la introducción de la variación sobre la regularidad.

Hoy en día, (...) la turbulencia y la irregularidad gobiernan la producción de objetos de función estética prácticamente en todos los niveles de sofisticación cultural. ${ }^{251}$

Sin embargo, lo que encontramos en las bodegas Bell-lloc no es una simple repetición. Se trata más bien del uso del recurso de la repetición para generar un continuo, pues la forma se encuentra des-compuesta, disgregada en elementos o piezas. Los elementos se repiten, y nuestra lectura genera un continuo, cerrando la forma. Si lo recursos de la inflexión, analizados en el anterior capítulo, apuntaban a una pérdida de valor de la forma a través de su disgregación en pliegues y superposición de recursos, la técnica actual alcanza la posibilidad de una auténtica desintegración formal.

Podríamos decir, tal vez, que el recurso de la repetición en este caso, es secundario, y se utiliza como motivo subordinado al efecto de descomposición formal. Si la puesta en cuestión de la forma era una consecuencia del uso de los recursos formales barrocos, en el caso de nuestra arquitectura, la des-composición se tomará literalmente.

Podría objetarse también, que el tema de la continuidad, la ley de la continuidad, aquí no tiene lugar, pues se trata de elementos separados, de piezas des-compuestas. Ya ha advertido Deleuze, en 


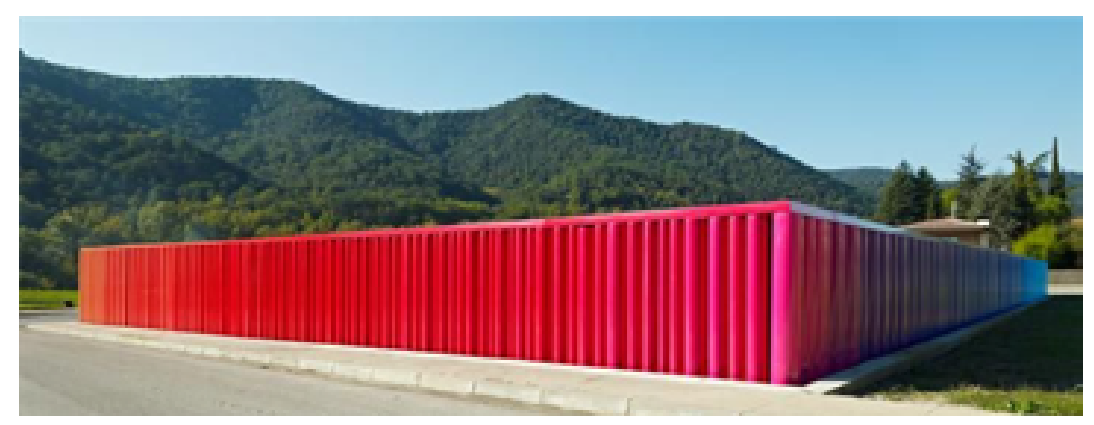

relación a la filosofía de Leibniz, y respecto a la posible contradicción entre la continuidad de la variación infinita y la discontinuidad del punto de vista, que basta con esforzarse en no confundir continuidad con contigüidad; no hay vacío entre dos puntos de vista $^{252}$.

Encontramos un tema similar en la guardería El Petit Comte, que los mismos arquitectos construyen en Besalú, donde la totalidad del edificio se enmarca en una reiteración de elementos verticales tubulares, de secciones y posiciones variables, donde los arquitectos juegan con la variación ordenada de los colores.

Las piezas tubulares difieren también en su material, y tienen, por tanto, transparencias diferentes. Algunas, de plexiglás, permiten la entrada alternada de rayos de sol, creando un juego de reflejos proyectado que potencia el tema de la repetición y de nuevo del claroscuro.

Las piezas de cerramiento se confunden completamente con los tubos sustentantes del edificio, camuflando de nuevo la estructura portante entre otras piezas similares.

Todo el efecto de la repetición de este proyecto incide en una sensación de inestabilidad, que se acentúa por las proyecciones de luz a través de las rendijas y por la variación cromática continua de las piezas en repetición.

Los elementos de repetición se utilizan de nuevo subordinados a la disgregación. El conjunto se encuentra íntegramente con-figurado por estas piezas disgregadas en sus cerramientos exteriores y en el cerramiento del patio.
2.35. Guardería El Petit Comte. RCR. Besalú, Girona, 2010.
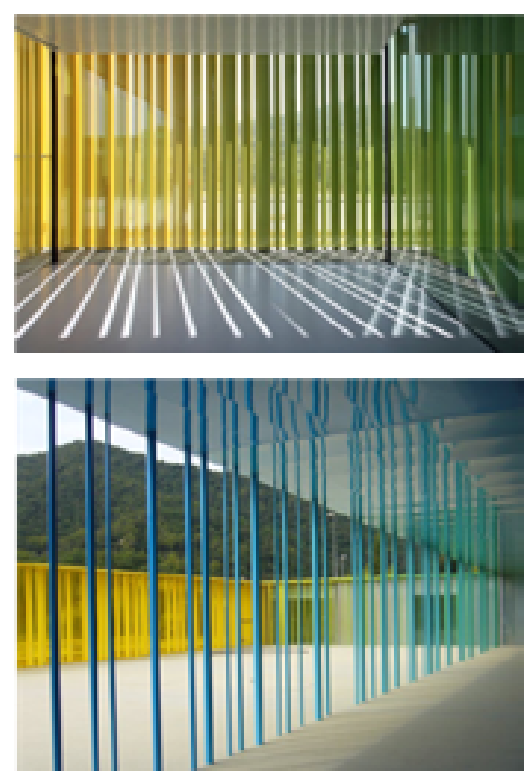

2.36. Exterior de la guardería El Petit Comte. RCR. 
Si en la obra de Borromini el recurso de la repetición se utilizaba con elementos integrados en la forma, que incidían en la sensación de inestabilidad sin poner todavía en cuestión su integridad, estas arquitecturas actúan como abriéndose, dejando entrar al espacio exterior en el espacio interior.

\subsubsection{La expresión de lo accidental}

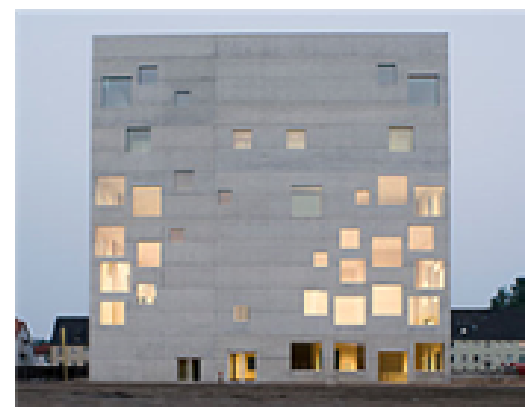

2.37. Escuela de diseño Zollverein. SANAA. Essen, Alemania, 2006.
El grupo SANAA construye, para la escuela de diseño Zollverein, en Essen, un cubo de hormigón armado de volumen compacto, horadado con huecos de tamaño y disposición variable, en una composición aparentemente azarosa y accidental, donde también opera una cierta disgregación de la forma.

La composición también tiene un carácter dinámico, como si la forma no hubiera alcanzado su estabilidad definitiva, como si lo aleatorio de los huecos pudiera ser modificado por una composición distinta, aunque el desorden compositivo oculta sin embargo una lógica funcional con el interior, la repetición de huecos de ordenes y dimensiones variables parece que apunta a una composición sin estructura que la regule. Los centros de la composición se han disgregado y funcionan más bien como puntos de acumulación, se multiplican y se tratan siempre como centros virtuales.

Los huecos repiten únicamente el hecho de su figura, siempre cuadrada, es únicamente este tema del cuadrado el que nos hace identificarlos como repetición. Ni los tamaños ni las posiciones guardan aparentemente orden alguno; se trata como de una versión ocasional de un objeto, que podría tener muchas variaciones siguientes o anteriores, como en un juego de dados. Un objeto que expresa una especie de inestabilidad temporal.

Diferenciación, policentrismo y ritmo, son los elementos constitutivos del gusto barroco, Calabrese señala que desde el punto de vista formal son componentes de un "universal" barroco. ${ }^{253}$

A estos componentes, hay que añadir la expresión accidental, una variable de lo aleatorio como orden-desorden compositivo, se manifiesta el caosmos, que sustituye a la armonía barroca en la incomposibilidad del mundo. Se encuentra siempre el fondo de la inestabilidad, es decir el fondo que opera produciendo la diferencia. 
En la fachada de la escuela de diseño de Zollvering, la composición, dispone más cantidad de huecos en la parte inferior, enmascarando así la componente de gravedad de la arquitectura, en definitiva, la razón de su estabilidad. De nuevo, como en los anteriores casos analizados encontramos este componente a-tectónico que va a acompañar todo el análisis. La expresión de posición ocasional de los huecos de fachada, converge con el cuestionamiento de la estabilidad estructural, resultando un objeto aparentemente inestable.

\subsubsection{Diferencia y repetición}

En el caso del Memorial del Holocausto de Peter Eisenman en Berlín, los elementos de repetición forman un conjunto variable y disgregado, que se percibe como un continuo ondulante.

En el espacio de una manzana, Eisenman dispone una densa concentración de paralepípedos de alturas variables de hormigón; una serie de bloques alineados, pero con formas y alturas cambiantes, que se disponen en una especie de topografía sinuosa, al modo de campo natural, donde las piezas emergen más o menos.

Los bloques se disponen a la misma distancia, y ello supone su elemento de repetición, pero varían en tamaño y forma, estando sensiblemente inclinados tanto en horizontal como en vertical, con el mismo modo de expresión aleatoria de los casos anteriores, representando una especie de ondulación natural. Se trata de un gran lienzo de repeticiones variables, sin jerarquía alguna; no hay entrada ni salida, es permeable desde todo el perímetro.

El piso, compuesto por una serie de losetas de piedra y por luces empotradas, describe una topografía ondulada, de esta forma uno se sumerge en esta especie de mar de repeticiones distintas, que parece moverse ondulante alrededor.

Si bien el valor del conjunto es esta poética de la repetición, la variabilidad es su componente más característica, tanto por su referencia al terreno, como por su valor simbólico, pues los bloques representan como un cementerio, o laberinto, en el sentido de callejón sin salida, como referencia al campo de concentración, y la singularidad de cada bloque, se refiere a la individualidad de cada víctima, diferente de las demás.

Eisenman parece querer representar esa identidad de la diferencia de la que Deleuze nos habla:

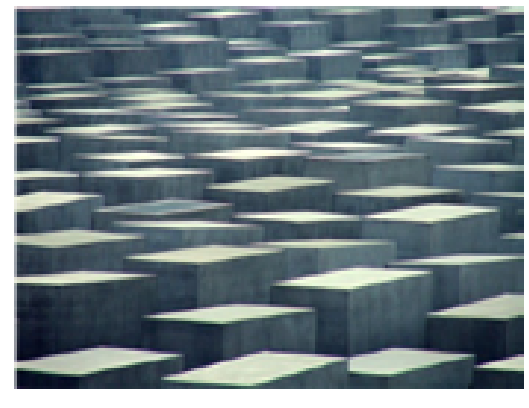

2.38. Vista del monumento al Holocausto, PETER EISSEMAN. Berlín, 2005. 
2.39. Secciones del monumento al Holocausto, PETER EISSEMAN.

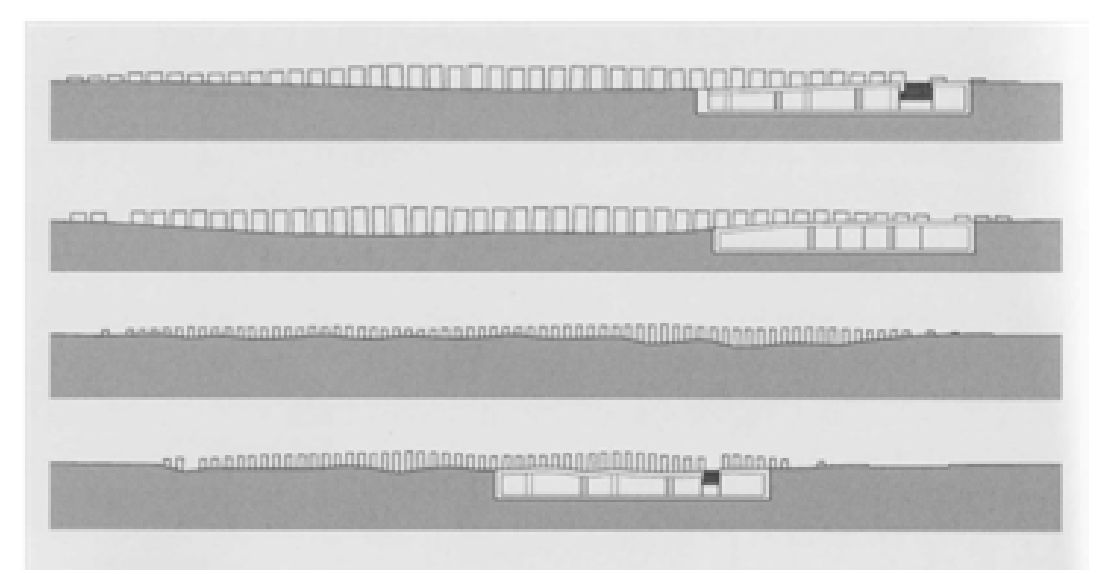

La paradoja de la repetición ¿no consiste en que no pueda hablarse de repetición más que por la diferencia o el cambio? ${ }^{254}$

Podemos decir que el museo no tiene forma determinada; representa una especie de continuo donde la repetición forma parte de la diferencia y la diferencia es la responsable de una diversidad final que expresa una individualidad de los elementos que con-forman el conjunto.

Estas arquitecturas tematizan la diferencia en la repetición llevándola al extremo, pues la apariencia de lo irregular, lo ocasional o lo aleatorio está presente en todos los casos, cuestión que va más allá de la pura variación ordenada de uno o dos elementos. ¿No tendrá también esta representación del azar un sentido común con la representación de un ámbito-fondo sobre el cual se produce lo posible? 


\subsection{DISCUSIÓN SOBRE LA REPETICIÓN}

El recurso de la repetición se extiende a las dos epocalidades tratadas, aunque con matices y formas de expresión diferentes.

Si el barroco histórico introduce sobre una reiteración simple de elementos, el motivo de la variación, contraponiendo formas invertidas, buscando un ritmo, o jugando con diferentes posiciones de elementos regidos todavía por una armonía que compone el mundo, nuestra arquitectura añade la irregularidad y lo accidental a la repetición. Si el Barroco componía variaciones ordenadas sobre un tema, el arte contemporáneo huye de todo orden, generando lo aleatorio, lo ocasional, como introduciendo la expresión del devenir en la obra, expresando el caosmos ${ }^{255}$ del que habla Deleuze y afirmando las divergencias.

Así como los recursos formales relacionados con la inflexión los tratábamos como elementos que expresaban una potencialidad, los recursos de repetición variada se vinculan también con esto potencial. En la obra de Borromini notamos la introducción de una especie de fuerza-potencia que está generando la variación, con la que se pone en juego la expresión del movimiento. En las arquitecturas contemporáneas la expresión del devenir a través de una especie de desorden o composición ocasional, intensifican la representación de un ámbito conflictivo, desordenado o incontrolado, quizás, el ámbito incierto de lo pre-individual. Deleuze nos recuerda este tema del fondo pre-individual en su relación con la repetición en su texto Diferencia y Repetición:

La repetición es el ser informal de todas las diferencias, la potencia informal del fondo que lleva a cada cosa a esa forma extrema en la que su representación se deshace. ${ }^{256}$

La repetición en la contemporaneidad expresa, más bien, la diferencia; el motivo que se repite es lo secundario, lo accesorio, algo casi oculto, la repetición consiste solo en el acto de repetir. Hemos visto como se repite la figura cuadrada en la escuela de diseño de Zollverein, o como en el caso del museo del holocausto, lo que se repite es la distancia entre las piezas, el fondo que las contiene. ¿No es lo esencial la posición accidental de las ventanas de la 
escuela de Zollverein, o las diferencias de altura e inclinación de los bloques en el Memorial de Berlín? La diferencia en las obras contemporáneas se presenta como lo principal.

En la expresión Barroca, con el recurso de la repetición, lo que subyace es la puesta en cuestión del modelo, el tipo o la idea, ya no hay original, ha perdido su protagonismo al haber sido diluido en una multiplicidad que expresa el modo o la particularidad de lo repetido, la variación, enfatizando la diferencia. En el caso de la variación contemporánea no se cuestiona el modelo se cuestiona la forma misma que se disgrega en elementos. La repetición postmoderna está más cercana a una des-composición de la forma que a una puesta en cuestión del modelo. Este cuestionamiento de la forma está ya implícito en el modo de expresión de las obras de Borromini, lo cual nos lleva a pensar en una intensificación, más que en una diferencia sustancial entre las dos epocalidades.

En algunos de los casos contemporáneos que hemos visto, la forma no es completa literalmente, se intuye su complitud, por la sucesión de elementos que leemos en continuidad. La disgregación formal opera en el mismo sentido que los movimientos infringidos a la expresión de la forma en el Barroco histórico. Por desvíos, llegamos a expresar el mismo sentido, aunque la expresión ahora se ha desembarazado de rigores formales que en la arquitectura barroca todavía existían, esa armonía, alcanzando una expresión intensificada del mismo tema. El modo de la repetición contemporánea lleva al extremo la desintegración formal a la vez que la variación ha perdido todo orden, entrando en juego el azar y lo accidental, se ha roto la armonía barroca. En esta intensificación del efecto, el estatuto de la forma se aproxima a una forma extrema, al límite de su disolución, al fondo incierto donde las fuerzas de formalización y las potencias actúan, y que imaginamos como caótico.

Nuestras arquitecturas actúan como dejando entrar al espacio, disgregando la materia en elementos empujados por el espacio, que se abre paso. El efecto de espacio que empuja, veremos, más adelante que es un recurso del Barroco en general, pero particularmente de la obra de Borromini ${ }^{257}$.

El tema de la repetición y la diferencia introduce el tiempo en el espacio. Lo hace a través del ritmo y el movimiento en el Barroco histórico, tiempo acompasado y rítmico, tiempo ordenado y con- 
ciliado con el espacio, y por ello, en parte, con la forma. Pero en los casos contemporáneo, el tiempo ya no es tiempo ordenado y cronológico, es puro devenir, devenir del acontecimiento y el kairós, o la ocasión, devenir sobre un fondo incierto e inexplorado, que contiene lo posible como matriz, pero matriz indescifrable, que representamos como azar o caos, ámbito o fondo que contiene, eso sí, la diferencia.

(...) solo la diferencia se repite. ${ }^{258}$ 
202 


\title{
3. LA CONDICIÓN DEL ESPACIO: TOPOLOGÍAS
}

\author{
El tópos - es decir, el espacio-lugar - parece algo \\ importante y difícil de captar. 259
}

Ya se ha señalado la singularidad de la obra de Borromini con respecto a otros arquitectos contemporáneos a él. La característica más notable a propósito de ello es su actitud crítica frente a la tradición, que en otros arquitectos no se manifiesta tan acusada, y el desarrollo de una innovadora metodología de proyecto. Aunque pueda parecer a primera vista así, la diferencia fundamental de su arquitectura con la de sus contemporáneos no está en el lenguaje que utiliza (sin perjuicio de que esté insertado en el sentido general de la obra y sea coherente ella), sino que se trata de una diferencia estructural y metodológica. Hay en su forma de abordar el proyecto una especie de extrañamiento ante los tipos renacentistas, se podría decir que ante los tipos o modelos en general. Conoce bien la arquitectura clásica, y asume en su obra la tradición renacentista y manierista. Sin embargo, muchas de sus soluciones tienen siempre como referencia arquitecturas menos estudiadas en su época, procedentes de la Antigüedad tardía, como la Villa Adriana de Tivoli o la Domus Aurea, y algunas obras extendidas por el imperio que probablemente conoció por grabados, y que podríamos calificar, frente a las grandes referencias del clasicismo, como residuales.

El apriorismo formal del tipo ideal de iglesia es abandonado en favor de soluciones que surgen del proceso proyectual. Su proceso proyectual va desde la contaminación de tipologías heredadas que no son modelos canónicos, hasta lograr una síntesis orgánica, que busca un espacio unitario y continuo, pero también complejo.

Hay una disociación entre la forma arquitectónica y la figura geométrica que genera aquella y que introduce una ruptura completa con el método proyectual del clasicismo. La articulación del espacio renacentista, en su mayoría, se realizaba por yuxtaposición de elementos que se leían en su autonomía formal y geométrica. Este modo de proyectar es sustituido por la generación de un 
espacio fluido, cuya información limitada a la planta o el alzado, por separado, resulta claramente incompleta, pues su carácter tridimensional requiere de otros modos de representación y, sobre todo, de la vivencia del espacio construido.

A través de la utilización de tensiones diagonales en la planta (que podrían tener como referencia la decidida experiencia previa de Miguel Ángel en la capilla Sforza), y la relación geométrica con el techo, Borromini remarca la tridimensionalidad del espacio. Incide en lo mismo el carácter envolvente de su tratamiento mural. La obra de Borromini señala el espacio como el hecho constitutivo de la arquitectura. Esta observación ha sido notada por muchos autores, desde Paolo Portoghesi, o Federico Bellini, que estudia el trazado de sus cúpulas, hasta el arquitecto Eusebio Alonso que incide en esta cuestión ampliamente a lo largo de todo su matizado texto dedicado a nuestro arquitecto ${ }^{260}$.

La idea de espacio unitario renacentista, cuyo paradigma se encuentra en la planta circular como imagen rotunda de una unidad espacial, es desplazada por la idea de espacio continuo que constituye uno de los temas específicos de la arquitectura barroca. Hay una especie de fuga de la centralidad; el valor de la centralidad es sustituido por la importancia de lo periférico, de la piel, de la envolvente. El centro se multiplica, se diluye, como desplazando la fuerza hacia el perímetro. Omar Calabrese señala también esta descentralización y ruptura de un orden unitario que opera en el Barroco:

(...) un general principio barroco del virtuosismo, que en todas las artes consiste en la fuga total de una centralidad organizadora, para dirigirse, a través de una especie de red de reglas, hacia la gran combinación policéntrica y hacia el sistema de sus mutaciones ${ }^{261}$.

\footnotetext{
260. La bibliografía de autores consultados a lo largo de la investigación sobre Borromini es la siguiente: Paolo Portoghesi, Francesco Borromini, (Milano: Electa, 1990); Anthony Blunt, Borromini, (Madrid: Alianza Editorial, 1979); Julio Carlo Argán, Borromini, (Madrid: Xarait, 1987 (1951)); Hans Sedlmayr, L'architettura di Borromini, (Milano: Electa, 1996); Cerare Brandi, Borromini, en Struttura e architettura, (Torino: Giulio Einaudi editore, 1975); Federico Bellini, Le cúpole di Borromini, (Milano: Electa, 2004); Erberhard Hempel, Francesco Borromini, (Viena: Schroll, 1924). Cada autor se ocupa de diferentes aspectos y sus interpretaciones difieren. Para el tema que nos ocupa, el estudio del profesor Eusebio Alonso San Carlino, la máquina geométrica de Borromini es el más oportuno. Este artículo se apoya fundamentalmente en él, pues es el más actualizado y además recoge ya muchos de los análisis anteriores.
} 
El proyecto de Borromini busca en esta red de reglas su sistema de mutaciones que le llevan a la generación de su espacio continuo inflexionado. Se ha observado que, en la búsqueda de este espacio continuo, Borromini utiliza la forma arquitectónica entendida como materia plástica ${ }^{262}$, que es susceptible de adaptarse y modularse. Este tema ya había sido explorado por Miguel Ángel. La forma, así, es sometida a sucesivas transformaciones a través de una evolución del proyecto que tiene su continuidad en el resultado formal construido. Hay en Borromini un proceso de metamorfosis para alcanzar la idea de un espacio complejo a través de la continuidad plástica de su envolvente; su método de proyecto consiste en explorar las posibilidades de transformación de la envolvente ${ }^{263}$.

Puestos estos términos (forma como materia plástica) en su medida justa, más bien se trataría de una forma plástica, compuesta entonces por materia plástica, pues la materia, sin su determinación formal, resulta ser una indeterminación que no admitiría calificativo. Pero una forma plástica se acerca más bien a algo sin forma estable, donde la forma, como determinación estable, pierde valor por su condición de plástica, que parece capaz de modificarse o adaptarse a las condiciones que la afectan, y estas, en el caso de la arquitectura, son las condiciones espaciales, la expresión del espacio. 
El esclarecedor y recíproco ofrendar-se de futuro, pasado y presente es él mismo pre-espacial; solo por ello puede espaciar, es decir, dar espacio ${ }^{264}$.

El espacio de la arquitectura es espacio extenso, medible. Pero no queremos referirnos únicamente a este sentido del espacio. En la arquitectura, como acción creativa, estará presente también una puesta en obra del espacio, en este sentido será también un espacio ontológico ${ }^{265}$.

Tradicionalmente y desde el siglo XVIII a partir de las propuestas filosóficas de Kant, el espacio es entendido como forma de la exterioridad, frente al tiempo, que es la forma de la interioridad. Si nos atenemos a ello el espacio atendería al cuerpo y a todo lo que con él se relaciona, todo lo que se refiere a la sensibilidad. La arquitectura del Renacimiento señalaba más bien a la imagen, como modelo o forma, y ello se da en el pensamiento, en la interioridad. El Barroco privilegia el cuerpo, la sensibilidad y con ello el espacio, que es su medio. Un espacio activo, plano cero de los sentidos, ámbito de potenciales experimentales.

Para Leibniz el cuerpo, punto de vista sobre el mundo, es resultado y reflejo del alma; el lugar de su existencia y de su contacto con lo inteligible. En la filosofía barroca hay un interés creciente por lo que supone el cuerpo. El cuerpo no se entiende más que por el exterior donde se experimenta en uno mismo. La sensación y el afecto remiten al espacio.

De ahí la importancia de las sensaciones en los diversos artes barrocos. El arte se centra sobre las expresiones carnales y vitales. Esta nueva manera de representar incita al espectador a identi-

\footnotetext{
264. MARTIN HEIDEGGER, Zur Sache des Denkesns, Auflage, Max Niemeyer Verlag, Tubingen, 2000. Edición en Castellano de Manuel Garrido, Tiempo y Ser, Tecnos 2011, pág.42. . Para ampliar estas cuestiones también en: TERESA OÑATE, ÓSCAR CUBO y Otros. Eds.: El Segundo Heidegger: Ecología. Arte. Teología. En el 50 aniversario de Tiempo y Ser. Dykinson, Madrid, 2012.

265. Para la diferencia entre espacio óntico y espacio ontológico véanse numerosos textos de la ontóloga española TERESA OÑATE, por ejemplo: Por la vía noética del espacio ontológico, en su libro: Estética y Paideía (Hermenéuticas contra la Violencia I). Dykinson, Madrid, 2019, págs. 65-86. O bien, dentro del mismo volumen: “La Hermenéutica como Ontología Estética del Espacio-Tiempo (perspectivas aristotélico-heideggerianas). Ibid, págs.. 213-234.
} 
ficarse por el canal de los afectos. El artista se pregunta sobre la representación de las sensaciones y las emociones. Esto explica entonces la expresividad barroca, las pasiones del alma descritas por las pinturas, los dramas de las óperas, las esculturas que parecen estar movimiento... Todo lo que afecta a la sensibilidad se da en el espacio como forma de la exterioridad, el arte barroco así, privilegia el espacio, el cuerpo, la sensación, el afecto...

Otro pensador Barroco, Baruch Spinoza, es aquí particularmente pertinente pues su filosofía se fundamenta en una teoría de los afectos. Estamos conectados por una red de relaciones causales gobernadas por leyes naturales de las que no podemos escapar. Todas las ideas, como todos los cuerpos, están involucradas en una comunidad de causa y efecto. Las cosas no pueden explicarse aisladamente y la existencia y acción de un cuerpo orgánico sólo puede explicarse por su relación con otros cuerpos. Toda esta red de relaciones solo puede tener lugar en el espacio. La filosofía de Spinoza pone de relieve la red de relaciones, una trama continua, a la que la realidad está sometida. Relaciones que solo se pueden dar en el espacio como ese sensus communis.

Así el espacio y el tiempo son el ámbito común, pues atraviesan todos los espacios perceptivos, por ello espacio y tiempo son estéticos. Son condiciones que no percibimos con un contenido concreto. Pero espacio, no pretendemos aquí solo entenderlo como mera condición vacía y pasiva, ideal, condición de la experiencia $^{266}$, como parece proponer la critica kantiana, sino que será además lugar de la experiencia real. No queremos obviar su aspecto potencial y creativo; el espacio no será solo condición sino potencia de lo posible, ámbito de intensidades potenciales.

El espacio es topológico y relacional, es el ámbito común, es el sensus communis que reúne y crea. Sensus communis, como traducción al latín los términos griegos koiné aisthetháis. Notamos ya en el aisthetháis la raíz que conforma el término estética. Se trata de una especie de sentir común, una sensibilidad común que necesariamente ha de darse en el espacio. El espacio va unido a la sensibilidad. Este sentir común es criterio y tiene la potencia de distinguir de un modo corpóreo, anterior al razonar. La kataleoti-

266. Esta sería la concepción kantiana de tiempo y el espacio en su Crítica de la razón pura; espacio y tiempo se tornan pasivos y se vacían o idealizan, condiciones de cualquier experiencia posible. En La Crítica de Juicio, Kant ya reflexiona sobre la experiencia real, teniendo en cuenta sus potencias experimentales. INMANUEL KANT, Critik der reinen Vernunft, 1781 (Crítica de la Razón pura), Critik der Urtheilskraft, 1790 (Crítica del Juicio). 
ké aristotélica tiene su relación con ello, es aquello que no puede errar y que nos devuelve al cuerpo como criterio ${ }^{267}$.

Tenemos así dos sentidos fundamentales del término espacio. Por una parte, como extensión geométrica, término abstracto y matemático, medible. Por otra parte, espacio como spatium, como orden de los posibles existentes. La primera es extensiva, la segunda intensiva, se trata de potencias y es creativa.

Pero hay un tercer sentido y es Heidegger quien lo introduce. Heidegger, en su texto dedicado a Eduardo Chillida, El Arte y el Espacio, se pregunta por el espacio en cuanto al lugar donde se dan las artes plásticas, y en este sentido se interroga por el espacio en cuanto a espacio. Heidegger analiza el término; el espacio como espaciamiento, el espacio espacia, abre, da lugar a.

Espaciar es la libre donación de lugares ${ }^{268}$.

El espaciar, para Heidegger, acontece en un emplazar, es decir, admitir algo, dejar que se despliegue lo abierto. El espacio es posibilitante. Pero además el espacio es relacional, pues proporciona a las cosas la posibilidad de pertenecerse mutuamente, estando cada una en su respectivo sitio, congrega a las cosas en su co-pertenencia. Él habla de comarca, como ese espaciar que congrega. El doble carácter de este espacio, que podemos llamar espacio ontológico, es posibilitante y relacional.

Este espacio, por tanto, así como el tiempo, y como nos recuerda la profesora Oñate ${ }^{269}$, no podemos reducirlo, como proponía Kant a condiciones a priori de la sensibilidad empírica, olvidando la diferencia o distancia que tensa, pero relaciona entre sí las formas del tiempo: presente, pasado y futuro y que Heidegger nos recuerda en Tiempo y $\operatorname{Ser}^{270}$. Este espacio es la condición de posibilidad del

267. Cifr. AMANDA NÚÑEZ, Gilles Deleuze. Una estética del espacio para una ontología menor, Arena libros, Madrid 2019.

268. MARTIN HEIDEGGER, Die Kunst und der Raum, Vittorio Kolestermann, Frankfurt del Meno, 2007. Traducción al castellano de Jesús Adrián Escudero, El Arte y el Espacio, Herder 2009. Este breve ensayo de Heidegger apareció por primera vez en el otoño de 1969 en una edición limitada de 150 ejemplares.

Heidegger también se ocupa del tema del espacio ontológico en MARTIN HEIDEGGER, Zur Sache des Denkesns, Auflage, Max Niemeyer Verlag, Tubingen, 2000. Edición en Castellano de Manuel Garrido, Tiempo y Ser, Tecnos 2011.

269. Cifr. TERESA OÑATE Y ZUBÍA, Por la vía noética del espacio ontológico, en su libro: Estética y Paideía (Hermenéuticas contra la Violencia I), op. cit., págs. 67 y 71. 
lenguaje, y, por tanto, del Ser en cuanto a Ser (si pensamos el Ser sin el Ente, que es la propuesta de Heidegger en este texto). Es este su significado ontológico, como lugar de apertura a la sincronía temporal. En este sentido se abre la posibilidad del pasado y de un futuro siempre anterior, en una especie de retorno diferencial ${ }^{271}$.

La obra de arte así, pone en obra el espacio, esto significa que, si la obra de arte pone en obra la verdad, como también Heidegger nos recuerda ${ }^{272}$, es preciso que sea también el espacio verdadero desocultando lo que le es propio, un espaciar, con todo el sentido de este espacio ontológico.

El espacio en arquitectura participa de todos estos sentidos; la arquitectura se construye en el espacio como extensión medida y medible, pero se proyecta antes en él como ámbito de la posibilidad creativa. La arquitectura como obra de arte también pone en obra el espacio, abre lugares para la relación, respectividades topológicas.

La forma de la arquitectura y el espacio se interelacionan constantemente pues la primera depende siempre del segundo. Pero el tratamiento de la forma puede señalar en mayor o menor medida la presencia del espacio, o señalarla apuntando al primer sentido o al segundo. En la obra de Borromini ${ }^{273}$, son los dos últimos sentidos de espacio los que se ponen en evidencia, a través de los recursos que se utilizan para hacer notar la experiencia del espacio como ámbito real de sensaciones, pero también como lugar productor, ámbito posibilitante y relacional, congregador de tiempos.

Podríamos decir entonces, que, en la obra de Borromini, la forma pierde entidad, se de-forma, frente a la presencia del espacio

tras la Kehre", en Estética y Nihilísmo (Hermenéutica contra la Violencia II), Dykinson, Madrid 2019.

271. En este sentido, la aportación del punto de vista hermenéutico de Hans Georg Gadamer, que ya habíamos advertido en la parte primera, es fundamental, pues el abre la posibilidad de un giro lingüístico en el que el espacio del ser es el lenguaje del habla, o que el lenguaje, es un lugar, el espacio ontológico del ser. Citado por TERESA OÑATE en Por la vía noética... op. cit. Para ampliar lo dicho en HANS GEORG GADAMER, Wahrheit und Methode, 1960. Traducción al castellano de Ana Agud Aparicio y Rafael de Agapito, Verdad y método, Fundamentos de una hermenéutica filosófica, ed. Sígueme, Salamanca 2012.

272. MARTÍN HEIDEGGER, “El origen de la obra de arte”, en Gesamtausgabe. Band 5: Holzwebe, Vittorio Klosterman, Frankfurt, 1984, traducción al castellano de Elena Cortés y Arturo Leyte, Caminos del Bosque, Alianza editorial 2010.

273. Hemos elegido la obra de Borromini porque, a nuestro parecer, es en esta donde mejor apreciamos el sentido del espacio al que nos queremos referir, que es su potencialidad creativa de la sensación. 


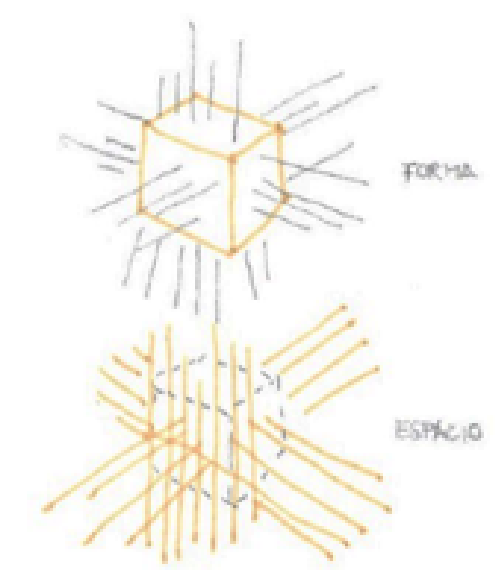

2.40. Forma intervenida por el espacio. Dibujo de la autora. donde se produce, casi se trata de una puesta en cuestión del estatuto tradicional forma-materia. Y así la forma parece encontrarse in-formada, o recibiendo la in-formación ${ }^{274}$ del espacio, por ello se muestra plástica, modulable, adaptable. Podríamos decir entonces que se trata de una forma relativa, relativa al espacio, que es lo que se pone en valor.

Si analizamos la imagen no tratada como mera representación y siguiendo el rastro de su sentido original en Grecia (phantasía), entonces imagen, remite a una cuestión pre-racional o algo intermedio como la ratio de la sensación, algo estético. Deleuze exterioriza esa mediación y para él se da en el límite, un límite como atmósfera, ese espacio donde algo deja de ser o comienza a ser ${ }^{275}$.

Los estoicos establecen un tipo de phantasía, la kataleptiké, que Aristóteles había ya nombrado, como aquello que el cuerpo percibe y que no puede errar, eliminando todo posible acceso a formas transcendentes. Hay un cambio de sentido en la concepción de la imagen, que es ontológico, pero también estético ${ }^{276}$. En mayor medida, o de una forma más inmediata, lo es en arquitectura. Hasta el siglo XVII la imagen enlaza con esta phantasía de un modo previo, mediador y anterior a la idea ( $\varepsilon$ i $\delta \circ \varsigma$ ), como forma ideal platónica. Más adelante el espacio comienza a concebirse como mero receptáculo pasivo y oscuro. Queremos ver en la obra de Borromini este sentido original del espacio como ámbito de potencia, nunca como vacío; no un echar en falta, sino un producir ${ }^{277}$.

Se establece así, por una parte, un criterio inmanente a la sensación que se sitúa en pie de igualdad con la razón, el entendimiento etc. De esta forma se puede notar que el espacio posee potencialidades a las que no se puede acceder desde la imagen ideal, como forma ideal o modelo, concebida como algo previo. Emerge así su devenir potencial (y por tanto creativo), en tanto que se desvía del modelo $^{278}$.

274. Para ampliar el concepto de in-formación ver GILBERT SIMONDON, Du mode d'existence des objetes techniques, Editions Flammarion, París. Traducción al castellano Margarita Martínez y Pablo Rodríguez, El modo de existencia de los objetos técnicos, Prometeo libros, Buenos Aires 2007. También del mismo autor: L'individuation à la lumière des notions de forme et d'information, 1958. Trans. de Pablo Irés, La Individuación, a la luz de las nociones de forma e información, ed. Cactus La Cebra, Buenos Aires 2009.

275. Cifr. AMANDA NÚÑEZ, op. cit.

276. Ibid.

277. MARTIN HEIDEGGER, El arte y el espacio, op. cit., pág. 31.

278. Cifr. AMANDA NÚÑEZ, op. cit. 
Atendiendo a lo dicho, la manifestación de la potencia-devenir que implica al pliegue y a la inflexión, tiene otra forma de manifestación en la obra de Borromini remarcando la presencia del espacio como medio fundamental de la arquitectura. El espacio es ámbito y medio previo. La forma siempre es dependiente del espacio donde se genera, del medio que la hace posible, solo intensifica en mayor o menor medida su presencia, que siempre es anterior.

Hay, en las obras de nuestro autor, una especie de contraste entre efectos de dilatación y de contracción, subrayado en los pliegues del perímetro de la envolvente y resaltando la tensión a la que se somete la materia, que la sitúa en un equilibrio inestable, incapaz casi de contener el espacio.

En San Carlino alle Quattro Fontane Borromini señala el espacio como el tema del proyecto. Hay una especie de presión ejercida sobre los arcos torales que conforman la cúpula, que se disgrega en poros orgánicos, desmaterializándose en cierta manera, esponjándose; un artesonado que atestigua una tensión expansiva. Las curvas rebajadas de los transeptos responden como a una presión ejercida por el espacio que explicita su voluntad expansiva, la voluntad de desmesura, de romper los límites, generándose un espacio tenso, tematizando el espacio mismo como conformador de la arquitectura. Hay una densidad del espacio interior que parece estar dando su forma al contorno, empujando, como fuerza que actúa sobre él.

La tensión, el exceso, la desmesura, la forma extrema, todo ello parece remitir al concepto de Pathosformel de Warburg ya considerado. Es a través de este concepto como Warburg consigue unir dos cosas que el pensamiento parece habitualmente concebir como contradictorias: la fuerza y la forma. Hay una tensión inconclusa en la obra que tensa el espacio. El pathosformel ${ }^{279}$ parece que se opone a la forma llevándola a su grado más alto, intensificándola, le da vida y movimiento. Deleuze señala que no se debe entender lo informe como negación de la forma, sino como el extremo donde la forma se desvanece en su expresión para pasar a otra distinta, es algo llevado al extremo, sobre-expresado, que contiene entonces ese pathos originario. 

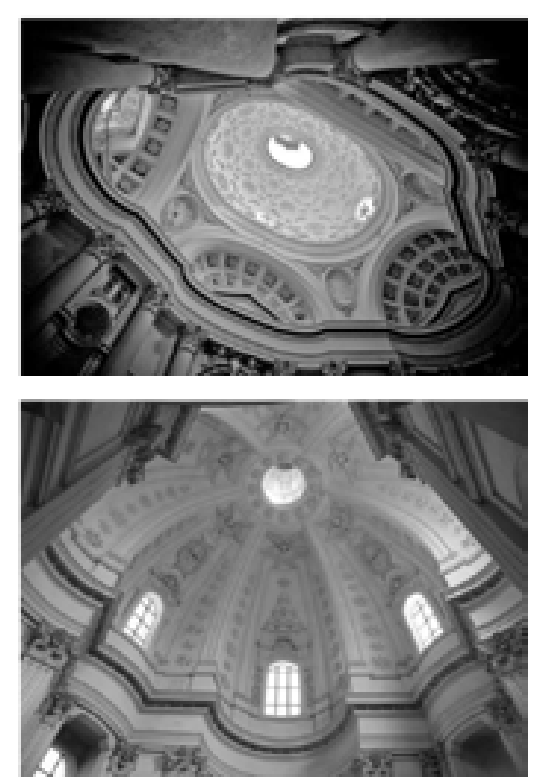

2.41. Interior de Sant'Ivo alla Sapienza. BORROMINI

2.42. Interior de San Carlino alle Quattro Fontane. BORROMINI
(...) lo informal, como producto de la formalidad más extrema. ${ }^{280}$

En la bóveda hay una cierta desmaterialización, pues la materia parece disgregarse en poros. Deleuze nota de las texturas barrocas que la materia formada presenta una estructura infinitamente porosa o cavernosa ${ }^{281}$. Una de las características que señala Wölfflin en el Barroco es el efecto de masa. Pero hay que observar que él dice masa, no materia, y a la vez señala una cierta tendencia hacia lo inmaterial en una búsqueda de lo atmosférico. El observa como la forma deja de ser significativa recurriendo a efectos de masa y de luz y sombra ${ }^{282}$. Esta observación lleva aparejada una emergencia del medio espacial donde los efectos se producen y al servicio del cual se encuentra la forma.

La disgregación en poros también tiene como referencia este infinitamente pequeño al que nos hemos referido más arriba, y al concepto de transfinito ${ }^{283}$.

Así, la luz en San Carlino, hará emerger esa diafanidad neutra sobre la que se actualiza cualquier efecto de visión. Una luz que no parece tratada por sí misma, sino en función de su visibilidad. Esto quiere decir que, para ver, hace falta un medio diáfano, transparente, donde la luz se actualiza. El espacio aquí es el medio. Christine Buci-Glucksmann se referirá a este medio como lo diáfano ${ }^{284}$, el fondo diáfano sobre el que se formaliza lo visible, que remite así mismo a la potencialidad del espacio.

Nos referimos así a lo diáfano, ${ }^{285}$ en el sentido de lo despejado, lo que posibilita o vehicula, donde hay virtualidad, nunca será un vacío en el sentido de una nada, pues, siguiendo la tradición aristotélica, lo virtual no se opone a lo real, solamente a lo actual, por ello es un aspecto de la realidad, es sustancial. ${ }^{286}$ Cuando todo

280. GILLES DELEUZE, Diferencia y Repetición, op. cit., pág. 180-181.

281. GILLES DELEUZE, El Pliegue..., pág. 13.

282. HENRICH WÖLFFLIN, Renacimiento y Barroco, op. cit., págs. 92 y 93.

283. Véase supra, pág. 159, nota 205.

284. Cifr. CHRISTINE BUCI-GLUCKSMANN, Esthétique de l'ephémère, Editions Galilée, París 2003. Trans. Santiago E. Espinosa, La Estética de lo efímero, (: Arena libros, Madrid 2006, págs. 54, 55.

285. Lo diáfano no será tampoco en ningún caso vacío, lo diáfano posibilita, vehicula. Se dice de un cuerpo que deja pasar a través de sí o que tiene claridad, pero siempre de una sustancia o entidad y no de una nada-vacío. Sobre el concepto de lo diáfano, también consultar: CHRISTINE BUCI-GLUCKSMANN, Esthétique de l'ephémère,

286. Sustancia (ov̉oía, ousía), en el sentido también aristotélico es entidad, es lo real. Los tres aspectos de lo real a los que cabe llamar ousía son: materia, forma y el com- 
remite a lo in-formal o hasta a lo in-material, emerge el medio, el espacio. La forma relativa parece configurada por la acción del espacio.

La iglesia de Sant'Ivo alla Sapienza, que es la obra cuya construcción se debe completamente a Borromini, parece ser el paradigma de la centralidad dentro de su obra construida. El profesor Alonso observa que la explicación, muy extendida, de la geometría de su planta a través de dos triángulos equiláteros invertidos uno respecto al otro, a partir de lo cual surge el hexágono regular, que refuerza en muchos estudios la idea de centralidad de la planta, no aparece en los croquis de Borromini, pues nuestro arquitecto no utiliza más que un solo triángulo equilátero a partir de cual se genera el resto de la geometría, siendo el otro triángulo innecesario para la solución geométrica ${ }^{287}$. Todo este tema le permite al profesor Alonso rebajar la importancia que tiene en esta obra la planta centrada, pues el carácter de centralidad del triángulo es menor que el de la estrella de seis puntas formada por los dos triángulos. Hay así una asimetría respecto al centro a partir del eje perpendicular al de la entrada-altar mayor.

Sitúa el vértice del triángulo principal, no en el lado del altar (que habría subrayado el eje principal) sino en la entrada, promoviendo así que la mirada deslice por los paramentos rectos que se abren según el vértice del triángulo y reconducen la mirada hacia la envolvente del espacio, hacia el perímetro, que cobra importancia con respecto al centro. La importancia del centro que orientaba a la composición renacentista se ha derivado a la envolvente muraria, a la piel, a la epidermis. La fuerza del Barroco se establece en las pieles-envolventes, que son el ámbito que recogerá el espacio, y su afán es remarcarlo, señalarlo en su condición particular, en relación con la idea barroca de límite. Es como si la piel recibiera una fuerza o efecto de empuje. En Sant'Ivo, desde la entrada, la mirada se desvía hacia el perímetro como si la presencia del espacio nos llevara hasta allí.

La piel se muestra casi como elemento textil, plegándose y encubriendo con ello su función portante, tomando profundidad, una profundidad que dota al límite de cierta ambigüedad, presentándose más bien como ámbito y no tanto como contorno. El profesor

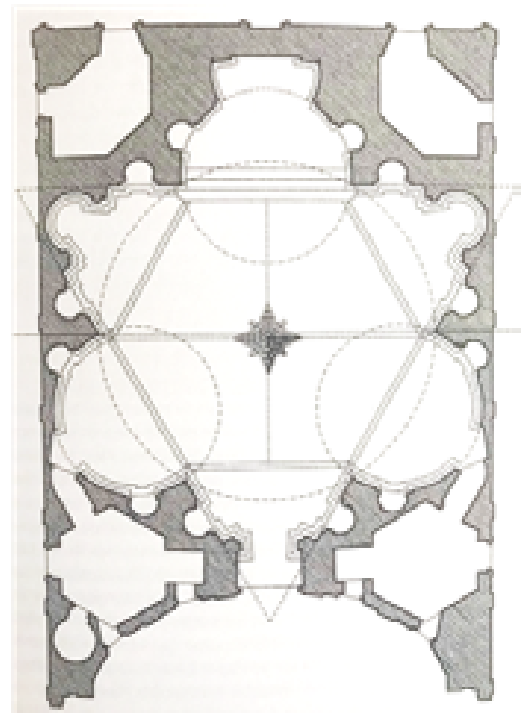

2.43. Sant'Ivo alla Sapienza. BORROMINI. Reconstrucción del trazado en planta del profesor Eusebio Alonso. 
Alonso ya había señalado que San Carlino era de piel profunda ${ }^{288}$, podríamos seguramente extender esta afirmación a Sant'Ivo. Toda la problemática del pliegue barroco es un problema de la piel; lo que se pliega es la envolvente, envolvente exterior y envolvente interior. La piel es como un límite activo ${ }^{289}$, que interactúa con un fondo-medio, que se dispersa en pliegues y en inflexiones, señalando el punto de inflexión como elemento que simboliza la potencia; la piel como la zona donde se ejerce la potencia.

En la iglesia de la Sapienza Borromini consigue hacer fluir el espacio que se conduce por la permanente continuidad entre la envolvente y la cúpula, entre las cuales no existe ninguna intersección o articulación que señale su encuentro. Todo ello es generado por mecanismos constructivos que extrae de la tradición; en el Panteón de Roma queda plasmada de forma rotunda la continuidad entre paredes y cúpula; esta solución también se anuncia en la sala octogonal de la Domus Áurea.

En el espacio interior se alternan secciones diferentes (seis lóbulos) que no son simétricas respecto al centro, originando esta sucesión no regular, una sensación de movimiento rotatorio. La alternancia formal de las capillas acusa aún más la tensión ascendente y remarca la continuidad. Hay una especie de metamorfosis completa y continua, desde el trazado de la planta hasta el óculo cenital $^{290}$. Pero, es más, esta tensión ascendente se acaba difuminando en el remate de la linterna que ya hemos estudiado, desmaterializándose como máxima expresión que apela al espacio. Las superficies parecen hinchadas por el espacio que contienen, y este, finalmente las desmaterializa en la linterna, como escapando.

\footnotetext{
288. Toda la construcción geométrica de la planta a partir de un solo triángulo la describe paso a paso el profesor Alonso en su texto. EUSEBIO ALONSO GARCÍA, San Carlino..., 15, 149.

289. Sobre el concepto de límite se pueden hacer muchas matizaciones y muy complejas, pues sus acepciones son múltiples y han sido minuciosamente estudiadas. Solo diremos que el sentido al que el texto se quiere referir, el límite no es contorno sino límite dinámico. Tiene un carácter positivo, en el sentido como lo entendían los griegos, como comienzo del ser, lugar donde una cosa se con-forma, no tiene connotaciones negativas en cuanto a limitación. Heidegger también se referirá a este límite como apertura: El límite no es donde alguna cosa cesa, sino, como los griegos habían observado, es donde la cosa comienza a ser, en Martin Heidegger, Batir Habiter Pender, en Esssais et Conférences (Vorträge und Aufsätze, 1954), Trans. de Eustaquio Barjau, Construir, habitar, Pensar, en Martín Heidegger, Conferencias y Artículos, (Barcelona: ed. El Serval, 1994) 
El espacio interior de Sant'Ivo muestra muy bien, el rechazo a una arquitectura generada por estratificación de cuerpos diferenciados; esta arquitectura remarcaba la tectonicidad muraria, superponiendo partes que explicitaban la gravedad, fuerzas sustentantes. Pero la continuidad ascendente de Borromini lleva el sentido inverso, el ascendente, retando a la gravedad y enmascarando la condición tectónica de la envolvente.

El protagonismo de la envolvente se realiza a través de tres mecanismos: El ritmo intensivo y rotatorio, la continuidad vertical de la piel, y las relaciones cruzadas, tensiones diagonales, que ejercen de relaciones topológicas para que el resultado formal singularice el espacio ${ }^{291}$.

Borromini nunca proyecta sus pavimentos como reflejo inferior de la composición de sus cúpulas. Esto era recurrente entre los arquitectos renacentistas e incluso en arquitectos coetáneos como Bernini $^{292}$. A cambio, Borromini anuncia o remarca con ellos la composición centrífuga del espacio. Toda la complejidad inicial del diseño de la planta que luego asciende por la envolvente se ve negada formalmente en el diseño del pavimento. Sin embargo, este, subraya intensivamente el efecto de rotación. Borromini introduce una geometría octogonal en los pavimentos en un ámbito que es hexagonal. Partiendo del centro, el pavimento genera ocho direcciones hacia la envolvente en una disposición centrífuga hacia los límites del espacio. El efecto de rotación es sintetizado en el remate exterior helicoidal de la linterna.

Así el efecto de rotación ascendente prevalece sobre cualquier perspectiva que no sea la ascendente, la fuga vertical, remarcando así la pertenencia del foco de la perspectiva al espacio y alejándose de la concepción renacentista de perspectiva, como plano del cuadro, separado del observador.

La forma resultante queda subordinada al espacio y su finalidad más inmediata es intensificar su presencia. Se trata de hacer hablar al espacio, de ese spatium misterioso, aquel que no se percibe, aunque no puede dejar de percibirse, al igual que la luz.

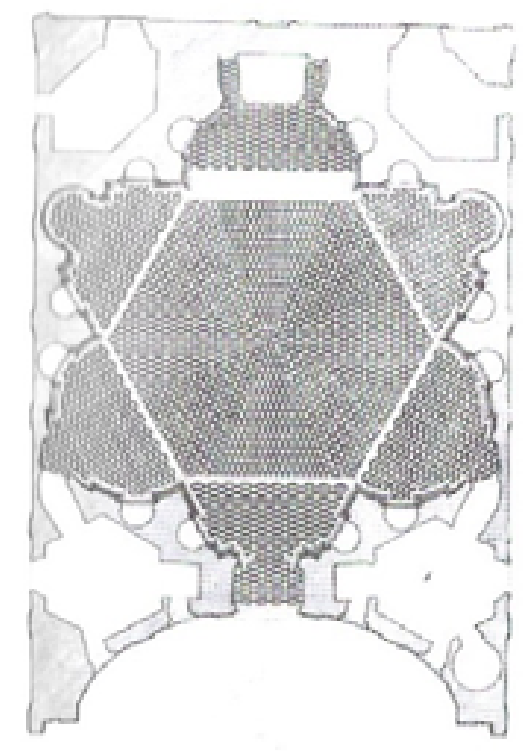

2.44. Planta de pavimentos de Sant' Ivo. BORROMINI. Dibujo de PAOLO PORTOGHESI 
No se trata ya de hablar del espacio y de la luz, sino de hacer hablar al espacio y a la luz que están ahí. ${ }^{293}$

En el recorrido crítico por la obra de Borromini que muchos autores han considerado y con respecto a su carácter espacial, Julio Carlo Argán ${ }^{294}$ considera las cosas de otro modo. Señala que Borromini ya no es el arquitecto que representa el espacio, sino el arquitecto que hace el espacio. Considera también que la arquitectura de Borromini es una arquitectura de determinación formal más que de composición. Creemos que el espacio, como condición de posibilidad de la arquitectura siempre es anterior y siempre está presente, solo será señalado en mayor o menor medida.

Sin embargo, el tema del espacio, se ha considerado tema central del Barroco en general. Riegl ${ }^{295}$ identifica el espacio como categoría central de la obra de arquitectura y facilita así las investigaciones sobre la espacialidad barroca. Giedeon ${ }^{296}$, sobre esta base, incluye la figura de Borromini en el desarrollo de la arquitectura europea desde el Renacimiento hasta la modernidad, consolidando la importancia de nuestro autor.

El interés principal de Borromini fue siempre dirigido a modelar el espacio. $^{297}$

Giedion, propone también el entendimiento del espacio como categoría central de la arquitectura. Esta cuestión tendrá eco en los trabajos de Julio Carlo Argan y Paolo Portoghesi, que subrayan el espacio como la sustancia constitutiva de la arquitectura de Borromini.

Riegl ya había introducido su distinción entre háptico o táctil, y óptico, y entiende la forma visible como experiencia del espacio ${ }^{298}$. Una concepción del movimiento vinculado a la percepción de la

293. MERLAU PONTY, El ojo y el espíritu, op. cit, pág. 46.

294. JULIO CARLO ARGAN, El concepto de espacio arquitectónico. Del Barroco a nuestros días, Buenos Aires 1980, pág. 77. Julio Carlo Argán dedica un además texto completo a Borromini, GULIO CARLO ARGAN. Borromini, Xarait libros, 1980, (1951), pág. 72.

295. ALOIS RIEGL, La arquitectura y las artes industriales tardoromanas (1901)

296. SIGFRIED GIEDION, Espacio, tiempo y arquitectura (1941), Ed.Reverté Barcelona 2009.

297. Ibid. Pág. 119.

298. Citado por EUSEBIO ALONSO, op. cit, pág. 87, sobre J.S. Ackerman, prólogo a P. Frankl, Principios fundamentales de la historia de la arquitectura (1981). 
arquitectura que dará lugar a la obra que Giedión titula: Espacio, tiempo y arquitectura, donde trata este tema particularmente.

Sedlmayer ${ }^{299}$ dedica una monografía a Borromini en 1930, donde incide en el análisis estructural de la obra y en la condición genética de la misma, sobre la que profundizará Paolo Portoghesi $3^{300}$. Este último autor desvela la geometría que subyace en sus dibujos autógrafos, y la manera en que Borromini utiliza esta geometría, como herramienta para modular y no como figura-modelo.

La inclusión espacial que genera la experiencia de la obra de Borromini incide en ello. Hay una disposición a excitar la sensibilidad, así parece explicarlo en su Opus Architectonicum, una especie de fricción entre lo tangible y lo subyacente. ${ }^{301}$

El placer nace más del diseño logrado cautivador que de la materia y el ornato ${ }^{302}$

En todo ello resuena una prioridad de lo corpral, un restablecimiento de la importancia de la exterioridad, de la cercanía del cuerpo y la obra, de la excitación de la sensibilidad. La importancia del cuerpo, la recuperación de la extensión y de la corporeidad en un plano de igualdad con la interioridad del alma, a través de un sistema de pensamiento que se estructura por los afectos. En Ética demostrada según el orden geométrico, Spinoza afirma que cuerpo y mente son atributos constituidos por relaciones que se fortalecen o se deshacen de acuerdo a leyes complejas. La vida implicará tanto las fuerzas corporales como las potencias intelectuales y ambas serán atributos de una única sustancia. A partir de sus reflexiones sobre el mundo, Spinoza propondrá un nuevo modelo: el cuerpo, y declarará: No sabemos lo que puede el cuerpo ${ }^{303}$. Los cuerpos son relaciones de fuerzas y potencias que tienen en mayor o menor medida el poder de ser afectados. Spinoza hace un rescate del cuerpo en tanto atributo desconocido, camino de infinito conocimiento y actividad de poder. La Ética es una teoría de los

299. HANS SEDLMAYR, L'architettura di Borromini, Electa, Milano 1996.

300. PAOLO PORTOGHESI, Francesco Borromini, Electa, Milano 1990.

301. Cifr. EUSEBIO ALONSO, op. cit., pág. 90.

302. Opus archiitectónicum Equitis Francisci Borromini es uno de los pocos testimonios escritos que quedó de Borromini, redactado en 1648 a raíz de la construcción del Oratorio de San Felipe Neri. La obra está ampliamente ilustrada y su introducción, aunque escrita en primera persona, fue redactadas según indicación del artista, por su protector y amigo Monseñor Vigilio Spada. 
cuerpos y la forma en que esos cuerpos se componen en un plano común, que sería el espacio.

La arquitectura de Borromini es una combinación de velocidades, fuerzas y remansos, y existe una composición entre ella y el cuerpo que la experimenta, que nos vuelve parte de una misma cosa, algo como el encuentro de un nadador con las olas del mar. La materia arquitectónica de Borromini roza los cuerpos. El historiador Anthony Blunt ha comentado sobre la obra de nuestro arquitecto que:

Los edificios de Bernini se ven con los ojos, los de Borromini se sienten con el cuerpo entero. ${ }^{304}$

La pertenencia al interior, la concentración se lleva a cabo a través del ritmo que marcan los despliegues de la materia, materia que no se deja atrapar en una unidad y que por eso envuelve. La inflexión deviene inclusión. Nuestro arquitecto, crea una espacie de proximidad, que toma todo su sentido en la forma de una carne fundamentalmente plegada.

El espacio no es uniforme, no es un abstracto continuo, en él suceden cosas, hay una intensión en los espacios de nuestro autor. El espacio se presenta así también como base de la sensibilidad, algo que comienza en el cuerpo como criterio, y en el espacio como lugar común de la sensibilidad y que se haya cercano a las propuestas fenomenológicas de Merlau Ponty; un espacio contado a través de la experiencia del cuerpo, no se trata de algo externo sino vivido.

Este espacio (...) es el lugar del cuerpo que el alma llama suyo, es el lugar que ella habita. ${ }^{305}$

Borromini, con todo ello, parece tematizar el espacio en sus composiciones, y así la forma de su arquitectura pasa a ser forma relativa al espacio que la hace posible como el lugar donde se dan las condiciones de su posibilidad. Ya nada depende de la forma, no se busca una esencia para representar, es la propia manifestación con sus condiciones, la que se hace esencial. La contingencia de la manifestación es ahora lo esencial, su diferencia, su particularidad. 
La arquitectura pone en obra este espacio que deja en ese momento de ser espacio extenso para instaurar un lugar ${ }^{306}$. Se trata, como siempre en arquitectura, de generar lugares, espacios y tiempos donde habitar, bloques de espacio-tiempo. Son haecceidades. ${ }^{307}$

Hay un modo de individuación muy diferente del de una persona, un sujeto, una sustancia. Nosotros reservamos para él el nombre de haecceidad. Una estación, un invierno, un verano, una hora, una fecha, tienen una individualidad perfecta y que no carece de nada, aunque no se confunda con la de una cosa y un objeto. ${ }^{308}$

Deleuze, coincidiendo en esto con las afirmaciones de Heidegger, dice que más profundamente que espacio, en el acto creativo, hay espaciación. El espaciar genera espacios nuevos de una temporalidad que está vinculada siempre a estos movimientos espaciadores, crean espacio de posibilidad, espacio nuevo como acto creativo. Es como una invaginación de un exterior, un bloque de espacio nuevo que habitar como acontecimiento. ${ }^{309}$

El espacio da, como Heidegger había anunciado, la posibilidad de pertenecerse mutuamente, de congregar las cosas. Se trata de un espacio de relación, pero una relación que también congrega los tiempos y es además la causa de la cohesión entre ellos.

(...) la concreción de una visibilidad universal, de un único Espacio que separa y reúne, que sostiene toda cohesión (e incluso la del pasado y la del futuro, puesto que no habría cohesión si estos no fueran parte del mismo espacio). ${ }^{310}$

306. MARTIN HEIDEGGER, El Arte y el Espacio, op. cit., pág. 33.

307. El concepto de haecceidad proviene de la filosofía de Duns Scoto.

308. GILLES DELEUZE, Mil Mesetas, op. cit.

309. Cifr. GILLES DELEUZE, Curso sobre Spinoza (17/02/81).

310. MERLAU PONTY, El ojo y el espíritu, op. cit, pág. 62. 


\subsection{REPRESENTAR LO DIÁFANO}

El Renacimiento se había caracterizado por una manera de proyectar que respondía a ciertas formas y modelos establecidos, de lo que dan fe los numerosos tratados sobre arquitectura de la época, y con ello también, por la autoridad de la forma como elemento central en la composición, tanto de la arquitectura como de otras manifestaciones artísticas. Deleuze, en sus clases sobre pintura coincide en decir que en el arte clásico es en el primer plano donde se elabora la forma y es la forma la que determina las relaciones con el segundo plano; se trata de un espacio estético del primer plano donde lo determinante es la forma. Con el paso al arte barroco el sistema se invierte y la forma pasa a estar supeditada al fondo, determinada por el segundo plano ${ }^{311}$.

Habla así, en estas clases, del cambio en el estatuto de la forma con el paso de una estética a otra:

¿Cómo quieren que una forma tenga el mismo estatuto al estar determinada por el primer plano - aún si reacciona sobre el segundo- y al estar, por el contrario, literalmente proyectada por el segundo?312

En la pintura barroca, las figuras o formas han perdido toda hegemonía, están subordinadas al fondo que es desde dónde emerge todo. Esto tiene su correlato en arquitectura donde es el espacio, como fondo o medio, el que se expresa en primer término. El espacio cobra presencia y lo hace a través de los medios inmateriales como la luz, a través de claroscuros, de sombras y contrastes.

Se crea así un espacio del valor, un espacio del claroscuro, a partir del cual la forma emerge, pero lo hace como condicionada, condicionada por el espacio, que guarda las condiciones de posibilidad.

A este espacio, la filósofa Christine Buci-Glucksmann lo ha llamado lo diáfano. La luz solo se expresa en el medio propicio que la hace posible. Un espacio de posibilidad: lo diáfano ${ }^{313}$.

311. Cifr. GILLES DELEUZE, Pintura, el concepto de diagrama, op. cit.

312. Ibid, op. cit., pág. 209.

313. CHRISTINE BUCI-GLUKSMANN, La Estética de lo Efímero, cap. 2: El nuevo paradigma del tiempo, ed. cit, pág. 24. 
La emergencia de este medio diáfano genera una especie de fascinación que el Barroco mantiene en orden a la ilusión entremezclada con opacidad y el carácter más o menos confuso de la realidad que pinta ${ }^{314}$. Hay una estética del claroscuro, que establece los niveles de luz y que iluminan solo una parte según una especie de legibilidad restringida.

¿Cómo establecemos que es claridad, qué es luz?, ¿cómo sabemos dónde está el rojo, o el azul, donde empieza el agua y acaba el aire?. No hay luz sin lo oscuro, ni color sin otro color distinto. Las cosas solo emergen por la diferencia con otras cosas. La actualización de las cosas sucede mediante un proceso de diferenciación. Así, la diferencia se presenta como constituyente y esta diferencia se da en el fondo, en lo diáfano, en el medio. Se defiende aquí que estos elementos son los que el Barroco y nuestro Neobarroco tematizan con su estética.

Hay entonces lo diáfano. Y por diáfano entiendo lo que, aunque visible, no es visible por sí, hablando con propiedad, más que con la ayuda de un color ajeno (...) 315

Aristóteles es enérgico en esta afirmación: hay entonces lo diáfano, y con ello ¿no está poniendo en cuestión la consideración de la luz como luz ontológica de la tradición platónica?. Esta luz ontológica procedía del sol inteligible de la Verdad o la Belleza, y había servido de paradigma del arte y su idea.

La luz, a la que parece referirse Aristóteles, solo se expresaría en el medio propicio que la hiciera posible. Un espacio de posibilidad: lo diáfano. Así dice Christine Buci-Gluksmann que lo diáfano en acto es luz y lo diáfano en potencia es invisible ${ }^{316}$, pero, sin embargo, nos parece, que es el espacio de lo posible.

Malevitch también ha notado este nuevo estatuto de la luz: si la luz, el brillo, había sido tradicionalmente el modo de la belleza en su aparecer como verdad, Malevitch la impugna como aquello que aclara la verdad, y reivindica una nueva noción de la luz como intensidad coloreada, en una especie de materialismo luminoso ${ }^{317}$.

314. Ibid.

315. ARISTÓTELES, Sobre el alma, cap. II-7.

316. CHRISTINE BUCI-GLUKSMANN, La Estética de lo Efímero, cap. 2: El nuevo paradigma del tiempo, op. cit, pág. 24. 

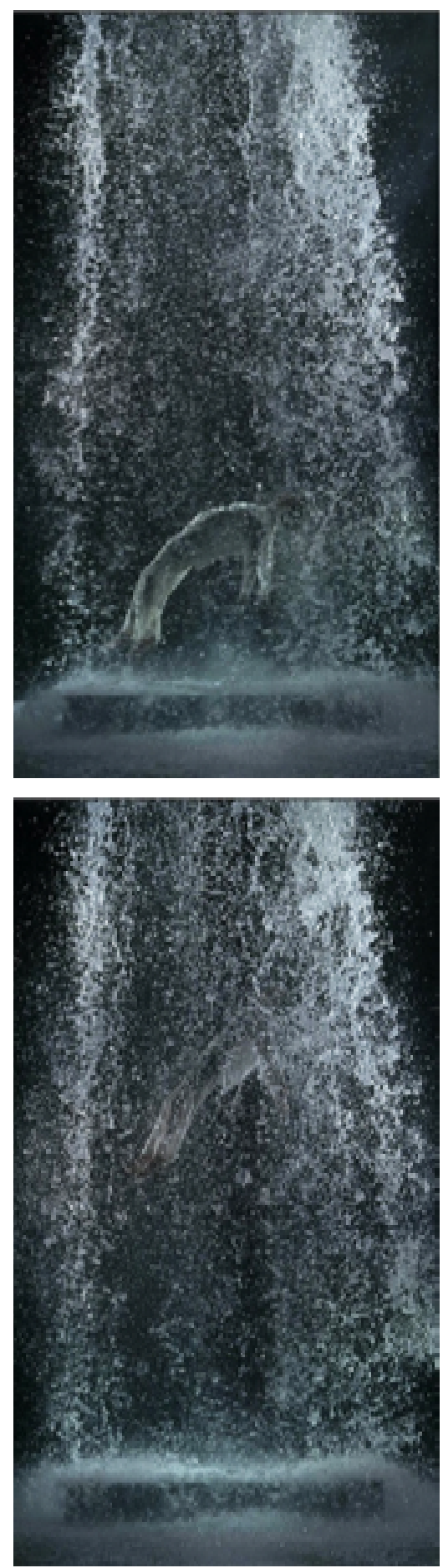

2.45. Tristan's Ascension. BILL VIOLA. 2005.
Deleuze, en el texto que dedica a Foucault, al describir el concepto de diagrama foucoltiano, habla también de un afuera como un elemento atmosférico:

Ese afuera informal es una batalla, algo así como una zona de turbulencias de huracán en la que se agitan elementos singulares y relaciones de fuerzas entre esos puntos. ${ }^{318}$

Bill Viola explora así los límites de lo diáfano, una relación casi imperceptible entre lo diáfano y lo adiafáno. Envuelve sus formas emergentes de un fondo turbulento del que surgen siempre, un fondo, que en sus distintas versiones siempre es fluido, transparente y posibilitante; el fondo diáfano. Así se muestra en Tristian 'ascensión, un fondo de agua mezclada con luz y niebla, los elementos de lo diáfano que dan lugar a la diferenciación (lo adiáfano), que emerge sobre el fondo.

No parece que Aristóteles concibiera nunca una oposición estática entre forma y materia, él se ocupó de la potencia y sus ámbitos. Bergson, en su tesis doctoral sobre el concepto de lugar en Aristoteles $^{319}$, ya hace notar que Aristóteles no concibe nunca una especie de espacio vacío inerte y abstracto a modo del de Demócrito o Leucipo, independiente de una potencia, Aristóteles, según la tesis de Bergson, habla de lugar, como el espacio topológico de posibilidad, en consecuencia, con este espacio diáfano que estamos estudiando.

Así el profesor Hernández León dirá, en la introducción de un texto que Georges Didi Huberman dedica a James Turrell, que el vacío está presumiblemente hermanado con el carácter peculiar del lugar y, por ello, es productor ${ }^{320}$.

Didi Huberman había comenzado a hablar de la obra de Turrell, haciendo referencias bíblicas al desierto, y a la búsqueda del $A u-$ sente. Nos dice que este ausente no se representa, pero se presenta,

por C. Buci-Glucksmann en La estética de lo efímero.

318. GILLES DELEUZE, Foucault, Les Éditions des Minuit, París 1986. Traducción al castellano de José Vázquez Pérez, Foucault, Espasa libros, Barcelona 1987.

319. HENRI BERGSON, Quid Aristoteles de loco senserit. Thesim facultati litterarum Parísiensi proponebat $\mathrm{H}$, Bergson scholae normalis olim alumnus. Lutetia Parísiorum, edebat F. Alcan, 1889. Traducción al castellano de Antonio Dopazo, El concepto de lugar en Aristóteles, ediciones encuentro 2013.

320. Cifr. JUAN MIGUEL HERNANDEZ LEÓN, Introducción a la edición en castellano de GEORGES DIDI-HUBERMAN, El hombre que andaba en el Color, traducción Juan Miguel Hernández León, Abada 201, pág. 8. 
lo que, en cierto sentido, es más, pues accede así a la autoridad. (...) Pero también mucho menos, en otro sentido, puesto que no consigue nunca la estabilidad, posible de describir, de una cosa visible ${ }^{321}$.

Pero, ¿Cómo representar la ausencia?.

Didi Huberman nota que la Biblia ya había advertido a todo el mundo que la evidencia del ausente se da en la desemejanza ${ }^{322}$. Así hay un límite que nos habla de la diferencia y que es precisamente esta región de la desemejanza; límite como fondo generador de las diferencias, como lo diáfano, como la haecceitas que Duns Scoto describía ${ }^{323}$, o como el fondo donde reside la diferencia, que Deleuze describe.

El relámpago, por ejemplo, se distingue del cielo negro, pero debe arrastrarlo consigo, como si se distinguiese de lo que no se distingue, se diría que el fondo sube a la superficie, sin dejar de ser fondo ${ }^{324}$.

Así hay una paradoja en el límite como portador de diferencias y como espacio neutro indiferenciado; siempre la cosa aparece en los bordes, entre la sombra y la luz, el color y el negro... El acto de limitar el espacio puede llegar a concebir la ilimitación del lugar. Así el vacío no es una falta sino una producción.

Deleuze y Guattari, retomando este concepto de haecceidad de la filosofía escolástica de Duns Scoto, hablan de esta haecceidad como de un clima, de un viento, niebla, luz cruda..., dicen que:

Una haecceidad no tiene ni principio ni fin, ni origen ni destino, siempre está en el medio ${ }^{325}$.

La haecceidad es para Deleuze y Guattari un modo de individuación, diferente a una persona o sujeto. Individuación como relación compleja de partes intensivas, de velocidades y de lentitudes;

321. Ibid GEORGES DIDI-HUBERMAN, pág. 28.

322. Cifr. Ibid, pág. 30.

323. Duns Scoto había distinguido la haecceitas de la quiditas. La primera se refiere a aspectos de una cosa que la hace ser particular, y quiditas se refiere a las cualidades universales de una cosa, los aspectos que comparte con otras cosas y por lo que puede formar parte de un género de cosas.

324. GILLES DELEUZE, Diferencia y Repetición, op. cit., pág. 61.

325 GILLES DELEUZE y FELIX GUATTARI Mil plateaux, capitalisme et schizophrenie, 1988. Traducción al castellano de José Vázquez Pérez, Mil Mesetas, Pretextos, Valencia 2002, pág. 266. 
una cuestión de intensidades, de potencia ${ }^{326}$. Y es a partir de ahí desde donde desarrollan su conocida distinción entre espacio liso (o nómada), y espacio estriado (o sedentario).

Pero, ¿no habrá entonces una relación entre el espacio liso de Deleuze y Guattari y lo diáfano a lo que se refiere Glucksmann a partir de las consideraciones aristotélicas?

Todo ese espacio liso permite el desarrollo de una topología que no se forma por objetos sino por relaciones. Vientos, ondulaciones, arenas, reflejos haces, luces, colores. ¿Dónde está la luz sin la oscuridad o el color sin su variabilidad? En el espacio liso siempre emerge la diferencia.

El espacio liso está localizado, recordándonos al lugar de Aristóteles, pero no limitado. El espacio estriado será limitado y limitante.

Por su parte Gilbert Simondón, pone en cuestión el sistema hilemórfico en su versión más tradicional de sistema estático y cerrado, definiendo en cambio la individuación como proceso continuo de intercambio entre forma e información ${ }^{327}$. Así, alzándose sobre la consideración estática de forma y materia, nos podemos situar en una dimensión energética, concibiendo lo material en términos de movimiento y fuerza, una cierta desmaterialización, convirtiendo así la materia en medio, donde se da lo virtual, lo potencial, una especie de materialismo aéreo, como dirá Glucksmann. Así lo diáfano, que podríamos hacer coincidir con este materialismo, aéreo es una noción de tipo relacional, topológica.

Glucksmann hablará de una estética de lo efímero, una kairología de la transparencia, marcada por una luz no ontológica que abandona todo modelo de permanencia y perturba la noción de forma desde ahora abierta y pensada como flujo de energía y fuerzas múltiples $^{328}$.

En el mismo sentido se expresa Deleuze cuando se refiere al cuerpo sin órganos, designa la materia en un estado aún no formado. La materia es una mezcla no formal de fuerzas y materiales.

326. Cifr. Ibid.

327. GILBERT SIMONDÓN, La individuación, op. cit.

328. CHRISTINE BUCI-GLUCKSMANN, La Estética de lo Efímero, cap. 2: El nuevo paradigma del tiempo, ed. cit, pág. 25. 
Todo lo dicho parece que está considerando poner la atención en una morfogénesis, en el proceso de individuación, más que en una morfología, que estudiaría únicamente la organización de una forma estática.

La actualización de las cosas ocurre mediante un proceso de diferenciación ${ }^{329}$.

Múltiples fuerzas parecen actuar sobre la forma; Deleuze identifica el vínculo entre fuerzas y formas, los dos vectores de la diferencia ${ }^{330}$.

Así, Bill Viola en su vídeo El Mensajero, parece escenificar esta morfogénesis que parte de lo diáfano-fluido, donde trata la luz y el agua como elementos de lo diáfano que expresan lo efímero, en un ciclo donde la diferenciación y la repetición son los elementos estructurantes.

La figura humana escenifica lo efímero-fluido, emerge desde lo informe para volverse a sumergir en un ciclo que se repite, captando las relaciones dinámicas y fluidas entre un cuerpo singular y todos los flujos naturales y tecnológicos que nos atraviesan con su energía; se trata de una imagen flujo como forma energía ${ }^{331}$.

El espacio liso deleuziano es así un espacio vectorial o topológico, mientras el espacio estriado equivaldría al espacio métrico parametrizado. Y así, al espacio nómada o liso le corresponde una línea nómada, línea libre de intención, línea potencial, liberada de una geometría que podríamos llamar clásica. Una línea movida por el principio de proliferación interna, como la línea activa de Klee ${ }^{32}$, cuyo elemento genético es la inflexión. Ya hemos visto cómo el punto de inflexión, es considerado por Bernad Cache, como una singularidad intrínseca333, que no remite a coordenadas, ni a un arriba, ni a un abajo, es un signo ambiguo, ingrávido. La inflexión es un acontecimiento de la línea, lo Virtual. Esta inflexión, propia del Pliegue, es, ya lo hemos señalado ${ }^{334}$, una característica

329. GILLES DELEUZE, Diferencia y Repetición, op. cit.

330. Cifr. Ibid.

331. Cifr. CHRISTINE BUCI-GLUCKSMANN, La Estética de lo Efímero, op. cit.
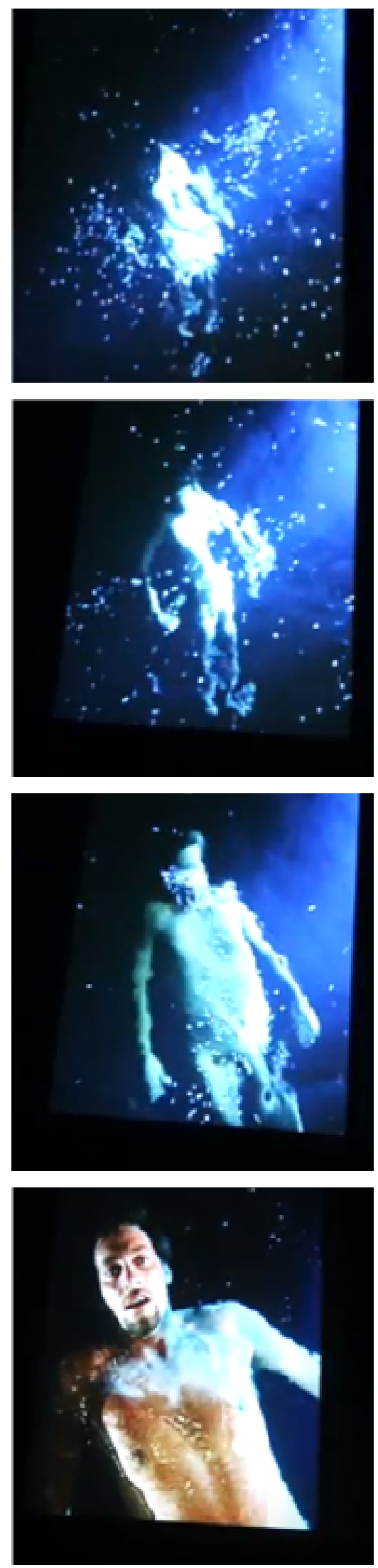

2.46. El mensajero. BILL VIOLA. 1996.

332. PAUL KLEE, en sus Cuadernos Pedagógicos, explica la línea activa como aquella que se mueve jugando libremente y cuyo agente es un punto en movimiento.

333. Citado por GILLES DELEUZE, El Pliegue... op. cit.

334. Véase supra. Capítulo 1, págs. 152-153. 
barroca. El Barroco se mueve en el ámbito de lo virtual, lo potencial; es propio entonces también del Barroco lo atmosférico y lo diáfano.

Tenemos pues un espacio liso y nómada, una topología relacional, tenemos lo diáfano y una línea nómada que supone velocidad y fluidez y que capturará fuerzas sobre los nuevos materiales.

Nuestra arquitectura contemporánea también se hace cargo de lo diáfano, el espacio recoge los flujos ondeantes de la luz como si fuera agua, pero también del agua como si fuera luz, multiplicando rayos y vibraciones, que ponen en cuestión la estabilidad de la forma en arquitectura, que se cuestionan sobre el estatuto de esta forma, su pertenencia al movimiento, a la energía, introduciéndose en el ámbito de lo posible a través de atmósferas neutras y cambiantes, que prometen escenas siempre diferentes, que recogen lo posible; un espacio que no es vacío sino productor.

El grupo de arquitectos catalanes RCR, proyectan lugares donde la forma arquitectónica parece haberse disuelto, lugares cambiantes que se multiplican en diferentes actos, se activan de diferentes modos, con la luz, la sombra y la presencia, haciendo emerger el fondo, lo diáfano posibilitante; es el modo contemporáneo de representar la potencia.

(...) ¿no han experimentado nunca al entrar en alguna de esas salas, la impresión de que la claridad que flota, difusa, por la estancia, no es una claridad cualquiera, sino que posee una cualidad rara, una densidad particular?335

En la Carpa del restaurante Le Cols, en Olot, proyectada por RCR en 2007, lo que se produce es una vibración en el espacio. Parece como si el objeto-edificio ya no fuera pertinente, solo queda una especie de estructura y de materiales que la acompañan que generan un lugar de encuentro. Una cubierta de tubos de acero y una membrana densa y transparente extendida en mitad de un bosque, resguarda un desnivel en el terreno, y ese es el lugar. Al plano de cubierta le atraviesan algunos patios como si los árboles no se hubieran dejado dominar y hubieran rasgado unas franjas 


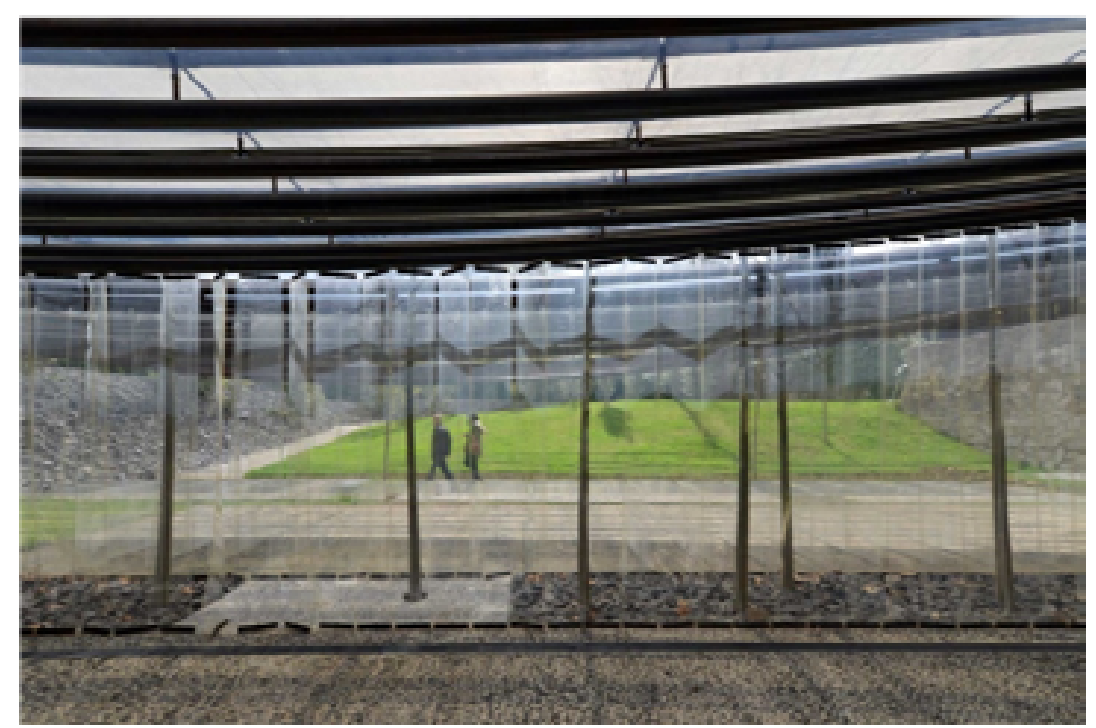

o roturas lineales, o como si los árboles hubieran sido invitados a participar en esa escenografía ${ }^{336}$.

La carpa es como un umbráculo expectante, y el umbráculo comparte raíz etimológica con la palabra umbral. También comparten su relación con el vacío, un vacío en el sentido aristotélico337, un vacío-lugar, como atmósfera, porque está lleno de luz, de textura, de temperaturas, es un vacío que remite a la presencia de una cercanía, un espacio cuyo ritmo es acompasado por la variación de la luz ${ }^{33^{8}}$. Es cambiante en su integración con el entorno, captando la luz, el día y la noche, las estaciones... , una multitud de percepciones que se concentran en una armonía de la que surge la atmósfera.

La arquitectura del Barroco histórico tematiza de múltiples modos la posibilidad y la potencia, teniendo en la base de su estructura proyectual la inflexión. Veíamos cómo la inflexión señala a un acontecimiento, pero también a una continuidad. Lo continuo es estructural, es lo que posibilita la inflexión, y la propia inflexión es en sí una singularidad, una potencialidad dentro del continuo.
2.47. Interior de las carpas de Les Cols. RCR. Olot, 2007.

337. Aristóteles no concibe nunca una especie de espacio vacío inerte y abstracto, a modo del de Demócrito o Leucipo, habla de lugar, como el espacio de posibilidad. Sobre este tema escribe su tesis Henri Bergson: HENRI BERGSON, Quid Aristoteles de loco senserit. Thesim facultati litterarum Parísiensi proponebat, Edebat F. Alcan, París 1889, Trans. Antonio Dopazo, El concepto de lugar en Aristóteles, Ediciones encuentro, Madrid 2013. 
2.48. Interior de las carpas de Les Cols. RCR, Olot, 2007.

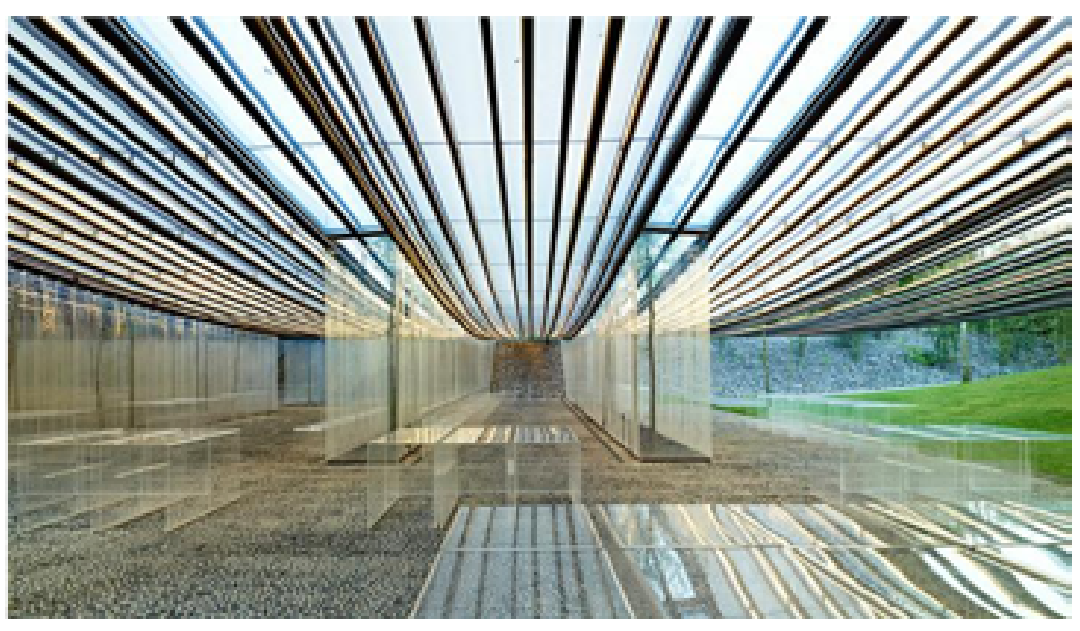

Si la inflexión, que emerge del fondo del continuo, de un fondo de posibilidad que en ella queda expresada, figura en la estructura o la esencia de la estética barroca, el arte contemporáneo lo modula de otro modo; hace suya la manifestación de lo diáfano, del espacio propicio (otra especie de Kairós), que permite la posibilidad. Ahora el fondo diáfano que permite cualquier acontecimiento es lo que pasa a ocupar el primer plano; una estética articulada sobre lo diáfano y lo efímero, como señala Glucksmann.

Ronald Barthes, también se ha referido a esa neutralidad activa, que permite establecer una distancia temporal en las cosas, tornasolar el mundo de luz indistinta y hacerlo estremecer con matices imperceptibles 339 .

Lo diáfano es ese ser de la luz, su medio o sustancia donde la luz de expresa. Lo diáfano es la base activa, es un fondo sobre el cual... Lo diáfano es un concepto relacional y neutro, como el mar en un archipiélago. Lo diáfano es necesariamente continuo y fluido. Es necesario lo sombrío para que se haga presente la luz. Esta neutralidad activa es la que permite un espaciamiento, dejando aparecer la vibración, como tematizando el paso del tiempo, una vibración del tiempo vuelta sensible.

Así, las membranas transparentes, pero de una densa transparencia, son como operadores de lo efímero, como diría Glucksmann, la estructura y las membranas suscitan ritmos, motivos, claros, penumbras, vibraciones en el espacio diáfano.

Lo efímero no es el tiempo sino su vibración vuelta sensible..$^{340}$

339. RONALD BARTHES, Le neutre, Le Seuil/Imec, 2002, citado por C. Buci-Glucksmann "La estética de lo efímer", op. cit.

340. Ibid. op. cit., cap 2: El nuevo paradigma del tiempo, pág. 21. 


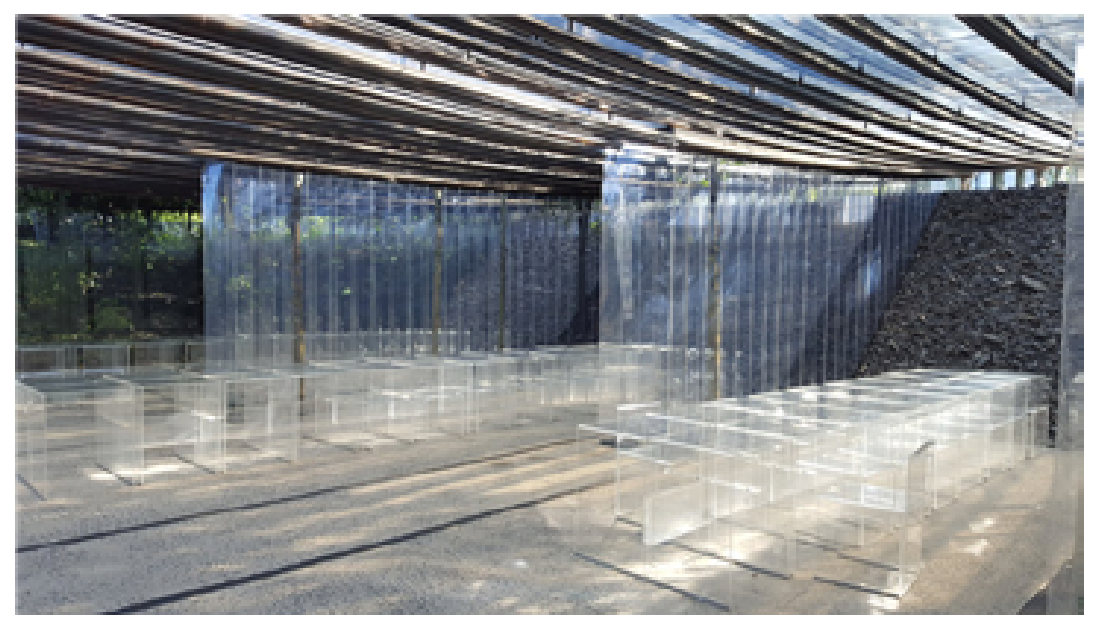

Ya no hay limitaciones espaciales, cerramientos o tabiques. Estos se sustituyen por lamas de PVC de espesa transparencia, que no desaparece del todo en el fondo neutro, sino que son como densidades de lo transparente. Esta especie de cortinas cuelgan de los cables de la estructura de la cubierta, pero, al no estar tensadas también producen cierto movimiento, una vibración. También el mobiliario densifica el espacio con su transparencia geométrica. Una especie de magia óptica hace emerger el fondo diáfano a partir de la vibración donde todo se multiplica y se duplica: reflejos sobre objetos delimitando su densidad.

El espacio se estructura a través de intervalos, produciendo espaciamientos, vacíos, dejando ver la vibración, como tematizando el paso del tiempo, en una especie de ficción, mostrando algo entre un es y un no es. Todos los materiales contribuyen a esta desmaterialización.

La iluminación nocturna de la carpa es como un flujo que escurre por los diversos materiales. En las membranas de la cubierta se alojan unos tubos de leds que siguen la forma curva de las catenarias de las membranas. La luz se quiebra en reflejos de distinta índole como disgregándose, deformándose, plegándose. Es como un espectro repetido que se va deformando, un simulacro del filamento de luz de una bombilla que se reparte por el espacio, vibrando en todos los paramentos, de forma que estos se materializan debido a la incidencia de la luz.

Una atmósfera, un lugar, que las posibilidades definen de manera inestable; una interrogación sobre la realidad de esa vista estable que llamamos forma ${ }^{34}$. La Carpa es una escenografía cambiante.
2.49. Interior de las carpas de Les Cols. RCR. Olot, 2007.
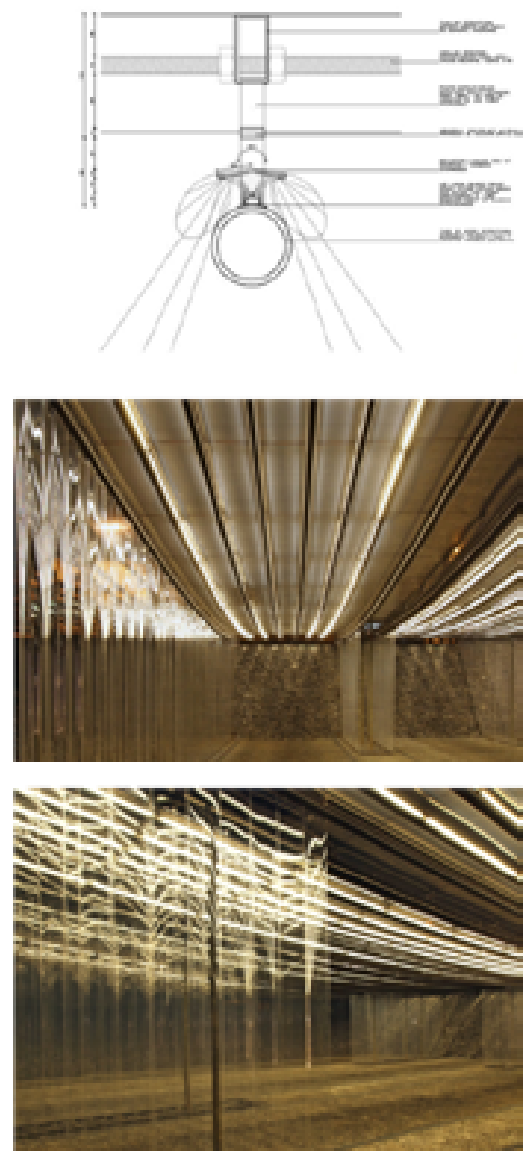

2.50. Detalle de las luminarias alojadas en las membranas. Carpas de Les Cols. RCR. Olot, 2007.

2.51. Interior nocturno iluminado de las carpas de Les Cols. RCR. Olot, 2007. 


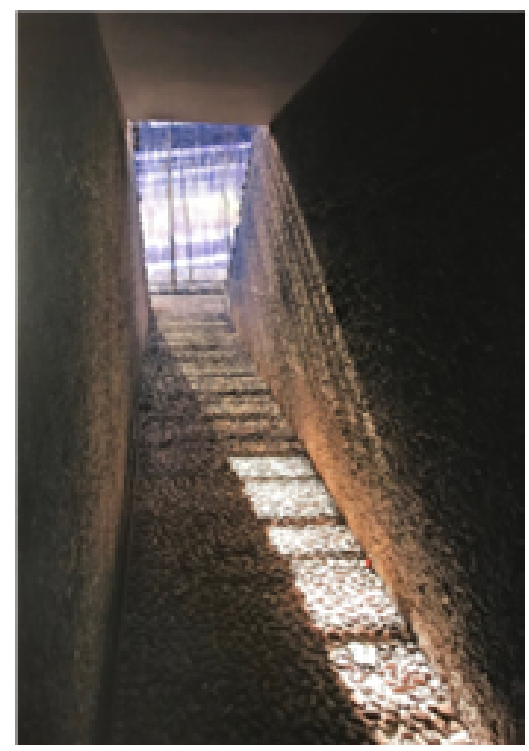

2.52. Acceso al interior de la carpa de Les Cols. RCR. Olot, 2007.
Christine Buci-Glucksmann, en su texto La estética de lo efímero, ha distinguido el plano-cristal del plano-fluido. El primero podría quedar caracterizado en una cierta forma de expresión de la arquitectura moderna, cercana a la arquitectura de Mies van der Rohe, entre otras. Esta transparencia moderna, dirá Glucksmann que es un modo de lo efímero:

(...) ser como efímero es el sueño realizado de una modernidad que ha borrado toda huella (...).342

Una abstracción cristalina, que remite a una pureza y que siempre depende de un límite; el cristal solo crece por los bordes ${ }^{343}$, de modo que, lo efímero del plano-cristal es solo un acontecimiento de borde o de ribete, un inter-ser de lo inmateria ${ }^{344}$.

El vidrio o el espejo siempre está entre la presencia y la ausencia. Lo efímero transparente del cristal no es más que un efecto del tiempo, de un tiempo a lo Bergson, una durée. Hace coincidir exterior e interior suprimiendo todo fondo.

Pero la Carpa tematiza más bien el otro tipo de lo efímero al que se refiere Glucksmann, el plano-fluido, que lo que tematizan es el espacio, lo diáfano, emergiendo así un espaciamiento o fondo, sin el cual no sería posible que nada tuviera presencia, aspirando así a representar lo posible, la potencia de ser.

El plano fluido, introduce, según Glucksmann un tipo completamente diferente de transparencia y de temporalidad, perdiendo toda arista dura, como hace el Barroco, y dejando ver el entre-dos, el fondo fluido donde se da lo efímero cambiante, hecho de variaciones luminosas, donde se pierde incluso el anclaje de la mirada. Tal es el estatuto de la forma en la que se expresa esta obra de RCR, tal es, más bien el modo, en el que la carpa de Les Cols tiene lugar, en esa estética de lo efímero, en ese fondo-escenario, eso diáfano que da lugar a su escenografía cambiante.

Pero no habría aquí que confundir lo efímero con una arquitectura provisional o desmontable. Lo efímero a lo que nos referi-

\footnotetext{
342. CHRISTINE BUCI-GLUCKSMANN, La Estética de lo Efímero, cap. 2: Las transparencias de lo efímero, op. cit., pág. 44.

343. GILLES DELEUZE: Los acontecimientos son como los cristales, no devienen y no crecen más que por los bordes, sobre los bordes. Citado pos C.Buci-Glucksmann, La estética de lo efímero, op. cit.

344. CHRISTINE BUCI-GLUKSMANN, La Estética de lo Efímero, cap. 2: Plano cristal y plano fluido, op. cit., pág. 30.
} 


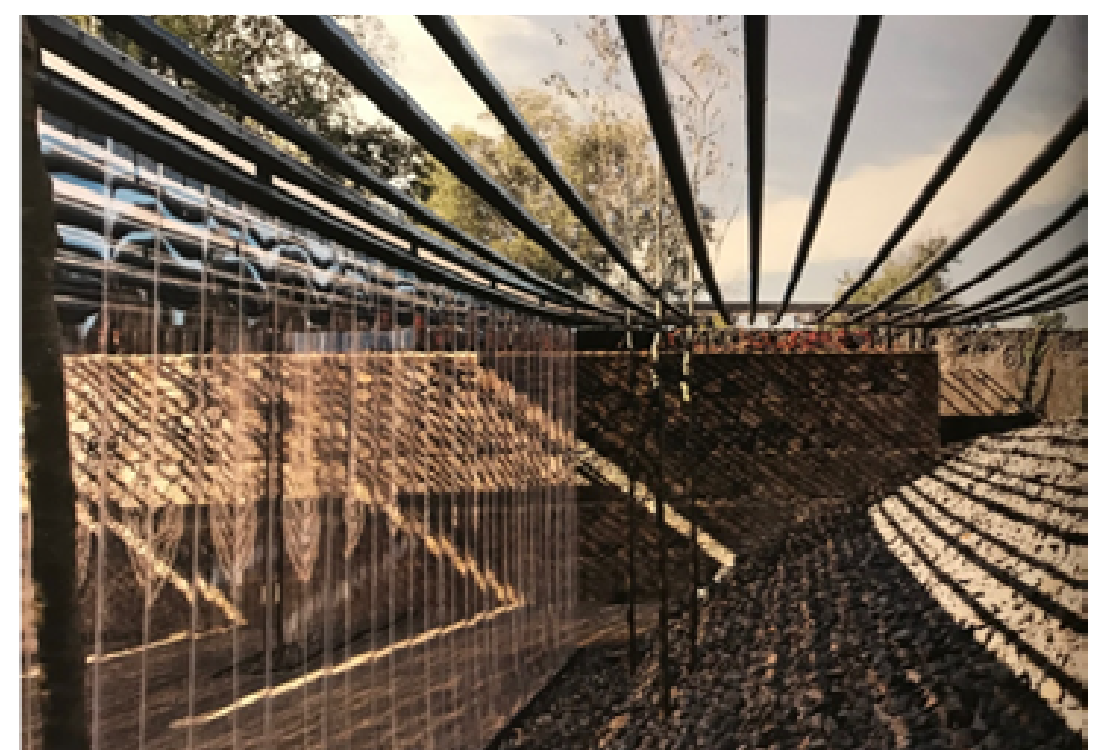

mos es una forma de expresión de cambio, de fragilidad, como lo perecedero, sometido al ciclo vida-muerte, al devenir. Lo efímero capta el tiempo en los intervalos y las vibraciones, en los flujos imperceptibles de la luz de los leds que escurren por las cortinas disgregándose, generando acontecimientos de luz.

El tiempo fugaz de esta imagen-flujo se expresa así en vibraciones de luz, en todo lo que crea una especie de inestabilidad centelleante, tornasoles, ondulaciones y juegos de reflejos. Lo efímero capta sus materiales, y se presenta prendido de transparencias, de tiempos-flujo y virtualidades 345 .

Un lugar suspendido, sometido a un movimiento fluido que le otorgará lentamente la luz del día o la luz de la noche que escurrirá también cambiante por los materiales. Transiciones ambiguas y cambios imperceptibles, como los lentos movimientos de los vídeos de Viola. Este movimiento fluido es el que realiza lo efímero de la imagen-luz a la que se refiere Glucksmann, propia de la nueva temporalidad de la cultura de flujos ${ }^{346}$.

Henri Bergson ya advierte de la apariencia de la forma estable; la forma únicamente se reduce a una vista estable, pues el cambio de forma se produce cada instante, lo que nos hace concebir una forma como constante resulta solo de la inercia de nuestra percepción. Solo cuando el cambio nos resulta relevante decimos que algo ha cambiado de forma. Nos dice:
2.53. Límite de las carpas de Les Cols. RCR. Olot, 2007. 

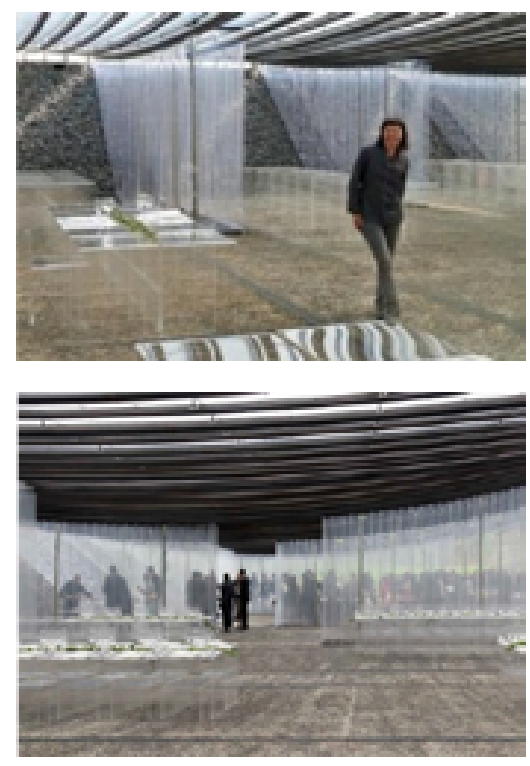

2.54. Interior de las carpas de Les Cols. RCR . Olot, 2007.
O más bien no hay forma, puesto que la forma es inmóvil y la realidad es movimiento. Lo que es real es el cambio continuo de forma. La forma no es más que una instantánea tomada sobre una transición. ${ }^{347}$

Hay una suerte de desmaterialización, que llevaría al extremo la pretensión de disolver la forma, que el Barroco llevaba a cabo fraccionándola, desplegándola y desdoblando su centralidad.

La expresión artística se ha convertido en algo efímero, un acontecimiento en el tiempo. Es en la instalación, donde se expresa la manifestación artística actual, y consiste en una combinación eventual de objetos en un espacio que no es propiamente un objeto, expresando una sustitución del tiempo por el espacio en un arte principalmente espacial.

La aceptación del tiempo, su alteridad y su alteración, son propios también, de las naturalezas muertas y de los motivos propios de la pintura barroca: las Vanidades, las naturalezas muertas, las calaveras...

¿Pero la asunción del tiempo como pasaje, que convoca al relevo, al cambio y a la transformación, no se da siempre en el espacio? El ser no es más que su aparecer inestable entre el hay y el no hay ${ }^{348}$.

Benjamin ya había señalado como en el Barroco la insuperable inmanencia abre una transformación de los datos originariamente temporales en una simultaneidad espacial ${ }^{349}$. El espacio como éxtasis de los órdenes del tiempo toma el protagonismo. Se activa diversificándose en escenas que ya no dependen del orden del tiempo; ya no hay recorrido temporal, hay un dominio de lo espacial.

La Carpa es casi una instalación, que aparece y se esfuma cada vez que es ocupada, que produce como escenas efímeras, que se activa con la ocupación del espacio; su espacialidad se expresa como potencia de la movilidad de los cuerpos que la ocupan.

Se trata de algo así como de hacer un lugar con la luz en un desplazamiento de lo material que lo inmaterializa todo, lo que vemos es

347. Cifr. HENRI BERGSON. Le évolution créatrice, traducción al castellano de Pablo Ires, La evolución creadora, Cactus, Buenos Aires 2007.

348. CHRISTINE BUCI-GLUCKSMANN, La Estética de lo Efímero, op. cit., pág. 20.

349. WALTER BENJAMIN Ursprung des deutschen Trauerspiel, Frankfurt am Main, 1989. Edición en castellano, El Origen del Trauespiel alemán, Abada editores 2012. 
menos la forma que la energía $3^{30}$. Se podría hablar de una transparencia sin resonancia, entendiendo la imagen como traducción de algo más originario ${ }^{351}$. Benjamin también ha encontrado en esto la manera de dar forma del Barroco:

El instante místico se transforma en el ahora actual y lo simbólico se transforma en lo alegórico. Del acontecer soteriológico se segrega lo eterno, y lo que queda es un cuadro viviente accesible a todas las correcciones de la dirección escénica. Esto corresponde muy intimamente a la manera barroca, divagante y voluptuosamente vacilante de dar forma. ${ }^{352}$

En la carpa de les Cols hay una renuncia a la forma, y como esta se disuelve, comienzan por desvanecerse sus límites, que se pierden en el entorno, y el entorno se incorpora al espacio según patios que se entremezclan. Es una captura de bosque, un filtro que conquista las potencias de la naturaleza. donde los límites tradicionales de la envolvente arquitectónica se diluyen.

El exterior y el interior se interrelacionan y se pierde su distinción. Hay una ambigüedad en el uso, en el espacio, en los límites, es un objeto sin definición.

Así los propios arquitectos nos dicen de su arquitectura:

(...) una arquitectura que desaparece, desmaterializarse para estar, adaptarse al lugar para convertirse en lugar...353

\subsubsection{Desmaterializaciones}

Turrell en su instalación Parísina Blood Lust (1989) hace un lugar vaciado de todo, únicamente saturado de un color atmosférico. Se trata de un gran rectángulo escarlata que flota en el espacio de la habitación oscura; un rectángulo frontal, sin sombra ni matiz que emerge masivamente. Pero este color es inmaterial, nuestra mano no puede encontrar nada, no hay límite. Se trata de una ilusión de la vista, se trata de lo inmaterial representado; un vacío lleno de nítido color rojo, el lugar del color. El rectángulo flota en lo oscuro

350. CHRISTINE BUCI-GLUCKSMANN, La Estética de lo Efímero, Nuevas fluideces, ed. cit, pág. 50 .

351. Cifr. Ibid.

352. WALTER BENJAMIN, El origen del Trauerspiel alemán, op. cit., págs. 185, 186.

353. Entrevista a RCR. Revista El Croquis no 20 dedicada RCR. 


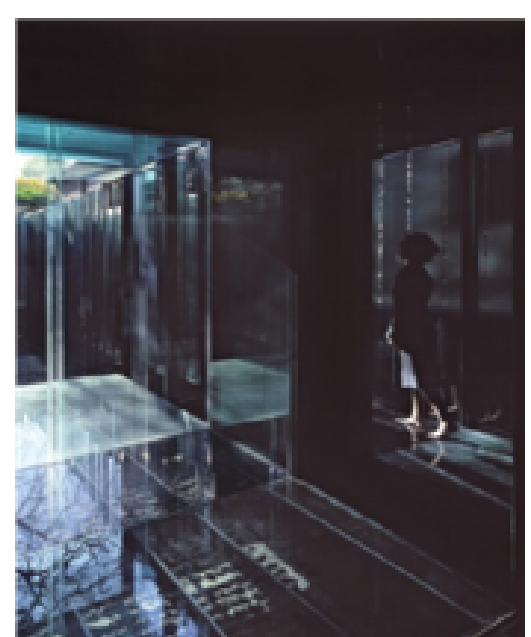

2.55. Interior de los pabellones de Les Cols. RCR. Olot, 2005. donde todo se ha desvanecido, donde todo es indefinible de inmediato; espacio portador de lo desemejante. Nos conduce a la inmanencia de lo ausente, a la rara experiencia de su figurabilidad ${ }^{354}$. Así Turrell dará a la ausencia la potencia del lugar. La materia que se contempla se reduce hasta no ser más que la evidencia luminosa del lugar, un lugar dotado de potencia en cuanto que matriz de las cosas.

Hay una desmaterialización de la forma; forma sin materia, o más bien, forma a partir del fondo, donde reside su posibilidad. Lo vemos también en la arquitectura.

Al lado del restaurante RCR construye una serie de pabellones, los Pabellones Le Cols, pequeñas construcciones a modo de hotel que se sitúan en el mismo recinto que la Carpa.

En los Pabellones_RCR juegan a fundir la planta con el entorno, con el exterior. Pero el conjunto tiene una interioridad propia, escenográfica, virtual, repleta de espejismos: luces, sombras y reflejos, de vidrio y de agua, de cielo y de planos brillantes de acero inoxidable y vidrio opaco. Nada tiene que ver la naturaleza circundante con este teatro propio que nos incluye al entrar, donde nos encontramos suspendidos en una interioridad concentrada, que llega a desorientarnos, ¿no es esto un nuevo espacio barroco?

(...) víctimas del aturdimiento de las pequeñas percepciones, no cesan de realizar la presencia en la ilusión, en el desvanecimiento, en el aturdimiento, o de convertir la ilusión en presencia (...) Los barrocos saben perfectamente que no es la alucinación la que finge la presencia, es la presencia la que es alucinatoria. ${ }^{355}$

Frente a la carpa, este espacio no es público, es ocupado casi individualmente en sus pequeñas celdas que nos transmiten una intensidad de interior, con su inmaterialidad flotante.

El espacio remite a una especie de nomadismo interior; en la soledad de las pequeñas celdas, que no están equipadas con ningún tipo de mobiliario convencional, somos nómadas de la conciencia de sí. Hay una especie de deslizamiento de las estabilidades, incluidas las de la subjetividad.

354. Cifr. GEORGES DIDI-HUBERMAN, El hombre que andaba en el Color, op. cit. 355. GILLES DELEUZE. op. cit., pág. 161. 
Así, la experiencia de la celda provoca una sensación de desconcierto.

Todas las cosas que uno suele sentir bajo su control estaban ausentes (...). Solo, rodeado de tanta transparencia, instintivamente me quité toda la ropa y esteré una iluminación. Todos los ingredientes del confort burgués- sillón, teléfono, televisión, alfombra- estaban ausentes y fui forzado a mirar a mi interior ${ }^{356}$.

El arte mínimal, con el que habitualmente se ha vinculado algunas de las obras de RCR, particularmente las celdas de Les Cols ${ }^{357}$, es una forma de interpretar la propia desaparición, se mueve en torno a la desmaterialización. Y también la desmaterialización es un tema del Barroco.

Es bastante inmediato el considerar el minimalismo y lo barroco como dos manifestaciones muy distintas, alejadas e incluso opuestas. Sin embargo, se pretende aquí demostrar su íntima vinculación.

Omar Calabrese ya señalaba en su texto la cercanía con el Barroco, en literatura, de los llamados minimalistas americanos, a través de una especie de anulación del texto narrativo, o la producción de lo indistinto, lo ruidoso sin armonía, de muchos músicos a partir de los años 7o. Se trata de producir el estado de no-distinción ${ }^{35}$. El propio Jean Francoise Lyotard organiza una completa exposición en el Beaubourg sobre el tema de los inmateriales ${ }^{359}$. La estética barroca también expresa de algún modo este ámbito pre-formal como hemos ya notado; se trata de expresar lo originario sin forma. Los fondos emergen, pero como señala Deleuze, ese fondo-nada contiene, sin embargo, la posibilidad de la diferencia. De eso se trata en el Barroco en sus diferentes modulaciones que estamos analizando.

La inmaterialidad es una de ellas, probablemente empujada por la emergencia de las nuevas tecnologías, pero creemos que no es esa su razón de ser. Lyotard en su exposición, la ofrece también como disgregación o disolución de los valores de la modernidad. Lo cier-
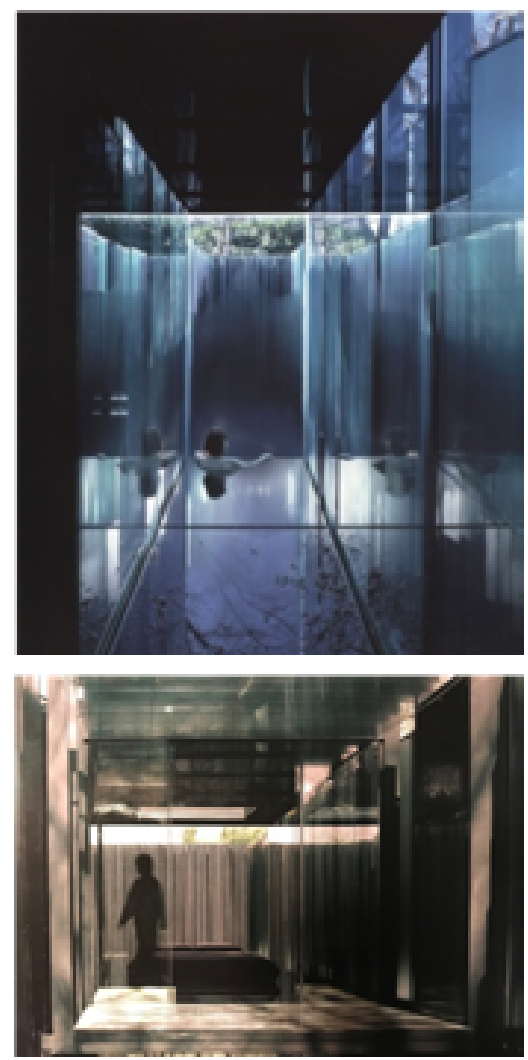

2.56. Interior de los pabellones de Les Cols. RCR. Olot, 2005.

356. RICHARD INGERSOL, narración de su experiencia en los Pabellones de Les Cols, Arquitectura Viva, RCR arquitectos 1988-2017, Madrid 2017.

357. Ibid. Lo hace, entre otros, Richard Ingersoll en el artículo citado anteriormente.

358. OMAR CALABRESE, op. cit., pág 185.

359. JEAN-FRANCOISE LYOTARD, Les Inmaterieux, Centre Pompidou, París 1984. 
to es que la expresión de esta especie de fondo originario, subyace en todo nuestro análisis.

Toda la profusión de sensaciones y transparencias confusas de los Pabellones de Les Cols, donde uno se encuentra rodeado de afecciones que remiten a lo corporal, una especie de profusión de imágenes donde no hay nada que ver, ¿no se relaciona también con las percepciones barrocas en el interior de los espacios de Borronini, cambiantes y rotantes, con sus efectos de luz desde la linterna y sus densidades espaciales?

Como en el Barroco, se trata de nuevo de volver visible algo del orden de lo oculto, de lo irrepresentable. Por ello la arquitectura se concibe en términos de simulación, de apariencia y el régimen de lo visual toma un lugar dominante. El concepto de parecer es entonces pertinente, se impone entonces la imagen frente al objeto real, y la arquitectura trata de crear imágenes en esa especie de des-matrialización, como la que se manifiesta en las carpas de Les Cols.

Resulta una locura, según Glucksmann ${ }^{360}$, esta pretensión de representar lo irrepresentable, el proceso de formalización, una especie de individuación, generada por las fuerzas de lo oculto, por la potencia, la posibilidad, una locura de ver. Todo este proceso hace que la arquitectura se conciba como objeto temporal, no solamente espacial, o que más bien el espacio muestre su capacidad temporal y su relación con el tiempo. Así se entiende que la intención última, tanto del Barroco como de esta su nueva versión, sea intentar verlo todo y con ello hacer del mundo un espectáculo.

Un arte gaseoso y líquido, como describe Glucksmann, la nueva locura de ver ${ }^{361}$, una estética de la fugacidad y lo etéreo, de imágenes-flujo, es el régimen de lo latente, lo virtual. Una nueva sensibilidad 'epocal', unida siempre al simulacro y a la apariencia, una cultura de flujos, sensibilidad plural y múltiple.

Pero Glucksmann nota una diferencia con el Barroco histórico y distinguirá nuestro arte, que llamará icáreo, frente al arte de Narciso que representará el Barroco histórico. Narciso, preso de su propia imagen reflejada, expresa lo efímero melancólico; una nostalgia por lo perdido, por lo perecedero. Pero ahora se trata de una

360. CHRISTINE BUCI-GLUCKSMANN, La folie du voir, op. cit.

361. Cifr. La folie du voir : del esthetique baroque, Galilee editions 2002. 
estética postmelancólica, vinculada al mito de Ícaro, que, desde lo alto, consigue captar lo cartográfico. Es lo efímero insuperable, inestabilidad ontológica de nuestra finitud.

A este arte de lo efímero postmelancólico, también lo llama efímero cósmico, que capta lo latente, lo virtual, pero no lo presente. En las celdas, lo virtual es lo que comprende el espacio; la forma se ha disgregado y los planos de vidrio que forman las habitaciones se deshacen en su estructura seriada, se distribuyen siguiendo criterios que parecen encontrarse en lo natural del entorno, al que incluyen, aunque excluyendo una exterioridad. Los umbrales son infinitos y el llegar a las celdas-habitaciones se prolonga y parece que no se acaba en el hecho de entrar.

La haecceidad, para Deleuze, tiene una especie de consistencia propia que la relaciona con fenómenos como el vapor, el vaho, la nube etc., que desdibujan cualquier límite o frontera definidos.

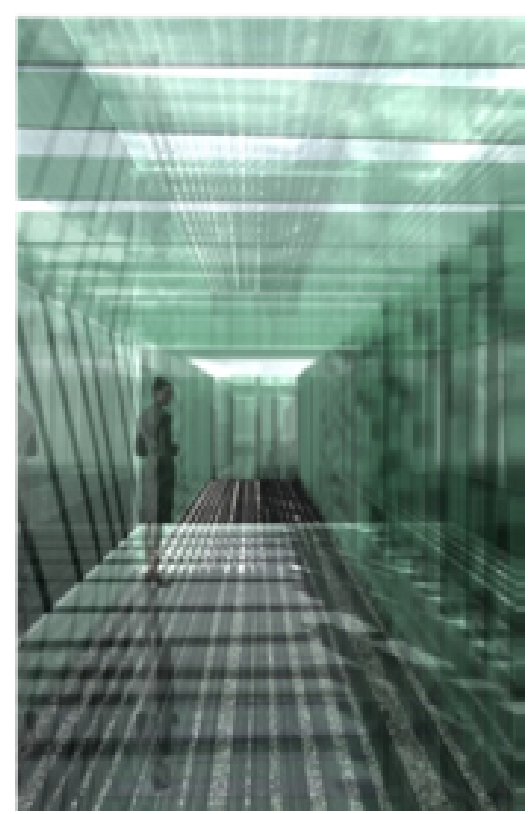

2.57. Acceso a las celdas de Les Cols. RCR. Olot, 2005.

Todo aquí contribuye a generar una impresión de des-materialización, hasta el punto de deslocalizar el lugar. No parece haber percepción estable, todo acontece cada vez, pues reflejos, luces y materiales cambian de aspecto. Se presenta la noción de vacío como una tensión entre el anhelo y la ausencia en una representación certera de lo diáfano ligado a la atmósfera donde ese vacío se inserta en la contingencia de lo temporal; también una estética de lo efímero.

En la transparencia de lo efímero Glucksmann ve como se engendran transparencias cada vez más complejas y fenoménicas, que desmaterializan todo, creando alternativamente efectos de superficie y profundidad de campo ficticia, proyectando el tiempo en el espacio $^{362}$.

Podría objetarse, que, en el Barroco, la materialidad está muy presente hay como un efecto de masa. Pero, sin embargo, es equívoca esa apreciación, pues en la medida en que la forma se cuestiona y se diluye, la materia también lo hará, pues la materia no subsiste sin la forma.

Wölfflin ya había señalado una cierta tendencia hacia lo inmaterial en el Barroco histórico: 
En la época barroca se busca una impresión de conjunto: menos percepción, más atmósfera. (...). La forma plástica deja de ser significativa, se compone recurriendo a efectos de masa: los elementos menos definidos, luz y sombra, se vuelven los medios de expresión. (...), el efecto de luz adquiere mayor importancia que la forma (...). $3^{63}$

Hay, así, lo diáfano-barroco en los espacios atravesados de luz tamizada del Barroco histórico, donde también emerge esa diafanidad neutra del espacio. Si el Barroco disgregaba la materia en poros y la diluía en pliegues, convirtiéndola en materia blanda, la arquitectura contemporánea la des-materializa, como llegando al extremo la pretensión barroca.

Los espacios del Barroco son densos. El propio espacio parece estar dando su forma al contorno, empujando, como fuerza que actúa sobre él, adquiriendo su dimensión energética, ámbito donde tiene lugar el movimiento y la fuerza.

Glucksmann describe como parece estarse dando una nueva dialéctica entre lo diáfano y lo adiáfano, donde lo luminoso deja de ser considerado como paradigma artístico, que hace emerger la belleza, la verdad. Ahora el fondo diáfano que hace posible cualquier acontecimiento es lo que pasa a ocupar el primer plano. Aristóteles descubría una luz que no era tratada por sí misma, sino en función de su visibilidad. Esto quiere decir que, para ver, hace falta un medio diáfano, transparente, donde la luz se actualiza. La transparencia de lo diáfano es un medio, un vehículo, pero también un entre, y actúa como límite, medio y fondo donde emergen las diferencias, donde no habrá luz sin lo oscuro, ni color sin otro color distinto. Por ello lo diáfano es inseparable de lo adiáfano.

Así, también sucedía en el Barroco, que todo pliegue se pliega y se despliega hasta el infinito, como nos describe Deleuze, en los intersticios del tiempo, con sus inflexiones que metamorfosean sin cesar la estabilidad de la forma. Ahora, cuando el mundo se vuelve global, la imagen del mundo también se quiebra y se desintegra, como la forma se metamorfoseaba (otra forma de desintegración) según el pliegue.

La multiplicación de los materiales de lo transparente permite lograr toda la complejidad temporal de los "entredós" en el origen de 
una estética multisensorial. Pues la transparencia no es un estado sino un desvío, creador de todas las inmaterialidades conceptuales, y autorizando en, y a través de lo efímero, la evanescencia y lo espectral como advenir del acontecimiento. ${ }^{364}$.

En los pabellones de Les Cols está presente una cierta ambigüedad; una destrucción entre las dicotomías: exterior-interior, naturaleza-artificio, materialidad-desaparición, abierto-cerrado; se juega en todo momento con la ambigüedad, con el entre, con el intervalo. Se establece como un movimiento fluido, de transiciones y ambigüedades, de cambios imperceptibles; la celda o habitación verá a la luz aparecer y retirarse, lentamente, transformando por completo la percepción del espacio.

Didi Huberman ha dicho que para presentar lo ilimitado es necesaria una mínima arquitectura, un arte de líneas, paredes y bordes, una dialéctica del juego, un encuentro entre cosas contradictorias que se reúnen en sus límites ${ }^{365}$. El límite de las celdas de les Cols representa lo ilimitado, donde el espacio se ensancha produciendo. El acto de limitar el espacio logra concebir la ilimitación del lugar en una paradoja donde el vacío no es una privación sino más bien representa lo fecundo.

Toda definición es diferida por la imposibilidad de la definición; los interiores inmateriales carecen de límites visuales, se multiplican en reflejos que imposibilitan una composición formal.

Estas nuevas transfiguraciones de las superficies tornasoladas y fluidas, introducen el movimiento de lo transparente en lo plano, creando una materia enmascarada ${ }^{366}$, un neo-barroco tecnológico. La pauta barroca ha sido modificada y reforzada por la tecnología, que ahora permite ir más lejos. En el Barroco la materia-forma ya insinúa su devenir en materia-fuerza., diluyéndose de un modo peculiar en su complejización a través de recursos concretos. Desde la inestabilidad que sugería el Barroco haciendo progresar y proliferar la forma en una forma relativa, (relativa al espacio-fondo que es el que se expresa), la contemporaneidad tematiza lo diáfano, diluyendo toda forma en una desmaterialización. El proceso de desmaterialización actúa como reflejando el modo de ser vir- 


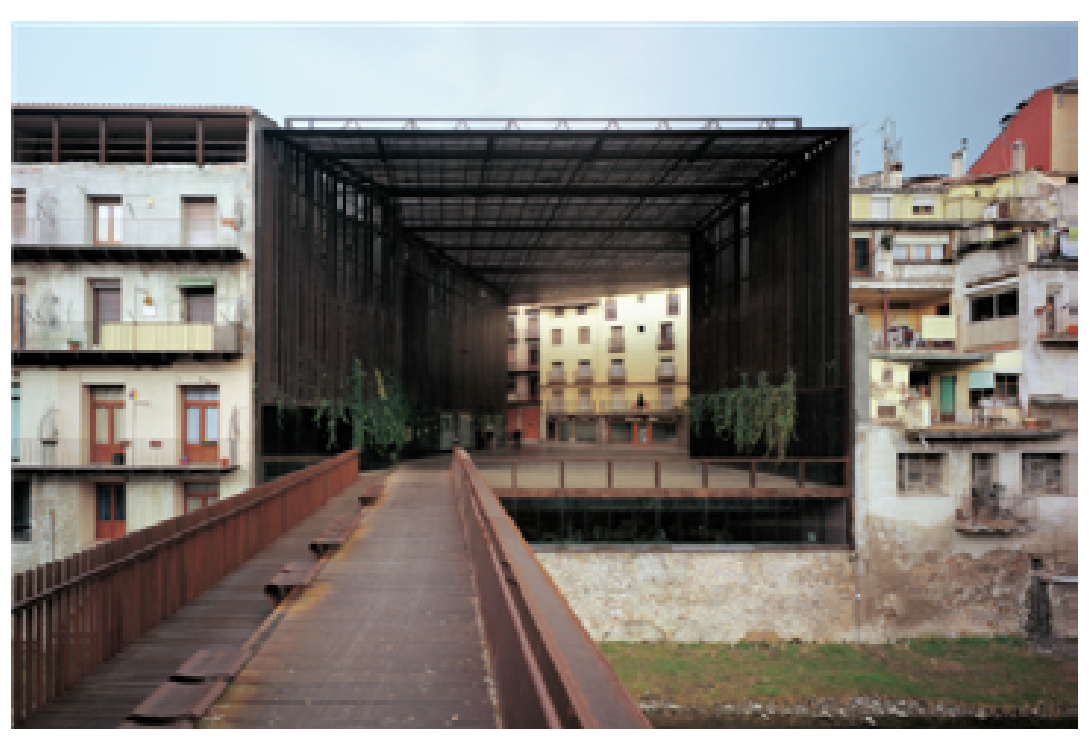

2.58. Espacio teatro La Lira (desde el otro lado del río). RCR. Ripoll, 2011. tual de la tecnología de la información, se manifiesta expresamente, los materiales lo permiten, la técnica lo propicia.

\subsubsection{Construir lo diáfano}

RCR llevan hacen explicita la expresión del espacio como lugar posibilitante. En el espacio público teatro La Lira., en Ripoll se trata de construir lo diáfano, de abrir un lugar, de espaciar.

Este lugar de Ripoll parece como vaciado para dotarlo de potencia, para hacerlo matriz de cosas que pueden suceder, para hacerlo lugar de presencia y de ausencia. La plaza cubierta de La Lira encierra el espacio en una trama de acero cortén, evocando su pasado como teatro mediante una configuración escénica.

Tras la demolición del antiguo teatro de La Lira surgió un vacío urbano frente al río Ter. Este vacío es aprovechado por los arquitectos para configurar una especie de plaza pública a modo de hueco en la trama urbana, un hueco que comunica la trama histórica con el río y deja ver la zona más industrial de Ripoll situada al otro lado. Una especie de balcón sobre el río que descubre el otro lado del cauce, la orilla más suave. De este lugar abierto en la trama urbana surge una pasarela peatonal que cruza el río.

El proyecto asume las trazas irregulares del solar, únicamente lo envuelve con lamas que producen rendijas de luz sobre el espacio diáfano. El acero cortén que conforma el lugar también lo envuelve, extendiéndose como pavimento, costados medianeros, cubierta y pasarela, configurando una envolvente para el vacío. La luz es matizada y controlada, toma una especial importancia como 
elemento que coloniza el vacío, pautando los ritmos de paso y estancia que conviven en el lugar ${ }^{367}$.

Se trata de un espacio con este doble carácter: como espacio dinámico abre un nuevo acceso peatonal al centro de Ripoll, pero también participa de un carácter estancial, una plaza pública, pero a modo de escena donde se representa el devenir de la gente que habita el lugar. Un escenario, sin escenografía preparada, un espacio neutro, que activará el movimiento de la gente, una arquitectura que cobra sentido al ser ocupada con la vida social del pueblo, su actividad.

Cuando enmarcas una actividad esta se convierte en algo distinto. Todo el mundo se convierte en protagonista ${ }^{368}$.

Los arquitectos remarcan un vacío, una plaza, la ausencia del antiguo teatro, que dejó en la densa trama urbana un sugerente hueco. Hay como una especie de eco o resonancia que deja la antigua construcción. El vacío a su vez comunica, interconecta ciudad-río-puente-margen-muralla, como nodo de relaciones, lugar de energías y flujos, son lo que Glucksmann llamará formas trayecto, nacidas de la interconexión de campos múltiples y heterogé$n e o s^{369}$. Pero ese espacio es, a su vez, conector de tiempos, replicando la escena del teatro, perdurando la memoria de un espacio expectante, que concede su nueva condición.

La sabia decisión de construir un vacío, de construir lo no construido es la que evoca la ausencia y por ello la presencia y la posibilidad, haciendo emerger lo diáfano. Y los materiales colaboran en la sensación de lo diáfano, reflejos y semi-transparencias, una especie de energía se desprende del lugar, lamas, luces, vidrios y reflejos sobre un suelo pulido, remarcan un límpido vacío.

El espacio de La Lira es la negación de lo material, es un espacio lleno de espacio, ese vacío sin el cual no es posible percibir objetos. El espacio, la chóra griega, en la que Platón también (como Aristóteles), reconoce como lugar del Ser. 

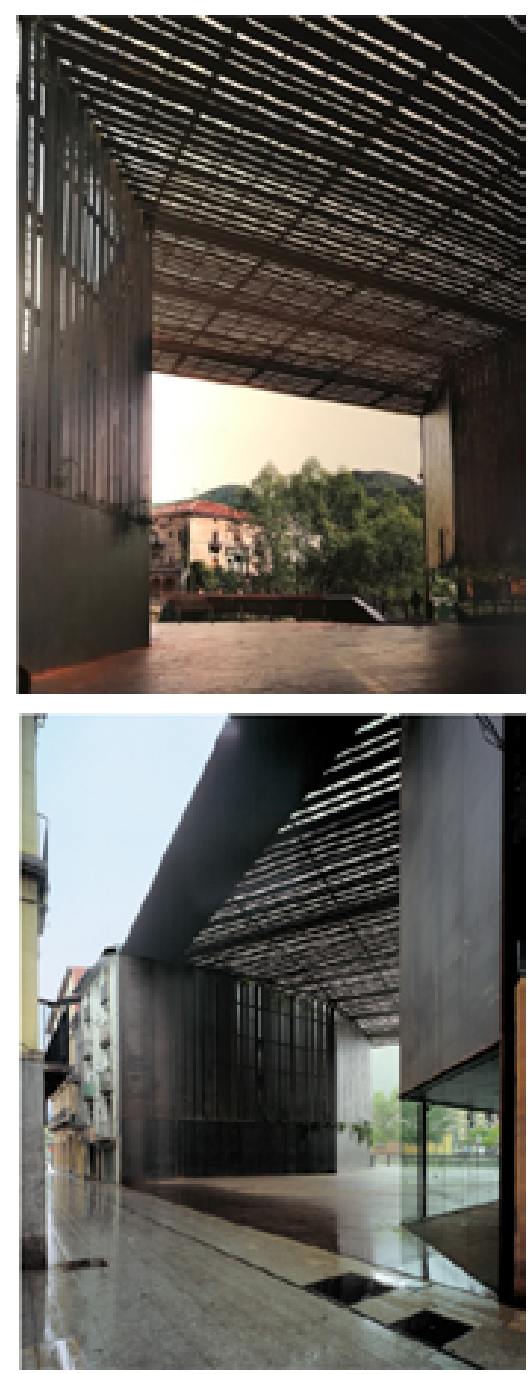

2.59. Espacio teatro La Lira (desde la trama urbana). RCR. Ripoll ,2011.
El lugar (chóra) no es perceptible más que gracias a una suerte de razonamiento híbrido que no acompaña en absoluto a la sensación (de realidad): apenas podemos creerlo. Es eso, con certeza, lo que apercibimos como en un sueño, cuando afirmamos que todo ser está necesariamente en alguna parte, en un lugar cierto, ocupa un cierto sitio ${ }^{370}$.

El revestimiento de lamas de acero deja rendijas que permiten que la luz atraviese el espacio disgregándose en haces. La materia del cerramiento semi-translucido, otorga al lugar un aspecto de cierta provisionalidad, simulando un material ligero, una cubrición eventual. Una especie de trampantojo o transgresión de lo material, una transfiguración de la superficie del cerramiento, creando una materia enmascarada que engendra una nueva transparencia, la de lo efímero. Es como si fuera una suerte de revestimiento textil, hecho de hebras, acercándose así a las superficies de la arquitectura japonesa o al arte japonés, como una estera de paja, un tatami, como un arte de lo efímero. En este sentido, el arte japonés sería desde siempre barroco. Un Barroco como sabiduría de la existencia expuesta a su fragilidad. De eso se trata el Barroco actual, donde tiene lugar lo efímero cambiante, lo que nace y que muere, lo diáfano, un espacio posibilitante.

Glucksmann ya señala esta vinculación del Barroco con la cultura oriental, en China o Japón, a través de la admiración de estas culturas por lo efímero; sus deslumbramientos estacionales contemplando los floridos cerezos o los arces rojos; una veneración a la belleza evanescente. Esta cultura de lo efímero, refleja la vibración del tiempo vuelta sensible.

Lo efímero es un arte del tiempo, que consiste en acoger, en ceder al tiempo y aceptarlo en cuanto a tal. Está mucho más cerca de la búsqueda del intervalo, propia de la cultura japonesa del Ma (espaciamiento, intervalo, vacío) que del solo regocijo hedonista del presente. ${ }^{371}$

La Lira evoca un arte de lo aéreo, como el que reivindica Glucksmann para el arte globalizado, un arte de lo abierto y lo posible, como el claro del bosque de Heidegger, el Lichtung ${ }^{372}$. Un arte del

370. PLATÓN, Timeo 52b-c.

371. BUCI-GLUCKSMANN, La estética de lo efímero, op. cit., Un nuevo paradigma del tiempo, pág. 21.

372. El Lichtung, o claro de bosque, es la metáfora que utiliza Heidegger para referirse a lo abierto, el lugar de la posibilidad de la presencia y de la aparición de la verdad como 
tiempo, de la metamorfosis, arte icáreo, donde lo pesado se transmuta en ligero. Es un intervalo de tiempo en la trama, un vaciamiento que dará lugar a..., que posibilitará. Una matriz o fondo activo.

Lo efímero, según Glucksmann, hemos visto que tiene dos modos de expresión. Ella distingue entre lo efímero melancólico y lo efímero cósmico, que también llamará trágico. El segundo modo, lo efímero cósmico, nuestra estética contemporánea, parece servirle de puente estético entre Asia y Occidente. Este modo de lo efímero se enraíza en la simple afirmación de la vida, un efímero de la impermanencia aceptada, un efímero de la transmutación, la transformación, el traspaso, que da sentido al Ser, en una inmanencia del hombre en el cosmos, acoplando lo efímero y lo cíclico común a la naturaleza y al hombre ${ }^{373}$.

En el espacio La Lira la superficie es como envolvente de una ficción, de una in-permanencia que se escenifica, que se remarca como teatro. La Lira es un espaciamiento, un vacío, un intervalo, que permite ver la vibración, el paso del tiempo, la fugacidad, la inestabilidad. Pues para poner en valor lo efímero, para captarlo, es necesaria una especie de neutralidad activa, que cambiará de aspecto, que permitirá establecer una distancia temporal de las cosas.

Hay un cierto minimalismo en el espacio público de Ripoll. Se trata de otra prueba de la vinculación del minimalismo con el Barroco. Bajo la expresión de una mínima acción sobre el lugar hay un cierto minimalismo, al menos en el modo de enfrentarse a la obra, se trata solo de un enmarcamiento del espacio, únicamente un ámbito, una zona neutra.

La arquitectura de RCR en muchas ocasiones se ha destinado a enmarcar el vacío, a señalar el espacio. A través de los materiales, el tratamiento de la luz, lo traslúcido, los filtros, los reflejos, crean un espacio no tratado a la manera convencional; un espacio representado a través de su propia inmaterialidad. Así lo hacen como ya hemos visto en el conjunto de Les Cols, pero también en el Pabe- 
llón de Baño de Tussls-Basil (1998), o en el pabellón de acceso a las pistas de atletismo en Olot.

Alois Riegl había señalado ya la dificultad, pero por otra parte el reto, de tomar el espacio como objeto de representación artística:

(...) De ahí que el espacio no pudiera originalmente convertirse en objeto de la creación artística antigua, pues no era posible individualizarlo materialmente (...) ese espacio profundo, infinito, existente entre los objetos materiales individuales. ${ }^{374}$

RCR consigue disolver la forma, disolver sus límites para hacerlos presentes a través de la neutralidad potencial del espacio, desarrollando así al máximo las posibilidades del vacío, un vacío que no es la nada, es, por el contrario, un vacío productor. Probablemente su arquitectura se caracteriza así, en la pérdida de la forma, la des-materialización, la incorporación del aire como material de construcción; ser lugar solo se consigue con una arquitectura que desaparece, desmaterializarse para estar, adaptarse al lugar para convertirse en lugar 375 .

374. ALOIS RIEGL, citado por Wiliam J.R. Curtis a RCR. Revista El Croquis no 20 dedicada RCR.

375. Cifr. RCR. Entrevista de Wiliam J.R. Curtis a RCR. Revista El Croquis no 20 dedicada RCR. 


\subsection{ESPACIOS TOPOLÓGICOS}

Siguiendo a Heidegger, advertimos el doble carácter del espacio que en su obra sobre el Arte y el Espacio ha señalado. Por una parte, el espacio es posibilitante, se trata de esta diafanidad que hemos visto en el capítulo anterior, lo diáfano despejado, un emplazar, que deja desplegarse a lo abierto, posibilitando un lugar. Pero además el espacio es relacional, pues proporciona a las cosas la posibilidad de pertenecerse mutuamente, congrega a las cosas en su copertenencia. El doble carácter de este espacio de Heidegger es ser posibilitante y relacional.

La generación de la forma en arquitectura puede seguir el procedimiento de una topología relacional. La forma se genera a través de relaciones espaciales que, así, ponen en obra el espacio. La expresión de las relaciones entre las cosas es generadora es productora de la forma, una forma que remite a este espacio relacional.

Borromini transforma el modelo en su arquitectura a través de una experimentación topológica que va evolucionando la forma como si fuera una forma plástica, favoreciendo al espacio, que se muestra, como hemos visto, como constitutivo de la arquitectura. Borromini no genera su arquitectura a partir de una planta, concibe el proyecto de una manera marcadamente tridimensional, jugando con secciones horizontales que van modulando una envolvente continua como modelada por el espacio que contiene.

Nuestro arquitecto utiliza en muchos de sus croquis el mecanismo de la planta transparente, donde superpone distintas secciones horizontales o plantas realizadas a distintas cotas. Este mecanismo es significativo en su proceso pues muestra las relaciones geométricas que se producen en altura; una serie de homomorfismos y semejanzas entre los diferentes desarrollos formales a distintos niveles: hay una envoltura muraria unitaria que evoluciona en permanente transformación ascendente. En San Carlino alle Quattro Fontane o Sant'Ivo alla Sapienza, el modo de proceso geométrico a través de sus croquis y el propio resultado formal de este, muestran un carácter telescópico del organismo arquitectónico construido: hay una sucesión de variaciones que hace imposible una visión estática del conjunto. ${ }^{376}$ La geometría mantiene analogías entre las formas continuamente cambiantes que se desarrollan en 


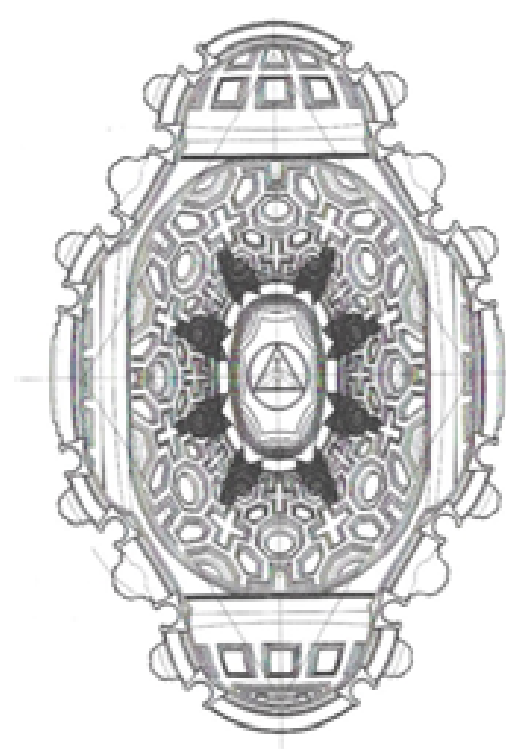

2.60. Planta de San Carlino alle Quattro Fontane seccionada a diferentes niveles simultáneamente. BORROMINI. altura. Es una red de respectividades que conserva la vinculación entre las diferentes formalizaciones dando lugar una topología, donde cada elemento cobra su forma precisa en función del lugar que ocupa en el espacio.

La geometría opera de forma relacional y no se persigue ningún desarrollo racional a partir de una geometría concreta; la forma varía según las relaciones espaciales que ella misma va sugiriendo. Borromini experimenta un sistema proyectual basado en la variación, buscando relaciones, un método topológico, es un organismo en proceso metamórfico. ${ }^{377}$ El primer croquis no es relevante en el proceso, supone únicamente una fase más del mismo, con el mismo nivel de importancia que cualquier otra; estamos tentados de decir que el resultado final tampoco es relevante, importa el proceso, que se vincula así con el carácter de la obra construida. El historiador y crítico de arte Julio Carlo Argán se refiere a (...) la frecuente imposibilidad de reconocer el tema inicial de una planta de Borromini. ${ }^{378}$

Se ha señalado el carácter genético de los organismos borrominianos. Parece ser Sedlmayer quien primero enuncia esta característica de nuestro autor. 379 Podemos rastrear los croquis de Borromini y encontrar la serie de las transformaciones operadas, pero esta metamorfosis no es lineal; no se trata de una forma lineal de evolución, más que una genética podríamos decir que se trata de una heterogénesis. Se trata de un movimiento que se desvía para incorporar algo nuevo; una especie de acontecimiento, que genera nuevas posibilidades, como puntos de inflexión que son puntos potenciales, puntos creativos, sobre los cuales la forma evoluciona. Todos estos puntos forman parte de esa heterogénesis. Se trata de un sistema variable y rizomático que es abierto y evoluciona creativamente sobre sí mismo.

El profesor Eusebio Alonso en su texto sobre Borromini, titula un capítulo topología versus tipología ${ }^{380}$, donde expone con claridad

377. El profesor Eusebio Alonso señala la condición de objeto metamórfico de la arquitectura de Borromini a través de su mecanismo proyectual. El carácter metamórfico, sugiere que su forma final podría admitir más variaciones; una arquitectura que da cuenta de una fuerza que impulsa la variación. ALONSO, La metamorfosis de San Carlino...

378. JULIO CARLO ARGÁN, Borromini, Xarait, Madrid 1987 (1951).

379. Así lo señala el propio Eusebio Alonso, op. cit., pág. 197.

380. EUSEBIO ALONSO, op. cit., pág. 227. 
como el método topológico de Borromini, lleva paralelamente implícito un rechazo a las tipologías convencionales.

El proyecto de San Carlino es abordado tridimensionalmente desde el origen actuando sobre el trazado de la pared y sobre las bóvedas de horno. Pero la envolvente de Sant'Ivo experimenta una progresiva y continua transformación que responde a un desarrollo topológico más marcado. San Carlino, al tratarse de una obra más temprana, se encuentra todavía articulada en sus tres estratos más tradicionales: la envoltura vertical muraria, la cúpula y las pechinas. Hay todavía ficciones entre la experimentación topológica del espacio y el residuo de una lógica formal que es aún heredera de soluciones tipológicas tradicionales. En las series de dibujos de la Albertina, se puede rastrear como la forma evoluciona fundiendo una tipología cruciforme en la solución final de continuidad muraria, vinculando el trazado de los ábsides al de la bóveda de la cúpula.

La continuidad espacial que Borromini parece perseguir se logra magistralmente en Sant'Ivo, donde el carácter unitario de la forma que envuelve el espacio se logra a través de relaciones geométricas y compositivas que relacionan la pared y la bóveda. El trazado murario surge de relaciones ajenas a las que la planta nos expresa, esta no registra los mecanismos compositivos, que son espaciales, re generan por relaciones tridimensionales. El ritmo rotatorio e intenso y la continuidad muraria total desde la planta al óculo central, se complementan con la red de relaciones cruzadas diagonales. Todo el conjunto relacional cubre y expresa el espacio entero de forma topológica.

La continuidad en el espacio es experimentada también, aunque de un modo diferente, en Santa María dei Sette Dolori, en la Capilla de los Reyes Magos y en la sala de Oratorio con recursos que consiguen la continuidad entra la pared y las bóvedas. Este tema ya viene anunciado en la Cripta de San Carlino.

La Capilla de los Reyes Magos o el Oratorio de los Filipenses gozan de un carácter diferente pues en ellos el plano superior se integra en el espacio de una manera más rotunda al tener una planta encima, al ser el espacio central del techo un espacio cubierto y carecer de posibilidad de aperturas en su cubrición. Se trata de espacios 

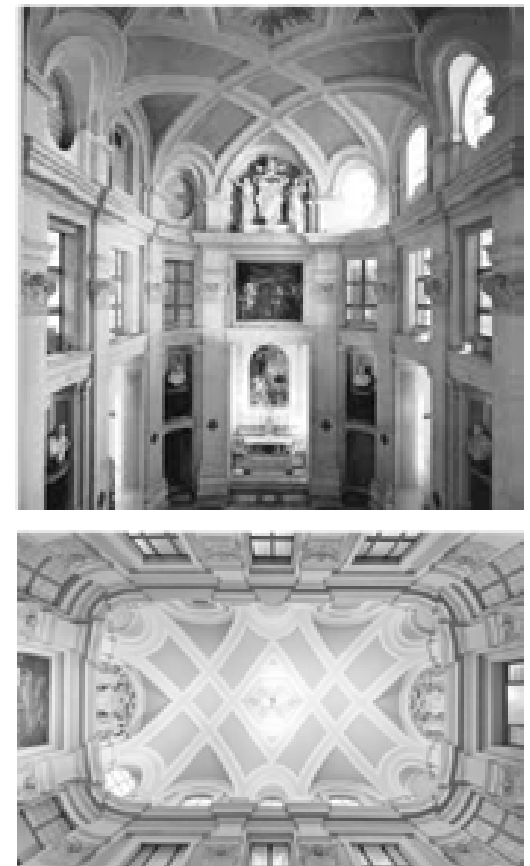

2.61. Interior de la capilla de los Reyes Magos. BORROMINI, 1662. abarcantes $^{38}$ ambos de una forma similar, aunque existen diferencias compositivas que generan ciertos matices.

El tema es un esqueleto estructural que vertebra las bóvedas y que nace de los planos de la envolvente muraria de las salas. El entrelazado de sus nervios-pilastras encierra el espacio en una continuidad envolvente, en una especie de inclusión explícita. El espacio parece que empuja y es retenido por los nervios que enlazan el interior en una unidad continua. Hay una idea de continuidad entre la pared y la bóveda, que también podemos ver en la cripta de la iglesia de San Carlino, con un tema parecido.

En el caso de la Capilla de los Reyes Magos, los nervios se entrecruzan en el techo, enlazando-envolviendo todo el espacio interior, resalta su interioridad abarcando el espacio en su cierre. Una interioridad cerrada, una inclusión, como una mónada, un cofre donde reposa el absoluto ${ }^{382}$.

Los interiores de estos dos proyectos se estructuran en el enlace, en la relación, creando unidades topológicas. Podríamos decir que forman unidades autorreferenciales, cerradas en sí mismas. Pero además podemos observar la falta de jerarquía en la composición. Esto hace que desaparezca todo principio, todo fin, se trata de un continuo, hay también en ello un carácter ambiguo, donde ni los encuentros entre planos (esquinas) se distinguen del resto de la envoltura muraria, elimina la esquina como cesura entre dos paramentos ortogonales; en la capilla de los Reyes Magos, coincide la esquina con un nicho, en el Oratorio con una pilastra simple. El efecto es aún mayor en el primer caso, pues completa en la bóveda las relaciones diagonales de los nervios que parten de los muros.

Además, la potencia de los nervios anula la condición tectónica de los lunetos, cuyas bóvedas recogen los empujes de la bóveda principal. Esta forma de enmascaramiento de lo tectónico a favor de la envolvente mural es una cualidad recurrente, como venimos observando, en la arquitectura de nuestro autor.

Este carácter de espacio homogéneo es debido a la relación topológica de la composición que otorga al conjunto una ausencia de jerarquía, y responde también a la relación preferente del espacio respecto a la forma.

381. EUSEBIO ALONSO, op cit., pág. 112.

382. JEAN ROUSSET La litteèrature de l'age baroque en France. Cita de Gilles Deleuze en El Pliegue... 


\subsubsection{Espacios de inclusión}

La obra de Borromini tematiza el espacio priorizándolo frente a la forma determinada, que se subordina perdiendo el lenguaje codificado de los órdenes para plegarse y convertirse en forma plástica. Pero estos espacios borrominianos son espacios inclusivos. Borromini utiliza de un modo muy especial la perspectiva, señalando así la experiencia del espacio, incidiendo en el estar dentro y lo que significa moverse en él. Se aleja así de la manera renacentista de concebir la perspectiva de una forma abstracta y exterior.

Se trata de un espacio contado a través de la experiencia del cuerpo, no se trata de algo externo, sino vivido, al modo como Merlau Ponty pudiera entenderlo:

(...) es un espacio contado a partir de mí como punto o grado cero de la espacialidad. No veo el espacio según su envoltura exterior, lo veo desde dentro, estoy englobado en él. ${ }^{383}$

La aparición de la perspectiva en la pintura renacentista se configura en torno a un objeto-imagen que presupone la existencia de un sujeto-artista. La imagen de la perspectiva establecerá una correspondencia entre el objeto y el ojo del sujeto siempre con la distancia necesaria de la abstracción ${ }^{384}$. Algo se ha interpuesto entre el artista y el objeto, entre la naturaleza y su imagen. El Renacimiento, al tomar la naturaleza como modelo, como objeto que se reproduce mediatizándola con la forma perspectiva, se crea una distancia, se abre un espacio vacío, que separa al sujeto de esta naturaleza objetivada. El mecanismo de la perspectiva como nueva técnica de representación gráfica tiene como consecuencia la aparición de esta distancia que se produce al procurar una representación objetiva de lo visible, en definitiva, una paralización-imagen de una naturaleza que, sin embargo, es cambiante y múltiple.

Las certezas del Renacimiento y su modo de concepción de la realidad, inventa para la arquitectura un sistema de valores que es a su vez un sistema del mundo; Alberti dio un paso fundamental haciendo que la analogía con el cuerpo humano resultara una referencia clave en la composición del edificio. Los numerosos cambios científicos del siglo XVII generan un abandono de la teoría tradicional del espacio. Así, la mirada hacia la naturaleza deriva en un estudio abierto a su mayor complejidad, y, en consecuencia, 
en su relación con la arquitectura, se introducen importantes matizaciones.

Borromini, en las trazas de sus proyectos ya no sigue pautas sencillas, ya no se apoya en una austera naturaleza que se mueve por principios de economía, ahora la naturaleza derrocha las formas que además no parecen concluirse en sí mismas, mostrando, más bien la potencia de formación. Se podría decir que la naturaleza de la que ahora se trata se acerca a este carácter que es propio de la naturaleza en el Barroco; una physis ${ }^{385}$ que se revela como reserva de potenciales, una naturaleza como materia en movimiento, siempre cambiante, como realidad inaprensible.

Se introduce entonces un dinamismo que va implícito en la forma, y que da cuenta de una naturaleza completamente diferente. Este carácter dinámico tiene como consecuencia lógica la definición formal de una envoltura que se nos presenta en permanente cambio y evolución. Este carácter se advierte en el proceso proyectual y se transmite a la obra construida, con un método que se basa en aproximaciones sucesivas; hay un margen para la aparición de singularidades que estimulan y orientan el desarrollo, una especie de autogénesis. ${ }^{386}$

Borromini, así, proyecta sus espacios inclusivos donde suprime esa distancia y utiliza la perspectiva de una forma completamente diferente. El punto de vista se ha instalado en el interior, la diferenciación entre objeto y sujeto se ha borrado, se han fundido en un mismo ámbito donde todo se da a la vez. Nuestro arquitecto ha introducido un dinamismo interno que genera una perspectiva de tipo secuencial, que introduce variaciones según el avance sobre el espacio; una especie de modificación dinámica del punto de vista que siempre es interior.

Esta condición dinámica de pertenencia al espacio, que revela una vinculación del cuerpo y un interior que proviene esencialmente de él, está ya señalada por la fenomenología:

\footnotetext{
385. Una Physis en el sentido griego original, que significa crecimiento, brotar, surgir. En la filosofía arcaica designaba el ser o la aletheia (verdad como desvelamiento), salir a la luz. Esta cuestión será abordada con más profundidad más adelante en este texto. Véase infra, págs. 379-384. 


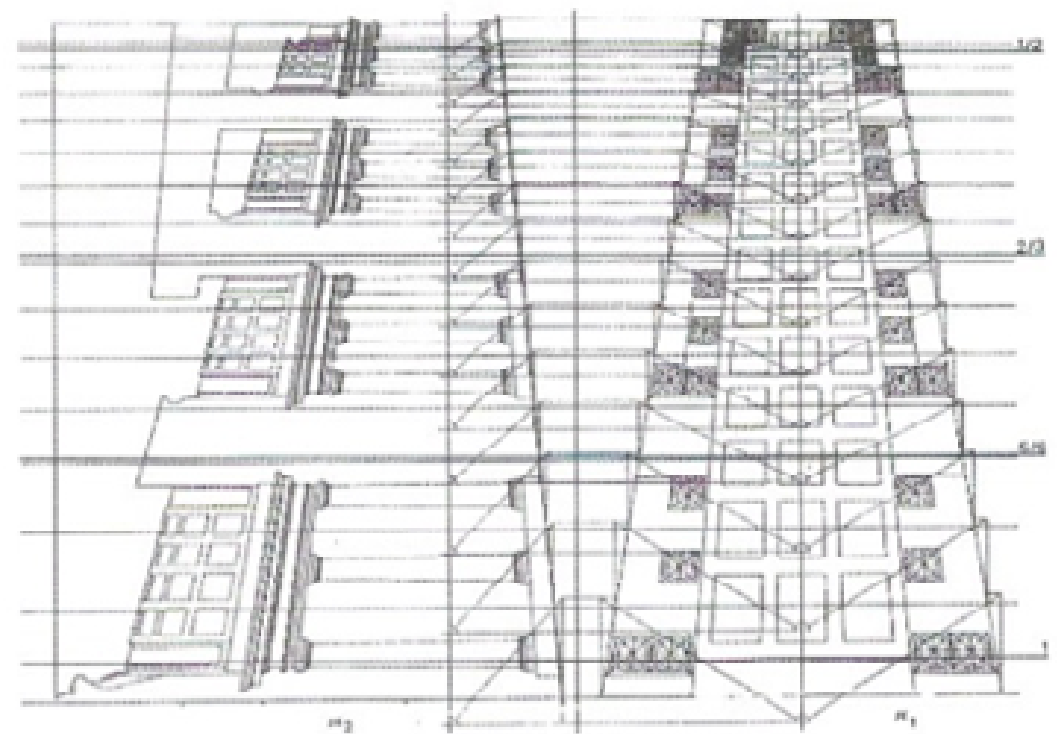

Todos mis desplazamientos figuran por principio en un rincón de mi paisaje y son trasladados al mapa de lo visible. ${ }^{387}$

Así, Borromini, en el proyecto de la galería Spada despliega su crítica sobre el mecanismo de la perspectiva renacentista, uno se los sistemas por excelencia de la cultura artística del Renacimiento. El profesor Alonso señala como en esta pequeña obra Borromini lleva a cabo una profunda reflexión sobre el espacio, considerando nuevas posibilidades alternativas a los mecanismos tradicionales.

La columnata no es solo una simple representación basada en el principio de disminución de las dimensiones para forzar la visión perspectiva. Se construye sobre quince puntos de vista distintos y alineados a lo largo del eje de simetría. Borromini decide construir un espacio en el cual la perspectiva no es solo utilizada para observar de una manera estática desde un punto de vista determinado, sino para una visión dinámica desde puntos de vista que van cambiando continuamente. Resuelve así el excesivo aplastamiento que hubieran sufrido las últimas columnas de haber aplicado de forma estática las reglas tradicionales de la perspectiva. Su perspectiva es axial, pero superpone imágenes análogas pero discontinuas produciendo un espacio sincopado ${ }^{388}$. Son quince puntos de vista, sucesivamente modificados a lo largo del recorrido.

El cambio operado es fundamental, pues introduce al observador en el espacio, fundiendo sujeto y objeto de tal manera que el $o b$ jeto se va modificando según el sujeto se mueve a través de él, se
2.62. Levantamiento y restitución geométrica de la galería Spada con los quince puntos de vista que regulan la deformación R Sinisgalli. BORROMINI. Roma, 1653 


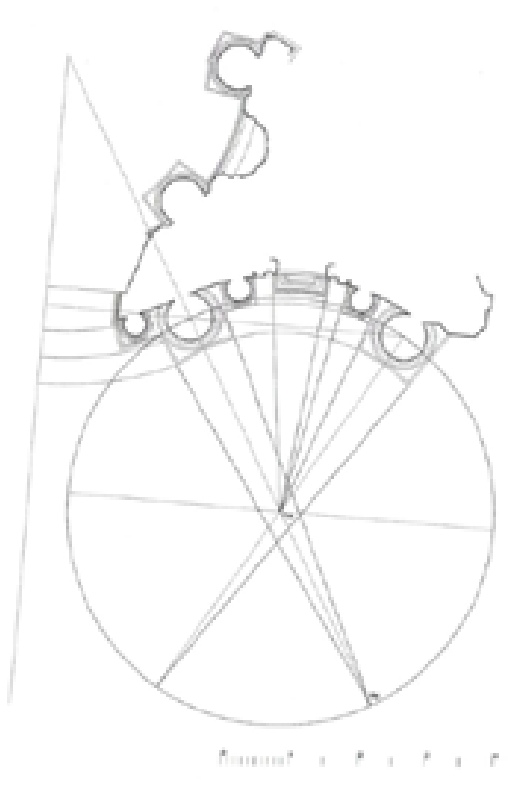

2.63. Fachada de San Carlino alle Quattro Fontane. BORROMINI. Geometría de las basas de la fachada. Diujo de Eusebio Alonso.

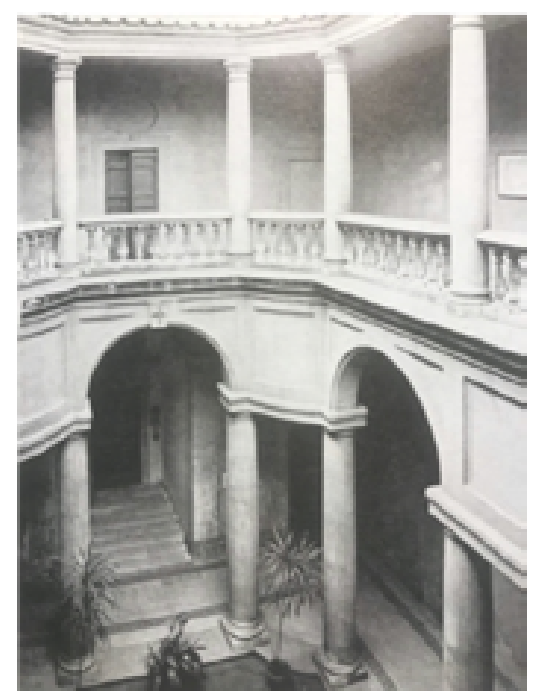

2.64. Vista del interior del patio del claustro de San Carlino alle Quattro Fontane. BORROMINI. mueve en su espacio, remarcando así que el espacio es el lugar de generación de la arquitectura. Podemos notar una utilización de la perspectiva como herramienta fenomenológica, que opera una modificación dinámica en ese plano-secuencia sincopado.

Merlau Ponty analiza esta condición de profundidad que, no es nada por sí misma, se limita a una participación en el espacio:

Lo que llamo profundidad no es nada, o es mi participación en un ser sin restricción, y en primer lugar, mi participación en el ser del espacio más allá de todo punto de vista. ${ }^{389}$

Una solución parecida utiliza Borromini para el dimensionamiento de las basas en la fachada de San Carlino. Los puntos de fuga de las caras laterales de las basas de las columnas mayores se encuentran más alejados del plano de fachada que las basas de las columnas menores. Borromini está teniendo en cuenta el avance hacia el plano de la fachada, reposicionando así el punto de fuga en relación al movimiento que se produce, reconfigurando la solución formal de una manera dinámica, en relación a la secuencia espacial.

La variación formal se opera desde el espacio y sus posibilidades, es el espacio el que afecta a la forma, y esta es producto de la variación generada por el movimiento en el espacio, es por ello siempreforma relativa. Esta manera de variación y proliferación de la forma hace de ella una especie de organismo vivo, en el que no hay jerarquía posible, pues no hay ley exterior de composición, se trata más bien de esa autogénesis ya nombrada. La geometría es herramienta que regula el crecimiento de este organismo y no es en absoluto ley de proporciones.

Otro ejemplo de espacio inclusivo es el claustro de San Carlino. Esta vez se trata de un espacio abierto, pero en el que igualmente ensalza al vacío espacial del patio ${ }^{390}$.

Borromini realiza tres operaciones que refuerzan esta idea de la negación de la lógica tradicional del espacio perspectivo como distancial, haciéndolo inclusivo. La primera es la disposición de

389. MERLAU PONTY, El ojo y el espíritu, op. cit., pág. 38, 39.

390. No se trata de un espacio entendido como vacío, ya hemos señalado el sentido de la cualidad productora del espacio. Se vacío únicamente como lugar abierto. 
los rincones biselados que ejercen una especie de contracción espacial negando la profundidad de la perspectiva. La segunda se produce con el rechazo de esta profundidad en el eje transversal al situar en los extremos la pareja de columnas que cierran la prolongación de la mirada; la mirada del espectador desde el patio es rechazada hacia el vacío del interior. La tercera es la presencia del pozo en el centro del patio, que actúa como objeto instalado en el espacio, objeto de percepción común, lugar común de la sensibilidad, configurando el carácter del patio como entidad espacial. La importancia del pozo puede probarse por la existencia de diferentes alternativas a la misma en los croquis de nuestro arquitecto. ${ }^{391}$

Borromini proyecta el espacio topológicamente, conformando el resultado formal a partir de relaciones espaciales complejas. Los espacios topológicos son complejos, pues no hay referencia a modelo ni forma idealizada, se generan por mecanismos internos y conexiones múltiples. Podríamos decir que responden a lo que Deleuze y Guattari han denominado, estructura rizoma, que no sigue una lógica de conexión jerárquica, sino que cada segmento es enlazable con otro segmento, donde hay una posibilidad de conexión múltiple de cada punto sin unidad generadora. Se trata de un modelo no causal, un modelo complejo, que, en este caso, se autogenera.

Omar Calabrese ha señalado el modelo rizomático como característico en su aproximación a su estética neobarroca. También señala como características las estructuras disipadoras, que surgen en la ciencia contemporánea, y que se oponen al proyecto de descripción de la naturaleza como consecuencia de comportamientos generados por un pequeño número de reglas repetidas que se había seguido tradicionalmente en la ciencia. Emerge, en cambio, la idea de un universo fragmentado, compuesta por comportamientos locales diversos ${ }^{392}$. Sería el modo de producción de forma que se ha observado en los espacios topológicos, no tipológicos de nuestro arquitecto.

Estas topologías espaciales, por tanto, carecen de jerarquía alguna, su modo de generación formal no lo permite, pues el modelo 
desaparece, en beneficio de una autogeneración interna más bien de forma relativa y rizomática,

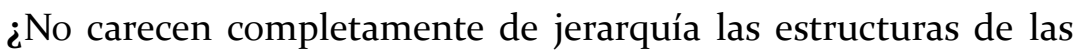
plantas de Borromini?. En la estructura de planta no se significa de ningún modo la posición del altar. En Sant'Ivo, la estructura del espacio fluye hacia lo alto por igual, es más, el vértice del triángulo del supuesto eje de la entrada, no tiene su vértice en el altar, niega cualquier disposición predominante, el vértice, situado en la entrada, despeja el espacio haciendo fluir la mirada al perímetro, que se eleva por igual en cualquiera de sus partes.

El método topológico arrastra consigo una ausencia de jerarquías, pues los elementos se enlazan por relaciones de respectividad. Podríamos decir que son los propios elementos mismos, a modo de nodos espaciales los que generan la composición de espacios, de forma que las partes, ya no son partes, sino mas bien puntos relacionales, motivos de la generación del conjunto.

\subsubsection{Topologías contemporáneas: espacios nómadas de la inflexión}

Aunque muchas veces la crítica ha reiterado en la arquitectura de SANAA su carácter de simplicidad y austeridad, que ha relacionado de una forma un tanto inmediata con la arquitectura moderna, defendemos que el carácter topológico de su arquitectura, así como la articulación de un espacio sin jerarquías, se enraíza en lo más esencial de lo que hemos podido ver en nuestra aproximación al Barroco a través de Borromini. Y encontramos un tratamiento del espacio, que, con lenguaje francamente alejado del lenguaje de la arquitectura barroca, se vincula a este modo de comprender la forma en arquitectura, que la debilita, la descarga como determinación cerrada, en beneficio del espacio que la con-figura, como lugar de posibilidad; un espacio sin jerarquías, articulado topológicamente.

SANAA se ocupa de crear espacios relacionales, donde los usos y las compartimentaciones se establecen siempre sin estructura jerárquica de ningún tipo.

Nosotros siempre tratamos de hacer una planta que no tenga una jerarquía- un comienzo y un final-. Nuestras plantas muestran 


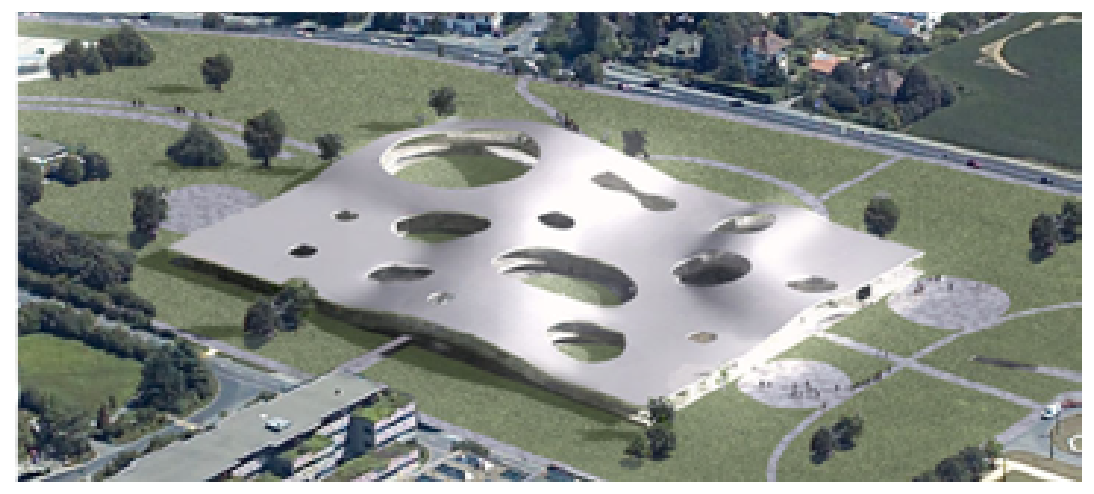

siempre un movimiento libre... la difusión de la luz a lo largo de la planta actúa también como una liberación de la jerarquía ${ }^{393}$.

En la mayoría de las obras de la arquitectura moderna, los elementos se integran en una composición que los determina por su tamaño y posición relativa; en las obras de SANAA, las organizaciones son casi aleatorias, con cierto grado de indeterminación y con un esquema que no responde a ningún principio jerárquico de composición, como centros, ejes, focos etc.

No hay ley de composición; la fluctuación de la norma sustituye a la permanencia de una ley ${ }^{394}$. El nuevo estatuto del objeto arquitectónico ya no se relaciona con ningún molde-modelo, con una relación convencional forma-materia, sino más bien por una modulación temporal ${ }^{395}$.

Hay una equivalencia entre los diferentes ámbitos que se estructuran ahora relacionalmente unos respecto a los otros, a través de bases esquemáticas de relaciones, una especie de diagramas, donde se producen agrupaciones, concentraciones o dispersiones, movimiento de los límites, continuidades o discontinuidades etc., respondiendo siempre a las relaciones entre los mismos, en vez de a un esquema geométrico o compositivo previo.

¿No encontramos en ello un paralelismo con la inflexión operada en el Barroco, cuando los espacios que hasta entonces se habían compuesto jerárquicamente, respondiendo a partes independientes con su valor en tamaño y posición relativa, se unifican en un escenario de continuidad a través de la integración de sus elementos en planos fluidos? ¿No es el mismo principio el

393. KAZUYO SEJIMA, Una conversación con Kazuyo Sejima y Ryue Nishizawa, Revista El Croquis dedicada a SANAA 2004-2008, Madrid 2008.

394. GILLES DELEUZE, El Pliegue..., Los pliegues del alma, op. cit., pág. 30.

395. Cifr. Ibid.
2.65. Vista aérea del Rolex Learning Center. Lousane. SANAA. Suíza, 2010. 
que opera en la planta de San Carlino y en su antecedente en la Capilla Sforza que hemos estudiado, aunque evidentemente con otro lenguaje y otros medios?

Aunque los lenguajes, materiales, construcción y técnica, están muy alejados, no lo están tanto los principios que rigen la organización del espacio, y ni siquiera el tipo de formalización que da lugar a ambos resultados, el tipo de mecanismos formales que operan en el conjunto, ambos basados en la inflexión, en una cierta flexibilidad formal que apunta a algo in-formado, a eso in-forme de lo que hemos ya hablado, al fondo potencial del espacio como lugar de posibilidad.

En el Rolex Learning Center dentro de la obra de SANAA, a la vez se observan aspectos relacionados con el uso de la inflexión, el tema del paisaje y sobre todo como ejemplo claro de espacio relacional y topológico. En cualquier caso, mucho de lo que se dice para el Rolex, es exportable para otras tantas obras de SANAA, de Kazuyo Sejima o de Ryue Nishizawa.

El espacio del Rolex tiene lugar entre dos losas de forjado que se ondulan formando colinas y valles. Todos los ámbitos están completamente abiertos y relacionados a través de este paisaje, distinguidos no por planos que las encierran sino por los horizontes que se van creando en esta topografía.

En el Rolex SANAA sigue el principio de considerar una equivalencia topológica entre formas que surgen de una de-formación de una forma originaria, algo parecido al objetil ${ }^{396}$ que señalaba Bernard Cache, pero también a ese procedimiento genético que el profesor Alonso había señalado respecto a la arquitectura de Borromini. En este edificio la deformación se hace en la sección, permaneciendo la planta constante: no afecta a su forma rectangular en planta, sino a la condición plana de la misma y del techo que lleva consigo. Se altera la horizontalidad del suelo que tradicionalmente había sido una referencia esencial en la arquitectura, afectando así a la propia naturaleza del espacio arquitectónico, a la vinculación de la arquitectura con la superficie horizontal de la tierra y a la inevitable existencia de la gravedad.

396. El objetil responde a la concepción de objeto tecnológico de Bernard Cache, en la que el objeto se sitúa en un continuo por variación; un objeto que prospera según la fuerza de la curvatura, podría decirse que no hay una relación estable de forma-materia, sino una modulación temporal que muestra variación y desarrollo continuo. BERNARD CACHE, op. cit. 


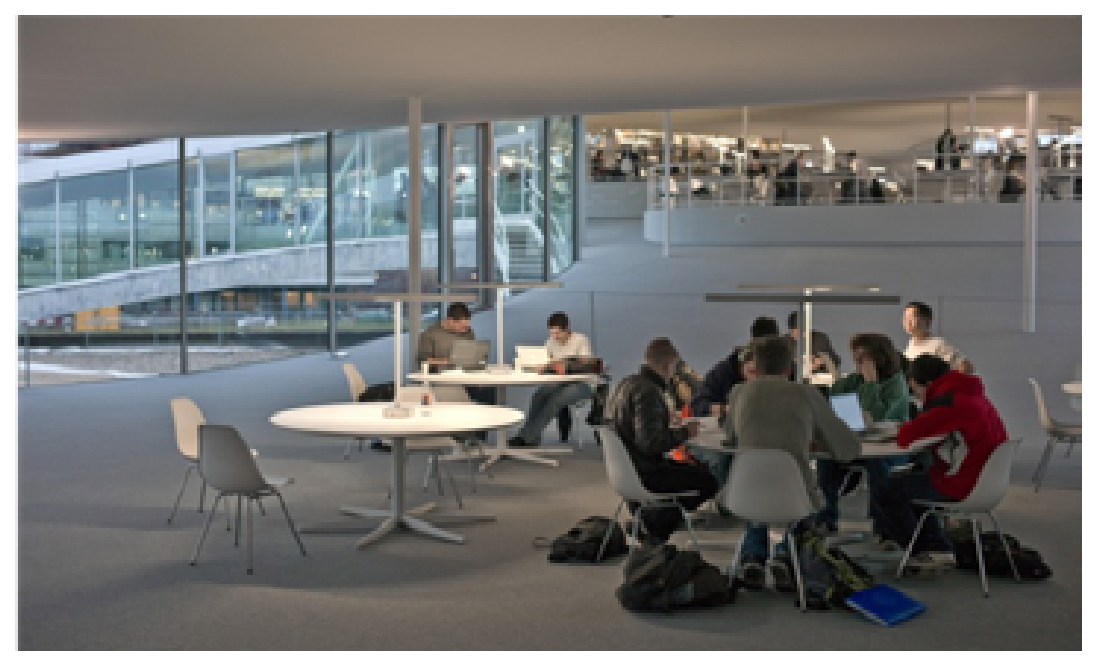

Esta cuestión se relaciona también con un carácter no-tectónico, que parece evidenciarse en nuestras arquitecturas en general. Hay una ingravidez que enmascara la estructura portante, que ya hemos notado en casos anteriores. Se pone en cuestión la componente tectónica de la arquitectura, camuflándola entre esos dos planos ingrávidos. Esta característica, está directamente relacionada con el estatuto que tendrá la forma, y por extensión con su materialidad, pues la materia, en arquitectura, está sujeta a la gravedad, a su tectonicidad, por lo que lo a-tectónico estará remitiendo todo el tiempo a una cierta inmaterialidad de la arquitectura ${ }^{397}$.

Así, el principio topológico pretende, dentro de los límites posibles, ser total en el espacio, en sus tres dimensiones, pero a través del tiempo-trayecto, también del tiempo, como cuarta dimensión del espacio, haciendo así que el espacio sea ese fondo neutro potencial del que surge la posibilidad.

El Rolex se proyecta considerando cuestiones siempre pre-geométricas, al modo del diagrama foucaultiano. Los espacios se definen por las relaciones que se crean y no responden a la figura geométrica que adoptan sus formas.

Ya no se trata de distribuir los usos en un espacio sedentario y configurado estáticamente para ellos, más bien se trata de repartirse en el espacio. Deleuze ha observado, en este sentido, que llenar un espacio repartirse en él, no es lo mismo que distribuir el espacio. ${ }^{398}$

397. Se viene señalado reiteradamente esta característica que se repite en las dos temporalidades, pero, más adelante, este texto dedica un apartado a analizarlo específicamente. Véase supra, págs. 333-340, y capítulo 5, parte II en general.
2.66. Interior del Rolex Learning Center. Lousane. SANAA. Suíza, 2010. 
2.67. Interior del Rolex Learning Center. Lousane. SANAA.

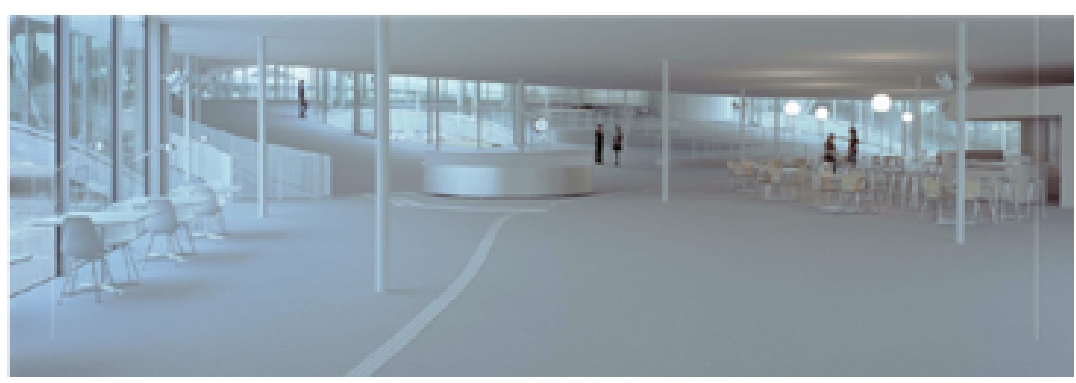

Se trata así de una distribución nómada, sobre un fondo, que genera una especie de anarquía sin jerarquía posible.

Son los propios horizontes topográficos los que ponen límites cambiantes y relativos, ya que dependen de la posición del observador en el espacio, estableciéndose una nueva relación entre el espacio y el ser humano que lo ocupa y recorre y que pasa a tener una participación activa en el mismo ${ }^{399}$.

Las estructuras nómadas dan lugar a locas reparticiones (...), loca distribución, distribución nómada, instantánea, la anarquía coronada, la diferencia. ${ }^{400}$

Tal como ocurría en la arquitectura barroca, hay en su configuración una curvatura variable que ha perdido todo centro, sustituyendo el centro por el punto de vista ${ }^{401}$.

La continuidad que genera acontecimientos es el sentido de la estructura espacial del Rolex. El edificio se eleva del terreno deformándose en altura, creando con su propia presencia un acontecimiento singular en él mismo, como pretendiendo reproducir un paisaje, una topografía de un terreno natural. En su modo de inflexión activa, no se presupone un origen fragmentario, sino que la propia línea o el plano genera la forma o lo-informe, lo que todavía no está informado o configurado. La masa entera del edificio aparece unida, no se articula, generando también un interior fluido.

El Rolex se estructura con secuencias espaciales. El edificio tiene un programa múltiple que se desarrolla en una única planta deformada. Se albergan todos los programas en un espacio úni-

399. JUAN ANTONIO CORTÉS, Topología arquitectónica. Una indagación sobre la naturaleza del espacio contemporáneo. Revista El Croquis dedicada a SANAA 20042008, Madrid 2008.

400. GILLES DELEUZE, Diferencia y repetición, op. cit.

401. Cifr. GILLES DELEUZE, El Pliegue..., Los pliegues del alma, op. cit., pág 33. 
co, pero con la continuidad interrumpida por patios de diferentes tamaños. Las diferentes deformaciones del plano crean distintos niveles para los ocupantes del edificio; el movimiento dentro del espacio es a través de trayectorias continuas, uno puede situarse en un nivel elevado sin perder la referencia del suelo. La distorsión de niveles sobre el plano es la que da lugar a la distancia necesaria entre los programas, a su topología de respectividades; una separación que sin embargo mantiene las relaciones y la continuidad. Los diferentes espacios se articulan en la planta unos respecto a otros por su posición en el paisaje interior; es como un plano inflexionado provisto de acontecimientos. Los usos funcionan como islas, relacionadas por un continuo que hace las veces de fondo fluido, acercándose así a las imágenes-flujo de las que habla Buci-Glucksmann, que se tematizan en las cartografías y en el protagonismo del paisaje en el arte contemporáneo en general. Un paisaje que se presenta como alternativa al modelo Albertino de ventana sobre el mundo, a modo de mapa o cartografía. El mapa como espacio abierto con varias entradas, donde la mirada se hace nómada, creando nuevas visibilidades. Glucksmann habla de un modelo basado en el mito icariano ${ }^{402}$.

Sin embargo, el espacio del Rolex no produce esa mirada icariana sobre el paisaje, no estamos delante ni arriba, sino dentro, como inmersos en un bloque de sensaciones. Así, nos dice Kazuyo Sejima:

Y lo más interesante es que no se puede ver de una sola vez todo el espacio interior. Puedes sentir la amplitud del gran espacio, puedes sentir la continuidad, pero no puedes ver el extremo del edificio. Lo que uno ve a su alrededor depende de la posición que tenga en ese momento. ${ }^{403}$

Se aproxima, más bien, a lo que Calabrese ha señalado como la mirada miope del laberinto, una inmediatez en la orientación típica del espacio laberíntico, que él utiliza también para caracterizar su estética neobarroca.

No podemos dejar de recordar aquí como la galería del palacio Spada que proyecta Borromini, se construye sobre quince puntos 
de vista que van cambiando continuamente, ese plano-secuencia sincopado ${ }^{404}$. Así introduce al observador en el espacio, y este es generado precisamente por el movimiento de aquel. Es un mecanismo de proyecto que introduce la participación en el espacio.

El Rolex es como una fracción de un plano en relieve, como un paisaje constreñido, donde la huella del hombre aparece introducida, donde la percepción se aleja completamente de esa ventana sobre el mundo, tomando en cambio conciencia de ese formar parte del paisaje-mundo: se trata de un paisaje-ficción, una escenificación, un teatro-paisaje.

El edificio así, en su estructura interior es mutante, se percibe siempre diferente, lo que uno ve alrededor depende siempre de su posición variable. El espacio es portador de sensaciones, el mundo cambia como en un paisaje, donde la ocupación del espacio es lo que se modifica, lo que traza trayectorias y respectividades, casi como en un paisaje de acontecimientos.

(...) uno de nuestros intereses es cómo podemos crear un paisaje para la gente. ${ }^{405}$

$\mathrm{Al}$ ser un paisaje mutante, se configura según las posiciones, las ocupaciones y hay entonces una suerte de perspectivismo; las personas solo captan una parte del paisaje completo del edificio, su parte clara, como siguiendo el concepto de composibilidad de Leibniz. El resto del edificio-mundo aparece formado por las diferentes partes claras de las distintas personas que se mueven o lo ocupan. No hay un solo punto de vista, el espacio solo puede ser captado por partes.

Las series convergentes me prolongan o continúan las unas en las otras a fin de reconstruir cada vez una sola y misma serie, el Mundo, compuesto de todas las series, la curva de variable única. ${ }^{406}$

El motivo del Rolex Center es su propia inflexión intrínseca; así, los usos y sus ámbitos se generarán por causa de la inflexión. Bernard Cache vio en uno de los cinco principios del Movimiento Moderno un modo de la inflexión. Consideró que el principio de la planta 
libre dejaba desplegar las inflexiones. Sin embargo, la continuidad de la planta libre, solo libera el espacio de compartimentaciones condicionadas por una piel o una estructura, articulando los usos con un sistema de continuidades, evitando así que la estructura condicione el uso del espacio. Este concepto responde más bien a un funcionalismo espacial que se genera por una articulación de tipo mecánico o maquínico, basado en principios de funcionalidad.

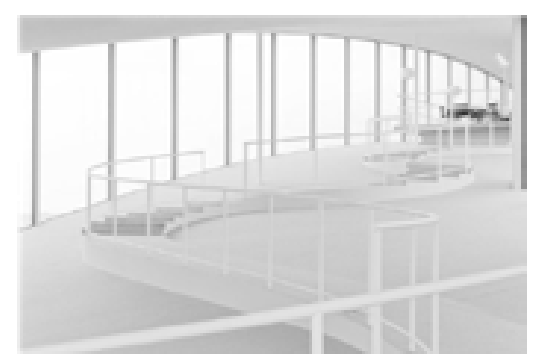

2.68. Rampa accesible. Interior del Rolex Learning Center SANAA. Suíza, 2010.

El espacio del Rolex, no responde a funcionalidades, es una topología no jerárquica, no condicionada, donde los espacios suceden según la propia estructura del plano, sus pliegues e inflexiones, sin sentido, dirección, ni orden aparente; espacios de respectividades donde la única estructura se encuentra en el intervalo entre ellos, en ese espacio-fondo. Gluksman dirá que la búsqueda del intervalo es propia de la cultura japonesa del Ma (espaciamiento, intervalo, vacío).

La continuidad fluida del Rolex Center, anuncia una potencialidad espacial siguiendo coherentemente esta estética de la inflexión, tematizando el contenido en su morfología concreta, apuntando a lo fluido y emulando la fluidez de un paisaje configurado por sus habitantes. El espacio de los flujos funciona como una cartografía, que se crea a partir de trayectorias efímeras, como forma-trayecto o formas-estancia. Así, el paisaje es testigo del tiempo. Tanto de sus estratos y movimientos forzados como de sus tránsitos y movimientos leves.

Podemos constatar que la vinculación del Rolex con el Barroco es de tipo morfogenético en cuanto al uso de la inflexión como modo de lo potencial, donde el empleo de la herramienta digital favorece su resultado formal llevando al máximo la expresión barroca. La forma in-formada del Rolex, no configurada, es análoga a la expresión barroca, que apunta al movimiento, pero ahora a un movimiento aleatorio, entrópico. 


\subsection{LOS CLAROSCUROS}

(...) la crueldad es solo LA determinación, el punto preciso en que lo determinado mantiene su relación esencial con lo indeterminado, esa línea rigurosa abstracta que se alimenta del claroscuro. ${ }^{407}$

Deleuze ha observado, a través de los textos de Wölfflin, como este autor considera que, en la pintura, el pasaje del siglo XVI al siglo XVII es fundamentalmente el pasaje de un espacio táctil-óptico a un espacio óptico puro. ${ }^{408}$ La diferencia es que en el primero los planos están bien distinguidos, y en el segundo todo viene del fondo; la forma surge del fondo y desde entonces se desdibuja el contorno, ya no sabemos dónde comienza ni dónde termina la forma. La forma está como impulsada por el fondo; el primer plano está en la sombra y la luz viene del fondo y es la forma la que depende de la luz. La luz, el fondo como medio, es primero.

La pintura barroca se concibe con claroscuros, que iluminan solo una parte según una legibilidad restringida. Las figuras emergen de un fondo opaco y sombrío. El Barroco mantiene una fascinación en orden a la ilusión entremezclada con opacidad. El claroscuro es un tema del Barroco. Así, los espejos de Velázquez en Las Meninas son muy opacos, y sus figuras, en la cercanía desdibujan su contorno; si nos acercamos, la pintura se desintegra, como lo hacían los límites en los croquis de Borromini. Los contornos de la pintura barroca ya no son curvas, ni siquiera curvas complejas, son una sucesión fina de trazos planos; se trata de un ámbito, un límite-ámbito que se modula por los valores de la luz, por los grados, por los claroscuros. La forma ya no puede definirse más que relativamente a su fondo, es un espacio de valores, donde la luz ha dejado de depender de la forma, la luz deviene independiente.

El claroscuro es el método de aparición de la forma barroca. Se trata de hacer subir el fondo y disolver la forma. La forma ya no está delimitada, su determinación se expresa ahora a partir del fondo,

407. GILLES DELEUZE, Diferencia y Repetición, op. cit., pág.62.

408. GILLES DELEUZE, Pintura, el concepto de diagrama, op. cit., pág.231. Deleuze cita, para referirse a ello, el texto de HENRICH WÖLFFLIN, Principios fundamentales de la historia del arte, op. cit. 
sin línea-contorno que la moldee, solo emerge por modulación de la luz. El fondo-espacio, es en arquitectura, constituyente.

El tema del claroscuro está íntimamente ligado a la forma de comprensión de la diferencia, pues, como en el caso del relámpago ya citado, la forma debe arrastrar su fondo para distinguirse: el fondo sube a la superficie sin dejar de ser fondo ${ }^{409}$.

El límite se diluye constituyendo una especie de zona. No es posible lo claro sin lo oscuro, ni un color sin otro diferente, las cosas emergen de los contrastes, de la diferencia y no de su delimitación como figuras.

Toda la problemática de la individuación formal en pintura a través de los contrastes, de los claroscuros, de las formas, la encontramos relacionada con el concepto de composibilidad que Leibniz define en sus textos. Él habla del mundo como una serie convergente, única, infinitamente infinita, que cada mónada expresa en su totalidad, aunque solo expresará claramente una porción de la serie. Pero la porción clara de una mónada se prolonga en la porción clara de otra, la porción clara se prolonga definitivamente en las zonas oscuras, puesto que cada mónada expresa el mundo entero ${ }^{40}$.

Las series que convergen se prolongan las unas en las otras, componiendo lo posible, reconstruyendo una sola y misma serie convergente que es el mundo. Podemos ver entonces que los límites entre series no son límites claros. Habría así una especie de des-limitación y ya no podríamos decir con precisión donde acaba una forma y comienza otra. No hay, por tanto, una sola región clara, hay una cierta imprecisión en la comprensión-percepción del mundo que se acaba en la porción de cada uno, sin límites precisos.

La expresión de la pintura barroca parece estar queriendo representar esta cuestión de la compatibilidad de las percepciones. El ejemplo vuelve a ser la pintura de Caravaggio.

Caravaggio trata el claroscuro en toda su pintura, es el tema de su pintura; solo hay una zona clara, la porción de la serie que se expresa claramente, el resto es el fondo oscuro, impreciso, donde se prolonga la serie. Lo claro es el modo o la manera de expresión del mundo, surge del fondo, como iluminando una parte de este. Las 


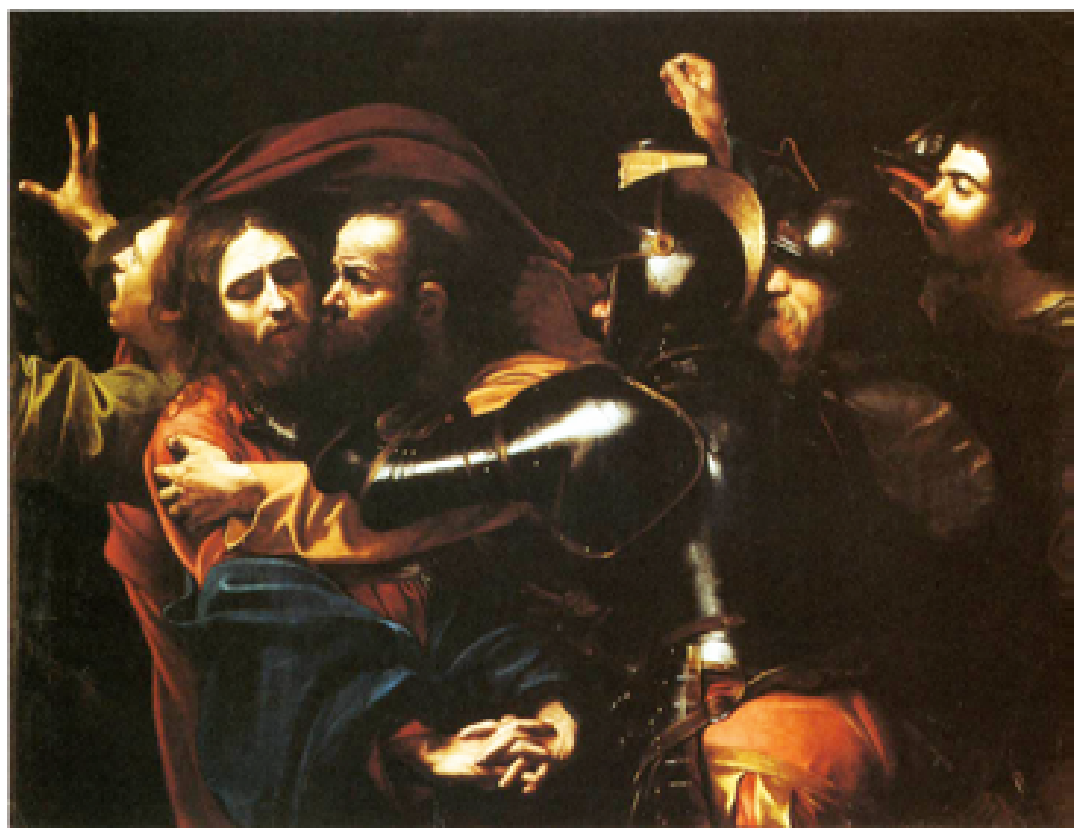

2.69. El beso de Cristo. CARAVAGGIO. 1602. figuras se definen por su recubrimiento más que por su contorno. Hay una inseparabilidad de lo claro y de lo oscuro.

La pareja fondo-maneras destrona a la forma o la esencia. ${ }^{41}$

En arquitectura, lo que importará en el Barroco, son las cosas con magnitudes intensivas, como la luz, el color, la fuerza, la potencia. Todas ellas manifiestan una espacialidad dónde los contrastes son los valores, las intensidades; una especie de intensidad luminosa de diferentes grados. Se crea así un espacio del valor, un espacio del claroscuro, donde la luz se considera por sí misma a partir del medio-espacio, poniéndolo en valor.

La estética del claroscuro tiene una íntima vinculación con el medio diáfano de Glucksmann. Hay una estética del claroscuro, que establece los niveles de luz, los valores. La limitación se realiza por contrastes; en arquitectura también la luz se manifiesta para dar el carácter a la forma, para establecer el contraste.

Borromini también produce claroscuros. Aunque este es un tema común con otros arquitectos barrocos, en él se hace más patente a través del uso especifico que hace se sus recursos formales. Hay claroscuros marcados sobre una piel profunda y plegada de San Carlino, contrastes de luz y sombra sobre las densa envolventes perforadas y horadadas en la fachada del Colegio Propaganda 
Fide. Sus pieles, al plegarse producen sus sombras, sombras contrastadas en relación a la profundidad de sus pliegues.

También hay claroscuros que enfatizan elementos en el espacio. El recurso del claroscuro va ligado al de la repetición. Volvemos a la intervención que Borromini hace en San Juan de Letrán. Ya hemos observado, como se ve condicionado, en las naves laterales, por el ritmo de tramos mayores y menores ya existentes y que impone la nave central. Lo que hace es subrayar la desigualdad de estos tramos dejando en oscuridad los pequeños e iluminando los mayores, lo que contribuye a pronunciar el ritmo y el movimiento al avanzar longitudinalmente. El régimen de variación en este caso es la luz. Borromini no puede imponer otra forma con las condiciones existentes en la basílica; es el ritmo en variación reforzado por la luz, lo que marca el carácter del plano: claroscuros que se suceden.

En las cúpulas, las linternas barrocas absorben la luz, que contrasta con un interior oscuro, he incide en la oscuridad del interior, resbalando por las texturas porosas que producen sus propios claroscuros en la profundidad de su piel. Así lo vemos en la cúpula de San Carlino donde la iluminada cúpula contrasta con la penumbra de la parte inferior, y donde la luz de la linterna se prolonga en rayos luminosos que inciden produciendo contrastes sobre los paramentos, aumentando el efecto de sus pliegues y texturas.

El claroscuro es la invención del Barroco y genera el valor de lo curvo y lo oblicuo. Los claroscuros apuntan a una tensión, y la tensión es una concentración temporal, que se aleja siempre de una estabilidad, introduciendo a cambio una vitalidad, buscando también en este artificio la resonancia de la vida.

Lo oscuro es lo infinito en el acto de la percepción; el espíritu está en la sombra, es sombrío, inmerso en lo indeterminado, pero el espíritu exige un cuerpo, y esta es su claridad ${ }^{412}$. Hay así una diferenciación a partir del fondo y lo claro nace de lo oscuro en el interior Barroco, no puede dejar de estar inmerso en él.

La forma perece que debe surgir de la luz y de la sombre, de la modulación de la luz, depende de la repartición de luces y sombras, pierde el contorno y se determina por contrastes.

412. Cifr. GILLES DELEUZE. El pliegue... op. cit.

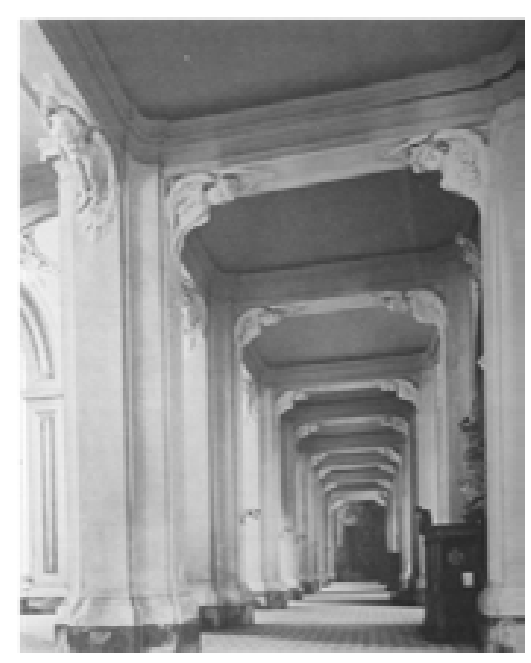

2.70. Naves laterales de San Giovanni Laterano. BORROMINI.
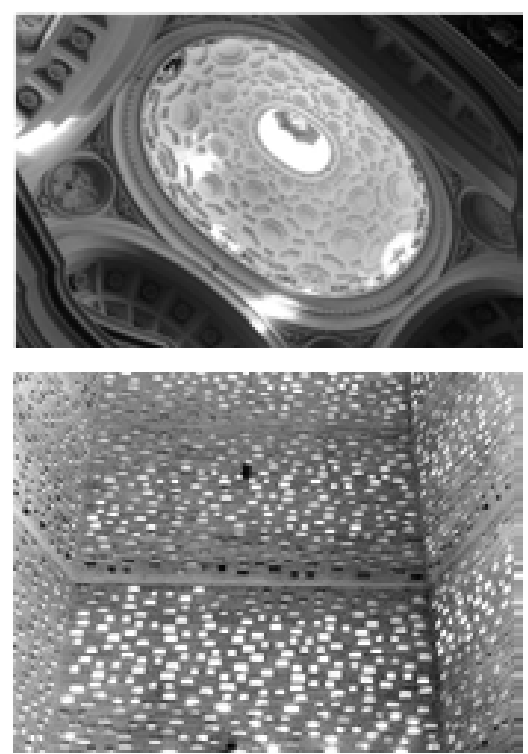

2.71. Cúpula de San Carlino alle Quattro Fontane. BORROMINI.

2.72. Museo Kolumba. PETER ZUM-

THOR. Colonia, Alemania, 2007. 
El ornamento de la cúpula de San Carlino produce sus claroscuros, la luz-espacio se cuela e incide en los poros que desintegran la materia. La luz de la linterna atraviesa el espacio en haces. Los interiores barrocos son siempre de contrastes y es un tema común con otros arquitectos romanos.

¿Pero no son también los poros contemporáneos mecanismos similares de claroscuro que diluyen el contorno más que nunca haciendo presente un fondo-luz que interviene el espacio?

En el Museo Columba, Peter Zumthor, se cierra con una piel porosa, donde la disposición de pequeños ladrillos dibuja unas aperturas por donde la luz se cuela produciendo fuertes contrastes en el interior, que inmaterializan o diluyen el cerramiento; es como si el espacio exterior se colara en el interior, desintegrando la piel, o haciendo confuso el límite.

\subsubsection{Dramatismo de las sombras: claroscuro y repetición}

El equilibrio entre la luz y la sombra cambia constantemente. Las bodegas se experimentan como un campo de espacios y líneas en vibración ${ }^{413}$.

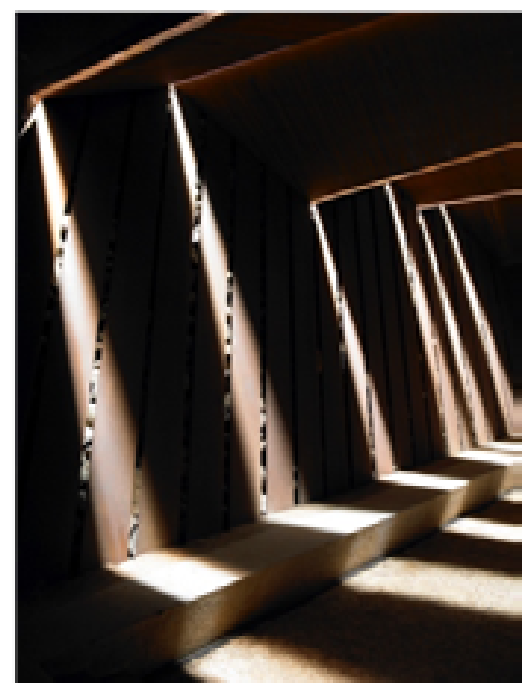

RCR construye en Palamós unas bodegas enterradas que se introducen en el terreno como invocando a la tierra, donde la vid se alimenta para llegar a ser vino, como indagando sobre el proceso del vino desde su producción.

En las Bodegas Bell-Lloc de RCR, donde ya habíamos localizado el tema de la repetición, encontramos, que, unida a ella, tal como sucede en las naves de San Juan de Letrán, aparecen marcados claroscuros intensificando su efecto y generando movimiento. Sobre la oscuridad del espacio se filtra la luz y así emerge la forma por contraste, sin contorno; una diferencia positiva y constitutiva; diferencia y repetición como tema. Se señala el intervalo, como captando el tiempo, expresando una continuidad cambiante, lo efímero como lo que cambia o se metarfosea, no dura como representación.

413. WILIAM J.R. CURTIS, The structure of shadows, traducción al castellano Jorge Sainz e Inés Fernández Arias, La Estructura de las sombras. Introducción a la publicación sobre las bodegas Bell Lloc, Imprenta Aubert, Sant Joan Les Fonts, 2009. Fundació Bunka.

2.73. Interior de bodegas Bell-Lloc. RCR. Palamós, 2007. 
Lo efímero no es el tiempo, sino su vibración vuelta sensible ${ }^{414}$.

La vibración que la sucesión de claroscuros provoca en el interior de las bodegas, se transforma en movimiento, una coexistencia de momentos que deforman la representación y no dejan congregar las sensaciones en una forma estable. El conjunto es escenográfico y teatral una representación hecha de metamorfosis y permutaciones. Más bien se abandona el campo de la representación que se convierte en experiencia.

Hay un dramatismo en los claroscuros contemporáneos que subrayan el contraste; lo importante parece estar en la línea común entre lo claro y lo oscuro, la que se remarca, se dramatiza, se intensifica. Ahí, en esa línea, reside lo que hace posible la determinación. No es una línea sin ser, sino, que, por el contrario, en ella habita la posibilidad.

Hemos visto cómo el Barroco producía claroscuros en sus espacios y en su pintura, cómo el contorno y la forma pasan a un segundo plano, y es del fondo y del espacio de donde emerge todo, con una forma desdibujada, que ya no percibimos en su integridad. ¿De dónde sale la figura cuando el fondo deviene determinante?, perece que debe surgir de la luz y de la sombra, de un cierto contraste, de la modulación de la luz en un espacio-luz, es decir, la forma ahora depende de la repartición de luces y sombras, es también forma relativa.

Los claroscuros son dramáticos, este espacio hecho de luz tiene un carácter alucinatorio; todo surge del fondo que contiene, tanto la blancura de la luz brillante como la oscuridad de los negros. Lo oscuro es la posibilidad de lo claro. El contorno no es ya una línea, será ámbito contrastado que dará lugar a la forma; una línea abstracta, que no es línea, sino el punto de relación de lo determinado con lo indeterminado; la forma no se determina por contorno, sino por contraste con el fondo.

La luz ya no procede de una forma esencial, no es luz ontológica de la verdad o la belleza, deviene expresión del espacio, evitando así lo luminoso como único paradigma del arte y dejando aparecer el sentido, la razón de lo claro en lo oscuro. Todo sucede como en esa imagen-flujo de nuestra era que Glucksmann ya 
2.74. Sección longitudinal de las bodegas Bell-Lloc. RCR. Palamós, 2007.

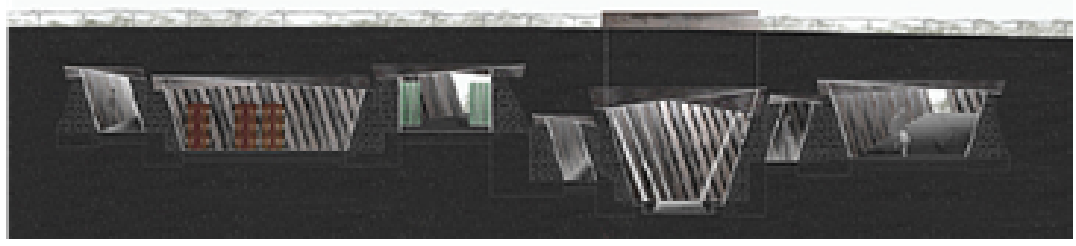

ha descrito, una imagen dinámica que metamosfosea la visión en todo momento.

La imagen-flujo, propia de la globalización de las culturas implica volver a pensar una nueva dialéctica de lo diáfano y lo adiáfano, que evita la epifanía de lo luminoso como único paradigma artístico ${ }^{415}$.

$\mathrm{Al}$ recorrido por el interior, lleno de acontecimientos, le acompaña un cerramiento de muros de acero cortén disgregado en franjas verticales; forma descompuesta con entredoses que permiten el paso canalizado de la luz provocando una vibración de claroscuros, en algunos casos, de rendijas finas, en otros o de oscuridad iluminada artificialmente.

La composición se estructura en masas de claroscuro, que prefieren una composición rítmica, más que uniforme, y más aún el agrupamiento accidental. Su tendencia es a destruir toda forma plástica.

Wölfflin también señalaba como característica esencial de la arquitectura barroca, su carácter pintoresco. Esto pintoresco estaba en su texto caracterizado entre otras cosas por la impresión de movimiento y el juego de luz y sombra ${ }^{416}$. El carácter escenográfico, también lo señala Wölfflin: la arquitectura no actúa por lo que es sino por lo que parece, por la impresión de movimiento. El Barroco, no menciona la plenitud del ser, sino el pasar a ser, el acontecimiento, no la satisfacción sino la insatisfacción y la inestabilidad $^{417}$.

Volvemos al concepto de parecer, tratando de volver visible lo irrepresentable. El espacio de las bodegas está inmerso en la teatralidad, en esa locura de ver, nada es lo que parece. Al respecto Jean

\footnotetext{
415. C. BUCI-GLUCKSMANN, La estética de lo efímero, ¿Un arte del tiempo globalizado?, op, cit, pág. 53 .

416. Cifr. HEINRICH WÖLFFLIN, Renacimiento y Barroco, op. cit.

417. Ibid. pág. 39, 40
} 
Baudrillar va a decir que no se trata de confundirse con lo real, sino de producir un simulacro con plena consciencia del juego y del artificiouri

Las bodegas generan rendijas accidentales, cuyo sugerir movimiento acompaña en el recorrido. Las piezas de acero son su límite disgregado, que expresa el contorno fugazmente, transformando la pesantez del acero cortén en material ingrávido, que se mueve inquietando la estabilidad de lo tectónico. También el Barroco alteraba la estabilidad de la concinnitas disolviéndola en juegos gravitatorios.

Las piezas de acero se presentan fragmentadas y, como en la alegoría barroca de Benjamin, el fragmento es una singularidad que sitúa el sentido en lo que no es visible, en la fuerza. A la vez deviene un límite difuso, un límite abstracto, que se aleja de la línea de contorno.

También lucernarios abiertos en lo alto generan focos de luz que atraviesan el espacio teatralmente; el medio diáfano puesto en escena. Algunas de las salas están iluminadas por pequeñas aperturas en la cubierta de donde provine una luz focalizada que otorga al espacio un carácter escenográfico propio de un Barroco casi dramático, donde la luz atraviesa el medio, evidenciándolo, como en una inmanencia aérea. Wölffling señala que el Barroco no piensa más que en masas: sombras y luz son sus elementos ${ }^{419}$; estos son los componentes de las Bodegas.

Se representa lo que no se deja estabilizar, lo que escapa a la determinación. Los espacios de las bodegas son como pequeños teatros de apariencia engañosa; en sus espacios se produce la teatralización de los espacios barrocos, la ilusión de la materia, los juegos de claroscuro. La arquitectura, esencialmente visual, remite al espectáculo de su formación y su transformación.

El acceso y la aproximación a las bodegas es fluida, así como todo el recorrido. Si nos adentramos por la rampa que se abre en el paisaje, siguiendo la línea de un sendero ya existente, descendemos por una rampa, que, con una cierta ceremonia, pues sus límites de
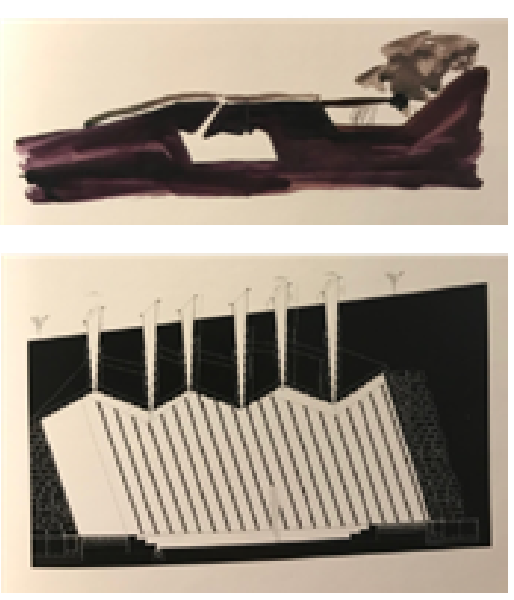

2.75. Esquema inical de las bodegas $\mathrm{Be}$ ll-Lloc. RCR

2.76. Lucernarios en la cubierta en la sala de catas, Bodegas Bell-Lloc. RCR 
2.77. Acceso a las bodegas Bell-Lloc. RCR. Palamós, 2007.

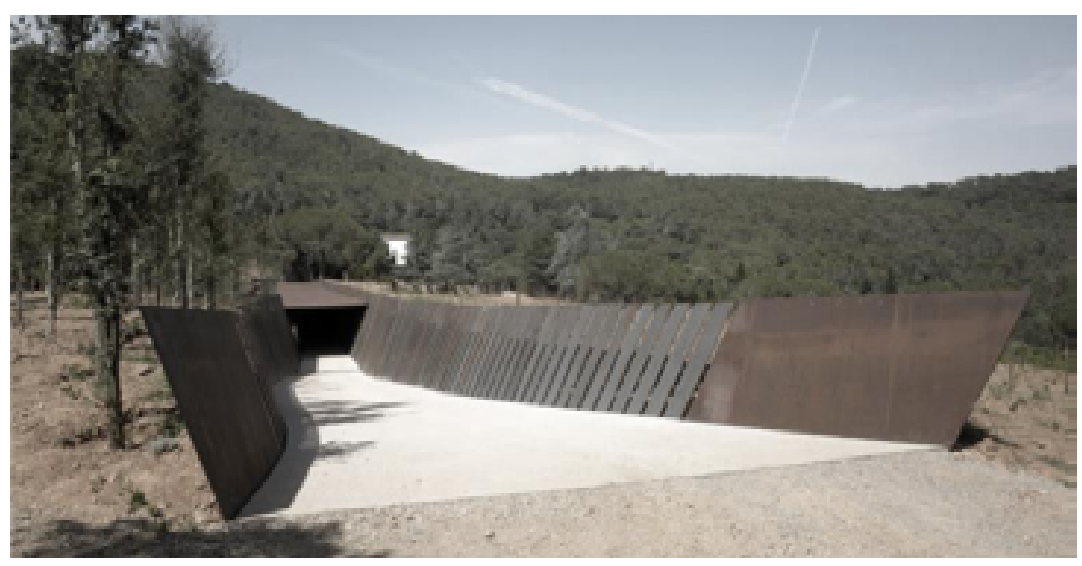

acero nos invitan a entrar con su inclinación, nos conduce hacia un interior enterrado. Los muros laterales se inclinan remitiendo a una especie de inestabilidad y formando un itinerario a la vez áspero y mullido.

Una vez dentro comenzamos a percibir lo oscuro, que nos va a acompañar hacia escenas cada vez más introvertidas. Paulatinamente hay una semioscuridad que nos aísla del mundo exterior, una cierta desorientación, donde la vista ya no nos guía, más bien el tacto o la temperatura del lugar.

Lo telurico se impone en el espacio; tanto el material procesado (acero y vidrio), como el natural propio del suelo con el que entramos en contacto. El espacio pesa en su densidad, como pesaba en la cripta de San Carlino. Hay también, una vez dentro, una cierta irrealidad, al igual que pasaba en los pabellones Les Cols, pero de otro modo. Esta vez producida por la oscuridad a la que todavía, al entrar, no nos hemos acostumbrado.

Pero como compensando esta irrealidad los materiales cobran presencia como residuos de lo real. Dentro del conjunto, los materiales de la estructura se muestran con su textura original, temperatura y color, con su materialidad propia, pero se trata de materia disgregada, que ha perdido su peso y volumen, que sigue también el principio de la a-tectonicidad, y una cierta ingravidez e inmaterialidad, a pesar de su presencia en su esencialidad fenomenológica. Las piezas de acero parecen flotar, pero en realidad están ancladas al terreno mediante unos tirantes que quedan ocultos, dejando un espacio pequeño entre ellas y las piedras sueltas que quedan detrás. 
El efecto es de una curiosa ingravidez, como si las piedras estuviesen suspendidas en la luz detrás de unos velos de acero. ${ }^{420}$

Los claroscuros hacen aparecer una de las condiciones de toda apariencia estética: el entredós, el juego del intervalo, el pasaje, el intersticio, que engendran acontecimientos de luz. Bell-Lloc representa la estructura de las sombras, sombras profundas y acentuadas, que remiten al espacio-oscuridad que las hace posibles.

La obra está hecha de secuencias, secuencias de interior. El recorrido va atravesando espacios de usos diversos en distintas escenografías interiores, algo teatral que involucra y envuelve. Artificios visuales que aparecen y desaparecen, juegos de luces, acoplando aparición y desaparición.

La cubierta está hecha de planchas plegadas de acero que se combinan con los soportes diagonales situados debajo. Se articulan en una planta sinuosa, como un organismo enterrado. Las piezas estructurales fluyen como en una serie, estableciendo múltiples ritmos según las percibamos desde uno u otro lugar. Zizaguean hacia adentro y hacia afuera y ofrecen superficies externas e internas, volúmenes, vacíos, sólidos y vanos; un espacio complejo, repleto de sensaciones.

La planta del conjunto se articula según los pliegues materiales de la cubierta, pliegues de acero que ya no son pliegues continuos, jugando a un simulacro donde el pesado acero se dobla como el papel. Parece como una pequeña apertura en el paisaje, una incisión o cicatriz. Plantas y secciones se componen como en forma de laberinto de volúmenes de espacio, que se van abriendo camino hacia una profundidad cada vez mayor.

La imagen percibida se vuelve irrepresentable, fragmentada, como no concebida, volatilizada, se ha plegado y multiplicado, generando un espacio vibrante, entredoses productores de sentido.

Los arquitectos hablan así en su memoria del proyecto:

La materia se desvanece gracias a la luz que baña el vacío en la sala de degustación de vino y los límites de la sala se disuelven en sombras ${ }^{421}$.

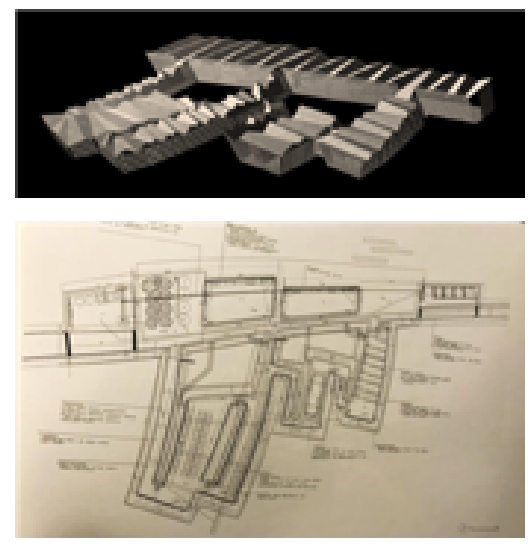

2.78. Maqueta de las Bodegas Bell-Lloc. RCR. Palamós, 2007.

2.79. Planta de las Bodegas Bell.Lloc. RCR. Palamós, 2007. 
Límites disgregados en ámbitos, formas que no se autodeterminan, que solo aparecen, si lo hacen, a partir de fondos-espacios.

\subsubsection{Acontecimientos de luz}
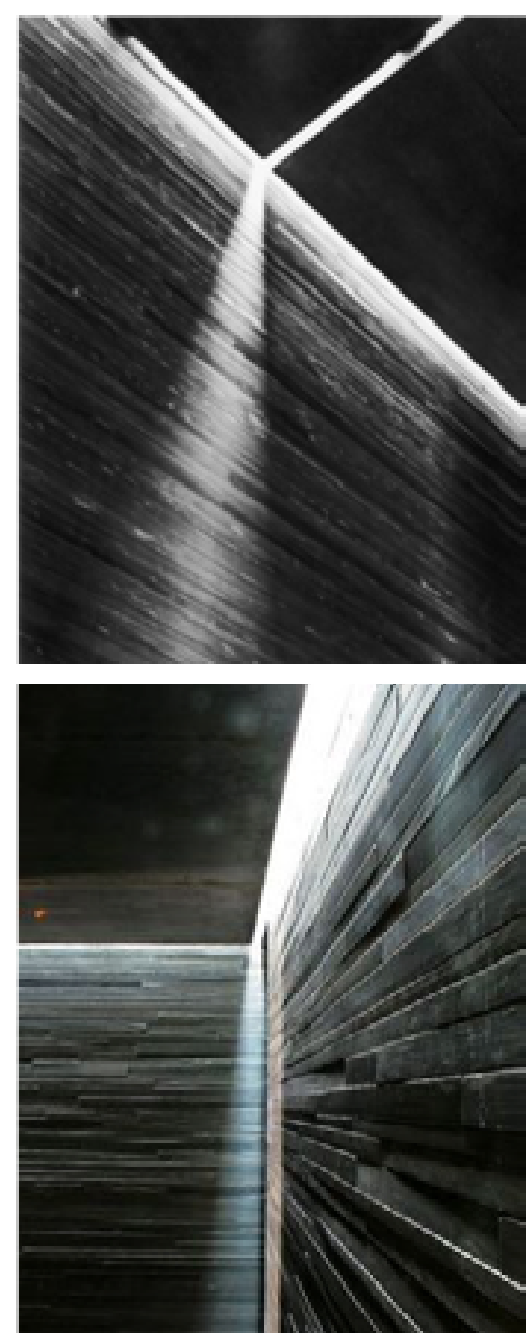

2.80. Rendijas de luz. Las termas de Vals. PETER ZUMTHOR. Vals, 1996.
En las termas de Vals de Peter Zumthor, la luz se cuela por rendijas formando acontecimientos. El claroscuro aquí, no va ligado al tema de la repetición, se trata de haces dispersos que escurren por los cerramientos o que se marcan en los techos, como diluyendo los contornos o enmascarándolos con artificios.

La luz se manifiesta con voz propia, dejando de depender ya de la forma.

Las termas de Vals se articulan por masas de luz y de sombras; el conjunto está compuesto por masas de claroscuro, grupos enteros se mantienen juntos y opuestos a otros por su tonalidad lumino$s a^{422}$. Hay una impresión de transformación constante.

En las termas de Vals, Peter Zumthor materializa la luz. La luz cobra presencia material, formalizándose en figuras y evidenciando así el medio que la hace posible y su condición. Esta tiene que ver con las rendijas y la oscuridad, que hacen que se individualice en focos y rayos, en líneas dibujadas, como rasgando lo oscuro.

Por otra parte, está el agua, material fluido que descompone los reflejos, que hace vibrar la luz, convirtiendo los haces nítidos en materia fluida.

El juego de contrastes, ya no es aquí entre lo cóncavo y lo convexo; ahora se da entre lo oscuro y lo claro, subrayando, como también lo hacía el Barroco histórico, una profundidad espacial. Hay, como en las bodegas Bell-Lloc, un evidente dramatismo, que intensifica los contrastes, como una representación del vacío, un vacío productor de luces siempre cambiantes, de vahos y vapores que provienen del agua, y que dispersan la visión del material duro de cerramiento, convirtiéndolo en ligero, negando su carácter tectónico.

Podríamos decir que los contrastes en este caso no transmiten movimiento, no hay ritmo no vibración. Pero lo que parece suceder es más bien que hay una lentitud, una calma en las transforma- 


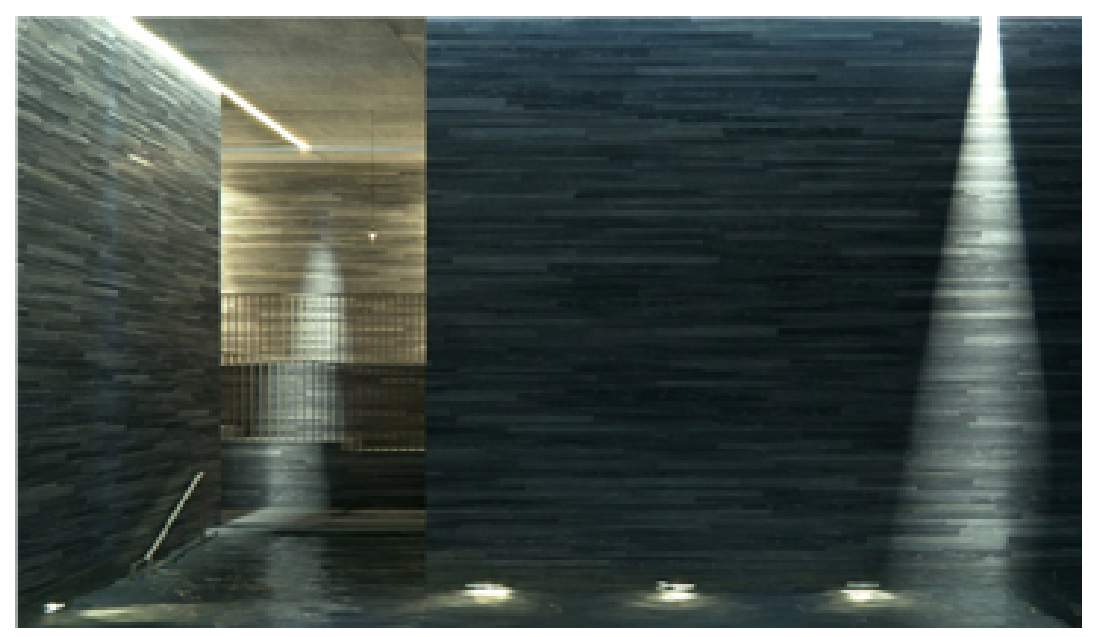

ciones a las que el espacio deja acceder. Son contrastes de grandes planos, atravesados por rendijas y focos. Predominan las grandes superficies, y predomina lo oscuro, convirtiéndose así la luz en focal y escenográfica, que toma cuerpo, como materializándose, verificando ese materialismo luminoso al que se refiere Malevitch, la luz y el color, donde el artista cuestiona el estatuto de la luz en el arte como luz que aclara la verdad y reivindica una intensidad coloreada, un nuevo corpus pictórico que es construido directamente sobre la luz:

\section{(...) la luz adquiere significaciones reales, y este atravesamiento es el índice de una especie de materialismo luminoso (...).423}

Hay en los juegos de luz un espaciamiento de las superficies; los intervalos y los intersticios engendran acontecimientos de luz. Estas singularidades luminosas implican cuerpos de luz, una materialidad de lo luminoso, una inmanencia que se expresa en esa neutralidad activa del espacio que se deja percibir.

Construida sobre las fuentes termales de Graubunden en Suiza, las Termas de Vals forman un conjunto de hotel y spa que combina una experiencia sensorial completa. Trabajando con el entorno natural, las termas están debajo de una cubierta verde semi-enterrada en el cerro. Zumthor proyecta su edificio de piedra descansando parcialmente dentro de la ladera, como si estuviera formado por la naturaleza y calentado por la masa térmica. La cubierta de hierba de los baños se asemeja a los cimientos de un sitio arqueológico, y revela la forma de las distintas salas de baño que se encuentran por debajo.
2.81. Interior de las termas de Vals. PETER ZUMTHOR. Vals, 1996. 
El espacio de las termas se genera como conducido por el agua, es como si el agua hubiera ido abriendo el camino, creando espacios distintos hasta depositarse. Zumthor nos dice que:

El meandro, como lo llamamos, es un espacio negativo diseñado entre los bloques, un espacio que conecta todo a medida que fluye a través del edificio, creando un ritmo pulsante y pacífico. Moverse por este espacio significa hacer descubrimientos. Estás caminando en el bosque. Todo el mundo está en busca de un camino propio.

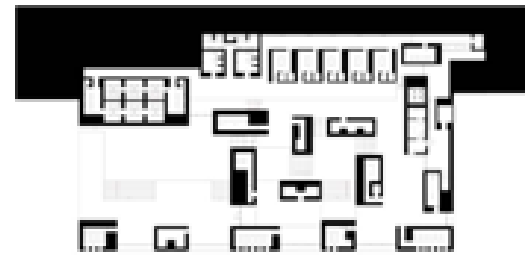

2.82. Planta de las termas de Vals. PETER ZUMTHOR. Vals, 1996.
En planta, el agua es como el fondo sobre el que surge la forma de lo construido, como replicando esta intención barroca de surgir del fondo. El agua haces las veces de fondo fluyente y cambiante sobre el cual, la luz y los claroscuros que determinan las formas, surgen.

El espacio está habitado por la oscuridad y la luz, por los reflejos de luz en el agua o por en el aire saturado de vapor, creando atmósferas repletas de sensaciones. El proyecto parece centrado en lo atmosférico.

Al enfrentarnos con su arquitectura nos viene inevitablemente a la mente el concepto de atmósfera. ${ }^{424}$

Los recorridos son inducidos por las sensaciones y por cierto engaño visual que nos conduce por el espacio. Hay una circulación por una especie de fondo acuático, a modo de sendero, desde donde vamos descubriendo los diferentes lugares. Es como una procesión de estímulos sensoriales; las vistas están permitidas o bloqueadas en una cuidadosa consideración de la experiencia sensorial. Es una naturaleza despojada de cualquier tecnología, sólo roca, agua y luz. Un espacio continuo, que se experimenta como un conjunto, pero no se ve todo de inmediato, el recorrido va descubriendo cada lugar.

Para nosotros era increíblemente importante inducir a la gente a moverse libremente, a su aire, en una atmósfera de seducción y no de conducción. (...) es uno de mis mayores placeres: no ser conducido sino poder pasear con toda libertad, a la deriva. ${ }^{425}$

\footnotetext{
424. Prólogo del libro Admospharen, Birckhauser Verlag, Basilea 2006. Traducción al castellano de Pedro Madrigal, basado en la conferencia: Atmósferas. Entornos arquitectónicos. Las cosas a mi alrededor, impartida en junio de 2003 en la Kunnstscheune del palacio Wendlinghausen.

425. PETER ZUMTHOR, Atmósferas. Entornos arquitectónicos. Las cosas a mi alrededor, op cit.
} 


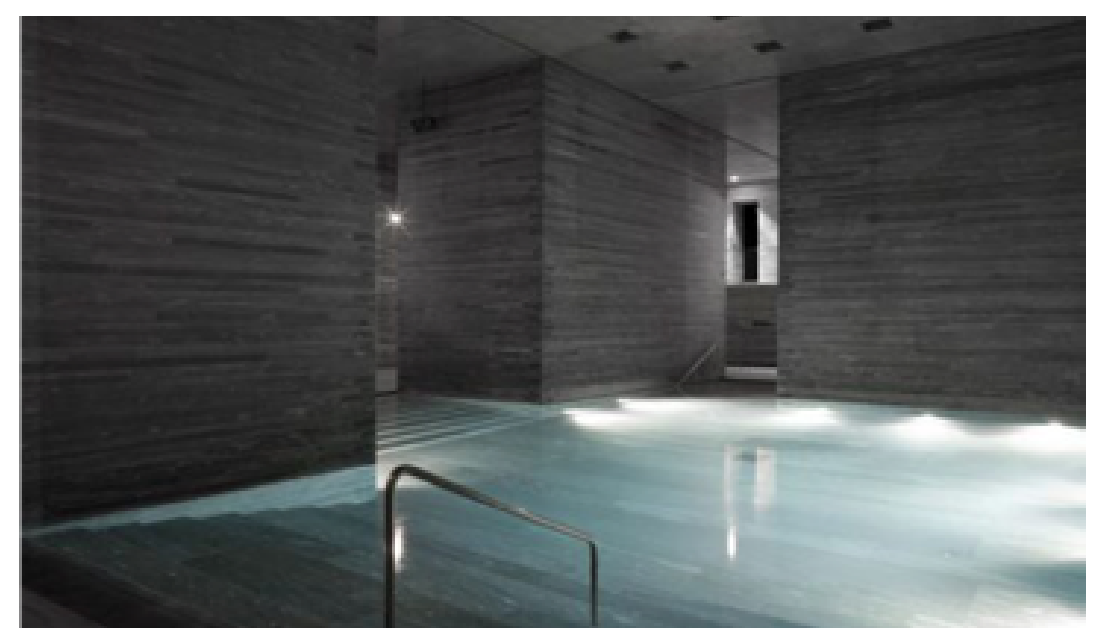

La experiencia se impone como fórmula del conocimiento de la obra, no hay representación, reconocimiento de la forma, pues esta se encuentra, disgregada en planos emergentes, vapores y fluideces. Su condición teatral está hecha de imprecisiones formales; teatro donde ya nada es fijo.

Deleuze había visto este carácter en la obra de arte moderna, en la que había notado un empirismo trascendental ${ }^{26}$, a partir de esta disolución de la representación en experiencia.

Cuando analizamos la planta, podemos observar que el espacio y el agua parecen estar representando ese medio neutro donde tiene lugar la diferencia, ese lugar de la posibilidad, que funciona aquí como el mar en un archipiélago, el medio de relaciones topológicas.

Peter Zumthor ha hablado de cuerpo de la arquitectura, para referirse quizás a una atmósfera, a un cuerpo atmosférico. Para ello es necesario enfatizar los contrastes, dramatizar la luz, actuar con la oscuridad, con los contraluces, en definitiva, señalar el espacio.

\section{(...) el primer y más grande secreto de la arquitectura: reunir cosas} y materiales del mundo, para que unidos creen este espacio. ${ }^{427}$

Las termas parecen proyectadas a partir de una masa de sombras a las que se han extraído, como un vaciado, las luces que las quebrantan. El dramatismo de los contrastes vuelve a estar inmerso en el mundo de la apariencia, reduciéndose a sus efectos, pertur-

426. Cifr. GILLES DELEUZE, Diferencia y Repetición, op. cit., pág. 101.

427. PETER ZUMTHOR, Atmósferas... op. cit.
2.83. Interior de las termas de Vals. PETER ZUMTHOR.

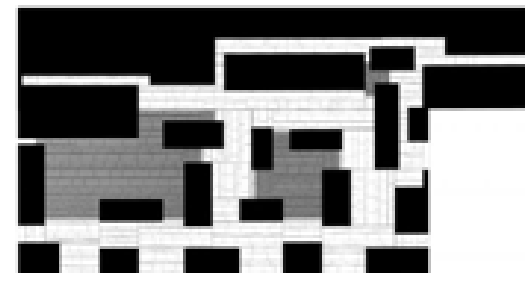

2.84. Esquema de la planta de las termas de Vals. PETER ZUMTHOR. 


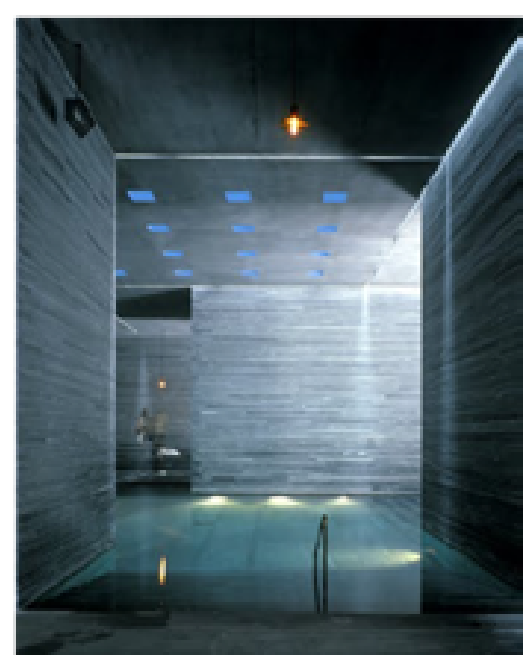

bando también la noción de forma, que se disgrega y es más bien concebida como flujo de energía.

La luz se independiza de la forma en todo momento. La concepción de la arquitectura se genera desde el interior hacia el exterior, a partir del espacio y el agua, como quebrando, en este caso, la materia, la montaña, disgregándola, espaciándola.

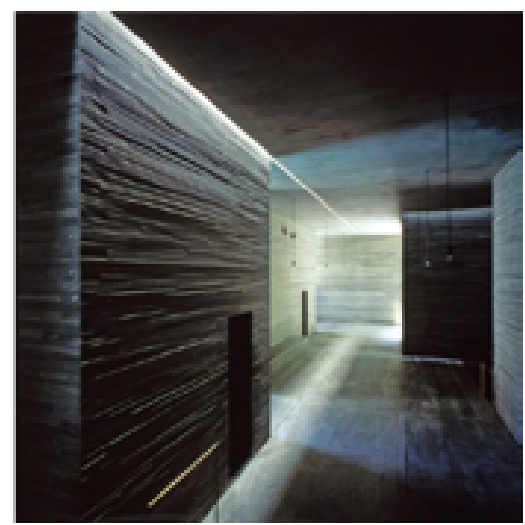

2.85. Vistas interiores de las termas de Vals. PETER ZUMTHOR. 
A través del uso de los recursos formales analizados podemos constatar que en la arquitectura de Borromini no hay jerarquía posible. El modo de proyectar los espacios, así como la propia obra construida que forma parte del mismo sistema, remite a espacios topológicos, a espacios generados, no a partir de modelos, sino de referencias intrínsecas a la obra; espacios más bien desarrollados, desplegados a partir del propio juego relacional, de configuraciones funcionales y siguiendo una trama geométrica que genera su variación, pero más que un modelo exterior compositivo.

La inflexión como acontecimiento generador de variación y el pliegue, como recurso especifico que va ligado a la inflexión, expresan continuidad y complicación, pero además son los mecanismos por los cuales la envolvente es afectada por la presencia del espacio. Ambos, pliegue e inflexión, generan topologías, relaciones de respectividad, son relaciones no jerárquicas, y lo son porque buscan la continuidad a través de una metamorfosis formal que se desvincula del tipo.

Las obras de Borromini señalan al espacio como configurador de la arquitectura y sus recursos formales se integran en un sistema coherente que, a partir de esta intención, de desarrollan como topologías unitarias cuyas partes ya no son partes sino modos de configuración espacial, modos que configuran un organismo continuo y unitario que prioriza el espacio sobre la forma. La obra y el proceso creativo de Borromini responde a un sistema variable y rizomático que evoluciona creativamente sobre sí mismo. Hay una heterogénesis, un movimiento que se desvía para incorporar algo nuevo, generando como puntos de inflexión, puntos potenciales, sobre los cuales la forma evoluciona. Los rasgos que caracterizan a la obra se configuran en el curso de su desarrollo, sin estar preconcebidos en ningún caso.

El tema del fondo en la estética barroca va unido a la singular significación del espacio que el método topológico por heterogénesis produce. Si la forma está condicionada por su espacio productor, su determinación proviene de este medio y su expresión entonces sucede por claroscuros, no por contornos. La forma se desdibuja, como sucede en la pintura y emerge a través de un espacio de valores, donde la luz y con ella el claroscuro la con-forman. La forma 
es dependiente de la luz, y esta, como magnitud intensiva, emerge por si sola, ya no ilumina la forma previa.

En nuestra arquitectura contemporánea todos los temas se reproducen y convergen también en la emergencia del espacio como constitutivo de la arquitectura.

El método topológico de significaciones relacionales en el espacio es una constante contemporánea. Los espacios no solo se proyectan con este modo, sino que dejan programáticamente un margen grande para el uso del espacio, que generará, posteriormente al proyecto, sus propios flujos a partir del movimiento. La jerarquía se elimina de la estructura formal, el espacio es únicamente topológico y relacional.

Notamos también la significación poética del espacio. Las tecnologías constructivas actuales añaden recursos múltiples potenciando los efectos del espacio en todos los sentidos. Pero aquí notamos diferencias en lo que se refiere a la materialidad. Si el Barroco hace efecto de masa, como notaba Wölfflin, con una materia ya blanda o disgregada en poros, la contemporaneidad alcanzará la emergencia de lo diáfano, inmaterializando con transparencias y límites difusos la arquitectura. El sentido es el mismo y la diferencia entre ambos periodos se inscribe radicalmente en las condiciones epistemológicas presididas por la cuestión técnica.

El fondo o lo diáfano contemporáneo, se reviste, como en el Barroco, de dramatismos que se producen por el uso del claroscuro, que, bien acompañando a la repetición-variación, acentúan un dinamismo, o como acontecimientos luminosos, logran un efecto-simulacro. Con los claroscuros, el fondo sube a la superficie y disuelve la forma.

La forma no tiene su referencia en sí misma, sino en el espacio donde se con-forma. Se trata, en las dos temporalidades, de una forma al servicio del espacio, que intensifica su presencia, lo hemos llamado forma relativa. 


\title{
4. LO IN-FORME. DESMESURA, METAMORFOSIS E INDIVIDUACIÓN
}

\author{
El elemento formal del pliegue (...) solo puede apa- \\ recer con lo infinito, en lo inconmensurable y en la \\ desmesura, cuando la curva variable ha destrona- \\ do al círculo. ${ }^{428}$
}

El texto de Deleuze sobre El Pliegue gira en torno a tres temas: la filosofía de Leibniz, el Barroco como cultura propia del XVII (aunque Deleuze lo extenderá también, en su último capítulo, a las manifestaciones culturales contemporáneas) ${ }^{429}$, y los recursos formales del pliegue y los efectos que este lleva asociados. Considera que la forma-pliegue, está implicada en el significado del concepto de alma-mónada de Leibniz, debido a la relación de esta figura con la potencia-devenir a través de la inflexión, vista como acontecimiento, pero también utiliza las categorías de plegado y desplegado, para acentuar cuestiones relacionadas con la individuación. Todo ello quiere referirse a una especie de potencialidad, una potencia de ser, remite al ámbito donde la individuación se produce, a una zona donde tienen lugar las fuerzas, el movimiento-devenir. Un lugar que nunca es estable, que está sometido a la variación, a la modificación. Pero la forma pliegue, la inflexión también necesariamente, manifiesta la continuidad, como noción esencial que hará posible todas las figuras de la inflexión.

Podría parecer de alguna manera contradictoria la existencia de esencias individuales (mónadas), causas finales del pliegue, según Deleuze, con la existencia de un continuo; pudiera considerarse que con la causa final del pliegue (que es la mónada) el proceso se para. Deleuze advierte (ya nos hemos referido a ello, pero aquí es de nuevo pertinente $\left.\mathrm{4}^{40}\right)$, como no habría que confundir continuidad con contigüidad, pues los puntos singulares pertenecen completamente al continuo, aunque no sean contiguos.

428. GILLES DELEUZE, El Pliegue... op. cit, ¿Qué es el Barroco?, pág. 54.

429. Deleuze dedica el último capítulo de su texto al barroco contemporáneo, y lo titula: La nueva armonía. Ibid, págs.155-177.

430. Véase supra, pág. 195. 
¿Pero cómo se produce un cambio en un continuo si no es por metamorfosis?

Hay un fondo continuo sobre el cual se dan las determinaciones, las individuaciones, y estas son los cambios que, en un continuo, siempre serán performativos, tendrán lugar a modo de metamorfosis. Leibniz se refiere a esta continuidad como plenum, y lo describe en su Monadología:

Pues como todo es un plenum - lo que hace que toda la materia esté conexa- y como en el plenum, todo movimiento produce algún efecto en los cuerpos distantes (...) Pues todos los cuerpos están, como los ríos, en un perpetuo flujo, y unas partes entran en ellos y otras salen de ellos continuamente. (...) Y lo que llamamos generaciones son desenvolvimientos y crecimientos, así como lo que llamamos muertes son Envolvimientos y Disminuciones ${ }^{43}$.

Podríamos también considerar el mismo tema en el pensamiento de Spinoza, donde la única Sustancia inmanente solo se manifiesta en modos ${ }^{432}$. No cabe la duda de que la continuidad es el tema del pensamiento Barroco, fundamentalmente a través de estos dos filósofos. ¿No es también un tema de la estética barroca? ¿No lo es también de forma evidente, al menos, en la obra de Borromini?

Y el continuo, la continuidad, solo se sabe expresar por metamorfosis y permutaciones; es el modo de expresión de sus singularidades. Todo fluye en ese plenum continuo de Leibniz, donde los envolvimientos o individuaciones tienen lugar, nada se para, no hay lugar para lo estable.

Toda la zona intermedia (plenum) de individuación es puro devenir, pero es también territorio, espacio liso ${ }^{433}$, como dirían Deleuze y Guattari. Y es ahí precisamente donde podría tener lugar el cuestionamiento de la representación como imagen cerrada, su significado último, lo que implica la clausura en una representación. Pues el fondo fluyente que contiene lo diferente muta continuamente; hay una potencia in-formal de fondo, que lleva a cada cosa a ser forma extrema, el punto dónde su representación se 
deshace ${ }^{434}$. Esa forma extrema que nombra Deleuze es como una desmesura.

Toda esta reflexión que venimos haciendo a través de las categorías formales que utiliza Borromini, a través del significado que adquiere el espacio en su relación con la forma, parecen expresar cuestiones relacionadas con la individuación, con la determinación en una forma, por ello con el ámbito o zona donde esta se da, por tanto, también con lo transindividual.

El tema del infinito en el Barroco es de gran importancia para comprender esta relación. Y es en particular la cuestión de lo infinitamente pequeño, que protagoniza el cálculo infinitesimal, pero que también está presente en la filosofía barroca, no solo en Leibniz, también en Spinoza. Frases como: el pliegue va hasta el infinito ${ }^{435}$, o la unidad de la materia es el pliegue y no el punto ${ }^{436}$, subrayan una continuidad y un infinitamente pequeño; apuntan a un continuo-lleno como ámbito de lo pre-individual, un espacio potencial que dará lugar a las determinaciones.

A partir de este ámbito de lo pre-individual, de la consideración del continuo, con su performación y su metamorfosis, del concepto deleuziano de forma extrema y de la desmesura, esta investigación va a proponer una vinculación de la forma barroca con la forma trágica. Se desarrollará desde un ámbito particular; a partir de las consideraciones de Nietzsche sobre la tragedia griega y el significado de la figura de Dionisos.

Nietzsche, en su Nacimiento de la Tragedia ${ }^{437}$ trata este tema y la relación del ámbito preindividual con la desmesura a través de la figura de Dionisos. Y en la tentativa de representar todo ese ámbito complejo, es donde encontramos un cierto carácter trágico, en relación con lo que Nietzsche considera. Las formas borrominianas y su proceso de proyectar son aquí relacionadas con el sentido trágico a través de la desmesura, como desbordamiento de las formas (representación de esas formas extremas de Deleuze), sometidas a los recursos del pliegue y la inflexión, sometidas a una densidad de trazos previos que anticipa las densidades plegadas

434. Cifr. GILLES DELEUZE, Diferencia y Repetición, op. cit., pág. 102.

435. GILLES DELEUZE, El Pliegue... op. cit., pág. 11.

436. Ibid, pág 14.

437. FRIEDRICH NIETZSCHE, El nacimiento de la tragedia, Alianza editorial, Madrid 1973. 
de la fachada de San Carlino, por ejemplo. Densidades que apuntan hacia lo infinitamente pequeño.

La relación con la tragedia no pretende ser tratada como una analogía o algo secundario. La arquitectura encuentra su medio de expresar la misma cosa. La tragedia, según la describe Nietzsche, remite, a través de la figura de Dionisos, a todo un ámbito pre-individual, potencial, que se pone en escena, que se representa. La arquitectura de Borromini parece estar como clausurándose trágicamente en una determinación, a la que quizás no quisiera llegar.

Es curioso que Julio Carlo Argán haya notado en la arquitectura de Borromini la falta de los signos de teatralidad escenográfica que se suelen atribuir al Barroco ${ }^{43^{8}}$. Probablemente la puesta en escena de Borromini no es tan grandilocuente y monumental como la de Bernini. O Cortona en muchos casos Pero Borromini escenifica otra cosa más cercana probablemente a lo teatral, a través de su origen en la tragedia griega (siguiendo las consideraciones de Nietzsche). Las escenas estables de otros arquitectos romanos (ya lo hemos visto), no tienen el mismo sentido que las obras de nuestro arquitecto; Borromini representa el cambio, con él la metamorfosis, cuestiones insertadas en las consideraciones más originarias de lo que significa el teatro. Nuestro arquitecto pone en escena el espacio, un espacio sin sucesión, una especie de ahora sin tiempo, que podemos encontrar en ese impulso centrípedo que retiene a otro centrífugo, por ejemplo. Se trata de una representación trágica, donde, lo que se pretende es intentar verlo todo, una génesis, una individuación y un espacio-fondo de donde todo surge, el sentido del acontecimiento y la potencialidad de las singularidades. Es una teatralidad más ligada a lo trágico que a una escenografía enfática provista de cierto estatismo. Se trata más bien, en nuestro autor, de un teatro hecho sin nada fijo, a base de metamorfosis y de máscaras.

Por otra parte, insistiendo en lo mismo, observamos como Gilles Deleuze señala la condición también espacial de la tragedia griega, a través de las observaciones del crítico de literatura Albert Thibaudet. La tragedia, a diferencia de la novela moderna no dura. Una tragedia son siempre vértices, momentos críticos, en 
cambio, la novela es el arte de la duración. 439 La tragedia se inscribe entonces en el mismo ámbito del espacio y el acontecimiento que venimos señalando en la obra de Borronini.

Así, partiendo del texto de El Pliegue de Deleuze, vemos como él considerará que lo in-forme no es negación de forma, plantea la forma como plegada. La materia deviene material al revelar su textura, igual que la forma que descubre sus pliegues deviene fuerza. La pareja materia-forma, es sustituida en el Barroco por la de material-fuerza. Y las fuerzas son las fuerzas del alma (o mónadas), que solo se manifiestan en su desplegamiento, ya no como formas, sino como formas de expresión ${ }^{44^{\circ}}$. El pliegue remite a lo in-forme a lo que subyace, lo anterior al despliegue individuante. Y tras la forma de expresión de Borromini, subyace su proceso de formalización, su principio de individuación, su método de proyecto, como una metáfora de lo informe plegado, que se desplegará en repliegues materiales.

Consideramos aquí de nuevo la vinculación de todo ello con la noción warbugiana de Pathosformel, ${ }^{441}$ como forma que contiene el pathos, la fuerza, deviene forma extrema. Una forma que invoca al Eterno Retorno, que afirma solo lo excesivo y lo desigual, lo extremo, la desmesura, el momento que marca la diferencia que retorna, la metamorfosis y la máscara. 


\subsection{LA INDIVIDUACIÓN Y EL DISPOSITIVO GEOMÉTRICO DE BORROMINI}

Borromini representa en su arquitectura la potencia, potencia no cinética, potencia-devenir, tanto en la condición de sus pieles, en el uso del pliegue y sus elementos y dispositivos, como en la configuración del espacio interior y la composición de sus elementos de construcción, en el tratamiento de la luz y los claroscuros, común esto último a muchos autores barrocos.

El ámbito de la potencia está relacionado directamente con el proceso de individuación, de creación en este caso. Por ello, subrayar la cuestión de la potencia nos remite a la consideración, muy especial, de los dibujos que se conservan de nuestro arquitecto. Tenemos la suerte de poder conocer muchos de sus croquis pues se conservan depositados, la mayor parte de ellos, en la Albertina de Viena, colección nacional austriaca de dibujos. Los dibujos son significativos en cuanto que respaldan o acusan ya el carácter de la obra construida en el sentido que venimos señalando; son el inicio de una potencialidad que parece no quererse cerrar en una determinación concreta. ${ }^{442}$

El resultado de los espacios que Borromini proyecta, su uso de la inflexión y del pliegue, y en esa especie de movimiento metamórfico, está estrechamente incardinado en su proceso de proyectar y en su modo de llegar a la forma final construida. El proceso que utiliza Borromini de búsqueda de forma tiene una estrecha relación con los resultados construidos de su arquitectura; él hace de la metamorfosis formal ${ }^{433}$ un argumento de proyecto.

Hay como una perdurabilidad del proceso de génesis del proyecto que se prolonga en la obra construida y que hace que su forma apunte a una inestabilidad formal, a una fuerza-potencia perdurable.

El trazo de la inflexión activa de Borromini todavía no es un trazo libre como será el pliegue contemporáneo, lleva implícita una

442. No se trata aquí de poner en valor el proceso proyectual frente a la obra construida, sino de señalar, en el caso concreto de Borromini, la vinculación que tiene el estatuto formal del proceso con el de la obra construida.

443. Para profundizar sobre la cuestión del método proyectual de Borromini, este ha sido explicado en profundidad, tras un análisis exhaustivo de todos sus dibujos autógrafos, en la tesis doctoral de Eusebio Alonso García, contenida en la publicación: EUSEBIO ALONSO GARCIA, San Carlino, La máquina geométrica de Borromini, op. cit. 


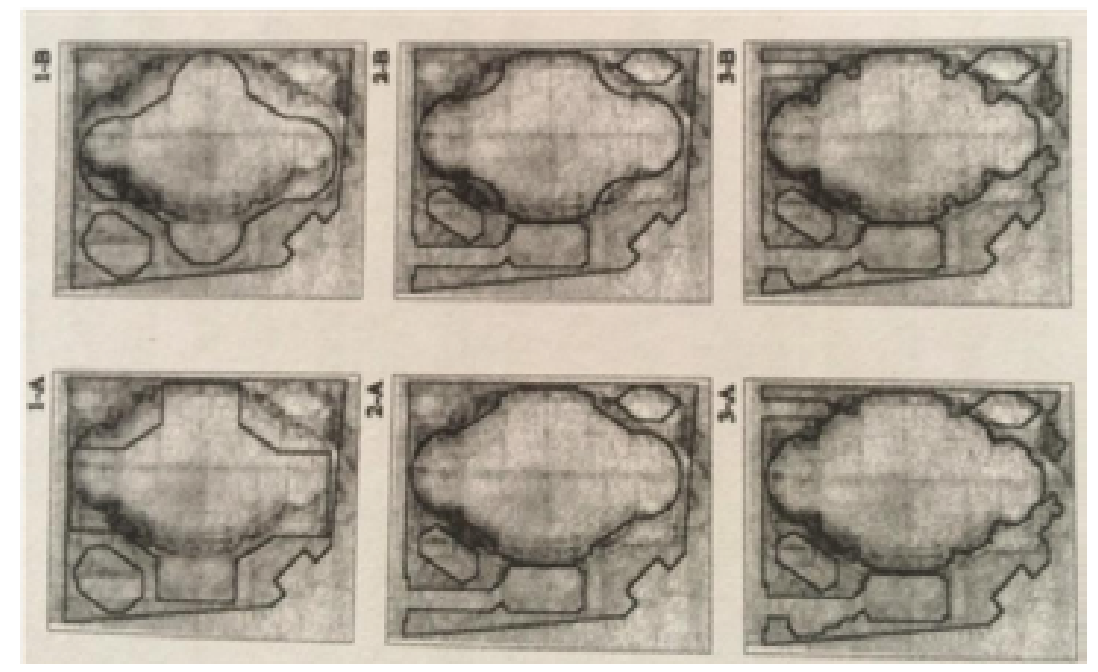

base geométrica por la que discurre. De esta forma la geometría es recuperada como espacio donde inscribir lo heterogéneo ${ }^{444}$, no ya como mecanismo de composición, sino como herramienta para la inflexión. Un dispositivo capaz de dar cuenta de las transformaciones que van sucediendo en el proceso del proyecto, constituyendo así el fundamento de la inflexión.

La línea activa era para Klee un agente o función de forma y pone en marcha un proceso de búsqueda de forma, por ello hay que tomarla de manera literal.

Todo el sistema de proyecto que reflejan estos dibujos con sus correcciones y superposiciones, a través de su rigor geométrico de base, evidencian la enorme destreza técnica del arquitecto a la vez que el debate interno que mantenía para resolver sus proyectos con brillantez innovadora. Los dibujos para el proyecto de San Carlino (Albertina 171 a 173), relatan muy bien en el análisis de sus correcciones, como a través del mecanismo geométrico se adaptan las necesidades funcionales que generan las distintas posibilidades formales. El profesor Eusebio Alonso ${ }^{445}$, ha ordenado este proceso deduciéndolo de los propios dibujos autógrafos, mostrando como una voluntad de rigor funcional se canaliza en una mayor complejidad y diversidad formal sin perder nunca la continuidad en el trazado murario, que se apoya en el dispositivo geométrico y que es lo que otorga a la obra su carácter de unidad compleja. En estos dibujos se reflejan las operaciones que el arquitecto sigue, en un espacio de muy reducidas dimensiones, para incorporar la
2.86. Evolución proyectual de San Carlino alle Quattro Fontane. BORROMINI. Dibujos del profesor Eusebio Alonso sobre el original (Albertina 171). 
sacristía que no existía en los primeros trazados, sin perder el carácter unitario del conjunto. Todo el sistema de modificaciones se ve apoyado en una geometría que le sirve de herramienta para la variación. Los esquemas forman series, series de variaciones sucesivas.

En sus dos proyectos más importantes, donde el arquitecto pudo lucir su genio sin ninguna circunstancia que le impidiera dar completa expresión a sus ideas, San Carlino y Sant'Ivo, es donde se manifiesta más explícitamente esta cuestión. Estos proyectos de Borromini parece que sufren sucesivas metamorfosis ${ }^{446}$ a lo largo de su proceso de creación. Su forma progresa a través de una geometría que es significativa, pues es su dispositivo de proliferación, su herramienta. Todo el movimiento complejo que sus obras parecen transmitir, va detrás respaldado por una correspondencia con el proceso de proyecto, como si la forma final no fuera más que una posibilidad, y como dando a entender una especie de continuidad posterior. La sensación de movimiento y variación que transmite su obra construida, apunta a un proceso que parece no haber cesado, y que, respaldado por su procedimiento de proyecto, manifiesta lo que sería esencial en una metaestabilidad. ${ }^{447}$

El concepto de metaestabilidad lo explica Gilbert Simondón como contrario al equilibrio estable. En este último se encuentra el nivel más bajo de energía potencial posible, todas las potencialidades y transformaciones han sido actualizadas y realizadas y ya no existe ninguna fuerza. El equilibrio estable excluye el devenir. Simondón hace intervenir la noción de energía potencial para definir la metaestabilidad. En ella la individuación no es un encuentro de una materia y una forma previas que existen como términos separados, sino una resolución que surge en un sistema no estable, rico en potenciales: forma, materia y energía preexisten en el sistema.

Simondón, al analizar el principio de individuación, prioriza este principio que prefigura la individuación constituida a las nociones de forma y materia. En el análisis del proceso hylemórfico, no podemos partir de la forma y la materia para conocer el principio de la individuación, más bien se trata de conocer al individuo a través de la individuación, de captar la ontogénesis en todo su desarrollo, considerando como primordial la operación de individuación.

446. Paolo Portoghesi en su prólogo al texto de Eusebio Alonso, destaca la acertada aportación del autor al hacer notar el efecto metamórfico de en las obras de Borromini. 
El individuo es entonces una realidad relativa, expresa una cierta fase del ser que presupone siempre una realidad preindividual anterior, que aparece siempre plegada, manifestándose solo en el individuo. También, a través de la interpretación que de Leibniz hace Deleuze, este observa que el individuo es una actualización de singularidades pre-individuales, y esto no implica una especificación previa, más bien la especificación supone la individuación ${ }^{44^{8}}$. Por ello todo consta en el proceso.

Borromini se encuentra dentro de los primeros arquitectos que utilizan en la base de sus proyectos complejas geometrías con las que generan sus resultados formales; pero sus proyectos no participan de un carácter geométrico, sino que a través de la geometría logran otra cosa: plegar el contorno, adaptarse, inflexionarse. Generan un sinfín de contornos que van modificándose como podemos apreciar bien en los croquis. Sus trazos complejos hacen y rectifican líneas generadas por puntos en movimiento, por líneas activas que se pliegan una y otra vez modificando los trazos precedentes. Suceden nuevos pliegues, pudiéndose registrar un proceso metamórfico del organismo. El proyecto resulta ser un registro de las posibilidades geométricas.

Es la geometría, no como modelo, sino como medio de movimiento en el espacio, la condición de posibilidad de las formas construidas.

Borromini, con su instrumento geométrico transmite las claves de la pura variación y el modo de la variación genera a su vez sus propios cambios, como si conservara en sí mismo su propio principio de individuación, insinuando su continuación. Parece que lo que importa no es tanto el movimiento sino captar la ley de la variación.

Coincide con el modo con el que Simondón describe los sistemas de individuación que no agotan toda la realidad pre-individual, esta queda contenida en el individuo posteriormente ${ }^{449}$. Lo que llama la resonancia interna de su sistema caracteriza al individuo, constituye su criterio, su modo de ser. El individuo es dependiente del modo de individuación, de la forma de ordenar lo pre-individual que ha tenido lugar, y esta forma de orden es en Borromini, la

448. Cifr. GILLES DELEUZE, El Pliegue... Incomposivilidad, individualidad, libertad.

449. En lugar de captar la individuación a partir del ser individuado, propone captar el ser individuado a partir de la individuación, que (...) debe ser captada como devenir del ser y no como modelo del ser, que agotaría su significado. Simondon, La Individuación... 

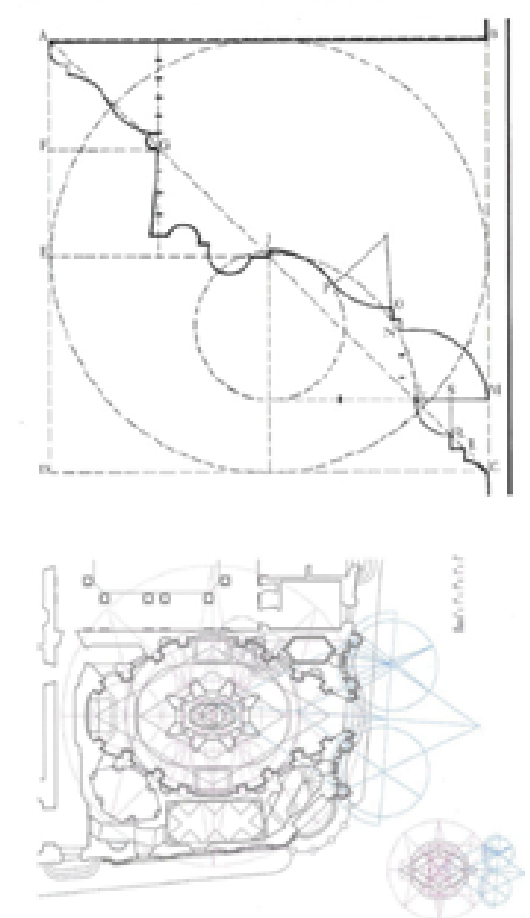

2.87. Grabado romano de moldura de San Carlino y estudio geométrico de Eusebio Alonso sobre la planta de San Carlino. geometría. Esta geometría ha pasado de ser un parámetro al cual los objetos artísticos debían de referirse, a ser un instrumento al servicio de la forma arquitectónica, a partir de la cual esta se despliega, se quiebra, se expande y se transforma. De una matriz para la forma pasa a ser una herramienta de la variación.

La geometría está vinculada a esa idea de infinito que impera en el siglo XVII. La idea de lo infinitesimal, de la posibilidad de lo infinitamente pequeño se encuentra siempre en la geometría. Es la geometría la que nos enseña que hay infinitos dobles, triples... etc. Todo infinito es irreducible a los números; el número está subordinado a la magnitud, y la magnitud es geométrica.

Deleuze habla de manierismo, como la manifestación de las maneras, bajo una misma cosa; el Barroco, como modo de manierismo reivindica una sustancia que es interior al movimiento, una unidad de cambio activa, y esta unidad de cambio remite a las series; la unidad de cambio contiene la ley, la ley que genera la metamorfosis, la ley geométrica que impera bajo los croquis seriados de Borromini.

El dominio de la geometría de nuestro arquitecto no impide una liberación de la forma. Sus contornos fluyen de forma tridimensional, podría decirse que se modelan en una geometría variable que casi podría ser una anticipación del modelado digital contemporáneo. Deleuze observa que los pliegues de Ucello continúan atrapados en estructuras geométricas inflexibles, y que, en cambio, el pliegue barroco conoce una liberación sin límites. El pliegue borrominiano, no es geométrico, solo fluye por la geometría, discurre entre ella, pasa entre sus límites contorneándose. La línea de contorno que modela el espacio se libera y busca la variación, con casi la pretensión de no acabar de cerrar la forma, envuelta en un proceso de operación infinito. Deleuze dirá que el problema no es como acabar un pliegue, sino como continuarlo ${ }^{45^{\circ}}$. La geometría que utiliza Borromini parece contener un principio de variabilidad.

Deleuze se referirá al Pliegue como elemento genético, que determina la Forma ontológica como forma de expresión. Esta forma de expresión es un modo. El modo es lo mismo que la manera a la que remite al manierismo. Pero estas maneras surgen siempre de un fondo sombrío en el Barroco, y este fondo se opone a la claridad

450. GILLES DELEUZE, El Pliegue... op. cit., ¿Qué es el Barroco?, pág. 50. 
de la forma, es lo in-forme pre-individual, y sin el cual las maneras no tendrían de donde surgir ${ }^{451}$.

El estatuto de la forma se ha modificado y ahora aparece subordinada al modo, al modo cómo se comporta el sistema de variación, al modo como la forma se individúa, que es lo que para Simondón supone lo relevante del proceso. En lugar de captar la individuación a partir del ser individuado, propone captar el ser individuado a partir de la individuación, que (...) debe ser captada como devenir del ser y no como modelo del ser, que agotaría su significado, nos dice. El método proyectual de Borromini, es más bien un mecanismo de regulación de la variación formal, sitúa el valor en el régimen de la variación, en el modo cómo la forma va a individuarse.

Este símil de la individuación física de una arquitectura como objeto técnico, con la individuación de los seres vivientes, que es a lo que se refiere Simondón o lo que significa la mónada-pliegue-fuerza de Leibniz según Deleuze, apunta a la asimilación de la arquitectura de Borromini a un organismo, a casi su consideración como ser viviente, en el cual el proceso de individuación no cesa.

Probablemente la obra de Borromini no se puede comprender bien prescindiendo de sus croquis y dibujos, pues la obra concluida, como en un ser viviente, parece que conserva en sí una actividad, una potencia. Obra y proceso parecen enlazarse en la manera de abordar la forma, en su estatuto, en como nuestro arquitecto parece querer expresarse; el sentido de variabilidad que vemos en muchos de sus croquis parece transmitirse a la obra construida. ¿Podríamos asimilar esta realidad pre-individual al elemento geométrico de Borromini?

La geometría se da en el espacio, y el espacio es así el elemento potencial en el que la arquitectura, como individuo tiene lugar. El espacio se pone en obra en la arquitectura de Borromini; es un espacio de representación, surcado internamente por las bases geométricas de sus desarrollos.

Así, vemos como en muchos de sus croquis, la variación deviene infinita, basada en la matemática Barroca, en el número irracio-

451. Deleuze nos dice que este fondo sombrío obsesionaba a Leibniz, pues las sustancias o las almas todo lo extraen de su fondo sombrío. GILLES DELEUZE, El Pliegue... Razón suficiente, op. cit., pág.77.
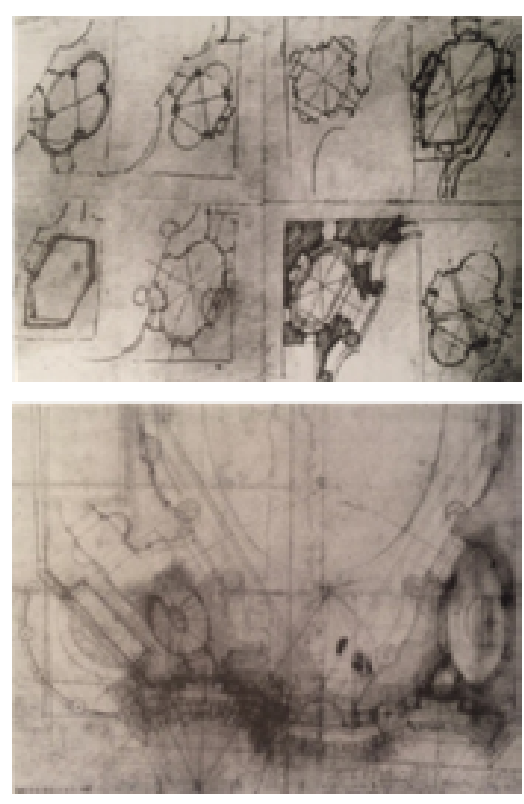

2.88. Serie de croquis de la capilla de la Madona en San Carlino alle Cuatro Fontane. BORROMINI. Albertina 174.

2.89. Fragmento de un croquis de la planta de San Carlino alle Cuatro Fontane. BORROMINI. Albertina 176
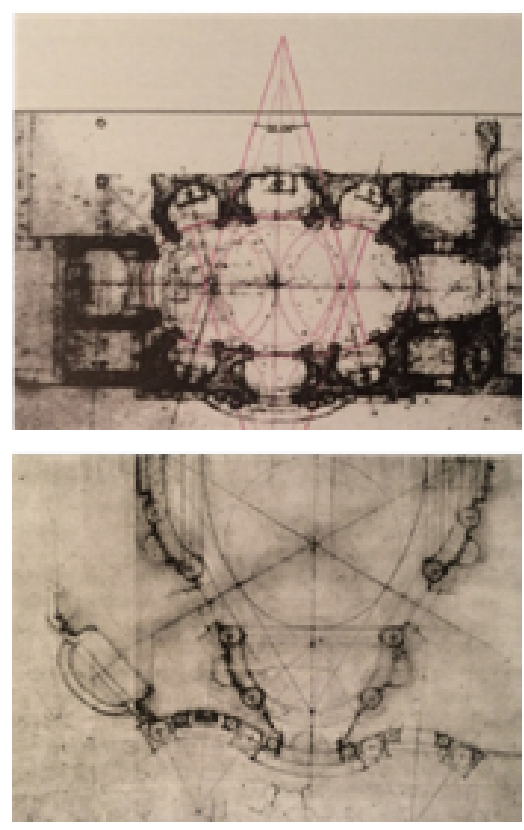

2.90. Capilla de los Reyes Magos. BORROMINI, 1662. Dibujo del profesor Eusebio Alonso sobre Albertina 887B

2.91. Planta San Carlino alle Quattro Fontane. BORROMINI. Albertina 175 

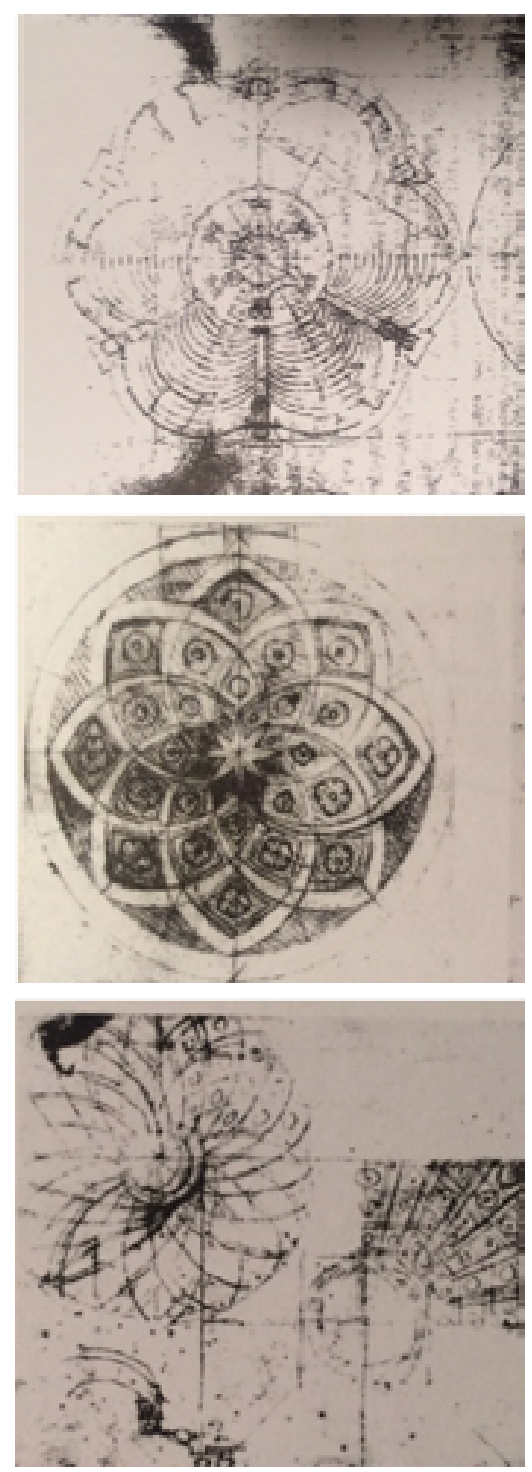

2.92. Croquis del suelo de la Iglesia de Sant'Ivo alla Sapienza. Albertina 509, 218 y 422 nal y en el cálculo infinitesimal. Ahora la causa es la curvatura; el número irracional implica la caída de un arco de círculo sobre una línea recta, concentrando puntos cada vez con más densidad. Al respecto Gilles Deleuze apuntará que:

La diferencia ya no está entre el polígono y el círculo, sino en la pura variabilidad de los lados del polígono; ya no está entre el movimiento y el reposo, sino en la pura variabilidad de la velocidad. ${ }^{42}$

Durante el Renacimiento el mecanismo compositivo había sido de tipo aditivo a través de la identificación de figuras geométricas con unidades espaciales, que se articulaban a través de la composición de las plantas, siguiendo modelos. Lo primordial parece ser, en la arquitectura del Renacimiento, la forma arquitectónica individualizada, reconocible, sujeta a sistemas formales a priori. En Borromini, lo que parece que es esencial es la operación de la individuación. Ya no es posible identificar células espaciales, partes o geometrías con entidad independiente, la forma es una unidad generada por transformaciones sucesivas y relaciones espaciales topológicas; un sistema de continuidades que deslizan por una geometría que le permite la variación necesaria para alcanzar soluciones singulares que ya no pueden darse con los presupuestos renacentistas. El resultado construido son espacios topológicos con un marcado carácter tridimensional. 453

452. GILLES DELEUZE, El Pliegue..., Incomposibilidad, individualidad, libertad, op. cit., pág. 89.

453. PAOLO PORTOGHESI, prólogo al texto de EUSEBIO ALONSO GARCÍA, op. cit., pág. 15. 
La determinación formal acabada, en la obra de Borromini, es el resultado de un proceso complejo donde lo que se ha puesto en juego es el estatuto convencional de la forma, donde se cuestiona la estructura hilemórfica tradicional. Simondón, en relación a esto, propondrá sustituir el término forma por el de in-formación, que será entonces el sentido según el cual un sistema se individúa, lo que informa a la materia para alcanzar su forma. Esta in-formación tendrá una resonancia en lo in-forme que propone Cache entre otras categorías formales que son también efecto de la inflexión: pliegue y topología, y que se refieren también a un ámbito pre-individual.

La forma construida en la arquitectura de Borromini parece estar más interesada en la transición de un estado formal al siguiente, en las relaciones que están implicadas en el cambio, que tienen lugar entre un estado y otro. Y es esto mismo lo que sus croquis tematizan: potencia y cambio. En este sentido Simondón se refiere al concepto de transducción una operación por la cual una actividad se propaga progresivamente en el interior de un sistema es una individuación en progreso; se debe considerar toda relación teniendo rango de ser, como una modalidad del ser ${ }^{454}$, nos dice.

Hay una tensión de base en las obras de Borromini que nos permite pensar este concepto de transducción; su configuración formal apunta a una potencialidad de la materia que no se acaba en el resultado construido; es una inmersión en lo posible.

La permanencia de una ley estable de composición que la arquitectura del clasicismo había utilizado, ha sido sustituida por la fluctuación de la norma. El nuevo estatuto del objeto ya no se refiere a una relación forma-materia al modo de un molde, sino a una modulación temporal, un desarrollo continuo de la forma (que ya no sería forma sino in-forma, según el esquema citado por Simondón), como una puesta en vibración, que puede producir desfases. Simondón distinguirá entre el molde y el modulador. Así, hará notar que moldear es dar una forma estable y definitiva, 


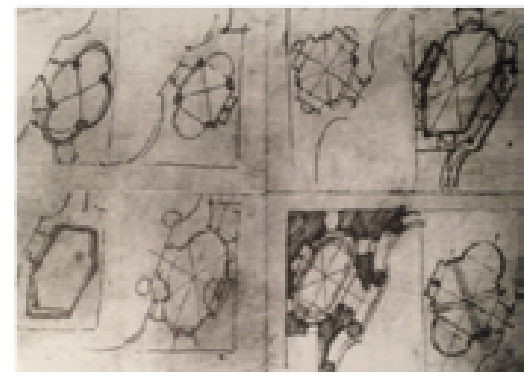

2.93. Serie de croquis de la capilla de la Madona en San Carlimo alle Cuatro Fontane. Albertina 174 modular es moldear de manera continua y perpetuamente variable. 455

El sistema de series de los croquis de Borromini, plasmado en la vibración de la forma se acerca más al sistema de individuación por modulador.

La relación entre materia y forma no se lleva a cabo entre materia inerte y una forma que viene de fuera, no hay formas a priori que cristalizan la materia; hay un nivel común que opera en ambas y este nivel común es la fuerza. La materia será centro de fuerzas y en ella se actualiza una energía potencial. Y el modulador geométrico borrominiano servirá de límite a la energía potencial de su materia arquitectónica: ladrillo estucado en blanco, material continuo, pero es un límite que sugiere la existencia de una cantidad de energía aún no actualizada.

Simondón también señala la diferencia del principio de individuación física y el principio de individuación del ser viviente. El paradigma de la individuación física no puede extenderse de forma análoga a la génesis de los seres vivos, pues la primera es completada en un tiempo y el objeto pasa a ser más o menos estable, y el ser viviente en cambio, posee en sí mismo su propio principio de individuación que no está agotado. Es en este sentido, como ya se ha observado en este texto, en el que los objetos arquitectónicos de Borromini se pueden asemejar a organismos. El dispositivo geométrico que llevan implícitos niega parcialmente el principio de individuación sugiriendo como único principio la conservación del ser a través del devenir, lo que significa el mantenimiento de la potencia de ser, de la transformación, de la metamorfosis.

El tipo o la tipología, modo de proyectar del clasicismo, se modifica a favor del modo o la variación. Ya no importa la referencia, el modelo, importa la individualidad específica de la cosa y el cómo esta cosa o individuo no es estable, está sometido al devenir. Y subsiste por ello un carácter de impredecibilidad del resultado formal que ya está presente en el proceso o mecanismo de generación geométrica de la forma y en la misma percepción del espacio, como si este tuviera todavía capacidad de variación. La obra de Borromini, y su mecanismo proyectual apuntan en esa dirección.

455. Simondón distinguirá entre el molde y el modulador. Así, hará notar que moldear es dar una forma estable y definitiva, modular es moldear de manera continua y perpetuamente variable. Simondon, La Individuación... 
La densidad de los pliegues pudiera intensificarse. El resultado formal lleva implícita una inconclusión. Es como una huida de la apariencia, una cierta resistencia a cerrarse en una forma definitiva.

Esta tensión inconclusa ${ }^{456}$ sintetiza el movimiento y la fuerza que lo produce. Semejante es la solución que artistas barrocos, de otras disciplinas como la pintura y la escultura, adoptan en sus obras. El Ragazzo morso da un ramarro de Caravaggio se representa en un instante que no concluye en la escena y el David de Bernini no se limita a exponerse en su inmutable belleza, se presenta en el proceso de lanzamiento de un proyectil, insinuando la inconclusión de su forma. Son instantáneas de un proceso que no se termina en el acto que se representa, sino que caracteriza más bien la fuerza que lo mueve.

La noción de Pathosformer de Aby Wargburg también ayuda a la comprensión de lo que venimos observando en su doble relación con el espacio, pero también con el tiempo. Se encuentra en el centro de los resultados del análisis de esta investigación.

La Pathosformer se constituye como una noción agitada, apasionada (...), combatiendo en cada instante con la complejidad hormigueante de las cosas del espacio, y la complejidad de intervalos de las cosas del tiempo ${ }^{457}$.

La forma en devenir, no podría nunca representarse. Hay una cierta contradicción entre forma y fuerza, que podría resolverse en este concepto de lo in-forme que venimos aplicando. Pero en la arquitectura, forma y fuerza deben unirse necesariamente en el intento de representar lo invisible. Es a través del concepto de Pathosformer como Warburg consigue unir estas dos cosas que el pensamiento parece concebir como contradictorias: la fuerza y la forma. El Pathosformer es por lo que la imagen late, se mueve, se debate en la polaridad de las cosas.

El Pathosformer, así entendido, encierra en su condición de forma subordinada, sometida a la fuerza, que es su instabilidad. Esta fuerza se desarrolla y tiene lugar en un fondo, que expresa su potencialidad.
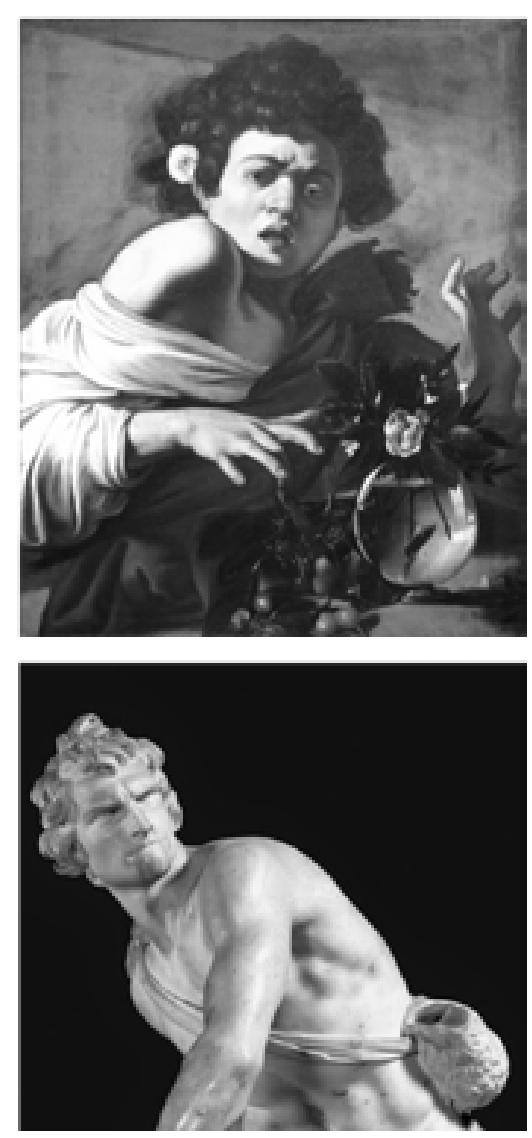

2.94. Ragazzo morso da in ramarro. CARAVAGGIO. 1594

2.95. David. BERNINI. 1624. 
La arquitectura no posee el recurso de fabricar móviles, tampoco la pintura o la escultura, pero la materia inmóvil puede sugerir siempre un cambio, las actitudes inestables en suspenso entre un antes y un después:

(...) las vistas instantáneas, las actitudes inestables, petrifican el movimiento. $45^{8}$

En todos estos casos hay una condición de mutabilidad que lleva una fuerza implícita; la sucesión de variaciones queda plasmadas en la solución formal adoptada dejando latente en la obra un proceso que, en el caso de la arquitectura, queda actualizado provisionalmente en los límites del espacio. Sin embargo, hay como una negación del contorno del espacio como límite estable, es, en definitiva, como una exigencia subyacente: la disolución de la forma.

Lo informe que señala Cache como consecuencia de la inflexión vuelve a manifestarse, así como la sustitución que propone $\mathrm{Si}$ mondón del término forma por el de in-formación ${ }^{459}$, dar forma, para Simondón es in-formar, lo que supone una aportación. Así el acontecimiento deleuziano, ya analizado, podría tomar valor de información. Todo apunta a una forma no cerrada, que sugiere un devenir, una inestabilidad. 
Como consecuencia podríamos sostener que la forma arquitectónica borrominiana lleva una dinámica implícita, una potencia de ser otra cosa. Así sus formas están más cerca de la desmesura que de la medida primera. Como Gilles Deleuze ${ }^{460}$ ha dicho en su texto sobre el Pliegue, existe una jerarquía ontológica que considera las cosas desde el punto de vista de la potencia. Borromini desarrolla la potencia, y parece llevarla hasta su límite. El límite ya no es aquí lo que mantiene a la cosa bajo una ley, que sería la ley de la mesura representada por Apolo en el templo de Delfos, sino aquello a partir de lo cual desarrolla su potencia hasta el final.

Borromini hace de la metamorfosis un argumento de proyecto a través de su obra construida y su forma de proyectar. Una metamorfosis que parece apuntar a una voluntad de traspasar los límites de lo individual, una huida de la apariencia, una fusión en la unidad del sistema pre-individual, del medio donde se da la determinación, obligada a descargarse en una apariencia concreta, que es casi una forma extrema.

Nietzsche al referirse a la tragedia griega señala como la mesura en sentido helénico, está referida al mantenimiento de los límites del individuo. Y la divinización de la individuación, representada por Apolo, exige mesura a los suyos. Por el contrario, la desmesura es reputada como cualidad propia de la época pre-apolinea, la edad de los titanes. Y esto titánico les parecía a los griegos producido por lo dionisiaco. Pero hay una necesidad en Grecia de lo dionisiaco de igual grandeza que la necesidad estética de belleza representada por lo apolíneo: la desmesura entera de la naturaleza se da a conocer en placer, dolor y conocimiento ${ }^{461}$, dirá Nietzsche. El individuo con todos sus límites y medidas se sumerge en el olvido de sí propio de los estados dionisiacos.

La tragedia ática y el ditirambo dramático encarnarán para Nietzsche el lugar común de estos dos instintos.

Las fiestas dionisiacas de los griegos tienen el sentido de redención del mundo y transfiguración, y esta transfiguración está emparentada con la metamorfosis y la variación. En ellas se alcanza el

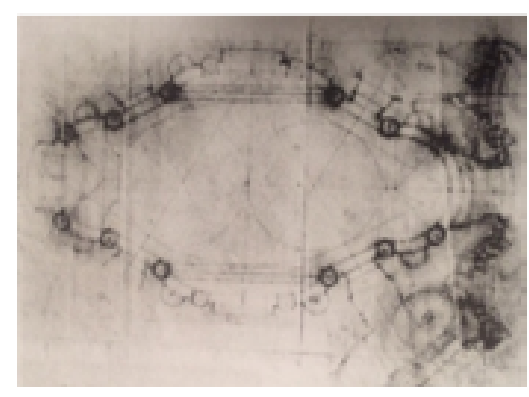

2.96. Croquis de San Carlino. BORROMINI. Albertina 169 
júbilo artístico a través del desgarramiento del principio de individuación. En ellas, dirá Nietzsche, irrumpe un rasgo sentimental de la naturaleza, como si esta hubiera de sollozar por su despedazamiento en individuos ${ }^{462}$.

Sitúa Nietzsche el origen de la tragedia en el coro trágico; esta al principio no era más que coro y solo coro. Y por este coro habla la sabiduría dionisiaca de la tragedia. El hombre griego se sentía absorto en presencia del coro trágico y adquiría un potente sentimiento de unidad, olvidando los abismos que separan a un hombre de otro y retrocediendo al mismo corazón de la naturaleza.

También Deleuze se ha referido de otra manera a esta cuestión:

Solo retornan las formas extremas, aquellas que-pequeñas o grandes- se despliegan en el límite y van hasta el fin de la potencia, transformándose y pasando las unas dentro de las otras. Solo retorna lo que es extremo, excesivo, lo que por el grado pleno de su intensidad traspasa dentro del otro y se vuelve idéntico. Ese es el motivo por el cual el eterno retorno se dice solo del mundo teatral, de la metamorfosis y de las máscaras (... 463

El organismo borrominiano sugiere una concepción renovada del concepto de naturaleza que se había tenido durante el Renacimiento; una naturaleza serena y estable, individuada en una apariencia placentera, basada en la proporción y el reconocimiento de figuras geométricas. En la arquitectura renacentista la geometría era un fin en sí misma, un reconocimiento de la individualidad de la forma según la sabiduría de Apolo. Pero la arquitectura barroca, en particular la versión que nos presenta Borromini, se acerca más a la presencia de Dioniso, que se expresa a través de sus croquis sometidos a continuas transformaciones, donde la densidad de versiones sobre la forma inicial, satura el dibujo; es como una sobresaturación del sistema homogéneo que dará lugar a una forma extrema, que parece llevar en sí potenciales no actualizados: forma en metamorfosis. La tensión que refleja su obra, y su debate interno entre la complejidad de sus encargos y su respuesta en una unidad formal que ya no puede resolverse con los presupuestos renacentistas, parece dar cuenta de lo que constituye la tragedia de la representación, la exigencia insuperable de manifestarse en una representación cerrada y concreta. 
Todo ello manifiesta ese sollozo de la naturaleza por su desgarramiento en individuos al que se refiere Nietzsche.

Vibración, plegado, fusión de espacios en una unidad compleja, con el ritmo intensificado de los pliegues como una corriente unitaria de una melodía: este es el nuevo estatuto de este espacio barroco. La forma (o lo informe, o lo in-formado) resultante parece ser solo una máscara, una de las transformaciones que se suceden en los croquis, así como el coro ditirámbico es un coro de transformados (...) el entusiasmo dionisiaco ve, en su transformación, una nueva visión fuera de sí, como consumación apolínea de su estado. ${ }^{464}$

El estatuto de la forma de la arquitectura se ve afectado; ya no importa la integridad formal, es más, importa señalar que la forma nunca será estable, que hay un fondo del que surge y que la condiciona, un medio que la hace posible. Se trata de representar, teatralizar, la tragedia constituida sobre la clausura de la representación, como lugar imposible.

Pensar la clausura de la representaciónes es pensar lo trágico: no como representación del destino sino como destino de la representación. Su necesidad gratuita y sin fondo. ${ }^{465}$

La mesura impuesta sobre el espacio renacentista se ve quebrada, y los límites del espacio se ponen en cuestión. Hay una negación del contorno como límite, pues este se disgrega plegándose, en una especie de generación sin fin aparente, que inducirá el punto de inflexión. Si el arte clásico se atiene a los límites y no admite ninguna forma que no se exprese en un motivo lineal determinado, el Barroco niega el contorno ${ }^{466}$ a través de pliegues, topologías, densidades. El límite no se manifiesta como contorno geométrico, es más bien el lugar donde una potencia se ejerce; un ámbito o zona, un lugar menos estable, donde actúa la fuerza. Y esta negación del límite como contorno responde a la voluntad de negar la individuación de la obra, su apariencia; un rechazo a presentar la forma en su integridad, y presentarla en cambio conteniendo una carga de realidad pre-individual que encierra potenciales.

464. FRIEDRICH NIETZSCHE, El nacimiento de la tragedia, op. cit., pág. 101.

465. JAQUES DERRIDA, El tiempo de una tesis: Deconstrucción e implicaciones, Anthopos, Barcelona 2017, pág. 7.

466. Cifr. H WOLFFLIN. Conceptos fundamentales en la historia del arte. Madrid, 1989.
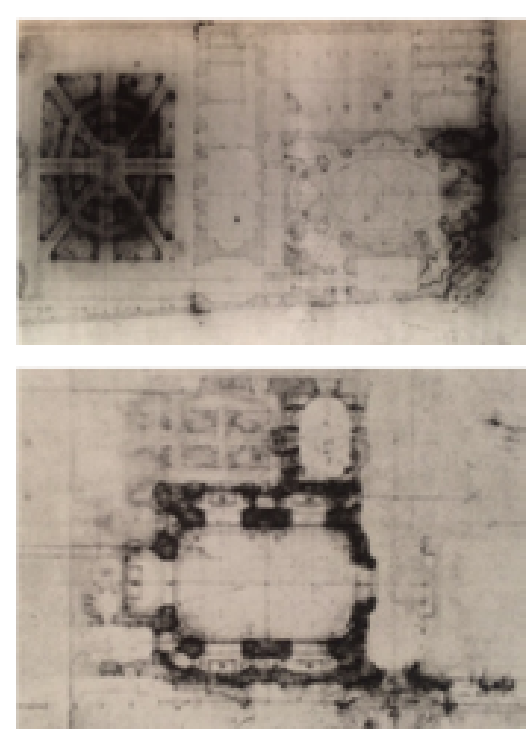

2.97. Croquis del conjunto de San Carlino. BORROMINI. Albertina 173 2.98. Croquis de la capilla de los Reyes Magos. BORROMINI, 1662. Albertina 889. 
2.99. Iglesia Sant'Ivo alla Sapienza. Remate de la linterna

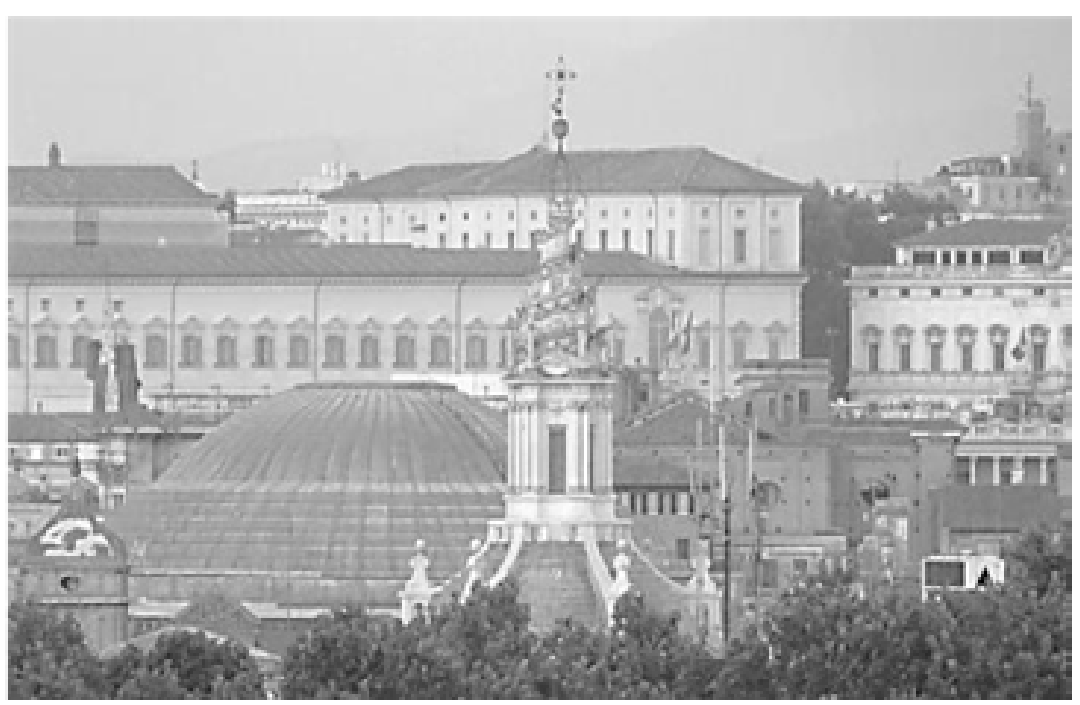

Así, tras la forma de expresión de Borromini, subyacía su proceso de formalización en sus dibujos, su método de proyecto, como una metáfora de lo informe, en la que los bordes aparecen desdibujados, diluidos, desmaterializándose. Borromini marca literalmente con sus dibujos el proceso de formalización. También, al acercarnos al cuadro de Las Meninas de Velázquez, podremos ver del mismo modo como los límites de las figuras se desintegran, se desdibujan en pequeños trazos. El Barroco no delinea, no provoca contorno, lo desintegra, lo desdibuja, cambia el contorno, por un ámbito, una zona compleja de formalización.

Nietzsche señala que el mantenimiento de los límites del individuo marchan paralelos a la necesidad estética de la belleza ${ }^{467}$. Pero ahora el estatuto de la forma se abre a la desmesura, a la Hybrys, lo individual-formal se ha olvidado de sí, ingresando en un continum, donde no es posible identificar lo individual, la diferencia, que retrotrae al corazón de esa otra naturaleza, una unidad, como diría Nietzsche, con el fondo más íntimo del mundo.

El Coro trágico que Nietzsche nos describe, es la expresión suprema, dionisiaca de la naturaleza, de esta naturaleza cuya noción es renovada en la expresión de los espacios borrominianos. Todas las fuerzas sentidas están obligadas a condensarse en imagen, como ese:

Coro dionisiaco, que una y otra vez se descarga en un mundo apolíneo de imágenes ${ }^{468}$. 
Yasí...

Borromini, partiendo de un triángulo equilátero, (por ejemplo, como hace en la iglesia de Sant'Ivo alla Sapienza), lo hace proliferar geométricamente a partir de sí mismo y a través de simetrías, circunferencias, ejes, tangencias, circunscripciones... Y todo ello produce una planta que muestra abiertamente la inestabilidad de un flujo fluido, y que evoluciona en una linterna, que ya no admite simetría, ni plano privilegiado de proyección; deviene turbulenta y se realiza por proliferación. La línea se repliega en espiral para desembocar en un movimiento suspendido entre el cielo y la tierra, y desaparece el contorno que se difumina en espuma o crines ${ }^{469}$ subiendo por encima de las cubiertas romanas y apareciendo junto al Pantheon, allí siempre, señalando al cielo a ese Dios de Spinoza, a La Sustancia, a la naturaleza. 
La aproximación metafórica al mundo forma parte del Barroco, y así el pensamiento analógico estructura toda la cultura de la épo$\mathrm{ca}^{470}$. En el siglo XVII, la sociedad occidental evoluciona en un momento de grandes turbulencias en el que son cuestionados todos los esquemas de comprensión del mundo; estamos en los comienzos de la concepción moderna de la ciencia. Hay un proceso de modernización y de racionalización de un mundo que induce a una etapa transitoria.

No hay que olvidar tampoco que el arte barroco es un arte de la Contrarreforma. La Iglesia católica se nutre de medios espirituales y materiales para comenzar una reconquista de las almas tomadas desde entonces por las Iglesias protestantes. Intenta así comenzar una cierta forma de renacimiento religioso a través del mantenimiento de su antiguo sistema de pensamiento (analógico, entonces), volviéndolo más actual y atractivo.

Una de las respuestas posibles, que se expresa en el arte, la elegida por la Iglesia, es el uso de la retórica, de la puesta en escena, de la teatralidad, gracias fundamentalmente a la enseñanza de los Jesuitas. La solución de los escritores y artistas barrocos para conciliar estas dos concepciones opuestas del conocimiento, se sitúa entonces en los juegos del lenguaje que pueden dejar fluctuar el sentido guiando sutilmente la interpretación, o por decir peyorativamente, manipulando las masas. Gracias a su fundación sobre el sentido, el pensamiento analógico es un elemento retórico importante.

La retórica no es solamente una herramienta privilegiada de la Iglesia. Ella infiltra todos los niveles de la cultura, artísticos y materiales. El gusto por la retórica y su teatralidad lleva a pensar que es lo que parece, y así a anteponer la apariencia y por tanto, la ilusión. La puesta en escena se vuelve más atractiva que la realidad, se da así, la arquitectura del espectáculo, la preponderancia de lo visual, el carácter afectivo que entra en juego en las experimentaciones. Así, los juegos del lenguaje Barrocos tienen su relación con la teatralidad, la representación, la metamorfosis o el performismo. 
Las cuestiones históricas podrían aportar razones a una evidencia que tiene lugar en las manifestaciones artísticas barrocas. Deleuze encuentra este espíritu de lo performativo en la filosofía de Leibniz, y así habla de la diferenciación en la materia como una epigénesis, la diferenciación a partir de un indiferenciado.

El performismo es la forma bajo la cual se percibe la verdad en el siglo XVII. 471

Se da así una metamorfosis sobre un continuo que otorga las condiciones de posibilidad de un modo de aparición, de una expresión performativa.

Si recurrimos al propio Leibniz, este habla expresamente de un performismo, de una metamorfosis. La materialidad para él, está en perpetuo flujo, todo cambia, lo llama plenum, como hemos visto; toda la materia está conexa y todo movimiento produce algún efecto.

Esta visión del mundo remite a la noción de lo virtual que tanto interesa a Deleuze. Para el filósofo, lo virtual es lo que existe potencialmente pero no de facto. Así, lo virtual no se opone a lo real, sino solamente a lo actual. Lo virtual posee una realidad plena, en tanto que virtual...472. Lo virtual debe igualmente ser definido como parte estricta del objeto real. Para Deleuze, lo virtual es potencial y esta potencia remite a una fuerza que opera más allá de su definición física, también ontológica.

La inflexión es aquí del orden de lo virtual, del potencial. Es una figura que permanece en el estado de lo posible en el imaginario y en el lenguaje, y puede desarrollarse en los numerosos niveles de la arquitectura y a un nivel más trascendental (su más alto poder), del pensamiento. Deleuze desea así sacar partido del poder de evocación de la inflexión.

El poder de inflexión actúa tanto en la mecánica de las ideas como en el surgimiento de las formas. Y la forma-pliegue puede ser considerada como paradigmática en este orden de lo virtual; el pliegue es siempre una operación (la operación de plegado), tiene un carácter dinámico, tiene la condición de un proceso generativo, no es solo una forma a aplicar. El pliegue además es siempre autore- 
ferencial, consiste en cubrir una parte con otra (esta es la analogía más directa con la mónada de Leibniz). La forma-pliegue remite a la vez a un continuo y a una variación. Acompaña a un proceso de pliegue-despliegue, intensificación-relajación de la materia, una materia en transformación, materia performativa. Los objetos son concebidos como acontecimientos del proceso, juegos de ilusión, efectos.

Esta performación trata en último término de una morfogénesis, de la elaboración de la forma. La forma es como un paro posible en el proceso entre tantos otros de su desarrollo. El objeto ya no existe más que a través de su metamorfosis, sus declinaciones. Todo este proceso teatral, performativo, remite a la representación de la serie de modos de formalización.

\subsubsection{Metamorfosis digitales}

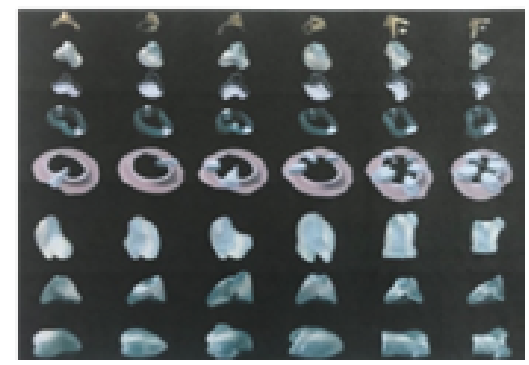

Los arquitectos Bernard Cache y Greg Lynn, ya citados en anteriores apartados de esta tesis, experimentan en los años 90 del siglo pasado sobre esta cuestión, en relación con el nacimiento de las herramientas digitales y los programas $3 \mathrm{D}^{473}$, que permiten una experiencia inmediata sobre la forma, parametrizandola desde los distintos ámbitos que intervienen en la arquitectura. Ambos obtienen así objetos como el Blob de Lynn, o el Objetil de Cache

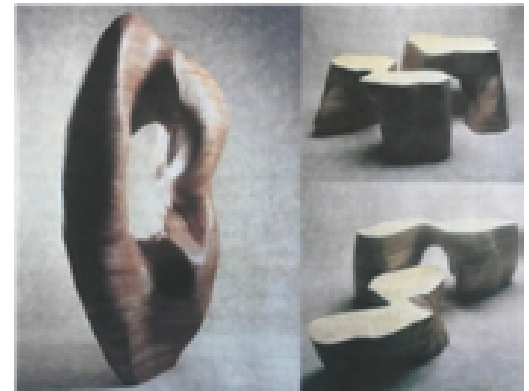

2.100. Embryological Houses. Descomposición de los constituyentes y su variaciones. GREG LYNN, 1997-2001

2.101. Objectil. Toro doblado entero y dividido en madera. BERNARD CACHE, 1991 (citado en varias ocasiones en El Pliegue de Deleuze), que representan objetos en perpetua formación; Blob u Objetil, no son formas concretas, son objetos posibles, diferentes modos de un proceso performativo.

El caso del blob de Lynn, remite a una serie que implica variaciones sobre la forma, personalizaciones. En el caso del objetil de Cache, se trata de aplicación de deformaciones sobre un mismo objeto que, por ello, no mantiene una forma estable.

Con ello, estos arquitectos proponen una especie de no estandarización ${ }^{474}$, contraponiendo así a la idea de estandarización de la arquitectura, que caracterizaba muchas de las reflexiones de la arquitectura moderna.

473. FLORENCE PLIHON, Architectures Numériques et Résurgence Baroque: Bernard Cache, Greg Lynn et le Pli de Deleuze, Architecture, aménagement de l'espace. Université Charles de Gaulle - Lille III, 2016.

474. En 2003 se inaugura una exposición dirigida por Frédéric Mygayrou en el Centro Pompidou de París titulada Architectures non standard, donde coinciden los dos arquitectos Greg Lynn y Bernard Cache. 
Así, en las Embryological houses de Greg Lynn, se propone una especie de customización a nivel de casa individual. Cada una es la resultante de un mismo modelo, aunque resultan muy diferentes pues se las hace variar en función de una serie de parámetros.

Se trata del intento de industrializar lo no estándar, al modo, por ejemplo, cómo lo hace la industria del automóvil. Hemos visto la autoreferencialidad que conlleva el proceso del pliegue; las referencias que se parametrizan pueden bien remitir al individuo, señalando así a la importancia que adquiera la diferencia, que se torna entonces en diferencia constituyente. Todo el proceso de cambio y diferencia es expresado siempre en series, con gran similitud a una serie de los croquis de Borromini en sus diferentes variaciones.

Los ejemplos del Objetil y el Blob son conceptos de objetos que son generados digitalmente y que cuestionan el principio de unicidad de la forma, puesto que esta está inscrita en una serie o bien se trata de una forma no estable. Estos experimentos permiten dar sentido y lugar a los posibles, explorando la forma y su génesis. Lynn no construye sus formas digitales experimentales. Bernard Cache lo hace a nivel de maqueta o mueble, pero la dificultad que encuentran es desarrollarlo como forma arquitectónica construida. Es quizás este su límite.

\subsubsection{Inestabilidad formal: series contemporáneas}

El despliegue no es lo contrario del pliegue sino su continuación o la extensión de su acto la condición de su manifestación. ${ }^{475}$

El tema de las series ha sido y es recurrente en otro tipo de manifestaciones del arte actual; las series muestran repetición de un tema que va variando en cada elemento de la serie, una especie de despliegue performativo sobre un motivo. Se trata de un despliegue temporal sobre transformaciones formales.

La forma está así en el centro de las experimentaciones, se trabaja sobre su manipulación, sus deformaciones y su capacidad de integrar las diferentes fuerzas que la afectan, imprimiéndola inestabilidad. La forma se torna contingente, se vuelve relativa, puesta
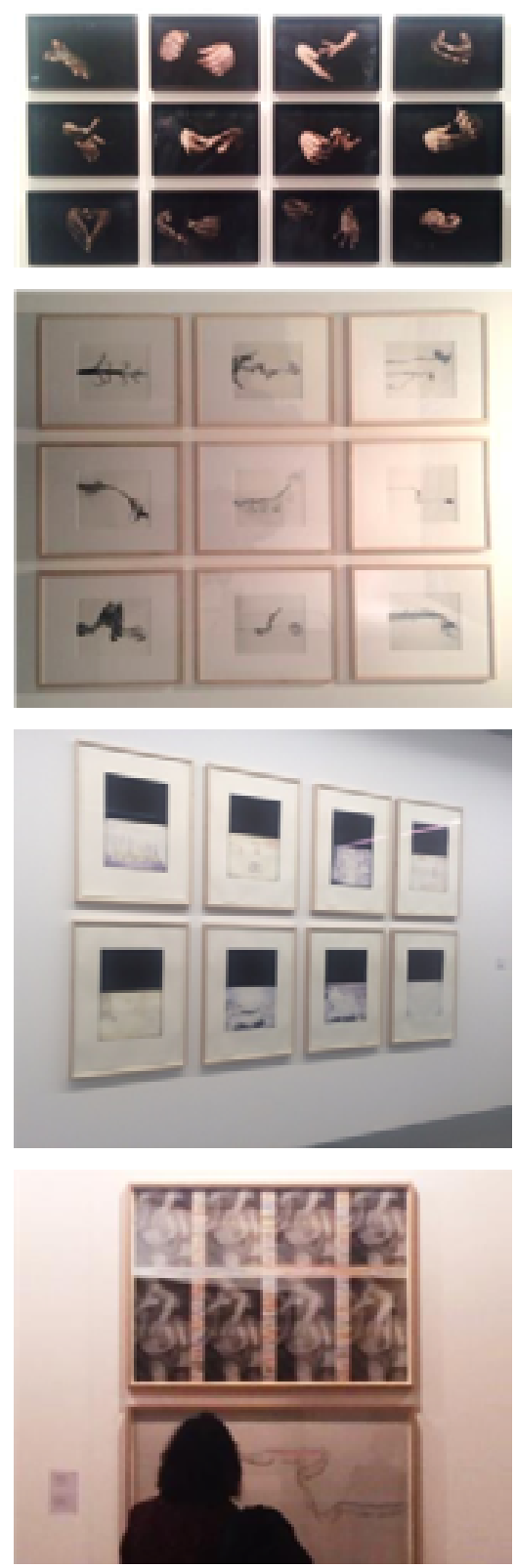

2.102. Series. Fotografía tomadas en Arco. Varios autores, 2018. 
$\operatorname{mog} 0000$
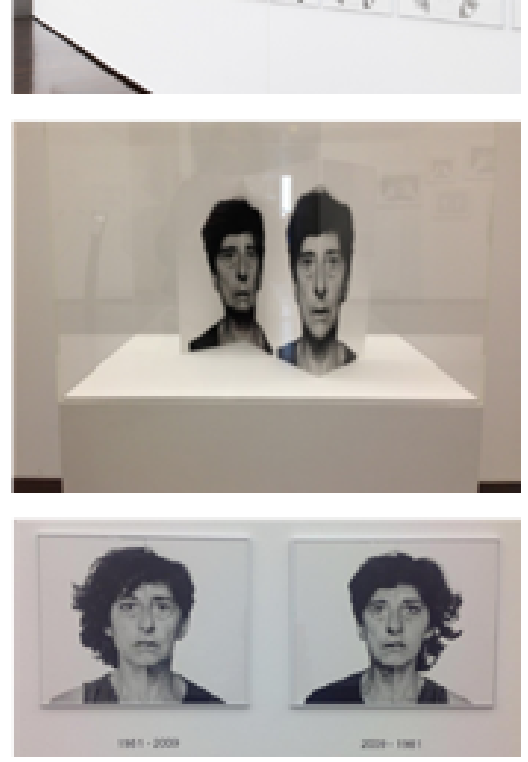

2.103. Autorretrato en el espacio. ESTHER FERRER. 1987-2014

2.104. Autorretrato en el tiempo. ESTHER FERRER, 1987-2014

2.105. Autorretrato plegado. ESTHER FERRER, 1986-2014 en perspectiva, no responde ya a modelo alguno ideal o finito. No es más que una fase en el flujo de deformaciones posibles. Tomada en una serie es una respuesta posible en el instante $t$. Pone en cuestión el modelo, el ideal, el original, a través de la repetición, del mismo modo como hemos visto en la repetición de elementos en arquitectura.

Las series contemporáneas son el despliegue de la forma en sus manifestaciones, que ya no se dan tanto como formas, sino, más bien, como formas de expresión, formas de presentarse, desplegamientos. La pareja materia- forma, se sustituye por la de material-fuerza.

Como ejemplo, la artista Esther Ferrer investiga sobre la inestabilidad real de la forma con sus propios autorretratos tomados a lo largo del tiempo, y que expone también a modo de serie. Ferrer nombra, así mismo la metamorfosis de forma similar y experimenta con el pliegue. Lo diferente performativo no se limita al tiempo sino también al espacio. La variación no solo está referida a la huella del tiempo, reside también en el punto de vista, que, como ya sabemos, está contenido en el pliegue.

Los autorretratos de Ferrer, ponen en cuestión el retrato tradicional, arrastrando con ello al sujeto moderno como determinación estable, incluyéndolo en un ciclo de vida perecedero y performativo, rebajando su valor central a partir del cual se desarrolla la modernidad. El tiempo arrastra consigo la imagen estable. Pero también el espacio lo hace. Autorretato en el espacio repite la misma imagen con diferente perspectiva o con distinta luz, se trata de la paradoja de la repetición según la tesis de Hume:

La repetición no modifica nada en el objeto que se repite, pero cambia algo en el espíritu que la contempla ${ }^{476}$.

Del mismo modo, el autorretrato plegado deforma la imagen de diferentes modos a partir de la perturbación de la propia imagen.

En los tres casos se alude a la inestabilidad de la forma, a través de un despliegue metamórfico.

476. DAVID HUME, Traducción al castellano de Félix Duque, Tratado de la naturaleza humana, Tecnos, Madrid 2008. Citado por Gilles Deleuze, Diferencia y Repetición, op. cit. 
Esta estética de lo performativo, se mantiene entonces vinculada al tema de la repetición-variación analizado más arriba ${ }^{477}$. La variación temporal-espacial como generadora de la diferencia. Se trata de un modo distinto de expresión de lo mismo. Si como Deleuze ha señalado, para que la diferencia emerja, hay que hacer subir los fondos, y disolver la forma, en estos casos, es la diferencia misma la que se determina en la propia forma, pero para ello, la forma no puede ser una única determinación, requiere de la serie, del despliegue, aunque se trate de otra forma de disolverla.

Por otra parte, la introducción del tiempo en muchas de las series, tiene también una relación con una cierta estética de lo efímero lo veremos más adelante ${ }^{478}$. La necesidad de mostrar lo efímero, queda impresa en estas obras contemporáneas, que expresan de nuevo ese aspecto trágico: la imposibilidad de representar la realidad inestable.

Borromini proyecta topológicamente en el espacio con referencias enlazadas que generan una forma que va variando sobre su croquis. El objeto a proyectar, es único, y los diferentes dibujos, puestos en forma de serie, inciden en la metamorfosis formal a lo largo del proceso, diríamos que son intensivos si los superponemos (plegados). Sin embargo, si lo que hacemos es mostrar los dibujos desplegados, tendremos una correspondencia con las series metamórficas contemporáneas, despliegue que señala una inestabilidad temporal; la imposibilidad de representar la realidad de una determinación que nunca será estable. El tema barroco de la metamorfosis.

\subsubsection{Organismos contemporáneos}

En arquitectura, los experimentos de los años 9o de Cache y Lynn, señalan un límite, que quizás esté en la escala. Lo que para la época son imágenes digitales que, por ejemplo, pueden ser imágenes impresionantes en el ámbito cinematográfico, en arquitectura plantea problemas en el paso a la producción. La arquitectura contiene en su esencia un fuerte condicionante tectónico ligado a la gravedad, y por otra parte la tecnología de los años 90 no era suficientemente sofisticada para producir ciertas superficies que sí que se generaban virtualmente por medios digitales. Pero en la

477. Véase supra, parte II, capitulo 2: repetición-variación, pág. 183-198.

478. Véase infra, Capitulo 6: Reflexión sobre el tiempo. El estatuto de la naturaleza, una estética de lo efímero, págs. 377-404.
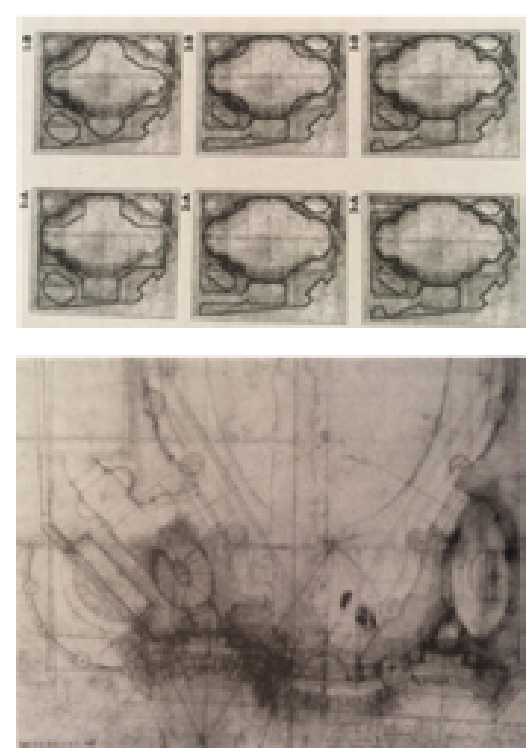

2.106. Dibujos del profesor Eusebio Alonso sobre el original (Albertina 171), de la evolución proyectual de San Carlino. 2.107. Fragmento de un croquis de la planta de San Carlino. Albertina 176
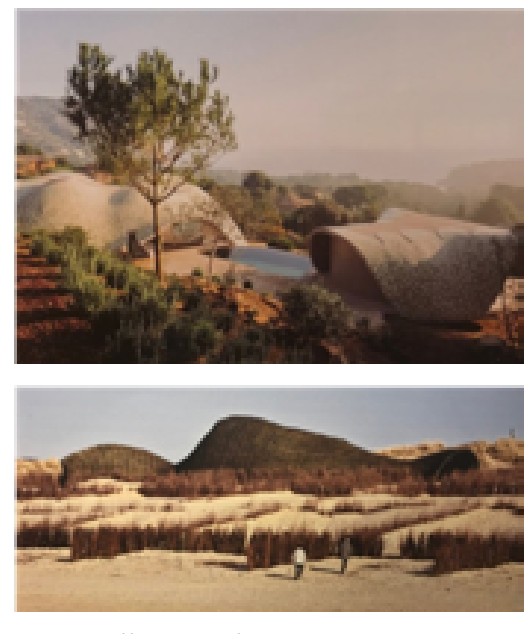

2.108.Villa Stgilat, Girona. ENRIC RUIZ-GELI, 2019

2.109. Sandworm, instalación artística en Wenduine, Bélgica. MARCO CASAGRANDE, 2019 

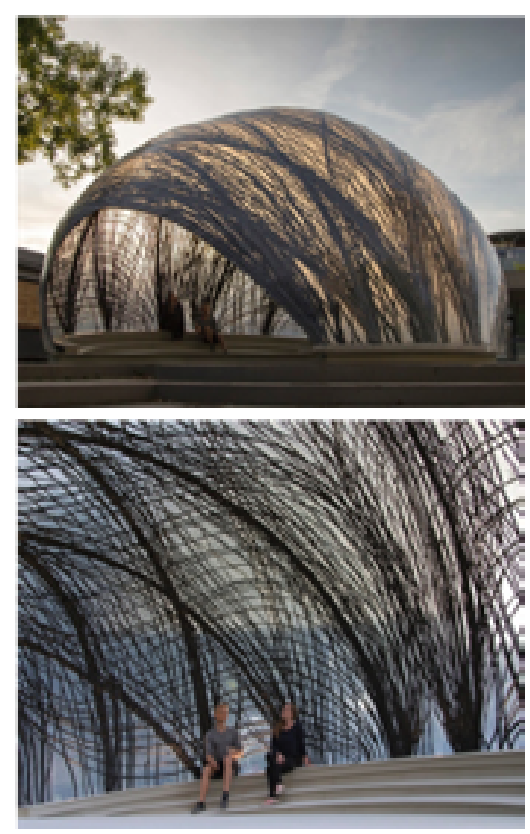

2.110. Pabellón ICD, Stuttgard. MENGES Y KNIPPERS, 2015.
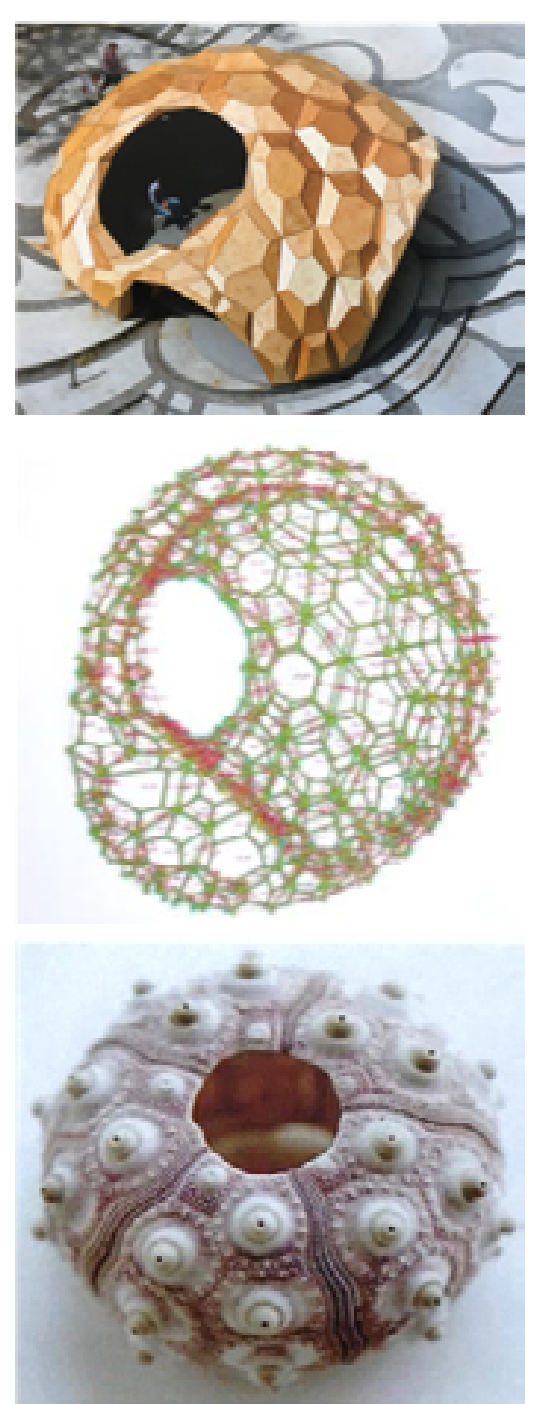

2.111. Pabellón ICD, Stuttgard. MENGES Y KNIPPERS, 2011. arquitectura contemporánea, más de 20 años después, podemos encontrar ejemplos que remiten a estos experimentos iniciales de los años 9o. La forma metamorfoseada por las condiciones, por las fuerzas, se abre camino en la arquitectura actual, donde las posibilidades técnicas de los materiales y la industria de la construcción, resultan definitivos para su producción.

Los objetos digitales de Cache y Lynn parecen ser construibles como arquitecturas reales en la actualidad. Estas arquitecturas remiten a formas metaestables, una especie de organismos en transformación. Se asemejan a formas animales u orgánicas, incluso se mimetizan con la naturaleza simulando su continuidad, simulando dunas de arena o montículos que forman parte del paisaje, y que se modificarán con el viento. Se trata normalmente de implantaciones adaptadas a la topografía que se constituyen con una geometría compleja con inspiración orgánica, evocando formas naturales, que, de serlo, no serían formas estables.

Sus formas construidas resultan de analogías orgánicas y son generadas por ordenador, parametrizando en muchos casos formas naturales o animales.

\section{El pabellón ICD de Stuttgard, creado en 2015 por Menges y} Knippers, en colaboración con el Instituto para el Diseño Computacional, está inspirado en la configuración del nido subacuático de la araña de agua. Como muchas de sus arquitecturas, es una singular construcción efímera. Su diseño se basa en criterios de investigación estructural que toman modelos de la naturaleza para aprovechar sus cualidades, en un singular intento de experimentación formal.

Los mismos autores diseñan otro pabellón en 2011; una pieza de madera cuya compleja geometría se inspira en la singular forma de un erizo de mar. Es el resultado de un proceso de investigación basado en el análisis de sistemas biológicos, en otro tanteo de la posibilidad de transferencias morfológicas desde el reino animal a la arquitectura. Siempre con el apoyo de herramientas y modelos de construcción robotizada. Se basa en el análisis morfológico de una variedad de erizo de mar, cuyo singular caparazón está construido de un sistema modulado de placas poligonales 479 .

479. Cifr. ARQUITECTURA VIVA №141, Espacios efímeros. Entre la celebración y la innovación. "Espacios efímeros. Analogías orgánicas, pabellón ICD”. Fernández-Galiano, L. (ed.), Madrid 2011. 


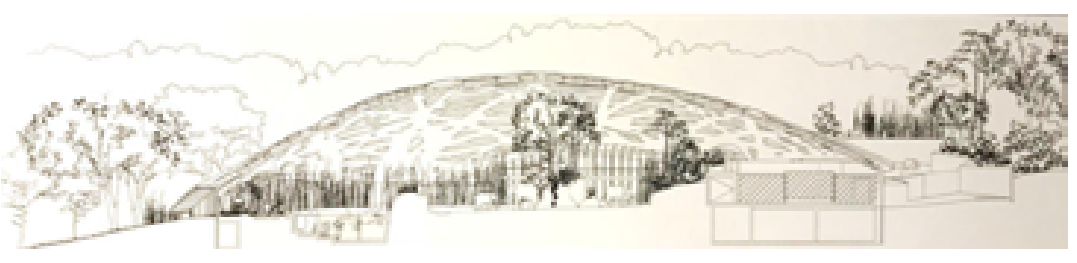

La casa para elefantes de Zurich de Markus Schietsch se conforma por una cúpula de madera que se mimetiza con el entorno, como capturando un trozo de naturaleza. La cúpula está realizada con piezas de madera formando 3 capas distintas que se diseñan por ordenador y se cortan por máquinas de corte numérico. La tecnología digital permite la construcción de esta especie de organismos capaces de regular un interior y de configurar superficies complejas. Así, una especie de parametrización de las condiciones configura el resultado formal, tal como lo anunciaban los modelos de Cache y Lynn.

Christine Buci-Glucksmann ha calificado la imagen-flujo como un nuevo régimen de la imagen en la época de la globalización ${ }^{480}$. La primacía de la pantalla de los flujos de todo tipo desestabilizaba el arraigo terrestre como lugar de sentido, y así, los modelos de Cache y Lynn no podían tener lugar más que en formas pantállicas y modelos a escala provenientes de ellas. Presa entre el aquí y el en otra parte, la imagen circula, alterada, de modo que la pantalla y los flujos han servido de paradigmas de una nueva modalidad de arquitectura.

Hay un nuevo modo de intervención que Jean Nouvel llama infiltración: Una arquitectura que se impregna del paisaje y se impregna en el paisaje ${ }^{48}$. Al modo de organismos, estas arquitecturas remiten a una estética de lo provisional, de lo cambiante metamórfico. Su forma de mímesis en la naturaleza evoca una inestabilidad, un flujo, parece ser solamente un modo de presentarse, algo que no tiene permanencia. Se trata de una tematización de la apariencia, que en último término es solo un efecto de superficie.

Estas arquitecturas, como muchas de las analizadas en este texto de ambas temporalidades, evitan toda referencia a lo tectónico, a su estructura, a la gravedad que las condiciona, poniendo el acento en la piel, en la superficie que las envuelve como una materia enmascarada. Son paisajes de pieles digitales que trabajan la
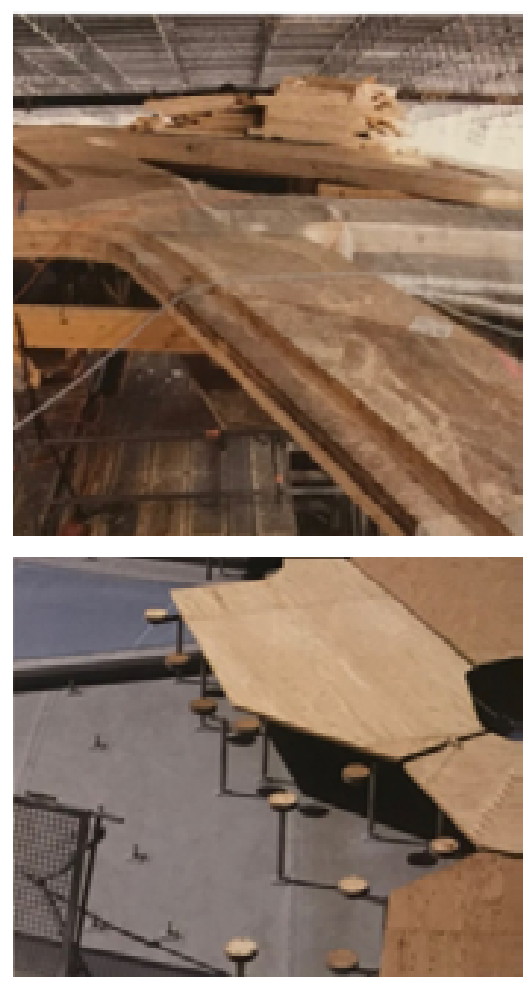

2.112. Casa para elefantes den Zurich, Suiza. MARKUS SCHIESTSCH ARCHITEKTEN, 2015 
noción misma de superficie cada vez más inmaterial y efímera, como un Neobarroco tecnológico. El elemento de la envolvente va a tener un papel radical en el estatuto de la forma que venimos estudiando; el análisis de la piel como límite formal va a darnos las claves de nuestro estudio en relación con todas las categorías que venimos observando. El carácter de las pieles sería como otro tipo de modulación de la misma cosa. 
Podemos considerar que el carácter metamórfico de la forma se vincula, una a una, con todas las categorías estudiadas hasta ahora. En todas ellas se encuentra implícita la idea de continuidad que la forma plegada anunciaba.

La inflexión, como recurso, es el elemento que introduce la variación en un continuo, el elemento potencial, el acontecimiento, que lleva implícita una creatividad, una aportación.

Pliegue, inflexión y continuidad, son los elementos propios del Barroco que se repiten en el libro de Deleuze, pero también nos hemos referido al propio Leibniz para encontrar en sus textos el concepto de continuidad. Se trata de ese plenum, ese fondo-espacio de posibilidad que se refiere al ámbito de lo pre-individual.

La forma pliegue podríamos considerarla como una forma extrema, y así enlazarla con la desmesura, como ha hecho Deleuze. Es en esa desmesura donde Nietzsche había visto lo esencial de las fiestas dionisiacas de los griegos, origen de la tragedia. El término in-forme, por otra parte, se refiere a algo informado o en proceso de información, algo no determinado todavía, pero también al exceso de esa forma extrema y desmesurada.

Se trata de un ciclo, de un eterno retorno, a la manera nietzschana, formas extremas, que han llegado al límite de su potencia, a la desmesura, y se metamorfosean y cambian; un proceso performativo, teatral y emparentado con la tragedia, donde el espíritu de Dionisos transmite ese júbilo artístico a través del desgarramiento del principio de individuación.

Borromini, con su procedimiento topológico de generación de la forma, que continúa en su obra construida, hace de la metamorfosis formal un argumento de proyecto. La forma parece variarse hasta determinarse en algo que se vincula con el movimiento y el cambio.

La estética contemporánea ha descompuesto definitivamente la forma en expresiones, en variaciones, que se refieren al proceso performativo explicitándolo en todos sus sentidos a través de series formales, que expresan el tiempo y el espacio, pero que también expresan de algún modo la diferencia. 
La aparición de organismos arquitectónicos también enuncia una forma provisional, en evolución o movimiento, por su propia condición de organismo. Una arquitectura metamorfoseada en animal o paisaje, siempre ajena a su condición tectónica, a las fuerzas estáticas que la condicionan.

La condición a-tectónica de todas estas arquitecturas, el encubrimiento de su componente estructural que es, en definitiva, su estabilidad, es la constante a través de la cual, todas las obras se identifican en esa paradoja barroca, a través de la cual, la condición de la arquitectura, su estabilidad tectónica, su necesario sometimiento a la gravedad, queda anulada, y lo que la obra expresa es inestabilidad formal en todos sus sentidos y modos de manifestarse. Se trata de simulacros. 


\section{EL ESTATUTO DE LA ENVOLVENTE}

La cuestión no es donde se detiene la forma, porque esta es una cuestión abstracta y artificial. La verdadera cuestión es: ¿Dónde se detiene una acción? (...) El límite de algo es el límite de su acción y no el contorno de su figura. ${ }^{482}$

No podemos dudar que el tema de la envolvente es por lo menos singular en la obra de Borromini. Hay una característica que podría aplicarse a todos los modos diferentes de tratar este tema en su obra: la intensidad. La intensidad en la frontera ${ }^{483}$ constituye uno de los temas específicos de Borromini. Pero la intensidad no tiene el sentido de claridad en la delineación; se trata de una intensidad que más bien diluye el límite como contorno, una intensidad de sucesos o recursos, que hacen que la delimitación no se haga precisa sino diluida o desdibujada, inestable.

Riegl ha señalado la negación del contorno que opera en el Barroco en general ${ }^{484}$. También Wölfflin nos dice:

El Barroco niega el contorno, no en el sentido de que sean excluidos los efectos de silueta, pero sí de evitar que la figura se fije en una silueta determinada (...). Desde ningún punto de vista se presentará la forma en su integridad. ${ }^{485}$

Se puede considerar que Borromini manifiesta en su obra esta negación del contorno como límite estable y así su forma-figura no podrá reconocerse en una silueta bien determinada.

La obra de Borromini responde a una serie de variaciones temáticas propias de la cultura barroca. Paolo Portoghesi enumera lo que considera operaciones típicas de nuestro autor: inversión, traducción, simplificación, metamorfosis, contracción, compenetración y deformación elástica ${ }^{486}$. Pero es muy significativa la caracte-

482. GILLES DELEUZE, Curso sobre Spinoza (17/02/1981)

483. EUSEBIO ALONSO, op. cit., pág. 154, nota 60.

484. ALOIS RIEGL, Problemas de estilo. Fundamentos para una historia de la ornamentación, Barcelona 1980.

485. HEINRICH WÖLFFLIN, Conceptos fundamentales de la historia del arte (1915), Madrid, 1989, pág. 94.

486. PAOLO PORTOGHESI, Borromini, op. cit. 
rización de los ritmos de un sistema dinámico que tensa la forma hasta la superación de sus límites.

El problema de la piel determina el carácter de la obra. La piel es el límite, y todo depende de las distintas maneras de abordar el tema del límite. Se trata de la tensión, la tensión tiene lugar en el límite. El límite no es ya el contorno de la obra, sino más bien hasta donde la obra llega. De la diferencia entre estas dos maneras de concebir el límite extraeremos el carácter de la obra.

El límite, por otra parte, tiene que ver con la materialidad de lo que contiene, con su cuerpo, pero también con el espacio que incluye y del que se genera. Materialidad y espacio están así íntimamente vinculadas con el límite-envolvente.

Tres son entonces las variables que juegan su papel en torno al concepto de la piel, de la envolvente: la importancia de la materialidad de la obra, la noción de límite, y la concepción del espacio.

Por otra parte, la problemática del límite-piel, trae consigo la relación interior-exterior en la arquitectura, que durante el Barroco histórico es singular. El límite podemos verlo no sólo desde el exterior, en arquitectura hay un límite visto desde el interior. Hay espacio exterior y espacio interior. Deleuze ha planteado ya este problema en su texto sobre el pliegue: la relación entre el exterior y el interior del pliegue.

Y Deleuze lo plantea, porque la cuestión tiene su paralelismo en el plano del pensamiento filosófico y es una problemática que da lugar a importantes reflexiones durante el siglo XVII. Se trata de la conexión de una interioridad que reside en el alma y una exterioridad común en relación con el mundo y las otras almas. La frase de Leibniz es muy significativa a este respecto:

Las Mónadas no tienen ventanas por las que pueda entrar o salir algo. ${ }^{487}$

El propio Deleuze en su texto utiliza el símil filosofía-arquitectura, como un deslizamiento teórico disciplinar, pero que resulta productivo para la reflexión paralela en ambos ámbitos, y lo hace precisamente refiriéndose a una obra de Borromini: 
Entre el interior y el exterior, la espontaneidad del adentro y la determinación del afuera, se necesitará un modo de correspondencia completamente nuevo que las arquitecturas pre-barrocas desconocían: ¿Qué relación necesaria y directa hay entre el interior de Santa Inés y su fachada?... Lejos de ajustarse a la estructura, la fachada barroca solo tiende a expresarse a sí misma. ${ }^{48}$

La cuestión de la relación exterior-interior atañe al proyecto de la envolvente y así, en el diseño concreto del ámbito del límite o la piel reside toda la carga teórica y práctica.

Vamos a analizar, en el primer apartado de este capítulo, la repercusión en la arquitectura de Borromini, de esta problemática exterior-interior, enlazándola previamente para contextualizar el problema, con las reflexiones filosóficas sobre la cuestión. 


\title{
5.1. LA RELACIÓN INTERIOR-EXTERIOR. EL INFINITO TIENE DOS PISOS
}

\begin{abstract}
El arte en su totalidad deviene Socius, espacio social público, poblado de bailarines barrocos (...) esta unidad colectiva en extensión, se supera hacia una unidad completamente distinta, comprensiva y espiritual, puntual, conceptual: el mundo como pirámide o cono, que une una ancha base material, perdida en los vapores, con una punta, fuente luminosa o punto de vista. ${ }^{489}$
\end{abstract}

El uso de todos los recursos formales vinculados a la inflexión, problematizan por sí mismos ya la distinción propia entre exterior e interior. Hay, por ejemplo, en el uso de la forma pliegue, un cuestionamiento de las nociones de dentro y fuera, que trae aparejada la reflexión sobre las relaciones entre ambos ámbitos.

Con la inflexión, la importancia concedida a la formalización del contorno es la de la experiencia ligada al límite entre las cosas. Toda la problemática del pliegue es la problemática de la piel; lo que se pliega en la arquitectura barroca son las pieles, la envolvente. Una envolvente que se examina desde ambos lados interior y exterior. La fuerza que partía del centro en el clasicismo se ha concentrado ahora en lo periférico y las pieles plegadas expresan la fuerza que ahora tienen en sí mismas a través de los pliegues, pero a su vez la disgregación de su contorno.

La cuestión del límite, o la envolvente en arquitectura, hace suscitar el problema de la relación entre interior y exterior. Podría objetarse que esta sería una noción de límite que atendería únicamente al límite como contorno, contorno generador de figura-forma cerrada y estática. Pero como hemos visto, la arquitectura de Borromini no solo atiende a esa dimensión del problema de la envolvente. La componente espacial pone en juego otra serie de variables que no se quedan únicamente en la figura limitada por el contorno: la continuidad del espacio, las singularidades, pliegues, inflexiones, como puntos potenciales, la emergencia de un espacio activo, que se pone en carga, e interviene en la formalización de la piel, etc. Es decir, todo apunta a lo que hemos llamado forma 
relativa, que nunca será la figura simple que marca un contorno cerrado.

Por otra parte, la conexión de un interior ligado al pensamiento, y un exterior, ligado a la extensión, constituye una problemática que está presente en la episteme cultural de la que forma parte nuestro arquitecto. En la filosofía del siglo XVII es un tema recurrente, comenzando por Descartes y Malebranch, y siguiendo por Spinoza y Leibniz. Problemática que, por otra parte, viene de antiguo y a la que la filosofía no ha sido nunca ajena, aunque con los filósofos barrocos la cuestión es primordial ${ }^{490}$.

Vemos como Gilles Deleuze en su texto, refiriéndose al pensamiento de Leibniz, plantea este problema desde el inicio. Comienza el libro con su conocido dibujo de los dos pisos; el inferior representa la materia, infinitamente plegada, relacionada con lo infinitesimal, con lo infinitamente pequeño, está perforado de ventanas; el piso de arriba representa el alma, con sus pliegues propios que van hasta el infinito, es ciego y cerrado, pero resonante, y recogerá los movimientos visibles de abajo. Así Deleuze nos dice que es como si el infinito tuviera dos pisos. También señala como Leibniz afirmará una comunicación entre esos dos pisos. El problema entonces residirá en cómo se da esa comunicación ${ }^{491}$.

A partir de la interpretación de Deleuze, Leibniz está pensando en un continuo en movimiento ${ }^{492}$, lleno de Pliegues-Mónadas que encierran un mundo cada una y que son los diferentes modos de expresión de ese mundo. Estos mundos permanecen en cada mónada y ya el problema pasará a ser, cómo se produce la relación entre ellos, cómo es posible la correspondencia entre los mundos que encierra cada una. Así, la importancia de la relación entre el exterior y el interior pasa a ser el punto central de atención; todo es una misma cosa y sus pliegues-piel pasan a constituir el criterio de constitución de las cosas.

Es Descartes el que plantea por primera vez esta cuestión, dividiendo la realidad en res extensa y res cognitas. Nos interesa más aquí, el modo de abordar el problema de los filósofos del Barroco

490. Más adelante, Kant, planteará el problema en otros términos; espacio y tiempo, serán respectivamente la forma de la exterioridad y la forma de la interioridad.

491. GILLES DELEUZE, El Pliegue, op. cit., pág 11-12.

492. Este movimiento no se puede entender como un movimiento físico espacio-temporal, como un cambio de lugar. Se trata más bien de un cambio o movimiento como devenir.

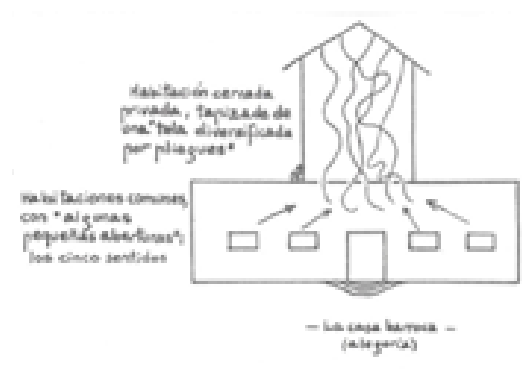

2.113. Dibujos del libro de Gilles Deleuze. El pliegue, Leibniz y el Baroco. 


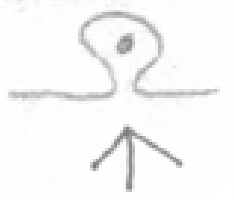

2.114. Dibujo de Borromini de la fachada de San Carlino y esquema de la autora sobre una "invaginación del afuera"

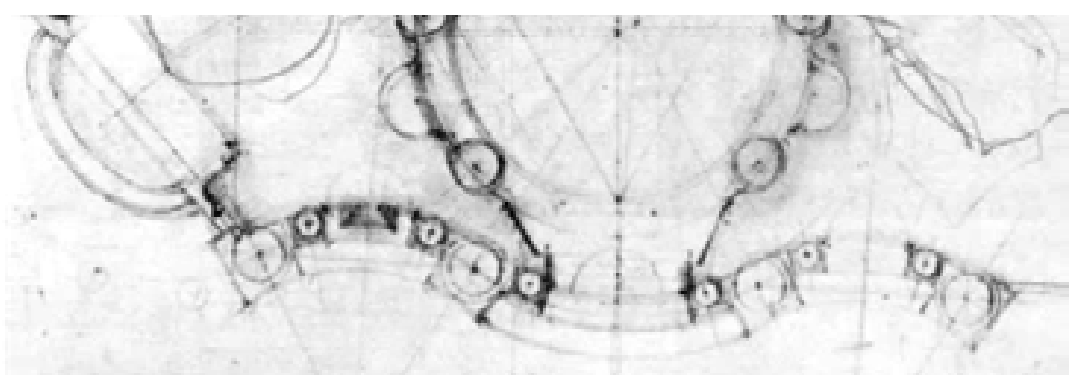

tardío, que creemos que más vinculación pueden tener (también Deleuze parece que se inclina por ello) con las manifestaciones arquitectónicas barrocas.

La cuestión también está presente en el pensamiento de Spinoza, para quien los dos atributos de una Sustancia única, son el pensamiento y la extensión, en igualdad de condiciones, con el mismo estatuto y sin jerarquía. Esto pone al cuerpo, y a la extensión donde este se desarrolla, en un plano de igualdad con el pensamiento (o alma), que durante largo tiempo había sido privilegiada. La importancia que Spinoza otorga al cuerpo está, como ya hemos visto, muy relacionada con la forma de abordar el espacio en Borromini.

Pero Spinoza también añade que estos dos atributos son paralelos, lo cual significa que nunca se tocan, pero también que discurren juntos siempre. Volvemos al problema de su relación.

La arquitectura barroca de algún modo expresa también esta problemática. El pliegue barroco separa entre el alma reflejada en el interior cerrado, y su cuerpo material volcado a los otros cuerpos, al espacio público. Y así la piel de la arquitectura también se pliega, como negando un contorno firme, desdibujando los límites físicos en la profundidad incierta de una piel plegada.

¿Estamos ante una doble exterioridad?493, ¿una interiorización del exterior?, ¿o como dirá Deleuze una invaginación del afuera? Todo exterior se cierra en un interior, que queda dentro del pliegue como una interioridad orgánica de espacio.

Pero esta invaginación del afuera en el Barroco es problemática, y el exterior y el interior, necesitan una correspondencia nueva que las arquitecturas pre-barrocas desconocen. Lejos de ajustarse a la configuración interior, la fachada barroca solo se expresa para afuera, mientras que el interior permanece cerrado.

493. Este concepto de doble exterioridad es desarrollado por el arquitecto Roi Salgueido en su tesis doctoral: Sobre los límites deformados. Inflexiones. Universitat Politecnica de Catalunya. ETSAB. Director de Tesis; Eduard Bru Bistuer. Mayo 2015. 
Todo parece responder a la distinción de los dos pisos descrita. La resonancia en el piso de arriba será individual para cada uno, será a su modo, a su manera. Esta cuestión traslada el problema a cómo estos modos o manierismos, se ponen de acuerdo, se concilian para conseguir una percepción común. Leibniz lo hará posible con lo que llama armonía universal, a través de su concepto de composibilidad, que resolverá esta escisión. Spinoza simplemente cree que ambas cosas son dos modos de expresión de la misma Sustancia.

Así, trasladando el problema a la arquitectura, el piso de abajo se encargará de la fachada que se desplegará respondiendo al exterior, se inflexionará orientándose hacia el afuera, como un espacio de receptividad. El piso de arriba corresponde al interior, que se cerrará sobre sí mismo, puro interior sin exterior, tapizándose de pliegues espontáneos ${ }^{49}$ al modo de una mónada. Pero que ese interior remita a las almas, y que el exterior sea algo físico y relacional, no impide que con todo se componga un mismo mundo regido por una misma y única armonía.

La cuestión principal reside en la piel, en el elemento plegado que ha hecho posible un interior, pero que permanece en una interioridad externa, pues contiene un mundo. Deleuze habla de una epigénesis, en el sentido de una diferenciación que va de lo general a lo espacial, diferenciación de un campo en principio indiferenciado, como una captura, concibiendo el organismo como un plegado original; el pliegue de esta epigénesis es la diferenciación de un indiferenciado.

Borronini concentra en el ámbito de la envolvente la energía del proyecto; su preocupación está en el espacio que esta acoge, pero envolvente y espacio trabajan en el mismo sentido. Por ello la piel adquiere espesor, es zona, es ámbito donde se ejercen las fuerzas, donde el espacio actúa. En San Carlino se puede apreciar bien el privilegio de la envolvente como espacio de proyecto y la definición de su superficie como geometría diferencial. El énfasis en la configuración de la piel da cuenta de este problema de fondo, esta relación exterior-interior, que desde varios ámbitos disciplinares, va a constituir la pregunta del Barroco. Todo exterior se pliega en un interior, y este interior que contiene el pliegue, contiene también el punto de vista, en la medida que representa la variación. $\mathrm{Y}$ ya hemos visto que este punto de vista en la obra de Borromini 
es inclusivo, ya no responde a esa distancia que el Renacimiento ponía, entre el cuadro y el espectador, ahora el cuerpo se incluye en el espacio, y no solo, se incluye también su movimiento en el mismo, como veíamos en San Carlino o en la galería Spada ${ }^{495}$. Se trata de una inclusión en el espacio plegado; se va del pliegue al envolvimiento, de la inflexión a la inclusión ${ }^{496}$.

Si analizamos la obra de Borromini, podemos observar como sucede esta aparente escisión entre un interior, como unidad conceptual, y un exterior en unidad colectiva, en relación con el entorno que articula.

Venturi, en su texto sobre la arquitectura de la complejidad y la contradicción, dedica un capítulo al tema de la relación exterior-interior ${ }^{497}$ y en él cita expresamente la arquitectura de Borromini al señalar que la continuidad de sus cuatro paredes en el interior, ayudan a exagerar la sensación de cerramiento horizontal y contribuyen a promover la separación y la unidad del espacio interior ${ }^{498}$. Los paramentos inflexionados del interior de la iglesia hacen del espacio, como hemos visto, un espacio inclusivo.

Entrar en la pequeña iglesia de San Carlino es como descubrir un cofre, la materialidad de su arquitectura de estuco, sin decoración apenas, sobria en superposiciones, te envuelve, parece como si el espacio impusiera su condición inestable. Se trata de ese espacio abarcante que hemos observado ${ }^{499}$. También Sant'Ivo se mueve hacia arriba, fluye en una geometría compleja y variable. Todo se disuelve en su linterna, y una especie de espuma exterior en su remate, desintegra la materia hacia arriba en una disipación del contorno. La iglesia se desarrolla en altura modelando un espacio interior que se estructura con respecto a si mismo en rotación ascendente y con un carácter envolvente.

Los espacios interiores de Borromini encierran e incluyen un lugar, envuelven como en el pliegue leibniziano generando un interior monádico, una especie de mundo, se trata de inclusiones. Se pasa de la curvatura variable al foco de la curvatura, al lado cónca-

495. Véase supra, capitulo 2: Topologías. 2.4. Espacios de inclusión, págs. 113-119. 496. Cifr. GILLES DELEUZE, El Pliegue... ¿Qué es el Barroco?

497. ROBERT VENTURI, Complejidad y Contradicción en arquitectura, op. cit., págs. 109-139.

498 Cifr. Ibid., pág. 110.

499. Veáse supra. pág. 248. 
vo, de la variación, al punto de vista, del pliegue al envolvimiento, a ese interior envolvente. Deleuze nota que la inclusión es la causa final del pliegue y convierte a la envoltura en la razón del pliegue ${ }^{500}$.

El pliegue es siempre autorreferencial y crea un interior que se separa radicalmente de un exterior. Como en la mónada, el foco (por analogía con el alma), se ha instalado en el interior del pliegue donde su mundo va a observarse, un mundo que lo incluye, un espacio que lo posibilita.

Por otra parte, está el exterior. Borromini proyecta la fachada de San Carlino muchos años después que el resto del conjunto. No acaba la fachada, pero está casi terminada cuando muere. Es su última obra. Puede ser que esta diferencia de años entre la construcción de una y otra cosa haya influido en el resultado, pero la cuestión es que en San Carlino la fachada se escinde, el plano se separa casi literalmente, atiende al exterior, al espacio de la calle, a las fuentes, a las sombras, al escorzo.

Borromini tiene en cuenta la fuente que se sitúa en la esquina y la incorpora desde el principio al diseño de la fachada, situando otro elemento similar al otro lado de la puerta, y pensando en una fachada simétrica. Gira levemente la fachada con respecto a la iglesia buscando el mejor ángulo para la calle; con este leve giro la fachada se despega; el exterior urbano es importante y sus condiciones son las que resolverán la traza.

La fachada se orienta al norte, por lo que únicamente recibe luz del sol lateralmente a primera y a última hora de la tarde. El juego de curvas cuando recibe la luz solar ofrece unos contrastes muy marcados que acentúan la curvatura del plano con el juego de sombras. Este exterior colectivo afecta al espacio público, urbano, y está pensado para él, para ser visto en escorzo, en una calle que quedará trasformada por un juego de pliegues acentuados con sombras; un exterior dramático, como en un teatro abierto, algo fantasmal, irreal. La fachada se ha desbordado ampliando los límites y extendiéndolos a la ciudad, con independencia de su interior, pero regida por los mismos criterios de proyecto.

Al contrario que en la utopía renacentista de perspectivas indiferentes y solitarias, la ciudad barroca es un gran teatro.

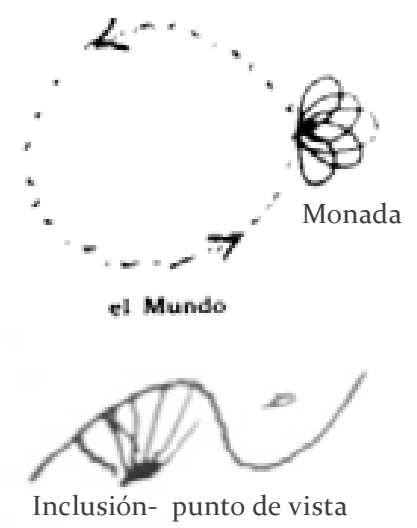

2.115. Dibujo en el libro de Gille Deleuze, El pliegue, Leibniz y el Barroco
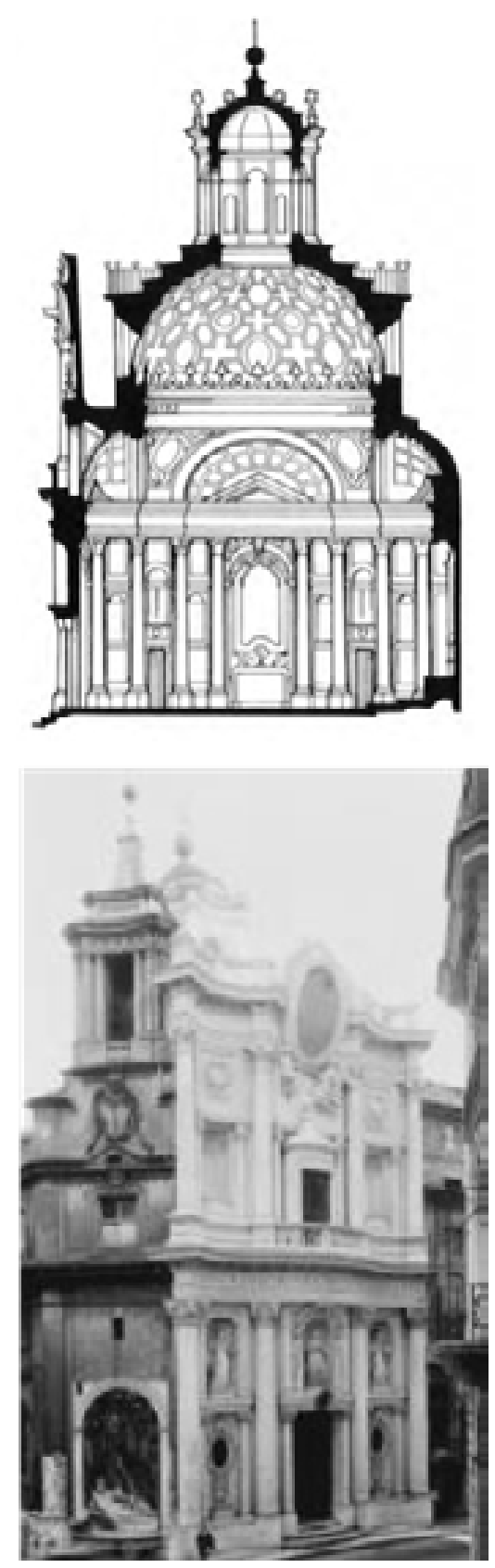

2.116. Sección y fachada de la iglesia de San Carlino alle Quattro Fontane 


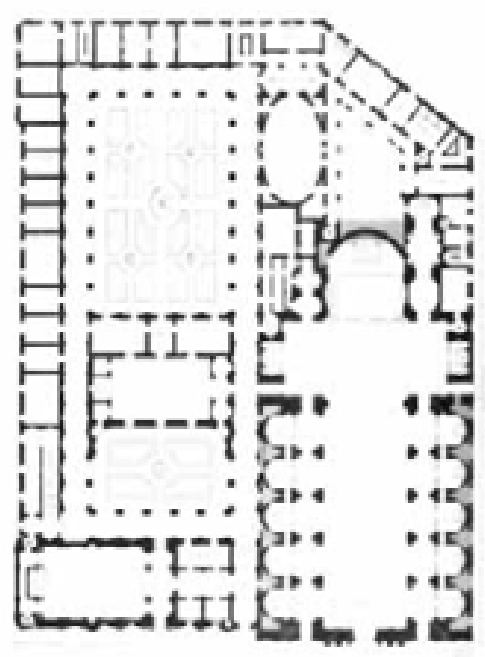

2.117. Oratorio de los Filipenses. Conjunto y posición del oratorio respecto a la iglesia. BORROMINI, 1667
También en la sección, la fachada se despega; en su parte superior queda superpuesta e independiente del espacio interior, ocultando la bóveda por completo. Es un plano separado, intercalado, que expresa el exterior público. Además, Borromini envuelve la verdadera cúpula en un cilindro de mampostería sobre el que recaen los empujes laterales, enfatizando de nuevo la falta de correspondencia. Esta solución, probablemente tomada de la tradición lombarda, la repetirá en muchas de sus obras.

Cuando Borromini se hace responsable del proyecto para el conjunto dei Filippini estaba condicionado por la iglesia (ahora llamada Chiesa Nuova) y la posición de la sacristía ya existentes.

El Oratorio es la pieza más singular de este conjunto se situaba en el ala entre el patio sur y la calle. Borromini lo separa ligeramente del extremo dejando detrás del altar un espacio para un pasillo que permitía la circulación en planta baja. Con esta disposición, la puerta centrada en la fachada no corresponde con el centro del oratorio, sino con el vestíbulo debajo de la galería, en el extremo este. Además, el eje principal del oratorio no es perpendicular a la fachada, como se espera, sino paralelo. La solución de acceso por el vestíbulo da respuesta a este problema, permitiendo el giro para entrar al oratorio por su eje mayor.

El resultado de la fachada no corresponde con lo que sucede en el interior. Borromini proyecta en la fachada cinco tramos a los que hace sobresalir y sobre los que compone su forma cóncava. Los tramos laterales tienen menos altura y se retranquean ligeramente. De esta forma la longitud del oratorio sobrepasa el cuerpo saliente de la fachada que señala al exterior, a la plaza y se compone según esta, no atendiendo al interior que se encierra en sí mismo en otra composición. El Oratorio queda a caballo entre el cuerpo central y los cuerpos bajos laterales, lo mismo que la biblioteca que se sitúa en el piso superior coincidiendo con la posición en planta del oratorio. Los últimos tramos de fachada alojan solo una parte de la iglesia; está detrás, pero la fachada no la señala en absoluto.

El interior del Oratorio, tal como sucede también en la Capilla de los Reyes Magos, es también un espacio de inclusión. Recorrido en su totalidad por un esqueleto estructural que vertebra las bóvedas y que nace de los planos del muro de la sala, y que se compone como abarcando espacio, cerrándolo sobre sí mismo; la envolvente envuelve literalmente. El entrelazado de sus nervios-pilastras encierra el espacio en una continuidad. Y si el exterior se compone 


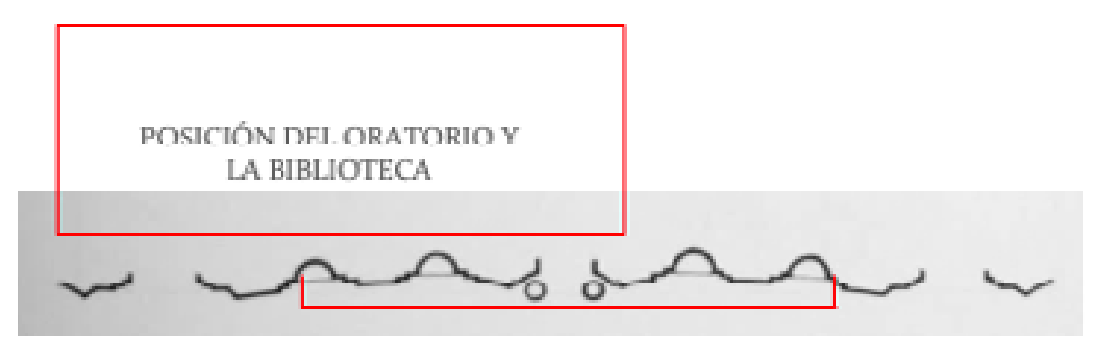

CENTRO DE LA FACHADA

con la plaza este interior se concentra y se pliega hacia dentro, es, como la forma-pliegue, autoreferencial.

En la iglesia de Santa Maria dei Sette Dolori, la relación entre la fachada y el interior es similar a la del Oratorio; también se dispone el espacio de la iglesia paralelamente a la fachada, y también utiliza el recurso de introducir un espacio intermedio, umbral que permite el giro de $90^{\circ}$ para acceder a la iglesia por su eje mayor. De nuevo se establece una escisión; la fachada se compone independientemente y el interior no es previsible. En este caso, una de las capillas laterales está alojada en el lado curvo y saliente de la fachada y es compensada en el otro por una escalera. La disposición interior no responde en absoluto a la simetría que se ofrece en el exterior, que actualmente se ha roto pues la iglesia se encuentra muy transformada con numerosas construcciones que se han adosado al conjunto. Pero mirando al piso primero sí se puede observar su simetría ficticia que aloja en los cuerpos salientes dos elementos dispares que nada tienen en común.

Dentro del conjunto del colegio Propaganda Fide, Borromini construye la Capilla de los Reyes Magos. Proyecta una puerta única en el tramo siguiente a la capilla, de forma que hay acceso fácil tanto al patio como a la iglesia. Vuelve a producirse la entrada a un umbral intermedio, a un espacio que permite el giro de $90^{\circ}$, para colocarse frente al eje de la iglesia, como en los casos anteriores. $\mathrm{Y}$ al igual que en los otros casos el diseño de la fachada no viene condicionado por el interior.

La fachada está compuesta de 7 tramos; los 3 de la izquierda cubren el largo de la iglesia y los 3 de la derecha llegan al vestíbulo y la escalera del colegio. Su traza se basa en una estructura de pilastras gigantes que marcan estos tramos. La fachada en planta es recta, menos el tramo central que retrocede en forma cóncava, respondiendo a una composición exterior que no señala la longitud de la capilla ni su posición interior, como ignorándola.
2.118. Esquema de la relación del Oratotario con la fachada del de los Filipenses. BORROMINI 


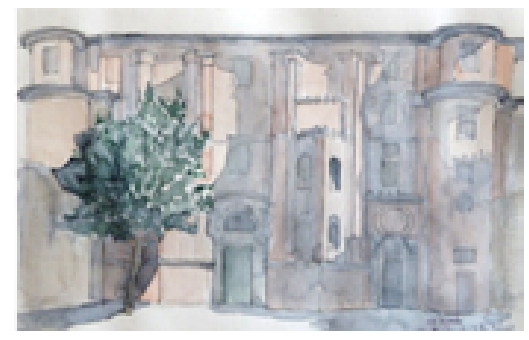

2.119. Planta del estado actual de la iglesia de Santa María dei Sette Dolori. BORROMINI, Roma, 1643.

2.120. Acuarela de la fachada. Dibujo de la autora.
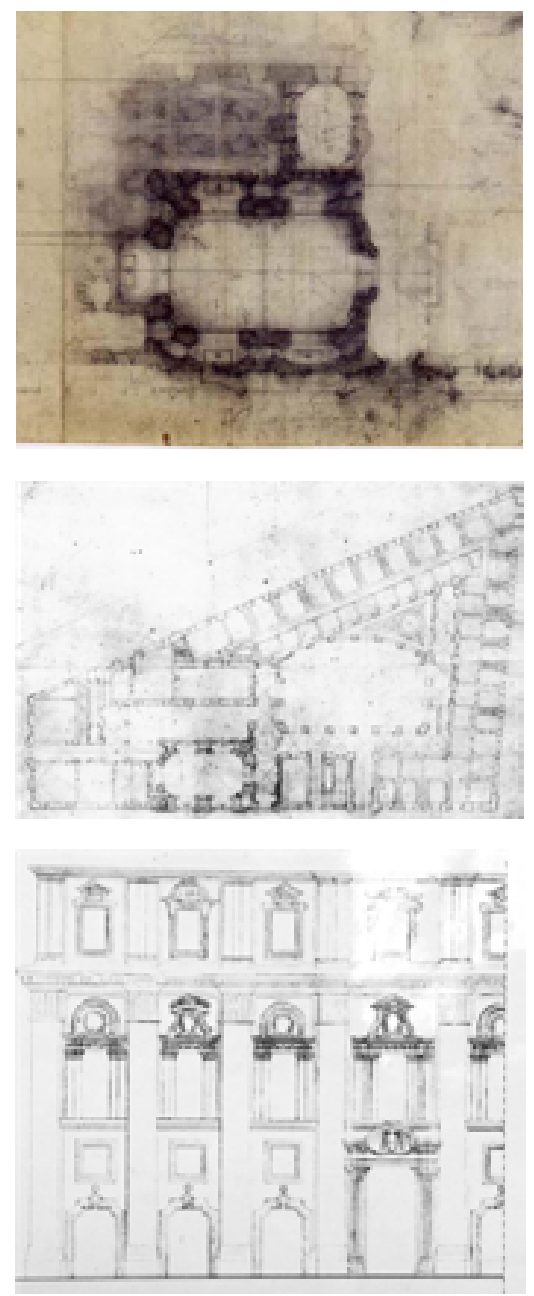

2.121. Planta de la capilla de los Reyes Magos, conjunto del Colegio Propaganda Fide y dibujo parcial de la fachada. BORROMINI.

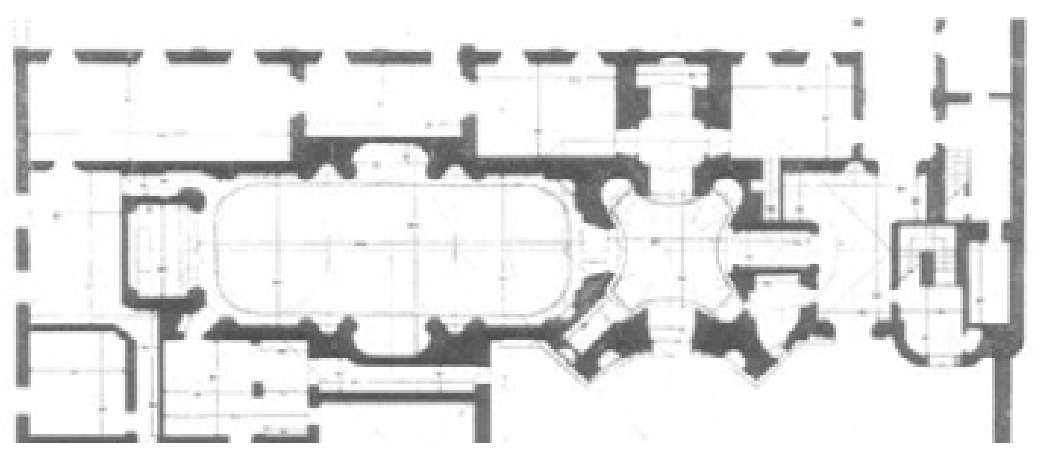

La composición de la fachada atiende al espacio público, una vez más, su unidad es colectiva. Parece calculada para verse en escorzo, ya que da a una calle estrecha, y de ahí el espesor de sus elementos y la complejidad de sus ornamentos un poco dispares. Los huecos y molduras sobresalen, y son marcados por las sombras que se producen. Los huecos del primer piso reflejan una complejidad formal muy marcada, pensados tridimensionalmente.

Su interior es también envolvente, con el mismo carácter que del oratorio, con la diferencia de que aquí el sentido de los nervios envolventes se intensifica, pues estos cruzan la bóveda en su totalidad, mientras en el Oratorio se detienen en su centro.

¿Cuál es entonces el vínculo, el enlace, esa armonía que hace que el exterior resuene en el interior?

El profesor Hernández León ${ }^{501}$ presta atención a esta problemática a través de las consideraciones sobre ella que aparecen en la obra de Sedlmayer y Cesare Brandi, el primero refiriéndose concretamente a Borromini.

Cesare Brandi, profundiza en lo que llama estructura de la forma proponiendo una teoría que hace indisociable el exterior del interior como dimensiones ambas de una misma espacialidad arquitectónica. Coincide aquí con Sedlmayer que, respecto al análisis de la arquitectura de Borromini, encuentra un motivo común en la formación del espacio externo y el interior de San Carlino. Nos señala cómo el interior está en el exterior y el exterior en el interior.

501. JUAN MIGUEL HERNÁNDEZ LEÓN, notas tomadas en el video en el seminario de investigación Ser arquitectura, organizado por UNED, Hercritia. En las sesiones del 14 de marzo de 2019 ver las fuerzas, representar lo invisible. Y en la sesión del 21 de marzo de 2019 la vida de las formas, la exasperación de las formas. Facultad de económicas de la UNED. Marzo 2019. 
Sedlmayer se refiere a esta integración completa de la obra como su estructura latente, que es aquella que no es perceptible de inmediato, pues no se aprecia en la forma material de la arquitectura, sino que es detectada situando la figura de aquella en el interior de una serie genética. El término que utiliza es el de Gebilde.

Solo después de un cierto tiempo emerge de este fluido caótico, articulaciones y relaciones ciertas, los nexos devienen más sólidos, las partes singulares adquieren una relación más estable y el todo se rigidiza, nace la figura (Gebilde)..$^{502}$

Gebilde no es exactamente figura sino algo así como producto formado. Parece hacer referencia a cómo el proceso formativo está presente en la formación definitiva de la obra, cuestión tan manifiesta en la obra de Borromini, como hemos visto. Es como un principio interno de organización que estará implícito en la disposición figurativa de la forma; un principio de relación entre los elementos que constituyen la unidad arquitectónica, y la inclusión del proceso que la genera ${ }^{503}$.

En la obra de Borromini esta estructura latente está singularmente presente como hemos tenido oportunidad de ver en nuestro análisis. Su método de proyecto parece continuarse en su obra construida y estar regido por los mismos presupuestos. Se trata de un mismo modo de hacer, una misma manera, común en toda la articulación de los espacios de la obra. Esto no impide, sin embargo, que la envolvente configure de diferente modo exterior e interior; un interior que expresa una unidad cerrada en sí misma; un exterior volcado a la ciudad, articulado con ella, que sin embargo se rigen por los mismos registros, con una misma estructura que emerge en su unidad. O lo que es lo mismo, la estructura latente no tiene que necesariamente establecer correspondencias inmediatas o transparentes; ella misma puede, como es el caso, configurarse de modo complejo. No es probable que esta gebilde se haya pensado como una especie de mera correspondencia inmediata entre las cosas, sino más bien como el fondo inherente sobre el cual el proyecto se concibe.

Hay así una diferencia entre la estructura interna de la obra como coherencia entre la manera de formalización del exterior y la del interior, una misma configuración, como un mismo modo 
de ser, y una articulación diferente que da cuenta de esa actitud diferencial entre el exterior y el interior.

Así, podríamos considerar que esta estructura latente es la que armoniza la obra y le otorga su valor como arquitectura. La que hace que ese exterior resuene en el interior. Una armonía que pudiera relacionarse con esa otra de la que nos habla Leibniz y que es la responsable del acuerdo, de la correspondencia entre las diferentes percepciones sobre el mundo, que es la que articula el espacio común.

Así, en esta estructura interna de la obra, están presentes todos los recursos que la articulan tanto internamente como externamente, y, es más, son ellos los que producen por ello una doble exterioridad, pues, en este caso, además, todo es un continuo. El uso del pliegue y de la inflexión está así insertado en toda la obra, una inflexión como modo de mezcla o desdibujo entre edificio y afuera. Con el uso de estos recursos, nuestro arquitecto crea una espacie de proximidad, que toma todo su sentido en la forma de una carne fundamentalmente plegada.

A través de su flexibilidad la línea activa y la inflexión pueden registrar y producir las condiciones de un afuera inmediato; facilitan la incorporación de un afuera ya no distante sino próximo. Línea activa, transitividad, movimiento y proximidad conforman una práctica que permite integrar la arquitectura en el entorno urbano o también producirlo, reconstruyendo cuales pueden ser la experiencia y el lugar del exterior.

La escisión en dos mundos, un exterior como extensión y un interior como cogito o pensamiento, que se comienza en el cartesianismo, pudiera tener su contrapartida en la fenomenología, que se funda en la raíz común de estos dos términos de la escisión, podríamos decir que la arquitectura de Borromini, de algún modo concilia las dos posturas de una manera unitaria, y es a través precisamente de esta estructura interna de la obra, que trata en todas sus dimensiones de hacer hablar al espacio y a la luz a través de una inclusión del cuerpo como grado cero de la espacialidad.

(Las líneas). Se suponía que circunscribían la manzana, o la pradera, pero la manzana o la pradera "se forman" por sí mismas, y 
descienden en lo visible como venidas de un trasmundo preespacial...504

¿Pero cómo se componen exterior e interior en nuestra arquitectura postmoderna?, ¿la arquitectura sigue proyectando interiores sin ventanas?

Deleuze nota como en la nueva armonía, propia de nuestro espacio posmoderno, este interior monádico cerrado sobre sí mismo, no deja subsistir la diferencia entre interior-exterior, de lo privado y lo público, estos ámbitos, se rompen, se quiebran, pues las mónadas dejan de constituir un mundo composible. Las mónadas de Leibniz incluían un mundo entero en su clausura, con zonas de expresión claras de cada una; todas componen un mundo armónico y composible. Se trataba de series convergentes. Pero la nueva armonía que nos propone Deleuze, está formada por series divergentes (caosmos) en un mundo incomposible. La mónada ya no puede incluir un mundo entero, se abre como en una espiral en expansión y exterior e interior entran en fusión, las mónadas se interpenetran ${ }^{505}$.

Las correspondencias actuales entre interior y exterior no responden ya a una monadología, sino, más bien, siguiendo a Deleuze, a una nomadología. Hay una misma constricción del punto de vista, pero ya no se trata del mismo punto de vista, ni de la misma visión: la figura y el plano se han modificado, están en movimiento en el espacio, las condiciones han cambiado. Ahora emergen las transparencias y exterior e interior, como las mónadas individuales, se interpenetran.

Christine Buci-Gluksmann ha notado el prestigio y predominio del plano-cristal propio del movimiento moderno:

El arte del siglo XX realiza todas las utopías cristalinas posibles ${ }^{506}$.

Así, lo propio del cristal es hacer coincidir exterior e interior, suprimir todo fondo. Se trata de una consideración negativa del límite, que pretende su supresión en beneficio de una continuidad lineal; un límite como impedimento. Nuestra Postmodernidad, en cambio, hace tema del límite, de una forma o de otra, como

504. MERLAU PONTY, El Ojo y el Espíritu, op. cit., pág. 56.

505. Cifr. GILLES DELEUZE, El Pliegue..., op. cit., capítulo 9: La nueva armonía, págs. 155-177.

506. CHRISTINE BUCI-GLUCKSMANN, La estética de lo efímero, op. cit., pág. 41. 
a continuación veremos, pero el límite tiene relevancia, y si la transparencia también tiene lugar como la tenía en los edificios modernos, esta no es inmediata, es matizada o sobrepuesta, confusa y compleja, llena de simulacros y reflejos. Glucksmann advierte la aparición de los planos fluidos en la actualidad, donde la imagen-flujo, disuelve toda arista ${ }^{507}$, y hace emerger el medio mismo, como hemos visto en el arte de Bill Viola, o de RCR. Pero se trata también de ese plenum ${ }^{508}$ al que se refiere Leibniz; un medium-plenum, que es propio de nuestra lectura del Barroco.

Los interiores barrocos, encerrados en sí mismos, quizás no tengan su correlato inmediato en la arquitectura contemporánea, pero, en la medida en que los límites se han vuelto de nuevo relevantes, se ha vuelto también la diferencia matizada entre exterior e interior. En lo que supone una negación del plano cristal moderno, la arquitectura actual torna hacia un interior, en el sentido de establecer de nuevo los matices, de mirar de nuevo a lo urbano, sea de un modo u otro, como preexistencia.

Por ello dice Deleuze que hay una misma construcción del punto de vista, pero con condiciones diferentes. Los reflejos, simulacros y flujos postmodernos, conmueven la noción de forma e interpenetran exterior e interior, aunque notando su distinción, pues el exterior sigue sin expresar el interior, solo interactúa con el. $\mathrm{Y}$ en este interactuar notamos ya la distinción entre las dos instancias.

Venturi marcará el cambio de paradigma con la modernidad, estableciendo la importancia del conjunto, del contexto, de lo histórico. Ya lo hemos señalado hablando de la inflexión, pero también Venturi habla de la inclusión como fenómeno de la arquitectura de la complejidad. Dedica un capítulo a la relación con el conjunto (El compromiso con el difícil conjunto). Pero la crítica a la continuidad exterior-interior, estará presente desde el inicio del texto:

El contraste entre el interior y el exterior puede ser una de las manifestaciones principales de la contradicción en la arquitectura. Sin embargo, una de las más poderosas ortodoxias del siglo XX ha 
sido la necesidad de continuidad entre ellos: el interior debería ser expresado al exterior ${ }^{509}$.

Venturi repasa muchas de las arquitecturas en las que esta contradicción está presente. Entre ellas se encuentran muchas obras de Alvar Aalto, San Carlino de Borromini (ya lo hemos visto), la Villa Saboya de Le Corbusier, Santa Maria della Pace, o el Teatro Marítimo de Villa Adriana en Tívoli.

Pero es el texto de Aldo Rossi, Arquitectura de la Ciudad, publicado en el mismo año que el de Venturi (1966), el que dedica más reflexiones al tema de la ciudad en su relación con la individualidad de la obra de arquitectura. Así nos dice en la introducción al texto:

Este contraste entre lo particular y lo universal, entre lo individual y lo colectivo, es uno de los puntos de vista principales desde los cuales está estudiada la ciudad en este libro. ${ }^{510}$

El tema de la compleja relación entre individual-colectivo es central en el texto, pero se presenta como cuestión clave para la arquitectura a partir de las últimas décadas del siglo pasado. El peso de la envolvente en la estrategia del proyecto actualmente es decisivo, y esta cuestión expresa ya una reflexión profunda entre lo que es interior y lo que es exterior.

El exterior es la huella de la historia como lugar común de comunicación atemporal, lo simultáneo de concebir una relación externa, no solo en el sentido de exterior, sino en el sentido de mundo, en el sentido al que se refería Leibniz. Rossi se refiere expresamente a la construcción de la ciudad en el tiempo ${ }^{51}$. Ese plenum fluyente en el que se envuelven y desenvuelven las mónadas que describe Leibniz ${ }^{512}$.

El interior, es ahora generado por su relación compleja con el exterior, reconociendo todos sus matices e intensidades, y desviando el peso de esta problemática hacia la envolvente del edificio, que recibe toda la carga de la reflexión: hay mundo, y puntos de vista

509. ROBERT VENTURI, Complejidad y Contradicción en la arquitectura, op. cit., pág. 109.

510. ALDO ROSSI, L'Architettura della cittá, Marsilio editori, S.P.A, Padua 1966. Traducción al castellano de Josep María Ferrer-Ferrer, La arquitectura de la ciudad, Ed. Gustavo Gili, Barcelona 1981 (1ª ed. 1971), pág. 61.

511. Ibid, pág. 60.

512. Cifr. G. W. LEIBNIZ, Monodología, op. cit. 
sobre él, aunque la figura y el plano estén en movimiento en el espacio, pero el problema siempre es habitar el mundo. Por eso Deleuze apunta que:

Seguimos siendo leibnizianos, aunque ya no sean los acordes los que expresan nuestro mundo o nuestro texto. Descubrimos nuevas maneras de plegar, como también nuevas envolturas. (....).513 
La filosofía en el siglo XVII, sobre todo a partir de Bruch Spinoza ${ }^{514}$, pone en el centro el tema de los afectos y los cuerpos, y a través de Leibniz cuestiona la relación del ámbito interior del pensamiento con el ámbito exterior a nosotros, lo que han llamado extensión.

El tema del límite parece que parte de toda esta problemática. A su vez, para hablar sobre la envolvente en arquitectura, su piel, parece que se hace necesario un previo análisis de los diferentes sentidos del término límite, al que en última instancia se refiere la envolvente.

La cuestión del límite irá íntimamente ligada a la de la espacialidad. Distintas consideraciones de lo espacial, sobrevendrán con las diferentes consideraciones de lo que es el límite.

Comenzando por la consideración filosófica, en la Grecia arcaica, la cuestión del límite es central para ellos, tanto como preocupación filosófica (estará presente en las primeras frases escritas que se conservan de Anaximandro de Mileto), como mitológica (a partir del oráculo de Delfos) o política (configurada a través de la mesura como mantenimiento dentro de los límites).

Límite en latín es limes, pero para los griegos es peras ( $\pi \varepsilon i \rho \alpha \rho)$. Las connotaciones son muy diferentes.

El latín remite a algo concreto que separa una cosa de otra, a una frontera entre dos cosas diferentes. Limes señala una franja entre una y otra cosa, que enlaza con las descripciones enciclopédicas: frontera territorial que se utiliza convencionalmente para separar países, provincias; camino que bordea una propiedad o sendero... etc $^{515}$. Esta concepción, tal como vemos, es excluyente.

Para los presocráticos, en cambio, el límite remite a un pasaje (per es pasaje y es la raíz de peras). Pero remite sobre todo al Á-peiron. La palabra es la transcripción del griego $\alpha-\pi \varepsilon ı \rho o v$, formada de péras (límite) y de $a$ (privativo). Á-peiron es sin límites, sin definición. En su sentido etimológico, el apeiron es lo que no puede limitarse, y por lo mismo, no tiene forma, no es definible. Ápeiron significa lo indefinido, lo indeterminado, lo que no tiene fin. Es decir, en 
griego, el límite remite a lo ilimitado, al indefinido donde se forma la determinación de una cosa.

La sentencia de Anaximandro parece que es la primera frase escrita que se conserva de la filosofía griega. Es muy significativo y determinante que aparezca tan tempranamente la problemática del límite como origen del pensamiento ya en la Grecia presocrática. La sentencia dice lo siguiente:

De donde las cosas tienen su origen, hacia allí deben sucumbir también, según la necesidad; pues tienen que expiar y ser juzgadas por su injusticia, de acuerdo con el orden del tiempo ${ }^{516}$.

El ápeiron es ese lugar donde las cosas tienen origen, es lo indeterminado, el fondo productor, y en última instancia el lugar donde todo va a parar. El ápeiron es algo potencial. El ápeiron, para Anaximandro es el arché (ápxฑ́) $)^{517}$, y por ello tiene un carácter positivo, generador.

Tiene así una vinculación con ese medio, o plenum, o con lo diáfano, de Glucksmann, que hemos estudiado en puntos anteriores. Todo ello tiene una connotación positiva y creadora.

Heidegger también señala el límite como apertura:

El límite no es donde alguna cosa cesa, sino, como los griegos habían observado, es donde alguna cosa comienza a ser ${ }^{518}$.

A partir de estas consideraciones del límite en su origen griego, como un sentido positivo, nos centramos ahora en analizar las consecuencias que tiene las diferentes consideraciones sobre el límite y su repercusión en la noción o el sentido que adquiere la espacialidad en cada una de ellas.

516. ANAXIMANDRO DE MILETO; Sentencia, traducción de Friedrich Nietzsche en su texto: La filosofía en la época trágica de los griegos, Valdemar 1999.

517. El arché, en griego antiguo, àpxń, es un concepto fundamental en la filosofía de la Antigua Grecia que significaba el primer elemento de todas las cosas. El arché, en la Grecia presocrática no parece remitir a un origen sino a un principio, en el sentido de causa, regla o fundamento. Cada filósofo deduce un principio, que no es exterior, en el sentido de trascendental, sino que está inmerso en la propia naturaleza (Фuбıऽ).

518. MARTIN HEIDEGGER, Batir Habiter Pender, en Esssais et conférences (Vorträge und Aufsätze, 1954), trad. al castellano de Eustaquio Barjau, Construir, habitar, Pensar, en Martín Heidegger, Conferencias y Artículos, Ed. El Serval, Barcelona, 1994. 
De una manera muy simple podríamos decir que el límite es el contorno de las figuras o los cuerpos: el contorno de la forma. Platón, según se deduce de la lectura de El Timeo ${ }^{519}$, tiene esta teoría del límite. Pero si nos quedamos aquí, si el límite es solo el contorno, ¿qué pasa con lo que hay entre los límites?, la esencia sería solo la forma relacionada con su contorno. Este modo de consideración del límite no nos dice nada sobre lo que la cosa es . Los estoicos, en su crítica a la filosofía platónica, encuentran una negatividad de raíz en esta concepción del límite.

¿Qué es el contorno de algo? Los estoicos dicen: es no-ser. Vemos que es una objeción muy fuerte. El contorno de algo es precisamente donde la cosa deja de ser (...)..$^{520}$

De la consideración del límite como contorno se deduce una noción negativa del límite que es dónde la cosa acaba, muere. Son límites-negaciones, y como consecuencia conllevan una concepción de la diferencia como algo negativo; hay una instancia que es la que limita y marca la diferencia que es excluyente.

La muerte es la Figura. Por una muerte un cuerpo se acaba, no solo en el tiempo, sino en el espacio, y sus líneas, forman, rodean un contorno. ${ }^{521}$

Por otra parte, remite a algo previo, a una especie de molde sobre el cual la cosa se formaliza; hay una cierta idea trascendente que impone el contorno, la forma, que viene de fuera. Ignora así la materia, el cuerpo y sus potencias esenciales centrándose en la figura-molde exterior.

La espacialidad que surge a través de esta noción de límite es la de un espacio abstracto, que no responde a ninguna materialidad y que se da entre unos límites, limita desde fuera y obvia la cualidad, lo sensible de la cosa. Es como un recipiente vacío que no tiene referencia al cuerpo que lo ocupa, y así olvida la cualificación misma del espacio ${ }^{522}$. Solo un cierto modo útil para matematizar la naturaleza y estudiarla desde fuera.

519. PLATÓN, Ión, Timeo, Critias, Traducción Jose María Pérez Martel, Alianza editorial, Madrid 2004.

520. GILLES DELEUZE, En medio de Spinoza, op. cit., (17/02/1981).

521. GILLES DELEUZE, Mil Mesetas, op. cit., pág. 109.

522. Cifr. JOSE LUIS PARDO, Las formas de la exterioridad, Pre-textos, Madrid, 1992. 
Este espacio resultante, si seguimos el rastro de Deleuze, es lo que el filósofo llamaría espacio estriado, en Mil Mesetas o también el modo de distribución sedentaria, al que se refiere en Diferencia y Repetición.

Pero esta concepción del límite y del espacio no es la única posible. Hay otra manera de abordarlo que tiene como referencia a los filósofos presocráticos, como acabamos de ver, pero también a loe estoicos $^{53}$. Esta imagen del límite no está enfocada desde la negación y la privación sino desde la afirmación y la diferencia. Atiende a la potencia y la intensidad y no únicamente a la extensión de sus partes. El espacio, en este caso, está cualificado y tiene tendencias; se trata de otro régimen del límite y del espacio, que se basa en una concepción vital de ambos ${ }^{524}$, más cercana al origen griego del término que acabamos de ver.

En esta noción, la diferencia aparece como afirmativa y no como subordinada a una determinación con carácter negativo. La diferencia se da en lo común, ámbito creador. El espacio y el límite aquí, serán unión y articulación de heterogéneos a modo de una red de relaciones; se trata de nuevo de una topología. Así, el límite-diferencia es la cosa misma, es la misma acción, la misma potencia, es como una zona, tiene entidad, no es solo un contorno estable, es dinámico, sometido al devenir, cambiante.

Este espacio es algo previo, lo que nos orienta, lo que posibilita la sensibilidad, la forma de la exterioridad. Pertenece al ámbito de la creación y de lo nuevo, pues es en este espacio donde se da el devenir, no entendido como serie cronológica de hechos, sino como sistema variable y creativo, ámbito de la potencia diferenciadora y creadora, desarrollado sobre una inmanencia nunca trascendente. El espacio es lugar común de sensibilidad y remite al cuerpo como criterio.

Deleuze ha utilizado la imagen de la luz para entender mejor este límite que es la misma acción, la misma potencia. La luz es una intensidad, es un grado, la luz no puede controlarse fácilmente, se cuela por las rendijas, por las fisuras, saliendo como un fluido que no se deja atrapar. Así, su límite está en sí misma, no es más que

523. Deleuze en sus cursos sobre Spinoza, y también en sus cursos sobre pintura trata el tema de la concepción de límite en la filosofía del estoicismo. GILLES DELEUZE, En medio de Spinoza, op. cit.

524. Cifr. AMANDA NÚÑEZ, Gilles Deleuze, Una estética del espacio para una ontología menor, op. cit. pág. 175. 
su misma potencia, es un grado, una intensidad. Esta concepción del límite es intensiva, el límite de un individuo (cualquiera, no solo un individuo vivo), no es su contorno, sino su potencia, lo que puede, su posibilidad.

El límite de algo es el límite de su acción y no el contorno de su figura (...). La cosa es entonces potencia y no forma. ${ }^{525}$

Notamos aquí entonces cual es el estatuto de la forma por el que nos preguntamos. A través de esta concepción del límite, la forma pierde su identidad figural, y se convierte en su potencia, lo que puede, su capacidad. Ya no es estable, se desarrolla, es dinámica y es intensiva.

El espacio que tratamos entonces, es un espacio-condición; condición de cualquier cualidad, de cualquier sensibilidad, de cualquier extensión, es como una matriz. Un espacio potencial, un ámbito cero, inaprensible, pero lleno. No hay nada negativo en este cero, como no hay intensidades negativas.

Los espacios de Borromini se valorarán así por su capacidad de desarrollar la sensibilidad del que los ocupa, por su cualidad. No tanto ya por su forma proporcional, por su jerarquía tectónica o por su composición geométrica. Sus obras remiten a la potencia, no como mera metáfora, sino como puesta en escena, formando parte del plano creativo y simbolizante, como potencia creativa, capaz de generar eso nuevo, que este tipo de espacialidad es capaz de aportar. Y en mayor medida lo observamos, si insistimos en la relación que en este caso la obra tiene con sus dibujos originales, con su proceso de proyecto, esa condición nos remite todavía más a organismos metamórficos ${ }^{52}$, formados por topologías referenciales, a este espacio-potencia, ámbito de acción. Así la metáfora a la que podemos recurrir, (y a la que ya se ha recurrido' como hemos visto) es a la de organismo vivo, en el sentido de semilla, de árbol, de fruto, con su potencia de desarrollo, su grado. Siempre que no consideremos el organismo como sistema todo-partes, con su jerarquía, sino como potencia de desarrollo continuo.

Deleuze hablará del cuerpo sin órganos, (ya se ha mencionado) tratando de tomar distancia de la consideración del organismo

525. GILLES DELEUZE, Spinoza: Philosophie practique, Presses Universitaries du France 1970, París, 1970. Traducción al castellano, Antonio Escohotado Spinoza: filosofía práctica, Tusquets, Barcelona, 2001.

526. Estos términos son del profesor Eusebio Alonso. EUSEBIO ALONSO, op. cit. 


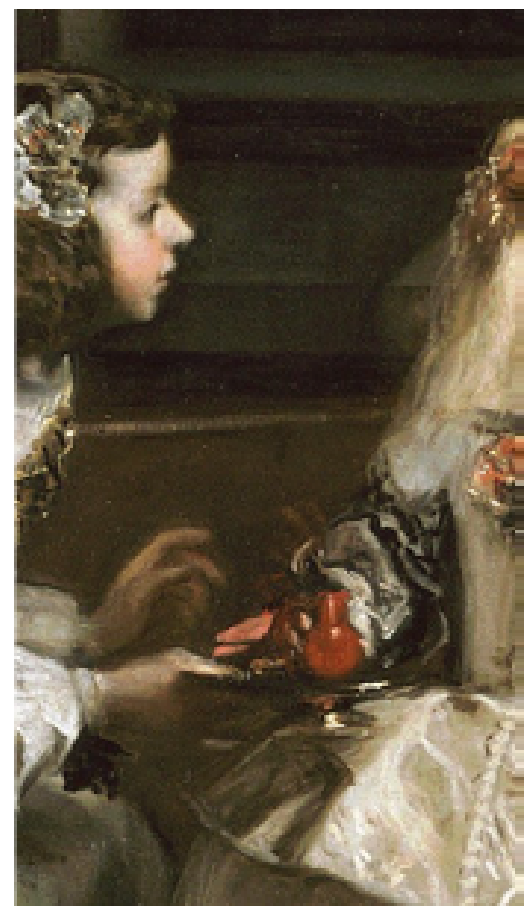

2.122. Fragmento de Las Meninas. DIEGO VELÁZQUEZ. Contornos desdibujados. como una totalidad formada por partes y estática. El cuerpo sin órganos remite más bien a algo que solo puede ser ocupado por intensidades.

El cuerpo sin órganos hace pasar intensidades, las produce y las distribuye en un spatium a su vez intensivo (...) Es la materia intensa y no formada, no estratificada, la matriz (...) $)^{27}$.

El organismo borrominiano, no está constituido por partes, Borromini no compone, proyecta resbalando por una geometría que es su condición de base, su spatium particular, espacio lleno y potencial, repleto de intensidades. Sus obras tratan de ser una arquitectura sin partes, continua, dinámica, generada por intensidades, y a través de una heterogénesis.

Hay una continua transformación que opera sobre los límites, que forma parte de su modo de proyectar y que parece no cesar en la forma construida. Señala a esta tensión inconclusa que ha remarcado el profesor Alonso y a la que ya nos hemos referido en el capítulo anterior en relación con las obras de Caravaggio y Bernini. Hay como una perdurabilidad del proceso en la obra.

Los croquis que conservamos nos recuerdan, por la forma de hacer que desvelan, a las palabras con las que A. Núñez nos describe en su texto dedicado a Deleuze, la noción de espacio del filósofo francés:

El spatium (...) se contornea, más bien, fluidamente a través de sus potencias y sus fuerzas vivas de cohesión, cambiando permanentemente su contorno y naturaleza a medida que deviene. ${ }^{528}$

La arquitectura de Borromini se acerca más a un vitalismo que a una geometría de formas. Y el resultado es un espacio vivo, donde la luz se filtra y la materia muestra su textura, un espacio de sensación y de intensidades.

Spinoza habla también de intensidades y afectos. Así la potencia es relacional, es un diferencial, algo que llega hasta dónde puede siempre que no haya otra potencia que se lo impida; el punto donde deja de ser es donde hay otra potencia. El filósofo nos dice en su Ética que:
2.123. Planta de San Carlino Albertina 173. BORROMINI
527. GILLES DELEUZE, Mil Mesetas, op. cit. 528. AMANDA NÚÑEZ, op. cit., pág. 184. 
Se llamará bueno a todo objeto cuya relación se componga con la mía (conveniencia); se llamará malo a todo objeto cuya relación descomponga la mía, lo que no obsta para que se componga con otras relaciones. ${ }^{29}$

La noción de límite que nos interesa es la de un límite-zona, lugar de potencialidades que contiene las condiciones de posibilidad. Un límite con entidad, límite como el lugar que interactúa con un espacio. El límite es el fin de la potencia, y es la potencia la que define a la cosa, no es su contorno, no es su figura.

Coincidiría esta noción con la concepción del límite de los estóicos, que, como venimos señalando, supone una aportación radicalmente nueva, bajo influencias orientales, como Deleuze nos recuerda en sus cursos sobre pintura. $53^{\circ}$ Esta noción rompe completamente con lo que es el contorno para decir que el límite es una zona, la zona hasta donde va una potencia, viene definido por lo que puede el cuerpo, por una intensidad. No en vano, parece que en la biblioteca de Borromini se encontraron varios textos de los pensadores estóicos. ${ }^{531}$

Se trata así, esta versión de límite que es la que nos interesa, de un límite como ámbito, como zona, la zona donde la potencia se ejerce, donde el medio actúa, donde tiene lugar la determinación. Si nos referimos al término diáfano que ya hemos tratado, los límites de lo diáfano serían una relación casi imperceptible entre lo diáfano y lo adiafáno, es un ámbito o límite activo.
529. GILLES DELEUZE, Spinoza: Philosophie practique, Presses Universitaries du France 1970, Paris, 1970. Traducción al castellano, Antonio Escohotado Spinoza: filosofía práctica, Tusquets, Barcelona, 2001.

530. GILLES DELEUZE, La pintura, el concepto de diagrama, op. cit., pág. 233.

531. Rudolf Wittkower, abordó las relaciones de Borromini con el estoicismo. RUDOLF WITTKOWER, "Studi soul Borromini" , en: F. Borromini, personalità e destino, Roma 1979, vol 1.. Traducción al castellano, Sobre la Arquitectura en la edad del humanismo.

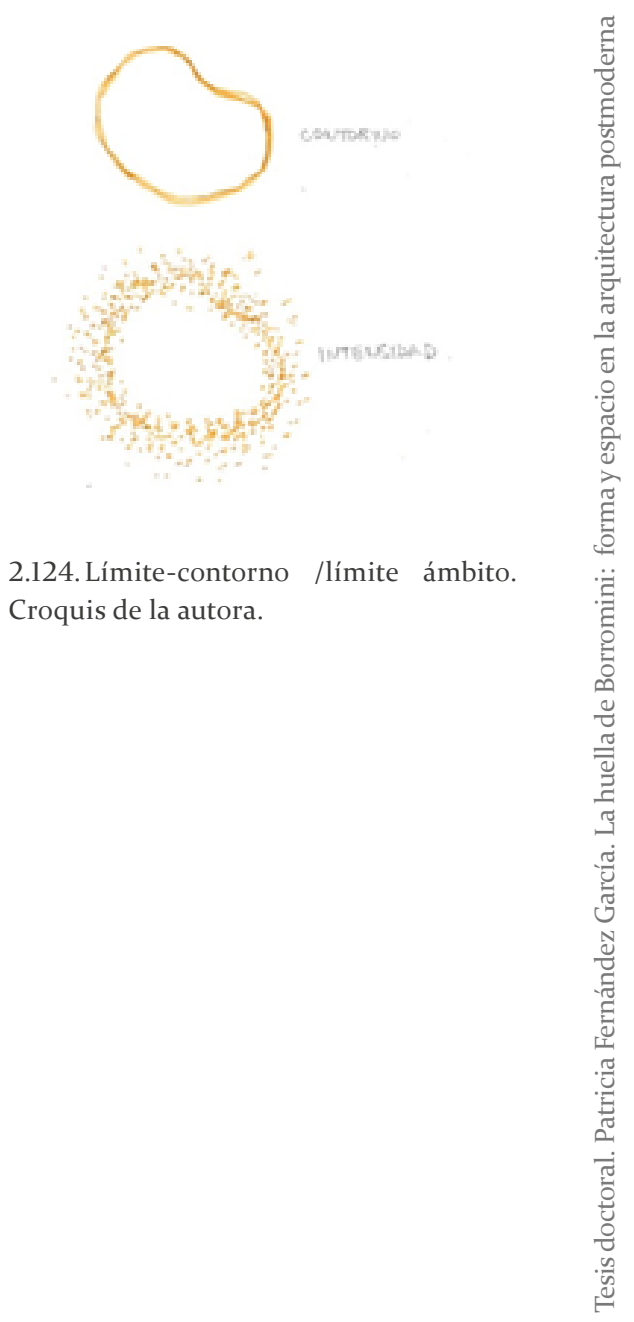


Podemos observar en muchas de las obras de Borromini, cómo nuestro arquitecto evita que en la composición de sus espacios se evidencie la lógica descendente de las cargas gravitatorias.

En Sant'Ivo, diversos mecanismos en la composición se complementan para subrayar el carácter ascendente de la tensión espacial. La forma configurada acompaña al espacio ascendente en un sentido contrario al de la gravedad, contrario a la tectonicidad constructiva de la arquitectura. Hay una tensión ascendente del espacio ${ }^{532}$.

En San Carlino, reconduce las tensiones verticales del espacio; la cúpula que descansa sobre los arcos torales y en último término sobre las pechinas de las esquinas, compositivamente niega estas cargas verticales y parece que es el anillo oval, en su posición que avanza sobre el espacio de la iglesia, el que recibe las cargas.

Por otra parte, la cúpula parece flotar sin peso sobre este anillo, pues sus motivos ornamentales así lo sugieren; se presenta como empujada hacia arriba por el espacio que cubre. Las bóvedas y pechinas que recogen las cargas también comparten esta condición esponjosa, que en nada delata su contribución estructural en el conjunto; es como Gilles Deleuze ha señalado, una dermis en carne viva. ${ }^{33}$

Los capiteles híbridos, jónico-compuestos, de las pilastras de San Carlino invierten su voluta volviendo el giro hacia el interior, consiguiendo una especie de efecto de rotación centrípeta del fuste que elimina la sensación de servir de base al arquitrabe, eliminando de nuevo el efecto de la gravedad en favor de un movimiento ascendente.

Además, en las bóvedas de las capillas, Borromini invierte la lógica tradicional de su ornamento que hubiera hecho converger los ejes radiales en la cima de la bóveda, que resulta más coherente con su razón tectónica. Nuestro arquitecto dispone los nervios de manera divergente hacia arriba. Este mecanismo, además hace que este ámbito se incorpore visualmente más al ámbito central, 
en dirección contraria a la forma perspectiva. Esto contribuye a subrayar el carácter unitario del conjunto ${ }^{534}$.

Las dos cuestiones convergen en un sentido por el cual, la superficie constructiva niega lo estructural; composición y tratamiento ornamental se orientan para designar una pérdida de importancia de lo tectónico-gravitatorio, en beneficio de la envolvente, envolvente que cobra el protagonismo que le otorga el espacio que contiene y que parece que la modula, es el responsable de la fuerza potencial que la con-forma.

La materia se trata, en su pretensión de des-hacerse, no como algo secundario, sino como el mecanismo para crear la atmósfera, para canalizar la luz y para dejar hacer al espacio, su medio, el medio de la materialidad que se muestra corpórea, en sus poros y texturas. Se manifiesta lo sensible; se trata de mostrar lo corporal en su medio de comprensión que es espacial.

Pero esta intención de desintegración forma-materia, se observa en más elementos de las composiciones de Borromini. En el campanario de San Carlino, las pilastras que se disponen diagonalmente en las esquinas y que se presentan flanqueadas por sendos pares de semicolumnas, aparecen exfoliadas y se descomponen en motivos florales. El remate del campanario de San Andrea della Fratte contiene un motivo similar, descomponiéndose finalmente en un elemento de corona con cruz que intensifica la sensación filamentosa, como de material descompuesto.

En la iglesia de la Sapienza esta cuestión llega a su máxima expresión y toda la envolvente, generada por relaciones topológicas evoluciona en una linterna, que deviene turbulenta y se realiza por proliferación. La línea se repliega en espiral para desembocar en un remate que parece descomponerse en el cielo.

Esta des-materialización, que ya se advierte en Borromini y que, como hemos visto, se lleva al extremo en la forma de expresarse nuestra arquitectura contemporánea, va necesariamente unida a la cuestión de la a-tectonicidad, de la ocultación de la componente estructural sometida a la gravedad; la materia se expresa como ingrávida, espumosa o cavernosa, no pesa, flota y, en apariencia, ni soporta nada, ni necesita estructura que la sustente.
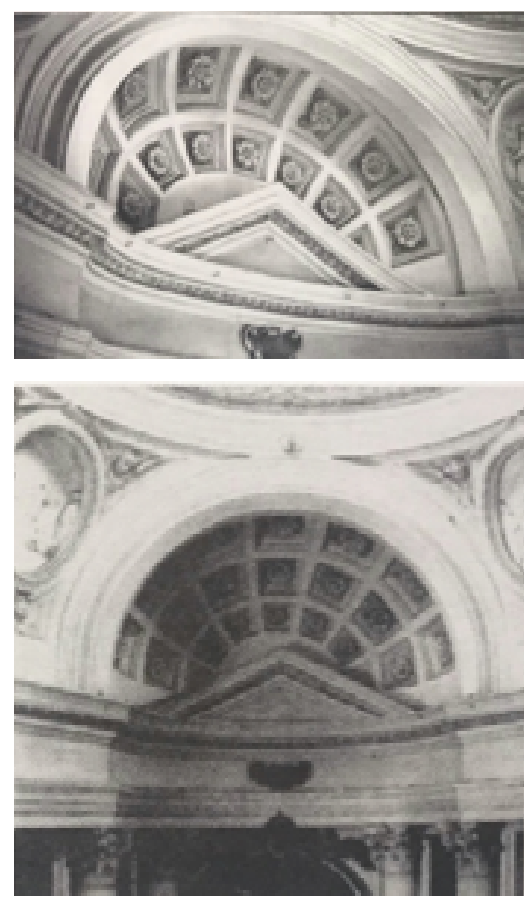

2.125. Ornamentos de las bóvedas de las capillas de San Carlino. 
2.126. Linternas de San Carlin, San Andrea della Fratte (dibujo de la autora) y Sant'Ivo alla Sapienza.
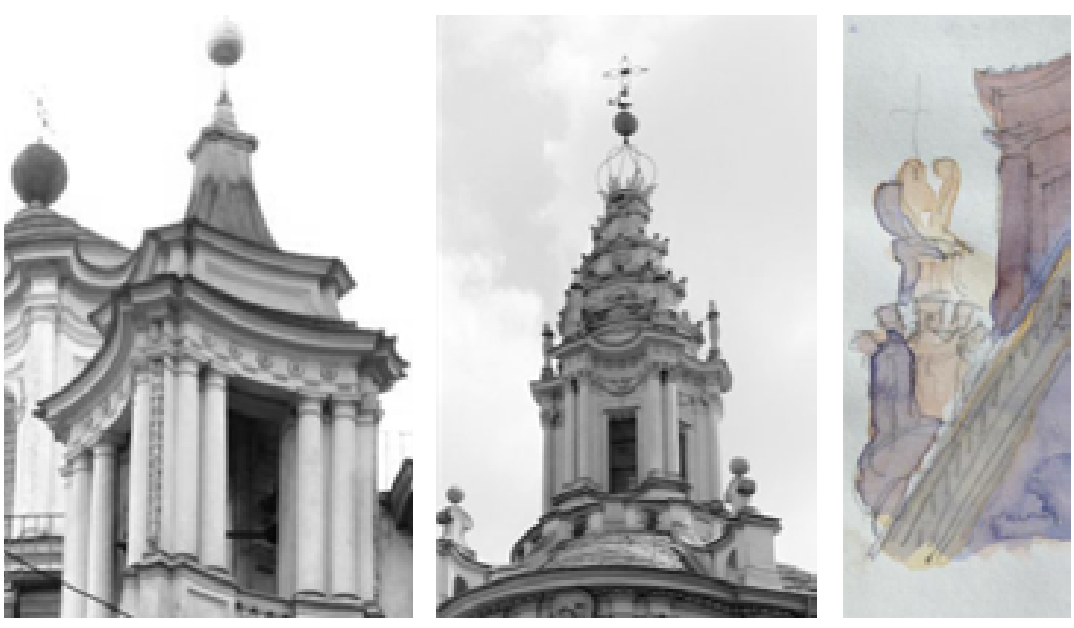

Sedlmayer ha señalado en las obras de Borromini su espesor espacial; un espacio de estructura comprimida y expansiva a la vez, un impulso centrífugo contrario a otro centrípeto, efectos de dilatación y contracción, subrayado en los pliegues del perímetro de la envolvente. Todo ello atiende a señalar la idea de un crecimiento infinito del contorno, resaltando la tensión a la que se somete la materia, que la sitúa en un equilibrio inestable, incapaz casi de contener el espacio. Así, el espesor espacial se produce en la agitación del muro, olvidando su condición tectónica. El muro parece responder más a solicitaciones y agitaciones que son ajenas a las fuerzas gravitatorias. 535

Si hemos observado una disolución de la forma en recursos formales que señalan más bien a una potencia, y ahora, notamos también una especie de desmaterialización y esponjamiento de la materia que parece des-hacerse, si forma y materia, el compuesto, pierden carga, emerge entonces el medio donde la individuación se produce, el medio dónde suceden las potencias y posibilidades, un medio abierto que como hemos visto es el espacio.

Si recurrimos a Wölfflin, y le otorgamos la autoridad de haber sido el autor que señala de una manera exhaustiva y sistemática las características del estilo barroco, se puede objetar que, como dice este autor, en la arquitectura del Barroco hay un efecto de masa. ${ }^{536}$ Dedica el capítulo 3 de su texto sobre Renacimiento y Barroco a este efecto de masa. Pero ahí ya señala la concepción nueva de la materia como, materia blanda, diciendo que la materia se debilita, que hay una masa fluida, y en particular señala el elemento

535. HANS SEDLMAYR, L'architettura di Borromini, Electa, Milano 1996. Citado por JUAN MIGUEL HERNÁNDEZ LEÓN, op. cit.

536. Heinrich Wölfflin, Renacimiento y Barroco, op. cit., págs. 92, 93. 
no-tectónico. La masa pierde su estructura interna, o hay un estado a-morfo ${ }^{537}$, son frases que nos remiten a esta des-materialización e in-formación. Las observaciones que ya hemos citado de Sedlmayer, Giedion o Portoghesi sobre el espacio como categoría fundamental del Barroco y en particular en nuestro autor, van en el mismo sentido.

Wölffling observa en el mismo texto, cómo en el Barroco la forma deja de ser significativa recurriendo a efectos de masa y de luz y sombra, como el efecto de luz cobra más importancia que la forma, cómo la impresión del conjunto es atmosférica, remite a un espacio.

Si en San Carlino, el tratamiento de las superficies murarias como porosas, hasta hacer que parezcan tener un fondo incierto, provoca como una sensación de desintegración de la piel, como una manera de difuminar la envolvente, una descomposición de la condición superficial de la pared ${ }^{33^{8}}$, hay una especie de importancia inversa entre lo tectónico y lo a-tectónico, y así, hemos podido observar cómo, nuestro arquitecto, evita mostrar la lógica descendente de las cargas gravitatorias de la estructura. La piel recoge la carga del proyecto, y sus matices son lo que importa. Esto a-tectónico se localiza en la envolvente, en la piel.

En el análisis del estatuto de la forma, y tal como vamos perfilándola, considerándola como objeto relativo, la materia, que es la parte potencial de la síntesis (materia-forma), también necesariamente debe des-figurarse; será materia disgregada, esponjada, aunque siga siendo masa, materia no formada. Como consecuencia, se produce una anulación de la presencia de lo tectónico.

Hay una verdad de lo estructural-tectónico en gran parte de la arquitectura renacentista, y esta tendencia se sucede en muchos momentos de la historia de la arquitectura. Esto remite al gran debate posterior, del siglo XIX, entre la lógica constructiva y la envolvente ornamental. La alternativa a la verdad de la estructura tiene como protagonista a Gottfried Semper ${ }^{539}$, que, basándose en su

537. Ibid. pág. 51-56.

538. El profesor Eusebio Alonso observa como este tratamiento de las pieles contrasta con la linealidad marcada de los arcos y elementos estructurales, a los que de esta forma otorga una preeminencia compositiva. EUSEBIO ALONSO GARCÍA, op. cit.

539. GOTTFRIED SEMPER, Escritos fundamentales de Gottfried Semper. El fuego y su protección, traducción al castellano de Manuel García Roig, edición Fundación Arquia, Barcelona 2014. 
investigación histórica sobre el origen textil de los cerramientos arquitectónicos, propuso un principio del revestimiento, que privilegia la envolvente ligera, ornamentada y cromática, sobre el soporte estructural.

En los cuatro elementos que Semper propone, como determinantes de la arquitectura, no se incluye la estructura; en torno al hogar, elemento sagrado en torno al cual todo adquiría forma y se ordenaba, se levantan los otros tres elementos, techo, recinto y suelo. Semper se fija primordialmente en el elemento recinto, que se genera, según él, por el arte del que entreteje esteras, remitiéndose así a un origen textil y ligero. Semper afirma que la arquitectura tradicional, que transformó las cercas primitivas de esteras en muros de sillería, conservó, sin embargo, su carácter y su significado inicial, como componente independiente (aunque forme parte de un mismo elemento), considerando la estructura únicamente como un andamiaje interno de esta envolvente visible que no pierde su consideración simbólica, y que, según este autor, asume un significado de máxima importancia en la historia del arte ${ }^{54^{\circ}}$.

La cerca rodea un espacio, lo significa, lo marca, y lo señala. Los límites del espacio son lo esencial para Semper. Pero la influencia de Semper, su pensamiento, fue ignorado y soterrado durante la configuración de la modernidad, aunque las polémicas sobre el dualismo referente a la repercusión en la forma arquitectónica de lo tectónico frente a lo a-tectónico, estructura muchas reflexiones a lo largo del siglo XX como las de Adolf Loos, Otto Wagner o Petrus Berlague ${ }^{541}$

En la arquitectura de Borromini, sin embargo, esta cuestión parece una evidencia. Lo tectónico, como elemento fijo desaparece en el espacio, se esfuma entre las cosas o se enmascara; es más, se invierte la forma tectónica, se invierte el sentido de la gravedad, y así, los balaustres de la barandilla del claustro de San Carlino, en vez de sustentar una barandilla, bailan y se permutan, como si su forma fuera indiferente a su función estructural, como ignorando la gravedad a la que se someten.

540. Cifr. Ibid.

541. Adolf Loos, sobre Bekleidung (revestimiento), Otto Wagner sobre Nutzstil (estilo funcional) y Petrus Berlage sobre la Waandarchitectuur (arquitectura de pared). Citados por GIOVANNI FANELLI y ROBERTO GARGIANI, El principio del revestimiento. Semper and the Textile Origin of Architecture, Arquitectura Viva № 174, 2015. 
Por otra parte, la desmaterialización como elemento ligado a la a-tectonicidad, trae consigo la invisibilidad de la componente tectónica de la arquitectura y en vez de ello el centro de atención estará en la piel, en la envolvente, como elemento en contacto con el espacio que es afectada por él, mostrando su fluidez, sus poros, su textura, su proceso de formalización.

La materia presenta una textura infinitamente porosa, esponjosa o cavernosa, sin vacío, siempre hay una caverna en la caverna, cada cuerpo, por pequeño que sea contiene un mundo (...).542 


\subsection{LA PIEL PROFUNDA}

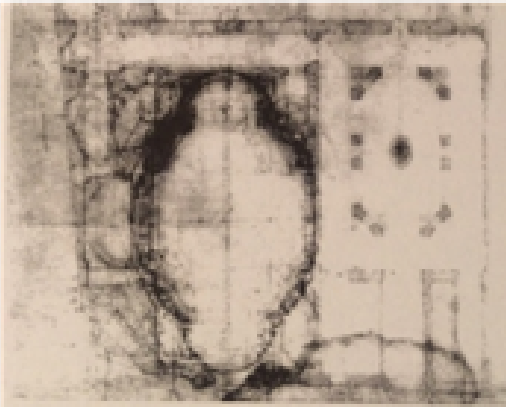

2.127. Croquis de la planta de San Carlino Albertina 171. El croquis es muy elocuente sobre la importancia de la envolvente, las variaciones a las que Borromini la somete.
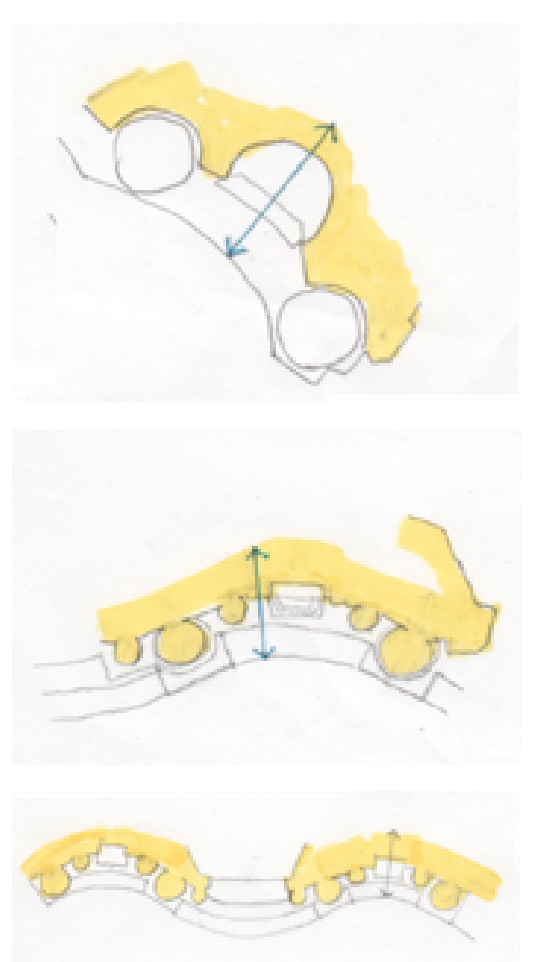

2.128. La piel profunda de San Carlino. Fragmentos de la fachada de San Carlino. Croquis de la autora.
En San Carlino, la cúpula se descompone en poros orgánicos, en una dermis profunda, intensificando esta sensación de interior (o piso de arriba) de Deleuze. En el interior de la cúpula de San Carlino, Borromini combina unos octógonos con la cruz emblema de los trinitarios, pero de tal modo que la dimensión de los elementos se reduce hacia lo alto según se acercan a la linterna, produciendo una especie de efecto de alejamiento o aceleración. Pero estos motivos que utiliza, a la vez, y desde el interior son como poros, tienen una textura orgánica, la textura de la materia.

Hay una paradoja, como hemos visto, en los ornamentos que Borromini elabora para la cúpula y las pechinas de San Carlino. Estos elementos dan una impresión de ligereza que no corresponde a su condición tectónica, pareciendo como hinchadas por el espacio. Pero además hace resaltar la profundidad de su piel, que contiene vacíos (en el sentido de espacio), como esponjamientos, que crean una profundidad. Es la idea de piel profunda que ha señalado el profesor Alonso con respecto a las envolventes de nuestro arquitecto, y que Paolo Portoghesi remarca en el prólogo a su texto: hay espacios de profundidad en las unidades superficiales. ${ }^{543}$ En las bóvedas de las capillas utiliza también casetones, en cuyo interior, para aumentar su sensación de profundidad coloca motivos florales. Similar recurso encontramos en las hornacinas de la pared, cuyas bóvedas se cubren con conchas.

La densa ornamentación que genera en estos elementos declina su condición de mera superficie de cerramiento, de simple contorno. La superficie es viscosa y densa y se desdibuja el límite-cerramiento, en la profundidad incierta de la piel, ${ }^{544}$ creándose como una zona densa, llena de intensidades.

En general, las columnas de San Carlino, tanto en el interior como en la fachada están tratadas al modo de un bajorelieve, hay un carácter estereotómico que prevalece sobre el carácter tectónico. Este carácter estereotómico es coherente con el modo de hacer de nuestro arquitecto, vinculando así este carácter estereotómico a una especie de continuidad con lo terrestre, con el territorio,

543. EUSEBIO ALONSO, op. cit., pág. 150. 544. Ibid, pág. 151 
mientras lo tectónico se desliga de él. De esta forma la idea de continuidad está siempre presente.

En la iglesia de la Sapienza, la idea de profundidad se logra de otro modo. La piel se pliega por completo adaptándose al empuje del espacio, topológicamente, se muestra casi como elemento textil en su totalidad, plegándose y encubriendo en parte con ello su función portante, tomando profundidad, una profundidad que la dota de cierta ambigüedad, presentándose más bien como ámbito y no tanto como contorno. La idea de profundidad está implícita en la propia transformación topológica que experimenta la superficie muraria en las capillas. Así la unidad topológica no tendrá un límite estable, será un límite dinámico que se opone al límite-contorno.

La idea de piel profunda que niega la condición meramente superficial de la pared otorgándole profundidad estará presente en toda la obra de Borromini. Es especialmente explícita en sus fachadas. La intensidad de las fronteras es un tema específico de Borromini.

En la fachada del colegio Propaganda Fide, la producción de sombras con la disposición y forma de las cornisas y con los nichos y pilastras, genera una profundidad, dando una sensación de ámbito denso en la fachada. La traza, se basa en una estructura de pilastras gigantes. Está recorrida por una cornisa con modillones dispuestos de forma irregular, dos sobre cada pilastra y dos entre pilastras. Se trata de un plano plegado en profundidad o agujereado. La cornisa sobresale considerablemente del plano del muro. Los elementos se marcan profundamente en el plano. La apariencia de la fachada es la de una zona horadada por huecos y modillones, por hornacinas y salientes, cóncavos, convexos, que confieren gran espesor y complejidad al plano.

Esta disposición sobresaliente de los elementos parece calculada para verse en escorzo, pues la fachada abre sobre una calle estrecha. Las sombras que se producen, junto con su visión lateral forzada, contribuyen aún más a producir la sensación de profundidad. La sombra se aúna con su densa textura para resaltar su espesura.

La fachada de san Carlino (ya se ha analizado), es como un pliegue espeso lleno de profundidad, donde se alternan formas contrapuestas, concavidades, convexidades, y hornacinas, para generar un ámbito intenso y lleno; un gran pliegue que contiene múltiples pliegues aumentando el espesor del plano, su entidad material.
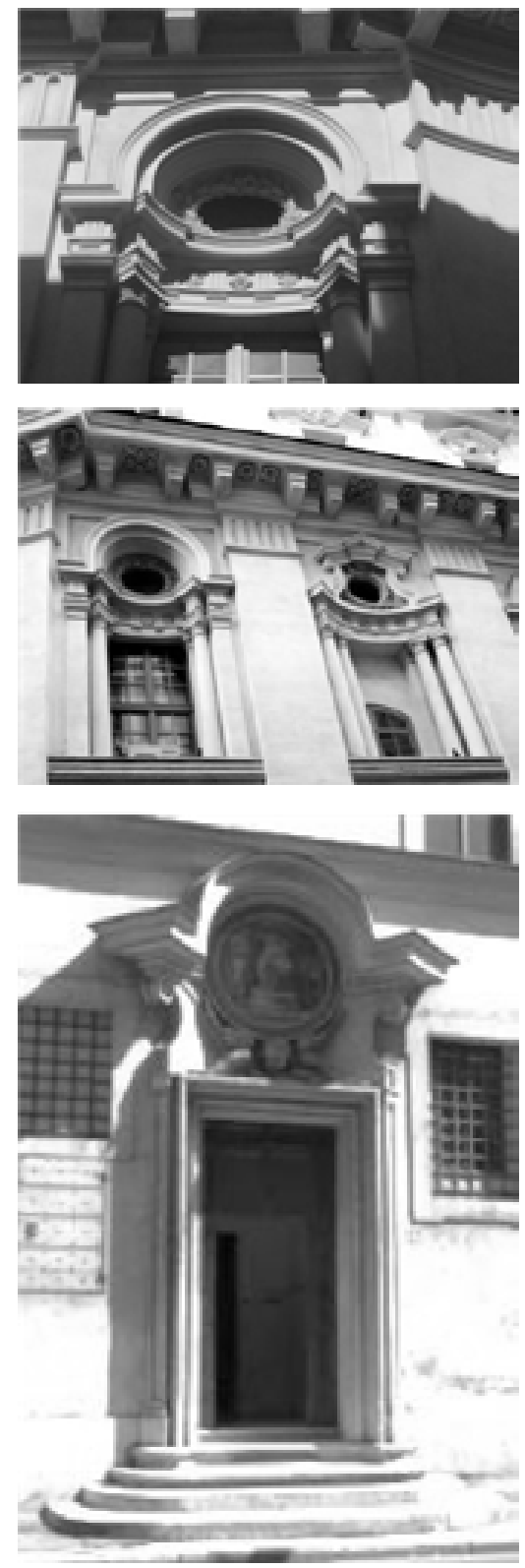

2.129. Detalles de la fachada del colegio Propaganda Fide.

2.130. Puerta del claustro de San Carlino 

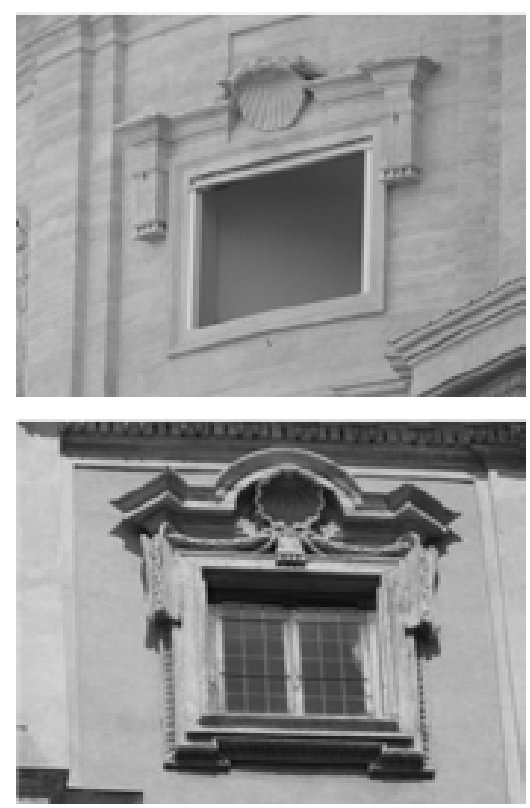

2.131. Ventana del piso superior de la fachada de San Pedro del Vaticano.

2.132. Ventana del piso superior del Palacio Barberini
Las columnas superpuestas en la fachada, dejan huecos entre ellas que admiten columnas de un orden menor, y entre ellas nichos que contradicen la curvatura convexa del plano sobre el que se sitúan las columnas. La sucesión de elementos en profundidad y la subdivisión de curvas en otras que las contradicen, remiten a una intensidad, a una infinidad de elementos posibles que podrían proliferar de los existentes.

Además de este trazado general, en las partes más lisas, Borromini dispone cornisas de gran tamaño, que como en el Colegio Propaganda Fide, sobresalen notoriamente del plano, produciendo sombras y escorzos que aumentan el efecto de profundidad. Lo vemos en el tejadillo de la puerta del claustro, por ejemplo.

Este motivo del tejadillo es una proliferación de un elemento tomado de Miguel Ángel, que es una constante en su obra y que se va modificando con el mismo motivo, metamorfoseando su forma hasta curvarse en las tres dimensiones. Paolo Portoghesi y otros autores ${ }^{545}$ han señalado como referencia de esta ventana la del piso superior de la basílica de San Pedro que proyecta Miguel Ángel. La primera vez que la utiliza Borromini es en la ventana que el arquitecto diseña para el piso superior de la fachada occidental del palacio Barberini. El remate o tejadillo de la ventana de Miguel Ángel en el Vaticano, Borromini lo complica y su forma se curva tridimensionalmente y se hace compleja. Lo utiliza en la ventana central de la fachada de los Filipenses, en la puerta central del Colegio Propaganda Fide, y por último en la puerta del claustro de San Carlino, donde toda la planta es también curva, una curvatura tridimensional continua que funde en un único elemento los del primer trazado del Barberini, otorgando al conjunto una profundidad y una continuidad propias.

La densidad y la profusión de pliegues, hornacinas, huecos, poros, pilastras concavidades y convexidades, cornisas o tejadillos, que generan una profundidad en las pieles, de las arquitecturas de Borromini, está dirigida a poner en cuestión la condición de mera superficie de sus envolventes, dotándoles de viscosidad y porosidad, en un intento de desdibujar los límites fijos del espacio. Hay como una descomposición de la superficie de cerramiento. La profundidad de una piel deviene el lugar de las transformaciones.

545. Ver Paolo Portoghesi, op. cit. Anthony Blunt, op. cit. 
En resumen, las envolventes-pieles de nuestro arquitecto cobran profundidad, generan, más que un contorno, un ámbito, una zona. De alguna manera tratan de diluirse, tratan más bien, de diluir la linealidad de un contorno, convirtiendo la piel del edificio en un ámbito donde suceden intensidades, donde se genera una potencia que formaliza la cosa. Las pieles profundas de Borromini pueden asimilarse a ese ámbito donde la potencia se ejerce. 


\subsection{LOS LÍMITES DIFUSOS}

Si las pieles de la arquitectura de Borromini están provistas de profundidad, si su contorno desaparece a través del movimiento inestable que logra con sus recursos: pliegues, inflexiones, poros etc., convirtiéndose en ámbitos activos más que en delimitaciones, en zonas de interacción, la envolvente contemporánea se provee de estas zonas-ámbitos a su manera, de otro modo, pero con el mismo sentido: se trata de diluir los contornos, de desestabilizar los límites, de crear, en este caso, zonas de intercambio.

En la actualidad, el tema de la envolvente es esencial en el proyecto de arquitectura. La reflexión sobre las pieles de los edificios está presente tanto en el ámbito teórico como práctico.

La disimetría del centro organizador es una constante en la estructura espacial de nuestras arquitecturas, hemos visto como los espacios se organizan topológicamente por relaciones internas de respectividad, más que respondiendo a geometrías externas centradas en formas exteriores. Esta disimetría genera siempre fuerzas expansivas hacia lo periférico, sobre la elasticidad del perímetro-frontera, sobre la envolvente, generando una tensión, que pone la carga expresiva en la piel del edificio.

Omar Calabrese también ha observado como el carácter de una tensión al límite de las reglas que hacen homogéneo un sistema se observa en todos los campos del saber contemporáneo. El Neobarroco, como todas las épocas dinámicas, trabaja en la periferia, frente a las épocas estáticas que promueven el centro del sistema.

(...) dado el confín de cierto dominio científico, se examinan sus bordes, los susceptibles de hacer avanzar en confín mismo allá donde no estaba e implícitamente se declara la existencia de una zona de frontera variable o irreconocible entre real y posible inactual5 ${ }^{46}$.

Calabrese confirma la pérdida del contorno a favor de una zona o ámbito, una frontera variable. Pero, además, en arquitectura esta zona trata de ser inter-activa, de intercambiar con el medio.

Toyo Ito ha relacionado nuestra era tecnológica con una nueva imagen del cuerpo que incorpora más claramente en nuestra con- 
ciencia esta red de relaciones y la pertenencia a una naturaleza común. Él señala como la percepción de nuestro cuerpo como una entidad independiente y aislada del mundo exterior se modifica, y así la imagen por ordenador, al modo de interface, nos remite a un cuerpo que forma parte de la naturaleza y se mezcla con ella ${ }^{547}$.

Siguiendo esta idea, y partiendo de la interpretación de la arquitectura tradicional japonesa y la técnica de la era informática, Ito propone una arquitectura cuya envolvente se proyecte a modo de membrana osmótica, de contorno difuso, situando así al límite o la piel en el lugar central de la reflexión sobre la arquitectura de la época contemporánea, en su interrelación con el exterior y en la con-figuración de su forma. El límite como elemento de trabajo, da lugar a una arquitectura que es capaz de reaccionar a los estímulos de su entorno directo, algo que caracteriza la producción arquitectónica reciente de estudios como SANAA, Sou Fujimoto y por su puesto el propio Hito.

El resultado es también una arquitectura que apuesta por la ligereza, flexibilidad y la transparencia, en la línea de la inmaterialidad que ya hemos explorado en otros casos. Aunque volveremos sobre ello ${ }^{548}$, en relación con la componente tectónica de la arquitectura, nos interesa primero indagar sobre la piel, sobre el límite como ámbito de intercambio a la vez que, como encuentro de las diferencias, por tanto, lugar de producción de la forma, del individuo.

El límite es lugar de las desemejanzas, es el fondo generador de la diferencia, el ámbito de lo virtual-potencial. El límite es un lugar paradójico, portador de diferencias y espacio indiferenciado a la vez; hemos visto ya todas las connotaciones que tiene el término en sus diferentes enfoques.

El límite, la piel, la envolvente, es siempre entonces lugar de intercambio, y esto es exportable a todos los ámbitos de la arquitectura, y es más notable en la arquitectura tradicional, tanto a nivel urbano, en relación con lo social (la muralla medieval, por ejemplo, donde el intercambio comercial se produce en torno a sus puertas de dónde nacen las grandes plazas, donde se abra espacio), como a nivel específico del edificio, donde la piel se postula como el elemento principal de protección- relación con el medio.

547. Cifr. TOYO HITO, Arquitectura de límites difusos, GG mínima, Gustavo Gili, Barcelona 2006. 

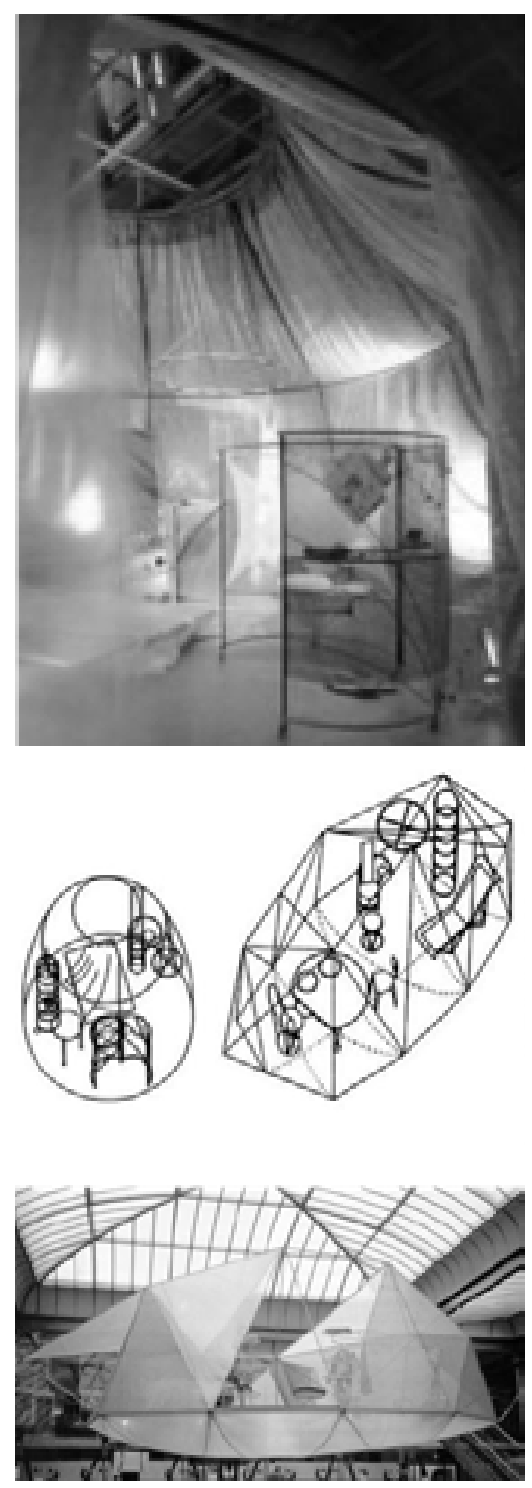

2.133. Pao 1. Alojamiento para la mujer nómada de Tokyo, 1985 y Pao 2. Alojamiento para 1 mujer nómada de Tokyo, 1989
Toyo Ito nos propone una arquitectura de límites difusos como respuesta a una cultura contemporánea de la comunicación y la información. La arquitectura de límites difusos es también una imagen de una arquitectura que parece no haber tomado todavía una forma definitiva.

Una arquitectura de límites blandos que puede reaccionar ante el entorno natural, adoptando un límite sensible que responda sensiblemente a la naturaleza, un límite que funcione a modo de una especie de sensor, semejante a la piel humana, que incorpore una relación interactiva entre el entorno natural y el artificial.

Esto significa tener un límite flexible que responde sensiblemente a la naturaleza. Debemos crear un tipo de arquitectura que esté equipado con un límite sensitivo similar a la piel humana y sensible como la piel suave. Debe ser una arquitectura que incorpore una relación interactiva entre el ambiente artificial y el medio natural, garantizando un hogar congenial para el nuevo cuerpo ${ }^{549}$.

El término piel, simplemente, ya remite a la condición orgánica de la envolvente en arquitectura, y al tema del organismo. La piel en el Barroco se pliega y se complica, desdibujando así también su límite preciso, otorgando espesor y complejidad a la envolvente. Las figuras horadadas a modo de poros que se repiten en algunas de las cúpulas barrocas ${ }^{550}$, son las primeras analogías orgánicas, metáforas de un interior en carne viva ${ }^{551}$, como señala Deleuze.

La metáfora de lo orgánico es recurrente en la arquitectura contemporánea, ya hemos visto algunos casos en el capítulo anterior ${ }^{552}$. Su preocupación por la piel, por la producción de interactividades con el medio, es quizás el centro o la razón de su emergencia.

Las propuestas de Toyo Ito a finales de los ochenta abrieron una reflexión que ha ido evolucionando hasta el día de hoy a nivel internacional y que resulta ahora de especial interés. El proyecto PAO1. Alojamiento para la mujer nómada de Tokyo que presentó a la Japan Creative Exhibition en 1985 fue una interesante reformulación teórica, al proponer una membrana translúcida fina, con

549. TOYO HITO, Arquitectura de límites difusos, op. cit.

550. Por ejemplo, cúpula de San Carlino alle Cuatro Fontane de Borromini o San Andrea del Quirinale de Bernini.

551. GILLES DELEUZE, El Pliegue... op. cit.

552. Véase, supra, Capitulo 4 de esta parte, págs. 305-307. 
una estructura ligera y efímera, que conformaba un espacio para la vida y el reposo en la metrópolis de finales del siglo XX, en la que se enlazan la espacialidad japonesa y la técnica de la era digital. La propuesta tuvo continuación en La Torre de los Vientos de Yokohama (1986) una nueva membrana dispuesta en torno a una estructura de hormigón preexistente y concebida a modo de piel reactiva sensible a los cambios de luz, las condiciones atmosféricas, el ruido,... mediante un sistema de luminarias controladas por un sensor conectado a un ordenador que provocaban diferentes configuraciones luminosas alterando la fachada de aluminio y vidrio, convirtiendo a la arquitectura en la plasmación fotosensible de sus condiciones de contorno.

En ambos proyectos Ito apostaba por materiales translúcidos, estructuras y cerramientos ligeros y las cualidades efímeras de los materiales, que exploró en diversas propuestas posteriores y escritos teóricos. Estas formulaciones fueron el origen del texto-manifiesto La Arquitectura de límites difusos, que venimos analizando, y en el que se propone el límite como elemento de trabajo, concebido como una membrana osmótica dúctil, capaz de reaccionar a los estímulos de su entorno directo, apoyándose en la tecnología informática ${ }^{553}$.

El espesor de la envolvente barroca, masiva y plegada, ese ámbito también difuso a su manera, ha sido sustituido por un ámbito tecnológico de interelación. Las membranas no funcionan como contorno, sino que extienden su ámbito de actuación entre interior y exterior. Son ámbitos activos y tienen espesor, y este es su espesor, un espesor tecnológico.

La Mediateca de Sendai, que Ito construye en 2001, es una apuesta similar evolucionada. En este proyecto se pone en cuestión la consideración de la forma y así se puede plantear si verdaderamente la Mediateca tiene una forma concreta, sus límites son transparentes y difusos y su interior dinámico, ambiguo y cambiante; es difícil asignarle una representación especifica.

El propio Ito nos dice:

553. Cifr. JUAN IGNACIO PRIETO LÓPEZ, Arquitectura de límites difusos: de la Glasarchitektur a la desmaterialización de la Arquitectura. Presentada en Arquitectonics: Congreso Internacional Arquitectonics Network. Arquitectura, Educación y Sociedad. Departamento de Proxectos Arquitectónicos e Urbanismo, Escola Técnica Superior de Arquitectura, Universidade da Coruña. 
2.134. Modelo de la mediateca de Sendai. TOYO ITO, 2011

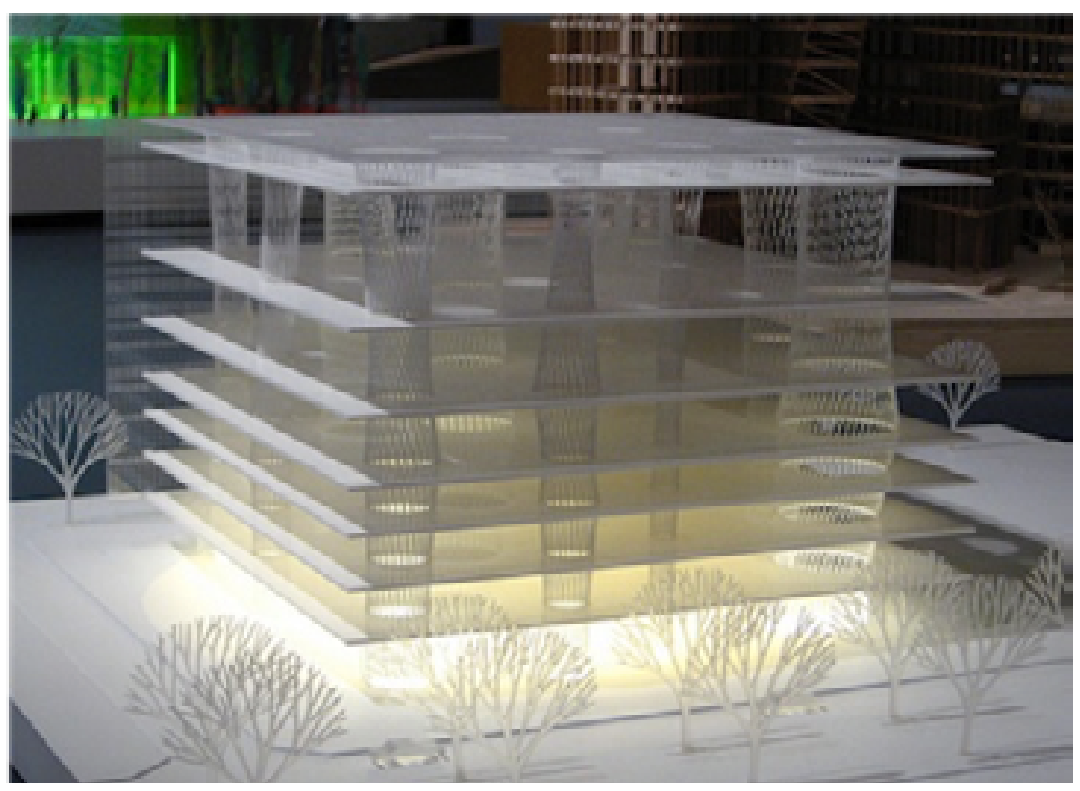

(...) lo que me atrae no es visualizar el viento, sino pensar lo maravilloso que sería si pudiera existir una arquitectura que no tuviera forma, ligera como el viento ${ }^{554}$.

La Mediateca es un receptor de vidrio, de planta cuadrada, con varias plantas a modo de plataformas, y una serie de pilares-patio que lo atraviesan desde la primera a la última.

Su forma ambigua alude también a un organismo, pues se sustenta en la metáfora del acuario, y sus pilares se asemejan a una especie de algas, contradiciendo su condición tectónica.

Se trata de un edificio multifuncional, abierto y dinámico, con multitud de micro entornos, cuyas actividades vienen condicionadas únicamente por los elementos móviles. Su implantación en la calle se hace de manera que su presencia no interrumpe el discurrir del usuario, el edificio se puede atravesar por su planta baja.

Este caso presenta elementos muy característicos donde poder investigar la condición singular que adquiere tanto la envolvente como la estructura en nuestras arquitecturas. Antes de pasar a analizarlas, serán necesarias unas aclaraciones sobre los conceptos que estamos utilizando en referencia a la tectonicidad en su relación con la envolvente. 


\subsubsection{Aclaraciones sobre tectónico-atectónico}

Llamaremos, y hemos ya llamado, tectónico, a la expresión manifiesta de los componentes estructurales de la arquitectura, de los elementos técnicos que la sustentan.

Por otra parte, hemos aquí enfrentado lo tectónico con otros dos conceptos que conviene aclarar:

Lo tectónico frente a lo estereotómico, quiere diferenciar una arquitectura donde la tensión de la gravedad se transmite de una manera articulada en sistemas estructurales tipo andamiaje, con elementos independientes de la envolvente del edificio, que sería el tipo tectónico, de una arquitectura donde todo el cuerpo del edificio participa en el sistema estructural, de una manera continua, transmitiendo las cargas al terreno en continuidad, que sería el tipo estereotómico. Las envolventes estereotómicas participan entonces en lo estructural.

Lo tectónico frente a lo que hemos llamado a-tectónico, quiere diferenciar las arquitecturas donde la expresión o la manifestación del sistema estructural resulta evidente, donde hay como una cierta expresividad producida por la resistencia estática de la forma constructiva, de las arquitecturas donde este sistema queda encubierto o camuflado en el conjunto de la obra.

Ahora bien, podría interpretarse entonces que lo mismo estereotómico podría llamarse a-tectónico. Pero se pretende aquí caracterizar lo a-tectónico con un grado más, en el cual, la estructura no solo se diluye en la envolvente o el material constituyente, sino que, pretendidamente, la forma de lo sustentante se tergiversa, se invierte, se desfigura, aparentando ligereza, esponjamiento, liquidez o desintegración, características que contradicen explícitamente su carácter sustentante. Esta cuestión ocurre cuando las cúpulas barrocas se esponjan en poros (San Carlino), o cuando los capiteles, que han adquirido su forma habitual precisamente de su función portante, invierten sus elementos (capiteles de San Carlino), o cuando la sensación espacial que la forma del edificio adquiere es ascendente (Sant'Ivo), o cuando los supuestos pilares o elementos sustentantes del edificio tienen aspecto relajado, simulando flotar (Mediateca de Sendai), o invierten su sección razonable, tomando una forma que aumenta su sección cuando asciende y apoya casi en un punto (crematorio de Kakamigahara), o en los casos donde el plano del suelo y la cubierta se han elevado 
del suelo como flotando ingrávidos sobre el terreno (Rolex Center) etc...

Con respecto a la relación de estas cuestiones con el estatuto que adquiere la envolvente, siguiendo a Semper, diremos que la importancia creciente de la envolvente juega un papel en contra de la tectonicidad del edificio, al menos simbólicamente. Si el recinto (envolvente) toma el protagonismo, la estructura solo funciona como ayuda (andamiaje) que lo sustenta, pasa a segundo plano y carece de significado simbólico. Si además la estructura se enmascara de otra cosa, su papel sustentante queda anulado en la expresión de la obra, pasando entonces el recinto de Semper, la piel, a reclamar la atención de la obra, a ser el elemento de expresión.

Que la envolvente (y lo a-tectónico como consecuencia) ocupen el primer plano en el resultado de la obra, necesariamente tendrá que ver con la problemática de la inter-relación del exterior y el interior y con el intercambio con el medio, el espacio.

\subsubsection{Lo tectónico en la Mediateca}

La tecnología está muy presente en este edificio, tanto en el interior como en la construcción de toda la caja. Las plantas se configuran con forjados de acero a modo de sándwich, y son atravesadas por una estructura muy singular de pilares, que esconden su condición tectónica, pues en ningún caso percibimos la tensión de carga. Se trata de formas orgánicas que encubren la tensión estructural aparentando relajación, la impresión es que se trata de elementos que flotan. Se trata de piezas tubulares metálicas de planta circular que va cambiando de sección a medida que aumentan en altura, variando así en cada una de las plantas. Son como haces de acero y están recubiertos en vidrio figurando una retorcida estructura orgánica semejante a un alga.

Dispersos libremente en el edificio, varían en forma, diámetro, inclinación y dimensión, a la vez que dotan de luz al interior. El tubo más grande alberga la circulación vertical que comunica los distintos niveles de la mediateca. Su apariencia es contradictoriamente a su función estructural, frágil y transparente.

En la Mediateca, hay una clara intención de encubrir lo tectónico, comenzando por la sofisticada técnica en la que se enmascara la estructura, que no solamente no delata la gravedad esencial que la 


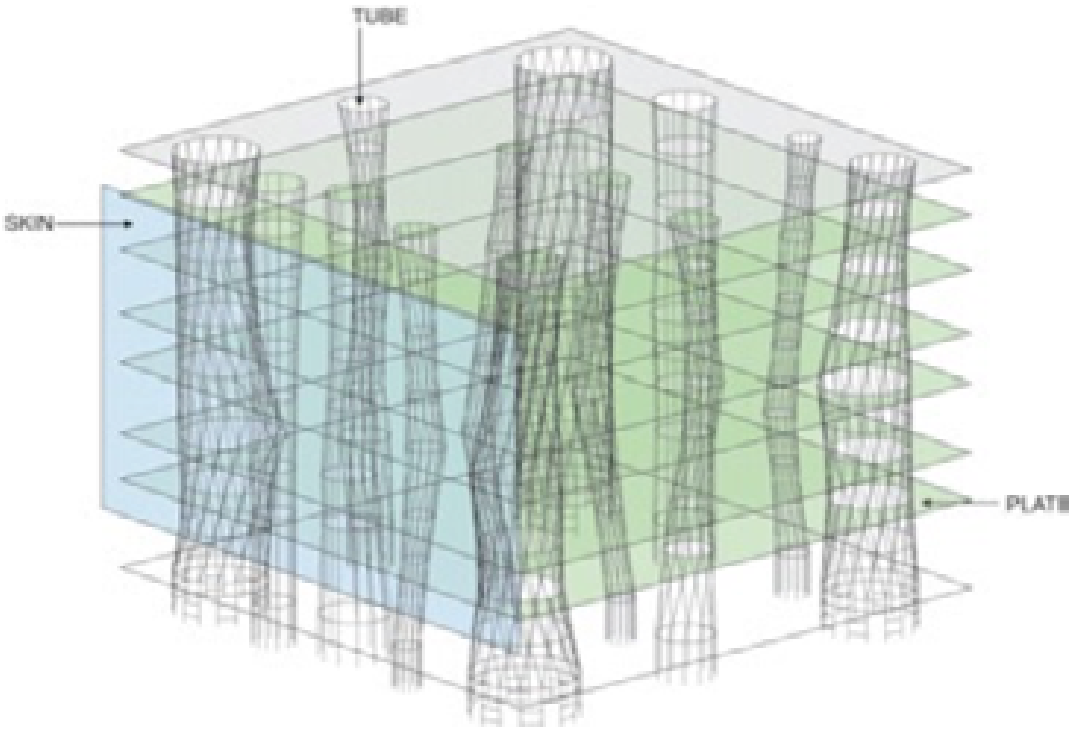

condiciona, sino que parece contraponerse a ella, como flotando y plegándose, como sumergida en un líquido.

\section{5·5.3. Lo a-tectónico, la piel de la Mediateca}

La envolvente de la Mediateca es una membrana transparente que permite la fluida comunicación visual del interior con el exterior, y por momentos el límite entre ambos parece desvanecerse.

Pero además los cerramientos se disponen para ser recibidos de diferentes modos por el medio según la vocación del entorno al que enfrentan y su orientación concreta, siguiendo la idea de interacción. Así, la fachada principal, ubicada en el lado sur, frente a un boulevard, es de una doble capa de vidrio, muy útil en los meses de invierno, de fuertes vientos, es la más externa y se extiende ligeramente incrementando el efecto de ligereza del edificio. La fachada lateral oeste es opaca, recubierta con una trama metálica que deja ver las escaleras de emergencia, y las fachadas norte y este, que dan hacia sendas calles vecinales, tienen acabados diferentes por cada piso: vidrio, policarbonato y aluminio, dependiendo de su altura.

La fachada se conforma a través de capas que otorgan un cierto espesor a los límites, un espacio sin asignar a un exterior o a un interior, donde se produce el intercambio. Se trata de umbrales que generan el límite difuso del que escribe Ito, zonas o ámbitos de interacción, tienen entidad.

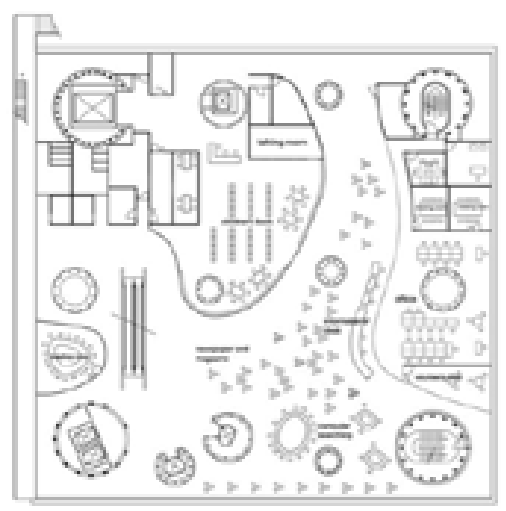

2.135. Planta y modelo digital de la mediateca de Sendai. TOYO ITO, 2011 


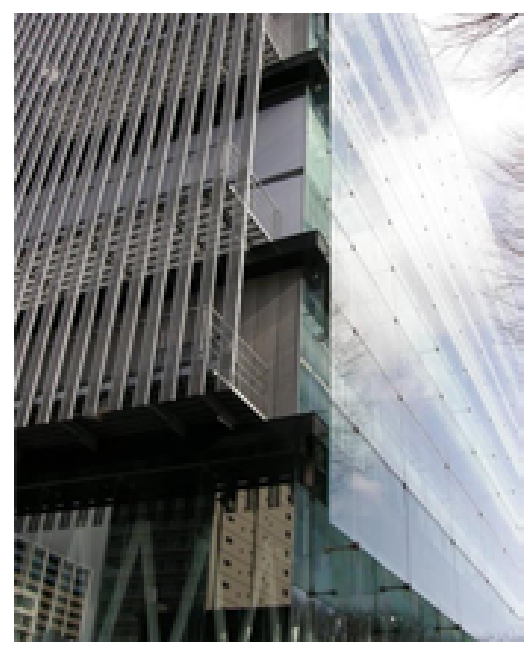

2.136. Distintas soluciones de envolventes que se aprecian en la esquina del edificio. Mediateca de Sendai, Toyo Ito, 2001

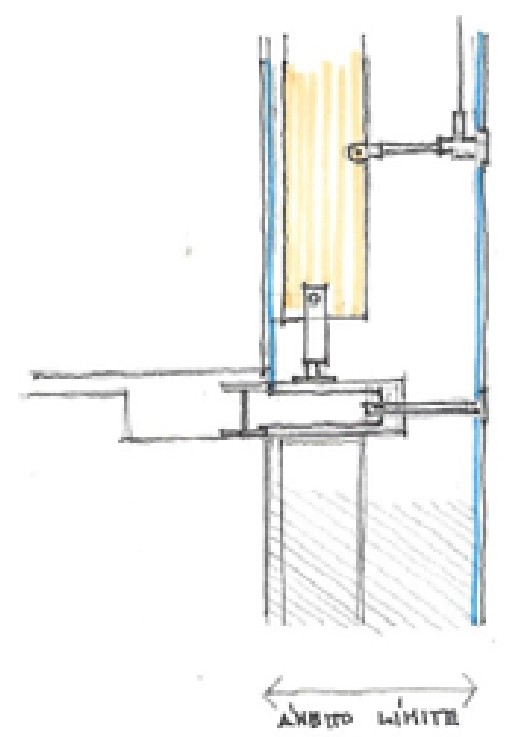

2.137. Sección fachada sur de la Mediateca de Sendai, TOYO ITO: espesor y capas de la envolvente. Dibujo de la autora.
Así, la piel es ámbito activo, se dota de espesor, de profundidad, otro modo de expresión muy diferente del de la piel profunda de Borromini, pero donde rige un mismo sentido.

Pero las implicaciones de la arquitectura de límites difusos no se limitan al cerramiento, sino que suponen una nueva concepción del espacio, dotado de un carácter flexible y efímero. Un espacio potencial, no determinado por simplificaciones funcionales, un espacio capaz, capaz de ser y ser utilizado en sus múltiples posibilidades.

El espacio creado por la comunicación electrónica no está localizado, es un espacio efímero. Por lo tanto, la arquitectura de límites difusos debe tener un carácter liviano permitiendo cambios temporales. Esto significa que la construcción de una habitación debe permitir cambios de programa. El programa sirve para implementar las acciones de las personas en el espacio. En la arquitectura moderna todas las acciones estaban marcadas gráficamente como funciones y simplificadas. El espacio se construía de acuerdo a esta interpretación estricta del programa. Esta es la razón por la que no puede responder a la flexibilidad del espacio de hoy en día caracterizado por grandes convulsiones 555 .

Uno de los tres elementos que caracteriza la arquitectura de límites difusos de Ito, es, según sus palabras, una arquitectura que transforma el programa en espacio, un espacio fluido y cambiante, que genera lugares por remolinos. Una arquitectura que forma parte del espacio potencial, que no condiciona el uso, es receptáculo de acontecimientos, se inscribe dentro del medio.

Todo apunta a señalar al medio, el agente, el espacio, como lugar de posibilidad, potencial, y no se trata de una potencia cinética, sino de significar, de expresar y dar presencia al medio productor, al espacio. Algunos de los ejemplos, ya analizados aquí en páginas anteriores, cumplen esta condición. Nos remitimos al Rolex Center de SANAA, o a la carpa Les Cols de RCR que hemos visto más arriba y analizado en este sentido ${ }^{556}$.

Llevando esta reflexión al ámbito urbano, la dinámica de los flujos y las redes remite a una nueva reflexión de la ciudad, donde los dualismos tradicionales entre centro-periferia, alto-bajo, distan-

555. Ibid.

556. Véase supra, capítulos 2 y 3 de esta parte. 
cia o punto, ya no parecen pertinentes, pues la nueva dinámica apunta al estallido de la ciudad en sentido histórico. El concepto de scape de Rem Koolhaas está aplicado a las ciudades genéricas que se autoproducen y se metamorfosean, hasta el punto de que la ciudad es tratada como paisaje para modelar ${ }^{557}$.

Lo efímero es así una experiencia de este espacio postmoderno, como ampliación del sentido de topología en el Barroco, una energía infinita donde todo es provisional. Coincide aquí Glucksmann cuando señala:

Si la imagen de vidrio y cristal era la del Espíritu nuevo de le Corbusier, la imagen flujo es lo propio de las nuevas ligerezas y fluideces, de las formas-trayecto nacidas de la interconexión de campos múltiples y heterogéneos $55^{8}$.

Todo ello remite a un fluido, el propio Ito se refiere a la analogía del agua. La tendencia apunta a eliminar los límites en todos los sentidos: espaciales y funcionales. La continuidad, y todas sus implicaciones que hemos ido repasando, es algo estructural y eminente en la forma de este planteamiento contemporáneo.

La red informática se asimila a un fluido que permite a nuestros cuerpos volver al cosmos del flujo primitivo como aquel otro tipo de agua. Ito se refiere también a la ciudad flotante, como superposición de la ciudad a la que se adapta el cuerpo biológico, y otra donde se encuentra el cuerpo ampliado por la red electrónica de la sociedad interconectada.

Lo fluyente y lo flotante fijan el carácter de esta arquitectura contemporánea, como en la estética de lo efímero de Christine BuciGlucksmann:

Lo efímero es acoger el espíritu de la ola, aceptar lo fluyente y lo flotante, una vida-paisaje y sin embargo esencial, que encuentra en el elemento acuático su realidad y su metáfora. ${ }^{559}$

Por ello, la Mediateca toma como referencia la metáfora del acuario, y la estructura portante se convierte en alga, ingrávida, a-tectónica, transparente, casi inmaterial.

557. FRANCIOSE CHASLIN, Deux conversations avec Rem Koolhaas, Sens et Tonka, 2001.

558. C. BUCI GLUCKSMANN, La estética de lo efímero, op. cit. pág. 63.

559. Ibid. pág. 17. 


\subsection{INGRAVIDEZ DINÁMICA DEL ÁMBITO-PIEL}

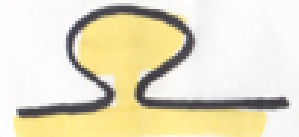

2.138. Invaginación del afuera. Croquis de la autora.
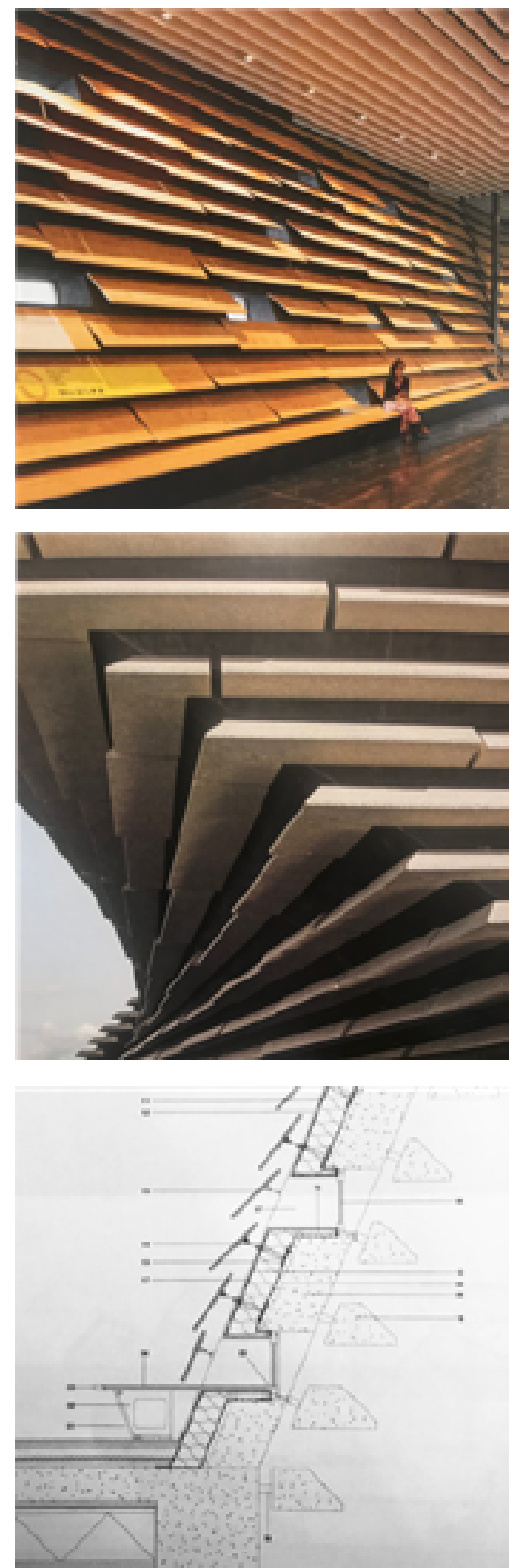

2.139. Museo V\&A, Dundee. Interior y estratos de hormigón exteriores y sección de la envolvente. KENGO KUMA 2018
Hay en toda la obra de Kengo Kuma una poética de la piel, una piel que vibra o se desvanece, que convierte la gravedad en levedad, donde la luz se filtra por el espacio, convirtiéndose en su medio de expresión. Su obra es a la vez corpórea-táctil y evanescente-inmaterial, tiene siempre algo de simulacro.

En su proyecto para el museo VEA en Dundee proyecta una piel dinámica que sobresale en el espacio del puerto de Dundee como un volumen en movimiento, donde a partir de una base más reducida el volumen se va abriendo hacia arriba, contradiciendo la acción gravitatoria o su forma tectónica adecuada; su envolvente se levanta, como movida por el viento y disgregada en una especie de lamas horizontales de las que está compuesta. Se trata de una serie de estratos de hormigón con piedra natural que rotan alrededor del conjunto, como encubriéndolo.

La piel no es contorno, es zona, tiene espesor profundo, capas, complejidad. Y así estos estratos dejan entre ellos una zona sombría que oculta un interior. La envolvente, está provista de capas, de estratos que la componen, y así la piel interior también es táctil y dinámica, siguiendo el mismo principio que la exterior, pero modificando el material que ahora es madera, material más delicado y cálido.

Todo el conjunto cobra espesor, profundidad. Formado, a partir del interior, por un acabado de finas lamas de madera; un grueso espesor de aislamiento térmico; una capa de muro de hormigón armado con ventanas de vidrio al que se anclan las lamas interiores; y por último, una capa exterior con los estratos de hormigón, su piel dinámica a-tectónica envuelve el conjunto y lo enmascara de un dinamismo aéreo.

Toda esta piel compleja es como un ámbito diluido que envuelve un interior que se articula de una manera escenográfica también, conectando los dos volúmenes que convergen en la planta de arriba, a través de una gran escalera-grada, generándose así un espacio unitario y fluido.

Rige un principio de fluidez exterior, llevada al interior, como una especie de continuidad total y fluida, puede vincularse a esa especie de invaginación del exterior, que observábamos en los interio- 


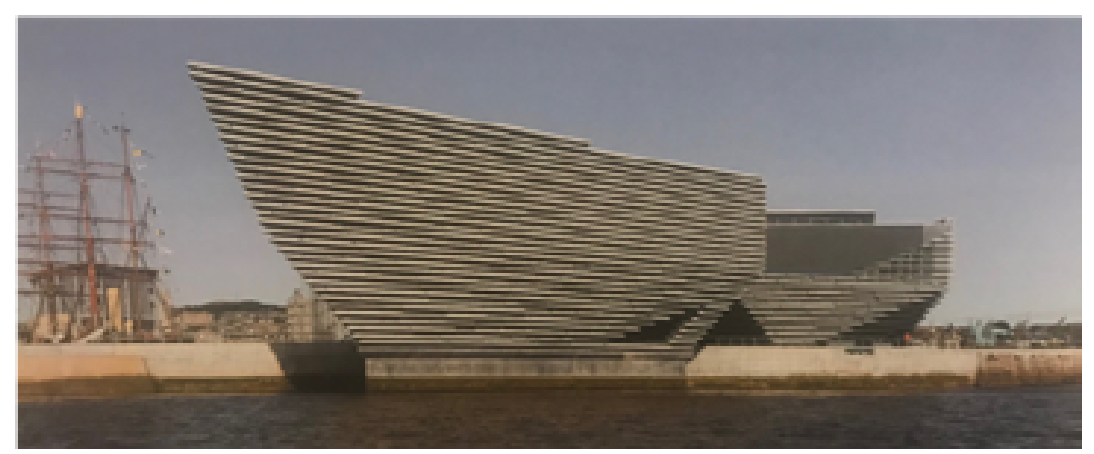

res borrominianos, especialmente en San Carlino ${ }^{560}$. Se evidencia esta cuestión en el acceso al edificio, fluyente desde la esquina y que se eleva, de un modo también fluido hacia el piso superior.

Aunque la composición del exterior responda a configuraciones urbanas, aunque el interior se cierre sobre sí mismo en una calidez material introvertida, los principios estructurantes son los mismos.

El Darling Exchange en Sidney, se compone de plantas de forma circular, descentradas las unas respecto a las otras, y envueltas por unas ligeras cintas de madera de forma desigual y dinámica sobre el volumen cilíndrico. Los diferentes forjados desplazan su centro unos respecto a otros, siguiendo el principio activo del conjunto, que parece enrollarse verticalmente, flotando sobre el suelo y negando también aquí, su peso propio, la acción gravitatoria. Este desplazamiento genera espacios aterrazados, que diluyen enormemente la figura de la envolvente, evitando siempre su percepción como contorno, creando un ámbito cada vez más interferido, disgregado e intervenido por la acción del intercambio, por la potencia del espacio que actúa en ambas direcciones.

La fachada desde dentro es como un filtro de luz casi natural, que tiene algo de organismo, de sensación de un exterior únicamente tamizado.

La envolvente se sustenta en una estructura metálica que va regulando la posición de las distintas cintas de madera, creando así un amplio ámbito de intercambio, al que se añaden los espacios de terraza.

De nuevo encontramos en esta obra una profundidad en la piel, que difumina y diluye el contorno, junto a una marcada a-tectonicidad. El espacio exterior y el interior interactúan sobre la forma
2.140. Museo V\&A Dundee: estratos de hormigón exteriores y sección de la envolvente. KENGO KUMA 2018
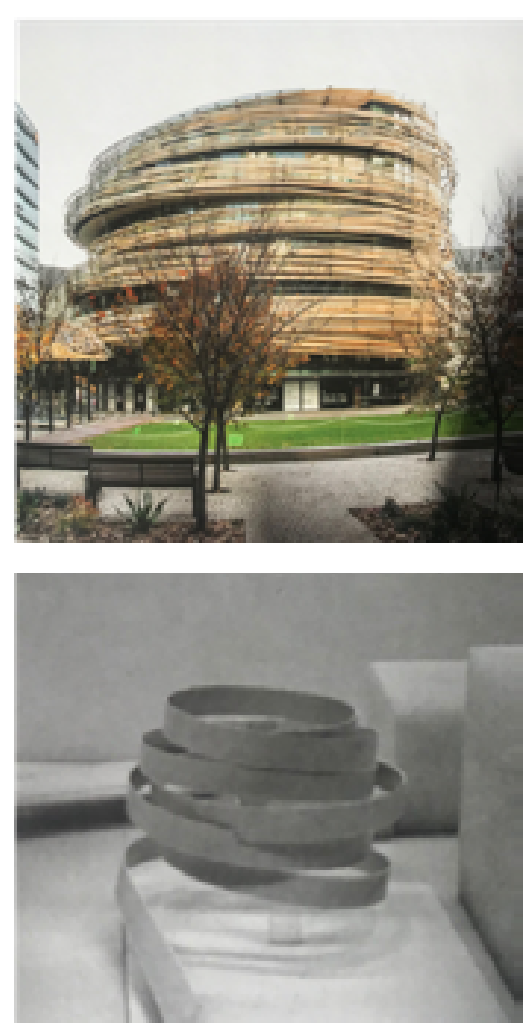

2.141. The Darling Exchange, Sydney KENGO KUMA, 2019. Vista exterior y maqueta. 


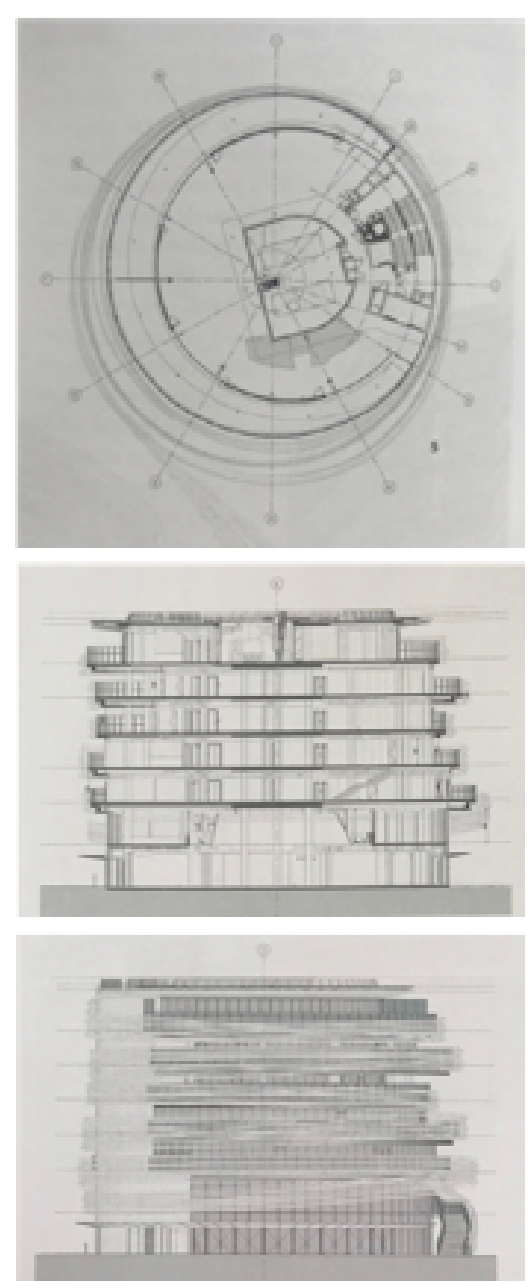

2.142. The Darling exchange, Sydney KENGO KUMA, 2019. Planta y seciones.
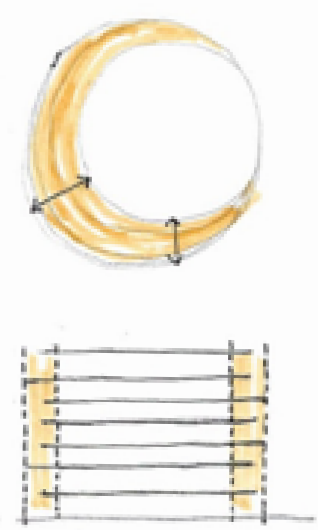

AMstros - HEL

2.143. Ámbitos de la envolvente del Darling Exchange. KENGO KUMA. Dibujo de la autora de-formándola, constituyendo un ámbito de relación compleja. El edificio flota en el espacio e interactúa con él a través siempre de la envolvente que se alza como el elemento que da presencia al edificio.

La envolvente contemporánea se extiende a la cubierta, y la arquitectura manifiesta la singularidad de la piel en la cubierta como sucedía con las carpas de RCR, dando protagonismo a la luz como canalizadora de la percepción de la presencia del espacio.

La construcción del museo de arte popular de Hangzhou está proyectada para adaptarse a la topografía y camuflarse con ella. Situado en una pendiente, se articula a base de una serie de módulos de planta paralelepípeda cada uno de ellos con su cubierta propia de piezas cerámicas que se enmascara con su color como si fueran piezas naturales. Pero las piezas cerámicas que forman las cubiertas tienen su continuidad en el cerramiento vertical, que se forma a partir de una malla de acero donde estas piezas se intercalan, como si de otro plano con menos densidad se tratara.

En el alzado del conjunto se alternan los planos de densidades distintas, constituyendo una especie de frente vibrante en el que no se distingue completamente la cubierta del paramento. Se trata de una especie de membranas alternadas, que se intensifican con la disposición en pendiente y los frontales intercalados con las cubiertas, resultando una especie de frente dinámico en profundidad; como planos que se van elevando en el paisaje.

Hacia el interior la luz se tamiza, también vibrante, señalando la espacialidad que la con-forma, colándose por los cerramientos, que se diluyen en el interior, desintegrándose su materialidad, desfigurando su contorno.

Volvemos a encontrarnos con los límites sin contorno, en este caso finísimas membranas que no consiguen que el interior se perciba como tal (de hecho, nada está cerrado o acondicionado, excepto determinadas salas del museo que así lo requieren), sino que crean una atmósfera única en la que la luz contribuye a fundir exterior e interior. 
La atmósfera produce una sensación vaga, que como Wölfflin señalaba respecto al Barroco: no se puede aprender el objeto, se desearía abandonarse al infinito ${ }^{56}$.

La cubierta del centro de interpretación de Yangcheng Lake, se presenta como una piel horizontal formada por perfiles ligeros de aluminio a modo de tejados de juncos o paja. Las piezas de aluminio se superponen irregularmente como caparazones ingrávidos sobre el espacio interior. Los juncos de aluminio tamizan la luz exterior produciendo el mismo efecto vibrante del museo de arte popular.

La piel-tejado se dispone sobre una estructura metálica tridimensional que la soporta a modo de caparazón flotante sobre el terreno. Se trata de una envolvente ingrávida que parece posada provisionalmente sobre el terreno, con un aspecto orgánico

La cubierta se confunde con el cerramiento vertical, que, en su interferencia, crea una espacie de ámbito intermedio entre el exterior y el interior en la zona ocupada por la estructura metálica que sujeta los tubos de aluminio. Hay una especie de indefinición del cerramiento que se produce en la articulación de los planos de cubierta con los verticales y que logran una especie de indefinición formal; una forma quebrada o descompuesta, cuya relación exterior-interior es un tanto incierta, pues surgen una especie de vacíos intermedios, ámbitos ambiguos encargados, por otra parte, de ocultar la estructura portante, enmascarando lo tectónico: planos ingrávidos flotando sobre el espacio.

\section{Las envolventes de estas obras de Kuma son como simula-} cros, su carácter a-tectónico es marcado; se trata de pieles ingrávidas a la vez que dinámicas, dos características que contradicen esencialmente la condición estable de la arquitectura.

Así, si la arquitectura se fundamenta en la estabilidad necesaria para mantenerse y ser habitada, sea su carácter más tectónico o más estereotómico, el simulacro mayor será el que niegue su estabilidad, a través de cualquiera de sus mecanismos: bajo la máscara del movimiento, o del flujo, bajo la desmaterialización y esponjamiento de la materia, o bajo la máscara de la ingravidez.
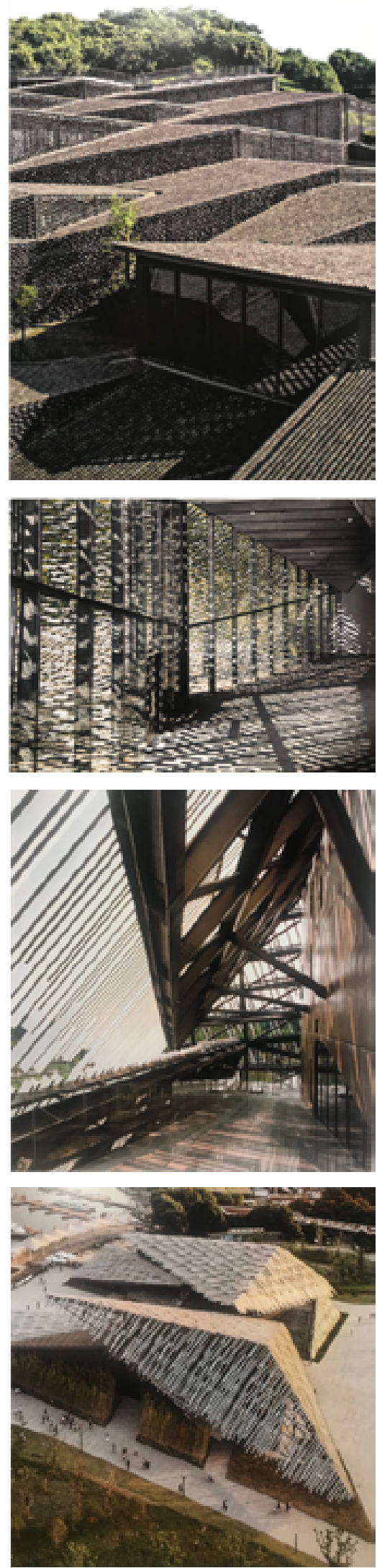

2.144. Museo de arte popular de Hangzhou: alazado exterior e interior. KENGO KUMA 


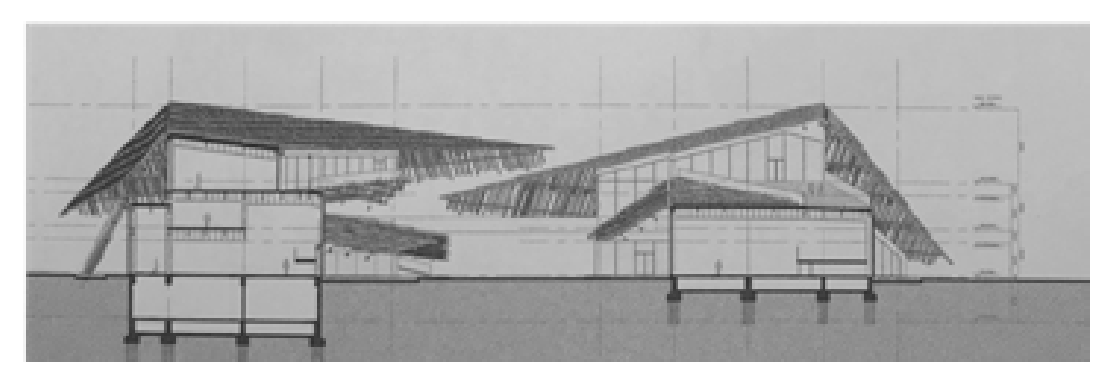

2.145. Centro de interpretación de Yangcheng Lake: sección. KENGO KUMA
Potencia, movimiento, acontecimiento, diferencia, repetición y continuidad, desembocan en lo metamórfico, lo que se presenta metamorfoseado en apariencias, simulacros y máscaras dionisiacas. El simulacro, la máscara, son elementos del Barroco, son también elementos esencialmente teatrales y, por ello, propios de la tragedia griega, como hemos visto. Son reclamados por Nietzsche y más tarde por Deleuze, como elementos propios del Eterno Retorno, donde es la metamorfosis la que hace nacer lo diferente sobre Lo mismo a través entonces del simulacro y la máscara.

El simulacro es el verdadero carácter o la forma de lo que es - el ente - en tanto que el eterno retorno es la potencia del Ser (lo informal) $)^{52}$.

¿No parecen ser también propios los simulacros de nuestro carácter, de una Postmodernidad neobarroca? 


\subsection{ENVOLTURAS TEXTILES: EL PRINCIPIO DEL REVESTIMIENTO}

El carácter marcadamente a-tectónico de los casos anteriores, desde el edificio de la Mediateca de Ito, cuya estructura se enmascara bajo formas ingrávidas y cuya envolvente se dispone de modo orgánico para recibir beneficios del medio o protegerse de él, según el caso, diseñándose según capas complejas y límites difusos, pasando por las pieles dinámicas y vibrantes de Kengo Kuma, remiten al debate entre la lógica constructiva y la envolvente ornamental.

Nuestra arquitectura contemporánea, se inclina generalmente por la supremacía de la envolvente en todos los sentidos, lo estamos viendo; hace tema de la envolvente, enmascarando marcadamente lo tectónico, lo estructural del edificio. Estos proyectos contemporáneos resultan muy ajenos a la lógica estructural de un racionalismo clasicista, pero adquieren todo su sentido como artificios expresivos fundamentados en el revestimiento.

Ya nos hemos referido más arriba a como la alternativa a esta verdad de la estructura tiene como figura principal a Gottfried Semper $^{563}$, que defendió un principio del revestimiento, frente al soporte estructural en el origen de la arquitectura, proponiendo su protagonismo como elemento primordial. Semper defiende el origen textil de los cerramientos arquitectónicos, y, como hemos visto, lo argumenta a través de su investigación histórica. Por ello da privilegio a la envolvente ligera, cromática y ornamentada, pasando a estar subordinado el soporte estructural, que supondrá entonces solo un andamiaje para sus cuatro elementos principales: el hogar, el recinto, el techo y el terraplén o suelo, de los cuales los tres últimos tienen la función de resguardar al primero y principal, el hogar, el elemento moral.

(...) qué técnica primigenia se desarrolló con respecto al recinto? No otra que la empleada por el que confecciona la cerca, es decir, el arte del que entreteje esteras y del que teje tapices ${ }^{56}$.

¿Pero no es ahora, cuando las cuestiones referentes a la piel del edificio, a la configuración de la envolvente toman el protagonismo que Semper quiso otorgarles?, ¿y no son además las texturas en-

563. Véase supra pág. 339, 340.

564. GOTTFRIED SEMPER, Escritos fundamentales de Gottfried Semper. El fuego y su protección, op. cit., pág. 158.
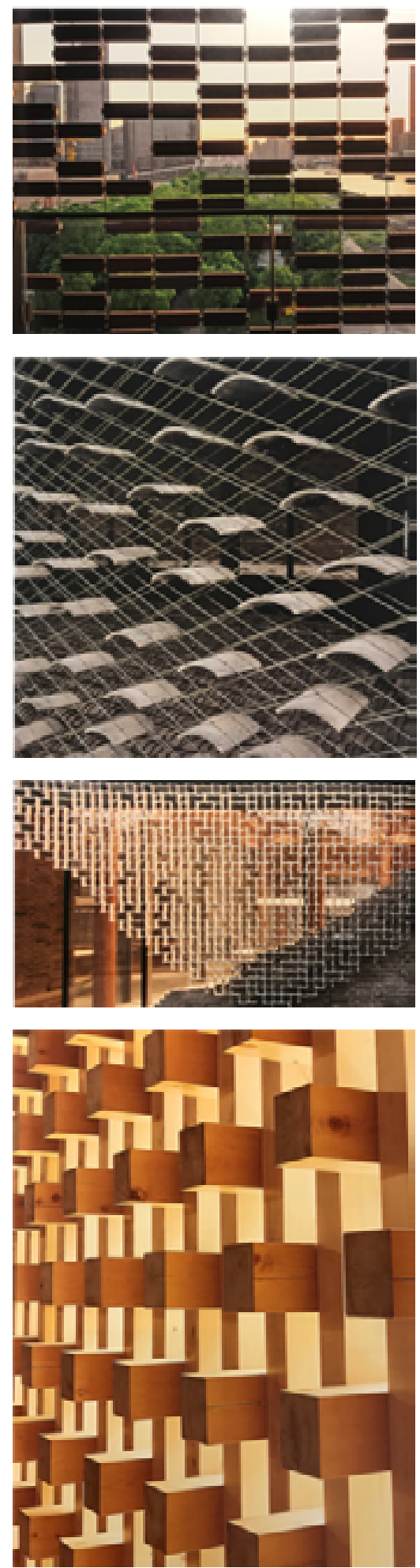

2.146. Pieles de aspecto textil en el astillero 1862 en Shangai. El museo de arte popular de Hangzhou, oficina Beijing Qianmen de Pekin y casa bosque 120c120 en Tokio. 

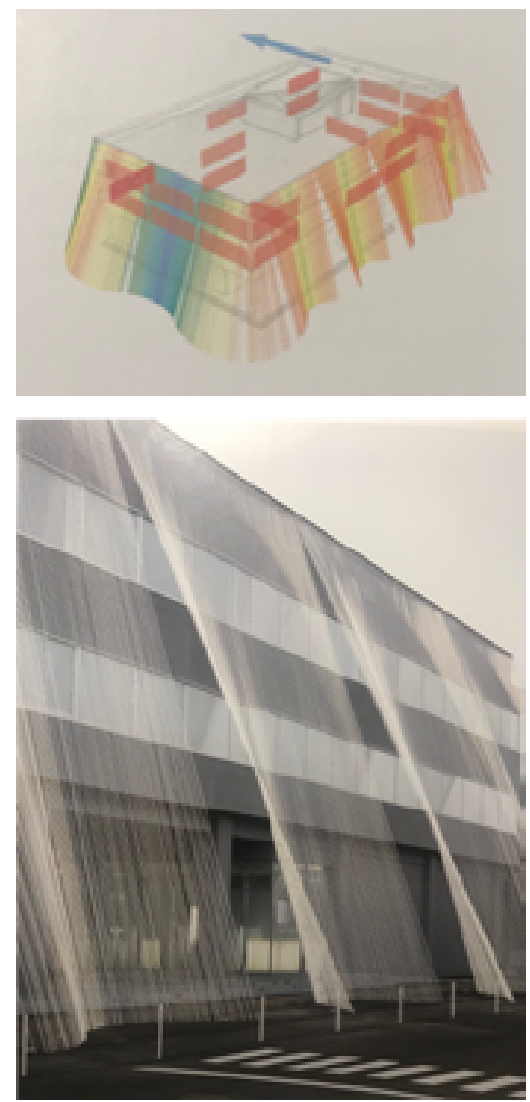

2.147. Showroom de Komatsu, Nomi, Japón. 2015 tretejidas y trenzadas, las soluciones más abundantes de los cerramientos contemporáneos?

Consideramos que esto se lleva casi hasta el final, conscientemente o no del pensamiento de este autor, cuando es significativo el número de nuestras arquitecturas que utilizan elementos de apariencia textil para resolver cerramientos, cuando se extiende por todas partes la utilización de materiales como mallas, textiles, membranas etc., en las envolventes de los edificios.

Si en el Barroco era el pliegue el elemento que evocaba lo textil, a través de su condición de elemento continuo, ahora el tejido, el entrecruzado, el trenzado y todos los recursos que expresen estas peculiaridades, han pasado a representar el carácter de lo textil, como si hubiéramos introducido una lente de aumento en los tejidos barrocos.

Para seguir con Kuma, la utilización de simulacros textiles es una constante en su obra. Lo hemos podido ver en los casos analizados, pero sus membranas pixeladas o entretejidas, protagonizan sus cerramientos. En la rehabilitación del astillero 1862 en Shanghái, vemos como superpone una estructura de hilos de acero con ladrillos suspendidos a modo de pantalla en los frentes de fachada.

El mismo tema encontrábamos en el museo de arte popular de Hangzhou, pero podemos verlo en muchas de sus obras como en la oficina Beijing Qianmen de Pekin o en la casa Bosque 120 x 120 en Tokio.

Un caso que merece especial atención es la rehabilitación de las oficinas Komatsu Matere que Kuma realiza en el año 2013. Las oficinas pertenecen a una empresa japonesa especializada en productos textiles. Kuma reviste el perímetro de la fachada, una construcción convencional de planta rectangular, con una superficie alabeada formada por finos hilos de un resistente producto de fibras de carbono que la empresa fabrica. Las cuerdas se anclan a la cubierta y a una línea sinuosa que discurre por el perímetro haciendo curvas y plegándose, formando como una fina capa transparente alrededor del edificio existente. Este mecanismo, por una parte, crea un ámbito, modifica su límite-contorno por un límite-ámbito, por otra genera un dinamismo visual del que el edificio carecía completamente en origen, un dinamismo que se intensifica con la incidencia del sol y la luz nocturna. La intervención es muy precisa, como ejemplo de transfiguración, por medio de la 
envolvente, de la forma-edificio, creando un límite difuso a la vez que un límite dinámico, que capta espacio y lo visibiliza.

Otro ejemplo podemos encontrarlo en el Art Museum de Aspen, Shigeru Ban proyecta un edificio con una envolvente entretejida que recuerda a una trama textil. El edificio es un cubo de hormigón que se reviste con capas de vidrio y una malla que lo envuelve. La capa exterior es de madera a modo de urdimbre tejida. Este plano exterior se complementa con otro de vidrio situado en el interior en diferentes posiciones con respecto a él.

Hay un continuo juego exterior-interior; la piel permite mostrar imágenes simultáneas del interior al exterior, difuminando los límites del edificio. La escalera es también un elemento híbrido entre exterior e interior, entre la pantalla tejida al exterior del edificio y su estructura interior. Se intersecta por un paño de vidrio, dividiéndola en un espacio exterior y un espacio interior. Este pasaje singular se localiza en un espacio ambiguo e intermedio y da cuenta del espesor de la piel que abriga al edificio. Piel desdibujada, diluida y difusa.

En el teatro Albi, Dominique Perrault, separa más radicalmente el revestimiento; el volumen se envuelve con una centelleante malla dorada, generando también intersticios en los límites. Hay en este caso un juego multicapa que incluye el espacio del teatro que queda envuelto en varias membranas.

Ahora, la técnica permite llevar al extremo lo textil, expresándolo con literalidad, pero ¿no está ya implícito en el Barroco, y asociado al recurso del pliegue al carácter textil del cerramiento que Semper propone?

Independientemente de las propuestas, que podríamos llamar a-tectónicas de Semper, la reflexión sobre el límite en relación a una cierta disolución o disgregación que se presenta en estas arquitecturas actuales, y que, en su reflexión sobre el límite en arquitectura, parece asociada a la que tiene lugar en el Barroco, y que se fundamenta en un cierto estatuto formal de la arquitectura contemporánea, parece ser una realidad.
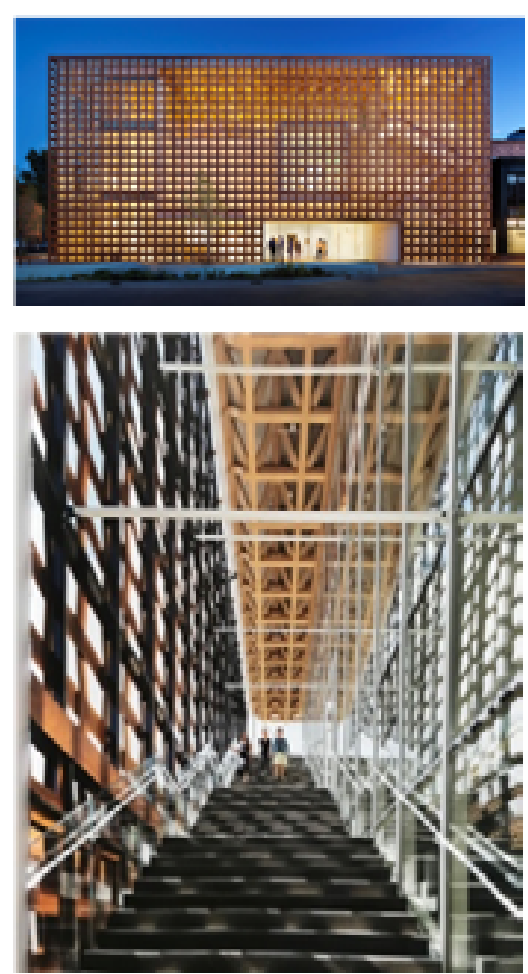

2.148. Fachada y escalera del museo de Aspen. Shigeru Ban, 2015
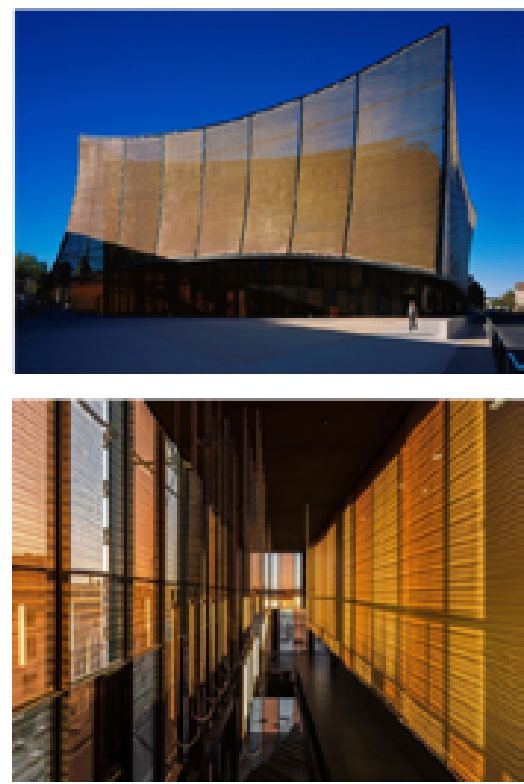

2.149. Imágen exterior e interior del teatro de Albi, Francia. DOMINIQUE PERRAULT, 2015 
La arquitectura japonesa de los últimos años manifiesta una especie de intención de interacción exterior-interior, una especie de indefinición de los límites, de eliminación de los contornos, a partir de la propuesta teórica de Ito a finales de los 80 y partiendo de una nueva sensibilidad poética en torno a la inmaterialidad de la arquitectura y su percepción fenomenológica. La indeterminación de los límites o la eliminación del contorno ya la habíamos visto en la arquitectura barroca, pero aquí, más bien, se trata de conectar, de relacionar, en vez de limitar en el sentido de excluir.

No es el mismo modo de abordar la envolvente que tiene lugar en la arquitectura llamada moderna. Podríamos poner de ejemplo algunos edificios de Mies van Der Rohe. La arquitectura moderna no evita el contorno, solo que el contorno es transparente, pero separa un exterior sobre el que el interior se alza como lugar de confort, como triunfo de la técnica moderna sobre una naturaleza hostil. La transparencia del vidrio moderno no produce zona superpuesta de reflejo (los Pabellones Les Cols), simulacro (el Darling Exchange), indefinición (las pieles textiles de Kuma), zona de interacción (la mediateca de Sendai), o límite difuso alguno, que serán las soluciones contemporáneas que ponen en cuestión el límite como contorno y lo conciben, sin embargo, como lugar de interacción.

Las propuestas de Toyo Ito abrieron una reflexión que ha ido evolucionando hasta el día de hoy a nivel internacional y que resultan de especial interés. Estudios como el de SANAA o Sou Fujimoto, se hacen eco de estas cuestiones y son de especial interés para nuestro análisis.

La arquitectura de SANAA logra plasmar esta condición de flexibilidad e indeterminación partiendo de esquemas diagramáticos que tratan de construirse sin perder la condición de inmaterialidad de los esquemas iniciales. Estos diagramas plantean límites que no actúan como fronteras divisorias, sino como conexiones, tratando de abolir todo tipo de jerarquía de espacios. Las relaciones entre cerramiento y estructura reciben una especial atención, pero no para asumir un papel protagonista: Kazuyo Sejima ya nos advierte: 
La estructura es muy importante para nosotros, incluso su desaparición lo es. ${ }^{565}$

Los materiales translúcidos, transparentes y reflectantes son esenciales en la obra de SANAA y conforman la atmósfera casi virtual en la que se mueven sus obras.

Estoy interesada en la creación de los límites. Empecé hace veinte años y siempre intento hacer tipos diferentes de límites... Me gusta pensar en los límites de todos los proyectos, no en límites sólidos sino en las conexiones ${ }^{56}$.

En la misma línea se encuadra la obra reciente de Sou Fujimoto, en la que se detectan relaciones con los postulados de Toyo Ito y SANAA. Sou Fujimoto nos habla de la arquitectura de lo intermedio:

La arquitectura ideal es semejante a un territorio "nebuloso". Un lugar donde lo interior y lo exterior se funden. Las innovaciones y desafíos de la arquitectura consisten en actualizar este dominio amorfo, y transformarlo en una realidad arquitectónica concreta y significativa. Por la razón anterior, me interesan las composiciones de anidación telescópica. En una estructura anidada multicapa, compuesta por cajas perforadas, emerge un territorio que es, simultáneamente, concreto y vago. Una caja dentro de otra caja, y así hasta el infinito, producen diversas gradaciones. Y sobre todo, la anidación telescópica no tiene escala (...), es una configuración flexible $^{567}$.

Podría parecernos que esta fusión de la que habla Fujimoto tiene su correlato en transparencia moderna, que de algún modo fusiona aplicando una transparencia. Sin embargo, notamos en este texto que a lo que se refiere más bien es a un ámbito ambiguo de intensidades, gradual; no se trata de una transparencia inmediata. No se trata de eliminar el contorno, sino más bien, de hacer que todo sea límite, todo sea intermedio, se trata de grados, de

565. Citado por JUAN ANTONIO CORTÉS en Topología arquitectónica. Una indagación sobre la naturaleza del espacio contemporáneo. Revista El Croquis dedicada a SANAA 2004-2008, Madrid 2008.

566. Kazuyo Sejima, Uno más en la casa de los SANAA. Una conversación de Agustín Pérez Rubio con Kazuyo Sejima y Ryue Nishizawa, en Casas. Kazuyo Sejima + Ryue Nishizawa SANAA. ACTAR, Barcelona y Musac, León, 2007, pág. 13.

567. SOU FUJIMOTO. Futuro Primitivo. En Fernando Márquez y Richard Levene (ed.), Sou Fujimoto 2003-2010, teoría e intuición, marco y experiencia. El Croquis 151, Madrid, 2010, p. 206 
potencias del plenum de Leibniz, que permite metamorfosear una forma que se ha perdido en favor de su límite-ámbito, que la ha aniquilado. Por ello se llaman arquitecturas de lo intermedio.

Una arquitectura que el propio Fujimoto define como capaz de mostrar las potencialidades de esta condición nebulosa. Este término que él explica como un estado transparente y único:

(...) un solo espacio que se deforma, ondula y palpita para crear multitud de lugares. Se puede incluso considerar el hecho urbano como un único gran ámbito que comprendiese la ciudad y su arquitectura. Con el ámbito único, lo interior y lo exterior dejan de ser elementos dispares, ya que se trataría sencillamente de una deformación provisional para una condición en la que ambos permanecen relacionados mientras se transforman ${ }^{568}$.

Sus palabras parecen una transcripción literal de lo que aquí se viene tratando desde el inicio a propósito de la continuidad y la metamorfosis. Todo parece coincidir con las consideraciones barrocas del pliegue (esa deformación, siempre provisional), del continuo-ámbito-fondo, lo diáfano (el ámbito único), de la metamorfosis (trasformación, también siempre efímera), o la topología (la relación entre ambas). Todo ello sucede en la piel-envolvente, el ámbito de la carga.

Podría objetarse que la teoría de los dos pisos, interior y exterior barrocos, nunca comunicados (la mónada no tiene ventanas), en este caso se contradice. Pero Fujimoto solo está pensando en un continuo metamórfico, que se deforma en pliegues (provisionales, efímeros); antes del plegado, ambos permanecen relacionados mientras se transforman, pero una vez plegado, mientras dura el pliegue (el tiempo de la máscara, siempre provisional), el interior permanece como tal. No hay que olvidar tampoco que la mónada contiene el mundo, y que este se compone de com-posibles, diferentes series enlazadas de mónadas.

¿No está Fujimoto también, por tanto, hablando también sobre el espacio como medio posibilitante, sobre el medio diáfano que hace posible que surja un lugar? Y así mismo, sobre lugares provisionales, efímeros, en proceso de cambio. Vuelven a ser aquí pertinentes los textos de Christine Buci-Glucksmann cuando define la imagen-flujo o la transparencia límite, una transparencia de los 


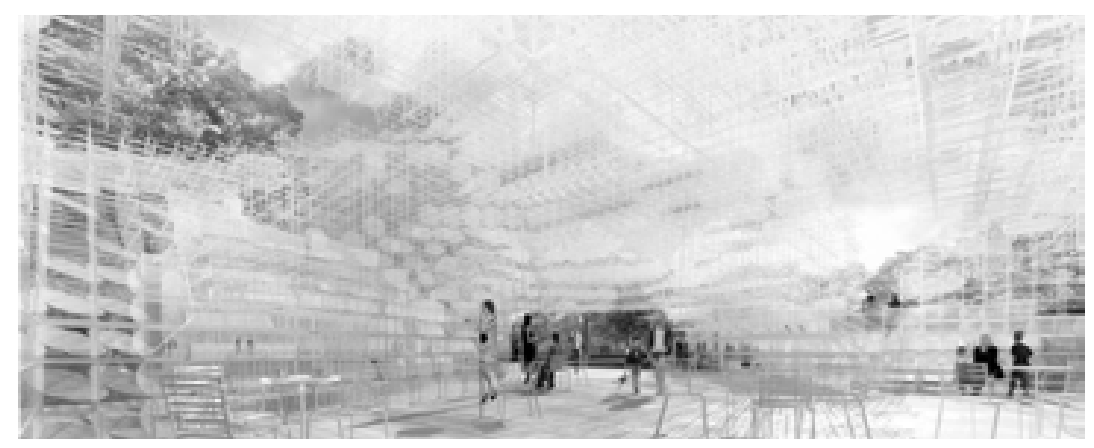

límites de lo diáfano. Lo efímero cósmico, característico de nuestro arte actual, surge entre apariencia y desaparición, y comprende la imagen como la traducción de algo sin forma, más originario ${ }^{569}$.

Nos encontramos ante un modo diferente de de-formación, una nueva manera de disgregar la forma, de, en definitiva, ponerla en cuestión. Calabrese ha notado también la natural inestabilidad e informidad en su era neobarroca; se trata de formas que no tienen propiamente una forma, sino que, más bien, están en busca de ella ${ }^{570}$.

(...) morfologías que propiamente no son forma, sino entidades en busca de su propia forma: las formas informes ${ }^{571}$.

Lo tectónico entonces, como elemento que es fijo se diluye en la forma, en el espacio, se enmascara, haciendo emerger el espacio de la relación y de la posibilidad. El énfasis en lo a-tectónico, en la piel, induce a visibilizar la componente tectónica de la arquitectura.

En estas arquitecturas recientes desarrolladas por estudios japoneses el elemento tectónico, referido a lo material, lo estructural, lo técnico, pierde importancia y reduce su presencia, su expresión, alcanzando además la disolución de los límites espaciales y físicos, jugando con los reflejos, las secuencias, los espesores multicapas... Se consuma en ellos la disolución de los límites precisos, la arquitectura de límites difusos, que lleva implícita la inmaterialidad y con ella la emergencia de lo diáfano.

El límite, el entre, como decíamos, ha aniquilado la forma, la ha tomado y todo es intermedio; un plenum, donde los flujos se pliegan provisionalmente en formas que se metamorfosean.
2.150. Serpentine Gallery Pavilion. SOU FUJIMOTO, 2013 


\subsection{HIPERSUPERFICIES}

Podríamos considerar que hay dos formas de referir la envolvente a un límite activo, sobre el cual el intercambio con el exterior se produce.

La primera sería proyectar una envolvente que sea realmente un límite-intercambio, creando una frontera disgregada que diluya el contorno como tal y con ello remita a una forma que podríamos llamar forma relativa, relativa al medio.

La segunda sería simplemente significando la piel del edificio en cuanto piel, con las consideraciones que supone en relación con la piel orgánica, que es límite sensible comunicador con un exterior; la piel, el órgano de relación con un exterior-medio. Este sería el caso que ahora analizamos de las hipersuperficies.

La relación del elemento estructural, siempre enmascarado, con la envolvente, siempre compleja, puede hacerse de varias maneras. La piel puede aparecer superpuesta a la solución estructural que, o bien se enmascara en el interior, o se diluye entre otros elementos. También puede ser que la propia piel acoja la estructura del edificio, incluyéndola en su espesor y de esta forma casi anulándola en su función, pues es la envolvente donde reside siempre la fuerza plástica de la obra.

La arquitectura contemporánea transfigura los muros en superficies y pieles digitales; tatuajes digitales de imágenes impresas sobre vidrio, camuflaje general biológico y táctil, o pieles onduladas e ingrávidas..., un gusto por las texturas y el revestimiento que crea una materia enmascarada. Es una arquitectura de las hipersuperficies, tratamientos múltiples de envolventes y cerramientos, que disfrazan la estructura y el sometimiento del espacio a la gravedad. Su condición a-tectónica y táctil remite a organismos vivientes, en movimiento; una cierta inestabilidad preside el carácter de estas arquitecturas, como si su forma definitiva no se hubiera consumado, dando cuenta de su naturaleza efímera, de su provisionalidad.

Todas ellas coinciden en su aspecto orgánico; un organismo que transmite dos consideraciones: el cambio, el movimiento, la vida, en definitiva, y la interacción de sus pieles, en su expresión de pieles orgánicas. 
Se trata de pieles creadoras de ficciones, son como máscaras, que envuelven una arquitectura enmascarada. La arquitectura interpreta, es la puesta en escena del espacio, hay siempre una teatralidad barroca.

\subsubsection{Las pieles tatuadas}

En la Biblioteca de Cottbus de Herzog y de Meuron en Brandenburgo, la envolvente está xerografiada en blanco con dibujos que tamizan la luz de entrada y se comportan como un gran mural de recubrimiento, que va modificándose con la distancia y con el día y la noche, ofreciendo un aspecto cambiante, como un objeto inestable. Se trata en este caso de un elemento independiente de la estructura a modo de muro cortina doble. La estructura portante no tiene relevancia y queda relegada a un sistema de vigas y pilares perdido en el interior. La planta de la biblioteca adquiere una forma orgánica que se deforma respondiendo a los flujos diferentes de movimientos tanto interiores como urbanos, como un organismo vivo que es sensible a la recepción de un exterior. Hacia el exterior, la biblioteca se presenta como un edificio de cristal curvado, sin bordes o esquinas, asemejándose a una ameba gigante.

En la Biblioteca del Campus de Eberswalde, los mismos arquitectos trasladarán la pintura de Warhol a la arquitectura, convirtiendo, a medias con el fotógrafo Thomas Ruff, el exterior de la biblioteca en un prisma puro pautado por una serie de franjas horizontales de vidrio serigrafiado y hormigón impreso donde cada elemento aparece literalmente tatuado por una fotografía de Ruff, siempre la misma para cada franja horizontal. El resultado final casi anula la escala del edificio o juega con ella, mientras da a la fachada una vibración que descoloca completamente la vista. El volumen queda afirmado con toda la rotundidad, sin enseñar, sin embargo, cuantas plantas tiene, que quedan camufladas en las franjas horizontales.

\subsubsection{Camuflajes biológicos y táctiles}

La envolvente pierde el carácter masivo y se convierte en una ligera protección inmaterial con poros, con el mismo sentido que los poros barrocos. Las técnicas que se emplean para ello son diversas; perforaciones de diferente índole en el material de fachada consiguen alcanzar este efecto. Incluso en algunos casos la propia envolvente es estructural, negándose esta condición bajo un aspecto esponjoso que enmascara su función.
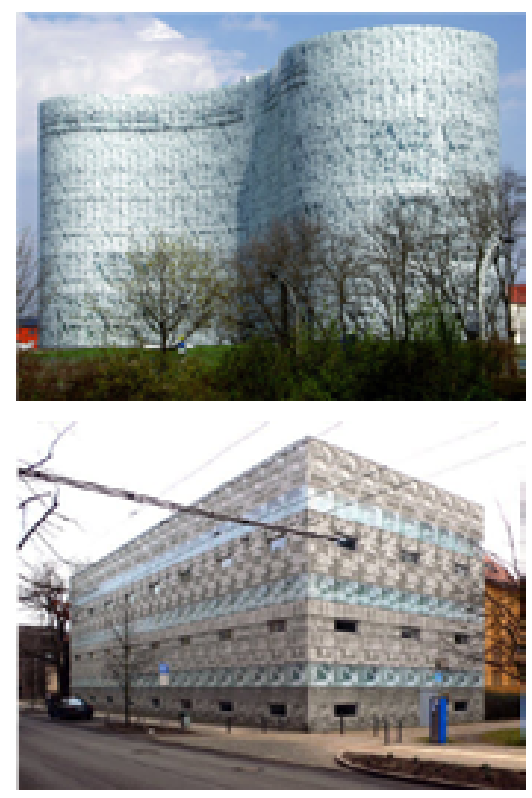

2.151. Biblioteca de Cottbus. HERZOG Y DE MEURON, 2004

2.152. Biblioteca del campus de Eberswalde. HERZOG Y DE MEURON, 1996 

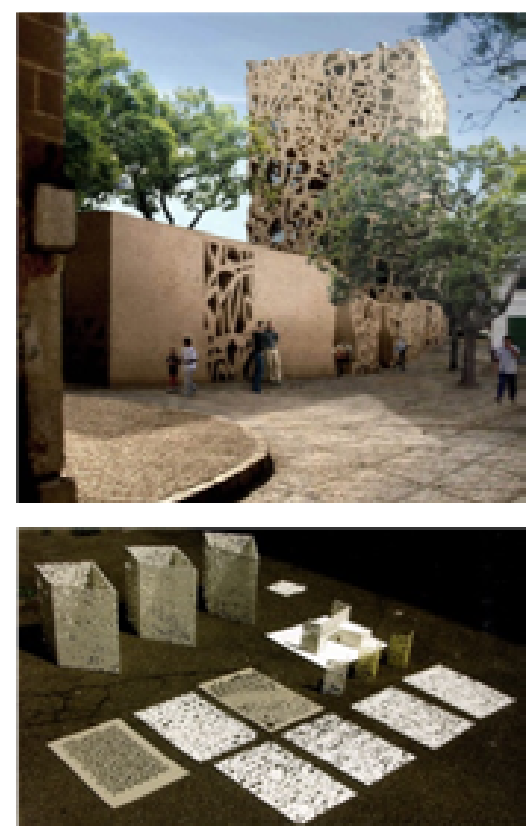

2.153. Museo del flamenco de Jerez. HERZOG Y DE MEURON, 2003

2.154. Abstracción de caligrafía árabe utilizada para la ciudad del flamenco de Jerez

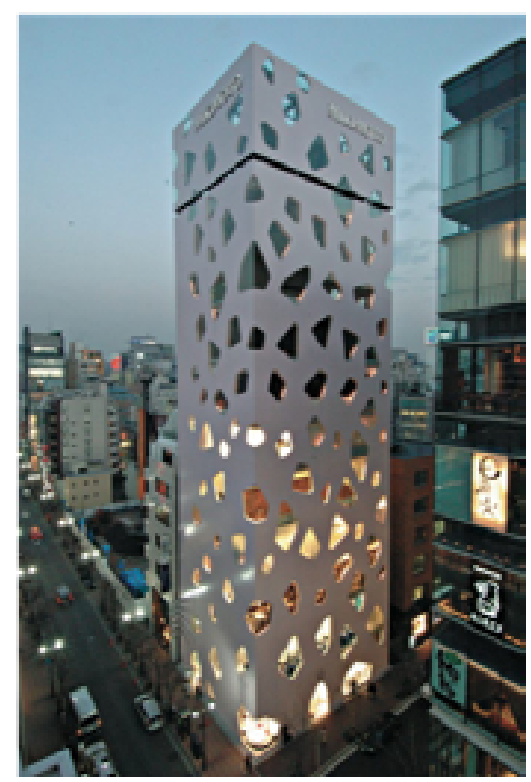

2.155. Boutique Mikimoto. Ginza, Tokio. TOYO ITO, 2005
El proyecto de Herzog y de Meuron para el Museo del Flamenco de Jeréz, es como un jardín tapiado y cercado por una envolvente significativa: una membrana biológica. El patio-jardín no tiene programa específico; se trata de una plaza para acontecimientos espontáneos. Su piel es el elemento configurador.

La fachada que proyectan, en este caso, comprende la estructura, es estructural, camuflando así la tectonicidad en una piel cuyo aspecto esponjoso y ligero niega su condición portante. Está formada por varias capas, la última de ellas, la que comprende la estructura, es de paneles de hormigón armado perforado y pigmentado, con motivos inspirados en la cultura flamenca y ornamentos árabes, que es la que le confiere este aspecto de membrana fibrosa e ingrávida.

No existe ninguna distribución específica de material en función de los esfuerzos, la envolvente contiene la estructura como para asegurarse de su no significación. La desdibuja perforándola con expresivos ornamentos que son los que dan carácter al proyecto.

Toyo Ito dispone en la Boutique Mikimoto los huecos de fachada de forma azarosa, perforando la envolvente aleatoriamente con una serie de ventanas con formas que, en este caso, también son irregulares. Algunos de los huecos ocupan las esquinas dando continuidad a la piel del edificio como si se tratara de una capa porosa que lo envuelve. Esta posición de esquina de los huecos también contradice el componente estructural que de nuevo soporta esta fachada. La estructura así, deja el interior libre de apoyos.

La fachada es de un sistema mixto de acero y hormigón y permite abrir huecos de forma aleatoria manteniendo una continuidad. Toda la tecnología que alberga el sistema constructivo está encaminada a transfigurar la realidad estructural y tectónica. Así el propio Ito comenta:

El sentido y el significado de la tecnología en mis trabajos está cambiando. En el pasado, la tecnología era muy visible. Se presentaba de una manera visible. Ahora es diferente. La tecnología es algo que escondo, tienes que buscarlo, usted no lo ve, usted no puede verlo. Es un elemento para ser utilizado y explotado de una manera indirecta. Antes, solía imaginar una arquitectura que nadie podía tocar, imposible de agarrar y sostener. Ahora, lo nuevo, es diferente, ahora quiero hacer una arquitectura que se pueda tocar y sentir, 
ahora estoy trabajando en la realidad física, en el objeto, en lo real. Esto me interesa en este momento...

La tecnología está al servicio de una arquitectura táctil; se trata de un objeto sensible, de piel significativa, en la envolvente reside su fuerza plástica como elemento configurador, negando su realidad tectónica. Se trata de una piel rota, que deviene difusa, conquistada por una especie de huecos de geometrías complejas de aspecto fractal, como una capa esponjosa.

El volumen, además, parece haber eliminado sus articulaciones, sus esquinas, pues las perforaciones de la piel están uniformemente repartidas dándole así una continuidad indiferente. Una cubrición desarticulada y continua que con su composición refuerza lo táctil, es decir, refuerza lo que la piel, como órgano sensible de intercambio, es.

En el aspecto masivo del cerramiento del Museo Kolumba de Peter Zumthor, de finos ladrillos grises, que están hechos a mano y cuya composición apenas se percibe, llaman la atención las perforaciones practicadas que conforman una especie de celosía hecha sobre la base de la trama de los propios ladrillos. Ya habíamos observado en esta obra, la similitud formal con la piel porosa de la cúpula de San Carlino.

Zumthor juega con la masiva piel del edificio desmaterializándola en las esquinas, como si estos puntos, estructuralmente significativos, estuvieran en proceso de desintegración, apareciendo como zonas porosas e ingrávidas.

Las zonas donde el material se desintegra dejan pasar la luz exterior generándose al interior como una especie de frágil límite que permite que el exterior se cuele en forma de luz, son como filtros. Así, en el interior se crean claroscuros al modo barroco, tamices de la luz que significan el espacio, el medio que conforma la arquitectura.

En el caso del museo Kolumba la envolvente se diluye por zonas, su aspecto contundente y masivo se transfigura. Su piel es aparentemente tersa, pero ya no puede serlo, los huecos, que en otro momento serían rotundas ventanas, han devenido zonas porosas, puntos frágiles a punto de escindirse. Es también una arquitectura ambigua, como la arquitectura de la contradicción de Venturi.

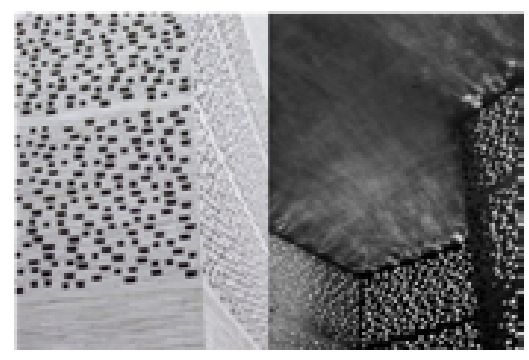

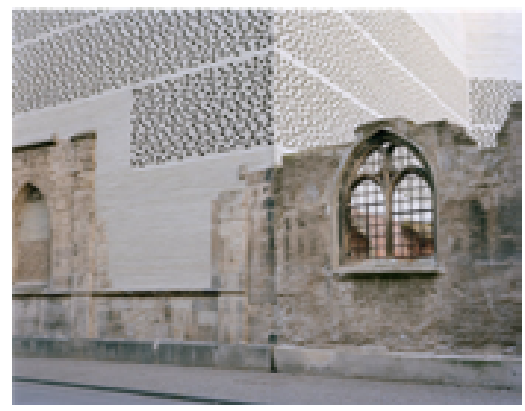

2.156. Museo Kolumbia, Colonia. PETER ZUMTHOR, 2007 
El ladrillo se abre dejando, en su propia textura, paso al exterior en forma de luz significada, de pequeños orificios que canalizan una luz que potencia el espacio y lo cubre con pequeños destellos. Piel disgregada en forma de poros que sugieren un intercambio como los poros de una piel orgánica.

En el perímetro estructural del Estadio olímpico de Pekín de Herzog y de Meuron, los arquitectos integran, las fachadas, escaleras, cubierta y espacios de acceso en el ámbito de la envolvente. La piel es una membrana con entramado estructural; una especie de tejido metálico.

En este caso la fachada de nuevo coincide con la estructura incluso con la cubierta y configura el espacio interior del edificio. Podríamos considerar que se trata de un edificio-piel: una madeja espacial formada por una malla estructural metálica.

Aparentemente simula una forma geométrica, que de lejos parece unitaria y bien delimitada, pero que se desdibuja según nos acercamos a ella, apareciendo entonces como una caótica maraña de estructura, escaleras, vigas y pilares. La piel se diluye y se descompone en miles de filamentos de acero haciéndola difusa; el contorno del edificio es ambiguo, exterior-interior se confunden en ese límite desintegrado.

El diseño se basa en los nidos de las aves, no sólo a nivel estético, sino también a nivel estructural. Toda la estructura visible desde el exterior imita las ramas entrelazadas de los nidos que al trabajar en conjunto. De nuevo hay una referencia a lo orgánico.

Las ramas de este nido están construidas de acero; entre una y otra, una serie de piezas hinchables de ETFE, hacen que desde el exterior el estadio devuelva una imagen acolchada. Este aspecto blando niega de nuevo su condición portante.

La envolvente es una estructura en profundidad, a la vez es espacio; hay una relación triple entre estructura y envolvente, y entre espacio y envolvente. Los arquitectos consideran que es aquí donde reside el interés del proyecto. 


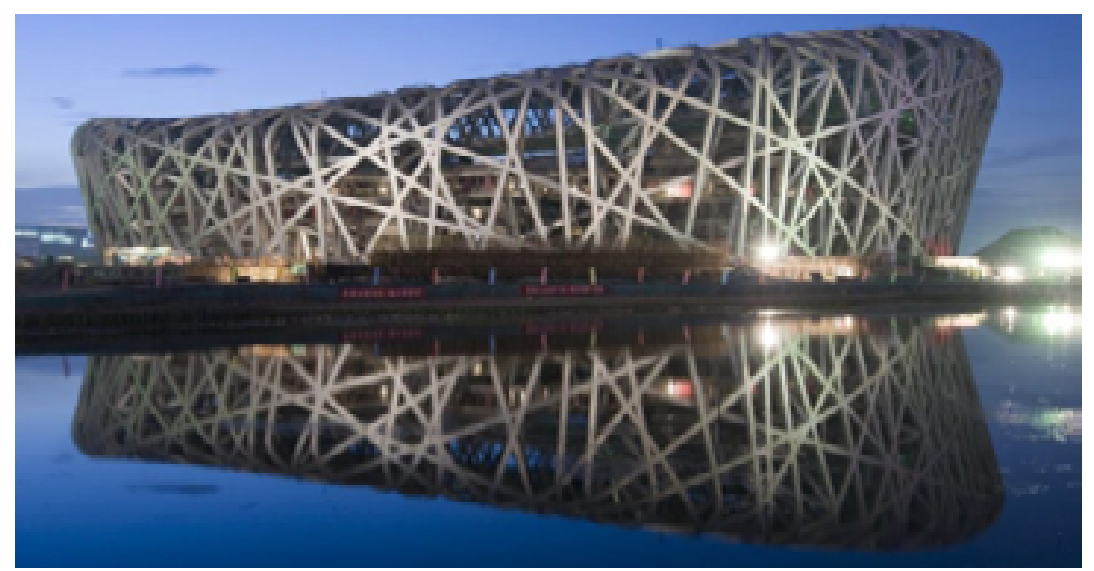

Los elementos por si solos no transmiten mucho, pero la integración de la estructura con el ornamento y el espacio es mucho más interesante. ${ }^{572}$

La envolvente y el espacio se funden e interactúan, la estructura está de nuevo enmascarada; el valor del proyecto está asignado a la envolvente que ya no es contorno sino ámbito, zona.

Todas estas arquitecturas de las hipesuperficies transforman sus muros en pieles digitales, en vestidos frágiles y esponjosos, que pierden su calidad de objetos sometidos a gravedad, convirtiéndose en planos fluidos; pieles plegadas, tatuadas, tornasoladas, que introducen el movimiento en lo plano, de otro modo diferente de como hacía el Barroco. Se trata de enmascarar lo material, de materia enmascarada, un Neobarroco tecnológico que explora la curvatura del mundo y su estratificado. Se trata de una metamorfosis de las superficies ${ }^{573}$.

(...) el vestido es por todas partes la verdad de lo desnudo, como lo quería Leibniz, con sus inflexiones, sus fluideces y su gusto por las texturas y el revestimiento de la materia. ${ }^{574}$

Hay una reflexión de la noción de superficie, cada vez más inmaterial y efímera, plagada de flujos y vibraciones. Cada vez más alejada de la noción de contorno.

572. HERZOG Y DE MEURON, Minimalismus and Ornament, ARCH+ № 120-130, Aachen 1995.

573. Cifr. CHRISTINE BUCI- GLUCKSMANN, La estética de lo efímero, op. cit., pág. 59. 574. Ibid, pág. 59

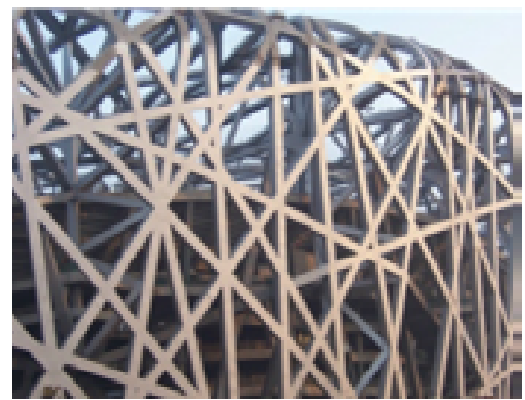

2.157. Estadio olímpico de Pekín. HERZOG Y DE MEURON, 2008 
Partiendo de la obra de Borromini se ha reconocido como, desde las consideraciones renacentistas, la obra desplaza la atención desde el centro a lo periférico. Se ha observado como la tensión ineludible de la gravedad que es condición de la arquitectura, es enmascarada, en una materialidad conformada por fuerzas que parecen venir de una exterioridad absoluta, ajenas incluso al sistema tectónico que sustenta la arquitectura.

Esta característica que es propia de las obras analizadas, desvía la atención hacia la envolvente del espacio; composición y tratamiento ornamental se orientan para designar una pérdida de importancia de lo tectónico-gravitatorio, en beneficio de la envolvente.

Pero que la envolvente contenga la fuerza y la potencia de la obra no quiere decir que este límite o piel tenga el significado de contorno, no quiere decir que la obra quede bien delimitada. Por el contrario, se trata de negar el contorno, de no presentar en ningún caso la forma en su integridad, sino más bien que su figura quede des-dibujada. Todo se canaliza hacia una concepción del límite, no como contorno, sino como ámbito, zona donde una potencia se ejerce, donde actúan las condiciones que con-forman la cosa. El límite ya no es el contorno de la cosa, sino, más bien, hasta donde su potencia llega.

Por ello decimos que los edificios de Borromini son de piel profun$d a$, pues en ella encontramos, no sólo una densidad de masa, que se pliega y se inflexiona, sino una intensidad, pues es en ella donde se ejerce la fuerza del proyecto, su potencia en todos los sentidos, donde reside el significado. Si la piel contiene la potencia, esta solo podrá medirse por intensidades, nunca por cantidades extensas.

Y esta profundidad de la piel es de la que participa toda la obra, es su estructura interna, su estructura latente. Que permite que el interior y el exterior participen de una continuidad, es como una doble exterioridad, una invaginación del afuera. En este movimiento se resuelve también la problemática de la relación entre un interior cerrado y sin ventanas donde resuena un exterior público y común. 
Como ya sugieren sus croquis, el contorno no es nítido, es indefinido, difuso, se disgrega. Deleuze señala como en toda la pintura del Barroco el trazo de la línea se disgrega y se convierte en una sucesión muy, muy fina de trazos planos 575 . Podemos observarlo bien en el cuadro de Las Meninas, por ejemplo, lo hemos visto: al acercarnos la pintura se desintegra, se trata de figuras sin límites precisos. Las figuras parecen surgir del fondo. Todo se reorienta en función de que la forma surja del fondo, y así, la figura ya no puede definirse por su contorno; se trata de una forma relativa a un espacio que se gradúa, en luces y sombras, en claroscuros, espacio modulado por la luz, pero también graduado por los límites que establecen un intervalo, un entre, como en la arquitectura de lo intermedio de Fujimoto.

La arquitectura contemporánea también se desmarca así de ese límite-contorno, pasando a un límite difuso, ambiguo, diluido, un límite que se ha erosionado y transmutado en superficies fluidas digitales o esponjosas inmateriales. Cumpliendo hasta el final esa tendencia de las superficies borrominianas a una cierta desmaterialización.

En el Barroco las pieles se disgregaban en forma de pliegues, pliegues profundos que cuestionan la fachada clásica, desestabilizándola, ocultando la función tectónica que asegura la sustentación del edificio. La piel contemporánea se disgrega y se entremezcla con el espacio creando ámbitos, cumpliendo con ambigüedad su función de límite, dejando mezclarse la figura con el fondo. Se trata de una piel-intercambio, o límite activo, que interactúa con un fondo-exterior, descomponiéndose en capas, se permeabiliza o se presenta como un tejido ambiguo que oculta o enmascara la estructura, velando lo tectónico, disfrazándolo. La piel profunda es ahora, más bien, límite difuso.

La relación problemática entre exterior e interior, que se vincula fácilmente, como Deleuze demuestra, con la consideración filosófica de las mónadas, cerradas sobre sí mismas y generadoras de puntos de vista sobre el mundo, no se mantiene en la contemporaneidad. Deleuze observa que las mónadas contemporáneas se hayan semiabiertas ${ }^{576}$, pues ya no se componen para expresar el 
mundo en series convergentes, la armonía barroca se ha roto en la actualidad, y las series ya no se com-ponen, son series divergentes y en expansión. En arquitectura se evidencia marcadamente: el ámbito espeso y profundo de las pieles borrominianas, sigue siendo ámbito-zona pero, en nuestra arquitectura, es permeable, y los límites son interactivos; exterior e interior se interpenetran.

La forma que había ya perdido su referencia a sí misma y remitía al espacio, ha dejado que el espacio la disuelva, en transparencias, fluideces y límites difusos, y lo interior y lo exterior dejan de ser elementos dispares para convertirse en tan solo esa deformación provisional que señala Fujimoto, donde ambos permanecen relacionados mientras se transforman ${ }^{577}$.

El estatuto de la forma de la arquitectura se ve afectado por ello; ya no importa la integridad formal, es más, importa señalar que la forma nunca será estable. La forma se metamorfosea en pliegues, y lo hace de diferentes modos: el modo barroco inflexiona y pliega, el modo contemporáneo desmaterializa, diluye. Cada caso genera, a su manera, su forma relativa.

577. Cifr. SOU FUJIMOTO. Futuro Primitivo. En Fernando Márquez y Richard Levene (ed.), Sou Fujimoto 2003-2010, teoría e intuición, marco y experiencia. El Croquis 151, Madrid, 2010, pág. 206. 


\section{REFLEXIÓN SOBRE EL TIEMPO.}

La noción de naturaleza: Una estética de lo efímero

(...) aquella en la que se imprime la imagen del decurso histórico es la naturaleza ya caída. La propensión del Barroco a la apoteosis es el reflejo del modo que le es propio de considerar las cosas. ${ }^{78}$

Si la condición singular de la arquitectura reside en la tensión inevitable de la gravedad, cuando esta condición es negada, cuando lo tectónico se enmascara y pierde su presencia en la obra, a favor de un espacio ingrávido que con-figura la forma con mecanismos que parecen ser radicalmente exteriores, ¿puede ser que la técnica (la techné griega), quede entonces olvidada en el dominio del arte, de la arquitectura?, ¿o que se trate de contradecir la verdad (constructiva) para aferrarse a una apariencia? 579

Para Benjamin, en el Barroco, mediante la técnica de la alegoría, se sustituye la condición simbólica del clasicismo, en un artificio donde la idea se hace verdad sensible. Se trata entonces, más bien, de representar la falsedad de toda apariencia de unidad ${ }^{50}$, como composición de fragmentos, reivindicando lo frágil y lo imperfecto, la imposibilidad de cierre en una representación inmóvil y unitaria.

Esta cuestión remite a la diferente consideración de la naturaleza que en el Barroco tiene lugar frente a la naturaleza idealizada del Renacimiento. La concepción Barroca de la naturaleza está más cercana a la physis griega, que reivindica el cambio, la vida, pero también lo perecedero, lo efímero, lo frágil, lo imperfecto, patente en la representación de la ruina, como nos recuerda también Benjamin. En contra de la tendencia a la abstracción, que tiende a apreciar más las semejanzas, considerando como estable un cambio continuo. La atención en el Barroco se centra en las di- 
ferencias, más que en las semejanzas; la naturaleza está llena de excepciones y diversidades.

Wölfflin señala que en el sistema barroco hay una voluntad de unidad de lo múltiple donde toda forma contiene la tensión expresiva de la presencia de las fuerzas..$^{51}$

El Renacimiento es el arte de la belleza apacible, (...) el Barroco persigue otro efecto, quiere cautivar con el poder del afecto, directo y arrollador. (...) No evoca la plenitud del ser sino el devenir, el acontecimiento; no la satisfacción sino la insatisfacción y la inestabilidad.

Cercana está esta definición, a la particular definición del fenómeno artístico que podemos encontrar en una de las líneas del pensamiento contemporáneo; la que considera su condición inquietante y perturbadora, como acontecimiento que propicia la apertura a un afuera que posibilita el devenir, permite vislumbrar el ser inestable del devenir..$^{52}$

Todo ello concurre en una concepción de la naturaleza, más próxima a la physis de los griegos presocráticos, que, a la pasiva imitación de su apariencia como modelo a imitar, lo que se llamó naturalismo en el Renacimiento. 


\subsection{LA NATURALEZA COMO PHYSIS}

La gran innovación de los artistas de los siglos XIV y XV, consistió en que hicieron volver al arte a su consideración clásica, concibiéndolo de nuevo como mímesis, volviendo al concepto de imitación. Pero junto con el retorno de la idea de imitación de la naturaleza, se introduce el concepto de superación de la naturaleza. La actividad del intelecto artístico era capaz de traducir de forma visible la belleza jamás totalmente realizada en la realidad, y por tanto debía hacerlo ${ }^{58}$. Parece que se exige a la obra de arte una imitación de una naturaleza idealizada.

Elegir siempre lo más bello entre la multiplicidad de los objetos naturales, a evitar la deformidad, sobre todo en lo que se refiere a las proporciones. ${ }^{584}$

¿Pero esto no encierra en sí mismo una contradicción?

¿No es precisamente la naturaleza, vista en su totalidad cambiante y múltiple, algo imperfecto y complejo, que incluye la decadencia, lo imperfecto y que no se deja dominar por una imagen ideal de belleza y perfección?

El movimiento renacentista estaba basado en un restablecimiento de lo clásico y en un naturalismo francamente poco clásico (... $)^{58}$

La Physis, para la filosofía griega tiene un sentido mucho más complejo que el que ha llegado a nuestros días, tiene un sentido ontológico. Para los filósofos presocráticos la naturaleza-physis corresponde con el fondo inmanente de vida, donde se cumplen los ciclos de nacimiento y muerte; la physis griega abarca el devenir, y su reserva de potencias. Los presocráticos encuentran siempre el arché (o primer principio) en la naturaleza: el agua de Tales de Mileto, el aire de Anaxímenes, el fuego y el rayo de Heráclito, el Poema de la naturaleza de Parménides, los cuatro elementos (aire, fuego, tierra y agua) de Empédocles, etc. La Physis significa

583. ERWIN PANOFSKY, Idea. Ein beitrag zur begriffsgeschichte der älteren kunttheorie, traducción al castellano de Margarita Súarez -Carreño, Idea, contribución a la historia de la teoría del arte, Arte Cátedra, 2013.

584. Ibid.

585. ERWIN PANOFSKY, ¿Qué es el Barroco?, en Sobre el estilo, Paidós, Barcelona, 2000. 
crecimiento, brotar, surgir; en la filosofía arcaica designaba el ser o la aletheia (verdad como desvelamiento), salir a la luz ${ }^{586}$.

Internamente entonces el modelo naturalista del Renacimiento, lleva en sí esta doble tensión: pretende, una mimesis sobre una naturaleza idealizada frente a una realidad cambiante que incluye la caducidad y el tiempo; y un retorno a un clasicismo basado en una idea alejada de esa physis que preside el mundo clásico de los griegos.

(...) por esencia al clasicismo le estaba negado percibir la carencia interior de libertad, la imperfección y fragilidad de la bella physis sensible. Pero es esta precisamente, oculta debajo de su pompa extravagante, proclama la alegoría del Barroco con un énfasis que no tiene precedentes. ${ }^{587}$

La naturaleza sigue siendo la gran maestra para los artistas del Barroco, pero no se manifiesta en su imagen más amable, sino en lo marchito y decadente de sus criaturas, con un sentido opuesto al concepto de naturaleza elaborado por el Renacimiento. Eugenio Trías escribirá sobre esta concepción de la vida y la naturaleza en el arte del Barroco.

La vida surge en todo su esplendor, pero también en todo su efectivo horror, delimitada por la corrupción, por la evanescencia, por el cambio. ${ }^{58}$

La naturaleza barroca da cuenta de lo híbrido, del tiempo y del movimiento; es expresión de un dinamismo que evoca una naturaleza diferente, la physis compleja que los griegos presocráticos temían y admiraban, la de los titanes, más que la de los dioses. Una naturaleza que pone en evidencia las fuerzas potenciales a través de una variación dinámica, una naturaleza ya sometida al devenir.

Pero la expresión naturalismo, referida al arte y a la arquitectura, se aplica habitualmente al seguimiento del modelo de perfección y de belleza que describen los tratados renacentistas, inspirado por las formas de una naturaleza idealizada, al equilibrio y la mesura. Y por ello se ha advertido, en ocasiones, una falta de naturalismo 
en la arquitectura de Borromini, y de algunas de las expresiones del arte barroco en general, reprochando que proceden de formas distanciadas de la naturaleza y de la belleza.

La fantasía de Borromini prescinde de cualquier experiencia naturalista; no procede jamás bajo la pauta de lo verdadero y por tal motivo tiende a expresarse en formas estéticamente imposibles, pero realizables por el rigor de su virtuosismo técnico (...) $)^{589}$.

Parece que fue la arquitectura de Borromini especialmente afectada por la aplicación de términos despectivos, tal vez por esta cuestión.

El clasicismo del siglo XVIII aplicó este término despectivo (barroco) sobre todo al tipo de arquitectura y ornamento que reprobaba, con especial referencia al estilo del gran arquitecto del siglo XVII Francesco Borromini. ${ }^{590}$

Sin embargo, también se ha señalado precisamente la naturaleza, como una de las autoridades a las que Borromini acude en sus proyectos de arquitectura ${ }^{591}$, a través de la presencia de la geometría y las matemáticas en la generación de las trazas de sus proyectos, pues la armonía subyacente en la naturaleza se asocia con frecuencia al principio matemático. La idea de la relación entre la matemática y la naturaleza estaba ampliamente extendida a través de la obra de Galileo que nos dice (...) la naturaleza no hace por medio de muchas cosas lo que puede hacer con pocas.

El módulo que Borromini escoge para el trazado de Sant'Ivo alla Sapienza prolifera hacia adentro en una complejidad cada vez mayor basada en una geometría precisa. Se despliega en un modo radial que se repite dividiendo hasta el infinito, sobre una base geométrica sencilla. La repetición es interna, las columnas se desdoblan en pares y se alternan en repeticiones subdivisibles, parece que infinitamente. Hay un desarrollo continuo de la forma a partir de una geometría radial.

Borromini, en las trazas de sus proyectos ya no sigue pautas sencillas, ya no se apoya en una austera naturaleza que se mueve por

589. GULIO CARLO ARGAN, Borromini, op. cit., pág. 72.

590. ERWIN PANOFSKY, Idea, contribución a la historia de la teoría del arte, op. cit.

591. Anthony Blunt señala que hay tres fuentes de autoridad en la arquitectura de Borromini: Miguel Ángel, los arquitectos antiguos y por último la naturaleza. Cifr. ANTHONY BLUNT, op. cit., págd. 15-55. 
principios de economía, ahora la naturaleza derrocha las formas que además no parecen concluirse en sí mismas, mostrando, más bien la potencia de formación. Una physis que se revela como reserva de potenciales, una naturaleza como materia en movimiento, siempre cambiante, como realidad inaprensible. En las obras de Borromini parece que entra en juego el tiempo, pues no hay movimiento sin el valor del tiempo.

La naturaleza lleva "historia" escrita en el rostro con los caracteres de la caducidad. ${ }^{592}$

Señala Erwin Panofsky que la calificación de antinaturalismo asignada por la historiografía a las obras del siglo XVII es común en las criticas artísticas posteriores a este periodo durante el clasicismo $^{593}$. El reproche que se hace se basa esencialmente en una falta de estudio fundamentado en la naturaleza. Pero hay otro reparo que se hace y que toma la misma fuerza, se refiere al extremo opuesto; contra un naturalismo demasiado fiel al modelo imperfecto, fundamentalmente representado en la pintura de Caravaggio, sin referencia a un estándar de belleza, exclusivamente imitador de la realidad tal como se presenta.

(...) sujeto exclusivamente al modelo natural, se habría conformado con reproducir, sin ningún tipo de criterio, los objetos en su aspecto exterior, incluso aunque fuera defectuoso. ${ }^{594}$

Caravaggio tiene una buena maniera de representar las cosas que había aprendido copiando del natural, aunque en la representación

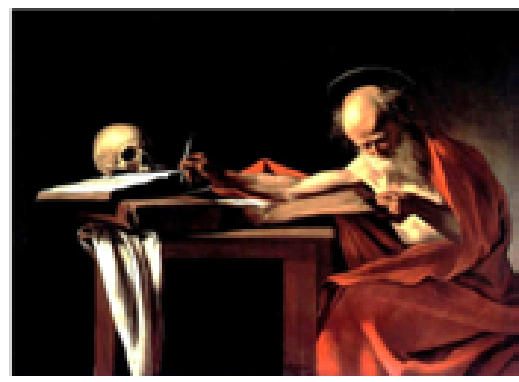
de las cosas no tenía mucho juicio para elegir lo bueno y dejar lo malo. 595

¿No hay una analogía con la arquitectura de Borromini en estas críticas a Caravaggio? ¿No pretenden sus formas en movimiento, la inestabilidad de sus interiores, sus despliegues sucesivos e incluso las impurezas medievales ${ }^{596} \mathrm{y}$ las referencias anacrónicas que encontramos en su arquitectura, mostrarnos una naturaleza

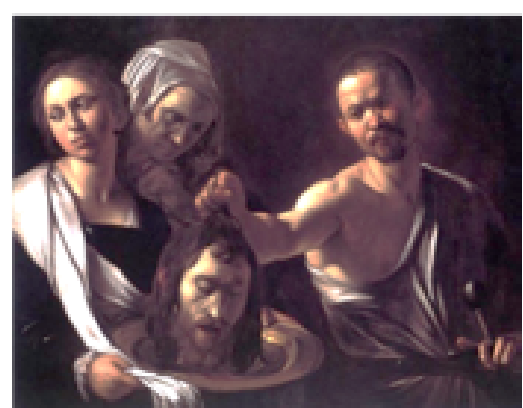

2.158. San Jerónimo. CARAVAGGIO. 1608. 2.159. Salomé con la cabeza de Juan el Bautista. CARAVAGGIO, 1609. imperfecta, inmanente de la que formamos parte?

592. WALTER BENJAMIN, El origen del treuespiel..., op. cit., pág. 180.

593. Cifr. ERWIN PANOFSKY, Idea, op. cit.

594. GIOVANI PIETRO BELLORI, L'idea dello pittore, dello escultore, e dell architetto (1664).

595. LUIGI SCARAMUCCIA, Le finezze de'Pennelli italiani (1674).

596. Veáse infra, pág. 385-392. 
Borromini expresa sus formas dinámicamente al tiempo que les otorga espesor material, densidad. Y la luz hace su parte, deslizando por ellas, teatralizando el espacio. Quizás la misma materialidad de los cuerpos de Caravaggio, la misma densidad y similar trato de la luz, claroscuros contrastados, en ocasiones tenebrosos.

El brillo y lo luminoso, elementos sobre los que tradicionalmente se había cimentado la idea de belleza, deben tener su contrapunto: la oscuridad, y sin ella nunca emergen. Materia y oscuridad son los nuevos elementos, y van unidos, pues la materia, en su sentido clásico y en su relación con la pareja materia-forma, es lo desconocido, la oscuridad de toda presencia597.

¿No parece entonces que, paradójicamente, en este arte del Barroco, el de nuestros dos autores, la naturaleza queda expresada en su más legítima realidad, esa autenticidad inmanente, fuera ya del ideal? ¿No son la imperfección, la decadencia y la muerte, elementos imprescindibles en la esencia de la naturaleza, según su significado griego original?

Borromini introduce algunos residuos medievales en sus obras, que inciden en el modelo natural de imperfección y dan cuenta del tiempo, de la decadencia. Anacronismos por los cuales se le tachaba despectivamente de gótico. Quizás la misma decadencia que introduce Caravaggio en sus pinturas cuando añade, o centra la escena en la calavera.

En todo lo que desde el principio tiene de intempestivo, doloroso y fallido, la historia se plasma sobre un rostro, o mejor, en una calavera (...) en esta figura suya, la más sujeta a la naturaleza (...) sin duda es la muerte la que excava más profundamente la dentada línea de demarcación entre la physis y el significado. 598

Bajo la categoría del tiempo Benjamin establece la relación entre símbolo y alegoría. Propone el concepto de alegoría como fenómeno barroco frente al símbolo; si el símbolo "tal como lo habían visto los mitólogos románticos, se mantiene tenazmente igual a sí mismo", la alegoría se muestra como un movimiento violento de desintegración. Benjamin detecta las posibilidades antiartísticas
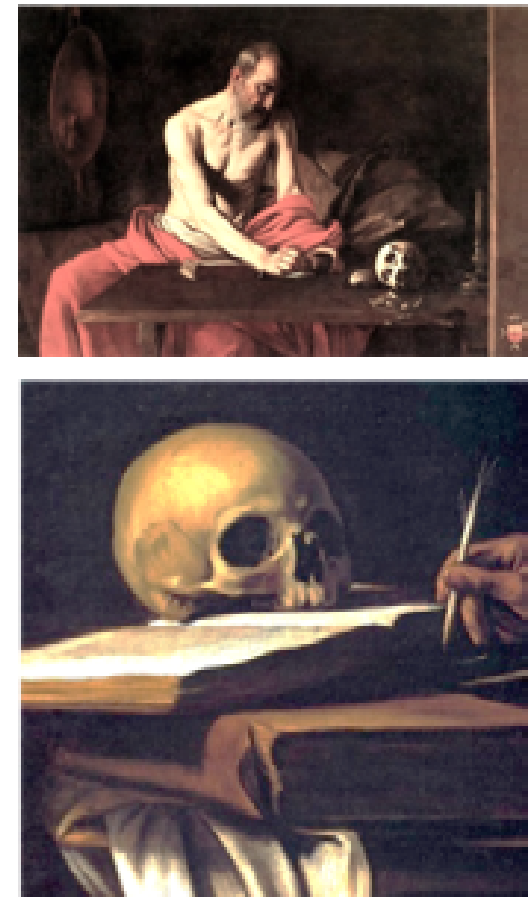

2.160. San Jerónimo. CARAVAGGIO, 1608 2.161. San Jerónimo. Detalle. CARAVAGGIO, 1608 de la alegoría y las vuelve contra el ideal clásico de la bella apa- 
riencia, oponiendo la desarticulación alegórica a la idea simbólica de totalidad ${ }^{599}$.

En el terreno de la intuición alegórica la imagen es fragmento, ruina. Su belleza simbólica se volatiliza al ser tocada por la luz de la teología. La falsa apariencia de la totalidad se extingue. Pues el eidos se apaga, la analogía perece y el cosmos contenido en ella se seca. En los áridos rebus resultantes se encuentra depositada una clarividencia aún accesible al que, confuso, medita rumiando sobre ellos. ${ }^{600}$

La naturaleza ahora es un continum inabarcable, que incluye la imperfección, la vida y también la caducidad y la ruina. En el ambiente ha entrado, la multiplicidad, el movimiento y con ello el pathos. La belleza objetiva ahora se disuelve en los abismos de esta nueva realidad dinámica, que ya no es modelo a la semejanza de un Dios exterior, sino pura inmanencia e infinitud, eterno retorno de un devenir ilimitado, de una multiplicidad.

Hay una mímesis de la naturaleza, pero esta está más próxima a la physis que a la estática imitación de su apariencia.

599. Cifr. LUIS IGNACIO GARCÍA, Alegoría y montaje. El trabajo del fragmento en Walter Benjamin. Constelaciones n2ㄹㄹ diciembre 2010. 
Los elementos en desuso, las formas con reminiscencias medievales, las múltiples impurezas formales que utiliza en su arquitectura Borromini, han dado lugar a diversas especulaciones. La mayoría de las críticas de sus contemporáneos se centraban en su modo de hacer gótico, en terminología de su época. Borromini no fue estudiado como artista plenamente barroco durante mucho tiempo. Su obra no se localizaba en un ideal artístico, estaba impregnada de anacronismos e imperfecciones, algo que se vino considerando como negativo a la hora de valorarlo como artista de relevancia. Esta cuestión se haya íntimamente ligada a la idea de naturaleza descrita más arriba, una naturaleza efímera, que incluye la decadencia, pero también, en cierto sentido una permanencia.

La historia del arte muestra en muchos casos una linealidad temporal forzada, que deja a un lado todo aquello que no se ajuste a la norma. En este sentido, Didi Huberman, en su texto sobre el historiador inglés Aby Warburg, señala como Winckelman construye su historia neoclásica recurriendo a la imitación, que no permite un renacimiento sino a condición de imitar un ideal ${ }^{601}$. Es así también como se había construido la historia humanista de Vasari en el Renacimiento. Foucault ve en esta manera de abordar la historia del arte, dos principios en acción: analogía y sucesión ${ }^{602}$, que son los que impregnan esta forma de historia positiva. Esta manera de enfocar la historia define un ideal artístico muy distinto del que conduce a nuestro arquitecto barroco. Es un ideal que se separa de términos como expresión, violencia, alteración; se delimita en la negación del pathos. Borromini, sin embargo, como también Caravaggio, favorece ese pathos en su obra.

Pero ¿No habrá un tiempo de los fantasmas, un retorno a las imágenes, una supervivencia (Nachlben) que no esté sometida a la inmitación? ${ }^{603}$

Señala Didi Huberman que Aby Warburg, un siglo después de Winckelman descomponía, y deconstruía todos los modelos epis-

601. DIDI HUBERMAN, L'image supervivante, Les Ëditions des minuit, 2002. Traducción al castellano Juan Calatrava, La Imagen superviviente, Abada, Madrid 2009.

602. M. FOUCAULT, Les mots et les choses, une archéologie des sciences humanes, Editions Gallimard, París 1966. Traducción al castellano de Elsa Cecilia Frost, Las Palabras y las Cosas, una arqueología de las ciencias humanas, Siglo XXI, Madrid 1999.
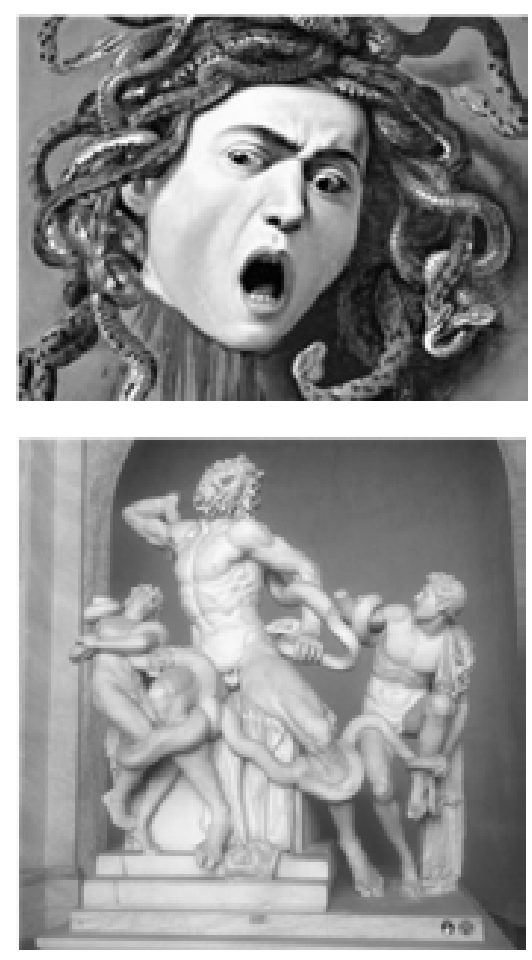

2.162. Medusa. CARAVAGGIO, 1597 2.163. Laocoonte. Museos Vaticanos 


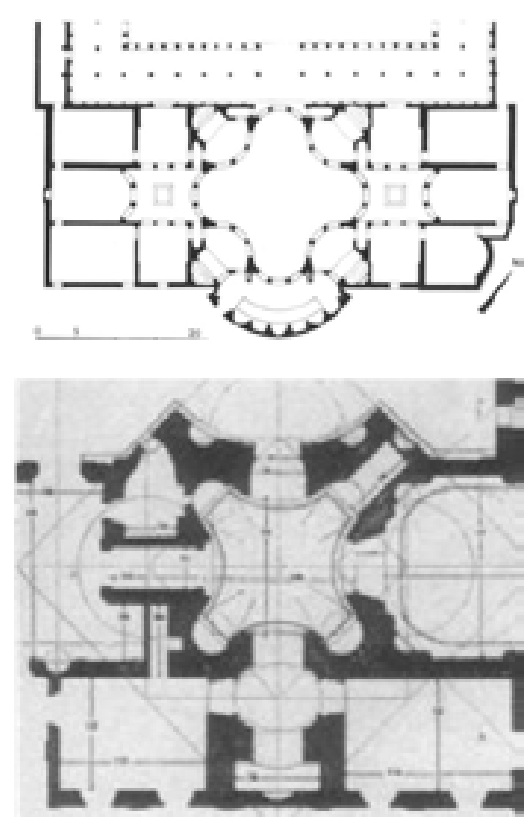

2.164. Plaza d'Oro. Villa Adriana, Tívoli. 2.165. Vestíbulo de acceso a Santa María del Sette Dolori témicos en uso en la historia del arte; sustituía un modelo natural (ciclo vida-muerte), por un modelo cultural de la historia, donde los tiempos se expresan por estratos, bloques híbridos, rizomas y complejidades. Sustituye el modelo ideal por un modelo que se expresa en supervivencias, en imágenes que se relacionan no cronológicamente. La arquitectura de Borromini podríamos decir que contiene ciertas referencias a esta concepción de la imagen de Warburg debido la presencia de arcaísmos en su obra. Se trata de activar una forma, nos dice al respecto Cesare Brandi. ${ }^{604}$

La idea de la imagen de Warburg es el resultado de movimientos que provisionalmente han cristalizado en ella ${ }^{605}$. Nos invita a pensar la imagen como un momento energético o dinámico. Warburg quiere comprender la vida de las imágenes a través de la fuerza que interviene en ellas, y estas fuerzas se refieren al tiempo, a la dimensión del tiempo como un juego de potencias. La imagen no se puede disociar del actuar social, de sus impulsos intervinientes. No hay morfología posible sin un análisis de las fuerzas. Y hay fuerzas manifiestas, pero también hay fuerzas latentes de las que somos ignorantes, hay una patología del tiempo.

Todo ello imprime a las obras un carácter complejo, que muestra la heterogeneidad y la imperfección, que niega el modelo estático y que analiza singularidades, que también quieren dar cuenta de una inmanencia. Queremos ver en ello cierta condición cercana a la obra de Borromini donde el pathos toma posiciones relevantes; la expresión de los movimientos invisibles, fuerzas y potencias. Piensa conjuntamente la diferencia y la distancia. La imagen-pathos, como diría Aby Warburg, trata de hacer visible lo invisible.

Borromini en su obra expresa la tensión entre la innovación que pretende y sus anacronismos medievales; entre una exigencia de alteración de la forma de hacer clásica, y una voluntad de identificación, quizás con su temprana formación en la Lombardía, con las imágenes medievales que le acompañaron. Pero también con lo clásico, aunque su compromiso con la arquitectura clásica se mueve en ámbitos que no fueron los habituales. Él no rechaza la antigüedad sino los principios de la antigüedad fijados en los tratados; reivindica el derecho a remontarse a las fuentes, prescindiendo de la tradición por la que se habían reducido a formas normativas. Borromini se fija en ejemplos domésticos, como la

604. Cifr. CESARE BRANDI, op. cit. 605. Ibid. 
villa Adriana o la Domus Áurea, o en la arquitectura de la última época del imperio, como las termas de Diocleciano y, sobre todo, en modelos de la época imperial extendidos por partes del imperio que recogían más fácilmente expresiones locales o permanencias también medievales.

En Sant'Ivo la planta es central y simétrica respecto a seis ejes. En la arquitectura del siglo XVI no hay ejemplos concretos de este tipo de planta. En el tratamiento de la Bóveda se puede estar inspirando Borromini en ejemplos antiguos como puede ser el Serapeum de la Villa Adriana.

En el exterior del conjunto de Sant'Ivo, sigue, como en San Carlino, la tradición lombarda de envolver la verdadera cúpula en un cilindro de mampostería sobre el que recaen los empujes laterales de aquella. Sobre el tambor hay una zona escalonada que al igual que la parte superior de la cúpula de San Carlino, recuerda al Pantheon. El contorno de esta zona es ligeramente convexo, como repitiendo el contorno de la cúpula que hay dentro, pero Borromini introduce un contraste al dar forma cóncava a los arbotantes que lo recorren.

Sobre esta zona se encuentra la linterna, que en su nivel inferior es una rotonda, que recuerda al templo circular de Baalbek. Esta rotonda asciende hacia el elemento de más carácter del conjunto; una rampa en espiral que va enrollándose en torno al cono de la linterna y que asciende hasta el punto culminante de todo el edificio; una estructura de hierro que, en forma de llama, sostiene una esfera y una cruz. Anthony Blunt ha señalado la semejanza de esta linterna con algunos dibujos de los zigurats mesopotámicos, y es probable también que Borromini conociera grabados de la torre de Babel.

Estos guiños de Borromini acusan su modernidad, en el sentido de puesta en cuestión del modelo clásico. La riqueza de su arquitectura contiene el tiempo, no deja cerrarse a la forma en una concepción acabada del arte, incluye elementos anacrónicos que se hacen eco de esa naturaleza ligada al retorno de las cosas. La actitud es completamente original y personal, no aparece en ningún ejemplo arquitectónico de su entorno, por ello fue rechazado en numerosas ocasiones y juzgado fuera de tiempo por la crítica inspirada en la ciencia historiográfica positiva.

Es singular el parecido de la fachada de San Carlino con la de uno de los sepulcros rupestres de Petra, o de la planta de la linterna de

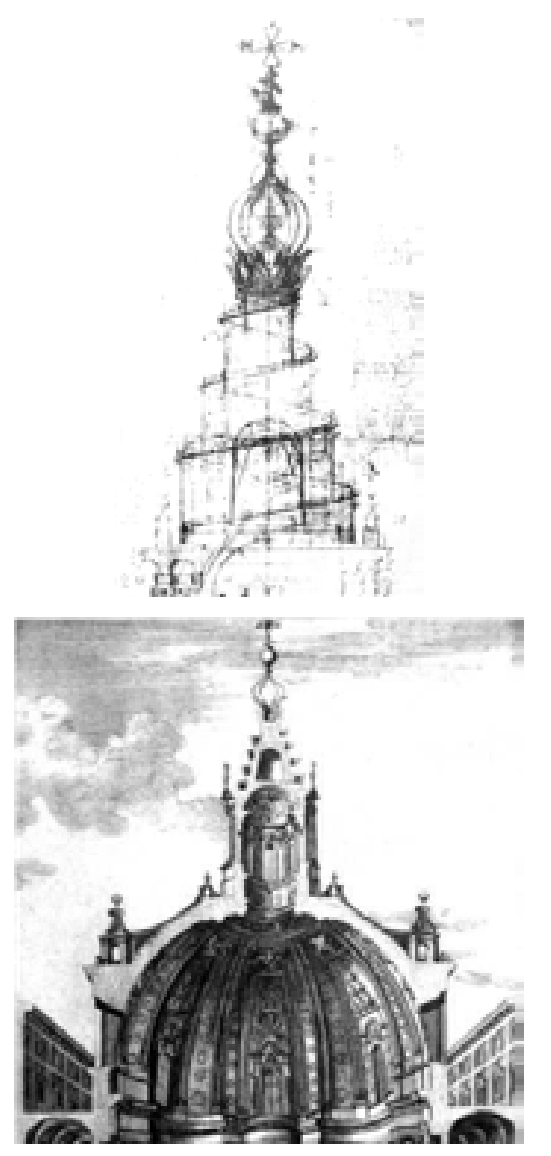

2.166. Linterna y sección de la cúpula de Sant'Ivo alla Sapienza
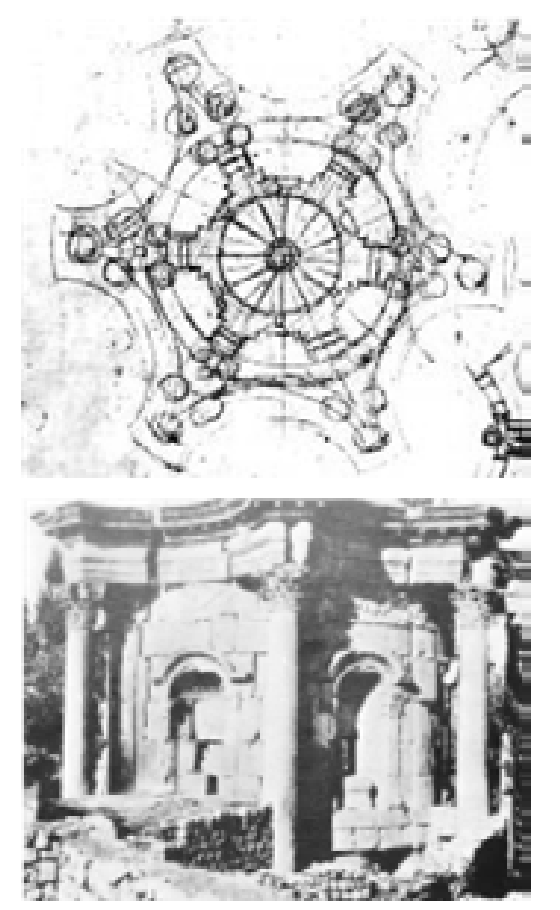

2.167. Templo de Venus. Baalbeck

2.168. Planta de la linterna de Sant'Ivo alla Sapienza 

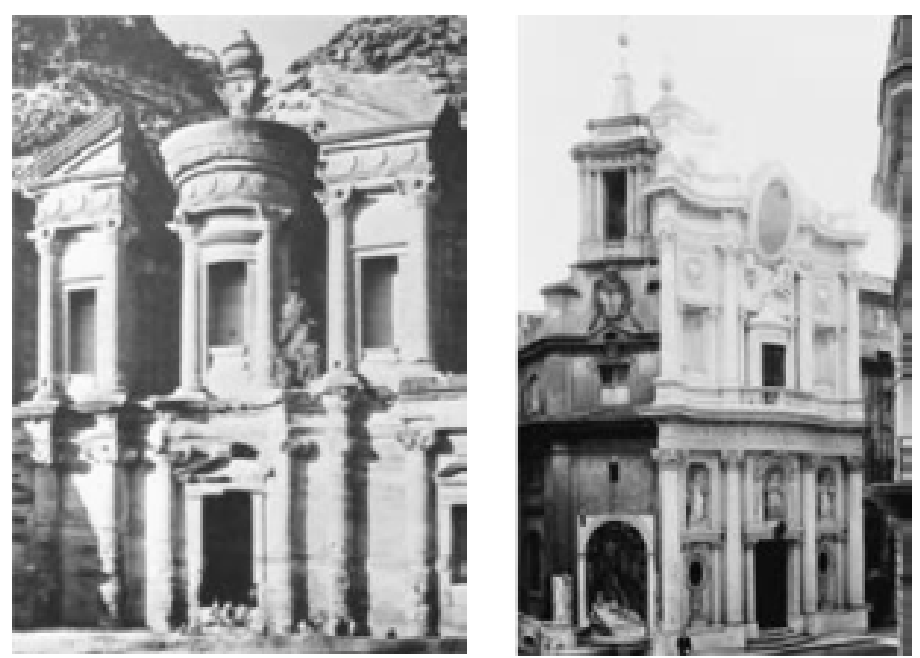

2.169. Fachada de uno de los sepulcros rupestres de Petra

2.170. Fachada de San Carlino
Sant'Ivo, ya comentada, y el templo circular de Baalbeck. Pero Borromini no pudo tener acceso a estas obras que se han descubierto con posterioridad. Anthony Blunt también nota en su texto, como el arquitecto pudo basarse en los dibujos de reconstrucciones de monumentos antiguos que Montano ${ }^{606}$ realizó a principios del siglo XVI, o en el Codex Corner, que representaban casos singulares y no tan canónicos de la arquitectura clásica, o en las reconstrucciones de Villa Adriana llevadas a cabo por Ligorio, así como a las descripciones de la Domus Áurea de Nerón. ${ }^{607}$

Borromini se nutre de estas imágenes, no convencionales, no habituales ni en el clasicismo ni en su época, para impregnar su arquitectura de permanencias y anacronismos que le ayudan a articular un discurso arquitectónico peculiar. Sus supervivencias representan una estratificación temporal donde emergen capas del tiempo, donde los pasados son posibles en una nueva lectura diversa.

La utilización de elementos de Miguel Ángel es otra constante que se repite en su obra. Reproduce algunos recursos formales que su maestro ya había utilizado libremente en una actitud manierista que atrae a Borromini. Miguel Ángel había experimentado gestos de ruptura con los ideales clásicos. Un ejemplo muy expresivo es la Porta Pía, que muestra un juego de disolución clásica en muchos de sus elementos y en su composición. En particular en la puerta,

606. Los dibujos de Montano aparecen en forma de gravados entre 1624 y 1664 en una serie de volúmenes titulados Li cinque libri di architecttura. El Codex Corner está actualmente en el Museo Soane de Londres, pero ambos documentos se encontraban entonces en poder del coleccionista romano Cassiano dal Pozzo.

607. Estas son las posibles fuentes que inspiran su arquitectura según señala Anthony Blunt en su libro Borromini, op. cit. págs. 29-55. 

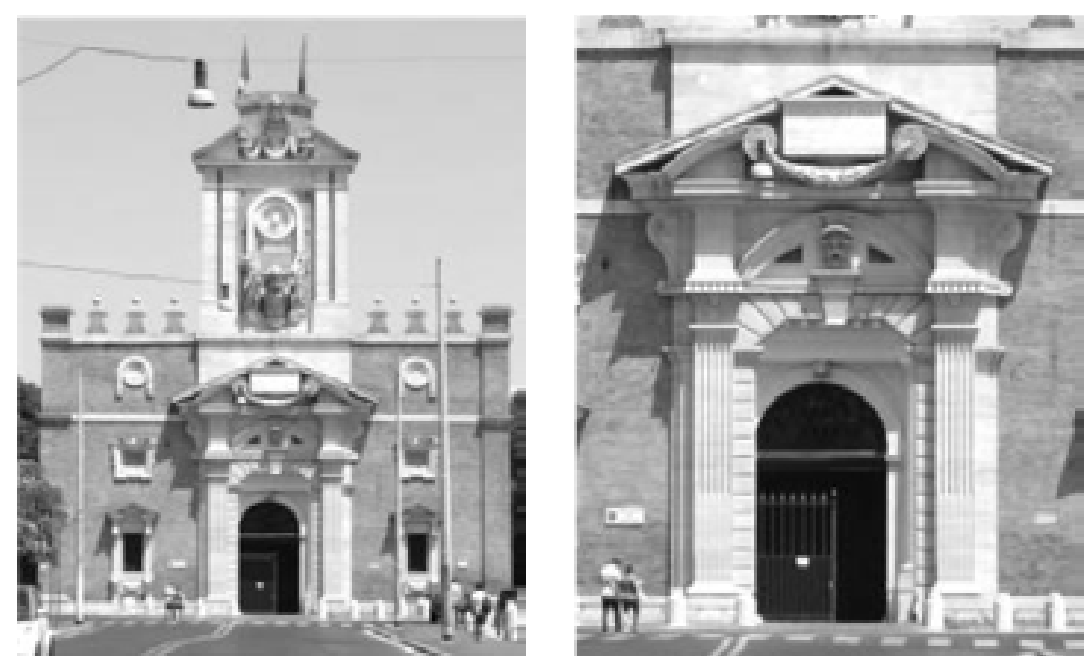

donde coloca dentro del frontón recto otro curvo y partido ${ }^{608}$. Una 2.171. Porta Pía. MIGUEL ÁNGEL. 1565 vez conocidos y estudiados estos motivos, Borromini los utiliza con total libertad, y los difunde por sus obras, como una especie de homenaje.

Borromini utiliza al revés este trazado; un frontón curvo por fuera de uno recto. Este recurso aparece en algunos de los bocetos para San Carlino, y posteriormente en la ventana del muro de entrada en el interior de la basílica de san Juan de Letrán. Pero al igual que en la ventana del palacio Barberini, fundió los elementos en una traza continua, inventando una forma nueva de frontón cuyas partes no se entrecruzan, sino que una fluye dentro de la otra.

Otro motivo de la Porta Pía que Borromini repite en su obra y esta vez casi sin variación, es el capitel jónico que sostiene una bola. Borromini lo coloca alrededor de la cúpula de Sant'Ivo, rematando los arbotantes.

Por otra parte, Borromini está influido por su educación de cantero en la Lombardía, y arrastra también con ello influencias medievales que ve y aprende en Milán. Repite en muchas de sus obras este contacto con el pasado medieval y no se limita a imitar las formas, sino que hace que sean parte de sus propias creaciones dándoles plena vigencia.

En San Carlino, mezclados con la ruptura formal que se extiende por todo el conjunto, encontramos algunos elementos extraños, como anacronismos. Por ejemplo, los capiteles octogonales del
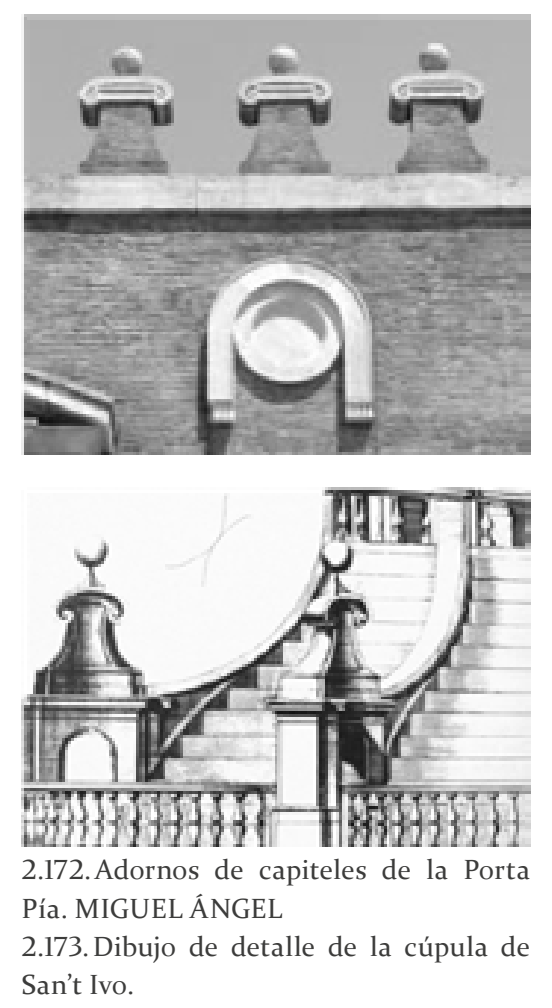


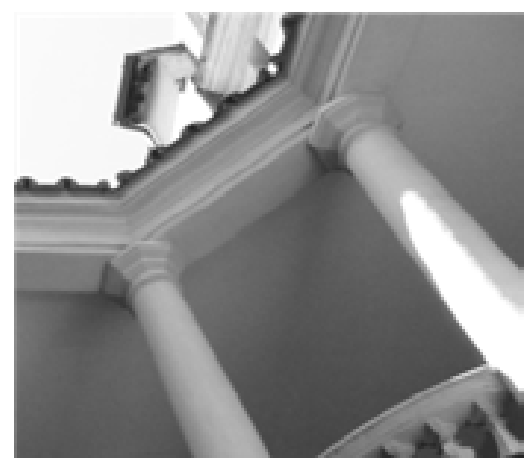

2.174. Capiteles poligonales del claustro de San Carlino orden superior del claustro recuerdan mucho más la arquitectura del gótico tardío que la de la Antigüedad Clásica. Esta forma octogonal se continúa en la cornisa de este piso alto en una transición formal paulatina.

Ya se ha hablado de los nervios que articulan la bóveda del Oratorio y la capilla de los Reyes Magos. Estos nacen de las pilastras, como si de una estructura gótica se tratara y recorren el espacio como atándolo sobre sí mismo.

En Sant 'Andrea della Fratte siguió para la cúpula el método lombardo de San Carlino y Sant'Ivo, encajonándola en una especie de tambor. La traza del tambor tiene semejanza con una tumba del último periodo romano cerca de Capúa y que tiene por nombre la Conocchia $^{609}$ (Más tarde Piranesi hará un dibujo de esta antigua tumba romana). Pero mientas el cuerpo que hay en el centro de cada tramo de esta es rectangular, en Sant 'Andrea es curvo, por lo que Borromini crea en cada cara del tambor una doble curva en S.

El caso de San Giovanni Laterano es singular, pues se trata de una intervención en un edificio paleocristiano. Borromini construye sobre lo existente, pero consiguiendo marcar su proyecto con su impronta nueva. El carácter de la rehabilitación de la iglesia se aleja de esta forma de planteamientos anteriores, como el que tuvo Julio II en San Pedro del Vaticano, advirtiéndose ahora ya un nuevo gusto por la conservación en el propio planteamiento de la intervención, que se integra y compone en continuidad con lo existente, pero introduciendo en la parte nueva un carácter diferente. Borromini consigue introducir el movimiento, un dinamismo que alcanza a través de la repetición y los claroscuros.

Pero, insistiendo en este nuevo gusto por la conservación, por el valor del tiempo, que ya venimos notando en todas sus intervenciones, Borromini realiza una actuación que incide de modo singular en esta cuestión. Se trata de la construcción de los sepulcros que lleva a cabo una vez finalizada la iglesia. San Juan de Letrán carecía de cripta y volver a poner los sepulcros como estaban originalmente carecía de coherencia. Borromini decide tomar fragmentos de los sepulcros antiguos e incorporarlos a sus nuevos diseños. Tiene aquí la oportunidad de introducir libremente estos motivos medievales, que, aunque ya había mostrado en otras ocasiones, aquí cobran un sentido reconocido y literal. La cuestión

609. Estas referencias están documentadas en los textos ya citados de Paolo Portoghesi y Anthony Blunt. 
del tiempo aparece entrelazada, pensando el tiempo mismo como un montaje.

La introducción de estos elementos fuera de tiempo, fuera del lenguaje habitual de la época, que llamaremos reminiscencias, permanencias o anacronismos, podemos considerar que son propios de un arte impuro, una especie de hybris. Remite también a una impureza del tiempo, rechazando la idea moderna de cultura que ignora las relaciones de esta con la memoria. En este sentido Venturi ha encontrado, que su arquitectura de la complejidad y la contradicción contiene la ambigüedad y la paradoja, pues estos elementos reminiscentes comparten un doble significado, asociándolo a uno u otro momento. Esta ambigüedad, lejos de resultar un defecto, confiere a la obra mayor riqueza; un arte que contiene varios niveles de significado, un carácter confuso de la expresión y una tensión subyacente.

Lo que puede denominarse elemento reminiscente es semejante al elemento de doble función. (...) Es el resultado de una combinación más o menos ambigua del viejo significado, evocado por asociaciones, con el nuevo significado, creado por la función modificada. El elemento reminiscente impide la claridad de significados; en su lugar fomenta la riqueza de significados ${ }^{610}$.

Venturi reclama para su arquitectura de la complejidad, una sensibilidad paradójica, que permite que aparezcan unidas cosas aparentemente diferentes. Todo lo que hemos observado sobre estas reminiscencias formales en las obras de Borromini, cumple este principio de sensibilidad paradójica, que pretende introducir la innovación barroca, pero que no renuncia a la permanencia integrada de formas del pasado. Es como si la obra acogiera en su seno una multiplicidad de tiempos y, por ello, siguiendo a Venturi, de significados.

Esta manera de integrar elementos heterodoxos en la obra, junto con los recursos formales que la configuran, supone siempre una intensidad en el sentido de pluralidad de significados en general; se trataría de una intensificación de la forma, en el sentido en el que Aby Warburg propone su concepto de Pathosformer. El Pathorformer, que ya se ha citado más arriba ${ }^{61}$, es expresión del devenir y el movimiento, es vida en movimiento de las imágenes,
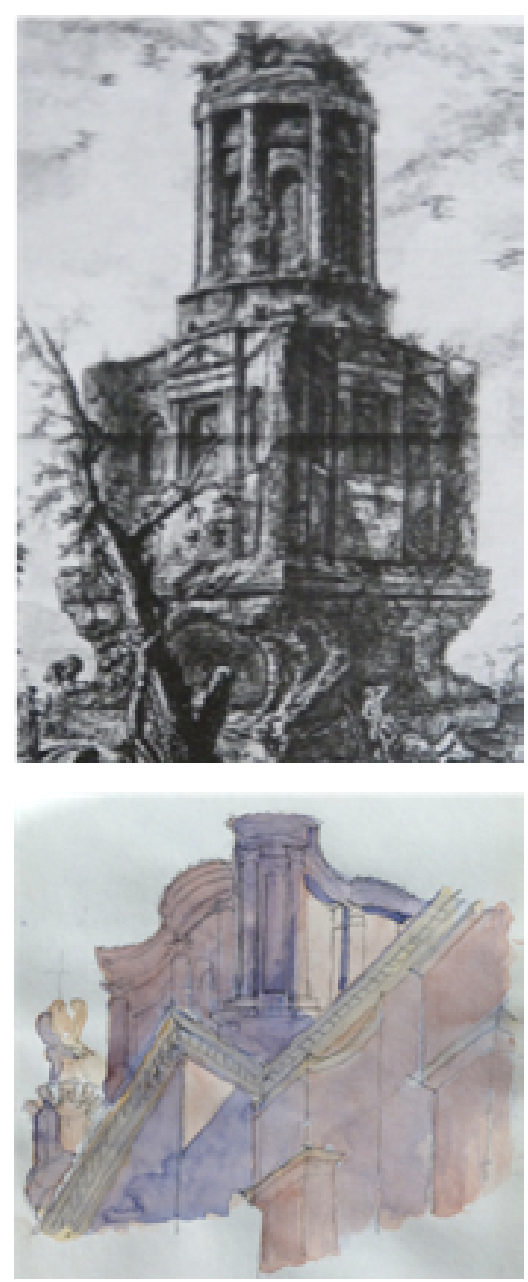

2.175. Dibujo de Piranesi de la Tumba de Capúa

2.176. Tambor de la cúpula de Sant Andrea de la Fratte. Acuarela de la autora 
una especie de manifestación de una energía que se actualiza en un cuerpo. Pero también se puede relacionar la obra de nuestro autor con el concepto warburgniano de Nachleben como supervivencia. Toda la interpretación transversal de la historia de Aby Warburg se articula en torno a este concepto de Nachleben como supervivencia o vida que pervive, que también hemos analizado en la parte I, y que sugiere una perspectiva de la historia fuera de la habitual linealidad, abriendo, a cambio, un panorama de tiempos múltiples. El Nachleben de Warburg sobrevive fantasmalmente, apareciendo en un momento donde no se le espera ${ }^{612}$, tal como sucede en la obra de Borromini, donde se presentan formas anacrónicas, trasladadas o inspiradas en modelos inéditos, no canónicos, o extraídas de un pasado medieval, o tomadas integra y literalmente de otros autores, fabricando un sistema de préstamos heterogéneos. Hay una noción de transversalidad que huye de toda división cronológica, y que des-orienta la obra y la anacroniza, constituyéndola en un lugar para la simultaneidad de tiempos y lecturas sobre el tiempo. 


\subsection{SOBRE EL TIEMPO}

Todo este juego temporal que Warburg plantea de latencias y crisis (por otra parte, tan presente en el sentido de toda esta investigación), es expresado por él en forma de una especie de oleadas de memoria que atraviesan a la cultura. Warburg recoge y registra en su trabajo estas oleadas a modo de sismógrafo del tiempo.

Nietzsche ya había planteado unos años antes que Warburg esta cuestión con su noción de eterno retorno. Nietzsche descubre desde temprano, que la única posibilidad de salvar la vida es que el pasado quede abierto, que el pasado sea posible.

O somos epigonales decadentes, meros eruditos como consecuencia del curso homogéneo de la historia de la cual nosotros ocupamos el último eslabón, o somos apócrifos ignorantes, neófitos ingenuos, que creemos crear por mera ignorancia. (...) A no ser que podamos modificar el pasado ${ }^{613}$.

Heidegger lo dirá a su manera: la ausencia es ${ }^{614}$, con el sentido de que sea posible el futuro solo como futuro anterior, siempre fundado en la posibilidad de los pasados, que retornan en su diferencia con el presente.

Por tanto, el tiempo al que se quiere referir este texto, para comprender bien ese lenguaje con los anacronismos de Borromini, pero también, para entender bien lo diferencial de la repetición, que ya habíamos intuido en los casos de arquitecturas estudia$\operatorname{dos}^{615}$, los elementos potenciales de la inflexión, o los simulacros que ocultan una tectonicidad enmascarada, y que "vuelven" a su modo desde el Barroco histórico, es el tiempo según este retorno de Nietzsche, de Warburg, de Heidegger o de Deleuze. En todos notamos este recurso de una continuidad que vuelve y se repite metamorfoseada en diferentes simulacros, máscaras del Barroco o Neobarroco.

\footnotetext{
613. Nietzsche describe esto en un texto muy temprano: Factum e Historia, en: De mi vida. Escritos autobiográficos de juventud (1856-18699, Valdemar, Madrid 1997. Citado por TERESA OÑATE, en Por la vía noética del espacio ontológico, op. cit., pág. 72.
}

614. Encontramos en el estar ausente, ya sea pasado, ya sea futuro, una manera de estar presente. MARTIN HEIDEGGER, Tiempo y Ser, op. cit., pág. 41. 
Cada cosa solo existe en la medida en que vuelve, como una copia más de una serie, que no deja subsistir modelo ni origen alguno. Lo que vuelve o retorna es en forma de un simulacro, y el simulacro es así el verdadero carácter de la forma, de lo que es, de lo ente. Y, por otra parte, el retorno mismo, el eterno retorno, es la potencia de Ser, no tiene forma ni identidad constituida, esa potencia que encontramos bajo la expresión de nuestras arquitecturas, enmascaradas de pliegues, reflejos y simulacros.

Por tanto, aquí, en nuestras arquitecturas y con el precedente de Borromini, los pasados son posibles, vuelven, retornan en su diferencia. En este sentido el ser es la diferencia misma que hace retornar una y otra vez, es el diferenciante donde reside la diferencia constituyente. Hay como una especie de pliegue ontológico, o apertura, o dilatación que refiere al ser y a la manera de constituirse el ente.

Es en este sentido en el que la repetición de lo idéntico no es posible, pues se modifican siempre las condiciones. Retorna lo mismo, pero no lo idéntico que sería una uniformidad vacía. Lo mismo, en cambio, es la pertenencia mutua de lo diferente ${ }^{616}$. Este diferenciante que retorna siempre es la potencia de ser, y se da en el espacio, en el espacio abierto relacional al que se ha referido Heidegger, un espacio posibilitante. Un espacio con el alcance que también Newton le daba (con otras connotaciones, pero con el mismo sentido), como sensorium dei, para quien todavía el espacio físico y noético es el ser de Dios porque es y está en todas partes a la vez ${ }^{617}$.

La obra de Borromini niega en su arquitectura el modelo o el tipo, su uso de la repetición y sus recursos formales así lo acreditan, pero también sus anacronismos y supervivencias. Y hay también un " retorno" en los modos de plantear la forma contemporánea aunque este modo se manifieste en su diferencia. Un retorno, como lugar donde reside el diferenciante. El lugar y la residencia, ya son términos espaciales. Espacio y tiempo se unen en esta noción del retorno. 
¿Qué será o significará entonces lo efímero, en relación a esta noción del tiempo que acabamos de discutir? Lo efímero no es aquí lo que se acaba, lo efímero es lo que no subsiste igual, porque se metamorfosea y cambia. No hay final ni origen en el eterno retorno, por lo cual, aquí, lo efímero no debe entenderse como un deshacerse, como lo perecedero sin más, sino como como un retornar. Un efímero positivo, como simple afirmación de la vida, un efímero de la impermanencia aceptada ${ }^{618}$.

Esta peculiar cualidad que encontramos en la arquitectura de Borromini, a través de su vinculación con el Nachleben de Warburg, ha sugerido la anterior reflexión sobre la temporalidad y tiene su correlato en un cambio de paradigma respecto a la concepción de la naturaleza en el Renacimiento, como hemos visto. Y esta nueva noción de naturaleza porta en sí el carácter de lo efímero, lo efímero barroco.

Y esto efímero puede haber sido negado - para salvaguardarse de ello, en último término, de la muerte - nombrando lo inmutable, La Idea o El Ser, como la imagen de una permanencia, o puede haber sido canalizado en la tragedia (recordemos que en la tragedia griega encontraba Nietzsche el origen del arte). Ya hemos propuesto en esta investigación, la vinculación de la forma borrominiana con la tragedia griega, a través de lo que supone para la forma el determinarse, el concluirse en una representación. Lo barroco o Neobarroco quisiera verlo todo, y hay una cierta tragedia en el arte, por su necesidad de cerrarse en una determinación formal. Por ello es la propia forma la que se cuestiona.

Nietzsche había reivindicado la historia como una cuestión vital, un devenir, que no podrá nunca reflejarse en una imagen fija, necesitando el movimiento, la metamorfosis, los flujos y los retornos intempestivos.

El Barroco es un arte de lo efímero en cuanto que se hace cargo de este cambio continuo, de una metamorfosis, donde, por otra parte, hay algo que permanece. La estética de lo efímero representa el cambio, un cambio metamórfico, pero para ello también hay necesariamente una permanencia o fondo (Lebniz la llama 
Plemun), en toda metamorfosis hay permanencia. Se trata de ver la diferencia en la repetición. El Barroco-Neobarroco como arte de lo efímero (que no es lo mismo que arte efímero), señala tanto al cambio como el fondo que permanece sin ser estático ni vacío, que está lleno de fuerzas y de diferencias. Repetimos aquí un texto de Nietzsche, que ilustra bien esta cuestión, ya citado en la parte I:

Solo pueden actuar fuerzas absolutamente modificables, fuerzas que no sigan siendo ni por un instante idénticas a sí mismas. Todas las fuerzas no son sino una función del tiempo. ${ }^{619}$

Buci-Glucksmann ha dedicado un texto completo a lo efímero Neobarroco; su Estética de lo efímero, ya citada repetidas veces. Comienza señalando la paradoja inicial del arte que desea que lo efímero se eternice. El arte se caracteriza por su capacidad de trascender el tiempo, por una a-temporalidad. Explorar esta paradoja inicial del arte significa romper con una concepción lineal del tiempo. El arte ha sido durante mucho tiempo pensado a través de lo subsistente, como Idea que descalifica el tiempo como puro devenir. Pero si abandonamos ese punto de vista, el arte se puede inscribir (de nuevo) en un tiempo impuro, un tiempo de rememoración, donde el pasado está inacabado o abierto ${ }^{620}$, como observábamos en el punto anterior.

En la arquitectura de Borromini las permanencias atemporales, sus sugerencias y reinterpretaciones, nos envían a una especie de constelación de tiempos plurales, donde el pasado es posible sin superación, como Benjamin ha propuesto ${ }^{621}$.

En el Barroco histórico la pintura se ocupa de las naturalezas muertas, de las Vanidades, de los espejos, cristales, las flores y otros motivos de lo efímero, pero también de las calaveras. Los temas son lo frágil, lo vano y lo perecedero. Esto efímero es un nuevo paradigma temporal, un nuevo conocimiento que pone en cuestión las relaciones del Ser y el devenir, que habían sido propias del humanismo del Renacimiento.

619. FREDERIC NIETZSCHE, Fragments posthumes, Gallimard, París 1990. Traducción al castellano Fragmentos póstumos, Tecnos 2008.

620. Cifr. CHRISTINE BUCI-GLUCKSMANN, La estética de lo efímero, op. cit. 
Se trata de un tiempo ocasional, un manierismo ocasional ${ }^{622}$. Un manierismo capaz de sustituir el hecho de ser por el de devenir, captar la llegada del acontecimiento, un kairós. Lo efímero capta tiempo en los intervalos de las $\operatorname{cosas}^{623}$, todo lo que está entre. El intervalo es un espaciamiento, y en ese sentido, da lugar a lo posible. Una especie de conciencia del tiempo, que puede estar en forma de testigos o vestigios, pero que también está representada por reflejos o paradojas, transparencias o impermanencias de todo tipo. Un efímero que pretende hacer ver el tiempo, atravesarlo y captarlo; y es así como las transparencias y lo diáfano se extienden en el arte contemporáneo.

El arte efímero se hace explicito con la aparición de las instalaciones in-situ en el arte, al final de la década de los 60 del pasado siglo, quizás coincidiendo con la emergencia de una Postmodernidad neobarroca. Pero no podemos confundir el arte efímero con el arte de lo efímero; si el primero es textualmente efímero, pues desaparece físicamente con el tiempo, es provisional y desmontable, el segundo es una expresión de lo perecedero, aunque se podría objetar que la literalidad del primero es otro modo de expresión de lo frágil y transitorio.

La fragilidad del tiempo en el Barroco, no se expresa del mismo modo que en la cultura de los flujos actual, que modifica las condiciones de la imagen, dando paso al nacimiento de modos de transparencia y ligerezas, propias ya de nuestra época. Nuestras imágenes flujo modifican nuestra relación con el mundo engendrando una nueva estética de lo efímero, que quizás no reconocemos a simple vista como común con la estética barroca, pero que comparte un mismo sentido último con ella. Gluksmann nota en nuestro Neobarroco, una nueva manera de pensar lo efímero con este valor positivo, propio de lo que vuelve, lo llama no melancólico. Según la autora, nuestro arte neobarroco expresa lo efímero cósmico, frente a lo efímero melancólico del Barroco histórico. Una especie de arte nietzschano, un saber de lo ligero, como el danzarín de Zaratustra, que acompaña lo trágico metamorfoseándolo ${ }^{624}$; una inestabilidad aceptada.

622. VLADIMIR JANKÉLÉVITCH, Le je-ne-se-pas-quoi et le presque rien, Le Seuil, 1980. Citado por C. Buci-Glucksmann, Estética de lo efímero, pág. 20.

623. Cifr. C. BUCI-GLUCKSMANN, Estética de lo efímero.
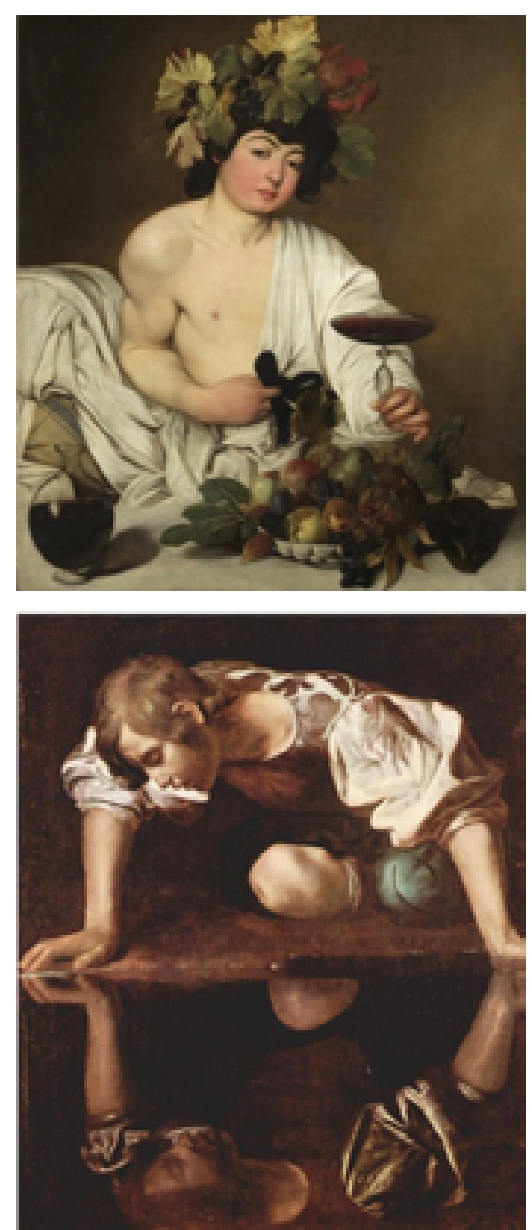

2.177. Baco. CARAVAGGIO. 1598 2.178. Narciso. CARAVAGGIO. 15 

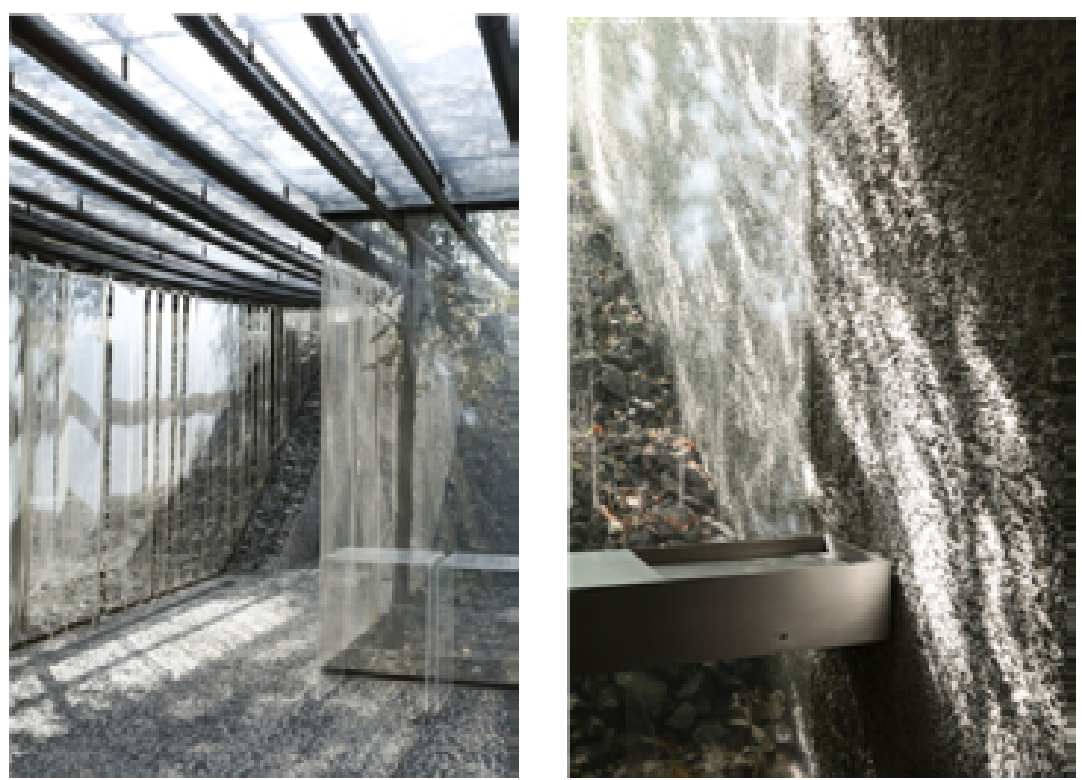

2.179. Interior de las carpas de Les Cols. Olot 2007. RCR
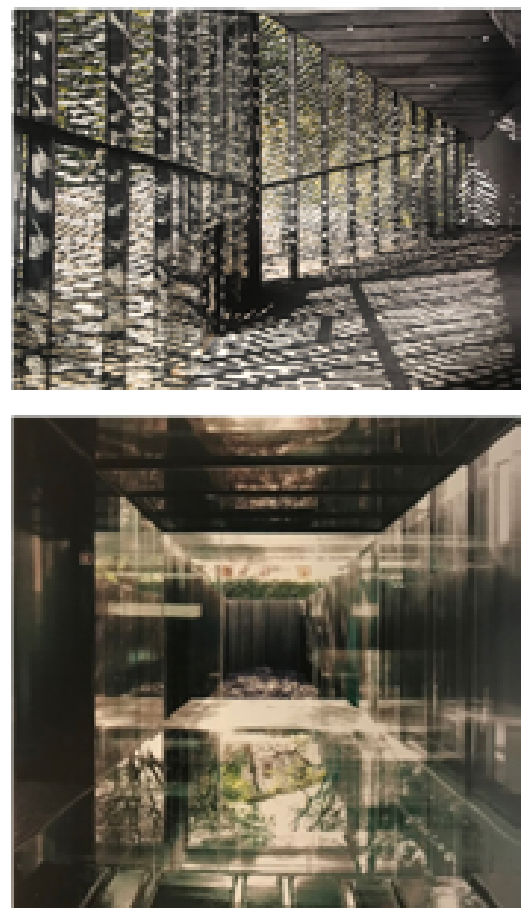

2.180. Museo de arte popular de Hangzhou: alazado exterior e interior. KENGO KUMA

2.181. Pabellones Les Cols. Olot 2005. RCR
En las transparencias y en ese materialismo aéreo que hemos observado en muchas de las obras actuales hemos encontrado esta promesa de lo efímero. Un kairós fugaz, hecho de vibraciones de luz, tornasoles o juegos de reflejos, como los que habíamos notado en La Carpa de Les Cols de RCR, o en Los Pabellones; en los reflejos de agua en las Termas de Vals de Zumthor; o en las vibraciones del centro de interpretación de Kuma.

El plano cósmico, propio de lo efímero cósmico, no tiene el mismo sentido que la arquitectura del vidrio moderna, una trasparencia abstracta y cristalina; el plano cósmico se compone con flujos y fluideces, introduciendo una forma totalmente distinta de transparencia y de temporalidad, se trata de expresar un intervalo, un entredós, que tanto representa el cambio, como el fondo potencial desde donde el cambio se produce. Desmaterializa y proyecta el tiempo en el espacio, expresa un tiempo efímero en una imagen que no dura, que se modifica con la luz, un espacio sin forma reconocible, que expresa menos la forma que la energía.

La expresión explícita de lo efímero la hemos visto también en el trabajo de Esther Ferrer ${ }^{625}$, hablando de la repetición y la variación en el arte actual. El tema de las series y la variación introduce el tiempo, como parámetro de lo efímero metamórfico.

El Libro de las cabezas, en su conexión entre dos imágenes modificadas por el tiempo, contiene una espacie de plegamiento de las series que aparecen desplegadas en su Autorretrato en el tiempo;

625. Véase supra, pág. 304. 
contiene en sí la diferencia y lo mismo (en el sentido ya explica$\mathrm{do}^{626}$ ), y la imposibilidad de lo idéntico. Es la paradoja de la repetición, pues esta no se da más que por la diferencia o el cambio. Por muy infinitesimalmente cercanos que fueran en el tiempo los momentos de las fotografías, nunca serían exactamente iguales; las condiciones han cambiado, llevan el pasado como sello de su figura. Se trata de expresar la diferencia como constitutiva de la repetición; la diferencia habita la repetición.

Pero se trata también de destruir el modelo o la imagen, de acabar, en definitiva, con la representación; abandona el campo de la representación para constituirse en experiencia.

Las piezas consisten en autorretratos realizados a partir de ensamblar dos mitades simétricas de fotografías tomadas en épocas diferentes. Son la expresión del tiempo que pasa, de las marcas que deja en el cuerpo. Las imágenes poseen el mismo encuadre, la misma iluminación, las comisuras se acoplan oportunamente... Todo encaja, pero se percibe una sensación de extrañeza, el paso del tiempo que todo lo transforma, y que se expresa en estas imágenes extrañas que se descomponen y vibran... La multiplicación que hace desaparecer el rostro, la vibración óptica, son la metáfora de un malestar, incluso de un sentimiento de terror, relacionado con lo perecedero. ¿No producen el mismo efecto las calaveras que Caravaggio representa en sus pinturas?

Esther Ferrer trabaja con el tiempo, el tiempo que pasa y todo lo transforma. Pero al decir el tiempo que pasa, se está nombrando también a la muerte en un juego de espejos y reflejos; lo vibrante, cambiante, solo aparente, la condición inestable del mundo.

La estética de lo efímero contemporánea genera cambios imperceptibles, perturbando la noción de forma, que se piensa, a partir de ahora, como flujo de energía y fuerzas múltiples.

Todos los cuerpos están, como los ríos en un perpetuo flujo (... $)^{627}$
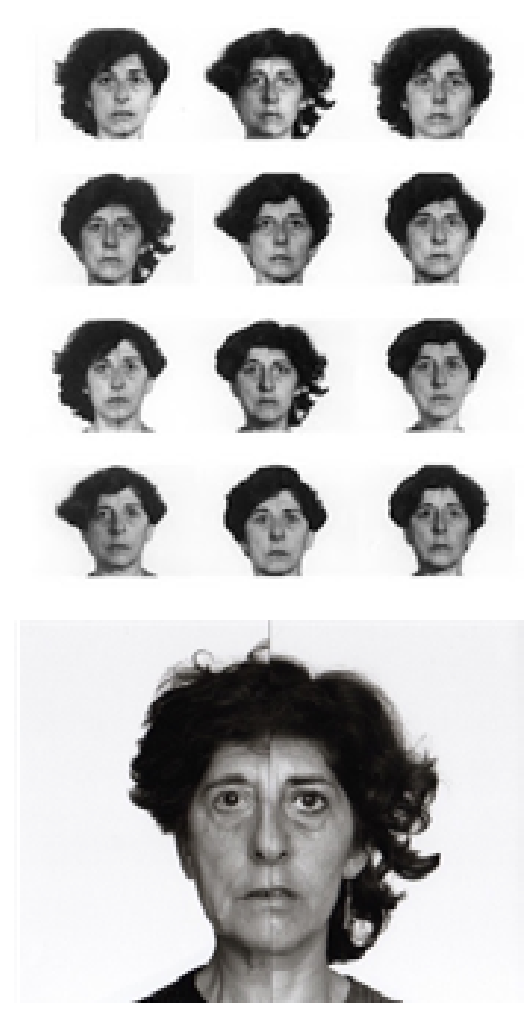

2.182. Libro de las cabezas. Autorretrato en el tiempo.

2.183. Autorretrato en el tiempo. Esther Ferrer. 1981-2014

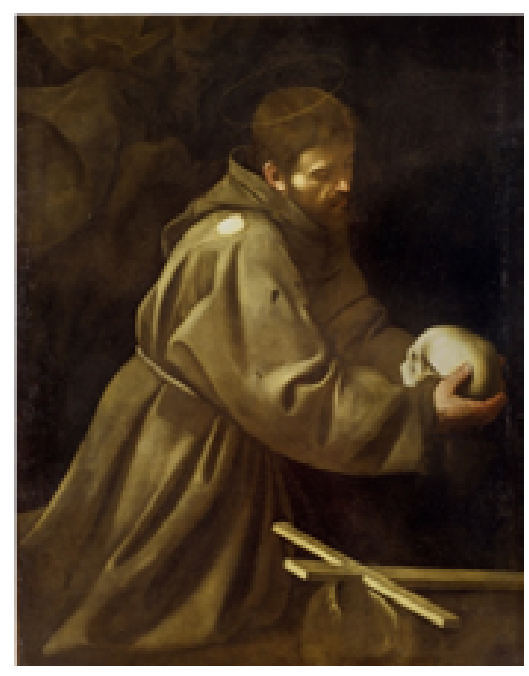

2.184. San Francisco en oración. CARAVAGGIO 
La toma de conciencia sobre lo perecedero, la transitoriedad, la falta de permanencia, la consideración del paso del tiempo, se hace principal; hay un nuevo paradigma del tiempo, en la nueva noción de la naturaleza; la naturaleza como physis. Esta physis griega abarca el devenir y su reserva de potencias; una naturaleza-physis como fondo inmanente de vida, donde se cumplen los ciclos de nacimiento y muerte. El arte barroco y neobarroco recoge este sentido del tiempo con una nueva dimensión, la que Paul Klee reivindicaba explícitamente:

(...) pienso en el reino de aquellos que no han nacido o de los que ya han muerto, en el reino de lo que puede venir, de lo que aspira a venir, pero que no necesariamente vendrá, un mundo mediador, un entre-mundo. ${ }^{628}$

La búsqueda de la representación de algo que siempre se fuga, la intención o la tentativa de representar lo invisible, ese fondo, potencia o energía, sobre el cual emerge lo visible, es lo que subyace bajo un nuevo modo de expresión del arte. Hay una locura de ver', una pretensión de verlo todo. Un arte de lo efímero, lo que no permanece, lo que fluye, pero, ¿cómo representar lo efímero? Lo efímero escapa a toda representación, el cierre en una representación no será más que su aspecto trágico. Inevitablemente esta pregunta hace emerger una reflexión sobre el tiempo y, sobre todo, sobre las formas del tiempo.

La cultura quizás reivindique y recupere el sentido de lo efímero (ya presente en el Barroco histórica a través de la representación de las vanidades, las naturalezas muertas y las calaveras), como una nueva dimensión del arte y de la vida; el sentido de un tiempo que nunca será ya recobrado, ese sentido trágico original, aceptando lo que fluye y pasa, aceptando el tiempo y su alteridad. Lo efímero será entonces un arte del tiempo, que lo acoge y cede ante él. Se trata de pensar lo efímero con un valor positivo, que como Nietzsche propone, puede, acompañar a lo trágico metamorfoseándolo ${ }^{629}$. 
Este es el recorrido que nos lleva de lo efímero a lo trágico, y de lo trágico al sentimiento positivo de la fiesta dionisiaca, con su olvido de sí, con la presencia de lo pre-individual. Un valor positivo de lo efímero que Glucksmann observa en nuestro arte, que acepta lo fluyente y lo flotante, con sus intervalos de luz, sus juegos de reflejos, tornasoles..., operadores de lo efímero.

Por otra parte, la obra de Borromini contiene restos formales, reminiscencias intempestivas, acumula, como en un palimpsesto, una superposición de tiempos plurales, recomponiendo y reutilizando algunos recursos fuera de tiempo, interpretados, que él hace que permanezcan abiertos y que su lectura no se haya agotado. El olvido, la transformación de sentido, el recuerdo provocado, el hallazgo etc.; formas que retornan, como las describe Warburg, en un encuentro dinámico de instancias históricas heterogéneas.

Así, el nuevo paradigma del tiempo lleva aparejado el retorno; lo efímero es cambiante, pero la vida sigue fluyendo. El flujo supone únicamente una modificación, algo que se metamorfosea, pero subsiste un fondo, un fondo de vida, precursor de diferencias ${ }^{630}$. Nietzsche observa una sintomatología del tiempo en relación con su noción del eterno retorno; tiempos redundantes, pequeños y grandes retornos, un entrelazamiento de los tiempos ${ }^{631}$.

Lo anterior converge con la reflexión Heideggeriana sobre el espacio, donde notaremos su vinculación con el tiempo y con el ser. Para Heidegger el ser es siempre histórico y no podría tener lugar sin la temporalidad. No se trata de una temporalidad cinética sino sincrónica: une presente, pasado y futuro. Para pensar el ser, hay que pensarlo de manera sincrónica. Esto es, como plegado, donde las diferencias se enlazan históricamente, y este enlace solo puede darse en el espacio. Por ello, el espacio, es condición de posibilidad. Heidegger está pensando como en una tetradimensionalidad del tiempo, donde el espacio, será la cuarta dimensión del tiempo. El espacio es así condición de posibilidad del enlace del ser, pensado de un modo ontológico; no se trata de un espacio físico, sino de un espacio intensivo. Pero la arquitectura, pone en obra el espacio como ese ámbito de la posibilidad.

630. Sobre la repetición y lo que Deleuze llama Dispar o precursor sombrío, ver GILLES DELEUZE, Diferencia y Repetición, op. cit., págs. 185, 199. 
Decimos "simultáneamente" y con ello adjudicamos al recíproco extenderse de futuro, pasado y presente. ${ }^{632}$

Este espacio enlaza los tiempos y abre entonces la posibilidad del pasado. Es un espaciar, como un abrir lugar ${ }^{633}$, un hacer posible, hacer posible un retorno, que el pasado sea posible en su diferencia con el presente; el espacio espacia, abre, da lugar a..., en el sentido de ser el ámbito donde el tiempo se da y dónde se dan todos los tiempos. Ese hacer posible está también implícito en el sentido de la temporalidad de Warburg.

Nos lleva, esta posibilidad abierta del pasado, a la reflexión sobre el tiempo cíclico del eterno retorno Nietzschano y en el que Heidegger, Warburg y Deleuze también están implicados. Un tiempo del retorno donde nunca retorna lo idéntico sino la diferencia, como veíamos en las series de Ferrer, donde el retorno mismo contiene las diferencias constituyentes, donde todo se metamorfosea en máscaras y simulacros.

Esta reflexión sobre el tiempo y el retorno lleva implícito todo el recorrido de la investigación que venimos haciendo, a través de los elementos potenciales de la inflexión, de nuestra reflexión sobre el espacio, o lo in-formal que se metamorfosea, las variaciones de la repetición, o los simulacros atectónicos. La investigación sobre el espacio a través del análisis de la forma, es, en último término la del espacio ontológico, la posibilidad de lo abierto, el Lichtung de Heidegger ${ }^{634}$, que reúne y acoge, que posibilita la presencia.

Concluiremos, por tanto, que nuestra reflexión sobre el tiempo, a la que ha dado lugar la obra de Borromini, y que, a través de una estética de lo efímero, de su consideración de la naturaleza, y una noción del tiempo cíclica de retornos diferenciales, hemos podido relacionar con la obra de arte contemporánea, se mueve en un mismo sentido que la noción de espacio que venimos analizando, y que emerge a partir del estatuto característico de la forma en las diferentes arquitecturas; un espacio posibilitante y espaciante, se trata de poner en obra este espaciar.

632. MARTÍN HEIDEGGER, Tiempo y Ser, op. cit., pág. 42.

633. Cifr. MARTIN HEIDEGGER, Tiempo y Ser, op. cit., pág.42.

634.El Lichtung (claro del bosque) en una metáfora que Heidegger utiliza para describir el sentido de este espaciamiento, lugar que reúne y acoge todo. MARTIN HEIDEGGER, El final de la filosofía y la tarea del pensar, en: Tiempo y Ser, op. cit. 


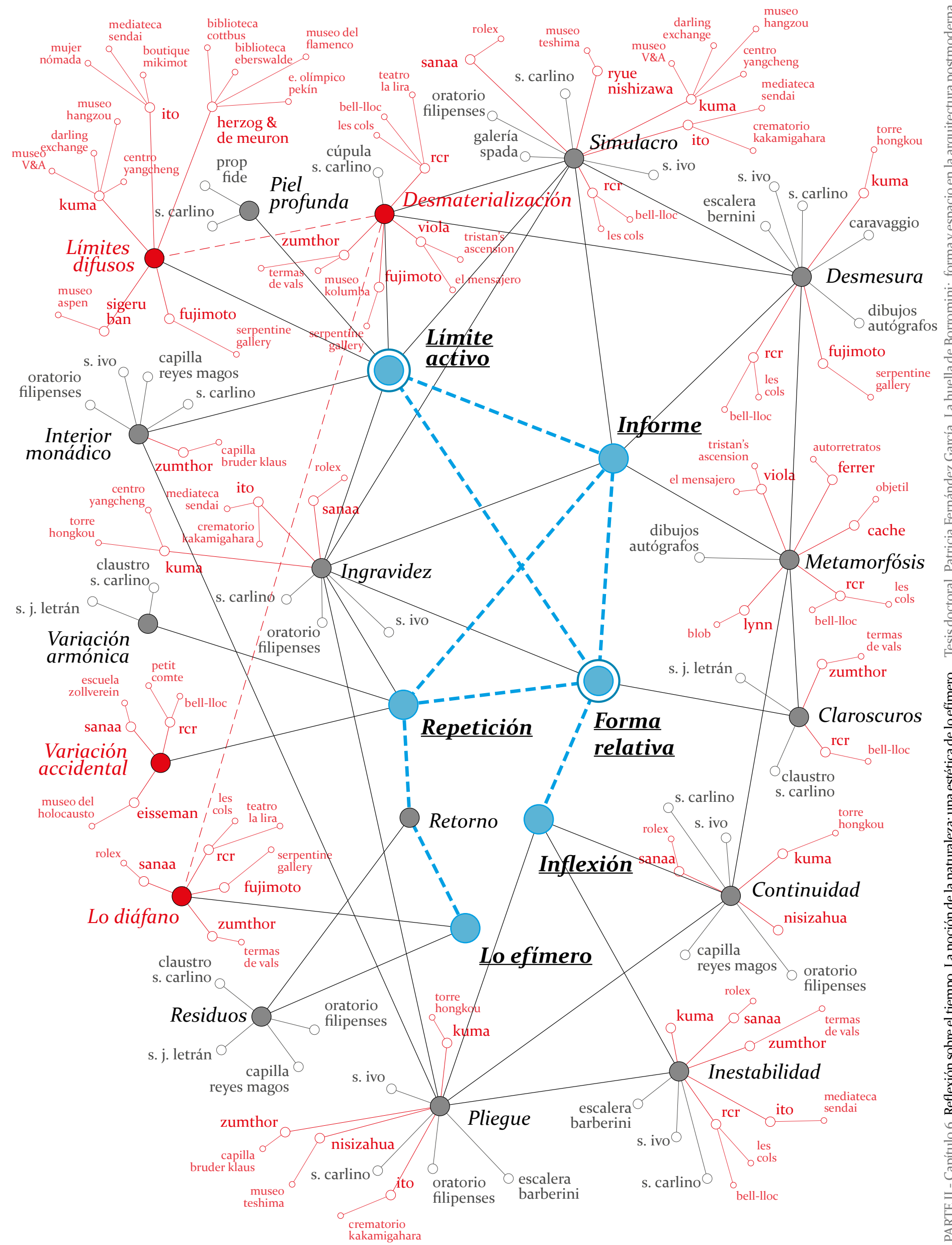


CONCLUSIONES GENERALES 
406 


\section{CONCLUSIONES GENERALES}

Omar Calabrese, en su texto La Era Neobarroca ${ }^{635}$, ha encontrado correspondencias del gusto contemporáneo con cierta gramática barroca, en la que se considera que la verdad solo está en el acto de la lectura sobre las cosas o de la realidad y en esa infinita búsqueda de un sentido que siempre se fuga. Así, el Barroco podría descubrirse en lugares tan dispares como el Libro de los Pasajes de Walter Benjamin, en los cuentos de Borges, en la forma de entender la historia de Aby Warburg...

En este mismo sentido, la filosofía de Leibniz, sitúa en primer plano la interpretación del mundo, la perspectiva sobre él, poniendo en pie de igualdad los distintos enfoques, creando un mundo relacional que precisamente se configura desde las diferentes perspectivas, una especie de topología de relaciones. Leibniz describe un mundo configurado bajo el concepto de composibilidad y esta com-posibilidad se estructura a partir de los "posibles"; posibles que se componen cada vez para dar lugar a un mundo actual. La problemática de la com-posibilidad del mundo gira en torno al concepto de potencia, que no es en ningún caso potencia cinética, es potencia como posibilidad. Los com-posibles establecen la topología como norma configuradora, como régimen de relaciones. La composibilidad simplemente compone los posibles y hace realidad la existencia de lo cognoscible común.

Por otra parte, y a través en este caso de Spinoza, el pensamiento filosófico trata de anular todo tipo de jerarquías. Spinoza elimina toda jerarquía del ser, toda subordinación a otros procesos de causalidad que establecerían jerarquías. Así, los entes no serán más que modos de ser de una única Sustancia infinita. Todos los modos son diferentes, y con el mismo valor. Una total univocidad del Ser hace que seamos modos, o maneras de ser. 
Perspectivismo, topologías, posibilidad y potencia de ser, ausencia de jerarquías, son los conceptos que presiden la filosofía barroca, y que no son ajenos a la estética barroca.

Si la vinculación con el Barroco se había hecho notar durante las útimas décadas del pasado siglo con los textos de Omar Calabresse o de Deleuze, entre otros, y, lo que hemos considerado en esta tesis como espacio postmoderno, arranca también en estas fechas, Neobarroco y postmodernismo parece que discurren paralelamente. Pero, ¿cuándo tiene su desenlace o su disolución este espacio postmoderno o neobarroco?, ¿no puede ser que el postmodernismo perdure, que sus planteamientos de fondo no estén extinguidos? Esta tesis ha tomado esta cuestión como hipótesis derivada, pues los antecedentes teóricos que ha considerado de base con respecto a un resurgimiento barroco, derivan de los primeros presupuestos postmodernos, tanto en el pensamiento filosófico como en la teoría de la arquitectura, y parece que siguen vigentes. Porque además se han encontrado, en el modo de abordar la relación forma-espacio en la arquitectura más actual, notables coincidencias con el Barroco, que, cada una en su modo de presentarse y en su lenguaje particular, apuntan a una misma manera de considerar la realidad y el mundo.

Las conclusiones de este trabajo, por ello, se centran en la confirmación, a través del análisis de obras de arquitectura, de la propuesta teórica de un neobarroco. Y, como consecuencia, al haberse considerado principalmente casos contemporáneos en el análisis, necesariamente se extiende el ámbito temporal del Neobarroco hasta nuestra actualidad, arrastrando esta extensión también al Postmodernismo, y fundamentándose, así, una conclusión sobre la hipótesis derivada. Es decir, los presupuestos del postmodernismo siguen vigentes, al menos en la interpretación de obras de arquitectura, lo que arrastra consigo la posibilidad de un espacio postmoderno que incluya la contemporaneidad.

El hilo conductor del análisis, dónde el estudio se ha apoyado, y lo que ha hecho manifestarse la vinculación de las "epocalidades", ha sido la observación del régimen de la forma arquitectónica en su relación con el espacio. Para valorar este estatuto de la forma se tomaron una serie de parámetros referenciales a partir de los cuales se ha desarrollado un análisis teórico, que es el que ha puesto en relación las obras de las dos temporalidades.

Por tanto, las conclusiones se centrarán en primer lugar, en observar los diferentes modos de presentarse los parámetros refe- 
renciales escogidos para el análisis en uno y en otro periodo. Y en segunda instancia, en la coincidencia o no, del significado de los objetos teóricos reflexionados a través de la filosofía, a los que los parámetros escogidos parecen remitir. A continuación repasamos las conclusiones que se extraen a través de los diferentes ámbitos que han articulado la investigación.

Pliegue- inflexión

En la forma pliegue encuentra Deleuze el trazo que caracteriza al Barroco. Para él es una forma operativa en la que subyace el modo de considerar el mundo. El pliegue y la inflexión llevan en sí mismos un carácter potencial, un carácter intensivo. Mas que formas determinadas son formas-potencia, capaces de desencadenase, de desplegarse. Por ello, más que a una determinación estable apuntan a una forma in-formada, diluida, des-integrada, caracterizan una cierta inestabilidad formal. Así, hemos hallado en la obra de Borromini, a través del uso múltiple de estos modos de la inflexión, que la forma se pone en relación con fuerzas que la intervienen, tornándose forma in-formada, forma en formación. Sus resultados construidos, por tanto, son siempre de aspecto inestable, transmiten movimiento y posibilidad de variación; una cierta negación a presentar una determinación cerrada y estática.

La expresión de inestabilidad se manifiesta también en el lenguaje tectónico de la obra, donde la presencia de una estructura sustentante, estable, es negada en la forma. No solo se trata de una continuidad constructiva que podríamos llamar estereotómica y que engloba las partes sustentantes, sino que su condición tectónica es impugnada a través de diferentes recursos en cada caso. La estructura portante, la que confiere el carácter estable a la obra, es enmascarada, y en su lugar se muestran fuerzas desestabilizadoras, como en una especie de simulacro.

En resumen, el régimen formal apunta a un debilitamiento de la integridad de la forma como objeto cerrado. La forma manifiesta el ámbito de formalización, la expresión de las fuerzas intervinientes, la potencia y lo virtual; señala al proceso de individuación, más que a la forma acabada. Esta expresión de lo potencial tiene su correlato en el sentido que Deleuze concede a la forma pliegue a través de la filosofía de Leibniz; un elemento potencial que contiene en sí su desarrollo y que se genera a partir de la inflexión, ligada al acontecimiento. El pliegue remite siempre también a una continuidad. 
Inestabilidad, a-tectonicidad, pliegue, inflexión, continuidad, son los rasgos referenciales que caracterizan el régimen de la forma. Estos rasgos remiten a la potencia, la virtualidad, el acontecimiento, al ámbito pre-formal de la individuación, al fondo (espacio) más que a la forma en sí.

Estos objetos teóricos han sido hallados también en las obras de arquitectura contemporánea investigadas a través de: espacios continuos formados por láminas plegadas sobre el terreno, o planos ingrávidos que flotan ondulando sobre el solar donde se asientan, o membranas que cubren un lugar apoyándose en formas que de nuevo pervierten la acción de la gravedad, o pieles dinámicas que se pliegan y deforman alrededor del espacio interior. Simulacros ingrávidos de la arquitectura que contienen además la virtualidad que manifiesta su inestabilidad, haciendo emerger el medio donde las fuerzas de lo virtual tienen lugar en detrimento de la forma.

\section{El modo de la repetición}

La repetición niega la existencia de un original; el modelo de imitación o el tipo desaparece y el tema de la variación se introduce en el modo de expresión de la arquitectura. Ya no hay original, como ya no hay tipo, referencia o analogía. Ahora, la propia diferencia es el tema del proyecto, o en todo caso una interpretación. La repetición se manifiesta en muchas obras de Borromini de diferentes modos. En todos los casos se introduce la variación dentro de la repetición, es decir, no se trata de una pura reiteración de elementos, estos se modifican en el modo de presentarse cada vez, pero siempre sometidos a una armonía u orden reconocible que rige la variación.

En el acto de la repetición variada se tematiza la diferencia. Deleuze ha observado que la repetición es el ser informal de todas las diferencias. Por otra parte, en la repetición también se diluye la forma, se disgrega, la representación del conjunto se desconfigura.

Hemos encontrado en las obras contemporáneas la repetición como tema recurrente que aparece en infinidad de casos. El modo de la repetición contemporánea lleva al extremo la desintegración formal a la vez que la variación ha perdido todo orden, entrando en juego el azar y lo accidental, se ha roto la armonía barroca. Podríamos decir que se tata de una intensificación del efecto, el 
estatuto de la forma se aproxima a una forma extrema, al límite de su disolución, al fondo incierto donde las fuerzas de formalización y las potencias actúan, y que imaginamos como caótico.

\section{La expresión del espacio: forma relativa}

La obra de Borromini se compone a través de referencias intrínsecas apoyadas en un entramado geométrico que ya no es modelo sino herramienta. El resultado formal renacentista parecía apoyarse más bien en una yuxtaposición de elementos que podían leerse en su autonomía formal y se componían según referencias y modelos. Este modo de hacer es sustituido en la obra de nuestro autor, por la conformación de un espacio fluido con un carácter tridimensional que se va conformando según referencias intrínsecas. Trabaja a través de una experimentación topológica que va evolucionando la forma como si fuera una forma plástica, favoreciendo al espacio, que se muestra como constitutivo de la arquitectura. Es una topología, que sustituye a la tipología ${ }^{636}$, y que diluye todo tipo de jerarquía, pues las posiciones de elementos no responden a modelo externo sino a su propia configuración interna. El espacio, tan presente en la obra de Borromini, como ya muchos críticos habían observado, es siempre relacional, es el ámbito común que reúne y con-figura. La sensación y el afecto remiten al espacio como forma de la exterioridad.

Espacio fluido, topología, ausencia de jerarquía, son también rasgos característicos en la obra de Borromini, que muestran al espacio-lugar como el ámbito constitutivo del resultado formal; estos recursos expresan el espacio. El espacio es el lugar de posibilidad, ámbito de las relaciones que se establecen al generar la forma. El espacio es productor, no vacío neutro.

El método topológico de conformaciones relacionales en el espacio consideramos que es una constante en el proyecto contemporáneo. La arquitectura contemporánea también participa de esta condición espacial. Y lo hace de modos diversos, especialmente a través de la presencia de lo que C. Buci-Glucksmann llama lo diáfano ${ }^{637}$. Lo diáfano se evidencia en las transparencias, reflejos y flujos que recorren los ámbitos de nuestra arquitectura, que se traducen en muchos casos en una inmaterialidad. Se trata de un grado más en la disolución de la forma barroca; si los recursos del 
Barroco hacían de la materia, materia blanda, ese efecto masa al que se refería Wölfflin, afectando a la integridad de la forma, nuestra arquitectura expresa des-materialización, y materia y forma van necesariamente unidas.

La forma ya no tiene la referencia en sí misma, sino en el espacio que la con-forma, se trata de una forma relativa.

Por otra parte, el espacio, tras su análisis teórico, manifiesta, en último término, un espacio ontológico, al que nos remitimos, esta vez siguiendo a Heidegger. Espaciar nos dice Heidegger, es dar lugar, la localidad es un juego interactivo de lugares $^{638}$. Heidegger considera que la posibilidad de las tres formas del tiempo solo se da en el espacio. Lo que él llama Lichtung (o claro del bosque), es el lugar abierto que reúne y acoge todo: el espacio puro y el tiempo estático, y todo lo presente y lo ausente en ellos ${ }^{639}$.

La arquitectura, como obra plástica, pone en obra el espacio.

Metamorfosis , desmesura, forma extrema

Hemos visto como Borromini hace de la metamorfosis formal un argumento de proyecto. ${ }^{60} \mathrm{Su}$ método de búsqueda de forma, parece trasladarse a su obra construida, que se expresa como un objeto en formación, con potenciales todavía no actualizados. Borromini proyecta espacios que fluyen por su herramienta proyectual que es la geometría, su mecanismo para el movimiento en el espacio. La continuidad que discurre por la geometría se extiende a la forma construida, que fluye en vertical (Sant'Ivo), alrededor de puntos descentrados (San Carlino), de forma envolvente (oratorio Filipinos o capilla de los Reyes Magos), o en espiral ascendente (escalera Barberini o la aguja de Sant'Ivo alla Sapienza) ... etc. Desde el inicio del proceso, hasta su resultado formal, podemos decir que su obra transmite una especie de inestabilidad a la que, la a-tectonicidad ya notada, contribuye.

Metamorfosis, continuidad, inestabilidad, tensión, caracterizan tanto la obra como su proceso de formación. Gilbert Simondon habla, en relación con estos rasgos, del concepto de me-

638. MARTÍN HEIDEGER, El Arte y el Espacio, op. cit., pág. 27.

639. MARTÍN HEIDEGGER, Tiempo y Ser, op. cit., pág. 106.

640. Cifr. EUSEBIO ALONSO, op. cit. 
taestabilidad $^{641}$, se trata de lo contrario al equilibrio estable, un sistema no estable, rico en potenciales. Este objeto metaestable es así una realidad relativa, expresa una cierta fase del ser que presupone siempre una realidad preindividual, remite al ámbito de lo preindividual o de lo virtual. Es la base de lo in-forme.

Recurrimos también al pensamiento de Leibniz, tanto en la interpretación de Deleuze, como en su propia obra, para observar la importancia de la continuidad de la materia. Esta continuidad no es contradictoria con la existencia de individuos o causas finales de la mónada ${ }^{642}$, al contrario, es necesaria para poder considerar la composibilidad del mundo ${ }^{643}$, y la posibilidad de la mónada como plegamiento. Así, el cambio en un continuo, tendrá lugar, necesariamente, por metamorfosis.

Hemos descubierto este carácter metamórfico en cada una de las obras contemporáneas antes referidas para caracterizar el pliegue y la inflexión. Pues el recurso del pliegue lleva implícita la inestabilidad y la continuidad y con ella la condición metamórfica. Explícitamente recogen este tema las propuestas teóricas y las tentativas de llevarlas a la práctica, de Bernard Cache y Greg Lynn; los objetiles de Cache y el blob de Lynn, llevan esta característica a la práctica. También descubrimos que la arquitectura contemporánea nos presenta objetos arquitectónicos a modo de organismos vivientes, que anuncian su inestabilidad, su movimiento, el perpetuo cambio que llevan implícito por su condición viviente. Hemos notado, así mismo, como la metamorfosis es tema recurrente en algunas obras contemporáneas de otros ámbitos distintos al de la arquitectura, que se materializa en series, y que contienen una reflexión sobre el tiempo.

Todos los rasgos que hasta ahora se han repasado convergen en este carácter metamórfico de la forma en relación con la continuidad. La inflexión, como recurso, es el elemento que introduce la variación en un continuo; pliegue, inflexión y continuidad, son los elementos propios de este sistema metamórfico. Podemos considerar la forma-pliegue como una forma extrema, y enlazarla así con la desmesura. Y es esta desmesura donde Nietzsche había

641. GILBERT SIMONDON, La Individuación, a la luz de las nociones de forma e información, op. cit.

642. Deleuze advierte que la continuidad es compatible con el principio de los indiscernibles, pues no hay que confundir, en este sentido, continuidad con contigüidad. GILLES DELEUZE, El Pliegue..., op. cit., pág. 57.

643. Véase supra, págs. 263,264. 
reconocido el carácter de la fiesta dionisiaca, donde él encuentra el origen de la tragedia. Tragedia y Barroco, quedan así de algún modo enlazados; ambos remiten al ámbito de lo pre-individual, que rozan, tanto la forma extrema, como la desmesura. Forma extrema y desmesura manifiestan la potencia del retorno y por ello se ligan también con un cierto sentido de la temporalidad.

Límite activo: el ámbito piel

Se ha notado que los edificios de Borromini son de piel profun$\boldsymbol{d a}^{644}$. Sus pliegues, sus convexidades y concavidades alternas, los orificios en forma de poros, o los motivos superpuestos sobre el plano de fachada, hacen que el límite del edificio sea, más que un contorno, un ámbito. Se trata de límites imprecisos, como zonas que remiten a la potencia de formación; una negación del contorno como límite estable, lo que contribuye a des-figurar su percepción, a diluir la forma. Además, las envolventes de nuestro autor, participan marcadamente de una tectonicidad encubierta, negando la acción de la gravedad con todo tipo de recursos. En ello encontramos una tendencia a la disolución de la materialidad de la envolvente, que notamos en las texturas porosas o cavernosas de sus pieles, por ejemplo. La dilatación de la piel en ámbito o zona apunta también a esa tendencia a desmaterializarse.

A través del análisis teórico realizado sobre el concepto de límite, basado en el pensamiento de diversos autores, se ha considerado que este modo de atender a la envolvente, se enmarca en una noción positiva del límite, que no es contorno como negación o privación, sino el espacio cualificado donde se formaliza la cosa. Un régimen del límite y del espacio, que se basa en una concepción vital de ambos. Así el límite de algo es el límite de su acción posible y no el contorno de si figura. Se trata de límites activos.

Toyo Ito ha hecho explicito este tema, proponiendo una arquitectura de límites difusos. Toda la problemática de la complejidad del límite en el Barroco, se evidencia con soltura en todas las pieles-envolventes de nuestra arquitectura contemporánea. Ya no se trata nunca de contornos simples, las envolventes actuales son zonas, pero, además, zonas de interacción. La envolvente es más que nunca el ámbito donde se ejerce la potencia. Las hipersuperficies tatuadas o textiles, o los camuflajes biológicos y táctiles, muestran la complejidad de la envolvente actual, y llevan al ex- 
tremo la tendencia de Borromini a desmaterializarla, a diluirla, y con ello a enmascarar de nuevo lo tectónico, el peso del material e incluso su existencia. Se trata de los nuevos simulacros.

La cuestión de la envolvente lleva implícita la consideración de la relación entre el exterior y el interior. Se ha podido observar como los interiores de Borromini se cierran en sí mismos, se vuelcan hacia adentro, mientras la fachada se hace eco del entorno, lo articula e incluso lo transforma. Sin embargo, esta relación problemática entre exterior e interior, que se vincula fácilmente, como Deleuze demuestra, con la consideración filosófica de las mónadas, cerradas sobre sí mismas (recuérdese que la mónada no tiene ventanas) y generadoras de puntos de vista sobre el mundo, no se mantiene en la contemporaneidad. Deleuze observa que las mónadas contemporáneas se hayan semiabiertas ${ }^{645}$, pues ya no se componen para expresar el mundo en series convergentes, actualmente se ha roto la armonía barroca (ya lo habíamos percibido con el tema de la repetición, ahora aleatoria), y las series ya no se com-ponen, se trata ya de series divergentes, en expansión. En arquitectura lo venimos notando, el ámbito espeso y profundo de las pieles borrominianas, que ya tendía hacia lo inmaterial, ahora es permeable, y los límites difusos son también interactivos; exterior e interior se interpenetran.

Así, la forma, que había ya perdido su referencia a sí misma, y remitía en cambio al espacio, ha dejado que el espacio la disuelva, en transparencias, fluideces y límites difusos, y lo interior y lo exterior dejan de ser elementos dispares, son solo una deformación provisional donde ambos permanecen relacionados mientras se transforman ${ }^{646}$.

\section{Consideraciones sobre la temporalidad}

La consideración de la naturaleza como physis en el sentido griego del término, que lleva la caducidad escrita en el rostro ${ }^{647}$, parece estar inscrita en la obra de Borromini, alejándose de la concepción idealizada de la naturaleza que había prevalecido en el Renacimiento. Surge así una estética de lo efímero, con el gusto por 
la representación de las naturalezas muertas y las calaveras en la pintura barroca.

Esta naturaleza forma parte de un tiempo cíclico, donde nacimiento y muerte tienen el mismo valor, como renovación. Es una consideración del tiempo que responde a ese Eterno Retorno de Nietzsche, retomado a su manera por Warburg, Heidegger o Deleuze, y que hemos podido analizar ${ }^{648}$. En todos notamos este recurso de un retornar que vuelve y se repite metamorfoseada en diferentes simulacros, máscaras del Barroco o Neobarroco. Lo que vuelve o retorna es en forma de ficción, como metamorfosis, como máscara, y el simulacro es así el verdadero carácter de la forma; lo hemos comprobado en el régimen de nuestra forma barroca y neobarroca. El retorno mismo es la potencia de Ser, no tiene forma ni identidad constituida, esa potencia que encontramos bajo la expresión de nuestras arquitecturas, enmascaradas de pliegues, transparencias, reflejos y simulacros.

En definitiva, todas las referencias investigadas convergen. Todas señalan a una forma diluida, intervenida por el espacio, forma que de un modo u otro ha perdido su integridad, que ya no es relativa a sí misma sino al espacio que la con-forma. La forma barroca es forma relativa, relativa al espacio donde se hace posible, y este espacio no es nunca un vacío neutro, no es un echar en falta, sino un producir ${ }^{649}$. Una forma que tampoco se determina en un contorno, sino que se enmarca en un ámbito donde se dan las condiciones de su posibilidad (el carácter de su envolvente). El límite es por ello, límite activo, la zona donde la potencia se ejerce.

No podemos decir que la forma en todas estas arquitecturas decline su protagonismo, lo tiene, lo adquiere, y la causa es precisamente su condición de in-formada, pues se trata de una forma extrema, cercana a la desmesura y al desbordamiento, cercana a su disolución como tal forma. Este régimen de la forma lleva también enlazado a un cierto sentido de la temporalidad, que tiene su referencia, como hemos visto, en el Eterno Retorno nietzschiano, pues la forma extrema se trans-forma, se metamorfosea y cambia, apareciendo como un nuevo simulacro, simulacro de arquitectura, ingrávida e inestable. 
La forma ha perdido la referencia a un original o tipo que en el clasicismo tenía, ya no hay modelo ni analogía alguna, ya no hay régimen único ni referencia superior donde fundarse. Ya no hay relato, las mónadas instauran puntos de vista sobre el mundo, interpretaciones, y, como Deleuze nos recuerda, el problema siempre es habitar el mundo ${ }^{650}$. El punto de vista es ahora la forma de articularlo, su interpretación, la forma es forma relativa, y se ha roto también cualquier discurso hegemónico. Por ello consideramos que la puesta en cuestión del proyecto moderno, que, de diferentes modos se traduce en su disolución o debilitamiento, tiene su correlato en arquitectura, y lo hemos leído en la paralela pérdida de integridad de la forma, en su paralelo debilitamiento, que queda compensada por la emergencia de la expresión del espacio como ámbito relacional, de posibilidad y de diferencia.

Por todo ello, estas arquitecturas al poner en obra el espacio de diferentes modos, bien pueden remitirnos a un espacio ontológico, pues, siguiendo a Heidegger la belleza se manifiesta cuando la verdad se pone en obra ${ }^{65}$. 


\section{BIBLIOGRAFÍA}


420 


\section{BIBLIOGRAFÍA}

o.1. LIBROS Y CAPÍTULOS DE LIBRO

\section{Bibliografía principal}

ALONSO, E., (2003), San Carlino: la máquina geométrica de Borromini, COACYLE de Valladolid, Universidad de Valladolid, 2003.

ARGÁN, J.C.:

(1952), Borromini, Mondadori, Verona, 1952. Trad: Borromini, Xarait, Madrid 1987.

(1961), Trad: Liliana Rainises, El concepto de espacio arquitectónico. Del Barroco a nuestros días, Buenos Aires 1980.

BENJAMIN, W., (1916), Ursprung des deutschen Trauerspiel, Frankfurt am Main, 1989. Trad: Alfredo Muñoz, El Origen del Trauespiel alemán, Abada editores 2012.

BLUNT, A., Borromini, (1979), Penguin Books, Middlesex. Trad. Fernando Villaverde, Borromini, Alianza Editorial, Madrid, 1979.

BUCI-GLUCKSMANN C.:

(1986) La folie du voir: del esthetique baroque, Editions Galilée, París 1986.

(2003), Esthétique de l'ephémère, Editions Galilée, París 2003. Traducción Santiago E. Espinosa, La Estética de lo efímero, Arena libros, Madrid 2006.

CACHE B., (1983), Terre Meuble. Traducción al ingles Earth Move: The Furnishing of Territories, Cambridge (MA): MIT Press, 1995.

CALABRESE, O., (1987), L'età neobarroca, Gius, Lacerta \& Figli Spa, Roma-Bari, 1987. Traducción al castellano Anna Giordano, La era neobarroca, Ed. Cátedra, Grupo Anaya, 1989. 
DELEUZE, G.:

(1968), Difference et Répétition, Presses universitairies de France, 1968. Trad: Maria Silvia Delpy y Hugo Beccacece, Diferencia y Repetición, Amorrortu, Buenos Aires 2003.

(1989), Le pli. Leibniz et le Baroque, Minuit, París, 1989. Trad: El pliegue, Leibniz y el Barroco. Paidós, Barcelona 2014.

DIDI-HUBERMAN G., (2002) L'Image supervivante, Historie de l'art et temps des fantomes selon Aby Warburg, Les editions des Minuit, 2002. Trad: Juan Calatrava La Imagen Superviviente, historia del arte y tiempo de los fantasmas según Aby Warburg, Abada, Madrid 2009.

HEIDEGGER, M.:

(1962), Zur Sache des Denkesns, Auflage, Max Niemeyer Verlag, Tubingen, 200o. Trad: Manuel Garrido, Tiempo y Ser, Tecnos 2011. (1969), Die Kunst und der Raum, Vittorio Kolestermann, Frankfurt del Meno, 2007. Traducción al castellano de Jesús Adrián Escudero, El Arte y el Espacio, Herder 2009.

LYOTARD, J. F., (1979), La condition postmoderne: rapport sur le savoir, Éditions de Minuit, 1979. Trad: La Condición Postmoderna, Cátedra, 1984

MARCHAN FIZ, S., (1981), La condición posmoderna en la arquitectura. Lección inaugural del curso 1981-1982 en la Universidad de Valladolid. Universidad de Valladolid 1981

MARTIN JAY, (1988), "Scopic Regimes of Modernity”, en: Hal Foster (ed.), Vision and Visuality. Dia Art Foundation Discussions in Contemporary Culture Nr. 2, Bay Press. Seattle, 1988. Trad: "Régimenes escópicos de la Postmodernidad".

NIETZSCHE F., (1872), Die Geburt der Tragödie, aus dem Geiste der Musik, 1872. Traducción al castellano de Andrés Sánchez Pascual, El nacimiento de la tragedia, Alianza Editorial, Madrid 1973.

OÑATE, T.:

(2019) "La Hermenéutica como Ontología Estética del Espacio-Tiempo (perspectivas aristotélico-heideggerianas)", en su libro: Estética y Paideía Hermenéuticas contra la Violencia I. Dykinson, Madrid, 2019. 
(2019) "Por la vía noética del espacio ontológico", en su libro: Estética y Paideía Hermenéuticas contra la Violencia I. Dykinson, Madrid, 2019.

PORTOGHESI, P., (1967), Francesco Borromini, Electa, Milano, 1967.

SIMONDON, G.:

(1958), L'individuation à la lumière des notions de forme et d'information, 1958. Trad: de Pablo Irés, La Individuación, a la luz de las nociones de forma e información, Cactus La Cebra, Buenos Aires 2009 .

(2007) Du mode d'existence des objetes techniques, Editions Flammarion, París, 2007. Trad: Margarita Martinez y Pablo Rodriguez, El modo de existencia de los objetos técnicos, Prometeo libros, Buenos Aires 2007.

VENTURI, R., (1966), Complexity and Contradiction in Architecture. New York: Museum of Modern Art, 1966. Trad: Antón Aguirregoitia, Complejidad y contradicción en la arquitectura, Gustavo Gili, Barcelona 1978.

WÖLFFLIN, H.:

(1968), Renaissance und Barock, Schwabe and Co, Basilea 1968. Trad: Alberto Corazón 1978, Renacimiento y Barroco, Paidós, Barcelona 1996.

(1915), Kunstgeschichtliche Grundbegriffe (revisado en 1933), Trad: Jose Moreno Villas, Conceptos fundamentales para la historia del arte, Espasa-Calpe, 2007.

\section{Bibliografía general}

AGAMBEN, G., “QQué es un paradigma?”, en: Signatura rerum. Bollati Boringhieri editore, Turin 2008. Trad: Flavia Costa y Mercedes Ruvituso, Signatura rerum. Sobre el método, Anagrama, Barcelona 2010 .

ALBERTI, L.B., De re aedificatoria, Akal, Madrid, 2007.

ANAXIMANDRO DE MILETO; Sentencia, traducción de Friedrich Nietzsche en su texto: La filosofía en la época trágica de los griegos, Valdemar, 1999. 


\section{ARISTOTELES:}

Sobre el alma, Trad: Tomás Calvo Martinez, Gredos, Madrid, 2010.

Física, trad: Guillermo R. de Echandía, Gredos, Madrid, 2008.

BARTHES, R., (2002), Le neutre, cours et séminaires au Collège de France (1977-1978), Le Seuil/Imec, París, 2002.

BENJAMIN, W., (1927-1940), Das Passagen-Work. Trad: Juan Barja, El libro de los Pasajes, Abada editores, 2013

BERGSON, H.:

(1881), L'évolution créatrice. Trad: Pablo Ires, La evolución creadora, Cactus, Buenos Aires, 2007.

(1889), Quid Aristoteles de loco senserit. Thesim facultati litterarum Parísiensi proponebat, Edebat F. Alcan, París, 1889. Trad: Antonio Dopazo, El concepto de lugar en Aristóteles, Encuentro, Madrid 2013.

BORROMINI, F., (1725), Opus archiitectónicum Equitis Francisci Borromini, Wentworth Press 2016.

BRANDI, C., (1967), Borromini, en Struttura e architettura, Giulio Einaudi editore, Torino 1975.

BURCKHARDT, J.:

(1855), Cicerone, Trad: J. Bofill y Ferro, El Cicerone. Iberia, Barcelona 1953.

(1929), Weltgeschichtliche Betrachtungen, R. Marx, Leipzig, , Alfred Kröner, 1929. Trad: Reflexiones sobre la historia universal, Fondo de Cultura Económica, México, 1999.

TOMÁS CALVO MARTÍNEZ, (2010), Presentación al Tratado sobre el Alma de Aristóteles, ed. Gredos, Madrid 2010.

CHAPTAL, J., (2012), Renaissamce y Baroque, Les charmes de l'analogie, Harmattan, París 2012

CURTIS, W.J.R., (2009), The structure of shadows, Trad: Jorge Sainz e Inés Fernández Arias, La Estructura de las sombras. "Introducción a la publicación sobre las bodegas Bell Lloc", Imprenta Aubert, Sant Joan Les Fonts, 2009. Fundació Bunka.

D'ORS, E., (1935), Del barroco, Tecnos, Madrid 2002. 
DELEUZE, G. y PARNET, C., (1997), Dialogues, Flammarion, París 1997. Trad: Diálogos, Pre-textos, Valencia 1995.

DELEUZE, G.:

(1964), Marcel Proust et les signes, 1964, Presses Universitaires de France, 1964.

(1967), Nietzsche et la philosophie, Presses Universitaries de France, París, 1997. Trad: Carmen Artal, Nietzsche y la filosofía. Anagrama: Barcelona, 2002.

(1968), Spinoza et le probléme de l'expression, Éditions de Minui, París 1968. Trad: Horst Vogel Muchnik editores, Spinoza y el problema de la expresión, Atajos, Barcelona 1996.

(1970), Spinoza: Philosophie practique, Presses Universitaries du France 1970, París, 1970. Trad: Antonio Escohotado Spinoza: filosofía práctica, Tusquets, Barcelona, 2001.

(1978), Kant y el tiempo, Cactus, Buenos Aires 2008. Curso dictado en la universidad de Vincennes en marzo/abril 1978.

(1981), Pintura, el concepto de diagrama, Buenos Aires, Cactus 2007. (Clases de Deleuze en el curso dictado en la universidad de Vincennes mayo/junio de 1981).

(1983), L'Image-mouvement. Cinéma 1, Editions les Minuits, 1983. Trad: La imagen-movimiento: cine 2, Paidós Iberica, Barcelona, 1984

(1985), L'Image-temps, Cinéma 2, Editions les Minuits, 1985, Trad: La imagen-tiempo: cine 2, Paidós Iberica, Barcelona, 1987.

(1986), Foucault, Les Éditions des Minuit, París 1986. Trad: José Vázquez Pérez, Foucault, Espasa libros, Barcelona 1987.

(1986), La subjetivación. Curso sobre Foucault. Tomo III, Cactus, Buenos Aires 2015. Curso dictado en la universidad de Vincennes en abril/mayo 1986.

(2002), Francias Bacon. Logique de la sensation, editions du Seuil, 2002. Traducción al castellano de Isidro Herrera, Francis Bacon, La lógica de la sensación, Arena libros, Madrid, 2002.

DELEUZE, G. y GUATTARI, F.:

(1972), L'Anti-Edipe, Minuit, París, 1972.Trad: Francisco Monge, El Antiedipo, Paidós Ibérica, Barcelona, 1985.

(1988), Mil plateaux, capitalisme et schizophrenie, 1988, Trad: José Vázquez Pérez, Mil Mesetas, capitalismo y esquizofrenia, Pretextos, Valencia 2002. 
(1991), Qu'est-ce que la philosophie?, Les editions des Minuits, París, 1991. Traducción al castellanao ¿Qué es la filosofía?, Anagrama, Barcelona 1993.

DERRIDA, J.:

(1968), Semiologie et Gramatologie, Information sur les sciences sociales VII, 1968. Trad: O. Del Barco y C. Ceretti, De la gramatología, Siglo XIX, México, 2003.

(1989), El tiempo de una tesis: Deconstrucción e implicaciones, Anthopos, Barcelona 2017.

DIDI-HUBERMAN G.: (2001), L'homme qui marchait dans la couleur, Minuit, 2001. Trad: Juan Miguel Hernández León, El hombre que andaba en el color, Abada, Madid 2014.

DURAND G., (1969), Les estructures anthropologiques de l'imaginaire, Bordas, París 1969

EDWARDS, T., (1924), Good and Bad Manners in Architecture, P. Allan \& Co., London, 1924.

FAUCAULT, M.:

(1966), Les Motes et les Choses, une archéologie des sciences humaines. Gallimard, París 1966.Trad: Elsa Cecilia Frost, Las Palabras y las Cosas. Una arqueología de las ciencias humanas, Siglo XXI, Madrid, 2010.

(1994), Le corps utopique. Les heterotopies, Nouveles editions Linges 2009, de: Des espacies Autres. Espace, savoire et pouvoire, Editions Gallimard 1994. Trad: Victor Goldstein, El cuerpo utópico y las heterotopías, Nueva Visión, Tucuman,2010.

FEDERICO BELLINI, (2004), Le cúpole di Borromini, Electa, Milano 2004.

FOCILLON, H., (1931), Vie des formes, suivi de Éloge de la main, Presses Universitaires de France, París, 2013. Trad: La vida de las formas y el elogio de la mano, El Ateneo, Buenos Aires, 1947.

FRANCIOSE CHASLIN, (2001), Deux conversations avec Rem Koolhaas, Sens et Tonka, 2001 


\section{GADAMER H.G.:}

(1960), Wahrheit und Methode, 1960. Trad: Ana Agud Aparicio y Rafael de Agapito, Verdad y método, Fundamentos de una hermenéutica filosófica, Sígueme, Salamanca 2012.

(1996), Estética y hermenéutica (recopilación). Trad: Antonio Gómez Ramos, Estética y hermenéutica Tecnos 1996.

(2017), Los caminos de Heidegger, Barcelona, Herder, 2017.

GIEDION, S., (1941), Space, time and architecture: The Growth of a new tradicion, Harvard University Press, Cambridge, Massachusetts, 1941. Trad: Jorge Sainz, Espacio tiempo y arquitectura, Reverté, Barcelona, 2009.

GIRARD C., (1986), Architecture et concepts nomads: traité d'indiscipline, éditions Mardaga, 1986

HAL FOSTER, (1983), The anti-aesthetic, Essays on postmodern culture, Bay Press, Port Townsend, Washington, 1983.

\section{HEIDEGGER, M.:}

(1927), Sein und Zeit, 1927, Trad: Jorge Eduardo Rivera, Ser y Tiempo, Editorial Trotta, Madrid 2009.

(1954), “Batir Habiter Pender”, en Esssais et Conférences, Vorträge und Aufsätze, 1954. Trad: Eustaquio Barjau, "Construir, habitar, Pensar”, en Martín Heidegger, Conferencias y Artículos, El Serval, Barcelona 1994.

(1961), Nietzsche”, Günther Neske, Pfullingen, 1961. Trad: Juan Luis Vermal, Nietzsche, Destino, Barcelona, 2000.

(1936), "El origen de la obra de arte", en: Gesamtaugsabe. Band 5: Holzwebw, Vittorio Klosterman, Frankfurt, 1984. Trad: Helena Cortés y Arturo Leyte, Caminos del Bosque, Alianza Editorial, Madrid 2010.

HEMPEL E., (1924), Francesco Borromini, Schroll, Viena 1924.

\section{HERNANDEZ LEÓN, J.M.:}

(2016), Ser Paisaje, Umbrales. Abada editores, 2016.

(2014), Introducción a El hombre que andaba en el color, Abada, Madid 2014.

HITO, T., (2006), Arquitectura de límites difusos, Gustavo Gili, Barcelona 2006 


\section{JAMESON F.:}

(1984), The Postmodernism or the Cultural Logic of Late Capitalism, New Left Review, Oxford 1984.Traducción al castellano de Jose Luis Pardo Torio, El postmodernismo o la lógica cultural del capitalismo avanzado. Paidós Ibérica, Barcelona, 1991.

(2012), El postmodernismo revisado. Ed. David Sanchez Ulanos, Abada, Madrid 2012.

JENCKS C., (1977), The Language of Post-Modern Architecture, New York, 1977. Trad: El lenguaje de la arquitectura postmoderna, Gustavo Gili, Barcelona 1980.

KANT, I.:

(1781), Critik der reinenVernunft, Trad: Pedro Rivas, Crítica de la Razón pura, Santillana, Madrid, 2013.

(1790), Critik der Urtheilskraft, Trad: Manuel García Morente, Crítica del Juicio, Espasa, Barcelona, 2013.

KIPNIS, J. y LEESER T. (1997), Jaques Derrida y Peter Eisenman, Monacelli Press, New York, 1997.

KLEE, P., (1956), Paul Klee notebook Volumer. The thinking eye. (Londres: Lund Humphries, 1961 [1956]); Paul Klee, Paul Klee notebooks Volume 2. The nature of nature. (Londres: Lund Humphreis,1973 [1970]). Para la redacción de este texto se ha consultado: Paul Klee, Esbozos pedagógicos en Théorie de l'art moderne, Trans. de Pablo Ires, Teoría del arte moderno, Cactus, Buenos Aires 2007.

KUHN. T.G. (1962), The structure of scientifíc revolutions, University of Chicago Press, 1962. Trad: Agustín Contin, La estructura de las revoluciones científicas, Fondo de Cultura Económica, México, 1962.

LACAN, J., (1975), Du baroque, Séminaire XX, Encore, 1975, París, Seuil, 2002.

LEJEUNE, A., MIGNON O. y PIRENNE R. (ed.) (2013), French Theory and American Art, Stenberg Press, Berlín, 2013.

LYNN G.:

(1993), Folding in Architecture, Architectural Design, № 63, 1993

(1999), Animate form, Princeton Architectural Press, 1999. 
LEIBNIZ, G.W., Monadología. Trad: Juan Velarde, Biblioteca nueva, Madrid 2012.

MACEL C., (2005), L'art en excés de flux uo le tragique contemporain, catálogo de la exposición Dyonisiac, dirigida por Christine Macel, Centro Georges Pompidu, París, marzo de 2005.

MALEVITCH, K., (1981), La lumière et la couleur, L'Âge de l'homme, 1981. Trad: Ángel Gonzalez, La luz y el color, Lampreave, Madrid, 2012.

MARTINEZ MARZOA F., (1994), Historia de la filosofía I, Ediciones Akal, Madrid 1994.

MERLEAU-PONTY, M.:

(1964), L'oeil et l'espirit, Gallimard, 1964. Trad: Alejandro del Rio Herrmann, El ojo y el espíritu, Trotta, Madrid 2013.

(1964), Le Visible et l'Invisible, suivi de notes de travail, Gallimard, París 1964.

MIGAYROU, F. \& MENNAN, Z. (Ed.). (2003), Architectures Non Standard, París: Centre Pompidou, 2003.

\section{NIETZSCHE, F.:}

(1883, I y II); (1884, III); (1885, IV) Also Sprach Zarathustra. Ein Buch für Alle und Keinen). Trad:. Andrés Sánchez Pascual, Así habló Zaratustra, Alianza editorial, Madrid, 2003.

(1990), Fragments posthumes, Gallimard, París 1990. Traducción al castellano Fragmentos póstumos, Tecnos 2008.

NOUVEL, J., (2002), Catálogo a de la exposición Centro Pompidou, 2002.

NÚÑEZ, A., (2019) Gilles Deleuze. Una estética del espacio para una ontología menor, Arena libros, Madrid 2019.

OÑATE, T.:

(2019), "Ho Skoteinós (el Obscuro): la ontología estética del espacio-tiempo tras la Kehre", en: Estética y nihilismo (Hermenéuticas contra la Violencia II), Dykinson, Madrid 2019.

(2005),"La teología de la esperanza oculta en el límite de la Hermenéutica”, en: Hans-Georg Gadamer: Ontología Estética y Her- 
menéutica, Oñate, T, García, Santos, C. y Quintana, M.A. (ed.), Dykinson, Madrid 2005.

OÑATE, T, CUBO, O. y Otros. Eds. (2012), El Segundo Heidegger: Ecología. Arte. Teología. En el 50 aniversario de Tiempo y Ser. Dykinson, Madrid, 2012.

OÑATE, T, GARCÍA, SANTOS, C. y QUINTANA, M.A., HansGeorg Gadamer: Ontología Estética y Hermenéutica.

PANOFSKY, E.:

(1924), Idea, Ein Beitrag zur Begriffsgechichte der älteren KunstTheorie. Trad: Maria Teresa Pumarega, Idea, contribución a la historia de la teoría del arte, Arte Cátedra, 2013.

(200o), “Qué es el Barroco?”, en Sobre el estilo, Paidós, Barcelona, 2000

PARDO J.L., (1992), Las formas de la exterioridad, Pre-textos, Madrid, 1992.

PAUL KLEE, Théorie de l'art moderne, Ed. Gonthier.

PLATÓN, Ión, Timeo, Critias, Trad: Jose María Pérez Martel, Alianza, Madrid 2004.

RIEGL A.:

(1893), Stilfragen, Grundlegungen zu einer Geschichte der Ornamentik, Berlín. Trad: Federico Miguel Saller, Problemas de estilo. Fundamentos para una historia de la ornamentación, Gustavo Gili, Barcelona 1980.

(1903), Der moderne Denkmalkultus,. Trad: Ana Pérez López, El culto moderno a los monumentos: caracteres y origen, Visor, Madrid 1987.

(1901), Spätrömische Kunstindustrie. Trad: Ana Pérez López, El arte industrial tardoromano, Antonio Machado, Madrid, 1993.

RILKE, R.M., (1929), Briefe an einen jungen Dichter, Leipzig 1929. Trad: Santiago Martín Arnedo, Cartas a un joven poeta, Hiperión Madrid, 2015.

ROSSI A., (1966.), l'Architettura della cità, Marsilio Editori, Padua. trad: Josep María Ferrer-Ferrer, La arquitectura de la ciudad, Gustavo Gili, Barcelona, 1971 
SCOTO, D., (1914), Opus Oxoniense II, ed. Fernández García, tomo II, Quaracchi, 1914

SEDLMAYR, H., (1996), L'architettura di Borromini, Electa, Milano 1996

SEMPER G., Escritos fundamentales de Gottfried Semper, Los 4 elementos. Trad: Manuel García Roig, Fundación Arquia, Barcelona 2014 .

SOKAL, A. y BRICMONT, J., Impostures intellectuelles, Éditions Odile Jacob, París, 1997. Trad: Joan Cariesy Guix Vilaplana, Imposturas intelectuales, Ediciones Paidós Ibérica, 1999.

SOLÁ MORALES, I., (1995), Diferencias: topografía de la arquitectura contemporánea, Gustavo Gili, Barcelona, 1995.

SPINOZA B. (1677), Ethica, ordine geometrico demonstrata, traducción al castellano de Vidal Peña, Ética demostrada según el orden geométrico, Alianza editorial, Madrid, 2011.

TANIZAKI, J., (1933), Éloge de l'ombre, Chouokoron-Sha, 1933. Trad: Julia Escobar, El elogio de las sombras, Siruela Madrid, 1994.

TEYSSOT, G., "El diagrama como mapa abstracto", en: Atlas de teoría de la arquitectura, Manuel Rodrigo de la O Cabrera (ed.), Madrid 2019.

THOM, R., (1973), Stabilité structurelle et morphogénèse, Denöel-Gonthier, París, 1978. Trad: Estabilidad estructural y morfogénesis, Gedisa 2015.

TRIAS E., (2013), Lo bello y lo Siniestro, Debolsillo, Barcelona 2013.

UMBERTO ECO, (1929), Opera Aperta, Milán, 1929. Trad: Obra Abierta, Planeta, Barcelona, 1985.

VATTIMO G., (1983), Il pensiero debole, ed. G. Vattimo y P. A. Rovatti, Feltrinelli, Milán, 1983. Trad: Luis de Santiago, El pensamiento débil, Cátedra, Madrid 1988.

WARBURG, A.:

(1988), Schlangenritual: Ein Reisebericht, Klaus Wagenbach, Berlín. Trad.: El ritual de la serpiente, Sexto Piso, Madrid, 2008. 
(1932), Die Erneuerung der heidnischen Antike. Kulturwissenschaftliche Beiträge zur Geschichte der europäischen Renaissance, Teubner, Berlín. Trad: El renacimiento del paganismo: aportaciones a la historia cultural del Renacimiento europeo, Alianza, Madrid, 2005.

(1932) Der Bilderatlas Mnemosyne. Trad.: Atlas Mnemosyne, Akal, Madrid 2010.

WITTKOWER, R., (1979) WITTKOWER, R., "Studi soul Borromini” , en: F. Borromini, personalità e destino, Roma 1979, vol 1. Trad: Sobre la Arquitectura en la edad del humanismo.

ZELLINI, P., (1993), Breve storia dell'infinito, Adelphi, Milán, 1993. Trad: José Martín Arancibia, Breve historia del infinito, Siruela, Madrid 1991.

ZUMTHOR, P., (2003), "Atmósferas. Entornos arquitectónicos". Las cosas a mi alrededor", conferencia pronunciada el 1 de junio de 2003 en el Festival de Literatura y Música Wege durch das Land.

ZUMTHOR, P., (2010), Architektur denken, Birkhäuser Verlag, Basilea 2010. Trad: Pedro Madrigal, Pensar la arquitectura, Gustavo Gili, 2017.

o.2. REVISTAS

ARQUITECTURA VIVA № 141, Espacios efímeros. Entre la celebración y la innovación. Fernández-Galiano, L. (ed.), Madrid 2011.

ARQUITECTURA VIVA, RCR arquitectes 1988-2017, Fernández-Galiano, L. (ed.), Madrid 2017.

ARQUITECTURA VIVA № 174, Textile vs Tectonic, Gottfried Semper Redux, Fernández-Galiano, L. (ed.), Madrid 2015.

AV no 218/219, Kengo Kuma 2014-2019, Fernández-Galiano, L. (ed.), Madrid 2019.

DOMUS n605, Editoriale Domus S.p.A., Milán 1980.

EL CROQUIS № 162. RCR arquitectes, 2007-2012, Abstracción poética. Márquez F. y Levene, R. (ed.), Madrid 2012. 
EL CROQUIS № 139. SANAA. Kazuyo Sejima. Ryue Nishizawa, 2004-2008, Márquez F. y Levene, R. (ed.), Madrid 2008.

EL CROQUIS № 151, Sou Fujimoto 2003-2010, Teoría e intuición, marco y experiencia, Márquez, F y Levene, R. (ed.), Madrid, 2010.

LA ESTRUCTURA DE LAS SOMBRAS. BELL-LLOC, Fundació Bunka,, 2009.

\section{o.3. ARTÍCULOS, CATÁlOGOS}

ARNAU, O.; PRUDENCIA, I.; BRUNS BANEGAS, S.; LOZANO VELASCO, J.M., "Loos y Venturi \& Scott Brown. Del ornamento en la modernidadal símbolo postmoderno", EN BLANCO. Revista de Arquitectura, $\mathrm{n}^{\circ}$ 27, oct. 2019, pags. 106-119,

CABADA CASTRO, M., "La fundamentación filosófica del transfinito en G. Cantor y la cuestión de infinito”, Revista PENSAMIENTO, núm. 246, 2009, pags. 669-711.

CORTÉS, J.A., “Topología arquitectónica. Una indagación sobre la naturaleza del espacio contemporáneo", en: El Croquis: SANAA, 2004-2008, Márquez F. y Levene, R. (ed.), Madrid 2008.

CORTÉS, J.A. Y MUÑOZ, M.T., La repetición en la arquitectura moderna 2, revista de Arquitectura no 230 mayo-junio, 1981, págs. 56-62.

EISENMAN, P., “On the Space and Time of Rebstock Park," en: In Unfolding Frankfurt, Eisenman P. (ed.), Ernst \& Sohn, Berlín 1991.

FANELLI , G. y GARGIANI, R., "El principio del revestimiento. Semper and the Textile Origin of Architecture”, en: Arquitectura Viva no 174, Fernández-Galiano, L. (ed.), Madrid 2015.

FERNÁNDEZ GALIANO, L., "RCR, Romanticismo con rigor", en: Arquitectura Viva, RCR Arquitectes. Fernández-Galiano, L. (ed.), Madrid 2017.

FUJIMOTO, S.. "Futuro Primitivo”, en: El Croquis no 151, Sou Fujimoto 2003-2010, Teoría e intuición, marco y experiencia, Márquez, F y Levene, R. (ed.), Madrid, 2010, pag. 206 
GARCÍA L.I., "Alegoría y montaje. El trabajo del fragmento en Walter Benjamin”, en: Constelaciones ํㅜㄹ, Revista de teoría Crítica, 2010.

HERZOG Y DE MEURON, Minimalismus and Ornament, ARCH+ № 120-130, Aachen 1995.

HITO, T., “Arquitectura diagrama”, en: El Croquis no 77, Márquez, F y Levene, R. (ed.), Madrid, 1996.

DAVID HUME, (1740), A Treatise oh human nature. Trad: Félix Duque, Tratado de la naturaleza humana, Tecnos, Madrid 2008.

INGERSOLL, R., "Los Pabellones de Les Cols," en: Arquitectura Viva, RCR arquitectos 1988-2017, Fernández-Galiano, L. (ed.), Madrid 2017.

LYOTARD, J-F., Exhibition Les Inmaterieux, Centre Pompidou, París 1984.

MONTANER, J.M., “El universo RCR”, en: El Croquis no62, RCR arquitectes, Márquez F. y Levene, R. (ed.), Madrid 2012.

PAOLO PORTOGHESI, Postmodern, Catálogo de la exposición para la Bienal de Venecia: La presenza del passato: il postmodern, Electa, Milán 1979.

PRIETO LÓPEZ, J.I. "Arquitectura de límites difusos: de la Glasarchitektur a la desmaterialización de la Arquitectura”, en: Arquitectonics: Congreso Internacional Arquitectonics Network. Arquitectura, Educación y Sociedad. Departamento de Proxectos Arquitectónicos e Urbanismo, Escola Técnica Superior de Arquitectura, Universidade da Coruña.

RCR y CURTIS, W.J.R. "Entrevista de Wiliam J.R. Curtis a RCR", en: El Croquis no 162. Márquez F. y Levene, R. (ed.), Madrid 2012.

RCR, ARANDA, PIGEM Y VILLALTA, "Límites y transiciones. Memoria del proyecto para las bodegas Bell-Lloc”. Palamós 2005.

SEJIMA, K. y NISHIZAWA, R. "Una conversación con Kazuyo Sejima y Ryue Nishizawa”, en: El Croquis, SANAA 2004-2008, Márquez F. y Levene, R. (ed.), Madrid 2008. 
SENRA FERNANDEZ MIRANDA, I., "La modernidad revisada en los textos de Venturi y Scott Brown”, REIA, Revista Europea de Investigación en Arquitectura ํㅡㄴ, 2013. pags. 145-163.

\section{o.4. TESIS DOCTORALES}

PLIHON, F., Architectures Numériques et Résurgence Baroque: Bernard Cache, Greg Lynn et le Pli de Deleuze, Architecture, aménagement de l'espace. Université Charles de Gaulle - Lille III, 2016.

RUIZ ESTEBAN, N., En los límites de la arquitectura espacio, sistema y disciplina. Universidad Politécnica de Cataluña. Departamento de Expresión Gráfica Arquitectónica, Barcelona 2013.

SALGUEIDO, R., Sobre los límites deformados. Inflexiones. Universitat Politecnica de Catalunya. ETSAB. Director de Tesis; Eduard Bru Bistuer. Mayo 2015.

0.5. MATERIAL AUDIOVISUAL

JUAN MIGUEL HERNÁNDEZ LEÓN, Seminario de investigación Ser arquitectura, organizado por UNED, Hercritia. En las sesiones del 14 de marzo de 2019 ver las fuerzas, representar lo invisible. Y en la sesión del 21 de marzo de 2019 la vida de las formas, la exasperación de las formas. Facultad de económicas de la UNED. Marzo 2019.

ALEJANDRO ESCUDERO PÉREZ, La modernidad explicada por Quintín Racionero, sobre una recopilación de artículos de Quintín Racionero. Apuntes UNED Campus virtual.

BAUDRILLARD, J., La Simulación en el Arte. La Simulación en el Arte es la segunda de tres conferencias dictadas en el Centro Documental de la Sala Mendoza por Jean Baudrillard.

Vídeos sobre la exposición vía mística de Bill Viola. Cuenca diciembre 2018-febrero 2019

(1996) El mensajero

(2005) Tristan's Ascension 

El antiguo y el actual, forman dos series coexistentes en función del objeto virtual que se desplaza en ellas con respecto a sí mismo, ninguna de estas dos series puede ya ser designada como la original o la derivada.

GILLES DELEUZE Diferencia y Repetición 
